Graduate Theses, Dissertations, and Problem Reports

2001

\title{
Women and physical culture in modern Poland
}

Nameeta Mathur

West Virginia University

Follow this and additional works at: https://researchrepository.wvu.edu/etd

\section{Recommended Citation}

Mathur, Nameeta, "Women and physical culture in modern Poland" (2001). Graduate Theses, Dissertations, and Problem Reports. 1439. https://researchrepository.wvu.edu/etd/1439 
Women and Physical Culture in Modern Poland

Nameeta Mathur

Dissertation submitted to the Eberly College of Arts and Sciences at West Virginia University in partial fulfillment of the requirements for the degree of

\section{Doctor of Philosophy}

in

Modern European History

Robert Blobaum, Ph.D., Chair

Robert Maxon, Ph.D.

Padraic Kenney, Ph.D.

Steven Zdatny, Ph.D.

Katherine Aaslestad, Ph.D.

Department of History

Morgantown, West Virginia 2001

Keywords: Women, Poland, Physical Culture, Sports, Nationalism Copyright 2001 Nameeta Mathur 


\section{ABSTRACT \\ Women and Physical Culture in Modern Poland}

\section{Nameeta Mathur}

This dissertation examines the interaction between the various forces of Polish "nationalism" and "feminism" in the construction of women's physical culture in modern Poland from the late nineteenth century until the end of the twentieth century. The basic premise of this work is that unlike most western countries where sportswomen have typically been marginalized in their athletic endeavors, Polish female athletes have earned far greater respect and recognition in the development of their physical culture. On many occasions, women's athleticism in Poland was a source of immense pride and prestige for both the state and society, albeit for varied reasons throughout the time period. This form of public acceptance, however, does not suggest that Polish sportswomen faced no discrimination in their efforts to become more athletic. Women's physicality remained the subject of much debate throughout the history of Poland. Such scrutiny became even more intense when the socio-economic conditions worsened and threatened the survival of Polish families. Still, despite the patriarchal and other barricades, the Polish struggles for independence and women's concerns to achieve greater equity with men created significant institutional spaces and ideological avenues for Polish sportswomen to build their physical culture. Although Polish sportswomen were not depicted as Soviet-style sports stakhanovites, neither were they portrayed as "abnormalities" quite typical of the western identification for their sportswomen. The Polish female athletes were not placed in either of these two ludicrous categories; rather, they were located in the middle of these two polarities. Polish sportswomen were simply "heroic" women who took advantage of the available opportunities to build their physical culture without causing much controversy in popular discourse and official rhetoric. In this manner, they made significant contributions to the feminist goals of self-awareness and self-authorization, albeit within the boundaries of a still patriarchal nationalist agenda. 


\section{Acknowledgements}

This work, submitted electronically to the West Virginia University Libraries, is a condensed version of my original study. Several individuals and institutions helped me to write my dissertation. I acknowledge their assistance, with deep gratitude, in my original manuscript. I would, however, like to take this opportunity to once again express my sincere thanks to Professor Robert Blobaum for his inspiration and encouragement as I made my academic journey across three continents. I would also like to thank Professor Robert Maxon for helping me at various stages of my graduate study in America. 
To my parents, Bina and Sat Narain Mathur for always being there for me

To my sisters, Mala and Sangeeta for their love and support

To Mani and Balaji

for their friendship and guidance

To dear Megha

for making me smile always 
TABLE OF CONTENTS

Pages

Introduction $1-17$

Chapter 1 The Development of Women's Physical Culture $18-76$ in Late Partitioned Poland

Chapter 2 Motivations and Logistics: The Ideological and $77-108$ Structural Organization of Women's Physical Culture in Interwar Poland

Chapter 3 The "New Woman" and Women's Physical

$109-133$ Culture in Interwar Poland

Chapter 4 Women's Sports in Interwar Poland

Chapter 5 Socialist Ideology, the Images of Women, and $170-210$ the Construction of Women's Physical Culture in Stalinist Poland

Chapter 6 Socialist Ideology, the Images of Women, and $211-263$ the Construction of Women's Physical Culture in Post-Stalinist Poland

Chapter 7 Socialist Ideology and the Images and Identities 264-306 of Female Athletes in the PRL

Conclusion $307-328$

Bibliography $329-373$ 


\section{Introduction}

The objective of this dissertation is to examine the participation of women in modern Polish physical culture. The dissertation attempts to analyze images of Polish sportswomen which appeared in the press, especially in sports newspapers and in the popular women's periodicals and magazines, from the late nineteenth century until the end of the twentieth century. My questions are really quite simple: what do these images mean? And are they "real" or mere illustrations of political propaganda? A related question would be why study these images at all? Certainly, the fact that Polish sportswomen competed in both domestic and international sports tournaments is by no means a revelation. On the contrary, their very participation in international sports also suggests the participation of sportswomen from other competing countries. Hence, Polish women's engagement in their institutionalized physical culture, in itself, was not something unique. Without doubt, most western nations, as well as some countries in Asia, Africa and the Caribbean trained their sportswomen to become more "athletic" and "sportive". However, what is of special interest is the fact that Polish sportswomen, similar to their counterparts in eastern Europe, frequently excelled in several of their sports events and, many times, emerged as the champions.

Indeed, the former 'eastern bloc' as a whole repeatedly churned out female "sports-heroines". East European sportswomen, by and large, performed extremely well in the various domestic and international sports competitions, especially after the Second World War. Their participation in the different sports competitions was unique for these women, at least on the surface, well demonstrated the theme of the 'emancipation of women' through sport at a time when such ideas were still being theorized by their contemporaries in other parts of the world. The overwhelming importance of women's sports in eastern Europe, at least up until the revolutions of 1989, would accordingly raise a number of questions. For example, how can we explain the meteoric rise of east European sportswomen to international prominence? How were they able to retain their privileged position in the world of sports? Who deserves the real credit for their successes- the state dicta and institutions, or the female athletes themselves? What was the larger significance of their repeated victories? More fundamentally, what messages were being relayed in the glorious representations of female athletes and did the projected official images of sportswomen accord with the reality of their everyday lives and experiences?

Given the fact that women in East European countries performed extraordinarily well in international competitions, the paucity of secondary literature in the English 
language on the organization of sports in this region is perplexing. The secondary English language literature on Polish sportswomen especially is virtually non-existent. The secondary literature in the Polish language on this subject is also very limited, and is concentrated more on late partitioned Poland. There is more secondary information on the larger development of sport in Poland, mainly in the Polish language. But the significant gap in the literature on women's sports in Poland and the near total neglect of women sports champions from eastern Europe as a whole remains confounding.

While the secondary literature on women's sports is scarce, gender (or women's) studies has recently begun to refashion Polish historiography. Several Polish and western scholars are now examining the "woman question" in Poland more closely. Unfortunately, this scholarship is more or less confined to either the period of the partitions or the contemporary situation of Polish women. Research on Polish women in the interwar period is limited, and that of the communist period only in its infancy. This scarcity of secondary literature on Polish women's history generally, and of Polish sportswomen specifically, endorses the need for the research embodied in this dissertation.

Accordingly, this study of women's sporting experiences in modern Poland is informed by two methods of "internal" and "external" analysis. The "internal" methodology examines the images of women in Polish sport in the context of the imposition of foreign rule, the emergence of "nationalist" and "socialist" ideologies, the widespread socio-economic transformations, the pervasive patriarchal constraints in the social structure and consciousness, and the struggles for women's emancipation. The research base for this "internal" method includes the available secondary literature in the Polish, English, and to a lesser extent, German languages. The primary source base for obtaining images of Polish sportswomen include sports newspapers, women's magazines and periodicals, and information derived from archives in Poland.

In addition, since the Soviet Union served as Poland's "athletic mentor" after the Second World War, the official images of Polish sportswomen are also examined in the context of the imagery projected by the Soviet ruling elites of their Russian/Soviet sportswomen. While the secondary English language literature includes books and articles on women's history and the history of sports in Russia/Soviet Union, the primary literature used for this purpose refers mainly to women's periodicals in the Russian and English languages. An analysis of all these primary and secondary sources is critical for integrating the 'official' imagery of Polish sportswomen with Polish women's history and the history of sport. Such an investigation illuminates the interaction between Poland's "national" sports and women's identities, and explains how these interactive forces of 
accommodation or resistance impacted the development of Polish women's physical culture. 1

The "external" method compares the participation of women in Polish sports with the experiences of sportswomen in other countries. Though play is intrinsically human and universally found in all cultures and times, the forms that play and sport assume reflect the values and structures of the particular society. ${ }^{2}$ For this reason, physical culture is an important and complex social phenomenon which can be used and abused for imagining and constructing various forms of political, social, economic and cultural identities at the individual, communal, local, regional, and national levels. Sport can serve as a multifunctional medium of communication which could be shaped as an area of relaxation and recreation, as a medium of socialization, as an avenue for making profits, as a veritable tool for disseminating propaganda, and as a representative force to symbolize expressions of pride, power, and prestige. ${ }^{3}$ Similar to other cultural forms and practices, sport is also profoundly affected by existing structures of power and social inequality in individual societies. And depending upon their circumstances, women's access to leisure and sport opportunities has varied tremendously both within and among different cultures. 4

Accordingly, the objective of this "comparative" methodology is to identify the ideologies and practices in other societies which facilitated or disadvantaged women from participating in their respective physical cultures. An examination of the difficulties and complexities that constrained women to play the game in other western and nonwestern countries provides a useful "global" perspective for understanding the gender dimension of physical culture in Poland and, more generally, throughout eastern Europe.

\footnotetext{
1 The Polish sports newspapers such as Sport, Sportwiec, Tempo and Przeglad Sportowy (PzS) are good official sources for examining the participation of Polish women in sport. A careful reading of these newspapers is critical for understanding the official dynamics of Polish women's physical culture. For a detailed list and descriptions of press sources on Polish sports see Bogdan Tuszynski, Prasa i sport, 18811981 (Warsaw, 1981), 495-516. This book provides descriptions of sports periodicals and newspapers for Poland's partitioned, interwar, and communist periods. My analysis for the dissertation is primarily based on a selected reading of a few women's periodicals and a summary glance at the sports newspaper Przeglad Sportowy.

2 Mary Boutilier and Lucinda SanGiovanni, The Sporting Woman (Champaign, Ill., 1983), 24.

${ }^{3}$ For all these issues see Grant Jarvie and Maguire Joseph, Sport and Leisure in Social Thought (London and New York, 1994), 2, 17, 18; Benjamin Lowe, David Kanin and Andrew Strenk (eds.), Sport and International Relations (Champaign, Ill., 1978), 11, 481; Donald Calhoun, Sport, Culture, and Personality (Champaign, Ill., 1987), 259; Janet Lever, Soccer Madness (Chicago, 1983); Alan Ingham and John Loy, Sport in Social Development: Traditions, Transitions, and Transformations (Champaign, Ill., 1993), 2; and James Riordan, Sport in Soviet Society: Development of Sport and Physical Education in Russia and the USSR (Cambridge and New York, 1977), 4.

${ }^{4}$ M. Ann Hall, Feminism and Sporting Bodies: Essays on Theory and Practice (Champaign, Ill., 1996).
} 
The issues related to the "genderization" of sports in the secondary literature have mostly been confined to countries such as Great Britain and the United States of America, and more recently to Australia and Canada. The interaction of the complex relationships between gender, power, culture and sport have been widely discussed by scholars of these countries. By contrast, we have a much limited resource base for understanding women's sports in developing countries. There is a small body of literature that refers to women's participation in sports in countries such as New Zealand, China, India, and South Africa. The nature of this literature suggests some interest in understanding the experiences of Chinese and Indian sportswomen, as well as examining the reasons that still restrain Muslim women from participating in sports. 5 However, by and large, the available secondary literature in the English language examining the history of sportswomen is focused particularly on the sporting experiences of American and British female athletes.

Since an examination of the prominent images and conventional stereotypes of women in sport in "western" societies provides an important comparative analysis for understanding the participation of Polish sportswomen in their physical culture apparatus, a brief discussion on the nature of women's sporting cultures in America and Great Britain is warranted to explain the reasons as to why sportswomen have typically struggled to "accommodate," "resist," and "transform" their physical cultures. A study of the predominant characteristics of "western" sports will not only enable us to comprehend the magnitude of the challenges which athletically-conscious women faced in overcoming established traditions, but also help us to appreciate the numerous successes of Polish female athletes at the individual and societal levels, especially in the midst of the various domineering constraints in the Polish political culture.

The principal hallmark of western physical culture has been the masculine construction of the sports complex. Sport is a gendered cultural space that has played an important role in the construction of masculinity in western societies. Such male domination in sports resulted from cultural patterns and perceptions which determined not only who participated in sport but how sport was conducted and experienced. ${ }^{6}$ Given this cultural heritage, it is not surprising to find that although men often have celebrated their physicality and defined their sexuality through sport, women have had to battle

\footnotetext{
${ }^{5}$ For a book (the only book perhaps) on Indian women and sports, see M.K. Singh, Indian Women and Sports (Jaipur, 1990). The author discusses the low level of recognition and promotion of sports and games for Indian women.

6 Mary E. Duquin, "The Androgynous Advantage," in Carole A. Oglesby, Women and Sport: From Myth to Reality (Philadelphia, 1978), 89-106.
} 
against cultural, pseudoscientific, and religious ideologies that identified being female with frailty and associated female athleticism with sexual deviance. ${ }^{7}$ Such traditional prescriptions against female participation in vigorous physical activity represented a type of social inequality and a form of sexism. Athletic participation was acceptable only if it did not challenge the traditional norms of appropriate feminine behavior. 8 The men who developed and promoted sports in this manner denied women adequate sports facilities and programs, ridiculed their attempts to become athletic, and threatened them with the specter of ill-health and 'race suicide'. 9

Thus, sport in the western world developed as a male preserve, a domain in which men expressed and cultivated masculinity through athletic competition. For example, American men confronting the changes wrought by industrialization, urbanization, and mass immigration, looked to sport as a crucial avenue for defining and expressing their manhood. 10 This male hegemonic control in athletics and the identification of sport as a natural male domain reproduced unequal gender relations in sport and fostered an acrimonious debate between those who welcomed the prospect of women's sports and those who feared that female athletes jeopardized their anatomical destiny as wives and mothers. And even today, in many parts of the world, sports are still largely viewed as an expression of male sexuality, physical energy, and power; a world in which women are intruders, not rightful heirs. 11

Since cultural practices such as sport and leisure have traditionally been defined by masculine standards in the western world, an examination of 'sporting females' in the west demonstrates their 'symbolic annihilation', their 'trivialization and marginalization', their objectification and sexualization (or heterosexualization), their 'tragic' involvement in sports, and their depiction as 'unnatural' women. 12 The nature of the participation of

\footnotetext{
7 Catriona M. Parrat, "From the History of Women in Sport to Women's Sport History," in Margaret Costa and Sharon Guthrie (eds.), Woman and Sport: Interdisciplinary Perspectives (Champaign, Ill., 1994), 5-14. For more on the association of women with the idea of 'frailty' in sports see Colette Dowling, The Frailty Myth: Women Approaching Physical Equality (New York, 2000).

8 Eldon E. Snyder and Elmer A. Spreitzer, Social Aspects of Sport (Englewood Cliffs, N.J., 1989), 191-222.

9 Bruce Kidd, "The Men's Cultural Center: Sports and the Dynamic of Women's Oppression/Men's Repression," in Michael Messner and Donald Sabo (eds.), Sport, Men, and the Gender Order: Critical Feminist Perspectives (Champaign, Ill., 1990), 31-43.

10 Susan Cahn, Coming on Strong: Gender and Sexuality in Twentieth-Century Women's Sport (New York, 1994), 8, 12.

11 Hall, Feminism and Sporting Bodies; Allen Guttmann, Women's Sports: A History (New York, 1991), 132; Stephanie L. Twin, Out of Bleachers: Writings on Women and Sport (New York, 1979), xvi, xxxvii; and Mariah Burton Nelson, The Stronger Women Get, the More Men Love Football:Sexism and the American Culture of Sports (New York, 1994), 1.

12 Hall, Feminism and Sporting Bodies.
} 
women in sport was determined by the patriarchal construction of western society and the restrictions imposed by various official and civil institutions and organizations to promote the cause of women's sports. 13 The male controlled definitions of sport and the exclusion of women from positions of power and responsibility in the sports apparatus maintained the masculine hegemony in sports and confined women's physical culture to the periphery. 14 While sport for men was often a confirmation of manhood and a journey to a known world, sport for women was certainly not a confirmation of womanhood; if anything, it called women's femininity into question. 15

In a western society that strongly associated sport with masculinity, superior performances by women could only be understood as excellent if they were simultaneously discredited as women. The athleticism, ambition, and independence which sport demanded stood outside the norm for "respectable" women. 16 And thus, to succeed as an athlete could be to fail as a woman, because she had, in certain profound symbolic ways, become a man. ${ }^{17}$ Because of this masculine construction of sports, western sportswomen found themselves in a 'Catch 22' situation with sports. To compete almost of itself seemed to promote dominant male values, because sport was defined in these terms. Yet to not compete tended to confirm the stereotype of women as lacking in those attributes of skill and power that the stereotype conveyed. 18

Because of this socially constructed contradiction in sport, female athletes in the west were exploited at the hands of patriarchal values and structures and were disadvantaged in a sport system that remained organized, administered, and dominated by men. 19 Thus, western sportswomen were required to show grace under the pressure of conservative prejudice in sport which resulted in their collective marginalization. 20 The systemic discrimination and harassment in the administration and organization of sport,

\footnotetext{
13 Helen Lenskyj, Out of Bounds: Women, Sport, and Sexuality (Toronto, Ont., 1986).

14 Lois Bryson, "Sport and the Maintenance of Masculine Hegemony," in Susan Birrell and Cheryl L. Cole (eds.), Women, Sport, and Culture (Champaign, Ill., 1994), 47-64, pp. 61, 62. This book contains various essays which explore the complex relationships between gender, sport, culture and power.

15 Susan J. Bandy and Anne S. Darden (eds.), Crossing Boundaries: An International Anthology of Women's Experiences in Sport (Champaign, Ill., 1999), ix, xiv.

16 Todd W. Crosset, Outsiders in the Clubhouse: The World of Women's Professional Golf (Albany, 1995), 107.

17 Paul Willis, "Women and Sport in Ideology," in Birrell and Cole (eds.), Women, Sport, and Culture, 3145.

18 Bryson, "Sport and the Maintenance of Masculine Hegemony," 61, 62.

19 Elaine Blinde, "Unequal Exchange and Exploitation in College Sport," in Birrell and Cole (eds.), Women, Sport, and Culture, 135-148, pp.145-146.

20 Adrianne Blue, Grace Under Pressure: The Emergence of Women in Sport (London: Sidgwick and Jackson, 1987), xv.
} 
the limited networking opportunities and lack of post-collegiate support for sportswomen, the blatant sexism in areas such as coaching, and the 'burdens of tokenism' imposed on female athletes, all forced western women's sports to long remain at the individual rather than at the team level. 21

The pervasivity of masculinity in western sports raises the question of whether Polish women's sporting experiences were constricted by similar gendered beliefs and practices which regulated sport in the western world. Since east European women participated in their physical cultures and won numerous accolades for their sports achievements, their sporting endeavors appeared, at least on the surface, markedly at variance with the Western experience. Following the assumption that Polish sportswomen were overwhelmingly important to the state, especially in the communist era, what kind of formal and informal power relations existed in the Polish women's sports apparatus? Was Polish sport 'gendered' in its organization and promotion? What kind of power relations existed between Polish sportsmen and sportswomen, and between coaches and female athletes? Did Polish women's physical culture also suffer from the yoke of masculinity?

The intrinsic linkage between female sexuality, physicality and male hegemonic control in western sports raises further concerns over issues related to "gender disturbances", the "blurring" of genders, the question of "mixed" identities, and the need for constant surveillance of female athleticism in western physical culture. The stranglehold of 'sporting patriarchy' forced western sportswomen into a matrix of vigilantism and policing practices so as to enable their athletic bodies to appear less "suspicious".22 Indeed, women's sport sparked public interest, dismay, and controversy because it "blurred" the sexual and gender categories that governed everyday life and "jeopardized" the femininity of western sportswomen. Although women's sport advocates did their best to 'prove' heterosexuality and suppress 'mannishness', hostile

${ }^{21}$ Hall, Feminism and Sporting Bodies; Mary Jo Festle, Playing Nice: Politics and Apologies in Women's Sports (New York, 1996), 273; Nancy Theberge, "Toward a Feminist Alternative to Sport as a Male Preserve," in Birrell and Cole (eds.), Women, Sport, and Culture, 181-192; Blinde, "Unequal Exchange and Exploitation," 145, 146; and Annelies Knoppers, "Gender and the Coaching Profession," in Birrell and Cole (eds.), Women, Sport, and Culture, 119-133. The IOC and its affiliated organizations also continue to be a 'world of men' infiltrated by a tiny number of women. See Jennifer Hargreaves, Sporting Females: Critical Issues in the History and Sociology of Women's Sports (London and New York, 1994), 234.

22 See Cheryl Cole, "Resisting the Canon: Feminist Cultural Studies, Sport, and Technologies of the Body," in Birrell and Cole (eds.), Women, Sport, and Culture, 5-29, p.19. Patriarchy is a system which broadly means a set of social relations which allows for domination of one group of people over another such group. Patriarchy is about power and male domination over women. For 'sporting patriarchy' in sport see Cheryl Roberts, Against the Grain: Women and Sport in South Africa (Cape Town, South Africa, 1992), 8 . 
observers perpetuated lesbian athletic stereotypes through their unrelenting ridicule of skilled athletes as 'grotesque', 'ugly', 'masculine,' and 'unnatural'. 23 The implications that western female athletes were 'pseudo-men,' 'unfeminine,' 'lesbian,' and 'mannish,' placed extraordinary pressure on heterosexual sportswomen to play the 'femininity game' by stigmatizing and closeting their "subversive" sexual identities. And this fear of the lesbian label in contemporary sexual culture continues to control women's sport. 24

The relationship between "sport and homosexuality" became more problematic in sports that emphasized physical contact and aggression toward others (e.g., football, rugby and wrestling), or suggested high levels of muscularity, physical strength, and power (e.g., track and field events and weightlifting), or required female bonding (most team sports). For this reason, western sportswomen were typically discouraged from participating in all such sports, including and especially team sports. On the other hand, individual sports, particularly those that emphasized the aesthetic and erotic elements of the body either through costume or movement, were encouraged for women (e.g., gymnastics, swimming, tennis and figure skating). ${ }^{25}$ However, not all individual sports

23 See Cahn, Coming on Strong, 162, 184, 185; Lenskyj, Out of Bounds, 107; and Dorothy V. Harris, "Dimensions of Physical Activity," in Dorothy V. Harris (ed.), Women and Sport: A National Research Conference. Penn State HPER Series No.2. College of Health, Physical Education and Recreation. The Pennsylvania State University. Proceedings from the National Research Conference, Women and Sport, held at The Pennsylvania State University, August 13-18, 1972, conducted by the College of Health, Physical Education and Recreation and the Division of Continuing Education, 3-15, 15.

24 Hargreaves, Sporting Females, 171. For more details on how women's participation in sports in western society was perceived to have supposedly threatened "heterosexuality" see Brian Pronger, The Arena of Masculinity: Sports, Homosexuality, and the Meaning of Sex (New York, 1990), 33, 177; and Pat Griffin, Strong Women, Deep Closets: Lesbians and Homophobia in Sport (Champaign, Ill., 1998), 42, 44, 49, 53, 62. According to Griffin, the shadowy image of lesbians in sport, cast against the silence of the closet where most lesbians in athletics reside, denies the diversity, complexity, and individuality of the real lives and experiences of lesbians in sport. See also Mariah Burton Nelson, "Sex and Sports," in Susan Ware, Modern American Women: A Documentary History (New York, 1997), 362-369. This article is about Mariah Burton Nelson who was fired from the Women's Pro Basketball League in America for being a lesbian. For more on "lesbianism" in women's sports see Cahn, Coming on Strong, 185, 189, 192, 203, 268; and Susan Cahn, "Crushes, Competition and Closets: The Emergence of Homophobia in Women's Physical Education," in Birrell and Cole (eds.), Women, Sport, and Culture, 327-339. This last article discusses the stronger lesbian presence in physical education today. However, while most western societies today are fairly tolerant of homosexuality, very few actually provide legal safeguards against discrimination (such countries are Canada, Australia, the Scandinavian countries and France). Almost all regions of the former Soviet Union, however, remain hostile toward homosexuality. Romania and Bulgaria share similar inhibitions. Attitudes of general social disapproval are equally visible in Portugal, Albania, and Poland. In Lithuania, Ireland and India, both male and female homosexuality is illegal. For China, homosexuality is a decidedly western import. Such regional diversity in social attitudes will not only impact how the relationship between sport and sexuality is perceived but also how women's (and men's) participation in sports is understood and written. For details see Joni Seager, The State of Women in the World Atlas (London and New York, 1997), 24, 25.

25 Sharon Guthrie and Shirley Castelnuovo, "The Significance of Body Image in Psychosocial Development and in Embodying Feminist Perspectives," in Costa and Guthrie, Sport and Woman, 307-322. See also Dana Robinson, “A League of Their Own: Do Women Want Sex-Segregated Sports?” in Journal 
which supported the institution of compulsory heterosexuality were "safe" from controversy. The entrance of transsexual Renee Richards into women's professional tennis, for example, created confusion and controversy for the players, the fans, and for organized tennis as a whole. Richards's mediocre performances on court and his inability to 'dominate' women's tennis were used by the press to suggest his acceptability as a woman-- a proof of his/her status as a woman. 26 Such gender scrutiny, meanwhile, also forced the popular tennis player Martina Navratilova to reveal her homosexual orientation. 27

The images of mannishness, lesbianism, ugliness, and biological abnormality certainly posed as formidable barriers to female athletic participation in the west. 28 But there were other ways as well in which western sportswomen were perceived to 'blur' the presumed natural gender differences in sports. The available literature has examined the consequences of athletic beauty pageants and the fitness craze among women to provide supporting evidence. Female bodybuilders, for example, were criticized by the social gatekeepers of sport who insisted that they must enhance their femininity and limit their muscularity. 29 On the other hand, the combination of sporting events with dances or athletic beauty contests was said to display sportswomen's femininity through her 'attractiveness' to men. But the depiction of athletes as beauty queens relegated them to the status of sexual objects for public consumption. 30

This discussion of 'sex and sexuality' in the western sports arena raises the question of how the female athletic body in Polish physical culture was visualized in popular and state imagination. Did these images remain constant or change with time and with different political regimes? Were the images drawn to project Polish sportswomen

of Contemporary Legal Issues, 9 (Spring 1998), 321-356, p.356. The author of this article hopes that someday women's teams will disappear; not because of lack of interest, or because of budget cuts on the campus, but because women and men playing together suggests women's equity in sport. This view, however, is subject to debate.

26 Susan Birrell and Cheryl L. Cole, "Double Fault: Renee Richards and the Construction and Naturalization of Difference," in Pamela J. Creedon (ed.), Women, Media, and Sport: Challenging Gender Values (Thousand Oaks, Calif., 1994), 207-237, pp. 208, 230.

27 While for most part of the 20th century, lesbian athletes concealed their sexual orientation, Martina Navratilova's continued popularity after her avowal of a lesbian relationship is evidence that the admission of homosexuality is no longer tantamount to the end of an athletic career. See Allen Guttmann. The Erotic in Sports (New York, 1996), 149, 150, 151.

${ }^{28}$ Cahn, Coming on Strong, 8, 20; and Lenskyj, Out of Bounds, 35.

${ }^{29}$ Maria R. Lowe, Women of Steel: Female bodybuilders and the Struggle for Self-Definition (New York, 1998), 159, 161. For a discussion on women's bodybuilding as a 'controversial sport' and images of such women as being unattractive, unnatural, freakish or lesbian, see Blue, Grace Under Pressure, 173; Lenskyj, Out of Bounds, 127, 137; and Leslie Heywood, Bodymakers: A Cultural Anatomy of Women's Body Building (New Brunswick, N.J., 1998), 3, 5, 27, 169, 171.

${ }^{30}$ Cahn, Coming on Strong, 78, 79, 82. 
as mere "value-objects" on display? In other words, were the roles of sportswomen merely symbolic and ceremonial, or were they substantive and authoritative? Did a 'sports patriarchy' exist in Polish physical culture? If so, were sportswomen able to successfully overcome the patriarchal pressures? Did women's participation in the various sport societies and clubs offer any 'rituals of female binding/bonding'? Was the female athletic body used in the service of resistance to gender domination, or in the service of docility and gender normalization in Polish sports? Did sportswomen in their efforts to aspire to 'excellence' compromise their athleticism and seek to develop a 'community of interest' between themselves and the patriarchal society? Or did their sports achievements contribute to the fundamental feminist principles of selfdetermination and emancipation? 31

Further, the scholars analyzing the participation of western women in sport have considered the imposition of unrealistic demands for weight control which resulted in anorexia nervosa, bulimia, and other common eating disorders among women athletes. Sport for women evolved into a form of physical coercion in which the body was controlled by external forms of discipline and supervision and by an internalized surveillance system, ironically under the rubric of health and physical enjoyment. This resulted in suicide attempts, eating disorders, broken bones, and 'battered child athletes'.32 This form of exploitation and victimization of western female athletes poses the question of whether Polish sportswomen were subject to such physical and substance abuse. What was the role of sports medicine in Poland and did the research conducted assist or de-humanize women in their efforts to construct their physical culture?

The western media has also constantly struggled with an appropriate language to define the presumed gender ambiguity of athletic womanhood which attempted to place athleticism and femininity on the same playing field. Accordingly, the media presented

\footnotetext{
31 Similar questions on feminist self-determination have been posed in Susan Bordo's work, Unbearable Weight: Feminism, Western Culture and the Body (Berkeley, 1993). This book is a well-written cultural analysis of the 'body'.

32 Hargreaves, Sporting Females, 225; Festle, Playing Nice, 270; Blinde, "Unequal Exchange and Exploitation in College Sport," pp.145, 146; Joan Ryan, Little Girls in Pretty Boxes: The Making and Breaking of Elite Gymnastics and Figure Skaters (New York, 1995), 14, 15; and Cahn, Coming on Strong, 274, 275, 277. On images of 'women's fitness' in magazines see Tina B. Eskes, Margaret Carlisle Duncan, Eleanor M. Miller, "The Discourse of Empowerment: Foucault, Marcuse, and Women's Fitness Texts," in Journal of Sport and Social Issues, 22, 3 (August, 1998), 317-344. According to one scholar, however, athletic men are more likely to resort to drugs than women. The male drug users frequently attempt to justify their behavior by saying that they want to improve their sports performance and become physically more attractive to the opposite sex. Horror stories about anorexia and the destructive effects of steroids on female athletes can be matched by reports of male athletes whose bodies have been ravaged by substance abuse. Thus, "what's bad for the goose is bad for the gander". See Guttmann, The Erotic in Sports, 5, 157, $158,160,163,165,168,169,170,172$.
} 
contradictory images of western sportswomen that praised and damned the 'athletic girl'.33 Women athletes were depicted as gorgeous, flirtatious, charming, seductive, vulnerable, elegant, and angelic. 34 Sporting pornography itself became a popular feature of the commodification and exploitation of female sexuality that permeated modern life. 35 Thus, when women's sports were covered, they were often subtly sexualized, trivialized, and devalued. A female sporting event was framed as less historically significant than a comparable male event. 36 This type of media portrayal therefore resulted in constructions of female athleticism as less important than male athleticism. 37 In response, the guiding principle of most sportswomen, especially in women's golf, was to remain "non-controversial" when interacting with the press. 38 They were forced to accommodate to the fact that women's sports were not only under-reported, but also awarded lower technical quality, less colorful visualization and less informative verbal commentary. In this manner, the media supported the myth of female passivity and frailty, and forced women athletes in the west to conform to the dictates of media fashion. 39 This 'forced conformity' in western women's sports would accordingly lead us to question if Polish sportswomen were subject to similar forms of social control by their mass media.

Women's participation in sports in the western world also suffered because of persistent "racist" attitudes in society. This enduring problem of racism adversely affected western feminine physical culture. 40 Society's standard of femininity, which

\footnotetext{
33 Cahn, Coming on Strong, 19, 212, 214.

34 Mariah Burton Nelson, "Introduction: Who We Might Become," in Lissa Smith (ed.), Nike is a Goddess: The History of Women in Sports (New York, 1998), ix-xix, p.xviii.

35 Hargreaves, Sporting Females, 163, 167.

36 See Nelson, The Stronger Women Get, 206; and Theberge, "Toward a Feminist Alternative to Sport as a Male Preserve," 181-192.

37 Mary Jo Kane and Susan L. Greendorfer, "The Media's Role in Accommodating and Resisting Stereotyped Images of Women in Sport," in Creedon (ed.), Women, Media, and Sport, 28-44, pp.31, 40.

38 See Crosset, Outsiders in the Clubhouse, 54. This is a very good book on the Ladies Professional Golf Association (LPGA). It examines women's professional golf against themes of gender, race, class stratification, sexism, conventional culture, and feminist politics. The LPGA, according to the author, was not an inconsequential social oddity or an isolated "bubble", but is instead pregnant with social relevance. Women's golf continues to operate within a minefield of contradictory images: women golfers as deviant women, countered with the equally damaging image of women golfers as male heterosexual fantasy girls or non- threatening feminine women. The LPGA's gender neutrality is enhanced by the tour's all-female work force. And for all their skill, the LPGA professional golfers remain outsiders within the golfing community. See in particular pages 27, 54, 107, 132, 133, 189, 218, and 225 of this book.

39 See introduction to Part IV, "Media, Sport and Gender," in Birrell and Cole (eds.), Women, Sport, and Culture, 246-248. See also Greta L. Cohen, "Media Portrayal of the Female Athlete," in Greta Cohen (ed.), Women in Sport: Issues and Controversies (Newbury Park, 1993), 171-184.

${ }^{40}$ Cahn, Coming on Strong, 268.
} 
applied to white, educated, middle class women and restricted their participation in sports, did not apply to black women or other minority groups. ${ }^{41}$ When black and white women went head to head in physical competition at a track meet or a basketball game, crowds gathered to watch an athletic battle that symbolized the larger possibility of a black challenge to white power. Usually in cooperation with male colleagues, black women educators geared their programs toward achieving two goals: improving the health of black students and communities in general, and training students to be athletic leaders in their communities. For example, beginning in the late 1930s, black women's entry into the sport of track and field largely abandoned by middle-class white women who deemed the sport unsuitable, began to blaze a remarkable trail of national and international excellence. African-American women not only participated in a variety of sports such as basketball, tennis, golf, swimming, and bowling, but also assumed wideranging leadership role in athletics. But their preeminent position in the sport had a double edge. On a personal level, success meant recognition and opportunities for education, travel and upward mobility. However, viewed through the lens of commonplace racial prejudices, African-American women's achievements in a 'mannish' sport also reinforced disparaging stereotypes of black women as less womanly or feminine than white women. Such racial parlance resulted in inferior resources, limited competitive opportunities, and media 'blackouts' for African-American women athletes. The double discriminatory burden of racism and sexism, and the myth that such women did not participate in sports because they were too poor, tired, or deprived, perniciously pervaded the representations of black female's physicality and athleticism. 42

Further, race as well as gender was a variable affecting the Olympic potential of women in countries such as Zimbabwe and South Africa. In Zimbabwe, there are still fewer black than white female athletes because sports have been part of the tradition of white culture. In South Africa, black South African women face a tremendous struggle to be represented in their country's elite sports squads. The majority of black South African

41 Linda D. Williams, "Sportswomen in Black and White: Sports History from an Afro-American Perspective," in Creedon (ed.), Women, Media, and Sport, 45-66, p.47.

42 Cahn, Coming on Strong, 41, 69, 112, 138, 139; Patricia Vertinsky and Gwendolyn Captain, "More Myth than History: American Culture and Representations of the Black Female's Athletic Ability," in Journal of Sports History, 25, 3 (Fall 1998), 532-561, p.552; and Linda D. Williams, "Before Althea and Wilma: African-American Women in Sport," in Kim Marie Vaz (ed.), Black Women in America (Thousand Oaks, Calif., 1994), 276-297. Regardless of what African-American men thought of female athletes at the personal and social levels, they seemed to recognize that the integration of national and international athletic competition for both males and females was an effective way of creating visibility and support of the larger agenda of the civil rights movement. See Cindy Gissendanner, "African-American Women and Competitive Sport, 1920-1960," in Birrell and Cole (eds.), Women, Sport, and Culture, 81-92. 
women suffer triple oppression on the basis of their class, color, and gender, and this inhibits their participation in various forms of leisure and recreation. Thus, in many African and Asian countries, the social position of women remains one of extreme subordination, and they bear the brunt of poverty and famine. When women are struggling to survive multiple pregnancies, when infant morality is excessively high, and when few women are educated and employed in the labor market, it is inappropriate to consider sports participation as a serious issue. 43

This examination of the intersections between race, gender and sport in western physical culture necessitates an evaluation of Polish women's sports in search for racist (especially anti-Semitic) or ethnic tensions as well. While Poland became more "homogenous" after the Second World War, the country was quite diverse in its ethnic composition prior to this time period. Thus, did popular norms limit sports to "Polish" women or did members of other ethnic groups and social classes enjoy equal opportunities to build a "united" Polish women's physical culture? If not, what were the constraints and limitations? And did the "fractured" women's sports apparatus cause larger political grievances for the minorities? More fundamentally, how did Poland's various "nationalist" struggles and "egoistic" attitudes interact with and impact women's physical culture?

Finally, the role religion in the construction of women's physical culture, both in the east and west, needs to be elaborated and explained. Understanding the forms of play and the religious life of a society furthers one's understanding of the values, motivations, and character of its people. 44 For example, family responsibilities, cultural values, and a lack of understanding and respect for Muslim women's views and needs in local leisure have all inhibited their involvement in physical culture. 45 Female sports are resisted in Muslim countries because they represent and reinforce radical and westernized ideas about women which threaten established gender values and relations. The first World Women's Islamic Games, dubbed the Muslim Women's Olympics held in Tehran in 1993, was an all-women affair involving competitors from 13 Asian and African Islamic nations in 8 Olympic sports. All events were held behind closed doors and audiences were all-female. 46 Even in western societies, the conservative and patriarchal Catholic

\footnotetext{
43 Hargreaves, Sporting Females, 232, 233; and Roberts, Against the Grain, 3.

44 Shirl Hoffman, Sport and Religion (Champaign, Ill.., 1992), vii.

45 Hasina Zaman, "Islam, Well-Being and Physical Activity: Perceptions of Muslim Young Women," in Gill Clarke and Barbara Humberstone (eds.), Researching Women and Sport (Houndmills, England, 1997), $50-67,61$.

46 Hargreaves, Sporting Females, 232. For some interesting examples on the relationship between religion, superstitions, and sport, especially in America see Hoffman, Sport and Religion, 1, 2, 6, 7, 137. Hoffman
} 
beliefs and traditions have undermined women's athletic interests and experiences. This intrusive involvement of religion in women's daily lives assumed alarming proportions in Poland, a traditional bastion of Roman Catholicism. Religion, mixed with "national" politics, eventually constrained the organization of Polish women's physical culture.

Thus, an analysis of western women in sport must address the interactions between sexism, racism, female physicality and male hegemonic control in the sporting apparatus. From this perspective, the complexities and contradictions of women's sports embody specific social, cultural, economic and political arrangements which intersect with such factors as class, age, ethnicity, and gender relations. At the same time, however, the fact that western women have always competed in sports across time is significant for it demonstrates their ability to resist and undermine this male hegemonic control in western physical cultures. Dedicated athletes, grounded in their own positive experience of sport and bolstered by its social rewards in high-level competition, accommodated their game with the stereotype of the mannish female athlete by their bold insistence on the right to play and their willingness to create and model expansive definitions of womanhood. Sports afforded them the opportunity to challenge and transform sexual stereotypes, gender inequality, and patriarchal control of women's sporting culture. Thus, women's physicality offered the space for potentially oppositional or transgressive practices which countered their role as the 'unwilling victims' and demonstrated their 'human similarity'. From this perspective, this study will examine whether female athletic sexuality in Poland also served as a discursive site for progressive body politics, explicitly challenging the passivity inscribed on 'women's bodies'. Was women's participation in sport in Poland an important source for their embodiment and empowerment? 47

gives the example of the 1978 American football season, when the Houston Oilers recruited a local minister to deliver the pregame talk and prayer for their match against the Pittsburgh Steelers. Following the Oilers' upset of the previously unbeaten Steelers, the minister's currency increased to the point that on the Oilers' return trip to Pittsburgh for the division play-offs, both teams vied for the minister's prayers. The minister opted to pray for the Steelers, who then won, extending his streak to 2-0! For the role of religion and superstitions in the "masculine" world of sport see also Jack McCallum, "Green Cars, Black Cats and Lady Luck" in Hoffman, Sport and Religion, 203. This article explains the tradition of throwing octopuses onto the ice at the Detroit Red Wing hockey games. It started in 1952, when a seafood merchant named Peter Cusmano tossed one out, reasoning that its eight tentacles would help the Wings achieve the eight victories they need to win the Stanley Cup. Sure enough, Detroit won, and its fans never forgot. It has also been contended that contemporary sport has all the trappings of formal religion. It has its gods (superstar athletes), its saints (those who have passed to the great beyond), its scribes (sports journalists and sportscasters, who disseminate the 'word' of sports deeds and glories, its houses of worship (stadiums), and masses of highly vocal 'true believers.' See Charles Prebish, Religion and Sport: The Meeting of Sacred and Profane (Westport, Conn., 1993), 79.

47 For all these issues see Cole, "Resisting the Canon," 5-29; Helen Lenskyj, "Female Sexuality and Women's Sport," in M. Ann Hall (ed.), "The Gendering of Sport, Leisure and Physical Education," A 
Thus, the purpose of this dissertation is to examine the participation of women in Polish physical culture and relate the images projected in their home-spun sporting culture to those that have been weaved in the secondary literature on western female athletes. This study of women's sporting experiences in Poland sheds new light on our understanding of the country's historical development, and also highlights the similarities and uniquenesses of Polish sportswomen in larger transnational contexts. More fundamentally, this dissertation reveals new insights into the various political, social, economic, and cultural patterns which were shaped as a consequence of the interactions between the Polish "nationalist" and "feminist" discourses on female physicality and sexuality in the arena of women's physical culture.

Chronologically, the study of Polish sports from its distaff side is discussed in seven chapters related to the histories of late partitioned, interwar, and communist Poland. The dissertation opens with an examination of Polish women's sports from the late nineteenth century until the outbreak of the First World War. During this period, Poland had disappeared from the map of Europe, and the country lay partitioned between the empires of Russia, Prussia, and Austria. Various strategies of resistance and accommodation included the romantic tradition of armed insurrection, "organic work", "triloyalism", and ultimately, modern mass political mobilization. The success or failure of these reactions and responses largely depended on the political structure and socioeconomic objectives of the individual partitioning power.

Accordingly, this first chapter of the dissertation examines the opportunities available, if any, in the three partitioned zones to create a women's physical culture in the context of imperial policies and an emerging modern civil society. The chapter focuses on the emergence of the "woman question" in partitioned Poland and elaborates the contentious issues related to the "women's movement" and the varied notions of women's sexuality and physicality. There is relatively recent literature which addresses the roles of women in the "nation", society, culture, politics, education, family life, and in the discourse on the 'emancipation' of Polish women. However, there is very little material explaining the place of women's sports in this 'woman question'. The chapter also identifies the place of women's sports in the larger sporting experiences of all the

Special Issue of Women's Studies International Forum, 10, 4 (1987), 381-386, p.381; Griffin, Strong Women, Deep Closets, 26; Helen J. Lenskyj, Women, Sport and Physical Activity: Selected Research Themes (Gloucester, Ont., 1994), 7; Willis, "Women and Sport in Ideology," 44; Hall, Feminism and Sporting Bodies; Hargreaves, Sporting Females, 24, 208; Nelson, The Stronger Women Get, 9; and Theberge, "Toward a Feminist Alternative to Sport as a Male Preserve," 191; Cahn, Coming on Strong, 208, 227, 231, 236, 237, 243, 245; and Nelson, "Introduction: Who We Might Become," ix, xi.. 
three partitioned zones. Overall, this chapter evaluates the creation of a "modern" women's physical culture in partitioned Poland. According to one scholar, the "small politics" of the emerging "modern" Polish civil society reflected pluralism and diversity. 48 Certainly, the impressive volume of "small politics" in its entirety suggests 'modernity'. Unfortunately, in its individual internal dynamics, the "small politics" shared much in common with the "elite politics" of partitioned Poland. And this appears to be true for the Polish women's sporting experience which was anything but pluralistic and diverse. Finally, this chapter will conclude with a brief insight into the role of Polish women's physical culture during the course of the First World War. At all times, the Polish female physical culture will be compared to the experiences of women athletes in other countries.

The next three chapters of the dissertation discuss the development of sports for Polish women in the interwar period. In November 1918 Poland regained its independence. The early years of reconstruction in the resurrected Polish state were soon followed by the breakdown of parliamentary government and the frequent recourse to authoritarian practices and policies. The place of women's sports in the larger political developments is the main subject of the second chapter of the dissertation. How did women's physical culture promote the state's ideologies and policies, and vice versa? The third chapter questions whether the experiences of sportswomen facilitated the interwar women's movement and promoted images of the 'New Woman'. Or were the multiple constraints in developing women's physical culture too overpowering so as to not only draw the boundaries of women's sport but also strengthen the 'strong hand' of patriarchy? The fourth chapter discusses the organizational developments in women's sports and investigates the theme of 'sport and gender' more closely. Once again, comparisons are made with sportswomen in other parts of the world.

The last three chapters of the dissertation examine the promotion of women's sports under communist rule in Poland. The secondary literature exploring the interaction of state and society for the communist period is still limited. Clearly, much work needs to be done to analyze the communist experience for the Poles. Such will be the objective of analyzing women's participation in the communist Polish physical culture. The development of women's sports in the context of 'socialist ideology' as elaborated in "Stalinist" Poland is explored in chapter five. The interrelations between the identities of women and the organization of sports under successive post-stalinist political regimes of

\footnotetext{
48 Robert Blobaum, "Modernization and Civil Society in Twentieth Century Poland". Paper delivered at the 29th National Convention of the American Association for the Advancement of Slavic Studies held in Seattle (November, 20-23, 1997).
} 
Wladyslaw Gomulka, Edward Gierek, Stanislaw Kania, and Wojciech Jaruzelski is the subject of examination in chapter six. The literature on the political ideologies characterizing "Stalinism", the "Polish road to socialism", "communism with a human face", and other "nationalist deviations" is vast. By comparison, the secondary source base for analyzing women's sports in this ideological context is limited. Finally, chapter seven discusses the interaction of the "official" images in the media and "real" experiences and identities of sportswomen in particular throughout the communist period. Once again, a global perspective is provided for purposes of comparison. In particular, the official images and actual experiences of Soviet sportswomen are used as examples.

The period of structural transformations after 1989 has adversely impacted the realm of physical culture. The commercialization and privatization of services, obsolete infrastructure and resistance to change, and economic tribulations have diminished the attention toward physical culture and sport. The contemporary literature is also replete with examples of the "feminization of poverty" and the infamous double burden for women. Thus, the conclusion of the dissertation discusses women's sport in the larger context of political and economic instabilities (and stabilities), women's issues, and the role of the Catholic Church in contemporary Poland. A special emphasis is also placed on identifying the main concerns of sportswomen globally.

This thematic and chronological approach to the study of women's physical culture in Poland provides a different perspective through which the twin themes of imperialism and nationalism have traditionally been examined. For this reason, such an interpretation of Polish sports is important not only for laying the foundations of a field of study largely ignored by scholars for eastern Europe, but for also presenting varied methods of examining themes of imperialism, nationalism, modernization, and "women's consciousness". Were Polish sportswomen the beneficiaries or losers in Poland's march toward "modernity"? Conversely, were the Polish civil and official societies any more "modern" and "emancipated" in their public and private perceptions of Polish sportswomen? Since women's participation in sport has been defined by the larger historical, political and national objectives of their countries, the ultimate goal of the dissertation is to encourage primary research into this rather neglected area of study on a global scale, drawing necessary correlations with the historical specificities of the various geographic regions. 


\section{Chapter One}

\section{The Development of Women's Physical Culture in Late Partitioned Poland}

This chapter examines the development of women's physical culture in Poland from the late 19th century until the outbreak of the First World War. During this time period, Poland lay partitioned between the empires of Russia, Prussia, and Austria. Polish women began to participate in sports in the annexed territories only toward the end of the 19th century. Several factors prohibited women's entry into sports prior to this period, especially the persistence of traditional ideas of femininity and womanhood, and the various foreign threats which excluded Polish women from the militarized male sporting culture. However, fortunately for the Polish women's physical culture specifically, and unfortunately for the Polish nation generally, the anachronistic economic, social, and administrative structure, and a degenerate "noble democracy" was forcing Poland into a state of anarchy. The licentious magnates remained weak and the powerless royalty, manipulated by the nobility's skewed rhetoric of equality, liberty and social solidarity, led the country into economic regression, wars, and destruction. For all its accomplishments, political instability, economic weakness, and foreign wars left Poland helpless before the rising power of the Germans to the west and the Russians to the east. Indeed, Poland was partitioned because of the ineptitude and class selfishness of the aristocracy and the gentry, both of whom were unable to see beyond their class interests to the national interest. 1

The partitions of Poland in 1772, 1793 and 1795, no doubt, inflicted great damage to the general development of pre-partitioned [male] Polish physical culture. But significantly, the partitions of Poland would also awaken "national interest" not only among the various social classes, but also among both men and women. The imposition of imperial policies forced the Polish society in the three zones to conceptualize frameworks for "national" resistance. The responses of the Poles to their triple political

\footnotetext{
${ }^{1}$ For a general historical background of Poland's territorial expansion and external threats in pre-partition times, as well as an analysis of the various reasons and debates explaining the causes of the partitions of Poland in 1772, 1793, and 1795 see Walicki, The Enlightenment, 7; Clifford R. Barnett, Poland: Its People, Its Society, Its Culture (New Haven, 1958), 7; Neal Ascherson, The Struggles for Poland (New York, 1987), 16, 17, 23; Zamoyski, The Polish Way, 4, 23, 59, 223, 230; various articles in Fedorowicz (ed.), A Republic of Nobles; Wandycz, The Lands of Partitioned Poland, 5, 7, 10; Jasienica, Jagiellonian Poland; Walicki, Poland Between East and West, 11, 12, 14, 15; Davies, God's Playground, Vol.1, 299, 371; Marian Balczewski, "Turcja a upadek Polski w XVIII wieku," in Jerzy Grobis (ed.), Oswieceni wobec rozbiorow Polski (Lodz, 1998), 263-282; Jerzy Lukowski, The Partitions of Poland, 1772, 1793, 1795 (London and New York, 1999), 5, 10, 14, 19, 25-27, 127; Jan Szczepanski, Polish Society (New York, 1970), 14, 15; and Richard Butterwick, Poland's Last King and English Culture: Stanislaw August Poniatowski, 1732-1798 (Oxford and New York, 1998), 315, 316.
} 
enslavement were varied and quite dependent on the nature of the political apparatus of the individual partitioning power. More generally, the responses ranged from foolhardy idealism to thoroughgoing realism, and included the romantic tradition of armed insurrection, 'organic work' which repudiated armed insurrection and directed efforts instead to cultural and economic endeavors for strengthening Polish national interests, the philosophy of 'triple loyalism' which emphasized that the best interests of the Polish nation could only be maintained by fostering harmonious relations between all three partitioning powers, and eventually to the birth of Polish socialist and nationalist political movements. Indeed, the 'national question' in partitioned Poland dominated intellectual culture, and initiated debates on the "modernization" of Poland. 2

It would be in these subsequent discussions on "nationalism" that Polish women will find the necessary space for laying the foundations of a real women's physical culture. Foreign rule created new possibilities for both men and women to participate in the largely clandestine physical culture and sports apparatus in the Polish Diaspora. For this reason, the development of Polish physical culture must be placed in the context of the emerging national consciousness marked by transformations in socio-economic conditions in a dismembered and partitioned country. Since sports and physical culture were part of Polish national aspirations, women's physical culture developed in response to this quest for national awakening. The abnormal political conditions in partitioned Poland, under reconnaissance of foreign powers, created sufficient space for women's sports to develop along with the other transformations in Polish social, economic and political cultures. The development of women's physical culture in partitioned Poland was thus related to the larger Polish goals of "modernization" and struggles for national liberation.

In addition, women's physical culture benefited from the presence of a male sporting culture and matured with the emergence of the "woman question" in late partitioned Poland. While the former provided the structural and organizational foundations for building women's physical culture, the latter provided the necessary theoretical and ideological formulations for constructing the apparatus of women's sports. This emerging discourse on women's roles in a modernizing society, economy,

2 For details see Adam Bromke, Poland: The Protracted Crisis (Oakville, Ontario, 1983), 1, 23; Davies, God's Playground, Vol.11, 33; Blejwas, Realism, 1; Zamoyski, The Polish Way, 308; Wandycz, The Lands, 101, 302, 303; Andrzej Walicki, The Three Traditions in Polish Patriotism and Their Contemporary Relevance (Bloomington, Indiana, 1988), 15, 16; Walicki, Poland Between East and West, 59, 60; Gaj and Hadzelek, Dzieje kultury fizycznej, 19; Waclaw Lednicki, Life and Culture of Poland (New York, 1944), 5; and Pawel Kudlorz, "Comparative Research in Regard to Physical Education in Poland," in Herbert Haag, Dietrich Kayser, Bruce L. Bennett (eds.), Comparative Physical Education and Sport, Vol.4 (Champaign, Ill., 1987), 83-89, p.83. 
and polity, as well as changing perceptions of women's sexuality and conceptualizations of patriarchal attitudes, challenged traditional epistemology on women's 'proper morality'. The early Polish women's movement had begun to articulate the necessity of questioning conservative patriarchal perceptions. But women's participation in physical culture became more visible with the first wave of Polish feminism in late partitioned Poland, which matured in response to pressures of industrialization and urbanization, and discussed women's "total" emancipation, including a departure from traditional conventions that held physical exercises harmful to the women's body.

Polish women's physical culture thus evolved under the combined forces of Polish nationalism and feminism in late partitioned Poland. Sports for women became more important only with the socio-economic transformations, scientific and pedagogical developments, appearance of the "woman question", and the larger struggle for national liberation in the latter half of the 19th century. Because the Polish women's movement emerged at a time period when Poland did not physically exist as a state, "national" priorities were juxtaposed with the newly reformulated women's identities, creating relationships of both accommodation and resistance between Polish nationalism and feminism in the realm of women's sports. Certainly, the interaction between Polish feminism and Polish nationalism was mutually irritating and not always supportive of each other. This friction became more visible in the first decade of the 20th century when Polish nationalism began to identify itself as an overwhelmingly Roman Catholic ethnolinguistic entity. ${ }^{3}$ Still, the concomitant processes of socio-economic modernization and politicization of the masses provided more substance to assist the formation of women's physical culture. The Polish women's physical culture evolved as a result of these processes of fusion and fission, both of which created the institutional space and initiated the dialogue about the importance of women's health and physical fitness, albeit for the good of "national health" than for women's personal enjoyment.

Thus, the purpose of this chapter is to examine how developments in Polish politics and sports, as well as the changing gender patterns and social identities, influenced the formation of women's physical culture in late partitioned Poland. The chapter examines how Polish sportswomen attempted to balance this tension between

\footnotetext{
${ }^{3}$ For this issue of Polish nationalism becoming more intolerant of other ethnic groups, and less pluralistic and diverse in its ideology see Walicki, Poland Between East and West, 59, 60; Andrzej Walicki, "Intellectual Elites and the Vicissitudes of 'Imagined Nation' in Poland," in Ronald Suny and Michael Kennedy (eds.), Intellectuals and the Articulation of the Nation (Ann Arbor, 1999), 259-287; and Robert Blobaum, "Modernization and Civil Society in Twentieth Century Poland," Paper delivered at the 29th National Convention of the American Association for the Advancement of Slavic Studies, held in Seattle (November 20-23, 1997).
} 
Polish nationalism and feminism in their efforts to build their physical culture in late partitioned Poland. The development of women's physical culture is explained in the context of late 19th century processes of modernization, urbanization, the emergence of the women's movement, and "national" resistance. The first section of the chapter explores the interaction between the imperial states and Polish sports to explain the "national" significance of the [male] physical culture for both men and women in the partitioned society. The second section places the development of women's physical culture in the context of the "woman question". While women's sports profited from the discussions on women's emancipation, the Polish women's movement, in turn, popularized its goals with the greater visibility of these "modern" sportswomen. The third section examines the suitability of some sports for women and the "inappropriateness" of other sports so as to provide a conclusion which explains women's limited success in building their physical culture in late partitioned Poland.

Finally, where appropriate, the experiences of Polish women is also compared with their counterparts in other western and Slavic societies. As western society matured, it underwent several "civilizing" changes, especially in the socio-cultural realm. Sports, too, became more "civilized". For western women, however, these transformations of "modernity" further bifurcated the dichotomous "public" and "private" spheres. These polarized domains of "naturally" sanctified and "societally" reinforced tasks for men and women played their own innings in the sports playground. More often than not, women achieved little to no success in their sporting endeavors. But significant numbers of others did manage to cross the boundary line of male hegemonic control in sport. Thus, the experiences of Polish sportswomen will be compared to western sportswomen to highlight the global scores of these "genderized" matches.

The principal question under investigation is how were Polish women able to build their sporting apparatus in cadence with the rather inpropitious circumstances. In particular, the development of women's physical culture is analyzed in the context of the policies of the imperial powers that sought to squelch all forms of Polish national resurgence, as well as the efforts of both Polish men and women to seize opportunities that allowed them to introduce important changes in their daily lives. Though Poland disappeared from the political map of Europe, the surreptitious masculine and feminine physical cultures merged with the movements of underground resistance to not only enable Poland to survive as a cultural entity, but ultimately to also serve as a veritable source of subalternism that undermined the tutelage of the partitioning powers. 


\section{Imperial States, Polish Sports}

The development of women's physical culture in late partitioned Poland was conditioned by imperial policies and the ability of the subjugated society to establish a sports culture, legally or in clandestine organizations. Polish women grafted their physical culture apparatus onto the established body of the largely masculine sports complex. Where opportunities permitted, they developed separate foundations. However, the status of Poland as a country divided between three imperial powers forced women to work alongside men in the various struggles for national liberation. This gender unity, which evolved in response to imperial control, operated in the realm of sports. Polish sportswomen 'played the game' in accordance with societal resistance to imperial rule. Thus, their sporting endeavors were not radical, and they judiciously used the male sporting apparatus to provide both quantity and quality to their physical culture. Since the presence of a male established and male dominated ideological, institutional, and organizational sports structure was critical to the formation of a women's physical culture, this part of the chapter will examine the expansion of [men's] physical culture in the Polish Diaspora.

In late partitioned Poland, the development of physical culture became integrally related to the awakening of Polish "cultural nationalism". The organization of sports societies and competitions, as well as press publications related to physical education and sports, directly challenged imperial authorities who were determined, in various degrees, to thwart all public expressions of Polish cultural identity. Thus, sports became a venue of Polish cultural resistance to the repressive policies of the powerful partitioning powers. Since cultural nationalism was, in turn, an essential component of the larger national resistance to imperial control, the organization of sports, by consequence, not only became politicized but also facilitated societal resistance to recover Polish independence and nationhood. Indeed, Polish physical culture, in its masculine and feminine forms, played a critical role in awakening national consciousness. For this reason, the purpose of this section is to understand the interaction between imperial states and Polish sports so as to place the development of Polish physical culture [male and female] in the three partitioned zones within the context of foreign imperialism and national resistance. This discussion of Polish sports, within the rubric of Polish nationalism, is important because women's physical culture was similarly influenced by "national" priorities and considerations. 


\section{Austrian Poland}

In Austrian Poland, the development of physical culture was facilitated by a more liberal political and cultural environment. At the same time, however, the region's overall weak economic growth and social evolution also constrained and undermined the proliferation of sports. In terms of chronology, Austrian attitudes toward developing physical culture in the Polish territories under its imperial control were decidedly negative between 1796-1809 and 1846-1859, slightly better between 1860-67, and more positive between 1868-1890. Thereafter, sports in Austrian Poland continued to expand, especially after the revolutionary upheaval of 1905. It was in the years between 19061914, under more active political participation from the Galician society, that the region witnessed a more popular blossoming of physical culture. In the last period, many more sports societies and competitions were organized. A number of infrastructural and organizational developments in sport aided this process throughout the latter half of the 19th and the beginning of the 20th centuries. 4

It is significant that during the first two decades of the twentieth century, Imperial Vienna itself became quite 'sportive' and developed all the features of a modern tourist culture. Indeed, Austria's great centers of entrepreneurial and cultural activity, cities like Budapest, Krakow, Prague, and Vienna became not beacons of decline, but dynamic places, full of creation, energy and speed. Tourism attracted domestic and foreign spectators, and became a useful vehicle for Habsburg myth-making, for presenting Franz Joseph as the father of the Habsburg 'family of nations'. 5

The first sports societies in Galicia emerged in the 1860s and 1870s. The more popular ones included the Lwowskie Towarzystwo Lyzwiarzy (Lwow Skating Society, 1869), the Krakowskie Towarzystwo Lyzwiarzy (Krakow Skating Society, 1870), the Krakowski i Lwowski Klub Cyklistow (Krakow and Lwow Cycling Club, 1886), Kluby Szermierzy in Lwow and Krakow (Fencing Clubs, 1891 and 1900 respectively), and the Krakowskie Towarzystwo Wioslarskie (Krakow Oaring Society, 1884). ${ }^{6}$ Major

\footnotetext{
4 Wasztyl, Wychowanie fizyczne $i$ sport, 200-204; and Hadzelek and Wroczynski, "Rozwoj wychowania fizycznego," 38, 39.

5 Jill Steward, 'Gruss aus Wien': Urban Tourism in Austria-Hungary before the First World War," in Malcolm Gee, Tim Kirk and Jill Steward (eds.), The City in Central Europe: Culture and Society from 1800 to the Present (Aldershot, England and Brookfield, VT, 1999), 123-145, p.136; and George V. Strong, Seedtime for Fascism: The Disintegration of Austrian Political Culture, 1867-1918 (Armonk, New York, 1998), 110.

6 For a detailed description of sports in Austrian Poland see Wasztyl, "Poczatki lekkiej atletyki w Galicji," 93-100; Gaj and Hadzelek, Dzieje kultury fizycznej, 73, 75, 84, 88; Dobieslaw Dudek, "Polskie organizacje paramilitarne na terenie Galicji w przedniu I wojny swiatowej wobec problemow kultury fizycznej," in
} 
universities and trade schools such as Jagiellonian University and University of Lwow also provided a suitable environment for the organization of sports for their students. During the 1905 revolution, the influx of students from the Kingdom of Poland into Galicia made the environment of educational institutions more radical, with emphasis on the intensification of social and political life. In this radicalized atmosphere, students willingly engaged in more penetrating social, cultural and political works, including sports and tourism so as to promote nationalist sentiments. ${ }^{7}$

In addition to student sports clubs, the workers also formed their own sports organizations and competitions in Austrian Poland. As such, the class of industrial workers was small and confined mainly to the major cities such as Lwow and Krakow. Still, under the inspiration of socialists from Russian Poland, Boleslaw Limanowski and Ludwik Warynski, the working class became more attracted to the socialist ideas circulating in Galicia. Working class sports provided sustenance to this emerging "Worker's Question" in Austrian Poland. 8

The organization of Polish physical culture and the development of nationalist struggle in Austrian Poland profited immensely from the patriotic and military traditions of scouting associations, Sokol (Falcon) nests and sharpshooters unions. The scouting organizations harbored political and military tendencies, and scouting became the favored method of military physical education after 1913.9 Meanwhile, the Sokol nests not only provided training in gymnastics, but also enhanced the cultural life of the region, fostered spirits of nationalism and patriotism, and eventually helped to create the cadre of a future

Sport na progu polski niepodleglej, 193-207, p. 203; Henryk Laskiewicz, Robotnicza kultura fizyczna w Polsce w latach 1918-1939 (Warsaw, 1971), 40; Zbigniew Schwarzer, "Towarzystwa i kluby wioslarskie na ziemiach Polskich w okresie zaborow jake osrodki zycia sportowego, spolecznego i narodowego," in Studia i Monografie AWF we Wroclawiu, 33 (1993), 19-48, pp. 20, 48; Hadzelek and Wroczynski, "Rozwoj wychowania fizycznego i sportu," 32, 36; Kus, "Stanislaw Barabasz," 30-31; Ster, 10 (25 April, 1896), 155; and Antoni Steuer, Sport na Gornym Slasku, 1896-1996 (Katowice, 1997), 11, 12.

${ }^{7}$ For the role of students and institutes of higher education in promoting sports in Austrian Poland see R. Wryk, "Poczatki sportu akademickiego w Polsce (1878-1908/09)," in Wychowanie Fizyczne i Sport, 26, 2 (1982), 81-96; Ryszard Wryk, "Akademicki Zwiazek Sportowy w latach dazen niepodleglosciowych," in Sport na progu polski niepodleglej, 223; Kazimierz Toporowicz, "Reforma systemu wychowania fizycznego w Galicji i jej znaczenie dla szkolnictwa w Polsce odrodzonej," in Sport na progu polski niepodleglej, 54-65, pp. 58, 63; and Wasztyl, Wychowanie fizyczne i sport, 194, 196.

8 For more details on the socialist movement in Galicia see Roman Wapinski, Historia polskiej mysli politycznej xix i xx wieku (Gdansk, 1997), 89, 90; John-Paul Himka, Socialism in Galicia: The Emergence of Polish Social Democracy and Ukrainian Radicalism, 1860-1890 (Cambridge, Mass., Harvard Ukrainian Research Institute, 1983), 4, 37, 71, 85, 86, 96, 104, 105, 170, 171, 173, 176-179; Kieniewicz, The Emancipation, 216; Wandycz, The Lands, 227; and Henryk Smarzynski, Dr. Henryk Jordan: Pionier nowoczesnego wychowania fizycznego w Polsce (Krakow, 1958), 32-35.

${ }^{9}$ Anna Zawadzka, Harcerstwo zenskie w Warszawie w latach 1911-1949 (Warsaw, 1995), 9, 10; Gaj and Hadzelek, Dzieje kultury fizycznej, 54; and Hadzelek and Wroczynski, "Rozwoj wychowania fizycznego," $31,34,35$. 
Polish army. ${ }^{10}$ From 1912 onward, however, the Galician youth became increasing disenchanted with the organization and ideology of the Sokol movement. The civil authorities of Galician Sokols failed to espouse strong anti-Russian sentiments. Moreover, the Sokol association failed to extend its membership to the rural inhabitants. Their failure to incorporate the countryside and refrain from tacit support of the Russians as war approached cost them the loyalty of the Galician youth. ${ }^{11}$

Disgusted with Sokol's moderate pro-Russian policies, the activities of the paramilitary organizations directed by Jozef Pilsudski became more attractive for the Galician youth. Taking advantage of the less restrictive political environment in Austrian Poland, Pilsudski came to Galicia in May 1901 and began training paramilitary units, notably the Riflemen's Unions which had sprung all over Galicia after 1905. ${ }^{12}$ The main core of members were students, either Austrian subjects or those from the Kingdom of Poland. It is to be noted that the Austrian army, in fear of an imminent war with Russia, supplied the Sharpshooters with rifles and ammunition. 13 The Sharpshooters Union itself considered an Austro-Russian war inevitable. ${ }^{14}$ The Austrian authorities appreciated the military value of the Polish paramilitary movement in Galicia in view of potential conflict with Russia, and Pilsudski eagerly exploited this opportunity by devoting all his energies to building up the nucleus of Polish armed forces for realizing the goal of Polish independence. ${ }^{15}$ For this reason, during the course of 1912-1913, the Sharpshooters intensified their military training by forming more teams. 16 Significantly, the Sokol organizations, traditionally associated with the National Democrats, now began to enter into closer relationship with the Union of Sharpshooters. 17 The National

10 Zolem ojczyznie, szponem wrogowi. Historia Sokolstwa Polskiego, 1867-1939, Wystawa CzerwiecListopad 1998 (Warsaw, 1998), no page numbers in this work; Kazimierz Toporowicz, "Geneza i poczatki sokolstwa polskiego, 1867-1892," in IV Krajowa Konferencja Naukowa Polonijna Kultura Fizyczna Rogi, 8-9 Stycznia 1988r. (Poznan, 1990), 5-15, p. 5; Liponski, "Still and Unknown," 12; and Gaj and Hadzelek, Dzieje kultury fizycznej, 48, 50, 51, 53, 66. Music in sport was very popular in the Lwow Sokol society. See Iwona Grys, Muzyka i sport (Warsaw, 1998), 97.

11 See Andrzej Garlicki, Jozef Pilsudski, 1867-1935, Edited and Translated by John Coutouvidis (Hants, 1995), 34, 35; Ascherson, The Struggles, 46; Dudek, "Polskie organizacje paramilitarne na terenie Galicji," 202; and Hadzelek, "Wychowanie fizyczne i sport na ziemach Polskich przed odzyskaniem niepodleglosci," 14.

12 Wapinski, Historia polskiej mysli politycznej, 131; and Dudek, "Polskie organizacje paramilitarne na terenie Galicji," 193, 198.

13 Archiwum Glowne Akt Dawnych, Pomocnik General-Gubernatora Warszawskiego (hereafter, AGAD Pom GGW) 370--Union of Active Struggle, 1912. Agent's Report of April 5 (18), 1912.

14 AGAD Pom GGW 396--PPS--Revolutionary Faction, 1913: Agent's Report of February 17, 1913 (o.s.).

15 Adam Bromke, Poland's Politics: Idealism vs Realism (Cambridge, Massachusetts, 1967), 23, 27.

16 AGAD Pom GGW 385: Compilation of Agent's Reports for December 1912; AGAD Pom GGW 390: Agent's Report of July 25, 1913 (o.s.); and Wapinski, Historia polskiej mysli politycznej, 133.

17 AGAD Pom GGW 396--PPS--Revolutionary Faction, 1913: Agent's report of January 29, 1913 (o.s.). 
Democrats also established their Polish Military Associations in Krakow and Lwow in 1908 and 1909, with the aim of preparing for a future European war by creating the nucleus of an officer corps, as well as to check and counter Pilsudski's sharpshooters. ${ }^{18}$ These Polish Rifle clubs and teams under the Polish Military Association no doubt influenced the Polish national movement.

Unfortunately, while the organization of physical culture in Austrian Poland contributed to the Polish nationalist struggle, its development for the purposes of expanding sports "for the sake of playing sports" was severely limited by the weak economic development of the region. Certainly, a number of sports publications and a few dedicated individuals did make the effort to patronize physical culture. For example, the founding of the Jordan Park in Krakow in 1889 and the Towarzystwo Zabaw Ruchowych in Lwow (Society of Games of Motion, 1905) under Dr. Henryk Jordan's patronage helped to popularize physical culture among all sections of society in Austrian Poland. Imitations of these playgrounds quickly surfaced in other parts of Poland. 19 Physical education theoretician Eugeniusz Piasecki also emphasized the importance of physical education and good hygiene to ward off illnesses, venereal diseases, and epidemics such as the scarlet fever epidemic that broke out in Lwow between 19071909. 20

At the same time, however, Galicia lacked a real middle class and the gentry remained more concerned with maintaining its own status and livelihood. The peasants grinded in their poverty, despite efforts by the rural activists to widen their "public sphere" and forge a "moral community" based on the universal values of brotherly love, religious piety, industriousness and personal enlightenment. This economic stagnation also heightened tensions between Poles, Ukrainians (Ruthenians), Jews, and other ethnic

\footnotetext{
18 Leslie (ed.), The History, 106-108.

19 Dr. Henryk Jordan (1842-1907) served as professor of medicine at Jagiellonian University. Jordan emphasized the importance of gymnastic exercises and games in natural surroundings not only for better health but also for the larger work of struggling for independence. For details see Smarzynski, Dr. Henryk Jordan, 10, 11, 72, 214, 240, 242; Gaj and Hadzelek, Dzieje kultury fizycznej, 59, 60; Grot, "Versuch eines Abrisses," 301; Ruch, 10/28 (26 May, 1907), 107-109; Dec, "Stanowisko medycyny wobec kultury fizycznej," 21, 28, 29; Toporowicz, "Reforma systemu wychowania fizycznego w Galicji," 56; and Hadzelek and Wroczynski, "Rozwoj wychowania fizycznego i sportu," 32, 33. For sports and hygiene related publications see also Gaj and Hadzelek, Dzieje kultury fizycznej, 44, 90, 96, 97; and Hadzelek and Wroczynski, "Rozwoj wychowania fizycznego i sportu," 28.

20 Born in 1872, Piasecki pioneered physical culture in Galicia, especially in Lwow. Piasecki also served as editor of Wychowanie fizyczne. For details see Kazimierz Toporowicz's, Eugeniusz Piasecki (1872-1947); zycie i dzielo (Warsaw-Krakow, 1988), 1, 22, 110, 147, 307; and Kazimierz Toporowciz, "Eugeniusz Piasecki i jego rola w rozwoju uniwersyteckiego ksztalcenia nauczycieli wychowania fizycznego $\mathrm{w}$ Polsce," in Nauki spoleczne a kultura fizyczna: Ogolnopolska Konferencja Naukowa, Poznan, dnia 3 Czerwca, 1988r. (Poznan, 1989), 45-61.
} 
and religious groups in Austrian Poland. Though politically, administratively, and culturally privileged, Galicia was economically poor, demographically overpopulated, and ethnically divided. 21

These economic and political factors deprived Polish physical culture in Austrian Poland of the much needed financial assistance and social engagement in sports. The absence of social unity and economic prosperity undermined the proliferation of sports in Austrian Poland. Physical culture remained largely compartmentalized along class and ethnic lines. The students and workers organized their separate sports associations, the aristocrats reveled in their elite clubs, and the Jews formed their own Jewish Sports Club, Zydowski Robotniczy KS Jugend in Krakow.

\section{Prussian Poland}

In Prussian Poland, sports among Poles became popular only after 1904. Prior to this period, the landowning and big magnate families from Prussia and Pomerania had traditionally belonged to the aristocratic German unions of hunting, horse-riding and shooting. 22 These German sports societies in Prussian Poland not only helped to raise their members' level of physical fitness, but also aided the process of germanization of the region. While the general reaction of Poles to these German sports societies was concealed hostility, there was one positive development. If nothing else, these organizational and methodological forms of German physical culture served as 'models' and as sources of inspiration for the later development of Polish physical culture in Prussian Poland. 23

21 For all these issues see Walicki, Poland Between East and West, 32-35; Wandycz, The Lands, 73, 223, 227, 269, 277; Kieniewicz, The Emancipation, 205, 214, 217, 220; Leslie (ed.), The History of Poland, 5, 8, 9, 10, 17; Davies, God's Playground, Vol. II, 143, 145, 155, 233; Smarzynski, Dr. Henryk Jordan, 26-29; and Alvin Marcus Fountain, Roman Dmowski: Party, Tactics, and Ideology, 1895-1907 (New York, 1980), 5. On Polish peasantry in Galicia see Keely Stauter-Halsted, "The Moral Community and Peasant Nationalism in Nineteenth-century Poland," in Judith Pallot (ed.), Transforming Peasants: Society, State and the Peasantry, 1861-1930. Selected Papers from the Fifth World Congress of Central and East European Studies, Warsaw, 1995 (New York, 1998), 73-89, p.86; Keely Stauter-Halsted, "Nationalism and the Public Sphere: The Limits of Rational Association in the Nineteenth-Century Polish Countryside," in Harvard Ukrainian Studies, 22 (1998), 555-568, p.557; and Keely Stauter-Halsted, "Patriotic Celebrations in Austrian Poland: The Kosciuszko Centennial and the Formation of Peasant Nationalism," in Austrian History Yearbook, 25 (1994), 79-95.

22 Jakubowsk, Wybrane zagadanie z historii kultury fizycznej, 212.

23 For a description about the German sports societies in Prussian Poland see T. Ziolkowska, "Niemiecki sport w Poznanskiem w okresie imperializmu (1890-1918)," in Wychowanie Fizyczne i Sport, 25, 1 (1981), 107-123, pp.111-114, 119, 122, 123. See also Steuer, Sport na Gornym Slasku, 13. 
In the interim, unfortunately, the development of an indigenous Polish physical culture in Prussian Poland was impeded by the lack of qualified teachers, inadequate halls and training equipment, limited financial resources, and a general lack of interest in sport. Moreover, Bismarck's anti-Polish policies in the 1870s, epitomized in the Kulturkampf, deprived the middle class of the opportunity to promote its self-confidence and pride in the sporting arena. 24

While Bismarck's Kulturkampf undermined the development of a Polish physical culture in Prussian Poland, all sports activities remained subject to strict surveillance even in the subsequent period of the "Era of Reconciliation". Prussian-Polish relations improved with the appointment of Leo von Caprivi as German Chancellor (1890-1894) who found it useful for domestic and international reasons to offer minor concessions to the Poles in return for their loyal cooperation and their votes in the Reichstag. However, the German nationalist opinion, Bismarckian holdovers, and traditional distrust of the Polish nobles made concessions under Caprivi government limited. 25

The imperial government did make the effort to make the region "livable" for ethnic Germans in the later half of the 1890s. For this reason, the government launched a crash program to "uplift" the material and cultural resources of the city of Poznan. For this purpose again, some attention was devoted to raising the health and hygiene standards of the city, which in turn contributed to the making of the Polish physical culture in Poznan. 26 However, Polish physical culture in Prussian Poland evolved only when societal support for loyalism began to wane in favor of more organized political and 'national' resistance. The most visible sign of societal resistance came in the form of the school strikes between 1901-1907 throughout Poznania as parents kept their children out of school rather than have them taught religion in German. While the strikes themselves were a failure to the extent that new measures of 1908 worsened the situation of the Polish-speaking population of Prussia, the strikes were still successful for they

\footnotetext{
24 See Seweryn Warsicki, Kultura fizyczne w Wielkopolsce w latach 1919-1927 (Poznan, 1966), 22, 26, 27, 29; Gaj and Hadzelek, Dzieje kultury fizycznej, 26, 47, 71, 82; and Ziolkowska, Kultura fizyczna w Poznaniu, 43, 45, 191. For Bismarck's Kulturkampf, see William W. Hagen, Germans, Poles and Jews: The Nationality Conflict in the Prussian East, 1772-1914 (Chicago, 1980), 118-158; Trzeciakowski, The Kulturkampf, 114, 116, 118, 132, 136, 139-146, 156, 158-162, 185, 188; Blanke, Prussian Poland, 6, 2532, 106; and Wandycz, The Lands, 94, 234, 235.

25 For developments in Prussian Poland at the turn of the century see Hagen, Germans, Poles and Jews, 169-180; Blanke, Prussian Poland, 121, 133, 147, 150, 151, 167, 177, 180, 194-202, 212; and Zamoyski, The Polish Way, 282, 284, 285, 304.

26 For developments in Poznan city see Wandycz, The Lands, 15; and Ziolkowska, Kultura fizyczna, 17-25.
} 
promoted Polish national consciousness and the enhanced visibility of social, cultural and political activities, including and especially sports. 27

Many sports clubs emerged between 1910-1914, all of which aimed at maintaining 'Polishness'. Those which were ethnically Polish came under the influence of the National Democrats. The Polish scouts in Poznan especially played an important role in conducting physical education and conspiratorial military preparation in Prussian Poland. 28 The Sokol gymnastic associations were also invigorated after the school strikes, and their various branches throughout Prussian Poland promoted a national spirit among Poles and stimulated Polish organizational life in sports. ${ }^{29}$ Finally, the Jews in Prussian Poland formed their own gymnastic societies which not only promoted physical development, but also cultivated Jewish national consciousness against rising antiSemitism. In 1908, the Jewish Gymnastics Association "Makkabi” was formed with its main seat in Bielsko. 30

27 For the gradual politicization of the masses see Zamoyski, The Polish Way, 302, 303; Wandycz, The Lands, 93, 129, 130, 263, 286, 326; Blanke, Prussian Poland, 151, 202, 216, 229, 231, 232; John J. Kulczycki, School Strikes in Prussian Poland, 1901-1907: The Struggle Over Bilingual Education (New York, 1981), 208, 209, 215, 218; Fountain, Roman Dmowski, 5; Leslie (ed.), The History of Poland, 35; and Ziolkowska, Kultura fizyczna w Poznaniu, 21, 22.

28 For sports in Prussian Poland see Marian Krawczyk, "Elementy historii wychowania fizycznego," in Ludwik Denisiuk, Kazimierz Fidelus and Marian Krawczyk, Elementy teorii $i$ historii wychowania fizycznego (Warsaw, 1969), 181-226, p.209; Liponski, "Still and Unknown," 11; Warsicki, Kultura fizyczna, 17, 18, 19, 21, 23, 24, 28, 31; Schwarzer, "Towarzystwa i kluby wioslarskie na ziemiach Polskich w okresie zaborow," 48; Ziolkowska, Kultura fizyczna w Poznaniu, 43, 45, 48, 88, 89, 146, 153, 159, 160, 182-185, 194, 198, 202; Miroslaw Ponczek, Geneza i rozwoj kultury fizycznej na Gornym Slasku 18951945, Zarys Problematyki (Katowice, 1989), 4; Gaj and Hadzelek, Dzieje kultury fizycznej, 82, 83, 84; Steuer, Sport na Gornym Slasku, 11, 12, 13; and Zdzislaw Grot, "Katedra i studium wychowania fizycznego na Uniwersytecie Poznanskim w latach 1919-1945," in Gaj (ed.), Dzieje Akademii Wychowania Fizycznego, 12-83, pp. 17, 18, 19, 20, 21, 33, 34. For the Polish scouts in Poznan see Ziolkowska, Kultura fizyczna w Poznaniu, 191-195.

29 For details of Sokol in Prussian Poland see Grot, "Versuch eines Abrisses," 300; Grot, "Katedra i studium wychowania fizycznego," 16; Warsicki, Kultura fizyczna, 20, 21, 31; Gaj and Hadzelek, Dzieje kultury fizycznej, 51, 83; Ziolkowska, Kultura fizyczna w Poznaniu, 180, 196; Hadzelek and Wroczynski, "Rozwoj wychowania fizycznego i sportu," 50; Jakubowsk, Wybrane zagadanie, 212; Grys, Muzyka i sport, 109; Jerzy Gaj, "Wychowanie fizyczne i sport na ziemi Gdanskiej przed i po I Wojnie Swiatowej," in Sport na progu polski niepodleglej, 109-130, pp. 111-113; Blanke, Prussian Poland, 196; Steuer, Sport na Gornym Slasku, 7, 8; Kulczycki, School Strikes in Prussian Poland, 204; Liponski, "Still and Unknown," 13; Henryk Rechowicz, "Wychowanie fizyczne i sport na terenie Gornego Slaska i Slaska Cieszyskiego przed i po odzyskaniu niepodleglosci" in Sport na progu polski niepodleglej, 66-93, pp. 66, 67, 68, 69, 70; Zolem ojczyznie, szponem wrogowi, no page numbers in this work; and Edward Jozef Kus, "Sokol Polski we Wroclawiu--Jego dorobek w walce o zachowanie polskosci w latach 1894-1920," in Sport na progu polski niepodleglej, 156-185, pp.157, 158, 161, 169-173.

30 See Warsicki, Kultura fizyczna, 24, 31; Ziolkowska, Kultura fizyczna w Poznaniu, 184, 194, 198, 202; Gaj and Hadzelek, Dzieje kultury fizycznej, 84; Teresa Ziolkowska, "A Contribution to the History of Jewish Sport and Physical Education in Poland: The City of Poznan, 1904-1939," in J. A. Mangan (ed.), Sport in Europe: Politics, Class, Gender (London, 1999), 54-62, 55, 57, 58, 59; and Steuer, Sport na Gornym Slask, 10, 13. 


\section{Russian Poland}

In Russian Poland, the development of sports was related to the transformations in the political and economic conditions of the region. Until 1905, sports and physical education lacked a mass character because of problems in the political environment, a general lack of understanding of the benefits of physical exercise, as well as inadequacies in the financial, organizational, and institutional facilities. 31 The tsarist practices of cultural russification and administrative repression imposed stifling imperial controls over daily life in Russian Poland, especially after the January Insurrection of 1863.32 From the 1880's in particular, the Kingdom was subject to intense 'denationalization' by which the Russian bureaucracy strove to divest the Poles of their national character. 33

During the epoch of Positivism (1864-1890s), the apolitical reformism of liberal intellectuals did not modernize the region's economy to the extent necessary for a social differentiation in wealth which would have been a prerequisite for building a popular physical culture in the Kingdom. 34 Positivism's emphasis on education certainly resulted in a tidal wave of self-education programs in private, informal, and underground Polish cultural and educational enterprises. However, prior to 1905, there was little discussion of the importance of physical education in such educational endeavors. The combined pressures of political realities and economic weaknesses deprived Russian Poland of the much needed social stability which would have created the interest and means to support sports and physical education.

But the Poles in Russian Poland could not blame themselves alone for their limited knowledge on the benefits of physical education and sports. The Tsarist regime itself was not particularly sport-minded. Russian imperial bureaucrats feared that laborers

31 Jakubowski, Wybrane zagadanie, 221, 224; and Hadzelek and Wroczynski, "Rozwoj wychowania fizycznego i sportu," 39-40.

32 Leslie (ed.), The History of Poland, 38, 39.

33 Robert E. Blobaum, Rewolucja: Russian-Poland, 1904-1907 (Ithaca, 1995), 3, 4, 6. For a detailed account of "de-Polonization” see Witold Rodkiewicz, Russian Nationality Policy in the Western Provinces of the Empire, 1893-1905 (Lublin, 1998).

34 For a detailed discussion on 'Warsaw Positivism' see Walicki, Poland Between East and West, 28-31; Blobaum, Rewolucja, 29-32; Wandycz, The Lands, 208; Blejwas, Realism, 96-107, 192-194; Wapinski, Historia polskiej mysli politycznej, 81; Fountain, Roman Dmowski, 4, 6; Walicki, The Three Traditions in Polish Patriotism, 23; Jerzy Jedlicki, A Suburb of Europe: Nineteenth Century Polish Approaches to Western Civilization (Budapest, 1999), 179, 280, 287; Theodore R. Weeks, Nation and State in Late Imperial Russia: Nationalism and Russification on the Western Frontier, 1863-1914 (DeKalb, 1996), 108, 112; and Brian Porter, When Nationalism Began to Hate: Imagining Modern Politics in Nineteenth-Century Poland (New York and Oxford, 2000), 44, 50, 56, 57. 
would use sports to mask gatherings for revolutionary purposes, and until 1914, they repeatedly rejected attempts by workers to establish their own sport clubs. Hence, all sports groups, like any organization in Tsarist Russia, had to be formally chartered by the Ministry of Interior. 35

Despite the lack of support from Tsarist authorities, Moscow boasted of several automobile, bicycle, and aviation clubs, as well as many other organizations and leagues promoting sports and physical education by the eve of the Great War. 36 Members of Russia's burgeoning bourgeoisie and liberal noblemen were the main patrons and practitioners of sports. 37 Such institutional structures outside the autocratic power tended to be fragile; however, sports societies and other voluntary organizations, in their attempts to develop the Russian obshchestvennost ('educated society'), became competing loci of power to the Tsarist autocracy. 38

Similarly, sports in Russian Poland were initially organized by the men of wealth. Before the 1904-1905 revolution in Russia, Warsaw emerged as an important socioeconomic and sports center in the Polish Kingdom. The city had a rich urban life with wealthy classes that provided a profitable environment for financing sports. Indeed, the Warsaw sports societies, in their early years of formation, were quite elitist and patronized exclusively by families of the industrialists, intelligentsia, traders, and merchants. ${ }^{39}$ This urban interest in sports and recreation found expression in three main sports societies: the Warsaw Association of Cyclists (Warzawski Towarzystwo Cyklistow, WTC) formed in 1878, the Warsaw Rowing Association (Warszawski Towarzystwo Wioslarskie, WTW) organized in the same year, and the Warsaw Skating Society (Warszawski Towarzystwo Lyzwiarskie, WTL) established in 1893.40

\footnotetext{
35 Riordan, Sport in Soviet Society, 44, 45.

36 Joseph Bradley, "Voluntary Associations, Civic Culture, and Obshchestvennost in Moscow," in Edith W. Clowes, Samuel D. Kassow, and James L. West (eds.), Between Tsar and People, Educated Society and the Quest for Public Identity in Late Imperial Russia (Princeton, New Jersey, 1991), 131-148; and Robert Edelman, Serious Fun: A History of Spectator Sports in the USSR (New York, 1993), 28-31. See also Catriona Kelly and David Shepherd (eds.), Constructing Russian Culture in the Age of Revolution: 18811940 (Oxford and New York, 1998), 74, 75, 77, 78.

${ }^{37}$ Riordan, Sport in Soviet Society, 44, 45.

38 For a discussion on civil society in Imperial Russia and the idea of Obshchestvennost see Alfred J. Rieber, "The Sedimentary Society," in Clowes, Kassow, and West (eds.), Between Tsar and People, 343366, p.343; Bradley, "Voluntary Associations," 147, 148; and the Introduction in Clowes, Kassow, and West (eds.), Between Tsar and People, 3. For a discussion on Russian civil society and private charitable and voluntary associations see Adele Lindenmeyr, Poverty is Not a Vice: Charity, Society, and the State in Imperial Russia (Princeton, 1996)

39 Gaj and Hadzelek, Dzieje kultury fizycznej, 75, 76; and Hadzelek and Wroczynski, "Rozwoj wychowania fizycznego i sportu," 46.

40 Liponski, "Still and Unknown," 15. For a good background history on WTL, see Sport, 50 (29 November/ 12 December, 1903), 1-3. For details on WTW see Kobieta i Zycie, (hereafter, KiZ) 32 (6
} 
The development of physical culture, in both theory and practice, became more popular at the turn of the century and for two main reasons. First, the political mobilization of the masses under the guidance of newly emerging political parties provided more inter and intra class communication and mobility in society. The emerging nationalist and socialist political organizations awakened social consciousness and preached national solidarity, albeit in varying degrees and using different methodologies. While the new political elites were not necessarily anymore "pluralistic" than their positivist predecessors, their discussions on Polish nationalism nonetheless reinvigorated society, not only in political terms, but also by their increased participation in a variety of legal and illegal activities, including and especially sports and physical culture. Both the exclusionary, masculine, authoritarian nationalism of National Democracy and the open, revolutionary nationalism of the Polish Socialist Party were different styles of 'national imagining' and were responses to the socioeconomic transformations and to the cultural pressures of russification. 41 The fact that Polish physical culture in Russian Poland matured in the context of this mass political mobilization would suggest that sports became an important avenue for the emerging "nation" to articulate its nationalist, socialist, Catholic, and populist forms of political expression.

Second, while the nationalist and socialist political parties lurched the Polish society in Russian Poland on to the path of 'sports nationalism', the Russian defeat in the Russo-Japanese War of 1904-1905 and subsequent domestic revolutionary upheavals provided the institutional and organizational impetus to develop a popular Polish physical culture movement in this partitioned zone. The post-revolutionary political environment witnessed an explosion of different professional, intellectual, economic, and cultural societies and associations, all of which contributed to national resistance and the

August, 1978), 15; and "Sto lat warszawskiego sportu, 1878-1978," in Sport Wyczynowy, 2/170 (1979), 45-60, pp. 45-47. Also, the entire issue of Sport, 34 (4/17 August, 1902) is devoted to the history, organization, and various activities of WTW.

${ }^{41}$ For the nationalist, socialist, catholic movements see Blobaum, Rewolucja, 9, 33-35, 38, 40, 190, 192, 198; Wandycz, The Lands, 210-213; Porter, When Nationalism Began to Hate, 195, 236, 237, 238; Wapinski, Historia polskiej mysli politycznej, 69, 87, 88, 90, 91, 98, 101, 110, 136, 137; Blejwas, Realism, 179, 181, 184; Leslie (ed.), The History, 49-60, 72; Davies, God's Playground, Vol. II, 52-53, 57, 65, 541, 542; Walicki, Poland Between East and West, 38, 44, 45, 52, 55; Roman Wapinski, Narodowa demokracja 1893-1939:Ze studiow nad dziejami mysli nacjonalistycznej (Wroclaw, 1980), 4, 59, 76, 326, 328, 329; Fountain, Roman Dmowski, 99, 100, 161, 162, 163; Walicki, The Three Traditions, 23, 24; Robert Blobaum, Feliks Dzierzynski and the SDKPiL: A Study of the Origins of Polish Communism (New York, 1984), 14-17, 59, 224; Wandycz, The Lands, 211, 296-300; and Joanna Kurczewska, "Moralnosc, polityka i narod w pogladach Boleslawa Limanowskiego i Zygmunta Balickiego," in Janusz Gockowski and Andrzej Walicki (eds.), Idee i koncepcje narodu w polskiej mysli politycznej czasow porozbiorowych (Warsaw, 1977), 267-286. For a more detailed description of the Union of Polish Socialists abroad see Timothy Snyder, Nationalism, Marxism, and Modern Central Europe: A Biography of Kazimierz KellesKrauz, 1872-1905 (Cambridge, Mass., 1997). 
contentious discourse of defining the race, class, and gender boundaries of "modern Polish nationhood". 42 It is in this background of an emerging civil society that sports and physical education gained popularity. The 'mass nation' not only became more 'enlightened' and politically conscious, but also more 'sportive' and 'healthy'!

Once again, Warsaw spearheaded the physical culture movement at the turn of the century. This urban and cosmopolitan city of Warsaw, with many different national and ethnic groups, remained the principal center for many patriotic and revolutionary activities, including sports and physical education. The organization of various sportsrelated societies and associations, press publications, works of health-conscious pedagogues, and exhibitions and symposia all became symbols of polskosc or "Polishness". 43

While Warsaw served as the principal center of sports and physical culture in Russian Poland, significant developments also took place in other parts of the Polish Kingdom which contributed to the evolution of Polish physical culture. For example, in Lodz, all sports societies espoused ideas that not only promoted physical education but also aroused national and patriotic sentiments for the larger struggle for independence. 44

\footnotetext{
42 The Polish civil society displayed a remarkable capacity for revival and expansion between 1911 and 1914. See Blobaum, Rewolucja, 113, 186, 226, 233, 288, 289, 291.

43 For a discussion on Warsaw city see Stephen D. Corrsin, Warsaw Before the First World War: Poles and Jews in the Third City of the Russian Empire, 1880-1914 (New York, 1989), 40, 68-70, 104, 106-108; and Edward D. Wynot, Warsaw Between the World Wars: Profile of the Capital City in a Developing Land, 1918-1939 (New York, 1983), 30-35, 114. For a discussion on the organization of sports circles and organizations in Warsaw see "Sto lat warszawskiego sportu, 1878-1978," 47; Grys, Muzyka i sport, 95, 111, 112, 116, 117; Hadzelek, "Wychowanie fizyczne i sport," 19; Hadzelek and Wroczynski, "Rozwoj wychowania fizycznego i sportu," 46, 61; Gaj and Hadzelek, Dzieje kultury fizycznej, 45, 46, 61, 77-79, 95; Leonard Nowak, Wystawa sportowo-przemyslowa w Warszawie w 1912 (Praca Magisterska, AWF, Warsaw, 1975), 1; Ryfowa, "Polska kultura fizyczna," 201, 211; Liponski, "Still and Unknown," 15; Tuszynski, Prasa i sport, 1881-1981, 83; Szymanski, Higiena i wychowanie fizyczne, 74, 126, 128, 151, 158, 164-168, 173, 182, 198, 199, 225, 226, 249, 265, 303; and Grot, "Versuch eines Abrisses," 297, 298, 301; Warsicki, Kultura fizyczna, 25; Liponski, Dzieje sportu polskiego, 14, 15; Ruch, 7/25 (11 April, 1907), 70-73; Maciej Demel, Pedagogiczne aspekty warszawskiego ruchu higienicznego, 1864-1914 (WroclawWarsaw-Krakow, 1964), 33, 52, 219; Jakubowsk, Wybrane zagadanie, 222, 226; K. Wybraniec, "Problematyka sportu szkolnego na lamach "Wychowania Fizycznego" i "Wychowania Fizycznego w Szkole" w latach 1927-1939," Wychowanie Fizyczne i Sport, 21, 2 (1977), 97-110, p. 97; H. Laskiewicz, "Adam Chetnik o kulturze fizycznej wsi polskiej, Cz. I," Wychowanie Fizyczne i Sport, 23, 1 (1979), 31 56; and H. Laskiewicz, "Kultura fizyczna wsi polskiej w pogladach Adama Chetnika, Cz. II," in Wychowanie Fizyczne i Sport, 23, 2 (1979), 77-91. See also Archiwum Glowne Akt Dawnych Kanceleria General-Gubernatora Warszawskiego (hereafter, AGAD KGGW), 7430; Archiwum Panstwowe m. st, Warszawy i Wojewodstwa Warszawskiego Zarzad Oberpolicmajstra Warszawskiego (hereafter, APW ZOW), 432; AGAD KGGW 7395; AGAD KGGW 7843; Archiwum Panstwowe m. st. Warszawy i Wojewodztwa Warszawskiego, Warszawski Gubernialny Urzad do Spraw Stowarzyszen (hereafter, APW WGU) 861; and APW ZOW 422.

44 Andrzej Bogusz, "Sport w Lodzi w pierwszych latach niepodleglosci," in Sport na progu polski niepodleglej, 186-192, p.187. For references to the Lodz Soccer Club Victoria, the Lodz Physical Fitness
} 
In Lublin, the Lubelskie Towarszytwo Cyklistow (Lublin Cycling Society, LTC) and Sokol contributed to popularizing physical culture as a medium of social integration. 45 Physical culture in the Dabrowa Basin played a special role in the evolution of "proletarian sport". Physical culture in the region was also promoted by voluntary firemen's societies and after 1910 by many conspiratorial paramilitary groups in union with riflemen's organizations. 46 There are also references in the years 1908 and 1909 to the Pabianice Gymnastics Society, the Pabianice Sporting Association, the Pabianice Association of Bicyclists, the Hiking Circle in Piotrkow province, the Gymnastics Club in Baluty and to the German Radogoszcz Gymnastics Society in Piotrkow province. 47 Further, oaring societies in Russian Poland also surfaced in several other places such as Plock (1884), Wloclawek (1886), Czestochowa (1893), Kalisz (1894), Konin (1900), Lomza (1902), and Wilno (1909). 48 While all sporting activities in Russian Poland were automatically subject to official surveillance, the activities of the Sokol nests, scouting groups, and riflemen's organizations particularly disturbed the Russian imperial authorities. $^{49}$

Thus, the political and economic conditions in all three partitioned zones fostered the growth of strong expressions of nationalism and patriotism in the sporting arena. The years between 1905 and 1914, in particular, witnessed an intensified patriotic movement among members of all sport organizations. Sports clubs and societies were important for conducting educational, cultural, patriotic, and socio-political activities, all with the objective of fostering national consciousness. While most Polish sports associations in the 19th century were organized by and for the landowners and the middle class, they became less segregated and more democratic at the beginning of the 20th century. Such organizational and infrastructural developments were also paralleled by the birth of a new

Society, the Lodz Sports Society, and the Society of Sporting Enthusiasts in Lodz, see AGAD KGGW 7864.

45 Marek Skawinski, "Lubelskie Towarzystwo Cyklistow (1893-1914)," in Wychowanie fizyczne i sport, 27, 1 (1983), 97-105; and Marek Skawinski, Kultura fizyczna na Lubelszczyznie w latach 1944-1974 (Warsaw, 1989), 11-13.

46 Miroslaw Ponczek, "Sport i wychowanie fizyczne w Zaglebiu Dabrowskim przed i po odzyskaniu niepodleglosci," in Sport na progu polski niepodleglej, 94-108, p.94; Ponczek, Z przeszlosci ruchu sportowego, 6-11, 17, 20; Jan Walczak, "Kultura fizyczna w ruchu robotniczym na Gornym Slasku, w Cieszynskiem i Zaglebiu Dabrowskim do 1939," in Rechowicz (ed.), Z dziejow kultury fizycznej, 33-54, p. 33; and Ponczek, "Kultura fizyczna w Zaglebiu Dabrowskim," 73, 75, 77, 78.

47 See AGAD KGGW 7864; and AGAD KGGW 7445.

48 Schwarzer, "Towarzystwa i kluby wioslarskie," 48.

49 See for example AGAD Pom GGW 377, Compilations of Agent's Reports for April, 1912 (Compilation of Agent's Reports on Union of Polish Student Youth in Warsaw); APW ZOW 435; and Archiwum Glowne Akt Dawnych Prokurator Warszawskiej Izby Sadowej (hereafter, AGAD PWIS), 8007. 
mass sports cultural media. This is evident from several periodicals devoted to different sporting matters and the participation of representatives from the Polish Kingdom, Galicia and Great Poland in international and domestic conferences on physical education and sports. Indeed, the intellectual and institutional activities of pedagogues, hygienists and physical educators were instrumental in promoting physical culture in late partitioned Poland, more so in Russian Poland than Austrian Poland, and least in Prussian Poland.

With the intellectual and ideological support of the various health advocates and their publications, as well as the financial support of the wealthy urban elite, many sports societies, unions, and clubs were formed, all of which contributed to the development of the Polish sports organizational apparatus. The riflemen's unions, scouting organizations and Sokols, under strict surveillance of the partitioning powers, assumed the main task of building social solidarity. The physical education and military preparation program of such organizations and unions, more than often clandestine, attracted Poles of various age groups and social classes. They actively sponsored ideas of national independence, patriotic education, and an intensification of work in military style physical education, especially in the years 1910-1914. In addition, the Sokols and riflemen's associations were targeted for indoctrination in socialist and nationalist ideologies. 50

The presence of this sporting culture in the three partitioned zones facilitated the development of women's physical culture. The value of sport as a significant cultural tool of "national" politics helped women to become part of the sports resistance movement. Women were perceived as co-resisters to imperial subjugation in the sports arena, and not necessarily as challengers to male hegemony in the heretofore masculine sports culture. For this reason, women were included in the "words" of sports pedagogues and hygienists, and in the "actions" of male sports societies and institutions. At all times, the [male] sporting culture was more 'sportive' and 'nationalistic' in Russian Poland, followed by Austrian Poland and then Prussian Poland. For this reason, women's physical culture was best organized in Russian Poland, and less so in the other partitioned zones. However, while the male physical culture accommodated women's fledging

\footnotetext{
50 All these issues have been discussed in several sources. See for example, Sport, 1 (18/30 November, 1888); Sport, 5 (3/15 June, 1889); Sport, 2 (19/31 December, 1888), 23; "Humanistyczne wartosci w dziejach wychowanie fizycznie i sportu w Polsce," 344; Andrzej Wohl, Spoleczno-historyczne podloze sportu (Warsaw, 1961), 63; Zbigniew Urbanyi, Zarys historii sportu Bydgoskiego 1886-1975 (Bydgoszcz, 1980), 3; Kalendarium XX wieku: fakty, dokumenty, opinie, Zeszyt 3, 1908-1911 (Wydawnictwo: "Albatros" S.C., Polska), 11; Toporowicz, "Geneza i poczatki sokolstwa polskiego," 13; Maria Rotkiewicz, "Sport kobiet w progu niepodleglej Polski," in Sport na progu Polski niepodleglej, 267-279, p. 269; and Sztandary sportu polskiego (Warsaw, 1996), 100. Also, the periodical Ruch contains many articles on gymnastics, Sokol, reports from various societies, sports and gymnastics news from abroad, physical education in schools, and pedagogical and medical developments.
} 
interest in sports, the female physical culture apparatus became more visible only after women themselves became more self-conscious of the need to improve their physical health and hygiene. But this process of women's "self-awakening", while assisted by the politicization of men's physical culture, was made possible only by the emergence of the "woman question" in late partitioned Poland.

\section{The "Woman Question" and the Development of Women's Physical Culture in Late Partitioned Poland}

The development of Polish women's physical culture was influenced by discussions on women's health and hygiene in late partitioned Poland. This discourse on issues related to women's physical and personal development was part of the larger "woman question" which debated the "modern" perceptions and aspirations of women's roles and needs at the turn of the century. During this time period, the traditional images of Polish women were in the process of being transformed by their increased participation in economic, intellectual, political, and 'national' work. The ongoing processes of industrialization and urbanization provided women with various opportunities to explore their talents, voluntarily or involuntarily. For this reason, these modernizing transformations impacted women differently. For some, the transition to modernity was enriching and rewarding; for others it brought more hardships and distress. In both cases, women effectively challenged conventional patriarchy.

Significantly, these "modern" identities of women also raised questions related to their "duties" in society and in the "nation", their family obligations, their "morality" and "sexuality", and for the purpose of this dissertation, their physical health and personal hygiene. Since women's sports became more visible in the midst of these overpowering economic transitions which not only changed the urban and rural environments, but also challenged conservative conceptualizations of gender relations, this section will discuss the popularity of women's physical culture in the context of women's "modern" images and the Polish women's movement which debated the construction of women's identities from these transformed images. At the same time, it must also be emphasized that women's participation in sport, in turn, provided more substance for the continued discussions on the "woman question". Ultimately, however, the discussions on the tensions between the "old-fashioned" and "re-fashioned" imagery of women depended on the impact of the processes of industrialization and urbanization in the three partitioned zones, as well as on the nature of imperial policies. For this reason, while the voices of the women's movement originated mainly in Austrian Poland, they resonated more 
vibrantly in Russian Poland at the beginning of the 20th century. It comes as no surprise, therefore, that women's sports and physical culture was, comparatively, best organized in Russian Poland. The sounds of the women's movement were far weaker in Prussian Poland and for this reason, sports appealed to far fewer women in this part of late partitioned Poland.

This section will explore the interaction between the "Woman Question" and the development of women's physical culture in late partitioned Poland by examining several questions. Why was the 'woman question' asked? Where was the 'woman question' being questioned? Who was asking the questions and to whom? How were the issues raised in the 'woman question' being questioned and answered? And importantly, how did the discourse on the 'woman question' impact women's participation in sports in late partitioned Poland? Did the accomplishments of the Polish women's movement facilitate the participation of women in sports, or did the limitations of the discourse on the 'women's question' further caution women from using their talents and abilities in constructing their physical culture during this time period?

The 'woman question' in late partitioned Poland was an attempt to question traditional epistemology on women's social and legal status, and express ideas of women's liberation in the spheres of economy, education and polity. In this question, women demanded equalities in voting rights, professional work, and higher education. The 'women's question' became related to various concerns of women such as their changing position in the family, women's need for an 'independent existence', as well as their demands for intellectual opportunities, material security and obtaining political and civil rights. The 'woman question' questioned the traditional passivity of women and urged them to come out of their marginal social status and aspire to participate in all spheres of daily life. The 'woman question' argued against the drastic confinements of women in their social life, and moved beyond the early 19th century Polish women's movement in which the women emancipationists had only questioned the traditional methods of training women in virtues of humility and decency. The focus of the late 19th century 'woman question' was on the traditional treatment of 'woman's body as a whole'. 51 In addition, the 'woman question' was 'humanistic' for it was an attempt to 'attain human rights for half of humanity'.52

51 For all these issues and more general details on women's various political, economic, social, cultural, and "domestic" roles see Ster, 9-10 (September and October, 1910), 326; Ster, 5-6 (May and June, 1910), 243; Ster, 4/61 (15 February, 1912), 6-7; Ster, 1/25(10 December, 1896), 14; Archiwum Akt Nowych (hereafter, AAN), Sygn. 237/XV-39 Wydzial Kobiecy (1949-1952), 128; KiZ, 2/ 374 (10 January, 1957), 4; 
Overall, the 'woman question' was a conscious attempt to undermine the Frenchinfluenced cultural "ideal" of the weak and helpless woman. 53 As a consequence of traditional prejudice, discrimination, and exploitation, women claimed that they were "choked" in their circumscribed domestic sphere with family obligations and social responsibilities of motherhood. 54 For this reason, the 'modern' woman needed to liberate her 'soul' through her own individual development, her material dependence through wage labor, and her 'body' by restoring equality within the family. 55 Because of the differing viewpoints expressed and contested, the 'woman question' was articulated in the context of 'national', ecclesiastical, socialist, and liberal frameworks. A related theme in the debate was whether women could preserve their femininity and still become, as defined in the discourse, more 'human'?56

Eventually, the discussions on this 'woman question', and especially the changing definitions of 'woman's body' and women's sexuality not only influenced the issues surrounding their increased participation in economic, political, and intellectual

KiZ, $7 / 487$ (1 March, 1960), 2; KiZ, 45/ 927 (10 November, 1968), 2; Kobieta Wspolczesna, 19 (11 May, 1930), 2, 3; Ster, 3 (March, 1908), 108; Anna Zarnowska, "Family and Public Life: Barriers and Interpenetration--Women in Poland at the Turn of the Century," in Women's History Review, 5, 4 (1996), 469-486, p.479; several articles in Rudolf Jaworksi and Bianka Pietrow-Ennker (eds.), Women in Polish Society (New York, 1992); Zbigniew Kuchowicz, Wizerunki niepospolitych niewiast staropolskich XVIXVIII wieku (Lodz, 1972), 5, 6; Barbara Jedynak, Obyczaje domu Polskiego w czasach niewoli, 1795-1918 (Lublin, 1996), 5, 47, 48, 51; several articles in the edited volumes by Zarnowska and Szwarc [see especially the books Kobieta $i$ swiat polityki; Kobieta i spoleczenstwo na ziemach Polskich $w$ xix wieku (Warsaw, 1995); Kobieta i kultura zycia codziennego; and Kobieta i edukacja, Cz.I and Cz. II]; Rotkiewicz, "Sport kobiet," 268; Jaworski, "Kilka refleksji nad dziejami wielkopolanek," 32, 33; Wasztyl, Wychowanie fizyczne, 97; Boguslawa Czajecka, "Z domu w szeroki swiat": Droga kobiet do niezaleznosci w zaborze austriackim w latach 1890-1914 (Krakow, 1990), 7, 14, 15, 205, 237, 239; and Walczewska, Damy, rycerze, i feministki, 8, 26, 27, 187. There are several images of 'happy mothers and wives' as well as articles on moral education and family life in the periodicals Kobieta Polska: Obywatelka, Matka, Gospodyni, and Bluszcz. See for example Kobieta Polska, 2 (26 February, 1915), 1; Bluszcz (1874); and Bluszcz (1909).

52 Kazimiera Bujwidowa, "Wyksztalcenie kobiet," in Turzyma and Bujwidowa (eds.), Glos kobiet w kwestyi kobiecej, 17-41, p.21, 22. On this idea of the woman question being part of general human striving see also Kuczalska-Reinschmit, "Z historyi ruchu kobiecego," (part II), 337; Kuczalska-Reinschmit, "Z historyi ruchu kobiecego," (part I), 245; and Meczkowska, Ruch kobiecy, 37.

53 Paulina Kuczalska-Reinschmit, Nasze cele i drogi. Szkic do programu dzialalnosci kobiecej, Dodatek do "Steru" (Lwow, 1897), 8, 9.

54 See Marya Dulebianka, "O tworczosci kobiet," in Turzyma and Bujwidowa (eds.), Glos kobiet w kwestyi kobiecej, 163-197; and Cecylja Walewska, Z dziejow krzywdy kobiet (Warsaw, 1908), 6, 16.

55 Maria Turzyma, "Kwestya kobieca," in Turzyma and Bujwidowa (eds.), Glos kobiet w kwestyi kobiecej, $1-16$, pp. $6,7,8,14$. For the idea of the need for the modern woman to become conscious of the importance of her economic, intellectual, and political independence see also Kazimiera Bujwidowa, "Przedmowa," in Turzyma and Bujwidowa (eds.), Glos kobiet w kwestyi kobiecej; and Paulina Kuczalska-Reinschmit, Mlodziez zenska i sprawa kobieca (Warsaw, 1906), 22.

56 See Iza Moszczenska, "Mezczyna i kobieta," in Turzyma and Bujwidowa (eds.), Glos kobiet w kwestyi kobiecej, 121-142, p.142. Moszczenska questioned if the "new kind of woman" would be no less feminine, but significantly more human. 
developments but also impacted the emerging discourse on the importance of women's personal health and hygiene. Indeed, the 'woman question' also undermined traditional notions about women's physicality. The discussions on the physical emancipation of Polish women in late partitioned Poland were integrally related to the ideological structure of the women's movement. Under the protective embrace of the 'woman question', the discourse on women's physical development was provided with a more 'modern' intellectual fabric. And women's participation in sport, in turn, gave further credence to the 'woman question'. However, this mentorship 'from above' and partnership 'from below' remained moderate and accommodating to the larger national agenda. For this reason, the formation of women's physical culture in late partitioned Poland did not signal a radical departure from conventional patriarchal norms.

While the 'woman question' was multi-dimensional in its questioning, it was more linear in its membership. The principal discussants included women from "splinter groups of the intelligentsia" in the Austrian and Russian partitions of Poland. 57 For example, Kazimiera z Klimontowiczow Bujwidowa (1867-1932), an eminent women's activist and publicist in Galicia, wanted equal rights for women, especially in education.58 Maria Dulebianka was another noted political feminist activist in Galicia. ${ }^{59}$ Iza Moszczenska, a Warsaw-based journalist in Russian Poland, fought for women's rights in Austrian Poland. 60 Paulina Kuczalska-Reinschmit, meanwhile, was known by contemporaries as the "hetman of the women's movement."61 Equally important were the individual activities of radical feminist Zofia Nalkowska and Janina

57 Bianka Pietrow-Ennker, "Frau und Nation im geteilten Polen," in Sophia Kemlein (ed.), Geschlecht und Nationalismus in Mittel-und Osteuropa, 1848-1918 (Osnabruck, 2000), 125-142, p.140. See also Najdus, "Zmiany spoleczno-ekocomicznej pozycji kobiety," 247; Najdus, "O prawa obywatelskie kobiet," 108, 109, 113; Chwalba, "Kobiety w zyciu politycznym Galicji,"123; and Czajecka, "Z domu w szeroki swiat," 7, 205, 239. For an in-depth investigation of famous women personalities and the various components and achievements of the women's movement see Kobieta Wspolczesna: Ilustrowany tygodnik spolecznoliteracki (Warsaw).

$\overline{58}$ For details see Najdus, "O prawa obywatelskie kobiet," 109, 110; and Agnieszka Kwiatek, "Kazimiera Bujwidowa : Poglady i dzialalnosc spoleczna," in Zarnowska and Szwarc (eds.), Kobiet $i$ swiat polityki, 255-260, pp.255, 256, 259, 260.

59 Natali Stegmann, “'Wie die Soldaten im Feld': Die wieder spruchliche kampf polnischen Frauen fur 'Vaterland' und Frauenrechte im Ersten Weltkrieg," in Kemlein (ed.), Geschlecht und Nationalismus, 197216, pp.198, 199, 201.

60 Pietrow-Ennker, “Tradycje szlacheckie," 14; and Kalendarz Kobiety Polskiej (Warsaw, 1910).

61 Pietrow-Ennker, "Frau und Nation im geteilten Polen," 125-142, p.139; Najdus, "O prawa obywatelskie kobiet," 109; and Pietrow-Ennker, "Tradycje szlacheckie," 29. 
Kodisowa who discussed the importance of co-education, women's professional work, and the need to establish social centers for women and children. 62

This dialogue on the 'woman question' generally took place in women's organizations and unions, in meetings and conferences, in protest marches and demonstrations, and in a variety of publications. Prior to the turn of the century, Galician feminists such as Kazimiera Bujwidowa, Maria Turzyma, Maria Wyslouchowa, and Stefania Wechslerowa formed the Kolo Kobiet Korony i Litwy (Women's Circle of the Kingdom and Lithuania) in 1886.63 Under the editorship of Paulina z Kuczalskich Reinschmitt, a women's periodical Ster made its first appearance toward the end of 1895 in Lwow. 64 After a break in publication from 1897, Ster was republished in 1907 as the periodical of the 'Union for Equal Rights for Polish Women' in Warsaw. The Stowarzyszenie Rownouprawnienia Kobiet Polskich (Association for Equal Rights for Women, 1905) was founded earlier with the objective of achieving complete political and economic rights for all women and in all spheres of public and private life. The first cohesive women's organization, the Union for Equal Rights for Polish Women (Zwiazek Rownouprawnienia Kobiet Polskich, ZRKP), was organized in 1906 by women from the intelligentsia. Both organizations talked about women's civil, economic, and political rights. In 1907, the Union for Equal Rights for Polish Women convened the first AllPolish Conference of Women in Warsaw to discuss ideas of women's equality not only among families of intelligentsia and landowners, but also among peasants and workers. The ZRKP itself was responsible for the publication of periodicals such as Ster (19071914) and Nowe Slowo.

The periodical Ster (Organ Rownouprawnienia Kobiet Polskich, Warsaw) published articles on themes of women's emancipation, morality, education, hygiene, activities of the different departments of the Union for Equal Rights in other regions of partitioned Poland (e.g. Lublin and Lwow), the material and intellectual upliftment of women and girls, equality and independence of women in the family and society, the idea of co-education in schools, struggles against alcoholism and prostitution, and the question of equal civil and political rights for women. Considerable attention was also given to the

62 See Czajecka, “Z domu w szeroki swiat,” 8, 41, 42, 44, 46, 47.

63 Dobrochna Kalwa, "Model kobiety aktywnej na tle sporow swiatopogladowych. Ruch feministyczny w dwudziestoleciu miedzywojennym," in Anna Zarnowska and Andrzej Szwarc, Rowne prawa i nierowne szanse: kobiety w Polsce miedzywojennej (Warsaw, 2000), 135-153, 137; and Czajecka, "Z domu w szeroki swiat," 8, 41, 42, 44, 46, 47.

64 See Najdus, "O prawa obywatelskie kobiet," 109; Pietrow-Ennker, "Tradycje szlacheckie," 29; and Walczewska, Damy, rycerze, i feministki, 83. 
women's movement in China and to the work of English suffragists. Ster expressed concern over the self-defense of women workers and also expanded the discussion of obtaining electoral and civil rights for women after 1911.65

A number of women's groups and women's periodicals subsequently debated the 'woman question'. Some women's publication were more conservative than the others; however, the very increase in the number of women's periodicals and other forms of literature between the years 1903-1909 is testimony to their more mature selfawareness. 66 Also, an increasing number of women's organizations and committees in the cities and larger towns of Warsaw, Lwow, Krakow, Poznan, Kalisz, Piotrkow, and Czestochowa articulated women's economic, social and political agendas. 67 The celebration of the International Women's Day in 1911 by women in the Austrian and Prussian partitions of Poland provided more energy to the women's movement in general. 68

The origins of the 'woman question' thus lay in the dramatically changing images of women in late 19th partitioned Poland. Women's increased visibility in their new economic, intellectual, political, and 'national' roles at the turn of the century raised concerns in society. Their participation in avenues beyond the domestic sphere of the home and family triggered a social contest between the defenders of patriarchy and the promoters of women's emancipation. However, to understand the severity of this societal

65 For details on Ster and activities of the Union for Equal Rights for Polish Women see Archiwum Akt Nowych (hereafter, AAN), Sygn. 237/XV-39 Wydzial Kobiecy (1949-1952), 129; Ster, 4 April, 1910), 170, 194-197; Ster, 2 (February, 1910), 64; Ster, 1 (1 January, 1912), 2, 3; Ster, 1 (1 January, 1912), 7; Ster, 2 (15 January, 1912), 8; Kobieta Wspolczesna, 15 (14 April, 1929), 5-6; KiZ, 45 (10 November, 1968), 2; Bluszcz, 2 (22 October, 1921), 7; Przyjaciolka, 10 (6 March, 1960), 5; Katarzyna Czajkowska, "Wzorce roli spolecznej kobiety propagowanie przez Zwiazek Rownouprawnienia Kobiet w Krolestwie Polskim na poczatku xx wieku," in Zarnowska i Szwarc, Kobieta i edukacja, Cz.I, 245-252, pp.245-247, 251; Adam Dobronski, "Wzorce i szanse awans spolecznego kobiet na prowincji Krolestwa Polskiego u schylku xix i w poczatkach xx wieku," in Zarnowska i Szwarc, Kobieta i edukacja, Cz.I, 171-185, p.180; Katarzyna Sierakowska, "Aspiracje polityczne Zwiazku Rownouprawnienia Kobiet Polskich," in Zarnowska and Szwarc, Kobieta i swiat polityki, 245-253, p.248; Walczewska, Damy, rycerze, i feministki, 60, 111; and Kalwa, "Model kobiety aktywnej," 135.

66 Chwalba, "Kobiety w zyciu politycznym," 132; Najdus, "O prawa obywatelskie kobiet," 110-112; and Przyjaciolka, 10 (6 March, 1960), 5

67 Kobieta: Dobra Matka, 1-2 (15 January, 1906), 4-5; Jan Molenda, "Postawy kobiet wiejskich wobec unowoczesniania gospodarki chlopskiej w pierwszym dwudziestoleciu xx wieku," in Zarnowska i Szwarc, Kobieta i kultura zycia codziennego, 191-218, pp. 207, 208; Najdus, "O prawa obywatelskie kobiet," 112, 114; Andrzej Chwalba, "Spor o wartosci: sympatyczki ruchu emancypacjynego wobec religii i kosciola katolickego," in Anna Zarnowska and Andrzej Szwarc (eds.), Kobieta i kultura, kobiety wsrod tworcow kultury, intelektualnej $i$ artystycznej $w$ dobie rozbiorow $i w$ niepodleglym panstwie polskim (Warsaw, 1996), 267-284, p.271; Kalwa, "Model kobiety aktywnej," 137; Nietyksza, "Tradycyjne i nowe formy," 91; Caban, "Kobiety i powstanie styczniowe," 64, 65; and Pietrow-Ennker, "Tradycje szlacheckie," 29.

68 Przyjaciolka, 10/624 (6 March, 1960), 5. 
conflict, an examination of the changing identities of women in this time period, especially in the rapidly transforming economic, educational, political, and 'national' systems is needed. In other words, what were the "modern" images of women being constructed and why did they precipitate a debate in society regarding the "woman question' in late partitioned Poland? The principal issues under debate included political and civil rights for women, economic and educational opportunities for women, the place of women in their families and the 'nation', and the changing definitions of women's sexuality and morality. Since the nature of this discourse, directed by women from the intelligentsia, also influenced the manner in which women's participation in sport was perceived, a brief analysis of this multifaceted debate on the 'woman question' is critical for understanding the physical liberation of Polish women. Such an examination of how the issues raised in the 'woman question' were contested will illuminate the interaction between the Polish women's movement and women's physical culture in late partitioned Poland.

The late 19th-century processes of urbanization and industrialization crafted new 'economic' images of women in both the urban and rural economies of partitioned Poland. Russian Poland emitted the most powerful radiance in this complex imagery. The changes in Austrian Poland were less dramatic, while women in Prussian Poland functioned more as spectators to the transitions in women's "self-awareness" in the other regions. 69 More generally, the development of capitalism and transformations in socioeconomic conditions and the political environment in Russian Poland provided favorable conditions for women to assume a variety of new tasks and roles. 70 Women worked in the household services, industrial and artisanal work, in financial institutions and medical establishments, as well as in trade, transport, and communications. ${ }^{71}$ They also worked as watchmakers, turners, book-binders, lithographers, florists, book-keepers, and

69 For the status of women in Austrian Poland see Czajecka, " $Z$ domu w szeroki swiat," 13, 153, 156; Pietrow-Ennker, "Tradycje szlacheckie," 23; and Najdus, "Zmiany spoleczno-ekonomicznej pozycji kobiety," 248, 249. For women's organizations in Prussian Poland during the partitioned period see Jaworski, "Kilka refleksji nad dziejami wielkopolanek," 29, 30; Stegmann, "Wielkopolskie wzorce kobiecej aktywnosci," 364; Nietyksza, "Tradycyne i nowe," 97; and Ziolkowska, Kultura fizyczna w Poznaniu, 11.

70 Anna Zarnowska, "Kierunki aktywnosci zawodowej kobiet w Polsce xx wieku (do 1939 r.)," in Zarnowska and Szwarc, Kobieta i edukacja, Cz. II, 161-175, p.161.

71 Nietyksza, "Przemiany aktywnosci zawodowej kobiet," 150, 153; Stanislaw Wiech, "Kobiety w zyciu codziennym srodowiska malomiasteczkowych rzemieslnikow Krolestwa Polskiego na przelomie xix i xx wieku," in Zarnowska and Szwarc (eds.), Kobieta i kultura zycia codziennego, 347-362, pp. 353-362; and Zofia Chyra-Rolicz, "Pionierki w nowych zawodach na poczatku xx wieku," in Zarnowska and Szwarc, Kobieta i edukacja, Cz. II, 221-236, pp. 223, 225-227. 
seamstresses. 72 Some others became part of the intelligentsia, engaging in the professions as writers, journalists, artists, teachers, doctors, and engineers. 73

Urban life for women of the upper class and working families in Russian Poland was marked by a variety of changes and new experiences. Generally, it was much harder for women to found "normal" families in towns, and those who did often faced problems, especially if pregnant. 74 In the various cities of Imperial Russia, women workers had to face the realities of urban life--late marriages, or at times celibacy, unwed motherhood, prostitution, increased vulnerability to rape and sexual harassment, general insecurity and unpredictability, the whims of the factory owners, and a double burden of housekeeping and market labor. 75 Still, though urban life was hard and lonely for some, it was also exciting and challenging for many others. The anonymity of the city forced a gradual departure from traditional conventions and a loosening of parental or guardian control and granted young people ever greater freedom in their daily lives. 76

Meanwhile, with industrialization and urbanization, the countryside also witnessed a gradual weakening in its cultural and social isolation in the Kingdom of

\footnotetext{
72 Stefania Kowalska-Glikman, "Kobiety w procesie przemian spolecznych w Krolestwie Polskim w XIX wieku," in Zarnowska and Szwarc (eds.), Kobieta i spoleczenstwo, (1990), 10-24, pp.10, 11, 19.

73 For details see Wereszycki, Historia polityczna Polski, 61; Danuta Rzepniewska, "Ziemianki w miescie. Krolestwo Polskie w koncu XIX wieku," in Zarnowska and Szwarc (eds.), Kobieta i kultura zycia codziennego, 31-57, pp. 32-35; Anna Zarnowska, "Social Change, Women, and the Family in the Era of Industrialization: Recent Polish Research," in Journal of Family History, (Translated into English by Robert E. Blobaum), 22, 2 (April 1997), 191-203, p.196; Nora Koestler, "Kobiety polskie miedzy spoleczenstwem tradycyjnym a nowoczesnym," in Zarnowska and Szwarc, Kobieta i edukacja, Cz. I, 3143, p.39; Winiarz, "Ksztalcenie i wychowanie dziewczat," 17; Kowalska-Glikman, "Kobiety w procesie przemian spolecznych," 11; Rzepniewska, "Kobieta w rodzinie ziemianskiej," 61; and Mariola Siennicka, "Rola 'pani domu' w kregach burzuazji warszawskiej w drugiej polowie xix wieku," in Zarnowska and Szwarc (eds.), Kobieta i kultura zycia codziennego, 317-333, p.318, 323-324, 328.

74 See Anna Zarnowska, "Kobieta w rodzinie robotniczej. Krolestwo Polskie u schylku XIX i na poczatku XX wieku," in Zarnowska and Szwarc, Kobieta i spoleczenstwo, (1990), 174-187, pp. 178, 181; and Zarnowska, "Kierunki aktywnosci zawodowej kobiet," 169.

75 For this topic on the roles of women in the urban and rural economies in Imperial Russia see the following: Barbara Engel, Between the Fields and the City: Women, Work, and Family in Russia, 18611914 (Cambridge and New York, 1994); Laura Engelstein, The Keys to Happiness: Sex and the Search for Modernity in Fin-De-Siecle Russia (Ithaca, 1992); several articles in Farnsworth and Viola (eds.), Russian Peasant Women; several articles in Mark D. Steinberg and Stephen P. Frank (eds.), Cultures in Flux: Lower Class Values, Practices and Resistance in Late Imperial Russia (Princeton, 1994); Hilary Pilkington (ed.), Gender, Generation and Identity in Contemporary Russia (London and New York, 1996); David Ransel, Mothers of Misery: Child Abandonment in Russia (Princeton, 1988); Mary Conroy, "Women Pharmacists in Russia Before W.W.I: Women's Emancipation, Feminism, Professionalization, Nationalism and Class conflict," in Linda Edmondson (ed.), Women and Society in Russia and the Soviet Union (Cambridge and New York, 1992), 48-68; Catriona Kelly, "Teacups and Coffins: The Culture of Russian Merchant Women, 1850-1917," in Marsh (ed.), Women in Russia and Ukraine, 55-77; and Judith Pallot, "Women's Domestic Industries in Moscow Province, 1880-1900," in Clements, Engel, Worobec, Russia's Women, 163-184.

76 Zarnowska, "Social Change, Women, and the Family,” 194, 195, 197, 198, 199, 201.
} 
Poland. The organization of secretive women's circles in the Polish Kingdom helped to arouse rural women's self-consciousness in their economic, cultural and 'national' identities. Such circles sought to educate rural women in matters related to health and hygiene, home economics, and modern science. They aimed to provide rural women with some degree of socio-economic independence and emancipation from the domineering influences of the church and patriarchal family. 77

Importantly, women's migrations to the towns and their attempts to balance employment with family obligations fostered societal interest in questions of women's pay, working conditions, prostitution and abortion, family life, and women's place in the "nation".78 The economic issues related to the 'woman question' proved contentious. While some women chose to focus exclusively on women's economic hardships, others viewed the economic question as another subset of the 'woman question'.79 Also, while the discussants of the 'woman question' debated the juxtaposition of women's economic work with family responsibilities, the marked visibility of prostitution expanded the discourse on women's labor from the factories to the streets. Prostitution was regarded as a natural, not as a social phenomenon in most European cities during this time period. 80 The Polish feminists sought to redress this problem and offer substantial reinterpretation

77 Wlodzimierz Medrzecki, "Kobieta wiejska w Krolestwie Polskim. Przelom XIX i XX wieku," in Zarnowska and Szwarc (eds.), Kobieta i spoleczenstwo, 1995, 93-98, pp. 93, 97; Wlodzimierz Medrzecki, "W spolecznosciach lokalnych i w parafi. Kobiety w zyciu publicznym wsi polskiej na przelomie wiekow," in Zarnowska and Szwarc (eds.), Kobieta i swiat polityki, 163-168, pp.166-168; Chamerska, "Sytuacja spoleczna drobnej szlachcianki," 80; Wlodzimierz Medrzecki, "Aspiracje oswiatowe kobiet ze srodowiska chlopskiego w Krolestwie Polskim na przelomie xix i xx wieku," in Zarnowska and Szwarc, Kobieta $i$ edukacja, Cz. I, 109-122, p.109, 115, 116, 119; Rzepniewska, "Kobieta w rodzinie ziemianskiej,” 61; KiZ, 7 (1 March, 1960), 2; Wlodzimierz Medrzecki, "Kowenans wiejski i nowe wzorce zachowan kobiet na wsi w Krolestwie Polskim na przelomie xix i xx wieku," in Zarnowska and Szwarc (eds.), Kobieta i kultura zycia codziennego, 71-87, pp. 85-87; Molenda, "Postawy kobiet wiejskich," 192, 206, 207; Tadeusz Stegner, "Zony pastorow i ich rola w ksztaltowaniu kultury dnia codziennego spolecznosci protestanckich w Krolestwie Polskim w xix wieku," in Zarnowska and Szwarc (eds.), Kobieta i kultura zycia codziennego, 335-345, pp. 338, 342, 345; Maria Kostrzewska, "Kola gospodyn wiejskich a oswiata w Polsce miedzywojennej," in Zarnowska and Szwarc, Kobieta i edukacja, Cz. II, 135-143, pp.135, 140-142; and Maria Nietyksza, "Kobiety w ruchu oswiatowym Krolestwo Polskie na przelomie wiekow," in Zarnowska and Szwarc, Kobieta i edukacja, Cz. II, 91-119, pp. 96, 97.

78 For a discussion of prostitution in Warsaw see Laurie Bernstein, Sonia's Daughters: Prostitutes and Their Regulation in Imperial Russia (Berkeley and Los Angeles, 1995), 30, 31, 32, 40. For struggles

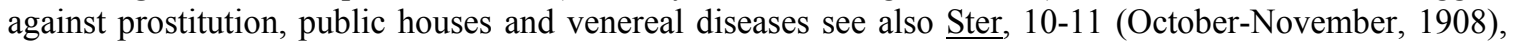
378; Ster, 5-6 (May and June, 1910), 229; and Ster, 1-2 (January, 1914), 3.

79 For the various viewpoints expressed in this debate see Dr. Felicja Nossig, "Ekonomiczna strona kwestyi kobiecej," in Turzyma and Bujwidowa (eds.), Glos kobiet w kwestyi kobiecej, 91-113, (editor's note, 113120); Isabela Mosczenska, "Kwestja kobieca w chwili obecnej," in Glos, 26 (June 14/27, 1903), 406-407; and Moszczenska, "Mezczyna i kobieta," 13

80 See for example, Susan Zimmermann, “ 'Making a Living from Disgrace': The Politics of Prostitution, Female Poverty and Urban Gender Codes in Budapest and Vienna, 1860-1920," in Gee, Kirk and Steward (eds.), The City in Central Europe, 175-195. 
of 'female immorality'. For this reason, they deplored the official and societal control of prostitution. 81

While the processes of industrialization and urbanization fashioned new images of women in the economic sphere in late partitioned Poland, women's pursuit of education not only provided them with the requisite qualifications necessary to sustain their economic initiatives, but also encouraged them to use their intellectual talents to debate the 'women's question'. In Austrian Poland, women students at both Krakow and Lwow came from upper and middle class families of landowners, intelligentsia, and industrialists. ${ }^{82}$ In Russian Poland, teaching was as an important women's occupation and working class women were instrumental in self-educating their children at home or in secret Polish schools. 83

Such women who aspired to higher education challenged traditional dogmas that considered higher studies for women superfluous. These intellectual women served as the vanguard of the women's movement and challenged conventional stereotypes of

81 For the discussion on prostitution see Turzyma, Wyzwalajaca sie kobieta, 48; Meczkowska, Ruch kobiecy, 24-27; Marya Turzyma, "Handel kobietami," in Turzyma and Bujwidowa (eds.), Glos kobiet w kwestyi kobiecej, 143-162; Zofia Rygier-Nalkowska, "Uwagi o etycznych zadaniach ruchu kobiecego (referat wyglosony za zjezdzie kobiet)," in Krytyka, 11 (November, 1907), 358-363

82 For women's higher education in Galicia see Przyjaciolka, 10/624 (6 March, 1960), 5; KiZ, 45/927 (10 November, 1968), 2; Urszula Perkowska, "Ksztaltowanie sie etosu studentki polskiej w dwoch pierwszych pokoleniach studentek uniwersytetu Jagiellonskiego z lat 1894-1939," in Zarnowska and Szwarc (eds.), Kobieta i kultura zycia codziennego, 387-403, pp. 388, 389, 394, 396, 399, 402, 403; Walczewska, Damy, rycerze, i feministki, 70, 71; Najdus, "Zmiany spoleczno-ekonomicznej," 252-253; Czajecka, " $Z$ domu w szeroki swiat", 78, 237; Czajecka, "Wokol wyksztalcenia kobiet w Galicji," 50, 51, 56, 57; Urszula Perkowska, "Formacja zawodowa i intelektualna studentek Uniwersytetu Jagiellonskiego z lat 1894-1918," in Zarnowska and Szwarc, Kobieta i edukacja, Cz.II, 59-72, pp. 61, 63, 67, 68; Zarnowska, "Family and Public Life," 479; and Najdus, "O prawa obywatelskie kobiet w zaborze austriackim," 100.

83 For details on women's education in Russian Poland see Ruch, 12 (11 July, 1907), 136; KiZ, 7 (1 March, 1960), 2; Nietyksza, "Przemiany aktywnosci zawodowej kobiet," 153; several articles in Zarnowska and Szwarc, Kobieta i edukacja, Cz. I and Cz. II; Wereszycki, Historia polityczna Polski, 99, 100; Zarnowska, "Family and Public Life," 470; Adam Winiarz, "Girls' Education in the Kingdom of Poland, 1815-1915," in Jaworksi and Pietrow-Ennker (eds.), Women in Polish Society, 91-111, pp.103, 108; Winiarz, "Ksztalcenie i wychowanie dziewczat," 14, 16, 21, 22; Anna Zarnowska, The Education of Working-Class Women in the Polish Kingdom; Chyra-Rolicz, "Pionierki w nowych zawodach na poczatku xx wieku," 230-234; Kuczalska-Reinschmit, "Z historyi ruchu kobiecego," (part II), 318, 319, 320; Sofja Rygier-Nalkowska, Kobiety. Translated from the Polish by Michael Henry Dziewicki (New York, 1920), 60, 145; KiZ, 7 (1 March, 1960), 2; Nietyksza, "Kobiety w ruchu oswiatowym," 93, 111-112; Grazyna Borkowska, "Literatura i "geniusz" kobiecji wiek XIX, wiek XX," in Zarnowska and Szwarc (eds.), Kobieta i kultura, 29-43, p.29; Anna Reading, Polish Women, Solidarity and Feminism (Houndmills, Basingstoke, Hampshire, 1992), 160; Jolanta Niklewska, "Autorki literatury dla dzieci i mlodziezy w zaborze rosyjskim w xix i poczatkach xx wieku," in Zarnowska and Szwarc (eds.), Kobieta i kultura, 6372, pp. 68-70; Nietyksza, "Tradycyjne i nowe formy," 93; Mazur, "Dzialalnosc dobroczynna kobiet," 309, 314; and Rzepniewska, "Kobieta w rodzinie ziermianskiej w xix wieku," 62. For details on the so-called "salon education", "salon science", and pejoratively "salon flirtation", see Skowronek, "Debiuty polityczne kobiet," 30, 39; and Szwarc, "Krytyka kobiecosci," 299, 300. 
women's "true vocation". The feminists stressed the importance of education (including co-education) for women as a requisite for professional advancement, personal liberation, and societal progress. 84 They also criticized those university educated women who failed to use their talents to support the cause of emancipation for all women, and not just a few. 85

Women's roles as teachers, students, writers, scholars, and patrons of higher learning in late 19th century partitioned Poland not only constructed positive individual identities for "educated" women, but also made valuable contributions in transforming the 'national' and patriarchal environments of Polish life. While some women intellectuals preached harmony between the two ideals by compromising more on the latter, others placed the "woman question" ahead of the "national" agenda. In both cases, however, the women's movement benefited from this discourse, which ultimately influenced the participation of women in sport in late partitioned Poland. Once again, women's pursuit of higher education, and participation in other intellectual and 'enlightened' societies was most pronounced in the Austrian and Russian partitions of Poland.

Women also cast new images in their participation in the emerging political parties of late partitioned Poland. Their involvement in the nationalist, socialist, and Christian political organizations seasoned the 'woman question' with condiments of varying degrees of spiceness. While some questioned the membership of women in political parties, others discussed the nature of their methodological and ideological approaches. 86 As "citizen-mothers", women were generally forced to place priority on

84 See Meczkowska, Ruch kobiecy, 32, 33; Kazimiera Bujwidowa, U zrodel kwestji kobiecej (Warsaw, 1910), 5, 6, 9, 10, 11; Bujwidowa, "Wyksztalcenie kobiet," 21, 22; and Kuczalska-Reinschmit, Nasze cele $i$ drogi, $15,16,24$.

85 See Isabela Mosczenska, "Kwestja kobieca w chwili obecnej," in Glos, 25 (June 7/20, 1903), 390-392.

86 For a discussion of women's participation in the emerging political movements in late partitioned Poland see Kalwa, "Model kobiety aktywnej," 138; Zarnowska, "Family and Public Life," 477, 479, 482; Ster, 4/61 (15 February, 1912), 8; Ster, 9-10 (10-25 May, 1913), 117; Czajecka, "Z domu w szeroki swiat," 7, 8, 151, 206, 215, 216, 223, 226, 233, 237, 238; Jaworski, "Kilka refleksji nad dziejami wielkopolanek," 29, 30; Stegmann, "Wielkopolskie wzorce kobiecej," 364; Nietyksza, "Tradycyne i nowe," 97; AAN, Sygn. 237/XV-39 Wydzial Kobiecy (1949-1952), 129, 130; Samus, "Socjalistki w Krolestwie Polskim," 194, 195, 204-209, 215-217; Sierakowska, "Aspiracje polityczne," 248-250; Skowronek, "Debiuty polityczne kobiet," 34, 35; KiZ, 7 (1 March, 1960), 2; KiZ, 37 (10 September, 1972), 6; Przyjaciolka, 10/624 (6 March, 1960), 5; Chwalba, "Kobiety w zyciu politycznym Galicji," 119, 122-125, 127, 129, 131, 134; Najdus, "Zmiany spoleczno-ekonomicznej pozycji kobiety," 246, 247; Najdus, "O prawa obywatelskie kobiet," 107-113; Walczewska, Damy, rycerze, i feministki, 83, 86, 112; Sliwa, "Wzorzec osobowy kobiety-socjalistki w Polsce," 233, 238-241; Witold Molik, "Z badan nad studiami uniwersyteckimi wielkopolanek na przelomie xix i xx wieku," in Zarnowska and Szwarc, Kobieta i edukacja, Cz.II, 39-47, pp.43-44; Zarnowska, "Prywatna sfera zycia rodzinnego," 10, 14-19; Sliwowska, "Kobiety w 
expanding their contributions to national culture, and not advance their rights to political participation. Women were to remain cautious and very moderate in their political activities. Even the programs of the emerging political movements ignored women's political and civil rights, much to the chagrin of the feminists. 87 For example, Dulebianka accused the Endecja of defending the interests of an 'abstract' nation rather than struggling for the various groups of people who actually comprised the nation, including women. 88 Kuczalska-Reinschmit castigated the National Democrats for maintaining that women's rights and national causes were mutually exclusive categories. 89 Turzyma mocked the Endecja's "national egoism" for "making a deal with the more powerful and oppressing the weaker." 90 Both Dulebianka and KuczalskaReinschmit were critical of the Social Democratic party as well. The socialists expected women to subordinate their own interest for the "good of the whole". But, as Dulebianka questioned, how could the 'good of the whole' be served when women were being asked to delay the struggle for their own political and civil emancipation for another time in the distant future? ${ }^{91}$ Similarly, Kuczalska-Reinschmit criticized socialist disinterest in women's rights and their callousness to address these issues until after their "better social structure" had been created. ${ }^{92}$

Deeply influenced by the experiences of women's suffrage movements in other parts of Europe, the Polish feminists argued for the importance of organizing a peaceful women's movement independently and be perceived as an "equal partner" to the other political parties. Only women themselves, increasingly conscious of their political expulsion, could coalesce and form separate women's organizations to peacefully

konspiracjach patriotycznych," 45; Joanna Kurczewska, "Der fruhe polnische Nationalismus und die Frauenthematik," Kemlein (ed.), Geschlecht und Nationalismus, 49-76, pp.60, 61, 62, 64, 66, 67, 70, 72, 74, 75, 76; Medrzecki, "Kobieta wiejska w Krolestwie Polskim," 97; Medrzecki, "W spolecznosciach lokalnych i w parafi," 165; Dr. Zofia Golinska, "Kobieta obywatelka," in Turzyma and Bujwidowa (eds.), Glos kobiet w kwestyi kobiecej, 198-216; Kuczalska-Reinschmit, "Z historyi ruchu kobiecego," (part II), 311; Helena Witkowska, "O prawach politicznych kobiet," in Turzyma and Bujwidowa (eds.), Glos kobiet w kwestyi kobiecej, 42-72; Turzyma, Wyzwalajaca sie kobieta, 106-108; and Martha BohachevskyChomiak, "How Real Were Nationalism and Feminism in 19th Century Galicia," in Kemlein (ed.), Geschlecht und Nationalismus, 143-152, p.149, 151. For Russian women socialists see Barbara Clements, Daughters of Revolution: A History of Women in the USSR (Arlington Heights, Ill., 1994), 26, 27; and Richard Stites, The Women's Liberation Movement in Russia: Feminism, Nihilism, and Bolshevism, 18601930 (Princeton, New Jersey, 1978), 153.

87 See Kuczalska-Reinschmit, "Z historyi ruchu kobiecego," (part II), 330, 334; and KuczalskaReinschmit, Nasze cele i drogi, 1, 2, 13.

88 Marja Dulebianka, Polityczne stanowisko kobiety (Warsaw, 1908), 3, 4.

89 Paulina Kuczalska-Reinschmit, Wyborcze prawa kobiet (Warsaw, 1907), 22, 28.

90 Turzyma, Wyzwalajaca sie kobieta, 112.

91 Dulebianka, Polityczne stanowisko kobiety, 6, 7.

92 Kuczalska-Reinschmit, Wyborcze prawa kobiet, 21, 22, 25. 
struggle for the attainment of national and human rights for all people. Paulina Kuczalska-Reinschmit presented various arguments to explain the importance of separating the "women's question" from the larger "national question" in its problematic and organizational aspects. Kuczalska also maintained that the emancipation of women included women from all classes and ethnic groups. 93

Unfortunately, the feminists call for universal suffrage "without distinction of sex" was undermined by the other contested debates over women's economic and educational opportunities, and their "place" in the "nation". Moreover, they emphasized political rights "without sex differentiation", which did not necessarily translate into equality between sexes. 94 Still, despite the obvious difficulties, women's engagement in politics generated more images of 'modernity', which directly contributed to the genesis of women's physical culture movement in late partitioned Poland.

The feminist discourse on the need for sexual equality in economic, intellectual and political work also permeated the domestic boundaries of institutions such as family, motherhood, and marriage. For example, Zofia Nalkowska was dismayed at the somber response of many of those present at the women's meeting in 1907 on questions of extramarital sex and "free friendships". Since these issues undermined the institution of marriage, several women found the topics too "indecent" and insuitable for "public discussion".95 Bujwidowa, another advocate for women's new self-liberating sexual morality, urged women to stop patronizing motherhood as a predestined and involuntary choice which resulted in their identity-destruction. However, Bujwidowa also emphasized that men needed an "internal rebirth" to make them cognizant of their mutual responsibility in creating a new sexual idea based on equality for both men and women.96 For this reason, Moszczenska reaffirmed that "one of most important and

\footnotetext{
93 Kuczalska-Reinschmit, Wyborcze prawa kobiet , 1, 12, 21, 22, 24, 30; Walczewska, Damy, rycerze, $i$ feministki, 177, 178; Meczkowska, Ruch kobiecy, 28-30, 34; Dr. Marya Lipszye Balsigerowa, "Stanowisko kobiety wobec prawa cywilnego," Turzyma and Bujwidowa (eds.), Glos kobiet w kwestyi kobiecej, 73-90, pp.83, 88, 89; Bujwidowa, U zrodel kwestji kobiecej, 11, 12, 14; and Dulebianka, Polityczne stanowisko kobiety, 1, 3, 8, 10, 12,14, 16, 18

94 Walczewska, Damy, rycerze, i feministki, 57, 58, 63, 64. At the first public meeting in Warsaw Philharmonic Hall in November 1905, J. Bojanowska called for universal suffrage "without distinction of sex". Thereafter, this phrase began to enter programs of women's associations and unions. See KuczalskaReinschmit, Wyborcze prawa kobiet, 24.

95 Zofia Rygier-Nalkowska, "Uwagi o etycznych zadaniach ruchu kobiecego (referat wyglosony za zjezdzie kobiet)," in Krytyka, 11 (November, 1907), 358-363, p.361; and Walczewska, Damy, rycerze, $i$ feministki, 26, 35, 36 .

96 Bujwidowa, U zrodel kwestji kobiece, 16, 18, 20-25, 28, 30, 35-39.
} 
strongest points in the program of the women's movement should be the physical and moral regeneration of men".97

According to Turzyma, women could liberate themselves from their triple enslavement of soul, spirit, and body by their own self-consciousness and self-awareness. They needed to have faith in their strengths in directing a "human renaissance" for both individual and "civilizational" progress. 98 Kuczalska-Reinschmit agreed that marital relations based on dependence and subordination brought unhappiness. She wanted parents to train their daughters to become independent so that they could live by themselves with personal and material freedom. 99 Meczkowska also articulated the need to reform the ethical and legal dimensions of the institution of marriage. 100 It is to be noted that during and after the 1905 revolution, many women supported the idea of divorce as a healthy solution for dissolving bad marriages. 101

It needs to be emphasized that the emerging women's movement endeavored to introduce women into public life, but did not demand that they should renounce their family life or maternal functions. To ease the tension between family obligations and women's market labor, one socialist commented that children could be raised 'collectively and effectively' in a proper institutional environment. 102 However, this idea of the collective nurturing of children was rejected by Kodisowa who recommended that mothers be compensated with higher wages and salaries in the workplace. 103 Kuczalska-Reinschmit also considered ideas for collective child-rearing "eccentric" and impossible to accomplish. 104 Moszczenska, castigated the feminists who denied women the right to their own [biological] bodies and who transferred the rights of child care to "qualified specialists" as if children were part of a manufacturing process. 105 Thus, the early feminists voiced a contradictory philosophy of women's liberation that exhibited their contempt for traditionalism, but at the same time identified familial duties as the

\footnotetext{
97 Moszczenska, "Mezczyna i kobieta," 140.

98 Turzyma, Wyzwalajaca sie kobieta, 1-15, 17, 24, 129, 132, 134, 141. For a detailed discussion of Turzyma's views on these issues see also pages $31,38,47,58,67,73,75,77,110,114,125-128,139,141$, $142,152,154,162,177$.

99 Paulina Kuczalska-Reinschmit, "Emancypacja a milosc," in Ogniwo, 48 (13/26 November, 1904), 11421144; and Kuczalska-Reinschmit, Mlodziez zenska, 27, 28, 30, 31, 36, 37, 38.

100 Meczkowska, Ruch kobiecy, 23.

101 For details see Chwalba, "Spor o wartosci," 271.

102 B. Darski, "Emancypacja i macierzynstwo," in Glos, 20 (May 4/16, 1896), 460-464.

103 Jozefa Kodisowa, Kwestja rodziny w sprawie kobiecej (Warsaw, 1909), 1-7.

104 Kuczalska-Reinschmit, “ Z historyi ruchu kobiecego,” (part II), 306, 308.

105 Isabela Mosczenska, "Kwestja kobieca w chwili obecnej," in Glos, 27 (21 June/4 July, 1903), 422-424.
} 
main social task of a woman. This dichotomy in ideology resulted in the imagery of women's organizations as being 'snobbish'. 106

Indeed, women's need to fulfill their societally determined family duties and responsibilities, especially in the given circumstances of imperial rule, ultimately thwarted the feminist attempts to radicalize the women's movement. The "nationalist" images of Polish women forced the 'woman question' to accommodate its revolutionary agenda with the exigent demands of Polish nationalism. While women assumed new identities in their economic, intellectual, and political engagements, the Polish Catholic heritage and the circumstances caused by the carving up of Poland into three spheres of foreign rule necessitated women to ultimately protect the 'home' as the last impregnable bastion of cultural and national "Polishness". This dual responsibility of women to defend Polish nationality and morality resulted in the image of the Matka-Polka, i.e., the Catholic model of the Polish mother struggling to defend Polish 'national identity'. For this reason, the programmatic structure of the Polish women's movement as a whole was less aimed at the freeing of women from male domination than preserving the national Polish heritage. The fight for cultural survival in the home was willingly undertaken by mothers who made sure that their families retained Polishness, patriotism, and love of national independence. The Matka Polka, as a vision of venerated motherhood, became the fortress against foreign oppression in the sacred sphere of private life. The image of the Matka Polka thus became the key to women's participation in Polish 'national community'.107

The implicit rigidity in the Matka Polka image implied that women's roles and obligations in the family took priority over their devotion to the goals of women's liberation and emancipation. The patriarchal model of the family and the national resistance movement which identified the family as the center of national life absorbed women in the affairs of the home and family. And any transformation in its formulaic conceptualization of the bonding between 'family' and 'nation' was equivalent to

106 Zarnowska, "Family and Public Life," 481; and Szwarc, "Krytyka kobiecosci," 303.

107 For images of the Matka-Polka, see Eva Stachniak, "Why Did We Not Become Feminists? Women in Poland," in The National Women's Studies Association, 7, 3 (Fall, 1995), 69-80, p.71; Skowronek, "Debiuty polityczne kobiet," 41; Zarnowska, "Prywatna sfera zycia rodzinnego," 11; Pietrow-Ennker, "Tradycje szlacheckie," 25; Barbara Jedynak, "Dom i kobieta w kulturze niewoli," in Barbara Jedynak, Kobieta w kulturze i spoleczenstwie (Lublin, 1990), 70-105, p.76; and Walczewska, Damy, rycerze, $i$ feministki, 53. For the idea of gender unity to fight germanization in Prussian Poland see Stegmann, "Wielkopolskie wzorce kobiecej aktywnosci spolecznej," 365-368; Chwalba, "Spor o wartosci," 270; and Rudolf Jaworski, "Polish Women and the Nationality Conflict in the Province of Posen at the Turn of the Century," in Jaworski and Pietrow-Ennker (eds.), Women in Polish Society, 53-70, pp.55, 64, 65. 
'treachery' to the principal goal of the restoration of the fatherland. 108 Thus, the question of women's emancipation remained of secondary importance. The popularly accepted image of women as mothers, concerned with the "patriotic mission" of educating their offspring in Polishness remained deeply embedded in the social consciousness. 109

For this reason, women either engaged in philanthropic efforts, 110 or in acts of passive resistance, 111 or supported parental self-help organizations to provide Polish instruction at home. 112 The revolution of 1905, in particular, allowed men and women to jointly participate in strikes and demonstrations, to create various cultural-educational societies and professional unions, and to struggle for Polish schools and courses for illiterates. They both also suffered from the police repression of the gendarmes. This in turn further strengthened the idea of solidarity, especially among women of various political and professional organizations. 113

From the above analysis of women's economic, intellectual, political, and 'national' roles, it is clear that Polish women's identities were in a state of flux in late partitioned Poland. The 'Woman Question' evolved from this changing women's imagery. The 'woman question' was a response to women's enhanced self-awareness of their individuality, to the changes in family patterns and gender relations, to the marked visibility of urban prostitution and abortion, to the juxtaposition of 'nationalism and feminism', and to the tensions between 'tradition' and 'modernity' in a politically repressive environment. However, discussions on the 'woman question' were moderated by a number of factors including tensions within the women's movement, the lack of

\footnotetext{
108 Pietrow-Ennker, "Frau und Nation im geteilten Polen," 129, 140.

109 Bogna Lorence-Kot, "Konspiracja: Probing the Topography of Women's Underground Activities: The Kingdom of Poland in the Second Half of the 19th century," in Jaworski and Pietrow-Ennker (eds.), Women in Polish Society, 31-51, p. 37; Chamerska, "Rola kobiet w mecenacie bibliotecznym," 293-294; Samus, "Socjalistki w Krolestwie Polskim," 194, 195; Sliwa, "Wzorzec osobowy kobiety-socjalistki w Polsce," p.232; and Nietyksza, "Tradycyjne i nowe formy," 84-86.

110 Bluszcz, 46 (12 November, 1938), 10; Caban, "Kobiety i powstanie styczniowe," 61; and Nietyksza, "Tradycyjne i nowe formy," 90.

111 Galician women, for example, were the first to observe the national mourning using traditional symbols of suffering such as wearing black dresses, black jewelry and black crosses. See Homola-Skapska, "Galicia," 72, 86. In 1883, women for the first time struck at the Zyrardow textile works. See KiZ, 7 (1 March, 1960), 2.

112 Kulczycki, School Strikes in Prussian Poland, 46, 157, 160, 161. In Poznan, women were best able to exercise their "citizenship' by promoting the study of the native language. See Kuczalska-Reinschmit, " $Z$ historyi ruchu kobiecego," (part II), 311.

113 Zarnowska, "Prywatna sfera zycia rodzinnego," 9; and Samus, "Socjalistki w Krolestwie Polskim," 204-205.
} 
women's solidarity, deep-rooted Catholicism, and foreign rule. For example, up to 1914, the Union for Equal Rights for Polish Women lacked any major influence among women from families of the gentry, landowners, workers, and peasants. On the contrary, the feminist elite disparagingly referred to women from the countryside and those from the working classes as 'younger sisters' in need of desperate intellectual awakening. 114

Further, many women themselves remained passive and apathetic to the "woman question' and viewed the women's movement as "excessive" and "premature". 115 The older generation, in particular, continued to accept their daughters position of dependence and subordination in marital unions. While parents in general had accepted the idea of encouraging their daughters to pursue higher education and market employment, they had yet to accept the goal of preparing girls to conduct life's responsibilities with independence and self-respect. 116

Meanwhile, some discussants of the 'woman question' were dismayed with the structure and organization of the women's movement and the content of it press publications. According to Kuczalska-Reinschmit, the women's movement in Poland lacked a systematic program of action. ${ }^{117}$ Mosczenska criticized periodicals such as Nowe Slowo and Bluszcz for publishing more 'data than actual discussion' of significant issues raised by 'intelligent and thoughtful' women. 118

While tensions between traditional and 'modern' interpretations of female morality and sexuality among women undermined the strength of the Polish women's movement, the "Catholic" and "nationalist" images of women further weakened the female voices in the "woman question". Catholicism, with its emphasis on the patriarchal model of the family, had to be given due respect in the face of anti-Catholic practices of the Prussians and Russians. 119 For this reason, the society formulated and regulated women's work and morality in deference to the traditional image of a devoted, sacrificing Matka Polka. This image required women to imbibe the qualities of self-sacrifice, selfabnegation, religious purity and patriotic fervor.

Polish women, no doubt, faced many social barriers and customary disapproval in challenging conventional patriarchy in late partitioned Poland. The voices of the "woman

114 Sierakowska, “Aspiracje polityczne,” 251, 252.

115 Bujwidowa, U zrodel kwestji kobiecej, 15. See also Turzyma, Wyzwalajaca sie kobieta, 104, 105.

116 Kuczalska-Reinschmit, Mlodziez zenska, 6, 7.

117 Kuczalska-Reinschmit, “ Z historyi ruchu kobiecego,” (part II), 334, 337.

118 Isabela Mosczenska, "Kwestja kobieca w chwili obecnej," in Glos, 25 (June 7/20, 1903), 390-392.

119 Zarnowska, "Kobieta w rodzinie robotniczej," 181-182; Chwalba, "Spor o wartosci," 283, 284; and Nietyksza, "Tradycyjne i nowe formy,” 84. 
question' were substantially weakened by the partitions of Poland and imperial rule. But Polish women were not alone in the moderated impact of their demands for personal liberation. Questions of sex, marriage, and family played a minor part in public discussions and activities of the 'woman question' in Imperial Russia. The discussants wanted a moderate amelioration of the condition of women, especially in education and employment opportunities, assuming that their role in the family would improve as these expanded. Only the nihilists insisted on total liberation and personal emancipation. 120 For this reason, Russian feminism never achieved a high degree of inter-group homogeneity since many women were reluctant to 'make a scene' in public. 121

In contrast to the Russian 'woman question', the Polish women's movement was constrained not only by social patriarchy, but also by the combined pressures of the Catholic Church and the Polish nationalist struggle in late partitioned Poland. In addition, the Russian annexation of a part of Poland impeded Russian and Polish women's solidarity. 122 The Polish women's movement was thus beset with religious and cultural difficulties, and suffered from a general lack of internal and international solidarity among women. 123 Despite the variations in standards and affiliations of the listeners and spokespersons of the women's movement, the Polish 'woman question' remained moderate and quite accommodating to the larger national interests of the partitioned country.

At the same time, however, while women's self awareness on the need for their personal emancipation was limited by several customary and 'national' barriers, the fact that the 'woman question' was being heard and discussed at various places was itself a sign of substantial progress. Certainly, resentment to the women's movement cut across all institutional and ideological boundaries. But, as Turzyma emphasized, the fact that such opposition "united the reactionary with the social democrat, the anti-Semite with the Kahalist, and the capitalist with the worker," provides sufficient proof that the "woman question' was not something thought up "by idle women of the middle class as the radicals maintained," or an "intrigue of subversives", or "the work of Satan", but resulted "from the general relationship of men to women". 124 Thus, while the membership of the

120 The nihilists adopted a revolutionary change in their dress and appearance, marked by short hair, cigarettes, and plain garments. Stites, The Women's Liberation Movement, 64, 101, 103, 104, 113.

121 Linda Edmondson, Feminism in Russia, 1900-1917 (Stanford, 1984), 53, 54.

122 Weeks, Nation and State, 33.

123 Wiktoria Sliwowska, "Kobiety w konspiracjach patriotycznych lat czterdziestych xix wieku," in Zarnowska and Szwarc (eds.), Kobieta i swiat polityki, 45-57, p.50; and Nietyksza, "Tradycyjne i nowe formy aktywnosci," 92.

124 Turzyma, Wyzwalajaca sie kobieta, 24. 
women's movement was more exclusive and linear, the audience of the 'woman question' included men and women with different economic, social, political, and ideological status.

A significant accomplishment of this "moderated" Polish women's movement was to raise important questions on women's health and hygiene in its discourse. The debate on women's professional and social emancipation also introduced discussions on women's individual physical appearance and personal health. Women's multiple economic roles, engendered by associated problems of prostitution, abortion, and reconfigurations in family life, raised questions of women's "proper" morality and sexuality, both of which impacted the development of women's participation in sports in late partitioned Poland. Thus, women's changing roles in economic, political, social, and scholarly work allowed them to provide intellectual strength to the developing women's physical culture.

The exigent concerns of feminists, hygienists, doctors, and pedagogues in the direction of physical culture contributed to the awareness of the importance of good health for girls and women. Indeed, women's participation in sports became more popular only with increasing societal interest in developing women's intellectual and physical attributes. Women received assistance from the more progressive sections in society who saw the importance of physical culture in fulfilling the biological, recreational and psychological needs of women. In the beginning, this interest in sport for women took the form of simple recreation rather than active competition. The idea of a "healthy mind and body" was targeted at improving women's physique not for her personal self as much as for the good health of her children yet to be born. For this reason, women's good health was perceived as important for making a 'healthy nation'. Moreover, the development of women's physical culture was patronized as an important curative remedy for women's supposed insomnia, migraines and paleness! Indeed, this kind of 'new education' was supposed to counterbalance women's presumed qualities of frivolity, incompetency, tractability, weakness, timidity, and artificiality. 125

Several prominent women discussed the importance of women's physical education in the discourse on the "woman question". For example, Iza Moszczenska,

125 Maria Rotkiewicz, "Geneza i poczatki sportu kobiecego w Polsce," in Sport Wyczynowy, 6-7 (1978), 5-23, p.7; Rotkiewicz, "U zrodel,”, 100-104; Bluszcz, 7 (17 February, 1912), 77; Gaj and Hadzelek, Dzieje kultury fizycznej, 54; Hadzelek, "Wychowanie fizyczne i sport," 18; Rotkiewicz, "Geneza i poczatki sportu kobiecego w Polsce," 7; Czajecka, "Z domu w szeroki swiat," 99, 100, 130, 237; Lidia Stanislawa Trybowska, Poczatki rozwoju sportu kobiecego w Krakowie do 1939 roku (Praca Magisterska, AWF Warsaw, 1978), 292-293; and Najdus, "O prawa obywatelskie kobiet," 103. 
Jadwiga Szczawinska-Dawidowa, Helena Landau, and Zofia Daszynska-Golinska all expressed concern over issues of women's physical and psychological development. Dawidowa, in particular, wanted more places for play and amusement, as well as gymnasium halls in girls' schools. 126 Kuczalska-Reinschmit wanted the education of girls to be "practical, professional and physical". She also wanted to ban the wearing of corsets in schools. 127 According to Dulebianka, male patriarchy was derived from masculine physicality. For this reason, women's physical culture was important for building their physical strength and to undermine traditional representations of women as weak and too emotional. ${ }^{128}$ Bujwidowa concurred that a new form of physical education and development of women must be part of future educational reform. 129

Another propagandist of women's physical culture, Dr. Justyna BudzinskaTylicka, favored the physical and moral emancipation of women. Born in Lomza in 1867, Tylicka worked in hospitals and in several women's social, charitable, sports, and feminist organizations, including the Union of Women's Emancipation and WKW. Within the PPS organization, Tylicka was active in the Rada Naczelna (Executive Council). ${ }^{130}$ According to Tylicka, changes in women's position in the domestic and public realms required a completely new approach to women's hygiene. Women's good strength and health was needed for them to successfully fulfill their responsibilities as mothers within the family and as workers in the labor market. Tylicka also favored limiting the number of offspring from both a "medical and social perspective". She emphasized the need to reform young girls' "physical upbringing" so as to create a "legion of women of healthy body and strong spirit who understood the importance of health and physical regeneration". Tylicka also addressed deformities caused by excessive wearing of corsets and improper footwear, as well as the "correct" postures of women for riding on bicycles. ${ }^{131}$

Further, the writings of Maria Weryho-Radziwillowiczowa and the sports activities of Noble prize winner, Marie Curie Sklodowska (1867-1934), provided more support to the development of women's physical culture in late partitioned Poland. The Curie family stressed the importance of sport, physical activity and tourism for

126 Marcinkowska-Gawin, “Jadwiga Szczawinska-Dawidowa, Iza Moszczenska, Helena Landau i Zofia Daszynska-Golinska," 256, 260.

127 Kuczalska-Reinschmit, Nasze cele i drogi, 14, 15, 24.

128 Marya Dulebianka, "O tworczosci kobiet," in Turzyma and Bujwidowa (eds.), Glos kobiet w kwestyi kobiecej, 163-197.

129 Bujwidowa, "Wyksztalcenie kobiet,” 21, 22.

130 AMR, notes.

131 Justyna Budzinska-Tylicka, Hygiena kobiety i kwestje spoleczne z nia zwiazane (Warsaw, 1909), 2-4. 
maintaining the "harmony" and "attractiveness" of family life. Marie Curie is also looked upon as the creator of "family sports activity". Curie's interest in cycling, rowing, swimming, and tourism, made her a role model for other sports-conscious women in Russian Poland. 132

The importance of women's physical culture and hygiene was raised at the various meetings of the Union of Women's Emancipation. 133 Sports such as rowing, cycling, skating, gymnastics, and dance were considered as very healthy activities in the report of the Polish women's meeting in Warsaw on 10 April 1907.134 The necessity of reforming physical education for girls was discussed at the general meeting of members of the Union of Emancipation for Women on March 12 and 13, 1910.135 Once again, the issue of women's good health and fitness was raised at the second major conference of Polish Women in September 1917, organized under the auspices of several women's organizations such as the Union of Emancipation for Women in Warsaw, the League of Women for Military Preparation, the Union of Polish Women's Societies, and the Polish Society for the Emancipation of Women. This meeting, presided by PPS member, Dr. Justyna Budzinska-Tylicka, was attended by 1015 members, including representatives of women's sports societies such as the Warsaw Women's Oaring Club and Grazyna. ${ }^{136}$

At the beginning of the 20th century, the Pabianickie Towarzystwo Rownouprawnienia Kobiet (Pabianice Women's Emancipation Union) also demanded women's admission to activities which thus far had been dominated by the men. This inspired women's struggles in the region not only to open more avenues for women in the political, professional and educational streams, but also to improve women's hygiene and health. No doubt, the development of women's sport in Pabianice was limited by the difficult political conditions. Still, their demands to be 'sportive' contributed to the 'modernization' of women's life in this region. 137

132 Radziwillowiczowa authored the book Gimnastyka dla dzieci w wieku 4-9 lat (Warsaw, 1887). For more on Rodziwillowiczowa see Wroczynski, "Wychowanie fizyczne w mysli pedagogicznej," 106; and $\underline{\text { Ster, }} 5$ (1 March, 1912), 2. For Marie Curie see Sport, 52 (13/26 December, 1903), 3; Trybuna, 280 (1993), 12; and Kalendarium XX wieku, 1 (1900-1903), 29. For details on the Curie family see Maria Rotkiewicz, "Turystyki i sport w zyciu rodziny Marii Sklodowskiej-Curie," in Zofia Zukowska (ed.), Kobieta jako kreatorka aktywnosci sportowej w rodzinie (Warsaw, 1998), 37-49; and John Senior, Marie and Pierre Curie (Gloucestershire, 1998), 46.

133 Rotkiewicz, "Sport kobiet," 275; Rotkiewicz, "U zrodel," 100-104; and AMR, notes.

134 Ruch, 24 (26 December, 1907), 260-263.

135 Ster, 3 (March, 1910), 129.

136 Rotkiewicz, "Sport kobiet," 275, 276, 277; and Rotkiewicz, "Geneza i poczatki," 7.

137 Zenona Adamczewska, Poczatki i rozwoj sportu kobiecego w Pabianicach (Praca Magisterska, AWF Warsaw, 1976), 21, 62. 
The importance of women's physical culture was discussed not only at various meetings of the women's organizations, but also in women's periodicals. While traditional attitudes restricted women's active participation in sport before 1905, this conservative social opinion did not decry the growing concerns for women's health and hygiene in general. Several women's periodicals and journals, as well as other publications at this time regularly published articles on the need to improve the diet and physical health of women. For example, periodicals such as Bluszcz, Ster, Zdrowie, Przodownica (Leader), Zorza, and Przyjaciela Ludu discussed the importance of good moral and physical hygiene of children and women. Zdrowie, edited by Jozef Polak, was the first important periodical that talked about the medical, educative, and prophylactic benefits of physical education and good hygiene for women in Poland. The women's periodical Bluszcz also discussed issues of health and hygiene of women, as well as the institutions and organizations of physical education and sports for women. Ster, along with other journals, reported on the sporting accomplishments of women in other parts of the world, as well as published a discussion of meetings of international conferences on women's health and hygiene. 138

No doubt, there were critics of women's physical education. For example, Julia Goczalkowska, an advocate of conservative Catholicism in Galicia, put forward antiemancipationist brochures and reaffirmed the traditional woman's place in the home and family. She spoke against the intellectual, economic, and political advancements for women, and even discouraged the importance of physical education for women. 139 Some women argued that questions of women's hygiene were the concern of doctors, not

138 See Bluszcz, (1868); Bluszcz, 31 (23 July/ 4 August, 1869), 194-196; Bluszcz, (1870); Bluszcz, (27 January/ 8 February, 1871), 47-48; Bluszcz, (17 February/1 March, 1871), 71; Bluszcz, 31 (21 July/ 2 August, 1871), 242-243; Bluszcz, 9 (26 February, 1910), 96; Ster, X-XI (October-November, 1908), 378; Ster, 4 (April, 1910), 183; Ster, 11-12 (November-December, 1910), 379; Ster, 13-14/70-71 (July-August, 1912), 7; Ster, 11-12 (November-December, 1910), 371; Rotkiewicz, "U zrodel," 100-104; Krystyna Zofia Kwiatosinska, Problematyka higieny $i$ wychowania fizycznego kobiet na lamach miesiecznika Zdrowie (1885-1933) i Zdrowie Publiczne 1934-1939 (Praca Magisterska, AWF Warsaw, 1980), 1, 110, 113; and Ewa Kaczkowska-Duda, Problematyka wychowania fizycznego i sportu kobiet na lamach tygodnika Bluszcz w okresie 1865-1939 (Praca Magisterska, AWF Warsaw, 1980), 3. Similar ideas of the importance of women's good hygiene, diet, and physical fitness were discussed in works such as Dr. Wladyslaw Hojnacki, Hygiena Kobiety (Warsaw, 1903); J.P. Muller, Moj system dla kobiet: jedyna droga do utrwalenia zdrowia oraz rozwoju i zachowania pieknosci (Warsaw, 1912), 3, 4; and Aniela Szye, "Udzial kobiet $\mathrm{w}$ wychowaniu fizycznym i koniecznosc przygotowania sie do tej roli," in Zdrowie, 9 (September, 1904), 719-736. See also Maria Rotkiewicz, "First women's sport organizations in Poland," in Wychowanie Fizyczne i Sport, 3 (1975), 37-43, pp.37-38; Chwalba, "Kobiety w zyciu politycznym," 132; Najdus, "O prawa obywatelskie kobiet," 110-112; and Tuszynski, Prasa i sport, 66.

139 Wasztyl, Wychowanie fizyczne, 97; and Czajecka, "Wokol wyksztalcenia kobiet w Galicji," 49. See also Czajecka, "Z domu w szeroki swiat," 14, 15, 237. 
the proponents of the 'woman question'. 140 Since the Polish women's movement was the weakest in Prussian Poland, the discussion on women's physical culture was extremely limited in this partitioned zone. Up to 1871 , there was no physical education for girls. Only toward the last decade of the 19th century did some women begin to appear in a rudimentary physical culture. Professional schools, such as the trade schools in Poznan, took the lead in discussing ideas of women's physical education. ${ }^{141}$

The discourse on women's health and hygiene was more pronounced in Austrian Poland, and best articulated in Russian Poland, especially after 1905. Popular advertisements at the beginning of the twentieth century in Russian Poland gradually portrayed images of the 'modern woman' with a new lifestyle and values. Advertising for women included cosmetics, hygiene issues, perfumes, books, new fashions in clothing (including the latest trends in sports costumes for women), shoes, jewelry, furniture, musical instruments, and schools and courses for women and girls. These advertisements probably catered to an audience that was wealthy and with much more leisure time. Still, it must have encouraged women from other social and economic backgrounds, especially the younger generation, to become more aware of these eclectic opportunities. ${ }^{142}$

While the notion of maternal well-being legitimized the efforts of Polish women to build their physical culture in late partitioned Poland, similar ideas of the importance of physical education and sport for improving the social and national contributions of mothers were being emphasized at the same time in other western countries. The participation of the gentle sex in the "sports of man" was now becoming more and more a song of the times and an indication of the "emancipation of woman". 143 While some western feminists perceived the importance of sports as an avenue and means to women's liberation, others supported women's physical culture to improve women's poor health and to promote 'race regeneration'. 144 English bourgeois women, in particular, used

140 According to Nalkowska, the hygienic conditions of women, especially the prostitutes, was the concern of doctors, not the women's movement. See Zofia Rygier-Nalkowska, "Uwagi o etycznych zadaniach ruchu kobiecego (referat wyglosony za zjezdzie kobiet)," in Krytyka, 11 (November, 1907), 358-363.

141 Teresa Ziolkowska, "O rozwoju sportu wsrod kobiet polskich,” 203; Gaj and Hadzelek, Dzieje kultury fizycznej, 48; and Ziolkowska, Kultura fizyczna w Poznaniu, 134.

142 Agnieszka Janiak-Jasinska, "Kobieta jako adresat ogloszen prasowych w Krolestwie Polskim na poczatku xx wieku," in Zarnowska and Szwarc (eds.), Kobieta i kultura zycia codziennego, 171-180, pp.172, 173, 175-178; and Chyra-Rolicz, "Pionierki w nowych zawodach," 234. See also Aleksandra Latek and Maria Rotkiewicz, "Ewolucja kostiumu sportowego kobiet jako ilustracja przemian obyczajowych," in Bernard Woltmann (ed.), Z najnowszej historii kultury fizycznej w Polsce, III (Gorzow, 1998), 301-312.

143 The Rand Daily Mail, (18 July, 1904), 5.

144 Vertinsky, "Body Shapes," 256-281; and Cahn, Coming on Strong, 12. 
physical activity creatively to reinterpret Social Darwinism in a way which legitimated a freer, more positive mode of physical expression, arguing persuasively that healthier women were more feminine and functional for national well-being. Even in America, the healthier female body was seen to be able to bear more healthy children and 'save' the race against an increasing immigrant population. 145

Further, some physical educators and women's advocates saw sport as an avenue toward female self-reliance and independence. Some outspoken feminists became avid athletes, creating an early association between women's liberation and sports in western physical culture. ${ }^{146}$ The schools and universities for the education of upper-and middleclass women provided the first institutional settings for female physical education and sports. With their programs in physical education, the women's colleges were able to emphatically disprove the hysterical claims of male medical practitioners and defy traditional middle-class convention. ${ }^{147}$ These 'physical education mistresses' used exercise and sport in their programs to prove that young women were capable of attending college and studying the same subjects as men. ${ }^{148}$

Meanwhile, urbanization and new technological developments brought many sports to new indoor facilities. For example, the first public gymnasium for women in America was opened in New York City in 1889.149 The rapid expansion and commercialization of leisure in late 19th and early 20th century America further altered the traditional structure of such popular working-class activities as dancing and excursion-going. Many young women, particularly the daughters of immigrants, came to identify 'cheap amusements' as the embodiment of American urban culture. Huge dance palaces and large amusements parks beckoned young women who desired spaces for

145 McCrone, Sport and the Physical Emancipation; Hargreaves, Sporting Females,111; Boutilier and SanGiovanni, The Sporting Woman, 33, 34; and Twin, Out of Bleachers, xxiv. See also The Rand Daily Mail, (18 July, 1904), 5.

146 Cahn, Coming on Strong, 19; Nelson, The Stronger Women Get, 13, 15; and Woolum, Outstanding Women Athletes, 6.

147 Guttmann, Women's Sports, 106, 108, 117; Woolum, Outstanding Women Athletes, 7; Cahn, Coming on Strong, 18; and Hargreaves, Sporting Females, 57, 61, 63, 78, 83, 85.

148 McCrone, Sport and the Physical Emancipation; Shelia Fletcher, "The Making and Breaking of a Female Tradition," in Mangan and Park (eds.), From "Fair Sex" to Feminism, 145-157; Park, "Sport, Gender and Society," 76-81; Blue, Grace Under Pressure, 106; Cahn, Coming on Strong, 13, 17; Hargreaves, Sporting Females, 8, 9; Guttmann, Women's Sports, 124, 129; Spears and Swanson, History of Sport, 140, 187; and Joanna Davenport, "The Eastern Legacy: The Early History of Physical Education for Women," in Quest, 32 (2) 1980, 226-236.

149 Woolum, Outstanding Women Athletes, 6. 
personal freedom and unsupervised fun. These new manners and mores permitted women to experience self-determined pleasure, sexuality and autonomy. 150

Thus, the development of Polish women's physical culture, similar to their western counterparts, was integrally related to the "woman question" in late partitioned Poland. The situation of Polish women in all three zones of partitioned Poland was determined by the traditional patriarchal structure and repercussions resulting from statelessness and foreign rule that meant the preponderance of struggles for national independence and self-determination over the demands for equal rights for women. The Polish women's movement remained subordinate to the larger struggles for Poland's freedom. Although women participated in various aspects of cultural, social and 'national' life, they entered the public domain under the triple scrutiny of the Catholic church, the individual partitioning power, and a patriarchal society that not only disapproved the formation of women's organizations but also institutionalized the subordination of women to men in daily life. Under these circumstances, the maternal role could alone acquire a special elevated status, as the family organization proved ultimately to be the only safe sphere in which Polish national culture could be completely preserved and passed on to the next generation. Indeed, the ordinary Polish home, under the guardianship of the mother, became a center for education in patriotism and national polskosc identified with the Polish language and the Catholic faith. At all times, women's first priority was to foster national identity and to maintain their Catholicism and Polishness.

However, this is not to suggest the complete passivity of women in the Polish Diaspora. On the contrary, the permanent state of emergency of Polish society throughout the whole period confronted Polish women with responsibilities that far exceeded their usual sphere of activities, forcing them to forge their own identity in the professional, political and other public spheres. Women's participation in building national consciousness through their family roles, their conspiratorial work as messengers and in underground publications, their philanthropic and humanitarian activities, their military role in cavalry and terroristic assaults, their intellectual work in salons and in the legal and non-legal academic institutions, their cultural advancement through art, theater, ballet, music and literature, and their leadership role in the family, especially in the absence of men who were arrested or deported, or who migrated to the towns, were some

150 Kathy Peiss, Cheap Amusements: Working Women and Leisure in Turn-of-the-Century New York (Philadelphia, 1986), 5, 8, 186, 188. 
ways that helped in the making of the Polish women's movement. Further, the gradual industrialization and modernization of the economy, and by consequence of this, the general increase in numbers of working women and their entrance into many professions could not but have an impact on their self-image and on their role within the family. Women's work in the various trades, services, and industries, as well their participation in the struggles for national liberation, affected their self-consciousness and social identity in the family toward greater self-independence. As a consequence, women also began to aspire greater personal independence and professional preparedness.

In this context of women's increasing self-awareness, women's participation in sports was perceived as important for reasons of improving their health, strength, and physical fitness. However, women's physical development was considered beneficial not for reasons of personal enjoyment. Rather, women's improved physicality enabled them to better serve their traditional responsibilities of motherhood and assist them to endure their new economic roles in the market place. This harmonious juxtaposition of women's physical liberation with their "proper" roles in the family and in the "nation" was consistent with their larger struggles for national independence and accommodation with the predominant conservative patriarchal attitudes. While their physical culture called into question the preexisting viewpoints regarding women's place in society, their moderate participation in sports did not radicalize the "woman question" which contested the new and more modern conceptualizations of gender relations in the private and public spaces in late partitioned Poland. This successful balance of 'tradition' with 'modernity' in women's physical culture will now be examined in the context of which sports were perceived as "appropriate" for them to participate and which were deemed to threaten a radical departure from the patriarchal and nationalistic construction of the Polish society. Once again, comparisons will be made with women's sports in the west so as to highlight the similarities and differences in the Polish women's physical culture.

\section{Women's Sports in Late Partitioned Poland}

At the turn of the century, and especially in the beginning of the 20th century, many sports became popular among women in all three partitioned zones of Poland. Their participation in different sports was facilitated with the emergence of the 'women's question', i.e. discussions on women's right to have equal access to political participation, university education, and economic opportunity. Women's participation in physical culture was thus related to the broader movement for their emancipation, as well 
as with a departure from traditional conventions which held exercises harmful to the women's physique and household responsibilities. Further, the physical emancipation of Polish women was directly related to the evolution of a "modern" Polish civil society which matured under and in response to foreign rule. No doubt, playing a sport does not make an individual any more or less "modern". However, Polish women began to formulate their physical culture in a "modern" ambiance identified by a number of "questions" such as the "national" question and the "woman" question. While these social, economic and political processes of modernization did not suddenly transform partitioned Poland into an "advanced" Western-style "civilization", they nonetheless initiated an ongoing re-imagining of gender relations in the three partitioned zones. While the fin de siecle period in the West was characterized with the rhetoric of progress and the exhilarating sense of the birth of a new age, fin de siecle Poland, under foreign rule, espoused a rhetoric of modernity which was very nationalistic, "populist", racist, "masculine", and Catholic in orientation. In both cases, women adhered to forms of participation, adjustment, and resistance in an increasingly mobile society which, at that time, seemed to constitute a radical break with the past. 151 But Polish women, faced with additional burdens of religious and nationalist politics in a colonial-like environment, remained more cautious in transgressing the traditional gender boundaries than their western counterparts. Their hesitancy in challenging social and religious patriarchy was evident in the forms and ways in which they participated in various sports in the Polish Diaspora. The following section will examine which sports Polish women played in this context and question the creation of "feminist consciousness" in women's physical culture.

Among the different sportswomen, women cyclists in partitioned Poland made their appearance in the 1880s. In 1895, women in Gdansk formed a cyclist club called Violetta. Karolina Kociecka won the first bicycle race for women in Poland in 1897. A few traditionally male sports societies, such as the Warszawskie Towarzystwo Cyklistow (Warsaw Cycling Society) and the Towarzystwo Automobilistow Krolestwa Polskiego (Society of Automobilists in the Kingdom of Poland, 1908) also permitted women to join their ranks as members. As such, women's cycling was perceived as 'fashionable',

151 See Porter, When Nationalism Began to Hate, 42; Rita Felski, The Gender of Modernity (Cambridge, Massachusetts, 1995), 22, 30; and Robert Blobaum, "The "Woman Question" in Fin-De-Siecle Poland," (Unpublished Paper), 1. The modern Polish nation called into being new and populistic forms of nationalism. See Andrzej Walicki, "Intellectual Elites and the Vissitudes of 'Imagined Nation' in Poland," in Suny and Kennedy (eds.), Intellectuals and the Articulation of the Nation, 259-287, p.281. 
especially in Russian Poland where advertisements for bicycles and tricycles for women became increasing popular at this time. However, the press, at times, refrained from mentioning names of these amateur cyclists so as not to 'prejudice or injure the good opinion of ladies'. 152

From a comparative perspective, women's cycling was becoming popular among middle and upper class women on both sides of the Atlantic in the late 19th century. The bicycle not only increased women's leisure options but also played an important part in liberating nineteenth-century women from rigid Victorian standards of acceptable dress and appropriate public displays of athleticism and social propriety. Bicycling in moderation was now said to even cure the supposed common ailments of women such as dyspepsia, torpid liver, nervous exhaustion, and melancholia. 153

Unfortunately, the lady cyclist was also the subject of much ridicule and she continued to risk public censure. 154 In France, moralists and physicians mocked female cyclists for abandoning household duties and jostling their reproductive organs. 155 In Russia, cycling's accessibility to women and the need to dress in appropriate public costume for this sportive endeavor sharpened the woman question. 156

In other sports, the number of women mountain climbers increased in late partitioned Poland, especially in the years 1908 and 1909. Indeed, women expressed a real fascination with mountains and displayed a passion for conquest. Women mountain climbers, such as Lucja $\mathrm{z}$ Giedroyciow-Rautenstrauchowa, were a real source of inspiration for the women's emancipation movement. Unfortunately, these 'legends' of Polish sport were forced to mountain-climb in long skirts! There are also references to women mountain-climbers in nineteenth-century France and Russia. ${ }^{157}$ In Imperial

\footnotetext{
152 For women's cycling and the accomplishments of Karolina Kocieka see Liponski, Dzieje sportu polskiego, 20, 21, 23, 24, 25; Cyklista, 38 (7/19 September, 1896), 5; Cyklista, 37 (31/12 September, 1896), 13; Kolarz, Wioslarz i Lyzwiarz, 26 (1901), 7; Sport, 15 (23 June, 1922), 251; Kolarz, Wioslarz i Lyzwiarz, 72 (1900), 8; Kolarz, Wioslarz i Lyzwiarz, 16 (1901), 4, 5; Kurjer Sportowy, 44 (1933), 2; Rotkiewicz, "Geneza i poczatki," 17, 20; Janiak-Jasinska, "Kobieta jako adresat ogloszen prasowych," 173, 174; Bernard Szymanski, Poczatki oraz rozwoj sportu kobiecego w Plocku $i$ w Wloclawku do 1939 roku-analiza porownawcza (Praca Magisterska, AWF Warsaw, 1979), 38; Echo Plockie i Wloclawskie, 43 (1904), 1; and AMR, notes.

153 Park, "Sport, Gender and Society," 76-81; Nelson, The Stronger Women Get, 13; Lenskyj, Out of Bounds, 19; Cahn, Coming on Strong, 15; McCrone, Sport and the Physical Emancipation; and Blue, Grace Under Pressure, 102, 104.

154 The Netal Witness, (May 22, 1896).; Nelson, The Stronger Women Get, 13; Lenskyj, Out of Bounds, 21; and Twin, Out of Bleachers, xxvi.

155 Stewart, For Health and Beauty, 163.

156 Kelly and Shepherd (eds.), Constructing Russian Culture, 78.

157 Maria Rotkiewicz, "Pionierki gorskich szlakow turystycznych w Polsce," in Kultura Fizyczna, 7-8 (1995), 1-10; Bluszcz, 36 (3 September, 1927), 11; and AMR, notes. For illustrations of French female
} 
Russia, Maria Preobrazhenskaya, a teacher at a religious school for girls in the town of Vladikavkaz, became the first woman to ever set foot on the summit of Mount Kazbek in August 1900. 158

Horse-riding, a traditional elite sport in Poland, was popular among the privileged women. Special riding schools were founded for these upper class "amazons" for whom horsemanship was a social obligation. 159 In the other western countries, however, women were not yet allowed to ride astride, still less flaunt themselves in breeches. 160

Skating was one of the most popular Polish women's sports at the turn of the century, especially after 1905. This sport was looked upon as being very healthy, "relaxing", and excellent for women. For this reason, skating, which supposedly fostered a spirit of comradeship and culturedness, attracted women in all three zones of partitioned Poland. However, the skating rink served more as a place for fashion, music and orchestra, for learning the most recent happenings and scandals, and an opportunity to search for young men in matrimony. 161

Around 1910, there emerged the first women's field hockey team in Lwow. ${ }^{162}$ This game, however, was more popular among English sportswomen who, clad in longsleeved, ankle-length dresses, attempted to wield hockey sticks forcefully. However, storming the male citadel of field hockey in England proved challenging. Some argued that this sport broadened the hands and feet of girls. Others wanted field hockey to be substituted by lacrosse, a sport more 'graceful and attractive for women's appearances'. 163

Lawn tennis began to make inroads into Polish sports in the 1880 s. It was basically a game for the rich since the expensive racquets and balls had to be imported

mountain-climbers see Cicely Williams, Women on the Rope: The Feminine Share in Mountain Adventure (London, 1973).

158 Soviet Woman, 4 (1958), 18, 19.

159 Maria Rotkiewicz, "First Women's Sport Organizations in Poland," in Renson, Roland, Pierre Paul de Nayer and Michel Ostyn (eds.), The History, the Evolution, and Diffusion of Sports and Games in Different Cultures: Proceedings of the Fourth International HISPA Seminar, Leuven, Belgium, April 1-5, 1975, Dept. Lichamelijke Opvoeding. HISPA, Brussel: B.L.O.S.O., 1976 (Bestuur voor de lichamelijke opvoeding, de sport en het openluchtleven, 1979), 479-489, p.481; AMR, notes; and Dr. Wladyslaw Hojnacki, Z dziedziny sportu: kobieta a sport i sport jazdy konnej (Warsaw, 1905).

160 See Derek Birley, Land of Sport and Glory: Sport and British Society, 1887-1910 (Manchester, 1995), 123.

161 Wasztyl, Wychowanie fizyczne i sport, 196, 203; Gaj and Hadzelek, Dzieje kultury fizycznej, 48, 82; AMR, notes; Liponski, Dzieje sportu polskiego, 20, 21, 24, 25; Rotkiewicz, "Geneza i poczatki," 17, 20; and Trybuna, 280 (1993), 12.

162 AMR, notes.

163 Twin, Out of Bleachers, xxvi; Guttmann, Women's Sports, 108, 123; Derek Birley, Playing the Game: Sport and British Society, 1910-45 (Manchester, 1995), 37; Birley, Land of Sport, 95, 254, 255; and The Transvaal Leader, (January, 1903). 
from England. Women were required to play in a long white skirt and a wide straw hat, both of which needed to remain in an immaculate condition throughout the game. Often families used tennis to allow their daughters to find suitable partners in matrimony. 164 Even in Britain, this elitist game was considered appropriate for women because it allowed for a skirt reaching to the ankles and it was not usually a matter of hard hitting. 165

Basketball in Poland was inaugurated by women and was considered the "best" sport for young women. 166 Physical education instructors such as Jadwiga Mayowna and Maria Germanowna helped to popularize basketball for women in Krakow and Lwow respectively. Their experiences in England acquainted them with this new game and they actively promoted the sport in Galicia. The first public competition in women's basketball took place on 29th April 1909. However, women were required to play in constrictive long skirts. 167

Women's basketball remained a popular sport not only in Poland, but in other countries as well. In America, for example, this was the first team sport in which women engaged, and because it was a vigorous game with the potential for roughness, women's participation quickly became highly controversial. Special women's basketball rules were subsequently designed to minimize exertion and physical contact, and its main feature, the divided court, lasted until the early 1970s in America. 168

Perhaps the most "important" women's sporting, social and 'national' organization was the Women's Oaring Club, WKW in Russian Poland. Formed in May 1912, this first women's sports club pioneered women's sport and physical culture in the Polish Diaspora. This association, under the first presidency of Wanda Stokowska, and with the help of the three large male sports societies in Warsaw, WTW, WTC, and WTL, conducted many sportive and social activities for women. 169 The festive inaugural

\footnotetext{
164 For details see Liponski, Dzieje sportu polskiego, 20, 21, 24, 25; Rotkiewicz, "Geneza i poczatki," 17, 20; and AMR, notes.

165 Birley, Playing the Game, 37; Birley, Land of Sport, 83; and Woolum, Outstanding Women Athletes, 9.

166 Przeglad Sportowy, 71 (13 April, 1999), 5; Hadzelek and Wroczynski, "Rozwoj wychowania fizycznego i sportu," 59; Trybuna, 280 (1993), 12; and AMR, notes.

167 Rotkiewicz, "Prekursorki wychowania fizycznego dziewczat w Polsce," 114; and Maria Rotkiewicz and Aleksandra Latek, "Maria Germanowna i poczatki koszykowki kobiet w Polsce (do 1939 r.)," in $\underline{\text { Sport }}$ Wyczynowy, 3-4 (1995), 71-86, pp. 72-77.

168 Cahn, Coming on Strong, 16, 85, 107-109; Woolum, Outstanding Women Athletes, 7; Twin, Out of Bleachers:, xxv, xxvi; Nelson, The Stronger Women Get, 14; Park, "Sport, Gender, and Society," 58-96; and Guttmann, The Erotic, 2.

169 Bluszcz, 14 (5 April, 1930), 13; Rotkiewicz, "Rozwoj spolecznych organizacji sportu kobiet w Polsce," 72; AMR, notes; Hadzelek and Wroczynski, "Rozwoj wychowania fizycznego i sportu," 59; KiZ, 32 (6 August, 1978), 15; and Ziolkowska, "Rozwoj sportu wsrod kobiet polskich,” 204.
} 
ceremony of this club was attended by J. Bojanowska, Vice-President of the Union of Polish Women's Emancipation. 170 Despite financial and political difficulties, membership lists of WKW became longer. ${ }^{171}$ This increase in the number of members was a reflection of the extensive sports, educational, cultural, and social program of WKW. These organizational and infrastructural details, as well as regular publications in matters of sports and hygiene, were financed through donations, gifts and membership registration fees. 172 WKW also received financial help from Grazyna, the illegal women's department of Sokol in Warsaw. 173 The WKW, along with other circles of oarswomen, helped to raise women's consciousness and contributed to the ongoing debates on women's emancipation. ${ }^{174}$ Meanwhile, even in Britain, rowing, or boating as it was usually called in its gentler feminine form, had such high status that the proximity of a river was a social asset not to be ignored. 175

The sport of 'automobilism' also made its appearance in partitioned Poland. But there were few women car-racing enthusiasts in Poland and elsewhere. The members of the elite Ladies' Automobile Club of Great Britain and Ireland were essentially motor tourists and not competitors in car-racing. In France, Mme. Camille du Gast, an automobile enthusiast, insisted on her essential femininity by telling about stopping to assist a hurt driver. Similar attitudes of social patriarchy permeated partitioned Poland, though Jerzowa Zdziechowska's participation in the first race in Polish lands on 4-6 July, 1913 served as a powerful symbol of changing gender relations. 176

A number of private institutes and individuals propagated the importance of gymnastics for women in the various parts of partitioned Poland. The Swedish system of gymnastics appeared in Poland in the 1890s and exerted a strong influence on the physical education of women. The Royal Central Gymnastic Institute in Stockholm trained many Polish women teachers of gymnastics. Of equal importance were the gymnastic courses led by Elli Bjorksten of Finland and Agnete Bertram of Denmark. 177

\footnotetext{
170 Ster, 9-10 (10-25 May, 1913), 67.

171 Ruch, 1 (11 January, 1914), 12.

172 See Statut Warszawskiego Klubu Wioslarek (Warsaw, 1912), 5, 6, 14, 15; and Bluszcz, 17 (26 April, 1913), 184. See also Rotkiewicz, "Sport kobiet," 274; and Rotkiewicz, "Geneza i poczatki," 21, 22. According to Rotkiewicz, in 1912 there were 30 members in WKW and in 1913 there were 175.

173 Schwarzer, "Towarzystwa i kluby wioslarskie," 28.

174 Ster, 9-10 (10-25 May, 1913), 67.

175 Birley, Land of Sport, 100.

176 Sean O'Connell, The Car and British Society: Class, Gender and Motoring 1896-1939 (Manchester and New York, 1998), 46, 48, 51; John Lowerson, Sport and the English Middle Classes, 1870-1914 (Manchester, 1993), 219, 220; Stewart, For Health and Beauty, 168; and AMR, notes.

177 Ryfowa, "Polska kultura fizyczna," 230-231; Rotkiewicz, "U zrodel," 100-104; Maria Rotkiewicz, "The Scandinavian Influence on Women's Physical Education in Poland (till 1939)," in Marjo Raivio (ed.),
} 
Helena Prawdzic-Kuczalska's Institute of Swedish Gymnastics and Massage (Warsaw, 1892-1915) laid the beginnings of women's gymnastics in the Russian partition of Poland. Kuczalska stressed the importance of gymnastics as an important factor in education for women. ${ }^{178}$ The employment of women gymnastic instructors in this institute provided a source of new and profitable professional work for women. ${ }^{179}$ Many of the institute's students organized their own gymnastics establishments in different Polish towns. Most of the members of these private institutes were women of wealth, though Kuczalska's institute did admit poorer girls as well. 180

Kuczalska's influence was not only limited to her own institute of gymnastics. Under her initiative, more societies were founded that stressed the importance of women's health, rest, recreation, and the idea of solidarity. ${ }^{181}$ Kuczalska also served as one of the Polish representatives (along with W.R. Kozlowski and E. Piasecki) at the gymnastics conference in Brussels in 1910. In addition, Kuczalska took part in the International Congress of Physical Education in Paris 1913, where she was accompanied by a group of 23 Polish teachers. ${ }^{182}$

Janina Maria Mieczynska-Lewakowska (1888-1981), teacher of rhythmic gymnastics and professor of art in schools in Lodz and Warsaw was another important

Proceedings of the Jyvaskyla Congress on Movement and Sport in Women's Life, August 17-21, 1987, Jyvaskyla, Finland. Reports of Physical Culture and Health, 66, Vol. 1 (Jyvaskyla, 1989), 152-163, pp. 152, 153, 159, 160; and Gaj and Hadzelek, Dzieje kultury fizycznej, 36. The importance of gymnastics for

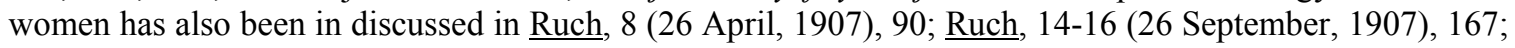
and Ruch, 18-20 (26 October, 1907).

178 Several authors have discussed the organization of Kuczalska's gymnastic institute and its larger significance for the development of women's physical culture in Russian Poland. See for example, K. Hadzelek, "Foundation and Development of the Academy of Physical Education in Warsaw," in Wychowanie Fizyczne i Sport, 26, 1 (1982), 79-101, pp. 80-81; Rotkiewicz, "U zrodel," 100-104; Rotkiewicz, "First women's sport organizations in Poland," 38-39; Gaj and Hadzelek, Dzieje kultury fizycznej, 54, 69; Ziolkowska, "Rozwoj sportu wsrod kobiet polskich w okresie zaborow," 204; Hadzelek and Wroczynski, "Rozwoj wychowania fizycznego i sportu," 44; and Rotkiewicz, "The Scandinavian Influence," 152; Sport, 48 (2 December, 1905), 18; Ruch, 10 (26 May, 1909), 233; Ruch, 6 (26 March, 1909), 71-72; and Ruch, 24 (26 December, 1907), 260-263. See also Bluszcz, 43 (27 October, 1907), 491; Bluszcz, 21 (23 May, 1909), 235; and Bluszcz, 14 (6 April, 1912), 165.

179 Bluszcz, 6 (9 February, 1908), 66.

180 Rotkiewicz, "U zrodel," 100-104; Rotkiewicz, "The Scandinavian Influence," 157; Jakubowski, Wybrane zagadanie, 221; and Skawinski, Kultura fizyczna na Lubelszczyznie, 12.

181 For examples of these new organizations see Sport, 49 (9 December, 1905), 21; Ruch, 3-5 (11 March, 1907), 37, 48; Bluszcz, 48 (27 November, 1926), 1530-1531; Ziolkowska, "Rozwoj sportu wsrod kobiet polskich w okresie zaborow," 204; Rotkiewicz, "U zrodel," 100-104; AMR, notes; Rotkiewicz, "The Scandinavian Influence," 157; Rotkiewicz, "Rozwoj spolecznych organizacji," 72; Rotkiewicz, "First Women's Sports Organizations," 41; Rotkiewicz, "Prekursorki wychowania fizycznego dziewczat w Polsce," 111; and Rotkiewicz, "Sport kobiet," 272-273.

182 R. Wroczynski, "Wychowanie fizyczne w mysli pedagogicznej na przelomie XIX i XX w.," in Wychowanie Fizyczne i Sport, 31, 1 (1977), 101-109, p.108; and Rotkiewicz, "The Scandinavian Influence," 157. 
pioneer of rhythmic gymnastics in Russian Poland. Janina went to Geneva where she was influenced by teachings of Emile Jaques-Dalcroze. On her return to Warsaw in 1911, she began to give lectures in gymnastics, particularly to women and children. ${ }^{183}$ The gymnastics institute of Boleslaw Olszewiski in Warsaw also promoted the idea of gymnastics for both boys and girls. ${ }^{184}$ Helena Mieczynksa, meanwhile, wrote about neglect of gymnastics and physical exercises in women's educational institutes. 185

In Austrian Poland, the founding of Jadwiga Mayowna's gymnastic institution in Krakow in 1896 marked an important stage in the development of physical education for girls in this partitioned zone. Her private Institute of Therapeutical and Salon Gymnastics not only symbolized the need of physical culture for women, but also contributed to the Galician women's movement. 186 In Prussian Poland, gymnastics became more popular among girls in private schools. 187 Jewish women, in particular, participated in gymnastics swimming and fencing. But women's physical culture in Prussian Poland, similar to that of their male counterparts, could only maintain a low profile under Prussian rule. 188

Similar to Polish women, American women picked up dumbbells, and enrolled in calisthenics and gymnastics classes for the implicit promise of improved appearance, the quest for better health, and the desire to feel stronger and more competent. Catharine Esther Beecher is regarded as the most significant popularizer of calisthenics for women in America. 189

183 "Slownik biograficzny wychowania fizycznego i sportu," in Wychowanie Fizyczne i Sport, 26, 2, (1982), 97-103, p.97-98. Dalcroze, a male Swiss teacher, came to Warsaw in 1911 and popularized rhythmic gymnastics that continued in the interwar years. For details see Bluszcz, 5 (4 February, 1911), 55; Maria Rotkiewicz, "The Influence of Emile Jaques-Dalcroze on the Development of Women's Rhythmical Gymnastics in Poland," in HISPA, International Association for the History of Physical Education and Sport, VII International Congress, Paris (March 28-April 2, 1978), 601-615, pp. 601, 605, 607. The Polish version of Rotkiewicz's article, "Wplyw Emile Jaques-Dalcroze na rozwoj gimnastyki rytmicznej w Polsce," was published in Wychowanie Fizyczne i Sport, 1/79, 57-76.

184 Program Szkoly Gimnastyki Szwedzkiej, Lecznicznej i Masazu w Warszawie przy istniejacym od $r .1894$ Instytucie Gimnastycznym Boleslawa Olszewiskiego (Warsaw, 1908), 5, 12, 13.

185 Ruch, 8 (26 April, 1914), 110-112.

186 See Ziolkowska, "Rozwoj sportu wsrod kobiet Polskich w okresie zaborow," 202; Rotkiewicz, "The Scandinavian Influence," 152, 157; Rotkiewicz, "U zrodel," 100-104; and Rotkiewicz, "Prekursorki wychowania fizycznego dziewczat w Polsce," 114.

187 Ziolkowska, Kultura fizyczna w Poznaniu, 133.

188 Ziolkowska, "A Contribution to the History of Jewish Sport and Physical Education in Poland," 57.

189 Twin, Out of Bleachers, xxvii; and Jan Todd, Physical Culture and the Body Beautiful: Purposive Exercise in the Lives of American Women, 1800-1870 (Macon, Ga., 1998), 3, 5, 6, 137. For Catharine E. Beecher, see also Nancy Woloch, Early American Women: A Documentary History, 1600-1900 (New York, 1997), 160-163. 
Women's fencing gained popularity in the cities of Lwow, Krakow, and Warsaw in the second half of the 19th century. Prior to this period, the sport was all-male and women seldom frequented the male-dominated tournaments. Many were rather scared of the complex fencing equipment! The press, however, did comment on women's fencing abroad. Women's fencing began in Paris and Vienna, and coincided with the larger movement for women's emancipation. Only gradually, and timorously, did Polish women take up this expensive and elitist sport. But though this sport was considered to be elegant and fashionable, the press refrained from giving names of women players lest it cause scandals in social circles! 190

Among several other sports, women's skiing in partitioned Poland made its appearance in 1911 in Zakopane and remained quite popular among women before the Great War. ${ }^{191}$ Sledding for women appeared at the beginning of the 20th century. 192 Women's hazena became popular after 1905.193 Skiing and swimming especially attracted women in Prussian Poland. 194 Women's wrestling also made an appearance, and it was quickly pronounced 'sensational'. 195 It is interesting that women were also keen spectators of the largely male-dominated sports of weightlifting and wrestling in nearby Estonia. 196

Polish women were conspicuously invisible in certain sports such as golf and cricket which were popular among other western women. For example, women in Britain played golf because of the greater exclusiveness of the game, greater conformity with male expectations and the claims of femininity in the matter of dress. ${ }^{197}$ Women on the cricket pitch, however, were laughed at and portrayed as 'freaks' or monstrosities. 198 Women who played soccer remained non-elitist and highly unfashionable, while the

\footnotetext{
190 For details on women's fencing in Poland see Maria Rotkiewicz, "Poczatki szermierki kobiet w Polsce, do 1939 roku," in Sport Wyczynowy, 2-3 (1988), 57-73, pp.57-61.

191 Start, 2(January, 1935), 7.

192 AMR, notes.

193 Trybuna, 280 (1993), 12. The game of hazena, similar to handball and played by seven individuals, emerged in Czechoslovakia in 1905 and thereafter came to Poland.

194 Gaj and Hadzelek, Dzieje kultury fizycznej, 48, 82.

195 AMR, notes.

196 Reet Howell, "Sport and Glasnost: A Case Study of Estonia," in Ralph C. Wilcox (ed.), Sport in a Global Village (Morgantown, 1994), 325. See also Reet Howell, "Sport and Glasnost: A Case Study of Estonia," (Unpublished Paper, 1993), Cited in Jim Riordan "Rewriting Soviet Sports History," in Journal of Sport History, 20, 3 (Winter, 1993), 247-258.

197 Birley, Land of Sport, 112; and Woolum, Outstanding Women Athletes, 9.

198 For women playing cricket in Britain and Australia see McCrone, Sport and the Physical Emancipation of English Women; Guttmann, Games and Empires, 25; and Birley, Land of Sport, 99.
} 
English lady balloonists were treated as privileged eccentrics. 199 In Imperial Russia, on the other hand, aviation as a sport for women became exceedingly popular when Russian aviationist L.A. Golanchikova established a new flying record at the International Aviation Meet in November 1912 at the Berlin aerodrome. 200

The nationalist struggle in partitioned Poland legitimized the participation of women in the sport of rifleshooting. Despite anti-feminist stereotypes, Jozef Pilsudski formed a women's department of the Polish Riflemen's Company (Polskie Druzyny Strzeleckie) in Krakow in 1911. This was followed by the opening of a women's department of Zwiazek Strzelecki in Krakow in 1913.201 And there were many women in the Sharpshooters Union, some of whom were well acquainted with the use of firearms. 202 Similar to Polish women who engaged in rifleshooting because of national priorities, English women were permitted into the game of shooting for reasons of eugenics, empire-building, and self-defense in "uncivilized" countries. 203

Women's scouting troops made their appearance in Lwow and Krakow in 1911.204 But these teams caused some societal distress for causing a 'revolution in traditional feminine mannerisms'.205 Scouting gained popular currency among women in Russian Poland from 1913 onward. In January of 1915, women scouts in Warsaw organized the Zwiazek Skautek Polskich (Association of Polish Women Scouts). According to the Vice-President of the Union of Emancipation for Women, Bojanowska, scouting was character-building and good for developing a strong physique. 206 Scouting was perceived by women to be not only a healthy activity but one that could also serve as a medium of education. 207 However, scouting in Russian Poland remained illegal and thus all work was carried out conspiratorially.

\footnotetext{
199 Lowerson, Sport and the English Middle Classes, 219, 220; and Birley, Land of Sport, 98.

200 Rabotnitsa, 8 (1978), 18, 19.

201 For details see Tomasz Nalecz, "Kobiety w walce o niepodleglosc w czasie pierwszej wojny swiatowej," in Zarnowska and Szwarc (eds.), Kobiet i swiat polityki, 73-79, pp. 75, 76; and Andrzej Chojnowski, "Aktywnosc kobiet w zyciu politycznym," in Zarnowska and Szwarc (eds.), Rowne prawa i nierowne szanse, 37-48, p. 43. The year when the women's department of Zwiazek Strzelecki was opened is not clear in the secondary sources. The first author puts the year as 1913 and the second at 1912.

202 AGAD Pom GGW 396--PPS--Revolutionary Faction, 1913: Agent's report of January 29, 1913 (o.s.).

203 Lowerson, Sport and the English Middle Classes, 219, 220.

204 Waclaw Gniewkowski, Rozwoj glownych europejskich systemow WF i ich wplyw na ksztaltowanie sie systemu WF w Polsce od oswiecenia do 1939 (Warsaw, 1972), 226, 232.

205 Zawadzka, Harcerstwo zenskie, 11.

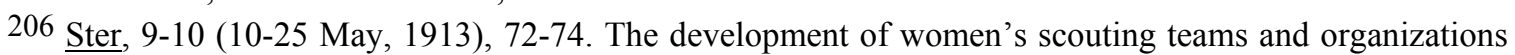
was aided by the efforts of several women. For details see Zawadzka, Harcerstwo zenskie, 14, 15, 21; Rotkiewicz, "Prekursorki wychowania fizycznego dziewczat w Polsce," 113; and Ziolkowska, Kultura fizyczna w Poznaniu, 179, 193.

207 Bluszcz, 3 (18 January, 1913), 1-2; and Bluszcz, 4 (25 January, 1913), 34.
} 
Polish women also joined the Sokol units in partitioned Poland. In spring of 1903, the Lwow Sokol founded its first independent 'women's department'.208 In the years before W.W.I, the membership of women in Sokols in Galicia increased and many women's teams were formed in several Sokol nests in 1912-1913. These centers conducted regular gymnastic exercises for military preparation. 209 On 6th July 1913, in celebration of the 50th anniversary of the January Insurrection, over eight thousand young members of Sokol, including girls, participated in a military sports exhibition. To the great surprise and often indignation of many, the girls showed perfect familiarity with military drill, and in the uses of rifles and maps. Unfortunately, these women sokolites tended to cloister in supporting services and sanitary units. 210 In Prussian Poland, women made their appearance in Sokol nests from 1900, though their much wider participation was possible only after 1908 when women were allowed to participate in mixed societies. 211 Meanwhile, the formation of Grazyna, the first women's Sokol nest in Russian Poland formed under Kuczalska's initiative, was a particularly important step in breaking through the conventional barriers in women's public life, including participation in sports. Formed in 1905, Grazyna joined the Polish Sokol Society a year later and continued its activities in sports and conspiratorial work until 1916. 212

Sokol societies also played an important role in the lives of many women from various Central and East European ethnic groups in late-19th century America. By 1879 Chicago had become the center of the National Sokol Union. In these clubs, Bohemian women were active in "Sokolky"- their gymnastics organizations. In 1892, Polish women in the city organized their own Falcon society for the purpose of practicing gymnastics, despite the protests of their husbands, who advocated a more traditional domestic role for them. More generally, women's participation in Sokols and other sports fostered ethnic pride and undermined male hegemony in athletics. Czech women, perhaps because of the greater number of non-religious free-thinkers, assumed active responsibility for change.

208 Maria Rotkiewicz, "Rozwoj spolecznych organizacji sportu kobiet w Polsce," in Zofia Zukowska (ed.), Sport w zyciu kobiety (Warsaw, 1995), 69-79, 71.

209 Rotkiewicz, “Sport kobiet w progu niepodleglej Polski,” 272.

210 Zolem ojczyznie, szponem wrogowi, Historia Sokolstwa Polskiego, 1867-1939, no page numbers.

211 Steuer, Sport na Gornym Slasku, 8; and Ziolkowska, Kultura fizyczna w Poznaniu, 179, 193.

212 Ruch, 3-5 (11 March, 1907), 37, 48; Bluszcz, 48 (27 November, 1926), 1530-1531; Ziolkowska, "Rozwoj sportu wsrod kobiet polskich w okresie zaborow," 204; Rotkiewicz, "U zrodel," 100-104; AMR, notes; Rotkiewicz, "The Scandinavian Influence," 157; Rotkiewicz, "Rozwoj spolecznych organizacji," 72; Rotkiewicz, "First Women's Sports Organizations," 41; Rotkiewicz, "Prekursorki wychowania fizycznego dziewczat w Polsce," 111; and Rotkiewicz, "Sport kobiet," 272-273. 
Polish women, in contrast, deferred to male leadership in their social and athletic clubs, particularly when the clergy assumed its traditional role of leadership. 213

\section{Resistance to Women's Sport: Extreme, Moderate, and Satirical}

No doubt, sport for women in partitioned Poland was restricted and limited by the idea implicit in the three German "Ks", i.e. Kinder, Kuche, and Kirche (Children, Kitchen, and Church). Pre-existing notions of feminine roles spoke against women's participation in sport. Women's engagement in physical exercises was presumed to result in the ruin of their 'femininity'; a ruin associated with the collapse of morality, disfigurement of women's bodies, and dissolution of family life, especially in the countryside. Thus, women's sports clubs were few and women's 'sections' of various sports organizations remained subservient to their male-dominated hosts. 214 Moreover, these Polish 'sports ladies', at all times, were required to be 'modest and elegant' and such virtues were supported by a conservative fashion industry that projected 'proper' images of women in sport. 215 This gender bias in the institutional and organizational structure of sports limited women's participation in club life in partitioned Poland throughout the period before the Great War.

But Polish women were not the only one who found their sporting experiences cloistered. Sportswomen around the world continued to face considerable opposition in their efforts to develop their athletic skills beyond the recreational level. To be sure, the first female sports enthusiasts in England, Australia and America challenged the cult of female invalidism by promoting the beneficial effects of physical exercise and undermining the myth of "weak women".216 Even in China, reform-minded

\footnotetext{
213 Gerald R. Gems, "Sport and the Americanization of Ethnic Women in Chicago," in George Eisen and David Wiggins (eds.), Ethnicity and Sport in North American History and Culture (Westport, Conn., 1994), 177-200; and Robert Knight Barney, "Forty-Eighters and the Rise of the Turnverein Movement in America," in Eisen and Wiggins (eds.), Ethnicity and Sport, 19-42.

214 Teresa Ziolkowska, "Rozwoj sportu wsrod kobiet polskich w okresie zaborow," in Roczniki Naukowe AWF w Poznaniu, Zeszyt 29, (Poznan 1990), 201-205, p.205; Bluszcz, 46 (10 November, 1928), 26-27; Wohl, Spoleczno-historyczne podloze sportu, 120; Barbara Krawczyka, "Rola spoleczna a uczestnictwo w sporcie," in Krawczyk (ed.), Sport w spoleczenstwie wspolczesnym, 297-315, pp. 298-299; Rotkiewicz, "Sport kobiet," 268-269; and Sport Polski, 4 (26 January, 1938), 7. Also see Mala encyklopedia sportu, Tom II (Warsaw, 1987), 446, for a general listing of women's sport organizations for the partitioned period.

215 Sport, 21 (10/23 May, 1903), 4, 5; and Sport, 16 (9/22 April, 1905), 7.

216 For a more detailed description of sportswomen in western societies see Karen Kenney, "The Realm of Sports and the Athletic Woman, 1850-1900," in Howell (ed.), Her Story in Sport, 107-140, p. 137; Patricia Vertinsky, The Eternally Wounded Woman: Women, Doctors, and Exercise in the Late Nineteenth Century (Manchester and New York, 1990), 20, 21; Joan Paul, "Heroines: Paving the Way," in Cohen (ed.), Woman
} 
intellectuals began to argue against footbinding in the 1890s. The leaders of the movement argued that one reason for the superior strength of the western powers was that since their women did not bind their feet and practiced calisthenics they produced stronger offspring. 217 Thus, similar to Polish women, the Chinese feminists identified their "woman question" with national liberation and used physical culture to create a "healthy manhood".

Unfortunately, the philosophy that real sport was masculine endured, and conservative opinion forced women to articulate an athletic philosophy captured in the word 'moderation'.218 It was imperative for women players to be in every way 'ladylike' in their playing demeanor. If women's sporting activity could be shown to have a utilitarian function (such as better health for reproduction, Social Darwinism, and national regeneration), if there were no associated immodesty or impropriety, and if women remained cautious in the level of exertion, then they could extend their physical horizons without threatening their existing set of social relationships with men. 219

A good indicator of these contradictory images of sportswomen is their participation in the Olympic Games during this time period. The modern Olympics, founded by France's Pierre de Coubertin, represented one of many attempts to accomplish masculine miracles through sports. The games celebrated in Paris in 1900 included women's golf and tennis. Seven American women competed in these events, but they were not accorded team status, uniforms, fanfare, or recognition by the

in Sport, 27-37; Woolum, Outstanding Women Athletes, 5; Guttmann, Women's Sport, 120, 124; Nelson, The Stronger Women Get, 13; Cahn, Coming on Strong, 14; Park, "Sport, Gender and Society," 76, 81; Ray Crawford, "Moral and Manly: Girls and Games in Early 20th Melbourne," in Mangan and Park (eds.), From "Fair Sex" to Feminism, 182-207; and Marion K. Stell, Half the Race, A History of Australian Women in Sport (North Ryde, Australia, 1991), 4-22.

217 Susan Brownell, Training the Body For China: Sports in the Moral Order of the People's Republic (Chicago, 1995), 43; and Fan Hong, Footbinding, Feminism and Freedom: The Liberation of Women's Bodies in Modern China (London and Portland, 1997), 103, 155, 164, 173, 215, 255, 279, 288-291, 297 299, 304, 307.

218 For the persistence of the cult of masculinity in sport see Woolum, Outstanding Women Athletes, 9; Park, "Sport, Gender and Society," 76-81, 87; Twin, Out of Bleachers, xxvi; Wray Vamplew, "Australians and Sport," in Wray Vamplew and Brian Stoddart (eds.), Sport in Australia: A Social History (Cambridge and New York, 1994), 1-18; Stell, Half the Race, 4-22; Susan Kingsley Kent, Gender and Power in Britain, 1640-1990 (London and New York, 1999), 244, 245; McCrone, Sport and the Physical Emancipation of English Women; Snyder and Spreitzer, Social Aspects of Sport, 191-222; Coates, Women and Sport, 9; Paul Atkinson, "The Feminist Physique: Physical Education and the Medicalization of Women's Education," in Mangan and Park (eds.), From "Fair Sex" to Feminism, 38-57, pp. 54, 55; and McCrone, "Play up! Play up! And Play the Game!," 101, 107, 121. For a discussion on the crisis of masculinity in late 19th century America see Todd Crosset, "Masculinity, Sexuality, and the Development of Early Modern Sport," in Messner and Sabo (ed.), Sport, 45-54; Michael S. Kimmel, "Baseball and the Reconstitution of American Masculinity," in Messner and Sabo, Sport, 55-65; and Guttmann, The Erotic, 58, 59, 63.

219 Jennifer A. Hargreaves, "Victorian Familism and the Formative Years of Female Sport," in Mangan and Park (eds.), From "Fair Sex" to Feminism, 130-144. 
American Olympic Committee. In 1904, at St. Louis, archery was the only sport in which women were allowed to compete and only seven American women competed in the sport. Tennis, archery, and figure skating were on the Olympic program in 1908 in London, where most participants were British. Women's swimming was introduced in the 1912 Olympics in Stockholm. W.W.I intervened to prevent the Olympics games in 1916 in Berlin, and the first postwar games held at Antwerp in 1920 limited women to tennis and the aquatic events. 220

Still, women's participation in sports before W.W.I confounded stereotypes of womanly weakness and inactivity. Sports made women more aware of their self-esteem and self-identity. While the 'Cult of True Womanhood' remained dominant, the athletic woman had begun to capture the spirit of modern womanhood, both in Poland and abroad. 221

\section{Conclusion}

Polish women's participation in sports was conditioned by foreign rule, socioeconomic transformations, patriarchal constraints in the social structure and consciousness, overpowering influences of the state and civil apparatus, and struggles for women's emancipation. However, while Polish sportswomen challenged the traditional moral, ethical, and pseudo-scientific theories which had restricted their participation in sport, their sporting activities remained subordinate to the exigent national agenda. These early sportswomen, mainly socialites, attempted to play in a manner that did not compromise nor contradict the traditional image of womanhood. Importantly, this nonconfrontational nature of women's physical culture enabled Polish sportswomen to escape the oversight of the male-dominated civil society in the Polish Diaspora. Their social obeisance to the Polish freedom struggle, however, did not consign their sporting endeavors to mere trifles. Their sagacity and riveting interest in learning new sports could

220 Nelson, The Stronger Women Get, 20; Hargreaves, Sporting Females, 210, 214; Paula Welch and D. Margaret Costa, "A Century of Olympic Competition," in Costa and Guthrie (eds.), Women and Sport, 123138, pp.123, 124, 125, 126, 135; Coates, Women and Sport, 12; Daddario, Women's Sport and Spectacle, 36, 40, 41, 42, 43 , 47; Guttmann, Women's Sports, 163, 164; and Maria Rotkiewicz, "Od Aten do Atlanty: ewolucja programy olimpijskiego w lekkoatletyce, 1896-1996," Sport Wyczynowy, 5-6 (1996), 13-26.

221 See The Rand Daily Mail, (November 24, 1904), 6; Cahn, Coming on Strong, 15, 19, 23, 30; Lenskyj, Out of Bounds, 18, 70; Donald J. Mrozek, "The Amazon and the American 'Lady'," in Mangan and Park, From "Fair Sex", 282-298; Joan S. Hult, "The Story of Women's Athletics: Manipulating a Dream," in Costa and Guthrie, Woman and Sport, 83-106; Peter Lindsay, "Woman's Place in Nineteenth Century Canadian Sport," in Howell (eds.), Her Story in Sport, 80-86, 84; Park, "Sport, Gender and Society," 7681; McCrone, Sport and the Physical Emancipation; and Hargreaves, Sporting Females, 88, 90, 105, 108, 111. 
not but cast modern images of women which integrated the disparate identities of women as being labile and obsequious, and yet strong, independent and healthy. Such turbid images must have been ubiquitous in all spheres of daily life in which women began to assert themselves, including sports and physical culture. However, the turgidity of this imagery varied. Polish women's physical culture achieved maximum popularity in Russian Poland, less so in Austrian Poland, and least under the Germans. The scarcity of literature on women in sport in Prussian Poland would probably suggest that women in this part of partitioned Poland closely identified themselves with the conventional images of womanhood that restricted their public visibility. Women in Prussian Poland were less truculent in challenging the proscriptions against women's participation in sport as in other zones of partitioned Poland. Instead, they preferred to synchronize their daily patterns in accordance with the more powerful ideologies in the political and societal matrixes that equated 'de-feminization' with 'de-sacralization'. But this is not to suggest that women's physical culture in Prussian Poland remained vacuous. Their limited participation in sport was not a short lived vanity affair, but a nascent physical culture that would serve as a foundation toward a more sophisticated sports apparatus in the interwar years.

In the meantime, however, the First World War disrupted all Polish attempts to build their physical culture movement. During the course of the war, the associations and societies of sportsmen and sportswomen assumed roles of civil administrative support services. They managed shelters for homeless war refugees and treatment centers for the wounded, operated communications systems, and generally aided the harried civilian officials. Polish women, in particular, took part in military activities, served in courier and intelligence services, and provided medical assistance. Some existing sports clubs sponsored athletic events for the local youth in order to raise public morale. Both the German authorities and the underground independence movement of Pilsudski fostered this trend, with conflicting goals in mind: they both assembled young Poles into organized groups that could be tapped easily for recruits into the German or Polish armies, respectively. The Germans even encouraged the larger organizations to stage "national" competitions that included teams from Krakow, Lwow, Poznan, and other Polish cities, and the Polish conspiratorial leaders urged their followers to participate. Spurred on by the absence of any German restrictions on their activities, and the willingness of their counterparts from the other regions of Poland to follow their lead, the main sporting organizations in Warsaw moved to give their existence a permanent legal legitimacy and a formal administrative structure that would facilitate the creation of a nationwide sports establishment in interwar Poland. Significantly, even the Polish 
women's movement also reaped dividends from the war since the wartime roles and activities of women provided more substance for the feminists to argue for equal rights. 222

For this reason, while women's sports suffered during the course of the war, the "women's question" was soon on the move again, and this time more ideologically enriched with the wartime heroic experiences of women. Moreover, the sports leadership also began to locate its "national" place in the soon to become independent Poland. Both these intellectual and organizational developments in the women's movement and the physical culture apparatus during the course of the war facilitated the rebirth of a more vibrant women's physical culture in interwar Poland.

222 For these issues see Chwalba, "Kobiety w zyciu politycznym," 133; Najdus, "O prawa obywatelskie kobiet," 115; Dudek, "Polskie organizacje paramilitarne na terenie Galicji," 104; Nalecz, "Kobiety w walce o niepodleglosc w czasie pierwszej wojny swiatowej," 75, 76; Kalwa, "Model kobiety aktywnej," 137; Warsicki, Kultura fizyczna, 29; Stegmann, "Wie die Soldaten im Feld'," 197-216; and Wynot, Warsaw Between the World Wars, 285, 286. 


\section{Chapter Two}

\section{Motivations and Logistics: The Ideological and Structural Organization of Women's Physical Culture in Interwar Poland}

In interwar Poland, women were provided with increased opportunities to participate in sports. Polish women's physical culture in the Second Polish Republic matured in response to the more structured ideological and institutional support from both the state and society. Several motivating factors prompted the Polish government and the various social classes to encourage the organizational development of women's sports. More specifically, women's physical culture was perceived by the state to have a positive impact on the development of the fledging Polish nation by creating a physically strong, united, and patriotic citizenry. For this reason, several state and civil, sports and nonsports organizations actively promoted women's physical culture with definite political, social, and military objectives. These motivations which articulated the need for women to participate in sports and the logistical details which defined the nature and governance of women's sports apparatus, though less committed and organized in the immediate years of independence, became more focused in the second decade of the interwar period.

Accordingly, the purpose of this chapter is to first examine the social and political forces which provided the ideological support for organizing women's physical culture in the Second Polish Republic. Thereafter, the women's sports apparatus, in its structural components, is analyzed in the context of the state's attempts to manage the country's political instability and economic tribulations throughout the interwar period. The organization of women's sports was markedly influenced by the political contests of the early interwar years, and substantially transformed by the state policies after Jozef Pilsudski's military coup in 1926. For this reason, the logistics of women's physical culture is examined in three chronological phases; namely, the early interwar period, the period from Pilsudski's coup in 1926 up until his death in May 1935, and the post-1935 years. Finally, to provide a comparative perspective, the development of Polish women's physical culture in the interwar decades is compared with some other countries, including and especially the newly created Soviet state.

\section{Motivations for Organizing Women's Physical Culture in Interwar Poland}

Several motivating factors explain the heightened popularity of women's physical culture in the Second Polish Republic. For one, women's popular magazines and 
periodicals emphasized the importance of sport for improving women's health and hygiene. Women's physical culture, along with their 'rational' use of cosmetics, was considered beneficial not only for enhancing women's individual health, strength, and beauty, but also for collectively nurturing and building a "healthy and militarily strong Poland". Women, in other words, were to become fit themselves in order to strengthen the physicality of the young generation that was yet to be born. 1

Women's participation in sport was medically endorsed for its prophylactic, psychological, anatomical, and physiological advantages. Sport purportedly enhanced women's cognitive abilities, including those of independent initiative, quick thinking, and attentiveness. Women's physical culture was also recommended for instilling the "proper" social and moral values in the reborn Polish nation. ${ }^{2}$ Further, while members of the medical profession used the mass media and their national conferences to propagandize the importance of sports for improving women's 'health and beauty', women of the upper classes became more attracted toward playing sports in order to bolster their fashionable social prestige, as well as to create a youthful image for themselves. Meanwhile, some sports articles exposed older women to the idea that it was 'never too late for sports'. 3 Most importantly, the sporting accomplishments of female athletes in international competitions was used by the state to solidify sentiments of national pride and prestige. Sports newspapers and women's periodicals remarked that Polish sportswomen had not only established themselves into an elite group of international professionals and world record holders, but that they had also frequently taken the lead from men in sporting competitions. 4

\footnotetext{
${ }^{1}$ For reports on women's health and hygiene see Kobiety w Pracy, 1, 3 (April, 1938), 10, 11, 28; Kobiety w Pracy, 1, 4 (May, 1938), 35; Kobiety w Pracy, 1, 5-6 (June-July, 1938), 27; Kobieta Wspolczesna, 3, 6 (10 February, 1929), 3; Kobieta Wspolczesna, 3, 12 (24 March, 1929), 19; Kobieta Wspolczesna, 3, 15 (14 April, 1929), 5, 6; KSD, 3, 12 (June, 1927), 12; Moja Przyjaciolka, 2, 3 (25 April, 1935), 126; Bluszcz, 4 (27 January, 1934), 114; Bluszcz, 19 (8 May, 1937), 12/404; Moja Przyjaciolka, 3, 3 (10 February, 1936), 35, 36; Sport, 10 (19 May, 1922), 151, 152; Sport Polski, 1, 8 (20 October, 1937), 3; Bluszcz, 46 (10 November, 1928), 29; Bluszcz, 2 (9 January, 1926), 33, 34; and Krawczyk, "Rola Spoleczna," 304. For the importance of physical education for women, see also Dr. Wladyslaw Hojnacki, Higjena kobiety $i$ kosmetyka (Lwow and Warsaw, 1925). On sports medicine for women see K. Muszalowna and E. Reicherowna (eds.), Uszkodzenia sportowe u kobiet (Warsaw, 1935).

2 Sport Polski, 1, 3 (15 September, 1937), 11; Bluszcz, 50 (11 December, 1937), 14-15/1182-1183; Bluszcz, 43 (23 October, 1937), 16/1016; Start, 2, 5 (1 March, 1928), 3; Start, 1 (10 April, 1927), 2; and Moja Przyjaciolka, 4, 6 (25 March, 1937), 138.

3 Bluszcz, 46 (15 November, 1930), 11, 12; Bluszcz, 20 (14 May, 1927), 12, 13; and Barbara Dworak, "Kobieta i Sport," in Wychowanie Fizyczne i Higiena Szkolna, 25, 221, 3 (March, 1977), 65-66, p.66.

${ }^{4}$ For the idea of Polish women's sport enhancing the nation's prestige see Bluszcz, 21 (26 May, 1923), 170; Bluszcz, 40 (4 October, 1930), 11; and Bluszcz, 25 (21 June, 1930), 12. See also the press coverage of the three days of the Third Women's Games in Prague in which Polish sportswomen competed and won many accolades. See PzS, 10, 70, 559 (30 August, 1930), 4; PzS, 10, 73, 562 (10 September, 1930), 1, 2;
} 
Thus, the interwar state promoted women's physical culture to project images of Polish female athletes as demonstrable evidence of women's "real" emancipation, and as celebrated national icons who championed the cause of national patriotism. The fact that female athletes served as glorified models of Polish nationalism and as powerful vanguards of Polish feminism suggests a double victory for Polish sportswomen, at least in the state sponsored imagery of the interwar period.

The state's interest in supporting women's physical education, sports medicine, and the various sports disciplines paralleled the government's perceived awareness of the benefits of physical culture for facilitating the harmonious development of body and spirit, for building "good" character, for promoting the intellectual advancement of the individual and ultimately the nation, and for helping men and women to construct healthy and happy "rational" lifestyles for themselves and their families. The fact that the Polish state recognized the responsibility of both parents in raising healthy children is significant for this may well have been the first time that fathers were encouraged to share the burden of child-care in the household. Prior to this period, only women were associated with the cult of domesticity. However, the state's emphasis on the need for both parents to serve as sports mentors to their children can be considered as the first "domestic" task officially assigned to men. This male and female partnership in building physical culture within the family suggested an alteration in the traditional patriarchal definitions of gender relations in the direction of greater equality.

Meanwhile, and quite oddly enough, participation in sports was thought to even reduce sexual urges and thus control the spread of venereal diseases. It is interesting that members of sports clubs were informed about the presumed sexual benefits of sports. However, it is unclear as to whether sports supposedly regulated male or female sexuality, or both. Further, engagement in sports was said to reduce alcohol consumption. But, once again, it remains uncertain as to whether this benefit supposedly accrued to both men and women, and to both the participants and the spectators!

Most importantly, the systematic organization of physical culture was viewed as extremely important for safeguarding the country's infant 'statehood', and for defending the national territorial body from external aggression. Such "national" and military considerations in sport assumed a more prominent place in political decision-making after 1926, and more so with the rise of Fascism and Nazism in Europe. 5

PzS, 10, 74, 563 (13 September, 1930), 1, 2; KSD, 6, 19 (October, 1930), 17-19; and Kobieta Wspolczesna, 4, 42 (19 October, 1930), 12-14.

${ }^{5}$ For all these issues see Bluszcz, 11 (17 March, 1923), 92; $\underline{\mathrm{PzS}}, 12$, 13, 814 (15 February, 1933), 4; Moja Przyjaciolka, 2, 11 (10 June, 1935), 164; Bluszcz, 9 (25 February, 1922), 69; Bluszcz, 6 (7 February, 1925), 


\section{The Structural Development of Women's Physical Culture Before May 1926}

In logistical terms, the theoretical and practical accomplishments of Polish women's sports in the interwar period must be evaluated in the context of wartime devastation and acute shortages in material, financial, and infrastructural resources. The independence of Poland was proclaimed in Warsaw on 11 November 1918, with Jozef Pilsudski, who had arrived in the capital only the previous day following his release from German captivity, as the putative Chief of State. Daunting problems faced this reborn Polish state at the end of the First World War. The overwhelming physical destruction, a war-ravaged economy marred by poverty and inflation, political instability, and the strain of military operations to secure the new state's borders, all imposed immense misery upon the country in the immediate aftermath of the war. ${ }^{6}$ The economic condition of interwar Poland was especially critical because the old hinterland markets of the partitioning empires were gone and the productive facilities of the country, which had been augmented by the acquisition of the larger part of Upper Silesia from Germany, were ill-adapted to the needs of an impoverished internal market. 7

In the political arrangements, Pilsudski remained the central figure in Polish life throughout the initial period between 1918-1926. However, Polish politics itself remained polarized. While Roman Dmowski and the National Democrats dominated the Right political bloc, the Center was represented by Wincenty Witos, head of the Peasant Party PSL-Piast. The Left political bloc was divided between the PPS and PSL-Liberation, a more radical peasant party. The multiplicity of parties, which reflected not only political differences, but also national, regional and religious allegiances, dissipated energies and hindered a rational approach to solving Poland's many problems. For example, the Polish Right called for cultural and economic "polonization" and rapid industrialization. The socialists and the Pilsudskists on the left, however, repudiated the integral nationalism, ethnic chauvinism, and clericalism of the Right.

Overall, the political infighting and inexperience of the fledging Second Republic contained Poland's economic recovery. Hyperinflation, industrial strikes in 1922-1923,

130, 131; and Kobiety w Pracy, 1, 3 (April, 1938), 15. For the importance of men's and women's physical culture in building a healthy family see Katarzyna Sierakowska, "Macierzynstwo-wizje a rzeczywistosc," in Zarnowska and Szwarc, Rowne prawa i nierowne szanse, 209-219.

6 Peter D. Stachura, Poland in the Twentieth Century (Basingstoke and New York, 1999), 7; Zamoyski, The Polish Way, 343; Leslie (ed.), The History of Poland, 148; and Richard M. Watt, Bitter Glory: Poland and Its Fate, 1918 to 1939 (New York, 1979), 81.

7 John Michael Montias, Central Planning in Poland (New Haven, 1962), 49. 
and peasant "land hunger" as a consequence of the absence of meaningful land reform exacerbated existing social tensions. The resulting extreme fragmentation of Polish political life also prevented the smooth functioning of the Polish Constitution of March 1921 which theoretically established a democratic republic with universal suffrage and a bicameral legislature comprised of a lower house or Sejm and a Senate. ${ }^{8}$ Because of these political shortcomings, the Polish state, though "democratic" in character, remained ineffective in improving the pressing economic problems, and failed to constructively address social issues related to class and ethnicity which divided the Polish society and, by consequence, the Polish "nation". 9

The organization of Polish sport in the first decade of the interwar period, accordingly, was handicapped by the absence of a solid material base, lack of training equipment and sports facilities, and hostile remarks from conservative critics. Throughout the interwar period, the development of sport was especially attacked by prominent writers, including Aleksander Swietochowski. Further, the re-unified nation now faced the overwhelming task of integrating the three disparate partitioned zones, each with their own individual strengths and weaknesses. For this reason, the development of sports, for both men and women, was contingent on forging new political linkages that were conducive to the organization of an integrated physical culture complex. Because the national government was preoccupied with more exigent issues in the immediate aftermath of the First World War, the revival of sports after the war-time devastation was initially achieved through local civil initiatives in the various regions of interwar Poland. In the years before Pilsudski's coup in May 1926, the Polish male and female physical cultures developed with little financial help from the government and outside its control. As a result, the sports structure of the re-united territories emerged mainly through the initiatives of society and with the spirit of enterprise inherently embedded in the popular sports institutions and clubs. For example, in women's sports, the Organization Committee of the Polish Federation of Sports for Women (Komitet Organizacyjny

\footnotetext{
8 For all these issues see Andrzej Korbonski, "Poland: 1918-1990," in Joseph Held (ed.), The Columbia History of Eastern Europe in the Twentieth Century (New York, 1992), 229-276, p.238; Ascherson, The Struggles, 62, 63; Antony Polonsky, Politics in Independent Poland 1921-1939: The Crisis of Constitutional Government (Oxford, 1972), 45, 52, 53, 60, 96, 100; Davies, God's Playground, Vol. II, 414, 418; Michal Sliwa, "Kobiety wsrod tworcow mysli spoleczno-politycznej w Polsce pierwszej polowy xx wieku," in Zarnowska and Szwarc (eds.), Kobieta i kultura, 225-239, pp. 234-236; Watt, Bitter Glory, 81, 197; Rothschild, East Central Europe between the Two World Wars, 28, 31, 33; and Bromke, Poland's Politics, 34.

${ }^{9}$ Mark Brzezinski, The Struggle for Constitutionalism in Poland (Basingstoke, 1998), 57; and Edward D. Wynot, Polish Politics in Transition: The Camp of National Unity and the Struggle for Power, 1935-1939 (Athens, 1974), 1-20.
} 
Polskiego Zwiazku Sportowego Kobiet) was formed on 28th February 1925 to coordinate women's physical culture. This women's sports organization was directed by Jozefa Gebethner, and included some members from the Warsaw Oarswomen Club such as Zofia Zabawska-Domoslawska and Kazimiera Muszalowna. The initial spontaneous development of Polish physical culture, patronized by the civilian social and cultural institutions, confronted a weak infrastructure, limited facilities, and complicated economic and ideo-political conditions.

At the more 'official' level, some ministerial support was eventually forthcoming. For example, several ministries established special departments of physical education, including the Ministries of War, Health, Foreign Affairs, and Religion and Public Education. In 1919, the Panstwowa Rada Wychowania Fizycznego i Kultury Cielesnej (State Council of Physical Education and Physical Culture, PR WFiKC) was founded through the Ministry of Public Health. The Council for the Affairs of Physical Education and Physical Culture (Rada do Spraw Wychowania Fizycznego i Kultury Cielesnej, RdSWFiKC) initiated discussions about the need for physical education instruction in schools, and for satisfying the nation's military needs. In order to emphasize the strong connection between physical culture and military preparedness, the office of Physical Education and Military Preparation (WFiPW) was established on 25th March 1925, and a month later, the State Council of Physical Education and Military Preparation (Rada Naczelna Wychowania Fizycznego i Przysposobienia Wojskowego, RNWFiPW) began to articulate the significance of physical culture for national defense. In the same year, several centers of physical education (Osrodki Wychowania Fizycznego) opened in cities such as Bialystok, Katowice, Krakow, and Poznan. Further, at the more elite level of competition, a preparatory meeting for founding a Polish Olympics Games Committee was held in Krakow on 12th October, 1919, and on 1st December, 1919 the constitutive assembly of the Polish Olympic Games Committee was formed with Prince Stefan Lubomirski as its first President. Meanwhile, the much needed patronage of wealthy social classes for the organization of male and female physical cultures continued in the early interwar years, only to be weakened with the later militarization of the state apparatus. 10

10 For details on the civil and official support in the early interwar period, as well as information on the other related issues see Przyjaciolka, 34, 648 (21 August, 1960), 9; Biuletym Informacyjny Glownego Komitetu Kultury Fizycznej i Turystyki (Nr.10-12, Warsaw, 1975), 7; Rotkiewicz, "Rozwoj sportu kobiet w Polsce," 4, 5; Gaj in Gaj and Hadzelek, Dzieje kultury fizycznej, 88-90, 105, 107, 110, 113, 114, 133, 135; Warsicki, Kultura fizyczna w Wielkopolsce, 4, 35, 36, 38, 43, 100, 106, 174; Leonard Szymanski, Kultura fizyczna w polityce II rzeczypospolitej (Wroclaw, 1995), 8, 13, 15, 18-20, 96; Grot, "Versuch eines," 306, 307; Laskiewicz, Robotnicza kultura fizyczna, 18; Bernard Woltmann, "Gegensatze in der polnischen Sportbewegung, 1919-1939," in A. Morgan Olsen (ed.), Sport und Politik 1918-1939/40. ICOSH Seminar, 
From a comparative perspective, it is interesting to note that while the Polish women's physical culture in the early interwar period emerged "spontaneously" with substantial social patronage, the Russian/Soviet women's physical culture evolved in a more "structured" fashion under direct state guidance during this time period. This is significant because the Polish women's sporting experiences would eventually begin to resemble the Soviet model in the 1930s.

Following the collapse of the Tsarist autocracy in 1917, the new Bolshevik leaders were faced with the formidable challenge of integrating the vast empire and defending their fledging government from domestic and foreign adversaries in the subsequent civil turmoil. In the midst of this socio-economic crisis, the crucial question under debate was not what form sport should take, but whether there was any place at all for sport in the new workers' state. As such, there were few sport fanatics among the men and women who made the October Revolution. Many revolutionaries argued that pre-revolutionary sports had always demonstrated strong ties to Tsarist militarism and to the political right.

However, some Bolsheviks, Lenin in particular, understood the medical benefits of exercise and sports participation. For Lenin, games-playing was conducive to moral as well as physical health; it was a valuable ingredient in character training. He also stated that there was more to sport than mere physical enjoyment; it could, and indeed should, contribute to forming the all-round individual of communist society, to character formation, especially for the youth, and to women's emancipation. ${ }^{11}$ Lenin saw in sport a convenient way for drawing women into public activity and an arena where they could relatively quickly achieve a measure of equality with men. Indeed, the sporting woman does seem to be a positive heroine in Lenin's Soviet Union.

Thus, the Bolshevik elite, from the very beginning of the interwar period, emphasized the utilitarian importance of formulating a sports policy for men and women to improve the society's health, to win the civil war with a physical strong and ablebodied citizenry, to facilitate the integration of the diverse peoples of the country, and to project images of women's liberation under communist rule. For these multifaceted reasons, a close relationship between military preparedness and physical culture was

1984, October 22-26, Proceedings/Bericht, Sormarka, Oslo, Norway (Oslo, 1986), 157-162, 157; Krawczyk, "Elementy historii wychowania fizycznego," 214; Skawinski, Kultura fizyczna na Lubelszczyznie, 13; "Poland and Olympism," in Olympic Review, 101/102 (March/April, 1976), 176-196, p.177; Jerzy Gaj, "Ideas, Conditions and Effects of Institutional Activity in the Physical Culture of Poland, 1919-30," in Studies in Physical Culture and Tourism, 3 (1994), 65-82, pp. 75, 76; and Liponski, "Still and Unknown," 16.

11 Riordan, Sport in Soviet Society, 65; and Edelman, Serious Fun, 26. 
fostered during the period of the civil war and War Communism (1917-1921). The early "militarization" of sport led to the requisitioning of sports equipment from the existing sports societies, and to the formation of military sports clubs at factories, railway depots and mines all over the country. The sports of particular interest, often because of their military bias, included, soccer, skiing, boxing, wrestling, fencing, speed skating and weightlifting. 12 Another indication of the government's preoccupation with educating the people in hygiene, nutrition and exercise was the campaign mounted during the civil war under the slogans, "help the country with a toothbrush", "help the country by washing in cold water", and "physical culture twenty-four hours a day".13

Meanwhile, sport was also viewed as a means of integrating the territories inherited from the old Russian Empire. In 1918, the government of the Russian SFSR issued a decree on general military instruction, which was automatically extended to include the various other Soviet republics. For example, in the Ukrainian SSR the first schools of physical culture came into being in 1918-1919 and physical education was introduced as a subject in Ukrainian schools and military service. ${ }^{14}$ Further, even before the civil war was over, the Soviet government organized the First Central Asian Olympics in Tashkent in early October, 1920.15 The organizers conceived of the festival as more than an effort to use sport to foster social integration in a multinational state. To a community in which women historically had been excluded from public life and discouraged from baring face, arms, and legs in public, the involvement of Uzbek and other Central Asian women in the festival, it was hoped, would be a vivid demonstration of opportunities for a new life and social liberation. Thus, the Bolshevik party wanted to promote physical culture for displaying images of the emancipation and mass employment of women in the Muslim areas, and to encourage progressive values

\footnotetext{
12 Riordan, Sport in Soviet Society, 78; and James Riordan, "Sport in Soviet Society: Fetish or Free Play?" in J. J. Brine, Maureen Perrie, and Andrew Sutton (eds.), Home, School and Leisure in the Soviet Union (London and Boston, 1980), 221, 222. For a more recent analysis of the Komsomol and youth culture in Russia during the 1920s see Anne E. Gorsuch, Youth in Revolutionary Russia: Enthusiasts, Bohemians, Delinquents (Bloomington, 2000). According to Gorsuch, the Komsomol articulated a masculine culture which made it difficult for young women to create an identity for themselves that could accommodate both the Komsomol and their familial responsibilities. (See page 111). This would imply that Komsomol's encouragement of sports was mainly for its male members.

13 James Riordan, Soviet Sport Background to the Olympics (New York, 1980), 28.

14 Volodymyr Kubijovyc (ed.), Ukraine: A Concise Encyclopedia, Vol. II (Toronto, 1971), 1034, 1035, 1037.

15 Riordan, "Sport in Soviet Society: Fetish or Free Play," 227, 228; and James Riordan, "Sport and Nationalism: CCP Socialist Internationalism Versus a Strong Russian State," (British Sociological Annual Conference, University of Reading, 1996), 3.
} 
supposedly imparted by sport that were seen as confronting the purported irrational, superstitious, mystical, and subservient aspects of the Muslim faith. 16

In the years following the civil war, and under the relative freedom that prevailed during the years of the New Economic Policy, several tendencies struggled to define a "proper" post-revolutionary sports culture for the Soviet society. The military's concern for producing competitive elite athletes was challenged by those who were highly critical of the pre-revolutionary traditions upon which Soviet sports had first been constructed. One such post-revolutionary faction, the Hygienists, rejected all competitive sports, contrasting sports with healthy exercise and physical culture. ${ }^{17}$ The Proletkult or the Proletarian Culture Movement, rejected all prior culture as bourgeois and sought to advocate a specifically class approach to all areas of culture, including sports. They invented unique proletarian games such as, "rescue from the imperialists" and "smuggling revolutionary literature across the Frontier."18 Overall, physical culture under NEP was less "militaristic" in nature, and was patronized by the state for encouraging men and women to lead "rational" and "healthy" lifestyles and to help construct a strong socialist Soviet state. 19

Thus, while Polish women's physical culture in the early interwar years developed largely through social initiative and in the midst of political confusion and socio-economic hardships, Soviet women's physical culture evolved in response to the Bolshevik state's concerted efforts to integrate the empire, win the civil war, "liberate" women from patriarchy, and improve the health of the workers who would enthusiastically build socialism in the country. With this ideological agenda, the Soviet state organized and directed its sports apparatus from the very beginning of the interwar

\footnotetext{
16 James Riordan, "The Rise, Fall, and Rebirth of Sporting Women in Russia and the USSR," in Journal of Sport History, 18, 1 (Spring, 1991), 191.

17 Riordan, "Sport in Soviet Society: Fetish or Free Play," 221, 222.

18 Edelman, Serious Fun, 34. Another novel "proletarian game" was played on Sparrow Hills in Moscow in the summer of 1924 with 6000 participants. The game was called 'Indians, British, and Reds,' the Indians being led by a plumed Chieftain, the British by 'Joseph Chamberlain' and the Reds by the 'Chairman of the Revolutionary Military Council', Trotsky. The plan of events was: (i) life goes on peacefully in all countries, with people engaging in games and sports: Indians in primitive games, hunting, dancing and fighting; the British pursuing sports and carrying out punitive expeditions; and the Reds simulating work in factories, engaging in proletarian recreation and workers' outdoor fetes; (ii) the British suddenly attack the Indians and conquer them; (iii) the Reds receive an appeal for help and join the struggle; (iv) the Indians join the Reds and together attack the British and defeat them; (v) Victory festivals take place in a new communist world. From the description of this game one can clearly see the allusions to the 'East-West' dichotomy and the Soviet belief in the triumph of communism. See Riordan, Sport in Soviet Society, 102.

${ }^{19}$ For all these issues see Riordan, Sport in Soviet Society, 89, 90, 93, 94, 118.
} 
period. In Poland, by contrast, society preceded the state in the formulation of its male and female physical cultures. The Polish ruling elite, overwhelmed by the legacies of partition and the challenges of reunification, marginalized the reconstruction of the prewar sports apparatus. However, with Pilsudski's military coup in Poland in 1926, the Polish interwar physical culture, similar to its Soviet counterpart, came to be governed more by state prerogatives than social interests. The organization of Polish women's physical culture directly benefited from this state direction and gradually expanded its popularity with greater political coordination 'from above'.

\section{Political Authoritarianism, National Militarism, and Women's Sports, May 1926-May 1935}

The organization of women's physical culture, while more restricted and "spontaneous" in the initial interwar years of Polish democratic state-building, became more systematic and "militarized" with the subsequent breakdown of parliamentary government, the use of political intimidation, and the radicalization of nationalist ideas. By 1926 it was clear that the parliamentary government, with its political uncertainty and factionalism between the multitude of political parties, had not been able to solve the pressing socio-economic and political problems of Poland. In May 1926, Marshal Pilsudski forcibly overturned the existing government by a military coup and established in its place a regime that was a combination of a personal military dictatorship and a centralized authoritarian oligarchy. In this Sanacja era, the effectiveness of the democratic opposition was gradually whittled away. In view of Poland's enmity toward both Soviet Russia and Weimar Germany, and her inability to improve her position effectively either through alliance with the other small Central East European countries or with West European powers (mainly France and Britain), the Poles could rely only on their own meager resources. In these circumstances, the aim of Pilsudski's regime was to defend Poland's territorial integrity and safeguard its state-preferred image as a high powered nation commanded by infallible political leaders. In order to accomplish this dual objective, Pilsudski sought a powerful, well-equipped and trained army, a strong, centralized state apparatus, and a country free from internal strife, political confusion and party corruption. For these reasons, the state now extolled the role of the army in national life and gradually became more authoritarian and intolerant of ideological variants. 20

20 Davies, God's Playground, Vol. II, 423; Ascherson, The Struggles, 70; Polonsky, Politics in Independent Poland, 147; Leslie (ed.), The History of Poland, 158, 159; Bromke, Poland's Politics, 34, 35, 
However, Pilsudski's coup, which ended the liberal representative democracy that had given Poland fourteen separate governments in slightly over seven years, did not introduce totalitarian rule in the country. Pilsudski retained the Parliament, as well as elections and significant civic liberties. Though badgered, the opposition parties operated legally; though harassed, the trade unions and press remained independent and active; outspoken foes of the regime continued to teach at the universities and to publish their criticisms; the autonomy of the judiciary from the administration was preserved, and the bureaucracy, while rigid, was technically competent. Thus, Poland appeared to be governed as a 'guided democracy' with a very strong executive authority working to secure a unified state. 21

The development of women's sports in the years after Pilsudski's coup was structured by the ideological preferences of the Sanacja regime and the predominant role of the military in the political apparatus. In its political priorities, Pilsudski's state sought legitimacy and popularity in the formation of the "Non-Party Bloc for Cooperation with the Government' (Bezpartyjny Blok Wspolpracy z Rzadem, BBWR). The BBWR was not a political party in the ordinary sense; it was simply a federation of separate political parties which pledged to submerge their partisan identities in favor of supporting the Polish state under Pilsudski against both "internal" and "external" foes. The BBWR emphasized the need for the professionalization of the state apparatus with an infusion of technocratic-managerial cadres, and stressed the importance of elevating general state interests above particular class, social, and party ones. As such, the group of men who ruled Poland from 1926 onward were drawn from many diverse backgrounds and represented a broad variety of experiences and viewpoints. In this political environment characterized by sharp ideological divergences and splits, only the recognition of Pilsudski as the sole competent authority in Poland and the willingness of the BBWR to subordinate itself totally to his leadership bound its members together into a unified and harmonious bloc. For this reason, the BBWR carefully nurtured the cult of Pilsudski and sustained its mass appeal through active use of state propaganda in all realms of governance, including the cultural sphere of sports and physical education for both men

37, 42; Wynot, Warsaw Between the World Wars, 48; Wynot, Polish Politics in Transition, 22, 37; Korbonski, "Poland: 1918-1990," 238; and Joseph Rothschild, "Marshal Josef Pilsudski on State/Society Dialectics in Restored Interwar Poland," in Timothy Wiles (ed.), Poland Between the Wars: 1918-1939 (Bloomington, 1989), 29-38, p.31.

21 Andrzej Chojnowski, "Polish National Character, the Sanajca Camp, and the National Democracy," in Ivo Banac and Katherine Verdery (eds.), National Character and National Ideology in Interwar Eastern Europe (New Haven, 1995), 23-38, p.35; Garlicki, Jozef Pilsudski, 158; Brzezinski, The Struggle for Constitutionalism in Poland, 57; Wynot, Warsaw Between the World Wars, 48; and Rothschild, "Marshal Josef Pilsudski," 36, 37. 
and women. ${ }^{22}$ Indeed, the organization of women's physical culture was conditioned in accordance with this state emphasis on creating an acceptable image of its publicized goals, and the government's attempts to arouse mass patriotic emotions which supported the ideological predilections of the BBWR.

While the political interests of the BBWR and the emerging cult of Pilsudski directed Poland onto the path of authoritarianism, the Polish armed forces also contributed significantly to the processes of state building and the "militarization" of the state apparatus and civic culture. The army, formed by compulsory male conscription and commanded by General Wladyslaw Sikorski, served as the principal instrument of the state for fostering social and national unity. Sikorski, though a staunch personal opponent of the Pilsudski regime before the war, nonetheless trained the cadre of interwar military officers who remained loyal to Pilsudski and, after 1935, to his memory. Pilsudski's authority reigned supreme in the military, and the Marshal introduced the military principles of discipline and loyalty towards the state in all spheres of administration, including sports and physical education. ${ }^{23}$ It comes as no surprise, therefore, that the apparatus of women's sports would also become "militarized".

Indeed, following Pilsudski's coup in May 1926 and his overwhelming concern with the nation's "self-defense", the structural apparatus of Polish sports became "militarized". Pilsudski extolled the values of centralization, uniformity, and unification in the organization of male and female physical cultures with the objective of improving military discipline and popularizing values of patriotism and good soldiery. Games that exhibited military potential, such as rifle-shooting and fencing, were particularly emphasized in the new paramilitary sports education of the youth. In keeping with Pilsudski's authoritarian approach to relations between state and society, the State Institute of Physical Education (Panstwowy Instytut Wychowania Fizycznego, PIWF) was founded in Warsaw in 1926 and transformed into the State Office for Physical Education and Military Training (Panstwowy Urzad Wychowania Fizycznego i Przysposobienia Wojskowego, PUWFiPW) the following year. The PUWFiPW was the main governmental organ for directing sports and coordinating the financial, institutional, and organizational development of physical culture until the outbreak of the Second World War. The various overlapping and competing governmental offices for physical culture

\footnotetext{
22 Wynot, Warsaw Between the World Wars, 53, 153; Watt, Bitter Glory, 275; Rothschild, East Central Europe between the Two World War, 58; Rothschild, "Marshal Josef Pilsudski," 32; Wynot, Polish Politics in Transition, 23, 34; and Garlicki, Jozef Pilsudski, 153, 154.

23 Garlicki, Jozef Pilsudski, 155; and Andrzej Korbonski, "Civil-Military Relations in Interwar Poland," in Wiles (ed.), Poland Between the Wars, 39-54, p.50.
} 
were eliminated in favor of this single and unified state sports authority to streamline sports management, and organize and upgrade sports performance levels within the country. The PUWFiPW, staffed with representatives of the ruling Sanacja camp, controlled the different activities of the various sports societies and federations. It also coordinated its work to increase sports contacts between the state and society with the assistance of the Ministry for Military Affairs, the Ministry of National Education and Social Welfare, the Polish Olympic Committee, and the various branches of WFiPW in voivodeships and towns. 24

Thus, from 1926 onward, Pilsudski attempted to regulate physical education and sports to promote ideas of Polish patriotism and militarism. Accordingly, the state placed all sports clubs under its surveillance. By the eve of the Second World War, the PUWFiPW had insisted on the amalgamation of all sports associations, including the endecja influenced Sokol and the Christian youth sports groups. ${ }^{25}$ The organization of sports in the armed forces received special attention from the central government. In Poznan, Colonel Walerian Sikorski established the Central Military School for Gymnastics and Sports (Centralna Wojskowa Szkola Gimnastyki i Sportow, CWSGiS, 1921-1929) which, together with the Center for the Study of Physical Education at Poznan University, trained instructors in physical education and military preparation. While the CWSGiS was organized mainly for military officers, it was open to civilians of both sexes. Sikorski also organized intensive instructional and organizational activities in physical education that included several publications and discussion seminars. Because Sikorski did not represent the political line of Pilsudski, he was replaced in October 1926 by Dr. Wladyslaw Osmolski (1883-1935) who remained a follower of the Marshal. In 1929, the CWSGiS was combined with the State Institute of Physical Education in Warsaw (1925) to become the Central Institute of Physical Education (Centralny Instytut Wychowania Fizycznego, CIWF). Osmolski commanded the Central Military School for Physical Education at its new location in Warsaw and also served as the first director of

\footnotetext{
24 For details see PzS, 15, 6, 1014 (19 January, 1935), 4; $\underline{\text { PzS }, ~ 18, ~ 91, ~} 1451$ (10 November, 1938), 4; Warsicki, Kultura fizyczna, 4, 33, 40, 80, 174; Gaj in Gaj and Hadzelek, Dzieje kultury fizycznej, 106-108, 118; Grot, "Versuch eines abrisses," 306; Gaj, "Ideas, Conditions and Effects," 75, 76; Henryk Laskiewicz, "Ideowo-wychowawcze funkcje sportu robotniczego," in Jerzy Krawczyk, Sport w spoleczenstwie wspolczesnym. Praca zbiorowa pod red. Zbigniewa Krawczyka (Warsaw, 1973), 55-81, p.67; Liponski, "Still and Unknown," 20; Chmielewski, Polish Sport, 13, 14; Jerzy Gaj, Wychowanie fizyczne $i$ sport w Polsce Ludowej (Warsaw, 1987), 15; Krawczyk, "Elementy historii wychowania fizycznego," 216; Wynot, Warsaw Between the World Wars, 288; and Jakubowsk, Wybrane zagadanie z historii kultury fizycznej, 244.

25 Woltmann, "Gegensatze in der polnischen Sportbewegung," 157-159; and Laskiewicz, Robotnicza kultura fizyczna, 118.
} 
CIWF. In both institutions, Osmolski stressed the importance of physical education and sports for the military, biological, and intellectual needs of society. Courses in boxing, swimming, rifleshooting, gymnastics, and fencing were part of the curriculum to improve the health and strength of the largely illiterate peasant soldiers. As a Sanacja supporter, Osmolski emphasized those ideas in physical culture which included the subordination of the amateur sports movement to state authoritarian control, as well as an increased focus on competitive sports and the organization of paramilitary youth groups, including a women's officer training corps. Osmolski's views ran counter to those of Eugeniusz Piasecki who, during the interwar period, continued his pioneering sports research and publications in the CSWGiS and in the medical department of the newly opened University of Poznan in 1919. An endecja supporter, Piasecki wanted sports to satisfy the "inner need", and not any external motives. For this reason, he viewed grandstands competitive sport with disdain. However, the militarization of the sports apparatus gave credence to Osmolski's ideological framework for the development of Polish physical culture in the interwar period. 26

Women's physical culture, meanwhile, enjoyed greater popularity following Pilsudski's coup of 1926 and the nation's drift toward political authoritarianism and militarism. While women's participation in the various sports was more "spontaneous" between 1918-1926, the increasing state interest thereafter provided the necessary institutional and organizational pillars to effectively support the construction of women's physical culture in the second half of the interwar period. 27 Although the country itself never became a one-party state, as was the fate of its two proximate totalitarian neighbors, the increased official concerns of indoctrinating the state and civil apparatus with notions of national patriotism and militarism resulted in strong authoritarian impulses which impacted the realm of women's sports as well. For example, with Pilsudski's coup, the PUWFiPW, RNWF, and the Marshal himself sought to use the

\footnotetext{
26 PzS, 18, 91, 1451 (10 November, 1938), 2; Bluszcz, 49 (8 December, 1934), 1535; Zygmunt Jaworski, "Conceptions of Higher Studies of Physical Education in European Socialist Countries," in Wychowanie Fizyczne i Sport, 22, 4 (1978), 287-293, p. 287; Szymanski, Kultura fizyczna w polityce, 20, 89, 91, 93-95, 114; Reczek, The Development of Physical Culture, 11; Grot, "Katedra," 12-83, 43, 46, 63; Grot, "Versuch eines abrisses," 308; Warsicki, Kultura fizyczna, 38, 41, 42, 48, 50, 53, 54, 56, 58, 59, 80, 175, 192, 195; Liponski, "Still and Unknown," 17, 18; Laskiewicz, Robotnicza kultura fizyczna, 25; Gaj, "Ideas, Conditions and Effects," 65-68, 70, 71, 73, 76; Gaj in Gaj and Hadzelek, Dzieje kultury fizycznej, 113, 147; K. Hadzelek, "Foundation," 1982, 79-101, pp.82, 82; Gaj, Wychowanie fizyczne, 36. For the organization of sports in the armed forces and its importance for raising the society's military fitness see Jan Kesik's, Wojsko Polskie wobec tezyzny fizycznej spoleczenstwa, 1918-1939 (Wroclaw, 1996).

27 Biuletym Informacyjny Glownego Komitetu Kultury Fizycznej i Turystyki (Nr.10-12, Warsaw, 1975), 8; Bluszcz, 46 (12 November, 1938), 62/1166, 63/1167; and Maria Rotkiewicz, "Rozwoj sportu kobiet w Polsce okresu miedzywojennego,” Sport Wyczynowy, 3-4/171-172 (1979), 3-21, pp. 5, 19.
} 
women's sports apparatus for the indispensable task of national military preparation. The PUWFiPW was bestowed with the principal responsibility of organizing women's sport until the eve of the Second World War. 28

One of the principal accomplishments of the PUWFiPW was the creation of the Society for the Propagation of Physical Culture for Women (Towarzystwo Krzewienia Kultury Fizycznej Kobiet, TKKFK) in March 1933 with the ambitious objective of patronizing and popularizing physical education and sports among the widest classes of women. This women's sports society convened regular meetings and conferences, and organized recreational winter and summer sports camps, especially for female workers and their families. The ultimate goal of TKKFK's intellectual and organizational activities was to promote sports and physical culture for women as a healthy and "rational" engagement with significant cultural and moral benefits for them personally, as well as for the nation at large. 29

Besides the TKKFK, several other organizations and institutions also promoted women's sport. For example, the State Council of Physical Education had exhibited an early interest in physical education and sports for women that was reflected in the formation of several women's associations and sports societies. ${ }^{30}$ According to the director of PUWF, Juliusz Ulrych, women's physical education helped to uplift the general moral and physical development of the nation. 31 The Society for Women's Physical Education (Zrzeszenie Stowarzyszen dla Wychowania Fizycznego Kobiet) also sought to increase contacts among women's sports clubs, and improve women's health and physical fitness. 32 The Zrzeszenie Towarzystw Wychowania Fizycznego Kobiet, with the support of PUWFiPW, helped to establish ten sports halls for girls in Warsaw

\footnotetext{
28 Wiz. H. Olszewska, "Historyczna rola pierwszego Marszalka Polski Jozefa Pilsudskiego na polu wychowania fizycznego w Polsce," in Wychowanie Fizyczne w Szkole, 8-9 (1935-1936), 223-228, pp. 224, 227; Bluszcz, 51-52 (23 December, 1924), 959; Bluszcz, 22 (28 May, 1927), 11; Kobiety w Pracy, 2, 5-6 (June-July, 1939), 2, 9, 20; Kobieta Wspolczesna, 1, 1 (3 April, 1927), 1; Rotkiewicz, "Rozwoj sportu kobiet w Polsce," 5; and Szymanski, Kultura fizyczna, 35, 36.

29 On TKKFK see Kobiety w Pracy, 1, 3 (April, 1938), 15; Kobieta w Swiecie i w Domu (hereafter, KSD), 11, 2 (January, 1935), 29; KSD, 14, 10 (15 May, 1938), 15; Start, 9, 9/10, 1 i 2 (May, 1935), 22; Moja Przyjaciolka, 4, 11 (10 June, 1937), 266; Bluszcz, 15 (14 April, 1934), 470; Bluszcz, 49 (8 December, 1934), 1538; Bluszcz, 21 (25 May, 1935), 647-649; Bluszcz, 51-52 (19-26 December, 1936), 22-23/12021203; Bluszcz, 37 (11 September, 1937), 12/892, 13/893; Bluszcz, 18 (29 April, 1939), 15/491, 16/492; Bluszcz, 17 (23 April, 1938), 10/394, 11/395; Bluszcz, 46 (12 November, 1938), 60/1164; Biuletym Informacyjny Glownego Komitetu Kultury Fizycznej i Turystyki (Nr.10-12, Warsaw, 1975), 8; Rotkiewicz, "U zrodel," 104; Rotkiewicz, "Rozwoj sportu kobiet w Polsce," 20; Laskiewicz, Robotnicza kultura fizyczna, p.28; Rotkiewicz, "Rozwoj spolecznych organizacji sportu kobiet w Polsce," 74, 75; Tuszynski, Prasa $i$ sport, 200-203; and Szymanski, Kultura fizyczna, 35.

30 Rotkiewicz, "Rozwoj spolecznych organizacji sportu kobiet," 73.

31 Start, 1 (10 April, 1927), 3.

32 Bluszcz, 23 (4 June, 1927), 11, 12.
} 
with instructors of physical education in every hall. ${ }^{33}$ Further, the Scientific Council of Physical Education also conducted research in developing physical culture and sports for women. One of its members, Dr. Eugenia Lewicka, made significant contributions in sports medicine for women in the interwar period. 34

The state also supported conferences which discussed the importance of women's physical culture, and representatives of the various women's organizations participated in the 1928 and 1934 sports conventions for women to popularize sports and physical education among women. The participants presented papers on the positive impact of physical culture for women's physical, psychological and physiological development. However, the majority of the participants concluded that the emphasis for women in sport should be on "good" performance and factors related to health and beauty, rather on strenuous competition and the quest for records. 35

Under Pilsudski, the political leadership endeavored to use sport as a tool of social integration that would not only build bridges between urban and rural areas, but would also unite the various strata of Polish society, including women, intelligentsia, workers, peasants, and the youth. The Second Polish Sports Congress (9th and 10th April, 1927), attended by about 300 delegates, discussed similar ideas of promoting sport for women, youth and peasants. Also, despite financial difficulties, the period after 1926 witnessed a phenomenal growth in sports facilities, especially in the construction of stadiums as well as tennis courts, gymnastic halls, swimming pools, and harbors for rowing. More money was also invested in the organization of sports between the years 1927-1935 so as to place equal emphasis on both the theoretical and practical benefits of physical culture. This stress on the mass character of Polish sport, which incorporated sentiments of active

33 Kobieta Wspolczesna, 1, 14 (3 July, 1927), 18, 19.

34 See Bluszcz, 34 (1925), 961-963; Stadjon, 25 (1931), 7; Bluszcz, 28 (1931), 13; and Start, 13 (1931), 2. See also R. Wroczynski and K. Hadzelek, "Development of Sciences on Physical Education and Sport in the Academy of Physical Education," in Wychowania fizyczne i sport, 22, 4 (1978), 87-104, p. 88.

35 Bluszcz, 19 (12 May, 1934), 580; Tuszynski, Prasa i sport, 200; Rotkiewicz, "U zrodel," 104; Krawczyk, "Rola spoleczna," 302; Laskiewicz, Robotnicza kultura fizyczna, p.28; Rotkiewicz, "Rozwoj sportu kobiet w Polsce," 20; Rotkiewicz, "Geneza," 9, 10; Guttmann, Women's Sports, 172, 176; and Biuletym Informacyjny Glownego Komitetu Kultury Fizycznej i Turystyki (Nr.10-12, Warsaw, 1975), 7. Some of the papers delivered at the 2nd Congress of Physical Culture for Women on 28th and 29th April, 1934 with representatives of institutions and societies of physical education, included Wladyslaw Kilinski's, "Matka i dziecko pod wplywem wychowania fizycznego"; Dr. Zofja Franio's, "Wplyw wychowania fizycznego na system nerwowy i psychike kobiety"; and Janina Miedzinska's, "Problem cwiczen ruchowych dla kobiet pracujacych." For these papers see Sprawozdanie z Drugiego Kongresu Kultury Fizycznej Kobiet odbytego w Dn. 28 i 29 Kwietnia 1934r. w Warszawie (Nakladem Towarzystwa Krzewienia Kultury Fizycznej Kobiet), 5-10; 21-30; 39-47. According to Kilinski, physical culture was an important issue for mothers and children. According to Franio, physical culture was important for women's physical, psychological and physiological development. For Miedzinska, physical education was needed for uplifting the health and physical fitness of working women. 
nationalism and patriotic militarism, led to the establishment of a systematic apparatus of awards and honors which successfully stimulated societal interest in physical culture. Significantly, both Polish male and female athletes were decorated with these sports laurels.

Unfortunately, for all its propaganda, Sanacja's anti-democratic thrust in building a patriotic sporting culture aroused opposition from sports organizations such as the Polish Olympic Committee (PKIO) and the Union of Polish Sports Societies (Zwiazek Polskich Zwiazkow Sportowych, ZPZS). Even the doctors and naturalists who understood the health benefits of physical exercises opposed the "militarization" of public life, including its impact in physical education instruction, in sports management, and in their own medical research. Further, problems in integrating women and peasants into the state- sponsored physical culture movement prevented sports from becoming a mass activity. Insufficient financial assistance and interest by certain ministries such as the MWRiOP made matters only worse. 36

This societal resistance towards Pilsudski's authoritarianism and militarism in the realm of sports and physical education was similar to the other political, economic, class, and ethnic tensions between the state and society in general during this time period. No doubt, the BBWR succeeded in raising Poland's international prestige and selfconfidence, and helped to balance the budget, professionalize of the civil bureaucracy, reintegrate all the preponderantly Polish-populated areas into one political system, and revive the morale of the armed forces. Also, the initial effect of the May coup in ending political instability greatly increased business confidence and fostered economic recovery. 37

Unfortunately, the militarization of the state and civil apparatuses under Pilsudski widened the gap between state and society. The authoritarian conduct of the largely incompetent and unprofessional governmental leaders cost the Sanacja regime the valuable loyalty of its citizenry. Pilsudski's actions were increasingly marked by arbitrariness and often dictated by whim which resulted in the progressive disunity and intellectual bankruptcy of the BBWR. The function of the BBWR was to insulate the

\footnotetext{
36 Laskiewicz, Robotnicza kultura fizyczna, 19, 20, 28; Tuszynski, Prasa i sport, 98, 99; and Szymanski, Kultura fizyczna w polityce, 22, 24, 25, 27, 31, 32, 36, 37, 71, 72, 118-131. For details on the II Sports Congress of April 1927 (the first was held in 1923) see Bluszcz, 19 (7 May, 1927), 12, 13; and Laskiewicz, Robotnicza kultura fizyczna, 19, 20. For ZPZS see Warsicki, Kultura fizyczna, 36; and Szymanski, Kultura fizyczna w polityce, 20.

37 Rothschild, East Central Europe between the Two World Wars, 61; Wynot, Warsaw Between the World Wars, 49; and Rothschild, "Marshal Josef Pilsudski," 34.
} 
regime from antagonistic social and ideological pulls and pressures, and not to draw the nation into political activism.

Moreover, Pilsudski's passionate commitment to only "state-building" undervalued the need for "nation-building". For this reason, the young interwar generation felt stifled by laws that restricted freedom of assembly, censored the press, and undermined the autonomy of universities. Instead, the youth found the government to be tired, repressive, and without any real solutions for the country's pressing problems. Pilsudski's policies displayed little understanding of the nature of parliamentary debate, or of tolerance of opposition. Even the minority groups such as the Jews, Byelorussians, Ukrainians, and Germans were denied political partnership with the Pilsudskist "statebearing" elite. Their indigenous political, cultural, intellectual, social, and economic aspirations, channeled into their own separate organizations, conflicted sharply with the territorial integrity of Pilsudski's state.

Meanwhile, with the deteriorating economic situation following the onset of the Great Depression, the hostility of the peasant and socialist parties to the government was especially intensified. The peasant movement become more radicalized, while industrial strikes in 1933-1937 fueled economic tensions. The combination of conservative monetary and fiscal policies with state-capitalistic investments in primary industrial sectors plunged the agricultural sector into deeper misery. These economic hardships further divided Polish society. While the territorial reunification of the Polish territories, the general rise in the level of education, and the state use of media for mass propaganda fostered images of social unity, the persistent economic malaise severely undermined the already weak foundations of these inter-class integrative bridges. The National Democrats strongly criticized the government for its lack of a "national and Catholic character,' and the communists castigated the socialists for their 'betrayal' of the working class. Meanwhile, the exaggerated importance of infantry and cavalry at the expense of artillery, tanks, aircraft and communications caused dissension in military circles.

Overall, the alienation of ethnic minorities, rural overpopulation and industrial "backwardness", and political decline from the original semi-democracy before 1926 to Pilsudski's semi-dictatorship caused the state to become increasingly isolated from the society in all of its manifestations. Pilsudski and his entourage succeeded in asserting their monopoly over the state apparatus and its power structure, but they lost control and leadership over Polish society to the allegedly corrosive political parties. 38 The

38 For all these economic, political, ethnic, social, and cultural problems in Pilsudski's regime see Leslie (ed.), The History of Poland, 148, 164, 165, 171, 177, 178, 180, 184; Polonsky, Politics in Independent Poland, 200, 203, 212, 238, 240, 283, 326, 332, 335, 358-360, 367, 391, 508-513; Bromke, Poland's 
organization of Polish sports was also impacted by these political, economic, and social weaknesses, and the popularity of mass physical culture, for both men and women, suffered from the state's lack of creative imagination to successfully build not only a Polish "state" but also, and more importantly, a Polish "nation".

True enough, the history of Poland in the interwar years is disheartening, marked by repeated failures in promoting economic development, integrating the minorities, and securing civil rights for the society. The repercussions of these failures resounded in all spheres of daily life, including sports. However, considering the initially low level of economic development compounded by the legacy of partitions, the loss of the Russian, German, and Austrian markets, the damage caused by W.W.I, the outright indifference if not hostility of the Western powers which, having put Poland on the map at Versailles, declined to provide it with economic support, and the effects of the global economic crisis, Poland's economic, intellectual and cultural achievements during the interwar period were far from negligible. 39 Moreover, the valiant struggle to secure Poland's borders and the momentous victory over the Soviet Bolsheviks in 1920, the promotion of social integration and national identity, at least among the ethnic Poles, the creation of a progressive welfare system, the emphasis placed on family values and civility, and the relatively low incidence of serious crime were some of the few unacknowledged or underestimated successes of this time period. 40 It is in this positive context that we must also place the organization and accomplishments of the male and female physical cultures in interwar Poland. Despite Pilsudski's dictatorial urges, there is no denying that Polish sport, for both men and women, reached a high state of development under active

Politics, 44, 55, 56; Davies, God's Playground, Vol. II, 411, 413, 414, 419, 542, 544; Jan Kofman, Economic Nationalism and Development: Central and Eastern Europe Between the Two World Wars (Boulder, 1997), 129-139; Korbonski, "Civil-Military Relations in Interwar Poland," 51, 52; Rothschild, "Marshal Josef Pilsudski," 29, 31, 33, 34, 35, 37; Wynot, Warsaw Between the World Wars, 51; Montias, Central Planning in Poland, 49; Garlicki, Jozef Pilsudski, 155; Rothschild, East Central Europe between the Two World Wars, 61; Andrzej Chojnowski, Koncepcje polityki narodowosciowej rzadow polskich w latach 1921-1939 (Wroclaw, 1979), 240; Wlodzimierz Rozenbaum, "The Status of the Jews in Poland Between the Wars, 1918-1939: An Overview," in Wiles (ed.), Poland Between the Wars, 161-169, p.163; Janusz Zarnowski, "Polish Society and its Cultural Stratification: 1918-1939 and After," in Wiles (ed.), Poland Between the Wars, 125-132, pp.126-128; Edward Wynot, "The National Minorities of Interwar Poland: An Overview," in Wiles (ed.), Poland Between the Wars, 149-160, pp. 149, 152, 153, 156, 157; and Korbonski, "Poland: 1918-1990," 243, 244, 248.

39 Korbonski, "Poland: 1918-1990," 241; Davies, God's Playground, Vol. II, 427; and Leslie (ed.), The History of Poland, 206, 207. On the importance of "houses of culture" which promoted social integration and enhanced cultural life in interwar Poland see Aleksander, "Tradycje domow kultury w Polsce," 60-65, 71.

40 Peter D. Stachura, "The Second Republic in Historical Outline," in Peter D. Stachura (ed.), Poland Between the Wars, 1918-1939 (Basingstoke and New York, 1998), 1-12, p. 7. According to Stachura, these achievements of the Second Republic have often been ignored. 
state patronage. For this reason, the death of Pilsudski in May 1935 was rightly mourned in the interwar Polish sports world. 41

\section{The Framework of Women's Physical Culture in the Post-Pilsudski Years, 1935-1939}

In the post-Pilsudski period, women's physical culture became even more militarily structured. Women were urgently encouraged to participate in sports to improve their physical fitness for national defense. The state's concern for building the nation's health for military purposes came amidst serious domestic upheavals which threatened the country's tenuous political and social stability. Pilsudski's death proved extremely disruptive to the coherence of the Sanacja, whose coalition was replaced with the Oboz Zjednoczenia Narodowego (Camp of National Unity, OZN) in 1937. Under the leadership of Marshal Rydz and Colonel Koc, the OZN reaffirmed its commitment to revitalizing Pilsudski's "state nationalism" through the militarization of the state and civil structures, and the insistence on public loyalty to state authority. However, unlike Pilsudski's objective of de-politicizing the nation, the OZN attempted to create a cult of the uncharismatic Rydz by re-awakening popular political consciousness in order to reaffirm his moral and spiritual leadership of the unstable political movement. An effort was now made to replace the officially encouraged passive subordination of the populace under the authoritarian personal rule of Pilsudski with a renewed sense of duty to the collective nation-state under the unimpressive Rydz. 42

The organization of sports and physical education for men and women benefited from OZN's ambitious plans to resolve Poland's pressing economic and social problems. OZN launched a campaign designed to overhaul the socio-economic structure and convert it as swiftly as possible into a highly industrialized and urban society that could offer the state a solid foundation upon which to expand its political power and bolster its internal strength. In its move toward central planning, OZN emphasized industrialization for strengthening the state's defensive capabilities and reshaping the economic and social structure of Poland by combating unemployment and raising the general standard of living. In the rural economy, the state called for the transformation of "checkerboard"

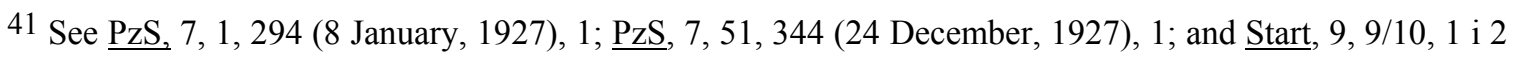
(May, 1935), 2, 3.

42 Wynot, Polish Politics in Transition, 34, 69, 71, 72, 73, 79, 86, 122, 265, 266. See also Brzezinski, The Struggle for Constitutionalism in Poland, 54; Bluszcz, 9 (27 February, 1937), 3/195-6/198; and Korbonski, "Poland: 1918-1990," 248. 
land holdings into viable economic units. ${ }^{43}$ The OZN also discussed plans to "modernize" the Polish society by eliminating illiteracy and creating a network of medical and health centers. The need to improve the physical and intellectual abilities of the Polish citizenry was perceived as critical to the state's agenda of military mobilization and preparedness. 44

In was in this context of 'advanced militarization' that from 1937 onward the PUWFiPW made concerted efforts to implement ideas of sports socialization and mobilization. The Camp of National Unity singled out mothers and children for "special care", with the physical fitness of the latter receiving extra emphasis. OZN expressly established that it was the civic duty of every Pole to raise "numerous and health offspring". For this reason also, the state committed itself to "protecting" large families. 45 Thus, women's physical culture, in the years 1935-1939, was supported by the state to enable physically strong mothers to raise militarily fit progeny. The Polish government, henceforth, directed its efforts to encouraging the formation of "large healthy families" with the assistance of "sportive" parents and athletic children. Women's physical culture, accordingly, was perceived as critical for nurturing a militarily strong citizenry capable of defending the increasingly vulnerable Polish state.

Meanwhile, a law of August 23, 1938 transformed the Central Institute of Physical Education, itself formed as a result of an earlier merger of the Central Military School of Gymnastics and Sports in Poznan (1921) and the State Institute of Physical Education in Warsaw (1925), into the Academy of Physical Education. The Academy was responsible for training physical education teachers, as well as assisting scientists and specialists in various fields of physical education in conducting their scientific research. The Academy shaped and developed scientific workshops, looked for new scientific proposals and methodological solutions, drew up the first drafts of a research program, and began the difficult and complex process of training its own scientific personnel, thereby creating in this way foundations for making the curriculum of physical education a separate science and establishing its relationship to other sciences. Interestingly enough, half of the graduates from this institute were women. 46

\footnotetext{
43 Wynot, Polish Politics in Transition, 91, 92, 93, 100, 101, 266; and Wynot, Warsaw Between the World Wars, 54, 55.

44 Wynot, Polish Politics in Transition, 114-116, 119.

45 Wynot, Polish Politics in Transition, 119, 120.

46 Wroczynski and Hadzelek, "Development of Sciences on Physical Education and Sport in the Academy of Physical Education," 87, 89.
} 
The nature of Polish physical culture in the late interwar period was thus conditioned by the specific policies of OZN and its relationship with the Polish society. Certainly, the regime attached special importance to cultural pursuits such as sports for their perceived utility as an indispensable factor in integrating the nation. OZN continued to reaffirm the multiple agendas of Polish sporting culture in improving the nation's health and hygiene, fostering national prestige and glory, facilitating social activism and mobility, indoctrinating a 'rational' education in the youth, and building national 'patriotism' for military preparedness. Because of these multifaceted goals, Polish sport occupied an important position in the larger political and cultural contexts, alongside other forms of entertainment such as theater, music, and dance. The development of Polish physical culture continued, as evidenced by the proliferation of sports in places such as Warsaw, Poznan, Lodz, Czestochowa, Upper Silesia, Krakow, Lwow and Gdansk-Pomerania. These principal centers of interwar sport nurtured a host of new governmental and societal sports organizations and federations, and maintained a greater focus of including the working class, women, and minority groups such as Jews, Germans, Russians, Ukrainians, and Lithuanians into the Polish sporting culture. 47

From a comparative perspective, the organization of male and female sports in the Soviet Union also became more "militarized" in the second decade of the interwar period. The militarization of the centrally planned Soviet economy and polity was an essential element of Stalin's revolution from above. Soviet women's physical culture was conditioned by the state's emphasis on rapid industrialization, military mobilization, and the "strengthening" of the family unit, which was in contrast to the earlier Bolshevik rhetoric of the "withering away of the family".

"Stalinism" prioritized competitive, high-performance sports that were to be used for the political purposes of glorifying the state, fostering social solidarity, improving physical fitness, enhancing the efficiency of production, and improving the condition of the military. Accordingly, "socialist competitions" in sports were organized, along with many other mass sporting festivals, pageants, Olympic style Spartakaids, and annual

47 These issues have been discussed in several works. See for example, Bluszcz, 42 (19 October, 1929), 11; Woltmann, "Gegensatze in der polnischen Sportbewegung," 157, 158; Laskiewicz, Robotnicza kultura fizyczna, 147; Warsicki, Kultury fizyczna w Wielkopolsce, 178; Szymanski, Kultura fizyczna w polityce, 5; Grot, "Versuch eines abrisses," 305, 309; Gaj, Wychowanie fizyczne, 16; and H. Mlodzianowska, "Rozwoj wychowania fizycznego i sportu w Polsce w latach 1914-1949," in Z dziejow kultury fizycznej w Polsce, 63-140, p.131. See article "Spread of Sports in our society" in Kobieta Wspolczesna, 3, 22 (2 June, 1929), 27-31 for the state's desire to make sports mass-based. Also, the relation between sports and music became more important now and sport emerged as a subject in popular music. See Grys, Muzyka i sport, 108, 118, $120,137,138$. 
Physical Culture days, all of which reflected the values and lessons the state and party sought to attach to sports. Sport was brought into line with the standard Stalinist pattern for all activities, becoming a centralized and hierarchical state functional organization. The state encouraged the development of athletic associations and training facilities, and sought the participation of both men and women in the "Ready for Labor and Defense" program which included a series of tests in various sports skills. Excellence in sport became the equivalent of the achievements of the shock-worker in industry and one of the most common slogans in the factories was "Every sportsman should be a shock-worker, every shockworker a sportsman." It is rather paradoxical that Soviet sport in the international arena also expanded its horizons when the popular culture as a whole was forced to look constantly inward. Efforts at integration in mainstream of European sporting life were made when Soviet policy was otherwise based on a deliberate cultural isolationism. 48

Soviet women's physical culture, accordingly, became imbued with notions of "Stakhanovism". In the 1930s, the most celebrated new traits of Soviet womanhood were physical fitness, strength, and the capacity for heroism. Women were applauded as heroines of labor, working alongside men and making no less of a contribution to the process of socialist construction. The Soviet regime especially used women's sports to facilitate women's emancipation in the heretofore "conservative" Soviet communities. Women were encouraged to enjoy good health and a high level of physical fitness since improving one's physical appearance through sport and physical exercise made the body stronger and more capable for increasing economic production. For this reason, throughout the 1930s great stress was placed on women's sport and physical culture. In order to fulfill the demands of industrialization and military defense, the state supported socialist women's physical culture so as to enable them to develop 'strong capable hands for working'. Thus, under state initiative, supreme courage in any sphere, including sports, was no longer a male preserve. 49

48 For details on sports in the Soviet Union under Stalin see Richard Stites, Russian Popular Culture: Entertainment and Society Since 1900 (Cambridge and New York, 1992), 95; Edelman, Serious Fun, 8, 9, 18, 23, 41, 64; Calhoun, Sport, Culture and Personality, 127; Klaus Mehnert, Youth in Soviet Russia (Westport, Conn., 1993), 76; Lowe, Kanin, and Strenk (eds.), Sport and International Relations, 336; Ralph Fisher, Pattern for Soviet Youth (New York, 1959), 205; S. L. Sobolev, Soviet Youth at Work and Play (Moscow, 1939), 6, 7, 29, 30; P.E. Hall, "Sport," in Hubert Griffith (ed.), Playtime in Russia (London, 1935); Riordan, Sport in Soviet Society, 124, 148, 150; Victor Peppard and James Riordan, Playing Politics: Soviet Sport Diplomacy to 1992 (Greenwich, Connecticut, 1993), 62; and Riordan, Soviet Sport Background to the Olympics, 33. For the militarization of the Soviet Union see David R. Stone, Hammer and Rifle: The Militarization of the Soviet Union, 1926-1933 (Lawrence, Kansas, 2000), 1.

49 Soviet Woman, 12 (1969), 34, 35; Lynne Attwood, Creating the New Soviet Woman: Women's Magazines as Engineers of Female Identity, 1922-1953 (New York, 1999), 71, 126-128. Stakhanovites 
While the Polish and Soviet "rational" and "ascetic" physical cultures welcomed women's active participation in sports in the 1930s, albeit for varied purposes, the Italian fascist state stressed the "spontaneous" and "erotic" virility of athletic competition.50 Mussolini served as an athletic mentor for the Italian men, but such an athletic zeal excluded Italian women. In Italy, there was no feminist sports movement along the lines of the British Women's League of Health and Beauty or the Scandinavian or German gymnastics societies, and there was no Italian affiliate of the Federation sportive feminine internationale founded by the French feminist Alice Miliat in 1921. The Italian socialist movement had never been especially sports-minded either. Its local people's houses and outing societies included women and men in family-style entertainments. In the mid-1920s, Catholic modernizers, Father Gemelli in the lead, endorsed promoting "a Catholic gymnastics," and in 1923, under the leadership of Professor Teresa Costa, the Gioventu femminile began forming "Strength and Grace" sections. But this "feminine" version, as Gemelli specified, meant "no shorts, no athleticism, and above all no competition with men's sports." Its ultimate purpose was to form "good, Christian mothers who were physically and morally healthy, hence capable of creating a generation of equally good and healthy Italians." This development was cut short, however, when on April 9, 1928 the fascist government banned all nonfascist sport groups. Thereafter, fascism's own sexual and cultural politics, particularly toward women, remained internally contradictory, demanding novelty yet beset by conflicting interpretations of what was new. The result was a thoroughly hybrid new woman: neither traditional nor coherently modern. She was more self-confident and freer than her mother had been, yet as little or less emancipated.

Fascism's manipulation of female physicality was manifested in its sports policy. Initially, fascist sports promoters were enthusiastic about female participation; modernity meant sports for women as well as for men. The sports policy thus contemplated women's involvement in the fascist recreational clubs and youth groups. By 1930, however, faced with church protests and the possibility that women would treat sports as

were untiring and devoted contributors to the Stalin cult. The Stakhanov movement turned out to be major vehicle of upward mobility. See Sheila Fitzpatrick, Everyday Stalinism. Ordinary Life in Extraordinary Times: Soviet Russia in the 1930s (New York, 1999), 75, 86.

50 In contrast to the comparative asceticism of the Polish and Soviet physical cultures, the Italian fascists were fully in tune with the erotic appeal of sports. Mussolini often stripped to the waist in public and sought to make a cult of his own and other male bodies. By contrast, Stalin never even spoke at the huge annual Physical Culture Day parades held in Red square. The fascists also stressed the spontaneity of athletic activity; this rejection of rationalism ran counter to official Polish and Soviet ideologies. See John Hoberman, Sport and Political Ideology (London, 1984), 92; and Edelman, Serious Fun, 10, 11. 
a step toward emancipation, the regime backed off. Pius XI, alarmed at the rapid growth of the fascist sports movement after 1926 and outraged at public parades of girl athletes in the holy city, condemned fascism's moral sensibility as "weaker" than that of pagan Rome. Subsequently, the regime promoted a highly regulated, medicalized model of physical culture for women. Pius's fulminations had worked, but perhaps only because fascist officials themselves suspected that women's sports lowered birth rates and fostered promiscuous behavior. Thereafter, the Italian National Olympic Committee, in consultation with the National Federation of Sports Doctors, were to determine activities appropriate for women on the guiding principle that "nothing to distract woman from her fundamental mission: Maternity." 51

Unlike fascist Italy, the German Third Reich could not display political athleticism at the top. Hitler did not exhibit any genuine interest in sports apart from its use as a form of political propaganda, such as the 1936 Berlin Olympics. Goring most certainly enjoyed being called "the Iron Man", but it was his beefy hedonism which caught the attention of most observers. The only athletic model among the leading Nazis remained Reinhard Heydrich, a tall and athletic man whom his subordinates sometimes called "the Blond Beast". Heydrich had a passion for all forms of sport; he was a fencer, a horseman, a pilot, a skier and modern pentathlon competitor; he was also SS inspector for physical training. 52

The primary significance of the body for Nazi ideology lay in its racial rather than its sportive properties, which were officially interpreted as evidence of racial superiority. Accordingly, sports were important more for raising the physical fitness of Germans as a racial group. For ideological reasons, only Aryans could participate in German team sports. The Nazi elite sports system was designed to reinforce the popular perception that selection was a 'good thing'. However, Helene Meyer, a half Jewish fencer was admitted to the 1936 Olympic German team as a demonstration of good will to the international community which had threatened to boycott the Berlin Games, if Jews were totally excluded. More basically, the Nazis lacked interest in creating superathletes. On the contrary, Hitler wanted Germans not to participate in competitions in which German superiority was in doubt. 53

51 For all these issues see Victoria De Grazia, How Fascism Ruled Women: Italy, 1922-1945 (Berkeley, 1992), 163, 218, 219.

52 Hoberman, Sport, 99, 162.

53 Graham McFee and Alan Tomlinson, "Riefenstahl's Olympia: Ideology and Aesthetics in the Shaping of the Aryan Athletic Body," in J.A. Mangan (ed.), Shaping The Superman. Fascist Body as Political Icon: Aryan Fascism (London and Portland, 1999), 86-106, pp. 74, 75, 80, 83; Arnd Kruger, "Breeding, Bearing 
The culmination of this German racial doctrine in sports was achieved in the "human breeding institutes" whose purpose was to produce "the aristocracy of the future".54 Indeed, the perfect expression of German superiority was a healthy, fertile mother at home tending five or six children while the father worked or went off to war. Following this rationale, Gestapo chief Heinrich Himmler instated the Mother Cross, an award honoring mothers of large families. Extending this policy even further, Himmler planned at one point a search for the "Chosen Women," possessed of "athletic grace and cultured intelligence, delicacy of feeling and subtlety of expression," whom SS leaders would be required to marry after having taken "honorable" leave of their wives. Thus, the female physical body in Germany was valued for its biological and aesthetic qualities. 55

It is interesting that the Germans permitted nudity in sports, for both men and women. When confronted with clerical accusations of pornographic intent, German physical educators professed injured surprise: "For us," wrote the editors of the ArbeiterTurnzeitung, "nudity is beauty, joy, and purity." This kind of nudity was not, they emphasized, erotic. Countering similar allegations of prurience, a contributor to Sport im Bild announced in 1928 that sports participation actually dissipated "the mists of the erotic" that had enveloped German women. Because of sports, women were "cleaner, more free, fresher." 56

Due to Hitler's unsportive physique and disposition, Nazism was not in a position to exploit the essentially fascist theme of "political athleticism". 57 No doubt, a large number of German male and female workers joined the mainstream Nazi sport organization. 58 But the Nazi elite sports system was only concerned to demonstrate that the Nazi method of "using" man power, and to a lesser extent, woman power was more efficient than in the Western 'decadent' countries. 59 From this perspective, it can be argued that German women and men, both together, were not provided opportunities to develop a real physical culture movement. According to the Swedish Idrottsbladet, one of Hitler's mistakes was to have ignored the spirit of sport and its strength, especially when

and Preparing the Aryan Body: Creating Supermen the Nazi Way," in Mangan (ed.), Shaping The Superman, 42-68, p.59; and Hoberman, Sport, 162, 163.

54 Hoberman, Sport, 162, 163.

55 Bonnie Smith, Changing Lives: Women in European History since 1700 (Lexington, Mass., 1989).

56 Guttmann, The Erotic, 2, 3.

57 Hoberman, Sport, 167.

58 Arnd Kruger, "The German Way of Worker Sport," in Arnd Kruger and James Riordan, The Story of Worker Sport (Champaign, 1996), 1-27.

59 Kruger, "Breeding, Bearing and Preparing the Aryan Body: Creating Supermen the Nazi Way," 59. 
his Nazi troops encountered fierce Soviet resistance by "militarily fit" soldiers during the course of the Second World War. 60

While "military" and "national" considerations dominated the construction of women's physical culture in interwar Poland, Soviet Union, Germany, and Italy, women's physical culture in the western countries of Great Britain and America became more popular with the transformations in population, consumption, and leisure opportunities in the 1920s and 1930s. With the expansion of corporate capitalism, enterprising businesses realized that leisure could be commercialized on a larger scale and sold to working and middle-class consumers in the form of recreational equipment, sportswear, and public entertainment. In this 'golden age' of sport, physical culture became integral to the commercialization of popular culture that included the cinema, dance-halls, gramophone, motoring, travel, communications and eating out. Technological advances improved transport networks, professionalism boomed, large stadia were built, and sporting spectacles and international events gained in popularity. 61

In Britain, the development of strong, healthy women was part of the British government's concern to improve the fitness of the nation, to a large extent as a reaction to the spread of fascism in Europe. Women were now encouraged to take part in physical exercises in municipal park facilities, playing fields and swimming pools. Several voluntary associations and commercialized organizations also catered to women's sports and leisure, along with the thousands of British firms that provided sports facilities and sports clubs for their employees. 62 Meanwhile, the Women's Amateur Athletic Association was founded in 1922, and the Keep Fit Movement and the Women's League of Health and Beauty, launched in the early 1930s, attracted large followings, the latter having a membership of 120,000 by 1937.63 But this female slimming craze in Great Britain had more to do with acquiring the approved tubular shape of their bodies than with health. Still, it encouraged taking exercise. 64

In interwar America, the rapid growth of female participation in community athletics improved women's skills, stimulated interest in women's sport, and spawned greater opportunities for elite competition. The city leagues and town industries sponsored inexpensive sports teams such as bowling, softball, and swimming. In

\footnotetext{
60 See Victor Louis and Jennifer Louis, Sport in the Soviet Union (Oxford and New York, 1980), 22.

61 Cahn, Coming on Strong, 33, 34; and Hargreaves, Sporting Females, 113.

62 Hargreaves, Sporting Females, 137, 138.

63 John Hargreaves, Sport, Power and Culture: A Social and Historical Analysis of Popular Sports in Britain (New York, 1986), 88.

${ }^{64}$ Birley, Playing the Game, 137.
} 
addition, the urban immigrant communities of African Americans, Mexicans, and the Europeans continued the work of establishing businesses, churches, welfare groups, social clubs, and recreation centers. Industrial and municipal athletic programs offered rural and urban communities a lively, inexpensive form of entertainment. 65

Finally, in Australia, most universities had women's clubs for hockey, tennis, swimming and athletics by the second decade of the 20th century. Rowing and hockey were also in evidence, especially in some of the girls' private schools which thought that these sports helped promote team spirit and create an institutional identity. In the $1920 \mathrm{~s}$, when women moved into the administration and control of their own sports, they also moved into one very significant area for the first time--sports journalism. The impetus for the rapid deployment of games and sport in girls' schools, particularly in Melbourne, can be explained by two reasons- the more general call for education reform in the state, and an imitation of similar events that were already occurring in girls' schools in England. The years up to 1939 saw a consolidation and growth of women's team and club sports in Australia. 66

Thus, while in Poland the male and female physical cultures were centrally structured with the objective of "national defense" in the late interwar period, sports for men and women in the Soviet Union were to be organized bureaucratically and rationally with the concrete goal of supporting the efficiency of production and promoting national unity for building a strong socialist state. In Italy, by contrast, the political and religious forces of conservative nationalism contained women's engagement in sports. In Nazi Germany, notions of racial superiority defined the parameters of women's physical culture. In other western societies, however, women's participation in sports increased, not so much because of state intrusion as evident in the Polish and Soviet sporting cultures, but more due to urban prosperity which provided women with greater opportunities and leisure time to become more athletic. Still, even though women's sports in Poland was subject to state control unlike in other western countries, their physical culture did not unduly suffer; rather, it became more structured as the degree of state control increased. The only real problem was that this structure was ridden with fissures.

Indeed, OZN's efforts to make sport 'mass-based' by facilitating the integration of the sports clubs of the bourgeoisie, workers, and national minorities proved difficult.

65 Cahn, Coming on Strong, 34, 42-47; and Spears, "Prologue: the Myth," 12.

66 Ray Crawford, "Girls and Games in Early 20th Melbourne," 182-207; Vamplew, "Australians and Sport," 1-18; and Stell, Half the Race, 39, 45, 49, 79, 100, 229. 
In the face of Endek-sponsored proposals for restrictive legislation against minorities, the successors to the sanacja found themselves competing with the nationalists in demanding the thorough polonization of social, economic, cultural, and political life. Given its role in the overall scheme of national unity, Polish culture was to be purged of any foreign elements. As the self-appointed "guardian" of Polish national culture, OZN sought to uniformly plan and direct efforts of the state in all sponsored cultural forms, including sports. 67 For example, in Ukrainian lands under interwar Poland, several Ukrainian sports organizations such as the Sokil, Sich and Luh were founded. This growth demanded an organizational superstructure for planning, leading to the founding of the Ukrainian Sports Union in 1925. It met with great success and was able to set up clubs and sections mainly in the countryside, and by its sports activity contributed to the awakening of the national consciousness of the masses. However, the Polish authorities, dismayed by the increased visibility of "Ukrainian nationalism", dissolved the Association in 1937 and took over the Sokil-Batko stadium. 68

As the Polish male and female physical cultures became more "Polish" in their expression and popularized the state's goal of self-centered nationalism, they increasingly lacked the momentum to facilitate the state's agenda of social integration. The political leadership wanted men's and women's sports to not only embrace all regions, but also all social strata of Poland. But given the widespread social and economic unrest among the workers, peasants, and national minorities, this task proved difficult. The economic portion of the regime's overall program was far-reaching, and perhaps too ambitious, especially given the severely limited funds available for state allocation and the subsequent demand for strict adherence to priorities. The forced industrialization and urbanization measures promoted by the regime aroused resistance among the land-starved peasantry who feared their conversion into an exploited proletariat. Workers and peasants seemed indifferent or hostile to OZN.

In the political sphere, OZN's desire to dissolve all parties as anachronistic and replace them with itself as the single supraparty organization alienated national minorities, conservative landowners, and industrialists. The organizational lethargy at the top was accompanied by a noticeable absence of popular enthusiasm for the OZN throughout the nation. Ferment within the Camp of National Unity was matched by a revival of energy among the opposition parties of conservatives, socialists, nationalists, and the national minorities, all of which experienced both a psychological and political

67 Wynot, Polish Politics in Transition, 103, 104, 110, 117, 118.

68 Kubijovyc (ed.), Ukraine, 1038-1040. 
regeneration. In particular, the regime's ethnic chauvinism alienated the national minorities and discrimination left them angry and disgruntled.

In the social spectrum, both the peasantry and proletariat began to question the hitherto unchallenged hegemony of the intelligentsia. Neither did the church, the youth, and the army abound in enthusiasm for the OZN. The OZN demanded popular subordination to its directives but lacked the self-confident determination and expertise to force such an arrangement upon a reluctant community. When Koc stepped down in January 1938, he left behind both a severely shaken regime and a reinvigorated opposition.

From January-November 1938, Koc's successor, General Skwarczynski, managed to balance the divided Sanacja, a revitalized opposition, and a turbulent community. The task was daunting for the peasantry and proletariat were mutinous, the intelligentsia and aristocracy disillusioned, the bourgeois youth became increasingly rightist-radical, and the minorities seditious. However, Poland's steadily worsening international position justified the regime's continued call for national consolidation in the face of certain war. The great power objectives and politics of Poland's eastern and western European neighbors facilitated the Camp's centralized impulses which were designed to regiment every facet of Polish life and to eliminate completely the opposition parties from the polity. Thus, the increasingly ominous international situation masked OZN's ideological poverty and lack of social anchorage. 69 For this reason also, the forced militarization of Polish male and female physical cultures, on account of urgent "national" considerations, forged an artificial semblance of social unity which the state hoped to use as a veritable force to defend the Second Republic against external aggressors.

Meanwhile, even in the Soviet Union, the interplay of politics and popular culture, as reflected in sports, did not always result in the social acceptance of statesponsored goals. For one, the lack of modern equipment precluded the possibilities of setting up sport facilities. Second, the presence of a "hooligan culture" in sports served as an impediment in the state's attempt to use sport as an icon of discipline. In an effort to impart "correct" political education in the realm of sports, "anti-state" sports personalities were purged. For example, the chairman of the All-Union Physical Council, Nikolai Antipov and his successor, Vasily Mantsev disappeared in the great purge of 1936-38.

\footnotetext{
69 For all these social, political and economic problems see Wynot, Polish Politics in Transition, 36, 102, 122, 135, 138, 140, 141, 148, 150-153, 176, 178, 225, 232, 255, 260-265; Rothschild, East Central Europe between the Two World Wars, 70, 72; Wynot, "The National Minorities of Interwar Poland: An Overview," 156; Rothschild, "Marshal Josef Pilsudski," 35; Rothschild, East Central Europe Between the Two World Wars, 28, 29; Korbonski, "Poland: 1918-1990," 238, 239; and Wynot, Warsaw Between the World Wars, 51-53.
} 
Third, Soviet propaganda proudly boasted that unlike sports in bourgeois society, 'our sports are sports of millions of working people, genuinely mass sports'. But there is no doubt that the masses were overlooked while the star athlete was pampered with favors. Finally, "republican sports resistance" often thwarted the assimilative pressures "from above'. 70

Thus the organization of male and female physical cultures, in both Poland and Soviet Union, were impeded by a host of economic, social and political problems. The situation was more critical in Poland where the serious political factionalization undermined the efforts to redress the veritable socio-economic problems. These fundamental difficulties adversely affected all forms of social and cultural relationships, including and especially women's sports.

Overall, the organization of the Polish male and female physical cultures became more "militarized", "nationalistic", and "family-centered" with the passage of years in interwar Poland. In the years before Pilsudski's coup, Polish sports remained more "civilian" than "military" in orientation. The spontaneous social reconstruction of Polish physical culture provided the independent state with some semblance of cultural vitality and hope for a "happy" and "healthy" future. In the years after 1926, the political interests of the authoritarian regime undermined the initial social voluntarism in sports. Instead, the regime's military predilections in the organization of sports for both men and women created avenues for both "national" integration and social resistance. Importantly, the state's paramilitary and social Darwinist political concerns secured greater ideological legitimacy and more mass-based popularity for the development of Polish women's physical culture. From 1935 onward, the organization of women's sports reflected the regime's emphasis on strengthening its precarious relationship with the various segments of "Polish" society through industrialization, urbanization, and military mobilization. In these years, the state sought to enlarge the sporting horizons of women to not only improve women's physicality, but to also defend the country from external threats and internal social unrest by encouraging sportswomen to use their physical culture in order to foster social solidarity in the "nation" and preserve "gender harmony" in the physically strong and "healthy" family. Thus, the organization of Polish women's physical culture in the interwar period became more structured in its formulation and more "obedient" to

\footnotetext{
70 For all these issues see Edelman, Serious Fun, viii, ix, 53, 57, 61, 63, 71, 75, 102, 170, 190, 191; Riordan, "Sport and Nationalism," 5, 7; and Henry Morton, Soviet Sport: Mirror of Soviet Society (New York, 1963), 142, 145, 196, 203.
} 
the state's patriarchal "militaristic nationalism" at the family, regional, and national levels.

From a comparative perspective, the ideological and structural organization of women's physical culture in interwar Poland was surprisingly more similar to the pattern of women's sports in the Soviet Union than in other countries. The Polish female body was recruited by the state to achieve its "national" objectives of military defense and strengthening the family institution. The Soviet female physical culture, in addition, was valued to a much greater extent for its contributions in enhancing economic production and fostering national unity in a large, multinational empire. By contrast, the German female physical body was perceived as important for helping the nation's biological needs and supporting the Nazi racial doctrine. There were no real military motivations for encouraging women's sports in Nazi Germany, as was evident in the Polish and Soviet female physical cultures. In fascist Italy, there was no place for women in the inherently erotic male-dominated athletic culture. While in Poland, women's physical culture developed amidst political and economic uncertainties, women's sports in America, Great Britain, and Australia became more popular in an age of prosperity characterized by urban glamour and technological glitter. The new patterns of consumption in these countries supported women's participation in sports, albeit to varying degrees. Still, while Polish sportswomen were "disadvantaged" in comparison to their western counterparts in the more "modern" societies, the Polish female physical culture movement in the interwar period was not all that poor, in both qualitative and quantitative terms. The new social and cultural relationships which accompanied the emergence of the "New Woman" in the west and sponsored women's athletic endeavors also transformed the Polish sports environment and permitted more women to engage in a host of sporting activities. The next chapter will discuss the emergence of this "New Polish Woman" and place her athletic contributions within the larger Polish nationalist political agenda. 


\section{Chapter Three}

\section{The "New Woman" and Women's Physical Culture in Interwar Poland}

The development of women's physical culture in interwar Poland was intrinsically related to the emergence of the "New Woman" in the resurrected state. In the Second Polish Republic, women's greater access to higher education, their increased participation in social, cultural, and economic activities, and their demands for and achievement of voting rights undermined the traditional patriarchal prejudices that were explicit in Poland during the period of partitions. In partitioned Poland, several conservative "national", social, cultural, and psychological barriers had limited women's public visibility and confined them to the domestic sphere of daily life. Further, the tensions between the "feminist" and "nationalist" ideologies had undermined the emancipatory discourse of the incipient women's movement and divided its members and audience along different paths of liberal, Christian, national-democratic, and socialist narratives.

During the interwar years, however, Polish women began to question critically their role in daily domestic life, and called for more self-awareness among both urban and rural women. The development of capitalism and enlargement of a market for mass culture facilitated the greater democratization of society with a wider range of intellectual and physical activities for women, including sports and physical education. Moreover, Polish women in interwar Poland were not only legally allowed to hold public office in equity with men, but could also participate in different spheres of professional work. This heightened involvement of women in socio-economic and cultural lifestyles resulted in the efflorescence of a more 'sophisticated' women's internal consciousness, at both the individual and collective levels of formation. The external expression of this enhanced maturity came in the form of projected images of women's intellectual activities, economic work, political interests, and cultural engagements, all of which exhibited women's eagerness to once again create a "national" culture, but one that was now more 'professional', 'democratic', 'modern', and 'physical' in nature. 1

1 Moja Przyjaciolka, 3, 3 (10 February, 1936), 35; Hanna Kirchner, "Pisarki miedzywojennego dwudziestolecia," in Zarnowska and Szwarc, Kobieta i kultura, 45-61, pp.45, 46, 47, 49, 53, 54; Kalwa, "Model kobiety aktywnej na tle sporow swiatopogladowych," 141; Michal Pietrzak, "Sytuacja prawna kobiet w drugiej rzeczypospolitej," in Zarnowska and Szwarc, Rowne prawa i nierowne szanse, 77-91, p.79; Roman Wapinski, "Kobiety i zycie publiczne-przemiany pokoleniowe," in Zarnowska and Szwarc, Rowne prawa i nierowne szanse, 25-36, p. 36; and Sliwa, "Kobiety wsrod tworcow mysli spolecznopolitycznej w Polsce pierwszej polowy XX wieku," 225, 226, 237, 238. 
Indeed, Polish women were exposed to a myriad of new material possessions and emancipatory ideologies, and this is quite evident in both the quantitative and qualitative women's literature available for this time period. ${ }^{2}$ Further, the intellectual and cultural ideas of several leading women in interwar Poland reinforced the earlier sentiments of the "feminist" elite in partitioned Poland to create a far more liberating environment for women in the Second Polish Republic. For example, Irena Kosmowska, a famous personality of the interwar women's movement, espoused radical notions on the importance of permitting freedom of individual conscience, and emphasized the need for a separation of Church from state. For Kosmowska, religion was a private and personal right, and the Church was not supposed to interfere in state politics nor in an individual's value-system. Kosmowska also called for a "civilizational" transformation of the countryside that would overcome class differences and stress ideas of cooperation and unity. Her beliefs, as written in the Wytyczne moralne (Moral Directives), were adopted in the program of the Polish People's Party in 1921. Meanwhile, Helena Radlinska also

2 Details of the more popular women's periodicals merits some evaluation. For one, the periodical Bluszcz: Spoleczno-Literacki Tygodnik Kobiecy (Ivy, Warsaw) is an excellent source for understanding women's life in interwar Poland. Its main themes include women's work, motherhood and children, physical education, theater, books, movies, politics, home economy, fashion, food, cosmetics, hygiene, global activities, and struggles with alcoholism and prostitution. The periodical Kobieta w Swiecie i w Domu: Dwutygodnik Poswiecony Zyciu Domowemu i Modom (Warsaw) discussed similar issues of fashion, play, home economy, foreign women, theater, art, hair-styling, women's hats, furnishings, food, cosmetics, health and hygiene, sports and recreation, and life abroad. This periodical, in particular, had an emphasis on the theme "Female Beauty and Health" as well as on water sports for women in and out of Poland, and a real fascination with horse riding for men and women--internationally and nationally. The women's magazine Kobieta Wspolczesna: Ilustrowany Tygodnik Spoleczno-Literacki (Warsaw) is a good source for themes and issues of feminism abroad, international conferences, in-depth investigations on the personalities and roles of important women in Polish history, especially during the time of partitions, women's work, cultural activities such as movies, music, art, and theater, alcoholism, education, home economy, the struggle for equal rights, health and hygiene, social protection for children, and prostitution. The conservative tenor of this periodical is evident from the omnipresent images of Christianity and motherhood. Also, this magazine was more urban-based with isolated references to rural issues. All the above mentioned themes were once again featured in Moja Przyjaciolka: Ilustrowany Dwutygodnik Kobiecy and Kobieta Polska (Poznan), though the former was more preoccupied with women's fashion. For featured articles on women's life in different foreign countries such as Serbia, Bosnia, Czechoslovakia, Japan, and India see Kobiety w Pracy, 1, 2 (March, 1938); Kobiety w Pracy, 1, 3 (April, 1938); Kobiety w Pracy, 1, 9 (October, 1938)--this entire issue was devoted to Japan, including women's sport in Japan; Kobieta Polska, 1, 1 (20 December, 1936), 21; and Start, 2, 5 (1 March, 1928), 6-8. For conservative imagery of motherhood and Catholicism see Kobiety w Pracy, 2, 5-6 (June-July, 1939), 10; Kobieta Wspolczesna, 1, 3 (17 April, 1927); Kobieta Pracy, 1, 2 (23 April, 1933), 14; Kobieta Pracy, 1, 1 (9 April, 1933), 2, 3; Kobieta Wspolczesna, 3, 47 (24 November, 1929), cover page; Moja Przyjaciolka, 3, 2 (25 January, 1936), 19; and Kobieta Polska, 2, 2 (1 February, 1937), 5. 
called for an "ethical" cultural transformation in the direction of greater democratic aspirations. ${ }^{3}$

Women's physical culture in interwar Poland benefited from this marked emphasis on women's professional and “modern" identities. Women's participation in sport increased as a consequence of concerted efforts to expand the range of women's political, educational, and employment opportunities. To be sure, women's domestic and public roles were still closely supervised by the civil and state authorities. This societal and official vigilance underscored feminist attempts to radicalize the interwar women's movement. Still, the new conceptions of "legality" created more avenues for the "New Woman' to enlarge her political, economic, and intellectual horizons. Significantly, the importance of women's physical culture was articulated in these very public spaces of political organizations, industries and factories, and schools and universities. For this reason, it is important to examine the role of female political activists, workers, and students in articulating the need for women to build and defend their physical strength for 'national' and 'feminist' interests.

Women's greater independence, autonomy, and mobility did not, however, devalue the importance of the role of the family as the pivotal social institution performing critical functions in safeguarding traditional public morality. While the 'new woman' sought to re-define her sexuality and physicality, the inherent conservatism of society limited the fruition of such libertarian expressions of women's modern identities. Thus, the 'new woman' was not guilty of feminist insubordination to elite national politics. Women in interwar Poland, as in partitioned Poland, used their professionalism to further the interests of the state and society, and not necessarily to pursue their personal goals of individual emancipation. This dichotomy between the political, economic, cultural, and sexual equality of women in theory, and the persistence of traditional social customs which in reality discouraged the dissolution of conventional family patterns, especially in the countryside, was well reflected in the development of women's physical culture in interwar Poland.

\section{Women, Politics and Sports}

The electoral law of November 28, 1918 conferred women with equal voting rights in Poland. 4 The political equality of women was further reinforced by additional

3 For the continued emphasis on 'feminist' questions regarding cultural enlightenment in rural areas, women's work in urban-industrial centers, educational aspirations of girls and women, and individual selfrealization and progress see Sliwa, "Kobiety wsrod tworcow mysli spoleczno-politycznej," 226-234. 
legislation in 1920 that culminated in the March 1921 constitution which provided women with complete political and civil rights. 5 Between 1918-1938, Poland was served by sixty-two female parliamentarians, both senators and deputies. 6 They expressed more solidarity among themselves than their male counterparts, although this unity did not destroy the basic division between women parliamentarians on the left and right of the political spectrum in the first decade of the Second Republic. 7

More generally, the women's political movement in interwar Poland was diverse in its ideology and methodology. All women's political organizations were, however, united to the major Polish nationalist, socialist, and Catholic currents in political life. The more popular women's political organizations included the League of Polish Women, the Central Committee for the Political Emancipation of Women (Centralny Komitet Politycznego Rownouprawnienia Kobiet), the Political Club of Progressive Women (Klub Polityczny Kobiet Postepowych), the politically neutral and urban-based Women's Cooperative League in Poland (Liga Kooperatystek $w$ Polsce), and the Central Women's Department of the PPS. ${ }^{8}$ While women from the various "feminist" and non-feminist

4 KiZ, 45, 927 (10 November, 1968), 2; Przyjaciolka, 10, 624 (6 March, 1960), 10; and Krystyna Niedzielska, Women in Contemporary Poland: A Sketch to a Portrait (Warsaw, 1985), 7.

5 Przeglad Kobiecy, 2, 1 (May 1920), 10, 19; Bluszcz, 6 (19 November, 1921), 2; Kobieta Wspolczesna, 4 , 19 (11 May, 1930), 2, 3; and Roman Wieruszewski, Rownosc kobiet i mezczyzn w Polsce Ludowej (Poznan 1975), 23.

${ }^{6}$ Bluszcz, 46, (12 November, 1938), 4-5/1108-1109.

7 Anna Zarnowska, "Obywatelki II Rzeczypospolitej," in Zarnowska and Szwarc (eds.), Rowne prawa $i$ nierowne szanse, 287-297, p.290.

${ }^{8}$ For the League of Polish Women see Kobieta w Sejmie, 2 (19 January, 1919), 1, 3; and Kobiety w Pracy, 1, 5-6 (June-July, 1938), 40. The Central Committee for the Political Emancipation of women was formed in January 1918 and fought for women's equal political rights. See Kalwa, "Model kobiety aktywnej na tle sporow swiatopogladowych," 137; and Wieruszewski, Rownosc kobiet i mezczyzn, 32. The elite Klub Polityczny Kobiet Postepowych founded in November 1919 by Justyna Budzinska-Tylicka, Zofia Doszynska-Golinska, Zofia Moraczewska and Zofia Praussowa, conducted active political work in Poland and abroad. Its members participated in the International Women's Congress and worked with the International Women's League for Peace and Freedom as well as the women's "small entente" which included countries from the Balkans and East Central Europe. This club called for equal political, national and social rights for women. For details see Kalwa, "Model kobiety aktywnej na tle sporow swiatopogladowych," 148. The strongest national organization of women was the Central Women's Department of the PPS. Formed in 1919, it sought to make the social, economic and political equality of women a reality, especially for the proletarian class. The maximum influence of the central women's department of the Communist party fell in the years 1923-33, after which it was subjected to increasing repression until its final closure in 1938. See Kobieta Wspolczesna, 2, 5 (29 January, 1928), 5, 6, 16; and Wieruszewski, Rownosc kobiet i mezczyzn, 32. For more details on all these organizations and many others see Wapinski, "Kobiety i zycie publiczne," 20; Andrzej Chojnowski, "Moralnosc i polityka. Kobiece lobby w bezpartyjnym bloku wspolpracy z rzadem," in Zarnowska and Szwarc (eds.), Kobieta i swiat polityki w niepodleglej Polsce, 161-176, p. 162; Zofia Chyra-Rolicz, "Kobiety i ruch spoldzielczy na przelomie xix i xxw.," in Anna Zarnowska and Andrzej Szwarc (eds.), Kobieta i swiat polityki w niepodleglej Polsce, 1918-1939 (Warsaw, 1996), 177-191, pp. 187, 188; Wieruszewski, Rownosc kobiet i mezczyzn, 32; and 
political organizations discussed women's emancipation in varying degrees, the members of the leftist parties underlined the need for women to participate in public life more strongly than their counterparts on the right. ${ }^{9}$ However, the activities of the socialist women's political movement, though important, did not awaken social consciousness among wider classes of women. The program of the Women's Department of the PPS tried to combine the socialist and feminist agendas by attempting to promote class and women's interests of the working class. They achieved limited success because of difficulties which included not only women's own reluctance to work outside the home and neighborhood, but also the traditional influence of the Church, not to mention the problems in the development of the socialist movement itself, especially the lack of financial sources and limited numbers of articulate supporters. ${ }^{10}$ Meanwhile, in response to the formation of "Polish" women's political organizations, the Jewish and Ukrainian minorities founded their separate women's unions. ${ }^{11}$

Unfortunately, women's political visibility, often limited to educated women of the higher social classes, was sporadic, cautious, and moderate in public appearance and expression. While women could now earn intellectual accolades, participate in the labor market, and voice their opinion in the Sejm, several social, economic and religious barriers impeded their path toward complete political emancipation, and by consequence, to their personal liberation. Several major political parties, such as the PSL-Piast, National Workers' Party, Peasant Alliance, and Christian Democrats, did not recruit female members into their ranks. The socialist and radical parties articulated the equality of women in theory; but women's participation was limited even in the PPS and PSL "Wyzwolenie". Ironically, the National Democrats, who never supported women's emancipation and always propagated traditional models of the role of women in society,

Regina Renz, "Kobiety i zycie spoleczno-polityczne kielecczyzny, 1918-1939," in Zarnowska and Szwarc (eds.), Kobieta i swiat polityki w niepodleglej Polsce, 201-215, pp.202, 203, 205, 211, 213-215.

9 Chojnowski, "Aktywnosc kobiet w zyciu politycznym," 46, 47. See also Kalwa, "Model kobiety aktywnej na tle sporow swiatopogladowych," 147, 148. For a detailed list of women's organizations affiliated to the nationalist, socialist, and catholic parties see Piotr A. Tusinski, "Kobieta w zyciu spolecznym i politycznym miasta przemyslowego Radom 1918-1939," in Zarnowska and Szwarc (eds.), Kobieta i swiat polityki w niepodleglej Polsce, 192-200, pp. 197, 198, 200.

10 For women socialists see Maria Nartonowicz-Kot, "Socjalistki w zyciu politycznym i spolecznym polski lat miedzywojennych, Lodz i okreg Lodzki," in Zarnowska and Szwarc (eds.), Kobieta i swiat polityki w niepodleglej Polsce, 100-118, p.118; and Kalwa, "Model kobiety aktywnej na tle sporow swiatopogladowych," 150.

11 For Jewish women organizations in Radom see Tusinski, "Kobieta w zyciu spolecznym i politycznym miasta przemyslowego Radom 1918-1939," 197-200. For Ukrainian women's organizations see Laskiewicz, Robotnicza kultura fizyczna, 70; and Bohachevsky-Chomiak, "How Real Were Nationalism and Feminism in 19th Century Galicia," 151. 
had some female representatives from the professional intelligentsia in their organizations.

Overall, despite the official equality of women in the constitution and their stronger political voice in parliamentary affairs, women's participation in state organs and administration remained minimal, and largely confined to the lower levels of the political hierarchy. Interwar Poland was never served by a female minister or ambassador. Also, while these female parliamentarians worked in Sejm commissions of education, public health, social protection, defense, foreign affairs, and others, they remained invisible in senate commissions. For this reason, the accomplishments of female deputies were more significant than those of female senators, especially before the 'parliamentary degradation' following Pilsudski's military coup in 1926. Finally, the position and work of female candidates in male-dominated municipal governments was not easy and their continued employment in political work was often contingent on their individual material resources, educational qualifications, professional abilities, and family obligations. Women's unsuccessful results in the elections also relegated the status of their state endorsed political equality to that of legalized fiction. 12

While women's participation in "elite" politics was weak, their political involvement in "small" politics remained extraordinarily strong. Throughout the interwar period, and especially after 1926, a number of women's civil and paramilitary organizations were formed that eventually hosted many other smaller women's political, social, charitable, and cultural societies. The larger objective of all these women's military and non-military associations was to improve public health, physical fitness, and "social morality". Thus, women's political participation, in its military, social and cultural agendas, was related to providing social protection for women and children, formulating plans for educational reforms in schools and universities, fighting against prostitution and alcoholism, and improving women's physical strength. All these projects reflected a greater degree of ideological maturity in women's political culture that

12 Kobieta Obywatelka, (11 November, 1930), 1; Dorota Mazurczak, "Kariery akademickie kobiet w polsce miedzywojennej--Uniwersytet Poznanski," in Zarnowska and Szwarc (eds.), Kobieta i kultura, 127138, p.138; Wieruszewski, Rownosc kobiet i mezczyzn, 24, 25; Andrzej Chojnowski, "Kobiety i polityka w drugiej rzeczypospolitej: Slowo wstepne," in Zarnowska and Szwarc (eds.), Kobieta i swiat polityki w niepodleglej Polsce, 9-16, pp. 9, 11; Wapinski, "Kobiety i zycie publiczne," 26, 31; Pietrzak, "Sytuacja prawna kobiet w drugiej Rzeczypospolitej," 35, 36, 52; Michal Sliwa, "Kobiety w parlamencie drugiej Rzeczypospolitej," in Zarnowska and Szwarc (eds.), Kobieta i swiat polityki w niepodleglej Polsce, 53-69, pp. 54, 55, 56, 68, 69; Grazyna Luszkiewicz, "Kobiety w samorzadzie miejskim drugiej rzeczypospolitej, Proba portretu zbiorowego," in Zarnowska and Szwarc (eds.), Kobieta i swiat polityki w niepodleglej Polsce, 119-131, p.128; Michal Sliwa, "Udzial kobiet w wyborach i ich dzialalnosc parlamentarna," in Zarnowska and Szwarc (eds.), Rowne prawa i nierowne szanse, 49-60, p.60; Zarnowska, "Obywatelki II Rzeczypospolitej,” 288, 290; and Niedzielska, Women in Contemporary Poland, 7. 
remained a positive source of inspiration for the women's movement in interwar Poland. Since many of these organizations articulated the need to develop women's health, hygiene, and physical fitness, the female physical culture in the Second Polish Republic expanded as a consequence of women's 'social politics' in both the urban and rural areas. Following the official logistics of national security and the state interest in building a physically strong citizenry for defending the fledging nation from external threats, many such civil and military women's societies provided its members with opportunities to participate in sports, especially scouting, gymnastics, swimming, rifleshooting, archery, volleyball, oaring, and skiing.

In consonance with the general militarization of the state apparatus, women's organizations made a conscious effort to use sports to prepare women in military training, especially in the years between 1927-1939. This policy was consistent with the larger Sanacja policy of building a national and patriotic male and female physical culture apparatus in this time period. For this reason, women's paramilitary organizations such as the Rodzina Wojskowa, the Rodzina Policyjna, the Social Committee for Preparation to Defend the Country (Komitet Spoleczny Przysposobienia do Obrony Kraju), the Organization for Preparation of Women to Defend the Country (Organizacja Przysposobienia Kobiet do Obrony Kraju, OPKdOK), the Main Council of the Social Committee to Prepare Women (Zarzad Glowny Komitetu Sp. Przysposobienia Kobiet), and the Polish Union to Defend the Fatherland (Unia Polskich Zwiazkow Obronczyn Ojczyzny), aggressively emphasized the need to improve women's physique for improved military preparation. The Sports Club of "Rodzina Wojskowa" (Klub Sportowy "Rodzina Wojskowa", KSRW, 1928) had sections of gymnastics, shooting, horse riding, cycling, fencing, archery, track and field, swimming, tennis, rowing, skiing, and skating for its female members. The KSRW club also attracted famous personalities, including Helena $\mathrm{z}$ Bujwidowa who was one of the pioneers of women's sport in Poland. A sports enthusiast, Bujwidowa was the first Polish woman to also obtain a doctorate in the inherently male dominated academic discipline of veterinarian medicine in 1923. Her mother, Kazimiera Bujwidowa (1867-1932) was an ardent social activist and publicist, as well as a member of the women's emancipationist movement in Galicia. Further, the Sports Clinic of the Committee to Prepare Women for the Country's Defense (Poradnia Sportowa Komitetu Przysposobienia Kobiet do Obrony Kraju) conducted medical and autropometric research on sport exercising. Its physical education club, Sprawnosc, promoted sports among the young employed and unemployed women workers, as well as among girls after school hours. Meanwhile, the Armed Preparation of Women (Przysposobienie Wojskowe Kobiet) and the Department of Physical Education and Military Preparation of Women 
(Wydzial Wychowania Fizycznego i Przysposobienia Wojskowego Kobiet, 1935) also exhibited intense militarism in their sporting objectives. On the model of Rodzina Wojskowa and Rodzina Policyjna, there emerged other smaller organizations such as the Rodzina Kolejowe, Rodzina Pocztowa, and Rodzina Urzednicza, all of which promoted sport, recreation, and tourism for women. ${ }^{13}$

While women's paramilitary associations and unions provided instruction in sports and physical education for explicit military purposes, the non-military women's organizations such as the Democratic Electoral Committee of Polish Women (Demokratyczny Komitet Wyborczy Kobiet Polskich, KWKP), the bourgeois and "feminist" Association of Women Citizens' Work (Zwiazek Pracy Obywatelskiej Kobiet, ZPOK), the Circle of Polish Women (Kolo Polek), the Endecja-influenced National Women's Organization (Narodowa Organizacja Kobiet) and the National Women's Council (Rada Narodowa Polek, RNP), the Volunteer Firefighters (Ochotnicze Strazy Pozarnych), and the Association for Enlightened Work (Zwiazek Pracy Swietlicowej)

\footnotetext{
13 The Rodzina Wojskowa was a powerful women's organization concerned with safeguarding the social, political and material conditions of families of army officers, especially those widowed. Formed in 1925, the Rodzina Wojskowa worked in consonance with Pilsudski's ideology and cooperated with other women's and paramilitary associations. See Bluszcz, 46 (12 November, 1938), 20/1124, 24/1128; KSD, 14, 4 (15 February, 1938), 2; Kobiety w Pracy, 1, 5-6 (June-July, 1938), 45; Marek Robert Jobda, Dzialalnosc stowarzyszenia "Rodzina Wojskowa" w zakresie kultury fizycznej kobiet (Praca Magisterska, AWF Warsaw, 1980), p.1; and Rotkiewicz, "Rozwoj spolecznych organizacji sportu kobiet w Polsce," 74, 75. On the Sports club of Rodzina Wojskowa see Kobiety w Pracy, 1, 5-6, (June-July, 1938), 45; Bluszcz, 1 (1 January, 1928), 16; Bluszcz, 19 (13 May, 1933), 10, 11; Bluszcz, 21 (27 May, 1933), 16; Bluszcz, 1 (5 January, 1935), 15, 16; Rotkiewicz, "Rozwoj sportu kobiet w Polsce," 20; Rotkiewicz, "Rozwoj spolecznych organizacji sportu kobiet w Polsce," 74, 75; and Maria Rotkiewicz, "Sport w zyciu Heleny Jurgielewiczowej," in Kobiety w Polskiej Weterynarri (Warsaw, 1997), 19-20. The Rodzina Policyjna was formed in 1929 by Jadwiga Maleszewska and expressed concern for the prophylactic, hygienic, intellectual, and recreational needs of mothers and children of families of policemen. See Bluszcz, 46 (12 November, 1938), 20/1124. The Komitet Spoleczny Przysposobienia Komitet do Obrony Kraju emerged in 1923 and coordinated many women's organizations. It played a critical role after 1926 in the formation of a women's military-style sports organization. See Kobiety w Pracy, 1, 5-6 (June-July, 1938), 37; KSD, 14, 4 (15 February, 1938), 2; Bluszcz, 46 (12 November, 1938), 24/1128; and Szymanski, Kultura fizyczna, 65, 74, 75. The OPKdOK was formed in 1928. See Rotkiewicz, "Rozwoj spolecznych organizacji sportu kobiet w Polsce," 74, 75. The Zarzad Glowny Komitetu Sp. Przysposobienia Kobiet organized instructional courses for the military preparation of women to defend the country. See Kobieta Wspolczesna, 1, 28 (9 October, 1927), 17. The Unia Polskich Zwiazkow Obronczyn Ojczyzny emerged in 1932 and was one of the largest organizations of Polish women. See Bluszcz, 46 (12 November, 1938), 24/1128; and Kobiety w Pracy, 1, 5-6 (June-July, 1938), 39. For a detailed analysis of the various paramilitary organizations of women and their objectives and accomplishments see Kobiety w Pracy, 1, 5-6 (June-July, 1938), 46; Bluszcz, 5 (2 February, 1935), 135, 139; Bluszcz, 35 (28 August, 1937), 26/814; Kobieta Wspolczesna, 1, 36 (4 December, 1927), 18, 19; Rotkiewicz, "Rozwoj sportu kobiet w Polsce," 20; Szymanski, Kultura fizyczna, 35, 74-76; Rotkiewicz, "Rozwoj spolecznych organizacji sportu kobiet w Polsce," 74, 75; "Wychowanie fizyczne kobiet i dzieci," in Wychowanie Fizyczne, 3-4 (1935), 97-105, p.97; and Elzbieta Zawacka, Czekajac na rozkaz: Pogotowie spoleczne organizacji Przysposobienia Wojskowego Kobiet w przededniu II wojny swiatowej (Lublin, 1992). See especially the chapter "Stowarzyszenia wspoldzialajace w Pogotowiu Spolecznym Przysposobienia Wojskowego Kobiet" (pp.77-99) in this book.
} 
also devoted considerable attention to improving urban and rural women's health and physical fitness. For example, the Kolo Polek had provisions for volleyball, basketball, hazena and rifleshooting, as well as community centers to review sports movies. The Rada Narodowa Polek, however, endorsed the importance of reinforcing a "Christian family spirit" in the intellectual, spiritual and physical development of women and children. 14 The Christian women's organizations, no doubt, popularized Church sponsored notions of women's physicality. Still, while their principal objective was to defend the nation's Christian and Polish heritage against communism, un-godliness, and Jewish influence, the Young Men's Catholic Association (Katolickie Stowarzyszenie Mlodziezy Meskiej) and the Young Women's Catholic Association (Katolickie

\footnotetext{
14 The KWKP emphasized the importance of women's work, struggles against prostitution and alcoholism, protection of maternity, reforms in civil and trade codes, equal wages for equal work, national solidarity for the country's defense, and women's electoral rights to gmina or township councils. See Kobieta w Sejmie, 1 (10 January, 1919), 1, 2; and Kobieta Wspolczesna, 2, 5 (29 January, 1928), 5, 6, 16). The ZPOK emerged in 1928 and worked closely with Sanacja for ideological and financial support. Representatives of ZPOK also took part in regional committees of BBWR. This organization had several smaller sections to work for the political, physical, social, moral, and intellectual uplifting of women. It also published its own periodical Praca Obywatelska between 1928-1932. Unfortunately, fractional fighting within this organization failed to create a united ideological front for women. For details on ZPOK see Kobiety w Pracy, 1, 3 (April, 1938), 28; Kobieta Obywatelka, (11 November, 1930), 1, 3; Kobieta Obywatelka, 2 (25 January, 1931), 5; Bluszcz, 46 (12 November, 1938), 15/1119, 16/1120; Kalwa, "Model kobiety aktywnej na tle sporow swiatopogladowych,"151; Wieruszewski, Rownosc kobiet i mezczyzn, 32; Chojnowski, "Kobiety i polityka w drugiej rzeczypospolitej," 14; Chojnowski, "Moralnosc i polityka," 166-168; Chojnowski, "Aktywnosc kobiet w zyciu politycznym," 44; and Zofja Moraczewska, Zwiazek Pracy Obywatelskiej Kobiet (Warsaw, 1932), 21, 39. The Kolo Polek was formed in 1917 and struggled for Polish independence. See Bluszcz, 46 (12 November, 1938), 24/1128; Bluszcz, 42 (18 October, 1930), 10; and Kobiety w Pracy, 1, 5-6 (June-July, 1938), 44, 45. The Catholic and Endecja influenced Narodowa Organizacja Kobiet (NOK) emphasized defending family life, the struggle against alcoholism and pornography, the protection of women and children, and improving the physical and moral health of youth. The Rada Narodowa Polek tried to maintain its political neutrality and worked in various women's affairs such as demands for equal political rights, peace, education, professional work, public health, protection for mothers and children, and struggles against prostitution. However, ideological differences within the organization forced thirteen women's societies to leave the RNP in 1930. For details on the Rada Narodowa Polek, which also included WKW in its organization, see Bluszcz, 46 (12 November, 1938), 24/1128; Wapinski, "Kobiety i zycie publiczne," 26; Kalwa, "Model kobiety aktywnej na tle sporow swiatopogladowych," 152; Chojnowski, "Kobiety i polityka w drugiej rzeczypospolitej," 13; Chojnowski, "Aktywnosc kobiet w zyciu politycznym," 46; and Wieruszewski, Rownosc kobiet i mezczyzn, 32. Some women also found Dmowski's endorsement of the traditional image of women within the RNP too conservative. See Urszula Jakubowska, "Kobiety w swiecie polityki narodowej demokracji," in Zarnowska and Szwarc (eds.), Kobieta i swiat polityki w niepodleglej Polsce, 145-160, pp.151-153, 158, 159. For more details on other women's organizations which actively patronized "social politics" and women's sports see Przeglad Kobiecy, 2, 1 (May, 1920), 19; Bluszcz, 46 (12 November, 1938), 15/1119, 16/1120, 18/1122, 24/1128; Bluszcz, 46 (12 November, 1938), 22/1126; Moja Przyjaciolka, 4, 24 (25 December, 1937), cover page; Bluszcz, 35 (28 August, 1937), 24/812, 25/813; Renz, "Kobiety i zycie spoleczno-polityczne kielecczyzny, 1918-1939," 204; Wapinski, "Kobiety i zycie publiczne," 20, 31; Sliwa, "Kobiety w parlamencie drugiej Rzeczypospolitej," 58-69; Kalwa, "Model kobiety aktywnej na tle sporow swiatopogladowych," 149; Wieruszewski, Rownosc kobiet i mezczyzn, 32; Warsicki, Kultura fizyczna, 128; and Szymanski, Kultura fizyczna, 32, 78, 82-87.
} 
Stowarszyszenie Mlodziezy Zenskiej) also played their part in promoting physical culture among the young Poles. These Catholic youth organizations, more popular in provincial centers and districts towns, imparted instruction in physical education to the rural and working class youth. At all times, however, this 'muscular Christianity' of interwar Poland emphasized a "proper" education in the moral and physical development of women. 15

\section{Work and Play: Women Workers and Sports}

The interwar period saw women working outside the home in increasing numbers and in a growing list of occupations. Women continued to work in overwhelming numbers in domestic service and the textile industry, especially in Lodz. Apart from these feminized sectors of the economy, work in school teaching, paper mills, trade, offices, and cooperatives also became increasingly dominated by women. Many women's committees of public health and social protection were also formed to struggle against illiteracy and prostitution, and to help raise the cultural and health levels of women more generally. On 25th October 1921, under the initiative of the Polish Women's Circle, a conference on women's work was organized to deliberate on all of these issues. Overall, women's professional work became more socially accepted in the interwar years, and many chose to pursue a variety of profitable and creative economic occupations.

No doubt, the increased economic engagements of women gave them a greater sense of independence and personal emancipation. However, the women's press of this time period also reported on the multiple constraints that limited their more complete participation in work beyond the home economy. The patriarchal model of family, lower wages for women (despite academic qualifications), oppressive working hours and unhealthy laboring conditions, limited assistance in sickness, lack of job security, poor material conditions of the working class families, and difficulties in balancing domestic obligations with work outside the home, all combined to create a stifling working environment for women. Thus, the enhanced opportunities for women's professional advancement in the labor market were also hampered by gross insufficiencies in childcare facilities, a disrespectful managerial class that blatantly ignored official resolutions

\footnotetext{
15 For Christian women's organization see Bluszcz, 46 (12 November, 1938), 15/1119, 16/1120; Kobieta Polska, 1, 1 (20 December, 1936), 7; Moja Przyjaciolka, 3, 23 (10 December, 1936), 488; Kalwa, "Model kobiety aktywnej na tle sporow swiatopogladowych," 150; Woltmann, "Gegensatze in der polnischen Sportbewegung," 159; Szymanski, Kultura fizyczna, 32, 33, 80, 81; Gaj in Gaj and Hadzelek, Dzieje kultury fizycznej, 171-176; and Warsicki, Kultura fizyczna, 117, 119, 121.
} 
concerning women's work, and conservative patriarchal pressures that still wanted women to manage their family obligations as "good" wives and mothers for maintaining the coherence and strength of the family social unit. Further, institutional discrimination forbade married women to work in state administration, despite the 1924 resolution of the Polish Sejm that sought to defend women's work. ${ }^{16}$ To a large extent, the economic subordination of female workers, which affected gendered employment patterns and the sexual division of labor in Poland, was similar to the plight of female workers in the Soviet Union during the interwar years. Soviet protective labor laws for women workers were never fully implemented in practice and were irregularly enforced. 17

Similar to Soviet women, professional work was hard for Polish women, and female workers remained victimized under numerous economic, legal, and family burdens, all which made employment for women a 'bad' situation, or at best, a poor alternative. Still, while employment did not enhance women's social status, the 'new young woman' of interwar Poland certainly had more opportunities than the older generation in the job market. For this reason, the younger generation of working women was more susceptible to change and, by consequence, more willing to indulge in exciting adventures, including and especially sports.

The PUWFiPW and the Main Workers Inspectorate of the Ministry of Social Welfare (Glowny Inspektorat Pracy Minsterstwa Opieki Spolecznej) directed physical culture for female workers to improve their health, hygiene, and physique, as well as to increase the quantity and quality of economic production. For this reason, the state recommended ten minute exercise breaks in factories for both men and women. Lodz, an

16 For this section on 'women and work' see Moja Przyjaciolka, 3, 2 (25 January, 1936), 20; Moja Przyjaciolka, 3, 23 (10 December, 1936), 489; Moja Przyjaciolka, 2, 3 (25 April, 1935), 114; Bluszcz, 13 (25 March, 1922), 99; Bluszcz, 46 (12 November, 1938), 3/1107, 6/1110, 7/1111, 15/1119; KiZ, 45, 927 (10 November, 1968), 2, 14; Przyjaciolka, 10, 624 (6 March, 1960), 10; Kobieta Polska, 1,1 (20 December, 1936), 3; Kobieta Polska, 2, 3 (15 February, 1937), 5; Wieruszewski, Rownosc kobiet i mezczyzn, 30; Kobiety w Pracy, 1 (3 April, 1938), 20; Kobieta Pracy, 1 (9 April, 1933), 4, 6; Kobieta Polska, 2, 3 (15 February, 1937), 4; Kobieta Pracy, 1 (9 April, 1933), 13; Wladyslaw Mierzecki, "Prace zarobkowa kobiet w srodowisku robotniczym w Polsce miedzywojennej," in Zarnowska and Szwarc (eds.), Kobieta i educkja, Cz.II, 177-219, p.177, 178, 190, 192, 198; Zarnowska, "Kierunki," in Zarnowska and Szwarc, Kobieta i edukacja, Cz.II, 161-175, pp. 162, 164; Michal Pietrzak, "Sytuacja prawna kobiet w drugiej Rzeczypospolitej," in Zarnowska and Szwarc (eds.), Kobieta i swiat polityki w niepodleglej Polsce, 33-52, pp.45, 48, 49; Jozef Miaso, "Ksztalcenie dziewczat w drugiej rzeczypospolitej," in Zarnowska and Szwarc (eds.), Kobieta i edukacja, Cz.II, 73-88, p. 79; Zarnowska, "Obywatelki II Rzeczypospolitej," 293, 294; Wladyslaw Mierzecki, "Praca zarobkowa kobiet w srodowski robotniczym w Polsce miedzywojennej," in Zarnowska and Szwarc (eds.), Rowne prawa i nierowne szanse, 109-133, pp.117, 120; Wapinski, "Kobiety i zycie publiczne-przemiany pokoleniowe," 35; Jan Jonczyk, Ochrona pracy kobiet i mlodocianych $w$ Polskim przemysle w latach, 1918-1939 (Warsaw, 1961), 21, 31; and Jolluck, Gender, Identity and the Polish Experience of War, 199-202.

17 Melanie Ilic, Women Workers in the Soviet Interwar Economy: From 'Protection' to 'Equality' (New York, 1999), 171, 176. 
important industrial-textile center for women, was the first town to organize a sports and recreation movement for its working class. Despite numerous financial and technical difficulties, substantial societal initiative enlarged the sporting horizon of interwar Lodz. The miserable working conditions, which resulted in the poor health of its male and female employees, served as an important incentive for introducing sports into the city's industrial premises. However, working women's sports, by and large, remained limited in Lodz. While women's sections in games such as basketball, volleyball, track and field, and hazena were organized, the participation of women in the Lodz worker's sport movement and tourism was relatively insignificant due to their own inhibitions and the hard economic conditions.

Meanwhile, courses in physical education were also organized by the Town Administration for Physical Education (Miejski Urzad Wychowania Fizycznego) for industrial workers in Warsaw. Women workers were encouraged to participated in sports by the workers sports clubs such as Legia (Krakow), Skra (Warsaw, 1925), Wizo (Warsaw), Ewa (Warsaw, 1929), the all-women's Start (Warsaw, 1928), Slawa, and Slonce. Divisions of women's firefighters also took pride in their strong physique and concomitant elevated social status.

Further, between 1929-1939, Stefania Krygierowa, the director of the women's department of the Main Council of the Union of Workers Sports Societies (ZG ZRSS) and a strong advocate of women's sports, popularized working women's physical culture. Krygierowa was one of the first activists of the female workers sports movement who thought it essential to combine the themes of 'sport and socialism'. A doctor by profession, Krygierowa was also committed to social work and improving public hygiene. She published many articles on workers' sports and sports medicine in Przeglad Socjalistyczny 'Robotnik'. From 1934, Krygierowa joined the Central Women's Department of PPS and acted as founding member of the Warsaw's women's department in 1935. In December 1938, Krygierowa was nominated as a candidate for the Town Council of the City of Warsaw. But the war stopped this election and she eventually died in 1951.18

18 For all these issues see Kobiety w Pracy, 1, 5-6 (June-July, 1938), 14, 34, 35; Jonczyk, Ochrona pracy kobiet $i$ mlodocianych $w$ Polskim przemysle, 120; Jolanta Kadziecka, Dzialalnosc kobiet $w$ robotniczym ruchu sportowym Lodzi do 1949 (Praca Magisterska, AWF Warsaw, 1980), 4, 14, 19, 85; Bogusz, "Sport w Lodzi w pierwszych latach niepodleglosci," 189, 191; Laskiewicz, Robotnicza kultura fizyczna, 43, 44, 96, 98, 105, 145, 151; Rotkiewicz, "Rozwoj sportu kobiet w Polsce," p.20; Rotkiewicz, "U zrodel," 101, 102; "Wychowanie fizyczne kobiet i dzieci," in Wychowanie Fizyczne, 3-4 (1935) 97-105, pp.97, 102; K. Muszalowna and E. Reicherowna (eds.), 10 minut gimnastyki pracownic fabrycznych. Wychowanie fizyczne kobiet (Warsaw, 1937), 1, 23; Wychownie fizyczne kobiet w przemysle i handlu (Poznan, 1935); and AMR, notes. For women firefighters and their strong physical appearance see KSD, 14, 18 (15 September, 1938), 
Overall, women workers in interwar Poland became more conscious of the need to improve their physicality. No doubt, their organizational efforts to build the apparatus of a working women's physical culture was less dynamic than in some other countries. For example, women workers organized their own sports federations in Germany, Finland, France and Great Britain. ${ }^{19}$ Still, the Polish female workers' physical culture movement became more popular and structured during the interwar period.

It must be emphasized that the working women's physical culture was part of the larger [male] workers' sports movement which matured greatly during the period of the Second Polish Republic. While the workers' movement was heterogeneous, sport served as an instrument of integrated cultural learning and social mobility. A number of factors influenced the development of workers' sporting apparatus during the interwar years. For one, the support of trade unions was critical in the formation of both the male and female workers' physical cultures. The trade unions of printers, railway workers, teachers and postal workers were especially active in promoting sports for their members. The workers' steady employment in such jobs ensured them regular salaries, reduced railway tickets and their employer's partial payment for their holidays. Their sporting and tourist activities, sponsored by the trade unions, not only contributed to improving the physical fitness of workers, but also served as an important source of social integration and educational enlightenment.

The organization of workers' sport was made more popular and 'democratic' with the founding of the Union of Workers' Sports Associations (Zwiazek Robotniczych Stowarzyszen Sportowych, ZRSS) in 1925. Under its aegis, Jerzy Michalowicz's Central Workers' Institute of Physical Culture was established in 1936. Meanwhile, the Workers' District Sports Committees (Robotnicze Sportowe Komitety Okregowe, RSKO), with centers in Warsaw, Krakow, Lwow, Lodz, and Silesia provided more substance to the regional workers' physical culture.

A host of other youth and workers' associations also contributed to the development of the worker's sports movement. For example, the Union of Sports Societies (Zwiazek Urzedniczych Stowarzyszen Sportowych "Zjednoczenie", ZUSS, 1929), with its main seat in Warsaw and sub-sections in Lodz and Poznan, included men and women in its membership. The Organization of Young Workers (Organizacja Mlodziezy Pracujacej, 1933) promoted physical education among young workers who had been adversely hit by the Great Depression. The Robotnicze Towarzystwo Przyjaciol

9; Bluszcz, 10 (10 March, 1934), 301; Moja Przyjaciolka, 2, 11 (10 June, 1935), 162; Moja Przyjaciolka, 2, 3 (25 April, 1935), 114; and Bluszcz, 46 (12 November, 1938), 27/1131.

19 Guttmann, Women's Sports, 162. 
Dzieci (RTPD, 1926), with its departments in various parts of the country, helped to develop the physical, moral and cognitive abilities of working class children. The Communist Association of Polish Youth (Komunistyczny Zwiazek Mlodziezy Polskiej, KZMP), a revolutionary, non-legal youth organization under the direction of the Polish Communist Party, also sponsored sports and cultural activities among the working class. Meanwhile, the Towarzystwo Uniwersytetu Robotniczego (TUR, 1923), with its Red Scouts, helped the younger workers to pay more attention to sports. Among other associations, the Organizacja Mlodziezy Towarzystwa Uniwersytetu Robotnicznego (OMTUR, 1926), Komunistyczny Zwiazek Mlodziezy TUR (1922), Zwiazek Robotniczych Stowarzyszen Spoldzielczych (1919), Organizacja Mlodziezy Socjalistycznej "Zycie”, and the Robotnicze Towarzystwo Turystyczne all facilitated the development of a physical culture for both male and female workers.

While trade unions and other youth and workers' associations patronized the emergence of a workers' physical culture, the interwar political leadership also awarded workers with some legal benefits and privileges which created the necessary leisure time and provided the required financial resources for sports participation. For example, a 46hour working week was introduced in 1918 for all manual and salaried workers, and remained in force until 1933 when it was increased to 48 hours. Annual paid vacations were introduced by a law of 1922. A compulsory insurance system for sickness and maternity benefits had been introduced in 1919 and, as amended in 1933, covered all categories of salaried and manual wage-earners and members of their families. These official developments, along with the independent fruition of the workers sports movement, had a positive impact on the political, social, cultural, intellectual and recreational forms of activities for male and female workers. However, the Sanacja regime, fearful of the communist and social democratic currents of the workers movement, carefully supervised all sports activities of workers. For example, the PUWFiPW remained unfavorable to ZRSS's requests for greater autonomy. The RTPD and KZMP were also subject to state repression and arrest. The RTPD succumbed to Sanacja opposition and eventually closed in 1929.

Still, despite official indignation, the discriminatory policies of the state did not result in substantial damage to the workers' sporting culture. While the workers had good reason to feel humiliated, they nonetheless continued to play sports such as football, table tennis, track and field events, scouting, and volleyball. Poland participated in the first Workers' Olympiad in Frankfurt in 1925, and in the following year, the first Polish Workers' Sports Congress was organized at home. More such conferences were organized in Warsaw (1927 and 1937), Krakow (February, 1929), Lodz (April, 1932), 
Katowice (December, 1934), and Cieszyn (February, 1939). Many sports clubs and gymnastic societies also continued to attract working class youth, becoming more popular and fashionable with time. 20

Overall, the workers sport movement in Poland made significant contributions to the development of interwar Polish sporting culture. The female workers' physical culture benefited from this increased attention on the part of both the state and workers' communities to remain healthy, united, and, physically strong.

\section{Women's Intellectual Scholarship and Instruction in Physical Education}

Physical education was a popular course of study for women in schools and universities during the interwar years. Courses in physical education, for men and women, were offered in universities and other state and military schools in several cities such as Poznan, Warsaw, Krakow and Lwow. Poznan, in particular, remained a very strong center of sports and physical education, in part because of the town's relatively good economy, substantial international contacts, and the presence of a class of rich landowners, urban dwellers, artisans, and merchants, all of whom expressed interest in sporting activities. At Poznan University, the teaching of physical education was integrally related to instruction in other courses such as anatomy, general hygiene, and physiology.

In Poznan, as well as in other cities, women's interest in sports studies developed as a consequence of the boom in women's higher education, especially between the years 1925-1936. Women, mainly from the intelligentsia, graduated from universities in increasing numbers, and with degrees in several academic disciplines, including law, literature, medicine, economics, pharmacy, stomatology, botany, biology, philosophy, humanities, math, history, dentistry, and physical education. Many women obtained their doctorates and opted for a career in school and university teaching. The first female professors at Jagiellonian University specialized in Sanskrit and Indian philosophy. In

\footnotetext{
20 For the development of workers' physical culture in interwar Poland see Woltmann, "Gegensatze in der polnischen Sportbewegung," 160; "Sto lat," 51-53; Moja Przyjaciolka, 2, 11 (10 June, 1935); Hadzelek, "Foundation," 84; Laskiewicz, "Ideowo-wychowawcze funkcje sportu robotniczego," 58, 70; Chmielewski, Polish Sport, 14; Gaj in Gaj and Hadzelek, Dzieje kultury fizycznej, 156, 177-180, 196, 206; Szymanski, Kultura fizyczna, 87; Urszula Kowieska, Kultura fizyczna $w$ programach $i$ dzialalnosci zwiazkow zawodowych w II Rzeczypospolitej (Wroclaw, 1997), 57, 68, 69, 228-232, 283, 284; Michael Kaser, Health Care in the Soviet Union and Eastern Europe (London, 1976), 199; and Laskiewicz, Robotnicza kultura fizyczna , 17, 22, 40-42, 45-58, 86, 87, 88, 113, 117, 120. Laskiewicz has also provided a tabular listing of all the major developments in the history of worker's physical culture in Poland. See pages 156-191 for this chart.
} 
1929, Helena Willman-Grabowska was named extraordinary professor of these two supposedly exotic fields of study. Many more women also traveled abroad on research stipends to places such as Prague, Hamburg, Paris, England, India, Ceylon, and America. The Women's Society of Higher Education (Stowarzyszenia Kobiet z Wyzszym Wyksztalceniem) sponsored scientific work and helped to organize funds to provide stipends for university studies. The Polish Women's Society for Higher Education (Polskie Stowarzyszenie Kobiet z Wyzszym Wyksztalceniem), in addition, maintained bibliographies of women authors and complied statistics of the participation of women in different cultural, intellectual, and professional occupations. The legal profession, meanwhile, attracted a number of talented women. The Society of Women Lawyers in Warsaw (1929) worked with family-related issues and women's rights, as well as with criminal justice that included legal protection for prisoners and interaction with police and relevant social organizations. Toward the beginning of the 1930s, women also served as judges. Many other women indulged themselves in creative work such as theater, music, art and architecture, and research publications. Helena Radlinska, co-founder of the Free Polish University (1919), worked with many civil and official institutions such as the Central Bureau of Courses for the Adults (Centralne Biuro Kursow dla Doroslych), Central Association of Peasant Women's Circles (Centralny Zwiazek Kolek Rolniczych), Wydzial Spoleczno-Wychowawczy Zwiazku Spoldzielni Spozywcow, Union of Polish Bibliographers (Zwiazek Bibliotekarzy Polskich), Biuro Zjazdow Samorzadu Ziemskiego, Polish Committee to Help Children (Polski Komitet Pomocy Dzieciom), and the Ministry of Labor and Social Protection.

Some problems, however, remained. Law and medicine, though prestigious, employed only a handful of women. Academic fields such as philosophy, logic, and mathematics were still quite male-dominated. Women at Warsaw University had to battle against conservative pressures that sought to limit their access to higher education. The traditional model of womanhood also resulted in a largely male-dominated university faculty. In Upper Silesia, female teachers were forced to live a life of celibacy in order for them to gain some measure of acceptability and respect from the patriarchal and Catholic society of the region. Moreover, some women themselves, such as Lucja Charewiczowa, were more concerned with women's "patriotic" duties and religiosity. Although Charewiczowa initiated a wide program of research which addressed the marginalization of women in Polish society, she opposed radical feminism. Further, while 
more women engaged in intellectual scholarship, the administrative work responsible for directing academic education remained male-dominated. 21

While women's physical culture in the academic institutions of higher learning may have raised concerns and questions on account of patriarchal resistance to women's education, the importance of their good health and hygiene was re-emphasized by sportsminded pedagogues who paid special attention to the military, economic, moral, social, and health benefits of sport for the society at large. Emboldened by the state's interest to conduct research in subjects of physiology, anatomy and hygiene, the doctors, pedagogues, and psychologists reiterated the beneficial values of systematic physical education in enhancing qualities of attentiveness, solidarity, perseverance, and discipline. Influenced by their intellectual discussions at conferences and publications, the state became more attentive to improving the health and hygiene of young boys and girls.

However, given the material, instructional, and financial shortages, the task was not easy. The development of physical education in schools was best directed in large

21 For this section on 'women and education' see Bluszcz, 46 (12 November, 1938), 8/1112, 10/1114, 12/1116, 28/1132, 29/1133, 33/1137, 36/1140, 42/1146, 45/1149, 52-53/1156-1157, 54-57/1158-1161; Swiat Kobiecy, 21 (1 November, 1925), 489; Kobieta Wspolczesna, 3, 6 (10 February, 1929), 3; Kobieta Polska, 2, 3 (15 February, 1937), 3, 4; Sliwa, "Kobiety wsrod tworcow mysli spoleczno-politycznej," 226; Helena Brodowska-Kubicz, "Helena Radlinska-Wspoltworczyni wolnej wszechnicy polskiej w Warszawie," in Zarnowska and Szwarc (eds.), Kobieta i kultura, 241-254, p.241; Maria Wierzbicka and Barbara Jakubowska, "Autorki i dziela--kobiety w polskiej nauce historycznej w dwudziestoleciu miedzywojennym," in Zarnowska and Szwarc (eds.), Kobieta i kultura, 75-88, pp.75-77; Elzbieta Pakszys, "Kobiety w polskiej filozofii analitycznej w stulecie szkoly lwowsko-warszawskiej 1895-1935," in Zarnowska and Szwarc (eds.), Kobieta i kultura, 89-98, p.97; Alicja Kusiak, "Lucja Charewiczowa-inicjatorka badan nad przeszloscia kobiet polskich," in Zarnowska and Szwarc (eds.), Kobieta i kultura, 99103, pp. 99, 102; Jerzy Halbersztadt, "Kobiety w murach uniwersytetu Warszawskiego 1915-1939," in Zarnowska and Szwarc (eds.), Kobieta i kultura, 107-126, pp. 107, 110, 111, 114, 126; Urszula Perkowska, "Kariery naukowe kobiet na uniwersytecie Jagiellonskim w latach 1904-1939," in Zarnowska and Szwarc (eds.), Kobieta i kultura, 139-155, pp.143, 152, 153, 155; Miaso, "Ksztalcenie dziewczat w drugiej rzeczypospolitej," 78, 81, 85, 86; Jolluck, Gender, Identity and the Polish Experience of War, 200; Roman Wapinski, "Kobiety i zycie publiczne w Polsce niepodleglej przemiany pokoleniowe," in Zarnowska and Szwarc (eds.), Kobieta i swiat polityki w niepodleglej Polsce, 17-32, pp. 22, 23; Janusz Zarnowski, "Kobiety w strukturze spoleczno-zawodowej polski miedzywojennej," in Zarnowska and Szwarc (eds.), Rowne prawa i nierowne szanse, 95-108, pp. 102, 103, 108; Ewa Kraskowska, Piorem niewiescim: Z problemow prozy kobiecej dwudziestolecia miedzywojennego (Poznan, 1999), 13; Mariola Kondracka, "Kobiety na uniwersytetach," in Zarnowska and Szwarc (eds.), Rowne prawa i nierowne szanse, 271-284, pp. 274, 276, 280, 284; Anna Glimos-Nadgorska, "Tradycjonalizm slaski a rownouprawnienie kobiet. Praca zawodowa i zycie codzienne nauczycielek wojewodztwa slaskiego (1922-1939)," in Zarnowska and Szwarc (eds.), Rowne prawa i nierowne szanse, 155-167, pp. 157, 161, 167; Zarnowski, "Kobiety w strukturze spoleczno-zawodowej polski miedzywojennej," 104; and Kalwa, "Model kobiety aktywnej na tle sporow swiatopogladowych," 148, 149. For courses and research in university departments of physical education in Poznan, Krakow and other cities see Szymanski, Kultura fizyczna, 115, 116, 125; Jaworski, "Conceptions of Higher Studies of Physical Education in European Socialist Countries," 287; Warsicki, Kultura fizyczna, 42-47, 80; Grot, "Katedra," 47, 60, 75, 79; Ryszard Wieczorek, "Problemy organizacyjne sportu Poznanskiego po drugiej wojnie swiatowej," in Wychowanie fizyczne $i$ sport w 40-leciu PRL (Poznan, 1987), 5-10, p. 5; Gaj in Gaj and Hadzelek, Dzieje kultury fizycznej, 119; and Liponski, "Still and Unknown," 18. 
towns and worst managed in the countryside. The condition of physical education in elementary schools remained poor in comparison to the middle schools. To redress some of the issues, a Physical Education Circle was formed in 1929 in Warsaw under the initiative of Zygmunt Orlowicz and Florian Wardas to train male and female physical education instructors for school teaching. Similar institutions of training soon emerged in other cities. Meanwhile, periodicals such as Physical Education (Wychowanie Fizyczne, 1920-1939) and Physical Education in School (Wychowanie Fizyczne w Szkole, 19331939) widely discussed the importance of physical education for school-going boys and girls. Further, many inter- and intra-school sports clubs and circles competed with each other, especially after 1934 in cities such as Warsaw, Krakow, Katowice, Lublin, Poznan, Plock, and Tarnow. Overall, the state endeavored to build an "active" youth that was both healthy and militarily strong to defend the nation. Accordingly, military preparation for boys and girls took the form of scouting and other paramilitary sports. ${ }^{22}$

Thus, despite limitations, the interwar period was important for providing young girls and women with more opportunities to acquire diverse theoretical and practical knowledge. The increasing number of professional and trade schools for girls, and women's larger enrollments in universities for a wide range of subjects, including physical education, not only symbolized women's progressive liberation and a more prestigious social status, but also marked a positive step toward the overall modernization of interwar Poland.

\section{Women's Sexuality and Physicality}

The discussion on women's physical emancipation in interwar Poland was closely related to the interactive dialogue between the 'traditional' and 'modern' definitions of women's sexuality. During these years, there was a heightened interest in issues related

\footnotetext{
22 For all these issues see Bluszcz, 20 (19 May, 1923), 158, 159; Bluszcz, 41 (11 October, 1924), 739; Bluszcz, 33 (17 August, 1935), 962; Leonard Nowak, Wychowanie fizyczne $i$ sport $w$ panstwowym szkolnictwie ogolnoksztalcacym w Polsce w latach, 1918-1939 (Poznan, 1996), 35, 39, 40, 72, 73, 204, 205, 218-228; Gaj in Gaj and Hadzelek, Dzieje kultury fizycznej, 110; Warsicki, Kultura fizyczna, 65-69, 74-77, 84, 87, 92, 94, 96; Wybraniec, "Problematyka," 97, 98, 101, 104, 106, 109, 110; Szymanski, Kultura fizyczyna, 32, 51, 52, 54, 65; Laskiewicz, Robotnicza kultura fizyczna, 18, 59; Leonard Nowak, "School Excursion Movement in Poland Between 1918 and 1939," in L'udovit Komadel (ed.), Physical Education and Sports of Children and Youth (Proceedings of the International Conference held in Bratislava, Slovakia, August 13-16, 1995; Slovak Scientific Society for Physical Education and Sports and Faculty of Physical Education and Sports, Comenius University, Bratislava, 1995), 76-79; Leonard Nowak, "Role of Doctors in Implementation of Physical Education Curricula in Poland Between 1918 and 1939," in P. Marconnet, J. Gaulard, I. Margaritis and F. Tessier (eds.), Book of Abstracts (First Annual Congress, Frontiers in Sport Science, The European Perspective, Nice, France, May 28-31, 1996), 856-857; and Toporowicz, "Eugeniusz Piasecki i jego rola," 53-61.
} 
to family planning, prostitution and alcoholism. The press frequently voiced concerns with the spread of venereal diseases and articulated the need to found rehabilitation programs for prostitutes and women with alcoholic husbands. Matters of family planning and abortion were also subject to complicated debates with varied viewpoints. Similar to many other parts of the world, interwar Polish culture cast new definitions of sex and sexuality, public morality, and fashionable esthetics and ethics, all of which represented a veritable threat to the traditional culture of religious conservatism and abstinence.

The question of family planning, in particular, radicalized the "woman question". In the interwar years, the liberal intelligentsia questioned the idea of family planning in the wider context of reforming the traditional and customary boundaries which had resisted a critical examination of gender roles in fear of a serious disturbance of the heretofore naturally ordained and "well-ordered" social harmony. The liberal-minded intellectuals supported the need to redefine conventional notions of motherhood and the sexual subordination of women in the family. The idea of family planning was propagated in brochures and other publication material, as well as in clinics which were established for performing abortions and for educating women on issues related to 'planned motherhood'. While the pro-feminist liberals discussed the futility of punishments to stop illegal abortions and infanticides, and the socialists expressed serious concerns with the consequences of uncontrolled pregnancies for the poorest families, all Christian women's associations typically criminalized abortion. On this issue of "free motherhood", conservative Catholicism clashed head-on with the liberal-utilitarian ideology. While the patriarchal Catholic opinion spoke against family planning and demanded punishments for abortionists, the liberals and socialists appeared more sympathetic with the neo-malthusian idea of planned motherhood. For this reason, all institutions and clinics which supported abortion in theory and practice risked ecclesiastical censure for their support of women's emancipation. However, while clerical opposition stifled the interwar women's movement, ecclesiastical premonitions about the presumed decay of the Polish family institution nonetheless initiated more dialogue on the changing definitions of women's sexuality. While the polemics of this debate weakened in the first decade of the 1930s, the discussions on women's "proper" morality and sexuality ultimately affected preconceived notions of "approved" female physicality in a " progressive" direction throughout the interwar period. 23

${ }^{23}$ For these issues see Kobieta Polska, 2, 4 (I-15 March, 1937), 21; Kobieta Wspolczesna, 1, 1 (3 April, 1927), 2; Kobieta Wspolczesna, 3, 15 (14 April, 1929), 5, 6; Kobieta Pracy, 1 (9 April, 1933), 6; Kobieta w Sejmie, 3 (25 January, 1919), 3; Bluszcz, 34 (20 August, 1938), 19/811; Kobieta Pracy, 1, 2 (23 April, 1933), 14; Magdalena Marcinkowska-Gawin, "Bojownicy i boyowniczki. Srodowisko "Wiadomosci 


\section{The "New Peasant Woman" and Women's Physical Culture in the Countryside}

While urban women debated the significance of new forms of motherhood, peasant women adhered to their traditional values and remained suspicious of city-bred feminists. However, increased interaction between women in the cities and in the fields facilitated cultural and intellectual exchanges, both of which moderately transformed the rural environment during the interwar period. Rural women's physical culture developed in response to these introductory courses in city-bred modernity which surveyed critically the conventional moral and ideological perceptions of the "natural" cultural roles of women in peasant society. More specifically, the "new peasant woman" became increasingly aware of the importance of good health and hygiene for her personal development and for the longevity of her family members.

Several factors contributed to the making of the "new peasant woman" in the Polish countryside. For one, a large number of young rural women migrated to the cities for better employment opportunities. They generally sought work beyond the rural home economy not as a matter of choice, but of necessity. At the same time, many urban female intellectuals formed several organizations and cooperative societies in the countryside to address the professional, recreational, and cultural needs of rural women. In both cases, peasant women became acquainted with the "modern" intellectualism of the "new urban woman", characterized by a determination to improve the quality of women's daily lives within the home and beyond. No doubt, the urban environment was intimidating for most peasant women. Due to lack of qualifications, women migrants from the rural areas could find work mainly in domestic service or in industries requiring physical labor. Still, while their work-related experiences in the cities may not have been exhilarating, the urban material possessions and "modern" gendered discourses permeated the peasant women's rural veneer to present them with new opportunities and realities in their economic, social, and cultural spaces.

Meanwhile, back in the countryside, the intelligentsia-sponsored rural women's circles, such as the Rural Housewives Circle (Kol Gospodyn Wiejskich) and the Kola

Literackich" wobec problemu regulacji urodzen," in Zarnowska and Szwarz (eds.), Kobieta i kultura zycia codziennego, 133-147, pp. 133, 135-139, 142, 145, 146; Pietrzak, "Sytuacja prawna kobiet," 51; Dobrochna Kalwa, "Glosy Kobiet wsprawie planowania rodziny w swietle prasy z lat 1929-1932," in Zarnowska and Szwarz (eds.), Kobieta i kultura zycia codziennego, 123-132, pp. 125-128; Jolluck, Gender, Identity and the Polish Experience of War, 298; Tusinski, "Kobieta w zyciu spolecznym i politycznym miasta przemyslowego Radom 1918-1939," 197-200; Sierakowska, "Macierzynstwo-wizje a rzeczywistosc," 217-219; and Magda Gawin, "Planowanie Rodziny-hasla i rzeczywistosc," in Zarnowska and Szwarc (eds.), Rowne prawa i nierowne szanse, 221-239, pp. 224, 235-238. 
Gospodyn Centralnego Towarzystwa Organizacji i Kolek Rolniczych (CTOiKR), helped to raise women's self-awareness and create conditions favorable for women's independent public activity in the rural areas. A large number of urban women themselves became more educated on issues pertaining to peasant women after reading and writing in popular women's periodicals such as Przewodnik Gospodyn, Voice of Rural Housewives (Glos Gospodyni Wiejskiej), Voice of Rural Women (Glos do Kobiet Wiejskich), Druzyna, Gospodyni, Calendar of Rural Housewives (Kalendarz Gospodyn Wiejskich) and Rural Women (Kobieta Wiejska). All these rural women's publications and organizations emphasized the importance of building a "rational" peasant society in which physically healthy rural women questioned traditional cultural practices and managed their home economies with greater independence and confidence. Indeed, notions of good health and hygiene were embedded in the urban intellectual matrix designed specifically to awaken peasant women's self consciousness.

While women's enhanced self-awareness was critical in the formation of peasant women's physical culture, the state also used its political propaganda and social activism to promote the systematic organization of physical education in rural areas. The radical Association of Rural Youth of the Polish Republic (Zwiazek Mlodziezy Wiejskiej Rzeczypospolitej Polskiej “Wici”), established in 1928, was bestowed with multifarious tasks of educating peasants in economic, social, cultural, and health-related practices, including physical education and sports. While shortages in material, financial and instructional facilities were omnipresent, rural sports competitions, in a variety of games, attracted the village youth. In addition, the activities of the paramilitary Przysposobienie Wojskowe Konne (1929-39), the Przysposobienie Wojskowe Lesnikow (PWL), and Red Scouts TUR, also helped to facilitate the development of physical culture and tourism in the Polish countryside. Meanwhile, some other youth organizations such as the Young Women's Christian Association and the pro-government Rural Youth Association "Siew" (Zwiazek Mlodziezy Wiejskiej RP "Siew") conducted wide-scale cultural and educational work to improve women's health in rural areas. Furthermore, the Society of Women Landowners (Stowarzyszenie Zjednoczonych Ziemianek) expressed an interest in women's physical fitness in its larger program of instructing landowners' wives in patriotic education, military training, and social solidarity.

However, while peasant woman were being guided into modernity by their urban sisters, the scale and scope of the concomitant transformations was limited. While modern influences and fashions were transmitted from urban to rural women, the average income of peasant families in the villages remained lower than working class families in interwar Polish towns. Moreover, patriarchal traditions remained more strongly 
entrenched in the countryside. Rural women still had to fulfill their customary obligations of raising children, assuring family stability, and performing duties associated with the domestic economy. Agriculture remained the predominant economic activity during the interwar years, and women's independent activities and growing awareness in the rural economy did not conflict with conservative patriarchal institutions. While peasant women became acquainted with modern ideas and practices, their conventional identities undermined rural women's professional interests and left the "new peasant woman", in essence, "old". For this reason, rural women's physical culture focused on improving women's health and hygiene, and not necessarily on facilitating peasant women's active engagement in sports. 24 It is interesting that the more "passive" images of rural women in interwar Polish physical culture was in contrast to the new images of Soviet peasant women who were displayed in the political posters of the 1930s with a far slimmer and more youthful body. 25

The development of women's physical culture in interwar Poland was thus influenced by women's interest in 'social politics', by their new educational experiences, and by their work in factories and industries. The revised description of women's sexual identity also supported women's interest in sports. In the countryside, peasant women, in response to the urban tremors of modernity, became aware of the importance of a healthy lifestyle, and accordingly laid the foundations of their rural physical culture centered on ideas of good health and hygiene. Ultimately, the state's concern with building a

\footnotetext{
24 For all these issues on peasant women see Zarnowska, "Kierunki," 161, 162; Zofia Chyra-Rolicz, "Kobiety a unowoczesnianie i uspolecznianie gospodarstw domowych w Polsce miedzywojennej," in Zarnowska and Szwarz (eds.), Kobieta i kultura zycia codziennego, 249-264, pp. 251, 256, 258, 260-264; Kostrzewska, "Kola," 135, 136, 139, 140; Zawacka, Czekajac na rozkaz, 84-86; Helena Brodowska, "Dziewczeta wiejskie w ruchu oswiatowym w Polsce miedzywojennej," in Zarnowska and Szwarc (eds.), Kobieta i edukacja, Cz.II, 145-157, pp. 145, 147, 149, 156; Wapinski, "Kobiety i zycie publiczne," 25, 31, 36; Arkadiusz Kolodziejczyk, "Kobiety w politycznym ruchu ludowym w latach 1918-1939," in Zarnowska and Szwarc (eds.), Kobieta i swiat polityki w niepodleglej Polsce, 132-144, pp. 132, 141, 143, 144; Renz, "Kobiety i zycie spoleczno-polityczne kielecczyzny, 1918-1939," 203, 206-208; Zarnowski, "Kobiety w strukturze spoleczno-zawodowej polski miedzywojennej," 108; Zarnowska, "Obywatelki II Rzeczypospolitej," 294, 295; and Wlodzimierz Medrzecki, "Kobieta w rodzinie i spolecznosci wiejskiej w Polsce w okresie miedzywojennym," in Zarnowska and Szwarc (eds.), Rowne prawa i nierowne szanse, 171-187, pp. 172, 174, 177, 183-187. For details on the popularization of physical culture in the countryside see Kobieta Wspolczesna, 4, 8 (23 February, 1930), 13; Bluszcz, 34 (20 August, 1938), 18/810; Szymanski, Kultura fizyczna, 32, 82, 87; Gaj in Gaj and Hadzelek, Dzieje kultury fizycznej, 156, 157; Jerzy Chelmecki, "Problematyka wychowania fizycznego i sportu w dzialalnosci Zwiazku Mlodziezy Wiejskiej RP "Wici"," in Kultura Fizyczna, 3 (1979), 9-14, pp. 9, 10; Laskiewicz, Robotnicza kultura fizyczna, 20, 22, 80, 81, 82, 84; and Tadeusz Daszkiewicz, "Jozef Pilsudski o wartosciach nadrzednych wychowania fizycnego," in Kultura Fizyczna, 3-4 (1999), 1-3, p.3.

25 Victoria E. Bonnell, Iconography of Power: Soviet Political Posters under Lenin and Stalin (Berkeley, 1997), 101, 105.
} 
physically strong citizenry for military defense, especially in the years between 19271939, popularized physical culture for both men and women in the cities and villages. The gradual militarization of the society, unfortunately, forced the women's movement to subordinate its agenda to the maintenance of the unity and strength of the increasingly vulnerable Polish state. For this reason, the "woman question", which had first been raised in partitioned Poland and then appeared to have been solved by the new theoretical legality of the interwar republic, remained in reality un-resolved. While the persistence of patriarchy undermined the success of the feminist agenda in the first decade of the interwar period, the 'woman question' was accorded a state burial with the drift toward militarization and political authoritarianism in the second decade of the interwar Polish Republic. Significantly, the vagaries and tribulations of the Polish women's movement did not adversely affect the apparatus of women's physical culture. On the contrary, the military impulses of the political elite enthusiastically supported women's good health and physical fitness. To be sure, the omnipresent patriarchal concerns contradicted women's supposed liberation and limited the numbers of female athletes in interwar Poland. At the same time, however, "national" concerns merited increased attention to women's physicality.

By way of comparison, it should be emphasized that such conflicting images of women's "theoretical" and "real" emancipation were visible in other countries as well, including and especially the Soviet Union. Soviet women were bewildered by the political repudiation of their earlier state-endorsed economic, political, and sexual equality. In classical Marxist theory, the abolition of private property and its replacement by social ownership and control of the means of production were seen as the most fundamental pre-conditions for the emancipation of women. The realization of sexual equality was thus thought to be brought about by two specific changes: the reintroduction of women into social production and the socialization of private domestic work and care of children. As inheritors of the Marxist theory on sexual equality, the Bolshevik leaders introduced several legal, economic, religious and familial changes to make Soviet society more egalitarian in gender relations and transform into reality a real "withering" away of the family. Accordingly, new legislation established civil marriage, easy divorce, abortion services, maternity pay and child-care facilities. The women's department (Zhenotdel, 1919), under its director Aleksandra Kollontai, predicted new harmonious relationships between women and men based on gender equality. But the early Bolshevik polices, despite their revolutionary agenda, were ridden with problems. In general, the lack of resources of the young Soviet government, the disruption of the economy because 
of the civil war and further economic transformations, the extreme conservatism of the population, the hostility of the Bolshevik Party to autonomous group activity, the multiple failures of the Zhenotdel, women's low wages and lack of child-care facilities, and peasant women's traditional resistance to the new forms of 'liberated sexuality', all contributed to serious shortcomings in the realization of the socialist vision.

For the early Bolsheviks, the abolition of the family, rather than gender conflict within it, held the key to women's emancipation. For this reason, the Soviet "woman question" was never addressed at its core. Moreover, in the mid-1930s, the Soviet state moved to a pro-family and pro-natalist stance, outlawing abortion in 1936, making divorce harder to obtain and more costly, rewarding mothers of many children, stigmatizing irresponsible fathers and husbands, and abolishing the Zhenotdel. It comes as no surprise, therefore, that the party was confronted by women who bombarded state agencies with complaints, requests and demands, instead of complacent women workers who gratefully acknowledged the party's concern over their miserable conditions. 26

Thus, neither the Soviet nor the Polish "woman question" was ever satisfactorily answered in the interwar period. The Polish state, however, was less dubious in its understanding of the "woman question". The Polish political elite, unlike the Bolshevik leaders, never attempted to engineer a "withering away" of the family unit. On the contrary, the Polish state remained committed to strengthening the family institution at all times. Certainly, the ruling elites in Poland preached gender equity. However, they never claimed to achieve this objective at the expense of traditional gender equations. Thus, Polish women could become more "modern", professional, and "sportive"; however, they were still to remain mothers and wives who carefully nurtured their families, preserve the

26 Several authors have discussed the "withering away of the family" and other Bolshevik plans and strategies for Soviet women. For a detailed description of women in the interwar Soviet Union see the books Wendy Goldman, Women, The State and Revolution: Soviet Family Policy and Social Life, 19171936 (Cambridge and New York, 1993); and Elizabeth Wood, The Baba and the Comrade: Gender and Politics in Revolutionary Russia (Bloomington, 1997). See also Gail Lapidus, Women in Soviet Society: Equality, Development, and Social Change (Berkeley, 1978), 3, 51, 52, 71, 72, 94, 97, 112; Alena Heitlinger, Women and State Socialism: Sex Inequality in the Soviet Union and Czechoslovakia (London, 1979), 16, 17; Mary Buckley, Women and Ideology in the Soviet Union (Ann Arbor, 1989), 19, 48, 49, 109, 113, 136, 137; Elizabeth Waters, "The Female Form in Soviet Political Iconography, 1917-32," in Clements, Engel and Worobec (eds.), Russia's Women, 225-242; Michael Paul Sacks, "Women in the Industrial Labor Force," in Atkinson, Dallin and Lapidus (eds.), Women in Russia, 189-204; Clements, Daughters of Revolution, 57, 73, 74; Beatrice Farnsworth, "Village Women Experience the Revolution," and "Rural Women and the Law," in Farnsworth and Viola (eds.), Russian Peasant Women; Elizabeth Wood, "Prostitution Abound," in Jane T. Costlow, Stephanie Sandler and Judith Vowles (eds.), Sexuality and the Body in Russian Culture (Stanford, 1993), 124-135, pp.129, 133; Fitzpatrick, Everyday Stalinism, 142; and Vladimir Brovkin, Russia After Lenin: Politics, Culture and Society, 1921-1929 (London and New York, 1998), 154. 
Church-endorsed vision of "good" and "rational" public morality, and moderate their feminist predilections to accomplish the state designated "national" duty of defending the country's territorial integrity in an increasingly hostile international climate. This feminist accommodation to state-defined goals of maintaining the cohesiveness of the traditional family structure and facilitating social mobilization for military purposes was quite visible in the apparatus of the "New Woman's" physical culture and in the projected images of female athletes as exemplars of Polish nationalism, patriotism, and moderated feminism. The next chapter will explore how Polish nationalism and feminism interacted in the public realm of women's amateur and high performance sports. 


\section{Chapter Four}

\section{Women's Sports in Interwar Poland}

This chapter examines the harmonious interaction between Polish "feminism" and "nationalism" in the realm of women's sports in interwar Poland. Despite several organizational and material difficulties, Polish sportswomen in the interwar period played many games and established several national and international records. ${ }^{1}$ The numerous sports newspapers and women's periodicals of the time contain a wealth of information on the accomplishments of male and female athletes. In particular, women were widely encouraged to participate in certain 'appropriate' sports that directly contributed to their improved physical health and intellectual development. Of these games, volleyball, hazena, basketball, sailing, tennis, oaring, skating, skiing (without leaps), archery, gymnastics, and camping were all highly attractive and popular disciplines of sport for women. The Polish women's sports movement was unusually strong in oaring and track and field events. At the same time, however, women were strongly discouraged from participating in male-dominated sports such as football, rugby, hockey, cycling, weightlifting, wrestling, and boxing. Meanwhile, some sports, such as sailing, tennis, and horse-riding maintained their traditional social elitism. On the other hand, tourism served as a mass sport which fostered a spirit of solidarity and friendship, especially for the younger generation.

\footnotetext{
1 Women participated in a variety of sports such as parachuting, track and field events, volleyball, basketball, handball, hazena, rowing, oaring, fencing, archery, water tourism, canoeing, yachting, table tennis, tennis, swimming, shooting, gymnastics, horse riding, roller skating, skiing, aviation, and auto and motorcycling racing. For a general description of the participation of Polish women in different sports see Kobiety w Pracy, 1, 5-6 (June-July, 1938), 28; Kobiety w Pracy, 2, 5-6 (June-July, 1939), 14, 15, 47; KSD, 3, 13 (July, 1927), 14, 18; KSD, 6, 19 (October, 1930), 17-19; KSD, 6, 12 (June, 1930), 20, 21; KSD, 6, 16 (August, 1930), 15; KSD, 9, 13 (July, 1933), 24-26; KSD, 8, 18 (September, 1932), 22, 23; KSD, 8, 19 (October, 1932), 20; Start, 2, 5 (March, 1928), 6, 7; Bluszcz, 21 (26 May, 1923), 171; Bluszcz, 41 (13 October, 1923), 394; Bluszcz, 27 (2 July, 1927), 11-13; Bluszcz, 37 (10 September, 1927), 14; Bluszcz, 46 (10 November, 1928), 28, 29; Bluszcz, 40 (4 October, 1930), 10; Bluszcz, 34 (22 August, 1931), 16; Bluszcz, 4 (27 January, 1934), 114; Bluszcz, 46 (12 November, 1938), 61/1165, 62/1166; Bluszcz, 20 (16 May, 1936), 14/454, 15/455; Bluszcz, 27 (3 July, 1937), 9/605, 10/606; PzS, 50, 1174 (27 April, 1956), 1;

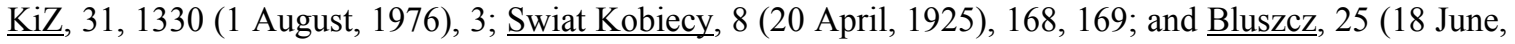
1927), 12-14. More specifically, for women's handball see $\underline{\mathrm{PzS}}$, 7, 27, 320 (9 July, 1927), 6; and PzS, 7, 6, 299 (12 February, 1927), 6. For women's table tennis, especially female players from Sosnowiec, Warsaw, and Lodz, see $\underline{\mathrm{PzS}}, 7,9,302$ (5 March, 1927), 6; and $\underline{\mathrm{PzS}}, 7,27,320$ (9 July, 1927), 6. For women in hazena see PzS, 8, 50, 395 (10 November, 1928), 3; Bluszcz, 44 (2 November, 1929), 11; and Bluszcz, 17 (21 April, 1928), 19. For photographs of women rowers of WKW in 1920s', women from Grazyna in training, women playing ice hockey in KS Korona, women pioneers in track and field from KS Polonii in 1923 and a women's handball team from the same place, see T.A Grabowski, Z lamusa Warszawskiego sportu (Warsaw, 1957).
} 
To make Polish society more competitive in sports, a special honorary badge called the State Sporting Medallion (POS) was created for both male and female athletes. Efforts were also made to increase the numbers of gymnastics halls, tennis courts, swimming pools, play gardens and heath resorts. Many more sports clubs and institutions were formed for men and women, including the disabled. Meanwhile, the Jordan center continued to serve as an important space for women and children to indulge in physical recreation. Overall, with active state and social interest in the interwar years, Poland became one of Europe's foremost nations in athletics in a short period of time. ${ }^{2}$

While Polish women played many games, their participation in sports was required to conform to state-directed expectations and social customs. This is quite evident in the sports they practiced, in the images displayed in the press, and in the popular opinion regarding the "duties" of Polish female athletes. Accordingly, this chapter first examines the development of Polish women's physical culture in the interwar period in the context of which sports were deemed "appropriate" for women and in which geographic regions of Poland. Thereafter, the press imagery and public opinion are both evaluated to explain the accomplishments and limitations of women's participation in sports in the interwar years. Finally, the Polish women's physical culture is placed in a global context to highlight the impact of "feminist" and "nationalist"

2 For all these issues see Kobieta Wspolczesna, 4, 34 (24 August, 1930), 12-14; Bluszcz, 2 (9 January, 1926), 35; Bluszcz, 24 (11 June, 1932), 11, 12; Bluszcz, 39 (30 September, 1933), 10; and Bluszcz, 32 (6 August, 1938), 19/763, 20/764. In more general terms, the popular [male] disciplines of sport included football, volleyball, track and field, boxing, gymnastics, basketball, handball, oaring, swimming, tennis, scouting, table tennis, skiing, shooting, and tourism. Tourist excursions, often promoted by the Zwiazek Polskich Towarzystwo Turystycznych (1927) and the Towarzystwo Zabaw Ruchowych (TZR), were referred to as "national pilgrimages" for their role in fostering social integration and national patriotism. There are many articles and references to tourist facilities and the importance of mountain and sea recreation. See for example Kobiety w Pracy, 1, 4 (May 1938), 28; Kobieta Wspolczesna, I, 16 (17 July, 1927), 15; Moja Przyjaciolka, 3, 13, (10 July, 1936), 257; Moja Przyjaciolka, 4, 12 (25 June, 1937), 274, 275; Bluszcz, 20, (16 May, 1925), 517; Bluszcz, 34 (18 August, 1928), 3, 4; Bluszcz, 31 (1 August, 1931), 17; Bluszcz, 2, 13 January, 1934), 55; Bluszcz, 10 (10 March, 1934), 296, 297; Bluszcz, 41 (13 October, 1934), 1281, 1282; Bluszcz, 25 (20 June, 1936), 10-11/570-571; Bluszcz, 26 (27 June, 1936), 10-15/594-599; Bluszcz, 25 (17 June, 1939), 18-19/718-719; Bluszcz, 22 (28 May, 1938), 12/492, 13/493; and Bluszcz, 25 (18 June, 1938), 10-11/586-587. For details on the various [male] sports disciplines during interwar Poland see Kobieta Wspolczesna, 3, 22 (2 June, 1929), 27-31; Woltmann, Polska kultura fizyczna, 222, 223, 276, 279, 300, 301, 308, 314, 319, 320, 322-329, 335, 345, 365, 367, 370, 371; Szymanski, Kultura fizyczna, 105, 107, 109, 110, 112; Laskiewicz, Robotnicza kultura fizyczna, 21, 133, 139, 146; Gaj in Gaj and Hadzelek, Dzieje kultury fizycznej, 110; Bluszcz, 11 (17 March, 1923), 92; Bluszcz, 5 (2 February, 1935), 135; Kobieta Wspolczesna, 3, 22 (2 June, 1929), 27-31; Woltmann, "Gegensatze in der polnischen Sportbewegung," 161; Grot, "Versuch eines," 308; Mlodzianowska, "Rozwoj wychowania fizycznego i sportu w Polsce w latach 1914-1949," 115; Liponski, "Still and Unknown," 18, 20; Ingvar Rors, "Survey of the Inter-War Period, 1919-1939," in Olsen (ed.), Sport und Politik, 13-21, p.17; Skawinski, Kultura fizyczna na Lubelszczyznie, 15; Wojciech Kalina, "Przyczynek do historii sportu inwalidzkiego w Polsce," Kultura Fizyczna, 6 (1977), 268-271, p.268; and Z. Dall, Kultura fizyczna i sport w Polsce Ludowej (Wydawnictwo Glownego Komitetu Kultury Fizycznej, 1951), 4. 
considerations in defining the pace of women's physical emancipation and directing the transformations in the constituent components of women's physical culture.

\section{Defining "Suitability": The “Appropriate” Sports for Women in Interwar Poland}

Among the "suitable" sports for women, female tennis champions received significant coverage in the press. This game was considered 'healthy' and 'esthetic,' and hence 'appropriate' for women. However, tennis continued to remain a costly sport, and tennis clubs still received the patronage of the mainly fashionable rich. And despite efforts to make the game more 'popular', 'athletic', and 'educative', female tennis players remained few and far between. Still, the accomplishments of national and international Polish champions such as Jadwiga Jedrzejowska and Wiera Richterowna provided Poland with a good reason to revel in its jubilant tennis triumphs. ${ }^{3}$

While Polish women played tennis to win celebrity, French women engaged in tennis for its social functionality. Private tennis parties were arranged to which suitable young men and women would be invited followed by tea on the lawn. ${ }^{4}$ In England public opinion remained suspicious of girls who took the game too seriously and treated it competitively rather than as an opportunity for socializing. 5

The most popular sport for Polish women in the interwar period was track and field. Many events in track and field for women, at the local, regional and national levels, were coordinated by male and female sports clubs, as well as by the Polish Track and Field Union (Polskiego Zwiazku Lekkiej Atletyki, PZLA). With this social interest and state initiative, Polish women won domestic and international accolades. It is significant that the press regularly published articles on women's track and field competitions and spoke highly of its champions. Several photographs of "elite" female athletes were displayed on the cover page of popular newspapers. Meanwhile, Halina Konopacka's superlative performances in the discuss throw placed Poland on top of the sporting map

\footnotetext{
${ }^{3}$ For coverage on Polish women's tennis during the interwar period see Kobiety w pracy, 1, 3 (April, 1938), 10, 11; KSD, 14, 9 (1 May, 1938), 14, 15; $\underline{\mathrm{PzS}}, 1,18$ (17 September, 1921), 12, 13; $\underline{\mathrm{PzS}}, 5,35,224$ (2 September, 1925), 11 and cover page; PzS, 3, 30, 115 (26 July, 1923), 8; PzS , 3, 40, 125 (3 October, 1923), 6; PzS, 9, 76, 478 (16 November, 1929), 3; Moja Przyjaciolka, 4, 14 (25 July, 1937), 321; Bluszcz, 12 (20 March, 1926), 366; Bluszcz, 19 (8 May, 1926), 654-656; Bluszcz, 36 (3 September, 1927), 15; Bluszcz, 47 (21 November, 1931), 22; Bluszcz, 20 (13 May, 1939), 16-17/548-549; Bluszcz, 23 (9 June, 1934), 711, 712; Bluszcz, 22 (29 May, 1937), 12/464; Bluszcz, 22 (28 May, 1938), 13/493; Bluszcz, 27 (2 July, 1938), 14/638; Bluszcz, 30 (23 July, 1938), 15/71; and Bluszcz, 32 (6 August, 1938), 20/764.

${ }^{4}$ For French women and sport see Richard Holt, Sport and Society in Modern France (London, 1981), 8, $158,163,164,177$.

${ }^{5}$ Claire Langhamer, Women's Leisure in England, 1920-1960 (Manchester and New York, 2000), 80.
} 
of the world. She won gold medals in the II Women's World Games (1926) and at the Amsterdam Olympics in 1928. Hers was Poland's first Olympic gold medal. Thereafter, the accomplishments of Stanislawa Walasiewiczowna and Jadwiga Waysowna in track and field not only increased Poland's Olympic medal count, but placed this sport ahead of all others for Polish women in the interwar period. 6

Women's rowing, considered a 'bold' and 'democratic' sport, received extensive coverage throughout the interwar years. This reportage included activities of the Warsaw Oarswomen Club (WKW) and the organization of women's regattas. Under the presidency of Dr. Zofia Zabawska-Domoslawska, the WKW organized itself systematically and promoted a variety of sports for women, including fencing, swimming, tennis, sailing, gymnastics, skating, skiing, and volleyball. Its membership increased from 268 in 1924, to 400 in 1929, and 692 in 1931. Women's oaring clubs were also formed in other cities such as Bydgoszcz (1926), Kalisz (1921), and Poznan (1928). All these rowing clubs popularized sports among women and contributed to the development of Polish women's physical culture, nationally and internationally. 7

\footnotetext{
${ }^{6}$ For women in track and field events, see Kobieta Wspolczesna, 4, 1 (5 January, 1930), 12, 13; PzS, 4, 51, 188 (24 December, 1924), cover page; PzS, 5, 20, 209 (20 May, 1925), cover page; PzS, 5, 21, 210 (27 May, 1925), 3; PzS, 5, 29, 218 (22 July, 1925), 17; PzS, 6, 16, 257 (22 April, 1926), 7; PzS, 6, 18, 259 (6 May, 1926), 8, 11; $\underline{\text { PzS }}, 6,20,261$ (20 May, 1926), 3, 6; $\underline{\text { PzS }, ~ 6, ~ 21, ~} 262$ (27 May, 1926), cover page; PzS, 7, 6, 299 (12 February, 1927), 5; PzS, 7, 7, 300 (19 February, 1927), 6; PzS, 7, 22, 315 (4 June, 1927), 3; Pz.S , 7, 27, 320 (9 July, 1927), 3, 6; PzS, 7, 28, 321 (16 July, 1927), 3; PzS, 7, 39, 332 (1 October, 1927), 1, 3; $\underline{\mathrm{PzS}}, 7$, 43, 336 (29 October, 1927), 1, 3; PzS, 7, 45, 338 (12 November, 1927), 6; PzS, 20, 365 (19 May, 1928), 6; Pz.S, 18, 78, 1438 (26 September, 1938), 6; Moja Przyjaciolka, 3, 15 (10 August, 1936), 297; Bluszcz, 26 (30 June, 1923), 217; Bluszcz, 43 (25 October, 1924), 787; Bluszcz, 44 (1 November, 1924), 809, 810; Bluszcz, 45 (3 November, 1924), 827; Bluszcz, 46 (15 November, 1924), 848; Bluszcz, 40 (2 October, 1926), 1273, 1274; Bluszcz, 48 (27 November, 1926), 1530, 1531; Bluszcz, 48 (24 November, 1928), 13; Bluszcz, 44 (1 November, 1930), 11; Bluszcz, 34 (22 August, 1931), 9-11; Bluszcz, 32 (11 August, 1934), 992; Bluszcz, 36 (8 September, 1934), 1119, 1120; Bluszcz, 21 (25 May, 1935), 650, 651; Swiat Kobiecy, 7 (5 April, 1925), 148; Zdzislaw Pawluczuk, "Miejsce sokolic w polskiej lekkoatletyce kobiecej w latach 1919-1939," in Woltmann (ed.), Z najnowszej historii kultury fizycznej w Polsce, 25-33, pp. 28, 29, 33; Waszytl, "Poczatki lekkiej atletyki w Galicji," 101, 102; Biuletym Informacyjny Glownego Komitetu Kultury Fizycznej i Turystyki (Nr.10-12, Warsaw, 1975), 7-10; Rotkiewicz, "Rozwoj sportu kobiet w Polsce," 10, 11; and AMR, notes.

7 For Polish oarswomen and their activities see Kobieta Wspolczesna, 1, 32 (6 November, 1927), 13; Kobieta Wspolczesna, 3, 15 (14 April, 1929), 5, 6; Kobieta Wspolczesna, 3, 37 (15 September, 1929), 18; Kobieta Wspolczesna, 3, 39 (29 September, 1929), 15; KSD, 3, 10 (May, 1927), 14; KSD, 3, 14 (July, 1927), 16, 17; KSD, 14, 13 (1 July, 1938), 14, 15; PzS, 2, 36, 69 (8 September, 1922), 12; PzS, 5, 26, 215 (1 July,1925), 3; $\underline{\text { PzS }}, 5$, 28, 217 (15 July, 1925), 12; PzS , 5, 31, 220 (5 August, 1925), 19; $\underline{\text { PzS }}, 7,31,324$ (6 August, 1927), 1; $\underline{\text { PzS }}, 17,4,1260$ (14 January, 1937), 3; PzS, 19, 66 (17 August, 1939), 3; Bluszcz, 41 (11 October, 1924), 738; Bluszcz, 4 (24 January, 1925), 83, 84; Bluszcz, 5 (31 January, 1925), 104, 105; Bluszcz, 22 (28 May, 1927), 14; Bluszcz, 37 (14 September, 1929), 10-12; Bluszcz, 32 (8 August, 1931), 13; Bluszcz, 33 (15 August, 1931), 10, 11; Bluszcz, 32 (6 August, 1932), 17, 18; Bluszcz, 28 (14 July, 1934), 866-868; Bluszcz, 36-37 (7-14 September, 1935), 1035, 1036; Bluszcz, 7-8 (15-22 February, 1936), 18/162; Bluszcz, 15 (11 April, 1936), 12/332; Bluszcz, 29 (18 July, 1936), 10/666, 11/667; Bluszcz, 33 (15 August, 1936), 10-11/762-763; Bluszcz, 35 (29 August, 1936); Bluszcz, 51-52 (19-26 December, 1936), 24/1204; Bluszcz, 6 (6 February, 1937), 14/134, 15/135; Bluszcz, 17 (23 April, 1927), 12, 13; Rotkiewicz,
} 
Women's fencing in Poland had traditionally been looked upon with disfavor since the sport was considered too "manly". And even in the 1920s, women preferred other sports over fencing. Still, the number of female fencers increased as the sport gained regional popularity in Warsaw, Poznan, Katowice, Lodz, Katowice, and Rybnik in the late 1920s and 1930s. Female fencers from Silesia, in particular, performed extraordinarily well in this sport, and their domestic and international successes made them the sports ambassadors of Poland. At all times, however, the female players were required to demonstrate their "elegance" by being uniformed in a "suitable" and "esthetic" attire of white blouses and white trousers or black skirts up to the knee. ${ }^{8}$

Rifleshooting was regarded as a suitable sport for women since it enabled them to overcome their presumed passivity and physical weakness. Such ideas became even more popular in the 1930s when women were urged to learn the art of rifleshooting to protect their families and defend the nation from external aggression. Different social and military organizations such as the Riflemen's Union (Zwiazek Strzelecki 'Strzelec'), the Riflewomen's Union (Zwiazek Strzelek), Rodzina Wojskowa, and the Organization for the Military Preparation of Women for the Defense of the Country (Org. Przysposobienia Kobiet do Obrony Kraju) coordinated women's championships at the local and national levels. The Zwiazek Strzelecki committed itself to a program of military preparation and anti-communism, and registered an impressive increase in its membership, especially after 1926. It remained popular in the countryside and among urban workers, particularly in Lwow, Lodz, Warsaw, Torun, and Silesia. More generally, rifleshooting as a sport enjoyed greater popularity in the provinces than in the major cities for both men and women. 9

"Rozwoj spolecznych organizacji sportu kobiet," 73; Statut Warszawskiego Klubu Wioslarek (Warsaw, 1927); Warszawski Klub Wioslarek, Regulamin Wioslarski (Warsaw, 1933); Warszawski Klub wioslarek swej prezesce czlonkini honorowej Dr. Zofji Zabawskiej-Domoslawskiej w dowod wdziecznosci i uznania dla jej pracy dla klubu w ciagu 10-letniej przesury (Warsaw, 15 December 1934), 8, 14, 15; Rotkiewicz, "Rozwoj sportu kobiet w Polsce," 6, 7; and AMR, notes. For women oarers in Kalisz see Gazeta Kaliska, (9 June, 1920). On the Bydgoszcz women's oarers club, see Urbanyi, Zarys Historii Sportu Bydgoskiego, 8. Also see K. Muszalowna and E. Reicherowna (eds.), Wioslarstwo kobiece (Warsaw, 1936). This last book is a general textbook about the methodology of rowing for women.

8 For women in fencing see $\underline{\mathrm{PzS}}, 6,21,262$ (27 May, 1926), 8; $\underline{\mathrm{PzS}}, 2$, 24, 57 (16 June, 1922), 11; PzS, 2 , 51, 84 (22 December, 1922), 53; PzS, 9, 412 (23 February, 1929), 1; PzS, 9, 11, 414 (9 March, 1929), 1; Sport, 13 (9 June, 1922), 225; Bluszcz, 10 (10 March, 1934), 309-312; Bluszcz, 1 (5 January, 1935), 17, 18; Bluszcz, 21 (25 May, 1935), 649, 650; Bluszcz, 20 (16 May, 1936), 15/455; Bluszcz, 73 (1-2 January, 1937), 9; Bluszcz, 1 (1 January, 1939), 15; Anna Mlodziankowska, Poczatki i rozwoj sportu szermierczego kobiet w Polsce do 1980 (Praca Magisterska, AWF Warsaw, 1982), 96; Rotkiewicz, "Poczatki szermierki," 62-72; and Tadeusz Karuga, "Rozwoj sportu szermierczego kobiet na Gornym Slasku do r. 1939," in Kultura Fizyczna, 2, 31 (February, 1977), 79-82.

${ }^{9}$ For women and rifleshooting see Kobiety w Pracy, 1 (4 May, 1938), 30; Kobiety w Pracy, 1, 5-6, (JuneJuly, 1938), 41; Kobieta Wspolczesna, 3, 13 (31 March, 1929), 19; PzS, 5, 9, 198 (4 March, 1925), 8; PzS, 
Similar to rifleshooting, the scouting and Sokol organizations also conducted active military training for women in sports. Women's scouting was looked upon as a form of women's work in interwar Poland. The Polish Scouting Union (Zwiazek Harcerstwa Polskiego, ZHP), ideologically committed to the endecja, was mainly comprised of young girls and boys from urban families of intellectuals and traders. Although its membership included peasants in the 1930s, the organization itself remained more urban-based, attracting secondary school youth. The ZHP, together with the Citizens' Circle of Scouts (Obywatelskie Kola Przyjaciol Harcerzy, 1919), and the University Scouts Circle (Akademickie Kolo Harcerskie), played an important role in developing the health and physique of boys and girls, and inculcating in them a spirit of national patriotism and social solidarity.

Meanwhile, the various branches of Sokol popularized the cultural, military, and 'educative' values of sport in women's physical culture. The Union of Sokol Gymnastic Associations was formed in 1920 to promote a variety of sports for men and women. In the interwar period, Sokol added sentiments of nationalistic militarism and social integration to its traditional reservoir of patriotism. This was quite evident in its active participation in the political insurrections and the regional plebiscites on the borders of Poznania and Pomerania in 1918-1921. Its popular slogan, "Chcesz miec pokoj, szykuj sie do wojny" (If you want peace, prepare for war) emphasized military preparation, more so after 1926. Politically and ideologically, however, Sokol maintained its linkages with the Endecja, and was thus denied state resources. Moreover, in the 1930s, Sokol avoided political engagements along Poland's western borders due to intensified German surveillance of their irredentist activities. Sokol's own failure to keep pace with the changing political environment lost it the sympathies of the Union of Poles in Germany. 10

8, 346 (7 January, 1928), 2; Start, 2, 5 (1 March, 1928), 10; Bluszcz, 23 (3 June, 1939), 17/633; Bluszcz, 33 (12 August, 1939), 22/918; Bluszcz, 46 (12 November, 1938), 25/1129; Bluszcz, 36-37 (7-14 September, 1935), 1038; Bluszcz, 46 (12 November, 1938), 24/1128; Wapinski, "Kobiety i zycie publiczne," 20; Szymanski, Kultura fizyczna, 75,77; Zawacka, Czekajac na rozkaz, 81-84; Rotkiewicz, "Rozwoj sportu kobiet w Polsce," 11, 13; Warsicki, Kultura fizyczna, 124, 127; Gaj in Gaj and Hadzelek, Dzieje kultury fizycznej, 155, 161, 162, 163, 165; and Laskiewicz, Robotnicza kultura fizyczna, 51, 52, 136.

10 For details on female scouts and sokolites see Kobieta Wspolczesna, 2, 5 (29 January, 1928), 5, 6; Kobieta Wspolczesna, 1, 18 (31 July, 1927), 3, 4; Bluszcz, 4 (21 January, 1939), 16/100; Bluszcz, 17 (22 April, 1922), 138; Eugenjusz Piasecki, Dzieje wychowanie fizycznego (Lwow-Warsaw-Krakow, 1925), 230; Regulaminy Organizacji Sokolic Zwiazek Towarzystw Gimnastycznych "Sokol” w Polsce (Warsaw, 1927), 3; Wapinski, "Kobiety i zycie publiczne," 25; Zawacka, Czekajac na rozkaz, 28, 38, 39, 68, 82, 84; Gaj in Gaj and Hadzelek, Dzieje kultury fizycznej, 155, 165, 167; Szymanski, Kultura fizyczna, 32, 79, 80; Warsicki, Kultura fizyczna, 106-108, 110-112, 114, 116; Woltmann, Polska kultura fizyczna, 180, 190, 191, 198, 203, 205, 206, 365, 372, 373; Zolem ojczyznie, szponem wrogowi, no page numbers; Gaj in Gaj and Hadzelek, Dzieje kultury fizycznej, 155, 157; and Skawinski, Kultura fizyczna na Lubelszczyznie, 13. 
While Polish scouting and Sokol organizations contributed to the development of women's physical culture in interwar Poland, it needs to be emphasized that women's engagement in these associations was more circumscribed in comparison to male participation. The male membership in scouting sections was often twice more than female registration. 11 Such differential patterns of male and female membership was most pronounced in Sokol organizations. For example, the absence of dynamic participation of women in Sokol nests in Silesia is evident from this table ${ }^{12}$ :

$\begin{array}{llll}\text { Year } & \text { Sokol Nests } & \text { Male Members } & \text { Female Members } \\ 1923 & 128 & 6501 & 1148 \\ 1924 & 113 & 5518 & 1317 \\ 1925 & 121 & 5560 & 1037 \\ 1926 & 108 & 4861 & 907 \\ 1927 & 114 & 5704 & 847 \\ 1928 & 112 & 5535 & 972 \\ 1929 & 109 & 5354 & 975 \\ 1930 & 108 & 5498 & 1046 \\ 1931 & 112 & 5857 & 893 \\ 1932 & 116 & 5960 & 860 \\ 1933 & 116 & 6812 & 914 \\ 1934 & 109 & 7805 & 1001 \\ 1935 & 113 & 8398 & 1036 \\ 1936 & 114 & 8470 & 885\end{array}$

In winter sports, many women participated in skating and skiing, and enjoyed recreational winter tourism in places such as Zakopane. Skating was considered a "democratic", 'healthy', and "excellent" sport for women. It was said to be 'absorbing', 'good for all ages', 'not bad for the heart or muscles', and with an 'esthetic' appeal for women. The main centers of women's skating included Lwow, Warsaw, Wilno, and

\footnotetext{
${ }^{11}$ For example, in the women's section of ZHP in Radom, there were 100 girls in 1930, 250 in 1933 and 290 in 1938. Male membership, however, remained twice as large. See Tusinski, "Kobieta w zyciu spolecznym i politycznym miasta przemyslowego Radom 1918-1939," 198, 199.

12 Henryk Laskiewicz, "Rozwoj organizacyjny ruchu sportowego wojewodztwa slaskiego w latach 19221939," in Rechowicz (ed.), Z dziejow kultury fizyczej na Slasku $i$ w Zaglebiu Dabrowskim, 117-191, pp.117, 153, 176.
} 
Katowice. 13 Ice-skating was considered an ideal sport for English women as well. Although an expensive sport, it was perceived as graceful, non-aggressive and noncompetitive for women. 14

While skating was considered elegant for women, skiing was looked upon as a healthy, splendid, powerful, enrapturing, and character-building sport. The level of women's skiing was very high and Polish women performed extremely well in the international skiing competitions which were often organized in Zakopane. The Commission on Women's Skiing (Komisja Narciarstwa Kobiecego), founded in 1928 under the direction of Kazimiera Muszalowna, provided the organizational inspiration for the development of this sport among women. 15

There is scant reference to women's mountain-climbing in interwar Poland. In the Soviet Union, on the other hand, women engaged in this sport. In 1923, Kazbek became the cradle of Soviet mountaineering when two parties of scientists and college students from Tbilisi scaled it. Among them was the Georgian mountain climber Alexandra Japaridze. She was the first woman climber to win the title of the Honored Master of Sport. A meteorologist by profession, Japaridze also gave instruction to young mountaineers, lecturing at a Palace of Young Pioneers. 16

\footnotetext{
13 For women and skating see PzS, 6, 3, 244 (20 January, 1926), cover page; Moja Przyjaciolka, 3, 1 (10 January, 1936), 7; Bluszcz, 1 (3 January, 1925), 16; Bluszcz, 4 (27 January, 1934), 119; Bluszcz, 6 (6 February, 1937), 14/134; Bluszcz, 9 (2 March, 1935), 265; Rotkiewicz, "Rozwoj sportu kobiet w polsce," 14-16; and AMR, notes.

${ }^{14}$ Langhamer, Women's Leisure in England, 80

15 For women's winter sports and especially skiing see Kobieta Wspolczesna, 3, 7 (17 February, 1929), 1517; Kobieta Wspolczesna, 4, 5 (2 February, 1930), 14, 15, KSD, 4, 21 (November, 1928), 11; KSD, 5, 2 (January,1929), 19-21; KSD, 6, 2 (January, 1930), 18-21; KSD, 7, 1 (January, 1931), 28; KSD, 9, 4 (February, 1933), 24-27; KSD, 8, 3 (February, 1932), 24, 25; KSD, 10, 3 (February, 1934), 22, 23; PzS, 2, 3, 36 (20 January, 1922), 7; PzS, 2, 12, 45 (24 March, 1922), 13; PzS, 7, 3, 296 (22 January, 1927), 3; PzS, 7, 14, 307 (9 April, 1927), 1; Sport Polski, 1, 12 (17 December, 1937), 8; Moja Przyjaciolka, 3, 2 (25 January, 1936), 20; Moja Przyjaciolka, 3, 4 (25 February, 1936), cover picture; Moja Przyjaciolka, 4, 3 (10 February, 1937), 54, 55; Bluszcz, 10 (4 March, 1922), 81; Bluszcz, 2 (10 January, 1925), 38; Bluszcz, 50 (13 December, 1924), 929; Bluszcz, 45 (6 November, 1926), 1443; Bluszcz, 14 (2 April, 1927), 13, 14; Bluszcz, 15 (9 April, 1927), 12, 13; Bluszcz, 2 (7 January, 1928), 20, 21; Bluszcz, 13 (24 March, 1928), 10-12; Bluszcz, 52 (28 December, 1929), 16, 17; Bluszcz, 1 (5 January, 1929), 12; Bluszcz, 8 (23 February, 1929), 13, 14; Bluszcz, 49 (6 December, 1930), 16; Bluszcz, 51-52 (19-26 December, 1931), 20-23; Bluszcz, 4 (24 January, 1931), 17, 18; Bluszcz, 4 (28 January, 1933), 12; Bluszcz, 5 (4 February, 1933), 6; Bluszcz, 6 (10 February, 1934), 175-182; Bluszcz, 2 (13 January, 1934), 49-51; Bluszcz, 9 (27 February, 1937), 20/212; Bluszcz, 74, 1 (1 January, 1938 )14/14; Bluszcz, 3 (15 January, 1938), 14/64; Bluszcz, 5, (29 January, 1938), 12/108; Bluszcz, 19 (7 May, 1938), 14/446; Bluszcz, 9 (26 February, 1938), 12/204; Bluszcz, 3 (15 January, 1939), 16/72; Bluszcz, 4 (21 January, 1939), 16/100; Bluszcz, 5 (28 January, 1939), 14-15/126-127; Bluszcz, 7 (11 February, 1939), 16/184; Bluszcz, 9 (25 February, 1939), 14/238; Bluszcz, 75, 10 (4 March, 1939), 12-13/264-265; and Rotkiewicz, "Rozwoj sportu kobiet w Polsce," 17, 18.

16 Soviet Woman, 4 (1958), 18, 19.
} 
In the interwar period, some Polish women participated in gliding and parachuting. The military demands of the First World War had demonstrated the importance of good piloting. In subsequent years, aeronautical sports elicited interest from both men and women. Women in aviation were referred to as "queens of the air," and these female pilots, between the "earth and sun," successfully undermined traditional biological conservatism according to which women possessed 'shortcomings' and 'defects' that deprived them of the abilities of rational reasoning, physical strength, and confidence. Gliding was perceived as an excellent sport that was 'practical', 'popular', and 'moral'. Likewise, parachuting was healthy and character-building. Interestingly, it was reported that in this sport, there was no need for women to "overtake" men! Women not only registered in the Aeroclub Academies in Warsaw, Lwow, Krakow, Wilno and Poznan, but also competed in professional international championships in these events. The women's circle of the League of Air Defense (Liga Obrony Powietrznej $i$ Przeciwgazowej, LOPP) also prepared women to fight in air raids and, otherwise, participate in air defense. 17

By way of comparison, Soviet women also participated in these "air-based" sports and their "heroic" achievements were translated into "love for Stalin, love of country, and enthusiasm for national defense'. 18 Female aviators were exalted as examples of strong and successful women who were willing to struggle in order to achieve their goals. They were elevated to the status of the "best people of the Soviet Union". The Arctic fliers were described in rhetoric as "reaching out into higher realms" or "flying higher than anyone else in the world". 19

The number of Polish women in these expensive aeronautical sports was, however, limited. Such "elite" women probably preferred the land-based rich country

17 See Moja Przyjaciolka, 3, 14 (25 July, 1936), 273; Moja Przyjaciolka, 4, 24 (25 December, 1937), 595; Bluszcz, 15 (10 April, 1926), 503-506; Bluszcz, 47 (20 November, 1926), 1498; Bluszcz, 21 (24 May, 1930), 8-10; Bluszcz, 42 (17 October, 1931), 10; Bluszcz, 50 (10 December, 1932), 15; Bluszcz, 22 (3 June, 1933), 15; Bluszcz, 40 (5 October, 1935), 1084; Bluszcz, 43 (26 October, 1935), 2075; Bluszcz, 48 (30 November, 1935), 2253, 2254; Bluszcz, 2 (11 January, 1936), 15/39; Bluszcz, 36 (3 September, 1938), 14-15/850-851; Bluszcz, 37 (12 September, 1936), 12/860; Bluszcz, 44 (31 October, 1936), 11-12/10231024; and Bluszcz, 49 (5 December, 1936), 14-1146.

18 Karen Petrone, "Gender and Heroes: The Exploits of Soviet Pilots and Artic Explorers in the 1930s," in Susan Bridger (ed.), Women and Political Change: Perspectives from East-Central Europe. Selected Papers From the Fifth World Congress of Central and East European Studies, Warsaw, 1995 (New York, 1999), 7-26, p.11.

19 Karen Petrone, Life Has Become More Joyous, Comrades: Celebrations in the Time of Stalin (Bloomington, 2000), 55, 56, 71, 75; and Katerina Clark, The Soviet Novel: History as Ritual. Third Edition. (Bloomington and Indianapolis, 2000), 124, 125, 137. 
sport of horse-riding to flying. These few female equestrians belonged mainly to wealthy families with a military background in interwar Poland. 20

Among other sports, regular 'rational' gymnastics was still perceived to be 'excellent' and 'healthy' for women. Gymnastic breaks of ten minutes were highly recommended at workplaces for both men and women. The training methods of Emil Jacques Dalcroze, Agneta Bertram from Copenhagen, and E. Bjorksten in Poznan, enjoyed popularity in Polish women's gymnastic exercises. 21 Similar to gymnastics, women's volleyball was looked upon as a 'friendly' and 'healthy' game in interwar Poland. 22 Meanwhile, women's basketball was patronized by the regional branches of Sokol. Between the years 1929-1939, regular national women's championships in basketball were organized in Krakow, Lodz, Warsaw, Torun, and Lublin. In international competitions, women's basketball had yet to be included into the Olympic program. But Polish women did participate in basketball at the Women's World Games. ${ }^{23}$

The Second Polish Republic also witnessed a heightened interest in the development of women's automobile racing, especially in international competitions. 24 Since driving skill had constantly been identified as a natural masculine quality in

20 For women horseriders, see $\underline{\text { KSD }}, 3,14$ (July, 1927), 14, 15; KSD, 4, 14 (July, 1928), 18, 19; KSD, 8, 15 (August, 1932), 22; Bluszcz, 21 (24 May, 1930), 8-10; Bluszcz, 14 (4 April, 1925), 324, 325; Bluszcz, 42 (18 October, 1924), 763; Bluszcz, 8 (21 February, 1925), 177; Bluszcz, 10 (7 March, 1925), 224, 225; Bluszcz, 11 (14 March, 1925), 249; Bluszcz, 28 (10 July, 1937), 14-15/634-635; Bluszcz, 28 (14 July, 1934), 868, 869; Bluszcz, 45 (6 November, 1937), 12/1060, and AMR, notes.

21 For 'women and gymnastics' see Kobiety w pracy, 1, 3 (April, 1938), 23; Kobieta Polska, 1, 1 (20 December, 1936), 17; Kobieta Wspolczesna, 1, 24 (11 September, 1927), 22, 23; Kobieta Wspolczesna, 1, 33 (13 November, 1927), 13; Kobieta Wspolczesna, 3, 40 (6 October, 1929), 12-14; Kobieta Wspolczesna, 3, 51 (22 December, 1929), 15; Kobieta Wspolczesna, 4, 2 (12 January, 1930), 16; KSD, 8, 11 (June, 1932), 23; KSD, 8, 14 (July, 1932), 20; KSD, 12, 10 (15 May, 1936), 7; KSD, 13, 5 (1 March, 1937), 24; KSD, 14, 19 (1 October, 1938), 28; Moja Przyjaciolka, 3, 2 (25 January, 1936), 18; Moja Przyjaciolka, 3, 13 (10 July, 1936), 258; Moja Przyjaciolka, 4, 7 (10 April, 1937), 161; Moja Przyjaciolka, 4, 1 (10 January, 1937), 24; Bluszcz, 39 (27 September, 1924), 691; Bluszcz, 40 (4 October, 1924), 714; Bluszcz, 48 (27 November, 1926), 1530, 1531; Bluszcz, 2 (8 January, 1927), 18, 19; Bluszcz, 4 (22 January, 1927), 19, 20 ; Bluszcz, 6 (5 February, 1927), 19, 20; Bluszcz, 7 (12 February, 1927), 20, 21; Bluszcz, 8 (21 February, 1931), 18-20; Bluszcz, 41 (14 October, 1933), 17; Bluszcz, 45 (11 November, 1933), 15, 16; Bluszcz, 10 (10 March, 1934), 312; Swiat Kobiecy, 8 (15 April, 1927), 160; Gniewkowski, Rozwoj glownych europejskich systemow, 256, 257; M. Rotkiewicz, "Wplyw Emile Jacques-Dalcroze'a na rozwoj gimnastyki rytmicznej w Polsce," in Wychowanie Fizyczne i Sport, 1 (1979), 71, 72; and Rotkiewicz, "Rozwoj sportu kobiet $\mathrm{w}$ Polsce," 9. See also D. Rosenberg, Teoretyczne podstawy cwiczen cielesnych dla kobiet ze szczegolnym uwzglednieniem gimnastyki Bertram (Warsaw, 1931).

22 See $\underline{\text { PzS }}, 7,5,298$ (5 February, 1927), 8; Bluszcz, 21 (22 May, 1926), 717, 718; and Bluszcz, 28 (8 July, 1939), 18-19/77-75.

23 For women in basketball see $\underline{\mathrm{PzS}}, 1,22$ (15 October, 1921), cover page; and Maria Rotkiewicz and Alexandra Latek, "Maria Germanowna i poczatki koszykowki kobiet w Polsce (do 1939r)," in Sport Wyczynowy, 3-4/363-364 (1995), 78-86.

${ }^{24}$ For women and automobiles see PzS, 11, 32, 625 (22 April, 1931), 3; Start, 2, 5 (March, 1928), 10; Bluszcz, 50 (12 December, 1925), 1485; Bluszcz, 45 (7 November, 1925), 1325; Bluszcz, 45 (10 November, 1934), 1410; Bluszcz, 40 (2 October, 1937), 12/940; and AMR, notes. 
western societies, the social acceptance of Polish women as motorists contradicted the western traditional gendered notions about femininity, masculinity and technology. In Britain, women did obtain driving licenses in the years following the First World War. But as the number of female drivers increased, many male motorists, car dealers, and manufacturers began to express their concern about what they believed was the 'feminization of the car'. 25

Swimming was a highly recommended sport for women. Unfortunately, women's participation in swimming remained low in Poland, and even this little enthusiasm came from women's interest in rowing rather than from the health benefits of swimming. On the other hand, women's recreational water sports such as kayaking, canoeing, or simple enjoyment on the beaches were extremely popular. ${ }^{26}$ Meanwhile, in England, swimming was a useful accomplishment for both men and women seeking either mild flirtation or a soul mate at a fashionable watering-place. ${ }^{27}$ The provision of public swimming pools, where swimming instruction was sometimes given free, encouraged the participation of young working-class girls. 28

While women's swimming enjoyed limited popularity in interwar Poland, women's football, archery, and cycling appealed to an even smaller audience. The interwar period saw rudimentary beginnings of women's football in Poland. It is significant that the first attempts at emancipating soccer for women took place in Poland in 1921, decades ahead of other European countries. The game, however, remained very male dominated. 29 By comparison, in England, there were some 150 football clubs for women by 1921, and an English Ladies Football Association was also founded. Male professionals, however, were quick to discourage the clubs from lending their grounds to such exhibitions, which they felt had little to do with soccer proper. 30

\footnotetext{
25 O'Connell, The Car in British Society, 44, 52, 53, 220.

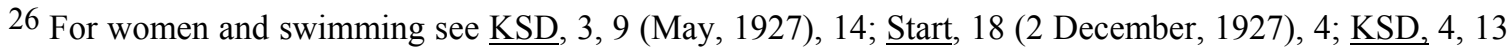
(July, 1928), 18, 19; KSD, 6, 15 (August, 1930), 18, 19; KSD, 8, 10 (May, 1932), 26, 27; KSD, 6, 20 (October, 1930), 20, 21; KSD 10, 3 (February, 1934), 26, 27; PzS, 2, 31, 64 (4 August, 1922), 11; PzS, 2, 29, 62 (21 July, 1922), 5; PzS, 2, 37, 70 (15 September, 1922), 6-8; PzS, 5, 32, 221 (12 August, 1925), 16, 17; PzS, 5, 34, 223 (26 August, 1925), 10, 11; PzS, 7, 27, 320 (9 July, 1927), 1; PzS, 8, 33, 378 (5 August, 1928), 6; PzS, 11, 69, 667 (29 August, 1931), 3; PzS, 13, 70, 871 (2 September, 1933), 3; Bluszcz, 39 (27 September, 1924), 691; Bluszcz, 40 (4 October, 1924), 714; Bluszcz, 12 (20 March, 1926), 365; Bluszcz, 20 (14 May, 1927), 13; Bluszcz, 33 (17 August, 1929), 17; Bluszcz, 35 (29 August, 1931), 12; Bluszcz, 27 (8 July, 1933), 14; Bluszcz, 29 (22 July, 1933), 16; Bluszcz, 30 (29 July, 1933), 14, 15; Bluszcz, 31 (5 August, 1933), 13-15; Bluszcz, 32 (12 August, 1933), 15, 16; Bluszcz, 15 (13 April, 1935), 457; Bluszcz, 1, (1 January, 1939), 16; and Bluszcz, 26 (25 June, 1938), 11/611.

27 On women's sports in England during this time period see Birley, Playing the Game, 204, 205, 208.

28 Langhamer, Women's Leisure in England, 79.

29 AMR, notes. See also Stefan Sieniarski, Sport in Poland (Warsaw, 1972), 111-113.

30 Birley, Playing the Game, 204, 205, 208.
} 
In archery, the Polish press reported the accomplishments of Janina KurkowskaSpychajowa, the Polish 'Mistress of Sports' in this game and the world's best archer. More generally, however, Polish female archers did not excel. ${ }^{31}$ Meanwhile, traditional opinion continued to restrict the development of women's cycling in Poland. ${ }^{32}$ Even in France, there were rarely more than a handful of female members in the French cycling clubs devoted to gentle touring. 33 This pattern of conservatism in women's cycling was in contrast to England where the old controversies over cycling and rational dress had ceased to rage in the interwar period. 34

From the above description of women's sports in interwar Poland, it follows that some sports were considered more appropriate than others for Polish sportswomen. The Polish female athlete was required to conform to the social definition of "suitability" and participate in those sports which were "approved" by the Polish state and society. Still, despite the rigid enforcement of the "proper" moral and ethical patriarchal norms in women's physical culture, Polish female athletes participated in the "acceptable" sports with greater dynamism, enthusiasm and dedication.

Significantly, Polish sportswomen were not alone in casting images of the "new athletic woman". From a comparative perspective, the working and middle class women in America were also abandoning the older model of womanhood based on female weakness, refinement, and propriety in the interwar period. Along with other "New Women" who demanded access to such traditional male realms as business and politics, female athletes of the interwar years claimed the right to share in sport as equals. 35 The sporting accomplishments of Mildred 'Babe' Didrikson best demonstrated that American women could participate in competitive athletics "unharmed". As an "amazon", an athlete, a tomboy, and a hustler, Babe constructed, molded, and amplified her selfidentity. 36 In forcing an acknowledgment of women's physicality, albeit in a limited

\footnotetext{
31 For women in archery see Kobieta Wspolczesna, 4, 45 (9 November, 1930), 18; KSD, 14, 21 (1 November, 1938), 11, 12; PzS , 19, 64, 1529 (10 August, 1939), 1; Moja Przyjaciolka, 3, 16 (25 August, 1936), 321; Moja Przyjaciolka, 4, 1 (10 January, 1937), cover page; Bluszcz, 8 (22 February, 1930), 16; and Bluszcz, 32 (11 August, 1934), 985, 986.

32 See Bluszcz, 30 (22 July, 1939), 18/19-830/831.

33 For French women and sport see Holt, Sport and Society in Modern France, 8, 158, 163, 164, 177.

34 Birley, Playing the Game, 39, 40; and Langhamer, Women's Leisure in England, 78.

35 Cahn, Coming on Strong, 8, 33-35, 42-47, 68.

36 Woolum, Outstanding Women Athletes, 10, 14; and Susan E. Cayleff, Babe: The Life and Legend of Babe Didrikson Zaharias (Urbana, 1995), 25, 81.
} 
way, this first wave of American female athletes challenged male hegemony in sports and laid the groundwork for more fundamental challenges. 37

In Britain, young women dressed in boyish fashions, cut their hair short, smoked cigarettes, drove cars, and generally pursued an active, adventurous lifestyle. 38 They were active participants in a variety of sports which signified a profound change in popular mores governing the position of British women. ${ }^{39}$ In New Zealand, the 'Cult of True Womanhood' had neither the credibility nor relevance for the demands of life in the isolated townships, hamlets, and sheep stations. Although lines of demarcation preventing women from achieving athletic parity with men were visible, there was a 'progressive spirit among some women' in recreational matters. They were the beneficiaries of a different image of the 'new woman'-- one with 'a cool brain, warm heart, courage and strong muscle' 40

In Denmark, young women's enthusiasm for organized sports and exercise reinforced the perception of unprecedented female vigor in the interwar period. To be sure, not all women were athletically inclined; however, many did acquire an interest for physical activities in the 1920s. Confronted with these exuberant young women brimming with energy and health, the medical predictions about the ill-consequences of female physicality failed to be convince the majority. Sports and physical exercise were simply seen as essential activities by young women keen on being "modern". 41

Thus, Polish sportswomen, similar to their counterparts in Britain, America, New Zealand, and Denmark, became more athletic in the interwar period. However, unlike in the other countries, the Polish "new sportswomen" did not conscientiously transgress gender boundaries in sports. Nevertheless, Polish women's more energetic engagement in sports, within the enclosed spaces of female athleticism, fostered the evolution of new social behaviors which positively influenced sportswomen's personal and professional development in the direction of greater physical emancipation than during the period of

37 Cahn, Coming on Strong, 51, 53, 54; and Michael A. Messner, "Sports and Male Domination: The Female Athlete as Contested Ideological Terrain," in Birrell and Cole (eds), Women, Sport, and Culture, 65-80, p. 69.

38 Kent, Gender and Power in Britain, 287.

39 See Birley, Playing the Game, 39, 40, 204, 205, 208; Stephen G. Jones, "Working Class Sport in Manchester Between the Wars," in Richard Holt (ed.), Sport and the Working Class in Modern Britain (Manchester, 1990), 67-83; and Hargreaves, Sport, Power and Culture, 88.

40 Scott Crawford, "Pioneering Women: Recreational and Sporting Opportunities in a Remote Colonial Setting," in Mangan and Park (eds.), From “Fair Sex," 161-181, pp. 166, 176.

41 Birgitte Soland, Becoming Modern: Young Women and the Reconstruction of Womanhood in the 1920s (Princeton and Oxford, 2000), 46-64. 
the partitions. Such momentous changes in women's lifestyles were, unfortunately, quite dependent on the regional variations in Polish women's sports.

\section{Regional Variations in Polish Women's Sports}

Women's participation in sport in interwar Poland was influenced by regional differences in political interests, economic conditions, social attitudes, and religious perceptions. Women's sports were best organized in the capital city of Warsaw. This comes as no surprise since Warsaw served as the national center of Polish sport. The city organized most of the major sports championships, convened the main conferences in sports and physical education, constructed the maximum numbers of athletic facilities, and headquartered several sports associations and clubs. No doubt, the organization of sports in the immediate aftermath of the First World War suffered from the lack of coordinated political and economic policies. The state authorities, faced with the more urgent task of building an independent and united Poland, could devote little attention to the need to reorganize Polish sports. In the absence of state assistance, the numerous private organizations and the sports clubs of the armed forces in Warsaw initiated the process of reconstructing Polish physical culture from its near total stagnation. They were subsequently joined by the Warsaw Club (Warszawianka Klub) formed by secondary school graduates and university students, the Christian youth associations, the workers' sports clubs, and the Jewish sports organizations such as the Jutrznia and Hapoel, the Jewish Academic Sports Associations, and the Polish Division of the Maccabee International Jewish Sports Association. The sports clubs of the workers, usually affiliated with the Socialist Party, functioned under the command of the Warsaw Workers' District Sports Committee (Warszawski Robotniczy Sportowy Komitet Okregowy). Using their own resources, all these private, military, workers, Jewish, Christian, and student sports clubs organized and coordinated sports competitions and tournaments, maintained their own sports facilities and athletic equipment, and even sent members to international competitions when federal or municipal support was unavailable.

After 1927, however, with more state concern in militarizing the sporting apparatus, the athletic facilities and opportunities for both men and women in Warsaw expanded. To be sure, Warsaw did not provide the majority of participants in most sports, and nor did sports teams from Warsaw dominate all championships. Still, the organization of sports in Warsaw exerted a powerful integrating influence over Polish sports in general. They were an important source of entertainment for Varshavians who 
watched or participated in them in substantial numbers that rose steadily throughout the interwar period. More significantly, the organization of sports contributed to the overall "urbanization" of Warsaw in the interwar years. After an inauspicious start, the Warsaw municipal authorities intensified the urban planning process to improve the city's transportation and communications, health and educational facilities, and cultural opportunities. Such issues come into the forefront when countless numbers of people migrated to Warsaw in search of employment and strained the available city resources. The city's dynamic population growth and subsequent socio-economic development suggests a thriving urban community on its way to becoming a modern metropolis. The organization of sports for men and women paralleled these transformations and contributed to the city's urban maturity. 42

In Poznan, women's participation in sports, especially basketball and handball, contributed to the imagery of the town as being quite "sportive". The organs of state, army and local governments, as well as a variety of social groups and sports clubs, organized and promoted sports and recreational activities for men and women. These included units of Sokol, the Scouting Union, the Riflemen's Union, the Military Sports School, the Physical Education Department of Poznan University, the Christian youth associations, and the Posener Turnerbund which resumed its activities among Jewish men and women. However, the city's deeply entrenched Roman Catholicism, and its political affiliation to endecja, adversely impacted the complete maturation of a sporting culture. Also, despite being a wealthy town, Poznan recorded high numbers of unemployed, prostitutes, homeless, and beggars. In this atmosphere of economic deprivation, sports could only attract the patronage of the urban elite who had the financial resources to benefit from the limited sports infrastructure.

However, while sports failed to build social bridges within the city, the male and female physical cultures in Poznan nonetheless facilitated the city's integration with the rest of the country. In most "national" issues of political, economic, social and cultural development, the Poznanians had maintained their exclusivity on the basis on their supposed "superior non-Polish" qualities of punctuality, righteousness, good organization, social discipline, excellent family and national tradition, officiality, professionalism, and experience. Though passionately anti-German, they regarded themselves as the sole bearers of such positive "Prussian" cultural values as industriousness, efficiency, and perseverance in restored Poland. Convinced that they

42 For women's sports in Warsaw see Wynot, Warsaw Between the World Wars, 113, 153, 190, 213, 254, 258, 284-292, 295, 299, 303-305. See also "Sto lat," 53, 54. 
alone worked hard and effectively, these "westerners" came to feel themselves exploited by the southern and eastern Poles, whom they viewed as economic parasites and political schemers. In the midst of these internally divisive forces within the country, the organization of male and female sports provided the various regions of "united" Poland to forge closer networks with each other, and especially with the heretofore "elitist" Poznanian society. 43

In Polish Upper Silesia, women played handball, basketball, volleyball, swimming, field hockey, bridge, skating, bowling, track and field events, and gymnastics. Their sporting interests contrasted sharply with male sports such as football, weightlifting, wrestling, boxing, rifleshooting, chess, horseriding, and fencing. More generally, sports in Silesian towns such as Opole, Mikulczyce, Zabrze, Bytom, and Gliwice received the patronage of town authorities, firemen's organizations, industries, churches, youth associations, paramilitary forces, and political parties. For example, the Union of Silesian Insurgents (Zwiazek Powstancow Slaskich) conducted courses in physical education and military preparedness for the youth, and organized several sports extravaganzas. In the Dabrowa Basin, many sports clubs were organized between 19181939, including the Jewish Gymnastic Sports Society Makkabi. Meanwhile, wealthy patrons, such as Aleksandra Ciszewska, wife of a famous industrialist, arranged a bridge tournament for women in 1933 in Katowice. Furthermore, Sokol nests promoted sports for women, especially gymnastics. Several working class sports clubs also contributed to the development of both male and female physical cultures in the region. The Union of Polish Workers' Sports Clubs (Zwiazek Polskich Robotniczych Klubow Sportowych) engaged the industrial workers in physical recreation. In 1933, there emerged a women's workers sports club in Zabrze led by Emilia Bogacz with 33 members. In the same year, a women's sports club was formed in Mikulczycach. Workers' sport, in general, aimed at improving the physical health, moral development, and military fitness of the working class. The working class sports movement also idealized notions of excellence, harmony, rhythm, honesty, and freedom. For this reason, their 'proletarian' activities often divulged a distaste for "bourgeois" sports, which were portrayed as brutal. Unfortunately, Silesian workers' organizations succumbed to multiple political, economic, and infrastructural problems. Moreover, internecine politics cast a dark shadow over independent working

43 For women's physical culture and the use of sports as an integrative agent in Poznan see Rothschild, East Central Europe between the Two World Wars, 29, 30; Zbigniew Dworecki, Poznan i Poznaniacy w latach drugiej Rzeczypospolitej, 1918-1939 (Poznan, 1994), 466-469, 471, 477, 484, 487, 488; and Ziolkowska, "A Contribution to the History of Jewish Sport," 54-62. 
class activities, including sports. These subterranean feuds resulted in caustic verbal exchanges between the local Polish political factions of multiple ideological variants. 44

In other cities, events in track and field and gymnastics were most popular among women in Torun and Bydgoszcz. Female oarers from Bydgoszcz also competed in domestic regattas. The city, in particular, maintained a high level of physical education in schools. 45 Meanwhile, the Catholic influence in sport was more pronounced in Czestochowa. The Young Women's Christian Organization organized 'rational' courses in physical education for women that emphasized the health and moral benefits of sport. Volleyball remained the favorite sports discipline for this Christian organization in the region. 46 In Kalisz, popular sports disciplines for women included events in track and field and oaring, as well as the not so recommended cycling and football. 47 Krakow boasted of many talented sportswomen, though not in the disciplines of automobilism, cycling and skating. 48 In Bialystok, women's sport emerged with the help of local schools, Sokol units, the Bialystok Sports Club (BKS "Jagiellonia"), and the Jewish Sports Gymnastics Society Makkabi. The region took pride in its few accomplished female athletes, especially in track and field between 1933-1936.49 Finally, in Kielce,

\footnotetext{
44 Rechowicz, "Wychowanie fizyczne i sport na terenie Gornego Slaska i Slaska Cieszyskiego," 73, 81, 84, 80, 87; Tomasz Falecki, "Wychowania fizyczne w dzialalnosci Zwiazku Powstancow Slaskich," in Rechowicz (ed.), Z dziejow kultury fizycznej na Slasku $i$ w Zaglebiu Dabrowskim, 55-63, p.60; Adolf Segner, Polski ruch sportowy na Slasku Opolskim w latach 1922-1939 (Wroclaw, 1966), 37, 48, 49, 53, 74, 75, 79, 80, 85; Ponczek, Geneza i rozwoj kultury fizycznej na Gornym Slasku, 6, 11, 13; Walczak, "Kultura fizyczna w ruchu robotniczym," 37, 38, 42, 43, 44, 45, 49, 50, 51, 52; Henryk Rechowicz, "Wychowanie fizyczne i sport--wazne czynniki ksztaltowania swiadomosci narodowej Gornoslazakow (1922-1939)," in Rechowicz (ed.), Z dziejow kultury fizyczej na Slasku i w Zaglebiu Dabrowskim, 7-20, p. 13-16; Woltmann, Polska kultura fizyczna, 85, 96, 152, 237, 250-254, 258-260, 265, 270, 301; Steuer, Sport na Gornym Slasku, 16, 18, 19, 22, 23 , 25, 27-31, 37, 39, 66, 70, 74; Eleonora Sapia-Drewniak, Aktywnosc kulturalna $i$ oswiatowa kobiet na Slasku Opolskim w latach 1922-1939 (Opole, 1991), 44, 45; and Ponczek, Z przeszlosci ruchu sportowego z Zaglebiu Dabrowskim do 1939 roku, 22, 35, 36, 41, 42, 50, 53, 54. Steuer's book, Sport na Gornym Slasku, provides a detailed description of individual sports in interwar Upper Silesia.

45 Boleslaw Makowski, Krzewienie i popularyzacja kultury fizycznej na Pomorzu od czasow zaborczych do roku 1939 w swietle dzialalnosci organizacji gimnastycznej "Sokol" (Ku czci 1000-lecia Panstwa Polskiego na 100-lecie polskiej gimnastyki 1867-1967, July 1966), 56-60; and Urbanyi, Zarys Historii Sportu Bydgoskiego, 4, 8, 14.

46 Eligiusz Malolepszy, Kultury fizyczna i przysposobienie wojskowe $w$ Czestochowie $i$ w powiecie czestochowskim w latach 1918-1939 (Czestochowa, 1996), 96-104, 139.

47 Elzbieta Fus, Poczatki i rozwoj sportu kobiecego w Kaliszu do 1939 (Praca Magisterska, AWF Warsaw, 1982), 105.

48 Trybowska, Poczatki rozwoju sportu kobiecego w Krakowie do 1939 roku, 293-295.

49 Wiktoria Niedbala, Poczatki i rozwoj kobiecego sportu w Bialymstoku do 1939 (Praca Magisterska, AWF Warsaw, 1983), 59.
} 
the communist-sponsored Sportowki organized popular recreation, dance and music for women. 50

While the accomplishments of Polish female athletes in regional, national, and international sports tournaments have been duly recognized, there is scant reference to their specific contributions in constructing an emigrant female physical culture. No doubt, the Poles living abroad formed a vibrant sports culture. But the achievements of Polish male and female athletes residing in foreign countries have not been analyzed separately in the secondary sources. For example, the 50,000 Poles in Latvia organized their own youth sports clubs. In France, the Poles concentrated on events in track and field, boxing, basketball and cycling. In the United States, track and field and swimming were popular sporting events for the Poles. In Austria and Canada, the Poles adopted swimming, and in Belgium, soccer and cycling. In the free city of Gdansk, the Poles remained multi-talented. Their sports clubs of aeronautics, scouting, sailing, yachting, track and field, and rifleshooting, as well as Sokol nests, indoctrinated members in patriotic and militaristic sentiments. The nationalist spirit was more lively in the physical education programs of Polish 'Motherland Schools' (Macierzy Szkolnej) than in the schools organized by the Gdansk Senate and modeled along German schools. In Czechoslovakia, sports was an important and popular activity of Polish daily life, and they enjoyed playing soccer and volleyball. Many Polish sports associations were organized in Czechoslovakia, including the Polish Association of Sports and Tourism (Polskie Towarzystwo Turystyczno-Sportowe), the Polish Worker's Society of Gymnastic Education (Polskie Stowarzyszenie Robotnicze Oswiatowo-Gimnastyczne "Sila"), the Union of Polish Sports Clubs (Zwiazek Polskich Klubow Sportowych), and the Union of Polish Scouts (Zwiazek Harcestwa Polskiego). The Polish Sokol in Czechoslovakia maintained contacts with its counterparts in Poland. 51

\footnotetext{
50 Renz, "Kobiety i zycie spoleczno-polityczne kielecczyzny, 1918-1939,” 210, 212.

51 For all these details see A. Gasiorowski, "Sport i wychowanie fizyczne w programie I i II zjazdu polakow z zagranicy w 1929 i 1934 r," in Wychowanie Fizyczne i Sport, 23, 1 (1979), 105-117, pp. 113, 117; Andrzej Gasiorowski, "Polski ruch sportowy na terenie Lotwy w latach miedzywojennych," in Kultura Fizyczna, 32/11 (November, 1978), 507-508; Gaj in Gaj and Hadzelek, Dzieje kultury fizycznej, 206, 209, 210; Andrzej Gasiorowski, "Z dziejow sportu polskiego w Czechoslowacji," in Kultura Fizyczna, 31, 8 (August, 1977), 375-376; B. Woltmann, "Polski Zwiazek Pilki Noznej we Francji 1914-1939," in Wychowanie Fizyczne i Sport, 4 (1989), 103-114; Jerzy Gaj, "Wychowanie fizyczne i sport na ziemi Gdanskiej przed i po I wojnie swiatowej," in Sport na progu Polski niepodleglej, 109-130, p.118; and Kazimierz Kubik, "Wychowanie fizyczne w Polskich organizacjach sportowych na terenie w.m. Gdanska, 1920-1939," in Kultura fizyczna ludnosci rodzimej na bylym pograniczu niemieckim $i w$ wolnym miescie Gdansku, do 1939 roku (Gdansk, 1975), 124-150, pp.124, 125, 140, 141, 146, 147. On a general description of Polish physical culture abroad see several articles in the following publications: I Krajowa konferencja naukowa Polonijna kultura fizyczna Lubniewice, 16-17 grudnia 1978r (Poznan, 1980); II Krajowa konferencja naukowa Polonijna kultura fizyczna, rogi, 25-26 Pazdziernika 1982r (Poznan, 1986);
} 
Meanwhile, the sporting activities of the Poles who lived in Germany and along its eastern borders such as Pomerania, East Prussia, Silesia, Wroclaw, Gorzow, Pila, and Szczecin gives us more insights into the organization of Polish physical culture (male and female) during the interwar period. By virtue of the Treaty of Versailles that concluded the First World War and the resulting decision to hold plebiscites, nearly 1,200,000 Poles remained within the borders of the German state. For this Polish minority, besieged by economic and material scarcities, only local intellectual and cultural resources helped to sustain the spirit of national consciousness and a state of independent social existence. Led by its central organization, the Union of Poles in Germany, the Polish minority struggled to maintain its identity in various spheres of social, intellectual, and cultural work, including music, theater, sports, and tourism. Indeed, physical education was recognized as one of the most basic ingredients in the national education of the Polish youth in the German lands. Among the various sports which contributed to the building of Polish nationalism in Germany, football remained the most popular game among Polish men, while the Church approved volleyball as an "appropriate" sport for women. 52

All the various sports and non-sports Polish organizations in Germany and on its borders struggled against the socio-cultural pressures of germanization, promoted ideas of improving society's health, physical strength and hygiene, emphasized the need to prepare for self-defense, and fostered a spirit of patriotism and national consciousness, especially among the youth. It is significant that all statutes of their youth organizations were composed in Polish. Even the language of instruction was Polish. Further, the patriotic names of sports clubs such as Polonia, Poniatowski, Mickiewicz, Piast, and Kosciuszko provided added significance to the nationalist cause of these sports associations. The financial burden for the maintenance of these organizations was borne mainly by departments of the Polish Foreign Office and the War Ministry, as well as by the voivodeship and district councils of the borderland regions in Poland. Some limited economic support was also forthcoming from the World Union of Poles (Swiatowy Zwiazek Polakow), Union of Western Poles (Polski Zwiazek Zachodni), PUWFiPW, and other committees abroad to help Poles.

III Krajowa konferencja naukowa Polonijna kultura fizyczna (Poznan, 1987); and IV Krajowa konferencja naukowa Polonijna kultura fizyczna (Poznan, 1990).

52 Bernard Woltmann, Polska kultura fizyczna na Wschodnim Pograniczu Niemieckim, 1919-1939 (Poznan, 1980), 7, 37, 43, 48, 207, 228-230, 240, 524-526; Rechowicz, "Wychowanie fizyczne i sport-wazne czynniki," 7; B. Woltmann, "Z dziejow polskiego ruchu sportowego w III Rzeszy," in Wychowania Fizyczne i Sport, 23, 1, (1979), 97-103, p.101; and Segner, Polski ruch sportowy na Slasku Opolskim, 23, 24. 
A variety of youth, peasant, and workers' organizations helped to provide a structure to the physical culture movement among the Polish minority in Germany. Some of these associations included the Young Poles in Germany, Poles from Malopolska in Germany, the Union of Polish School Societies in Germany (Zwiazek Polskich Towarzystw Szkolnych, ZPTSwN, Berlin), the Union of Poles (Zwiazek Polakow), the Union of Polish Scouts (Zwiazek Harcerstwa Polskiego), and the Union of Polish Sports Clubs (Zwiazek Polskich Klubow Sportowych "Sila"). The sports activities of the Polish workers in Germany, however, blossomed only in the years between 1933-38. Prior to this period, young Polish workers generally belonged to German organizations. But with the signing of the German-Polish non-aggression pact in January 1934, they established their own sporting organizations. The workers sports movement also attracted some interest in rural surroundings. It is interesting that women's participation in the Polish sports clubs also registered an increase during this time period of 1933-1936 in Germany.

Meanwhile, the Polish press paid special attention to sport and tourism, and served as an important source of inspiration in the founding of new Polish organizations

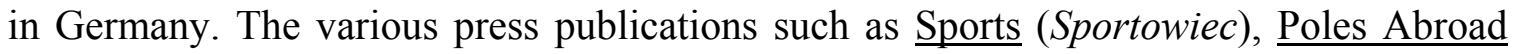
(Polacy Zagranice), Life of Youth (Zycie Mlodziezy), Spring (Zdroj), and Young Poles in Germany (Mlody Polak w Niemczech) contributed to the making of this Polish male and female physical culture in Germany. 53

No doubt, the male and female Polish sports movement in the German lands was important for maintaining a Polish national identity, for resisting pressures of germanization, and for enhancing solidarity among Poles in a hostile environment. Unfortunately, the various organizations that promoted physical culture for the Poles in Germany faced many obstacles which impeded the accomplishment of their nationalist objectives. Clearly, their task was not easy. The German administration, police, and other social and political organizations knitted a matrix of surveillance, terror and merciless persecutions, more so after 1938 and in the first months of 1939. Many Polish teachers, youth activists, and scouts suspected of arousing a nationalist fervor were arrested. While German vigilantism and material shortages deserves a good part of the blame for

53 For all these issues see Rechowicz, "Wychowanie fizyczne i sport--wazne czynniki," 9, 10; Woltmann, "Z dziejow polskiego ruchu sportowego w III Rzeszy," 101; Segner, Polski ruch sportowy na Slasku Opolskim, 26, 27, 28, 79, 86-88; Woltmann, Polska kultura fizyczna, 59, 60, 64, 66-70, 76, 78, 79, 81, 83, 91, 118, 220, 221, 246, 248, 277, 361, 363, 364, 366, 526, 527; Gasiorowski, "Sport i wychowanie fizyczne," 105, 107, 108, 110, 112, 113; L. Nowak, "Problematyka kultury fizycnej na lamach czasopisma “"Mlody Polak' w Niemczech w latach 1930-1939," in Wychowania Fizyczne i Sport, 24, 4, (1977), 6772; and Bernard Woltmann, "Wychowanie fizyczne i sport wsrod ludnosci Polskiej na Babimojszczyznie, Krajnie Zlotowskie i Zachodnich Kaszubach 1918-1939," in Sport na progu Polski niepodleglej, 142-155, pp.142, 144, 147, 149. 
the weaknesses of Polish physical culture in these regions, the various sports organizations and circles themselves cannot be absolved of guilt. Their failure to create a single sports organization for greater unity and cohesiveness left the dispersed associations and unions rudderless. Despite several attempts by the Legation of the Polish Republic in Berlin, as well as by the Union of Poles in Germany and the Association of Polish Sports Clubs "Sila," the inherent immaturity and inexperience in organizational statecraft transferred the functional arrangements of sports activities to regional leaders of youth associations who succeeded neither to incorporate workers sports clubs nor gain a full cooperation from the other more sophisticated organizations such as Sokol and the scouting union. Thus, their amateurism, compounded with the souring of Polish-German relations on the eve of the war, restrained their physical culture to a level of unprofessional adolescence. Even the weakened nationalist rhetoric of Sokol in the 1930 s substantially reduced its popularity among the youth.

Meanwhile, the Union of Poles (Zwiazek Polakow) displayed deep reluctance to reconcile itself with the more proletarian Main Committee of Physical Education (Komitet Glowny Wychowania Fizycznego) established in November, 1938 in East Prussia and in Zabrze (KGWFwN). Instead, the Union of Poles in Germany established its own games committee of physical education on 9th December 1938. Such mutual distrust and hostility, evident in the interpersonal relations between sports-related organizations, was visible in other Polish political factions in the region as well. For example, the Union of Poles in Germany accused the KPD for being too "utopian" and the Polish Socialist Organization in Germany (PPSwN) for being excessively "unPolish". The Christian youth organizations, such as the Union of Polish Catholic Youth (Zwiazek Polsko-Katolickiej Mlodziezy, ZPKM), alone aimed at the "harmonious development of all in spirits of Catholicism and Polishness". Eventually, from 1938 onward, all Polish organizations which promoted sports for men and women in Germany succumbed to the proximate political turmoil that initially forced them to limit their independent work, and finally resulted in their dissolution a week after the outbreak of the WW II. 54

While the combined pressures of organizational immaturity and German opposition frustrated the nationalistic and sporting accomplishments of the Polish male and female physical culture in the German lands, the evolution of a German sports movement in western Poland was even more restricted by comparison. The German

\footnotetext{
54 See for details Woltmann, Polska kultura fizyczna, 66, 79, 231, , 272, 273, 276, 360, 362, 364, 371, 372, 526-530; and Segner, Polski ruch sportowy na Slasku Opolskim, 85, 87, 88.
} 
minority in Poland organized their own sports activities and clubs during the early postwar years. In the later 1920s, however, the exigent external circumstances caused by the rise of Hitler resulted in efforts to integrate this incipient German sports movement in Poland under the patronage of the anti-Polish irredentist ambitions and activities of the NSDAP. Subsequently, an array of official restrictions and petty decrees imposed by the Polish government stunted the efflorescence of organized German cultural life in Poznania and Pomorze. Continued efforts to enforce the status of Polish as the only acceptable language, as well as other economic and cultural barriers, testified to the Polish government's unwillingness to recognize the German presence in the western provinces as something natural and permanent. The increasingly repressive political atmosphere of the 1930s adversely impacted the German physical culture movement. In 1930, a number of leaders and members of the German Scout Movement in Poland were arrested for traveling illegally to Germany and participating in 'paramilitary' exercises. Subsequently, several scouting organizations were disbanded for engaging in 'military' activities and for carrying weapons (the scouts' knives). The minority German youth were especially targeted, for they were most attracted to the new ideas emanating from the German Reich. 55

Thus Polish women's physical culture was much better organized in the larger cities and towns within the country, and in the Polish emigrant cultures of the west. Polish female athletes in the rural areas and along the country's border with Germany faced more political and economic difficulties in participating in sports. However, those women who did seize the opportunities available to become accomplished athletes were well-received in popular opinion and glorified in the national and regional press coverage.

\section{Public Opinion and Press Imagery of Polish Sportswomen in Interwar Poland}

In interwar Poland, the sports newspapers and women's periodicals played a critical role in popularizing women's physical culture. The numerous sports magazines, regional newspapers, and periodicals of this time period contain a wealth of information on the organization of sports and the accomplishments of male and female athletes. Some of the more popular press publications which discussed the achievements of Polish

55 Richard Blanke, Orphans of Versailles: The Germans in Western Poland 1918-1939 (Lexington, Kentucky, 1993), 9, 75, 100, 198; and Gaj in Gaj and Hadzelek, Dzieje kultury fizycznej, 201, 202, 205. 
sports included Gymnastics Review "Sokol" (Przewodnik Gimnastyczny "Sokol"), Poznan Express (Kurier Poznanski), Sports Review (Przeglad Sportowy), Worker (Robotnik), Young Friends (Przyjaciel Mlodych), Physical Education in School (Wychowanie Fizyczne w Szkole), and Young Mother (Mloda Matka). The women's sport periodical, Start (1927), discussed the organization of physical education for women, as well as the participation of female athletes in various sports at both the national and international levels. Under the editorship of Kazimiera Muszalowna, Start served as an important source of inspiration for women to participate in sports and projected images of their physical emancipation through the medium of physical culture. 56

In addition to reporting women's results in sports competitions, the readers of the popular women's magazines were also aware of developments in women's sport in other western countries. For example, the periodicals reported on foreign female aviators, English women playing lacrosse, a women's football match between Belgium and France, and the achievements of the French and American female tennis players. Meanwhile, the press provided information on the international conferences related to women's sport, and also published reports of dissension within the medical community in England over women's participation in soccer. 57

Further, the discussions on the physical aspects of women's sport in the women's periodicals and popular sports newspapers were paralleled by the publication of many articles and advertisements on the contemporary trends in women's sportswear fashion. This reportage especially included costumes for women's winter sports, tennis and

\footnotetext{
56 Kobieta Wspolczesna, 3, 12 (24 March, 1929), 19; Biuletym Informacyjny Glownego Komitetu Kultury Fizycznej $i$ Turystyki (Nr.10-12, Warsaw, 1975), 7; Krawczyk, "Rola Spoleczna," 303; Rotkiewicz, "Rozwoj sportu kobiet w Polsce," 20; AMR, notes; Warsicki, Kultura fizyczna, 57, 59, 61, 62; Liponski, "Still and Unknown," 19; "The European Sports Newspapers: Przeglad Sportowy," in Sport Europe, 7, 29 (July, 1996), 35; and Laskiewicz, Robotnicza kultura fizyczna, 108, 109. There are many references and illustrations of women in sports in Przeglad Sportowy. Prior to 1927, this newspaper was published at the soccer club 'Cracovia' in Krakow. In 1927, its publication shifted to Warsaw. It is interesting that in the same year, this sports review underwent a change in form and size, i.e. the newspaper became much longer in length and breadth of coverage.

57 For coverage on a women's football match between Belgium and France see Moja Przyjaciolka, 2, 7 (10 April, 1935), 98; for female aviators abroad, see Bluszcz, 11 (15 March, 1924), 131; Bluszcz, 5 (31 January, 1931), 15; and Bluszcz, 18 (3 May, 1924), 265; for female tennis players see Bluszcz, 31 (2 August, 1924), 528; for women in sport in England see Bluszcz, 10 (17 December, 1921), 6; and Bluszcz, 2 ( 7 January, 1922), 18; for women's physical education in Finland see Bluszcz, 9 (27 February, 1926), 269; for French women playing field hockey see Start, 9, 9-10, 1-2 (May 1935), 18; and for women's sports abroad in general see Bluszcz, 22 (30 May, 1931), 13. For the International Sports Federation of Women, and the Women's World Games (1926, 1930, 1934), see Rotkiewicz, "Rozwoj sportu kobiet w Polsce," 35 .
} 
golf.58 More generally, it appears that the interwar popular press had no reservations about reporting Polish women's participation in domestic and international sports competitions. The only problem was that women's sport, in comparison to men's sport, was itself limited which affected the extent of its coverage.

While the literature on Polish sportswomen may not have been extensive in quantitative terms, the quality of this limited reportage was characterized by exceptional praise of the female champions. The interwar press provided excellent coverage of the accomplishments of the few Polish female athletes who won accolades in the international area. The famous 'sportsmenki' such as Halina Konopacka (track and field), Zofia Nehringowa (skating), Stanislawa Walasiewiczowna (track and field), Jadwiga Jedrzejowska (tennis), and Jadwiga Wajsowna (discus) were well received by the press, both in the women's periodicals and in the sports newspapers. For example, articles with titles such as Brawo nasze panie ("Bravo Our Women") were common. The press, in particular, extolled Halina Konopacka's enthusiasm, excellence, persistence, dedication, ambition, and goodnature. Apart from these qualities, the press also commented on her participation in the various women's organizations and societies for social work. Konopacka's Olympic gold medal performance in Amsterdam in 1928 earned her a good deal of publicity abroad, not to mention the honor for Poland and its leaders, Pilsudksi and President Ignacy Moscicki. Further, Stanislawa Walasiewiczowna not only received excellent domestic coverage, but was also voted one of the best sports athletes in a poll in the United States. Indeed, Polish sportswomen competed for the highest national and international honors in sports, and the most talented among them were awarded state honors and titles. For example, the prestigious Panstwowa Nagroda Sportowa (State Sports Award) was awarded to Halina Konopacka in the years 1927 and 1928, to Stanislawa Walasiewiczowna in 1932 and 1933, to Jadwiga Waysowna in 1934 and 1936, and to Jadwiga Jedrzejowska in 1937.59

58 For women's sporting fashion see KSD, 3, 1 (January, 1927), 1; KSD, 4, 14 (July, 1928), 1; KSD, 10, 20 (October, 1934), 17; Moja Przyjaciolka, 4, 10 (25 May, 1937), 229; Moja Przyjaciolka, 4, 24 (25 December, 1937), 592; Bluszcz, 22 (28 May, 1927), 17; and Bluszcz, 31 (31 July, 1937).

59 There was a good deal of celebratory coverage in the press on the accomplishments of individual female athletes such as Konopacka, Walasiewiczowna, and Wajsowna. For details on them see Bluszcz, 32 (11 August, 1934), 995; Bluszcz, 38 (20 September, 1930), 10, 11; PzS, 7, 29, 322 (23 July, 1927), 1; PzS, 12 , 52, 749 ( 29 June, 1932), 2; PzS , 8, 33, 378 (5 August, 1928), 1; PzS, 8, 50, 395 (10 November, 1928), 1; PzS, 8, 6, 351 (11 February, 1928), 3; Bluszcz, 2 (11 January, 1936), 10/34; Bluszcz, 32 (6 August, 1938), 20/764; Bluszcz, 34 (20 August, 1938), 17/809; PzS, 5, 26, 215 (1 July, 1925), 19; PzS, 5, 28, 217 (15 July, 1925), 11; PzS, 6, 23, 264 (10 June, 1926), cover picture; KSD, 4, 15 (August, 1928), 19; KSD, 6, 19 (October, 1930), 17-19; KSD, 14, 5 (1 March, 1938), 29, 30; $\underline{\text { PzS }, ~ 11, ~ 17, ~} 610$ (28 February, 1931), 2; PzS, 14, 9, 913 (31 January, 1934), 3; PzS, 14, 8 (27 January, 1934), 4; PzS, 18, 14, 1374 (17 February, 1938), 6; $\underline{\text { PzS }}, 18,80,1440$ (3 October, 1938), 3; $\underline{\text { PzS }}, 81,1441$ (6 October, 1938), 1; $\underline{\text { PzS }, ~ 18, ~ 83, ~} 1443$ (13 October, 1938), 4; $\underline{\mathrm{PzS}}, 18,91,1451$ (10 November, 1938), 4; Moja Przyjaciolka, 2, 11 (10 June, 1935), 
Meanwhile, the results of the popular annual plebiscites (see table) organized by the leading Polish sports magazine Przeglad Sportowy to vote for the top ten outstanding sportsmen or sportswomen of the year is suggestive of a popular social opinion that made no gender differentiation in awarding the nation's highest honors to female athletes. In eight of these fourteen years, women were voted Poland's top athlete!

162; Bluszcz, 33 (11 August, 1928), 12; Bluszcz, 29 (16 July, 1932), 13; Bluszcz, 6 (6 February, 1937), 14/134; Bluszcz, 36 (4 September, 1937), 15/871; Bluszcz, 45 (6 November, 1937), 13/1061; Bluszcz, 32 (8 August, 1936), 12-13/740-741; PzS, 8 (1928), 6; Sport Polski, 1, 12 (17 November, 1937), 11; Reczek, The Development of Physical Culture in Poland, 12, 13; Grot, "Versuch eines abrisses," 308, 309; and M. Petruczenko, "70 Years of Polish Sport: Memories from the Sports Paper Przeglad Sportowy," in Olympic Review, 291 (January, 1992), International Olympic Committee, Lausanne, Switzerland, 44-49, pp.45, 46. For Stanislawa Walasiewiczowna's nomination as one of the best sportspersons in a US poll see Bluszcz, 9 (26 February, 1938), 13/205. For honors, see $\underline{\mathrm{PzS}}$, 18, 14, 1374 (17 February, 1938), 6; Bluszcz, 15 (13 April, 1935), 463; Bluszcz, 21 (25 May, 1935), 650, 651; Bluszcz, 51-52 (19-26 December, 1936), 24/1204; Bluszcz, 5 (29 January, 1938), 13/109; and Bluszcz, 9 (26 February, 1938), 13/205. On another sport's personality, Janina Maria Mieczynska-Lewakowska, see "Slownik," in Wychowania Fizyczne i Sport, (1982), 98, 99. For a good summary of Halina Konopacka's life and sporting accomplishments, see Halina Konopacka: Wznosilam swiat miloscia (Spolka Wydawnicza Heliodor, Lomianki, 1994). 


\section{Results of Popular Plebiscites Conducted by Przeglad Sportowy 60}

\begin{tabular}{|c|c|c|c|}
\hline Year & Name & Event & Position \\
\hline 1926 & Halina Konopacka & Track and Field & 2 \\
\hline \multirow[t]{2}{*}{1927} & Halina Konopacka & Track and Field & 1 \\
\hline & Janina Loleczkowa & Tennis, Skiing & 7 \\
\hline \multirow[t]{2}{*}{1928} & Halina Konopacka & Track and Field & 1 \\
\hline & Halina Polankowa & Skiing & 9 \\
\hline \multirow[t]{2}{*}{1929} & Stanislawa & Track and Field & 3 \\
\hline & Walasiewiczowna & & \\
\hline \multirow[t]{5}{*}{1930} & Stanislawa & Track and Field & 1 \\
\hline & Walasiewiczowna & & \\
\hline & Halina Konopacka & Track and Field & 5 \\
\hline & Jadwiga & Tennis & 6 \\
\hline & Jedrzejowska & & \\
\hline \multirow[t]{5}{*}{1931} & Jadwiga & Tennis & 3 \\
\hline & Jedrzejowska & & \\
\hline & Jolanta & Track and Field & 6 \\
\hline & Manteuflowna & & \\
\hline & Halina Konopacka & Track and Field & 7 \\
\hline \multirow[t]{6}{*}{1932} & Stanislawa & Track and Field & 1 \\
\hline & Walasiewiczowna & & \\
\hline & Jadwiga Waysowna & Track and Field & 3 \\
\hline & Jadwiga & Tennis & 7 \\
\hline & Jedrzejowska & & \\
\hline & Zofia Nehringowa & Skating & 10 \\
\hline \multirow[t]{5}{*}{1933} & Stanislawa & Track and Field & 1 \\
\hline & Walasiewiczowna & & \\
\hline & Jadwiga Waysowna & Track and Field & 2 \\
\hline & Jadwiga & Tennis & 5 \\
\hline & Jedrzejowska & & \\
\hline 1934 & Stanislawa & Track and Field & 1 \\
\hline
\end{tabular}

60 The results of the plebiscite for each year were declared toward the beginning of the following new year in this sports newspaper. 


\begin{tabular}{|c|c|c|c|}
\hline & Walasiewiczowna & & \\
\hline & Jadwiga Waysowna & Track and Field & 2 \\
\hline 1935 & Stanislawa & Track and Field & 3 \\
\hline & Walasiewiczowna & & \\
\hline & Jadwiga & Tennis & 5 \\
\hline & Jedrzejowska & & \\
\hline 1936 & Jadwiga & Tennis & 1 \\
\hline & Jedrzejowska & & \\
\hline & Jadwiga Waysowna & Track and Field & 4 \\
\hline & Stanislawa & Track and Field & 6 \\
\hline & Walasiewiczowna & & \\
\hline & Maria Kwasniewska & Track and Field & 9 \\
\hline 1937 & Jadwiga & Tennis & 1 \\
\hline & Jedrzejowska & & \\
\hline & Stanislawa & Track and Field & 3 \\
\hline & Walasiewiczowna & & \\
\hline 1938 & Stanislawa & Track and Field & 3 \\
\hline & Walasiewiczowna & & \\
\hline & Jadwiga & Tennis & 4 \\
\hline & Jedrzejowska & & \\
\hline 1939 & No Plebiscite & & \\
\hline
\end{tabular}


While popular opinion celebrated the successes of female sports champions, the press frequently displayed the professional images of Polish sportswomen alongside those of their domestic responsibilities within families. Female athletes were portrayed as good mothers and wives, and the newspapers and periodicals often showed pictures of sportswomen with their children. For example, Stanislawa Walasiewiczowna was reported to be a good housewife and an excellent cook. 61 Many female athletes were married, and some were mothers of two or more children. Some sportswomen married their collegeaues, while a few others took pride in their "sportive" fathers. This was in contrast to Nazi Germany which frowned upon marriages between its male and female elite athletes. ${ }^{62}$ Moreover, female sports champions were not only projected to have successfully balanced their training regimen with family obligations, but also continued their professional service as sports teachers, pedagogues, trainers, and journalists in their post-athletic careers.

Many female "sports-activists" were committed to struggling for more opportunities for women, not only in the realm of physical education and sports, but also in spheres of higher education, military training, and economic development. However, while the majority of such "sports-feminists" served in several "small" educational, cultural, and social institutions and organizations, few became members of "elite" sports organizations. For example, very few female athletes joined the membership ranks of the Polish Olympic Committee and the PUWFiPW.

Moreover, the impact of "sports-feminism" was geographically contained within the larger cities. Generally, Polish women's sport encompassed urban and rural areas. More specifically, however, female athletes came mainly from families of the intelligentsia, less so from workers families, and least from families of peasant background. This membership pattern was in contrast to the male athletes who mostly came from peasant and workers' backgrounds, and least of all from the intelligentsia. 63

61 See Bluszcz, 32 (7 August, 1937), 12/728, 13/729. For a picture of ice skater Zofia Nehringowa with her two children see PzS, 18, 1, 1361 (3 January, 1938), 1.

62 Marriages between male and female elite sports athletes were rare in Nazi Germany. See McFee and Tomlinson, "Riefenstahl's Olympia: Ideology and Aesthetics in the Shaping of the Aryan Athletic Body," 74.

63 For these issues see AMR, notes. See especially the available biographies of female athletes in AMR, as well as in the bibliographic portraits of Polish sportswomen in Anna Pawlak, Polskie olimpijki z lat 19241994: Miniatury czyli filigranowe portrety wielkich dam polskiego sportu (Warsaw, 1995), 17, 34, 37, 38, $42,44,48,54,57,66,67,78,83$. Most of the biographies in AMR were written as seminar papers by students at AWF, Warsaw. See also Wychowanie Fizyczne i Sport, 3 (1996), 119-121; Feliks Fidzinski, "Jadwiga Mayowna. Zycie i dzialalnosc na polu wychowania fizycznego," in Wyzsza Szkola Wychowania Fizycznego w Krakowie, 51-74, p.74; Krawczyk, "Rola Spoleczna," 315; and Szymanski, Kultura fizyczna, 35. 
This "elitism" in women's physical culture was fostered by the persistent conservative social climate which limited women's access to both money and leisure time required for participation in sports.

\section{The “New Polish Sportswoman": “Manly", “Crazy”, and "Barbaric”}

The development of women's physical culture in the interwar years was certainly more sophisticated and dynamic than the organization of women's sports in partitioned Poland. In interwar Poland, several women's sports associations, along with a host of political, civil, military, and medical institutions promoted physical culture for women. The increased variety of sports deemed "appropriate" for women, as well as the sport successes of female champions at the national and international levels, strengthened the Polish women's movement and further legitimized its demands for women's physical and personal liberation in the interwar period. 64 Unfortunately, this impressive growth in women's sports in the Second Polish Republic was beset with numerous problems that stunted its further maturation. The organization of women's physical culture was constrained by limited finances, persistence of social patriarchy, lack of women's solidarity, and class and ethnic issues which undermined the achievements of women in sport.

For one, the organization of women's physical culture in the sports clubs, associations, and institutes of academic learning was plagued by material, instructional, institutional, and infrastructural shortages. Women trainers were few, investment opportunities were limited, and the multiple contradictory bureaucratic interventions caused irreparable structural damage to women's physical culture. 65 There were voices of concern for the declining level of women's sports when champions were not reproduced, for the limited number of instructional courses in physical education available to women, for the need to construct facilities for women to practice sports, and for the relatively low number of sports circles for women in schools and universities. 66 The scarcity of financial and infrastructural resources adversely affected the

$64 \underline{\text { KSD, }} 4,15$ (August, 1928), 18; Bluszcz, 12 (21 March, 1925), 275; Rotkiewicz, "Rozwoj sportu kobiet w Polsce," 19, 20; and Laskiewicz, Robotnicza kultura fizyczna, 23, 146.

65 Kobieta Wspolczesna, 1, 30 (23 October, 1927), 3; Sport Polski, 1, 8 (20 October, 1937), 3; KSD, 4, 15 (August, 1928), 18; Bluszcz, 12 (21 March, 1925), 275; Bluszcz, 51 (15 December, 1928), 11; PzS, 14, 85, 989 (24 October, 1934 ), 5; $\underline{\text { PzS }}, 18,91,1451$ (10 November, 1938), 2; and PzS, 8, 13, 358 (31 March, 1928), 4.

66 Sport Polski, 1, 4 (22 September, 1937), 12, 13; Sport Polski, 2, 30 (27 July, 1938), 6; Bluszcz, 48 (1 December, 1923), 477; Bluszcz, 19 (9 May, 1925), 483, 484; and Bluszcz, 13 (28 March, 1925), 298, 299. 
popularization of most sports for women. For example, in women's skiing, the majority of female athletes came from Krakow, mainly because women in Warsaw lacked the necessary support from their sports clubs to participate in far away Zakopane. The absence of women skiers from Lwow, meanwhile, was criticized as 'inexplicable'.67

The persistence of conservative tradition further restricted the development of women's physical culture in interwar Poland. Sports for women were still frequently perceived as unethical, harmful, brutal, barbaric, 'manly,' and wasteful. 68 Even in other countries, the patriarchal definitions of femininity which stressed women's passivity and dependence were much slower to change. In Canada, strain, sweat, dirt and improper clothing were simply incompatible with the traditional view of femininity. 69 Women's participation in the English "national" sports such as football and cricket was restricted. 70 Their participation in acrobatics, boxing, weight-lifting, and wrestling remained marginalized as well. ${ }^{71}$ In France, the postwar angst about low births revitalized aversion to women in competitive sports. ${ }^{72}$ In the Soviet Union, there was some confusion over what constituted an "appropriate" sports outfit for women. Swim suits may not have been an acceptable attire, but shorts apparently were when women were taking part in sporting activities. ${ }^{73}$ In interwar America, short hairstyles, and streamlined swimsuits and track shorts were widely considered indecent for women. ${ }^{74}$

In the male-dominated host sports organizations in Poland, women were often treated as "subordinate" members or as "guests" without opportunities to participate in sports life. 75 Even British women were accorded an inferior status in the cricket clubs. ${ }^{76}$ In France, in order to preserve the nation's femininity and natality, the various

${ }^{67}$ Bluszcz, 42 (20 October, 1923), 405.

$68 \underline{\mathrm{KSD}}, 3,12$ (June, 1927), 12; Bluszcz, 7 (14 February, 1925), 154, 155; Bluszcz, 3 (17 January, 1925), 59; $\underline{\text { Start }}, 18,2$ (December, 1927), 4; and Sport Polski, 1, 8 (20 October, 1937), 3.

69 Helen Lenskyj, "Physical Activity for Canadian Women 1890-1930: Media Views," in Mangan and Park, From "Fair Sex", 208-234.

70 Langhamer, Women's Leisure in England, 82.

71 Hargreaves, Sporting Females, 144.

72 For women's sports in interwar France see Stewart, For Health and Beauty, 166, 167, 172; and Holt, Sport and Society in Modern France, 8, 158, 163, 164, 177.

73 Attwood, Creating the New Soviet Woman, 70.

74 Doris H. Pieroth, Their Day in the Sun: Women of the 1932 Olympics (Seattle, 1996), xi.

75 Bluszcz, 12 (21 March, 1925), 274; and PzS, 10, 503 (15 February, 1930), 4.

76 Jack Williams, "Recreational Cricket in the Bolton Area Between the Wars," in Holt (ed.), Sport and the Working Class in Modern Britain, 101-120. 
sporting clubs were reserved for men. Occasionally, wives or girlfriends were invited to ladies' nights. 77

The propagandists of women's physical culture in Poland were careful to place more weight on the esthetic femininity and attractiveness of female athletes amidst derisive images of strong and 'crazy' sportswomen. Their cardinal aim was to project an image of "moderation" in women's sport. 78 Many physical education teachers in Europe and America, both male and female, also believed that rigorous training and competition "damaged" women.79 They clung to conservative notions of sexual difference and female vulnerability because such concepts helped to establish their professional legitimacy. 80

Family obligations also constrained many Polish women from participating in sports training camps organized in the interwar period. 81 Although the state supported the idea of women's equality in political, educational and economic spheres in theory, reality was quite different. The state and the society remained co-joined in patriarchy, and lacked the resources, motivation, and determination to ease women's double burden. As a consequence, women were still expected to fulfill their domestic responsibilities in both the old and new patterns of household management. 82

Certainly, the more 'modern' images of the 'New Polish Woman' were explicit in the various print media; however, women in interwar Poland generally lacked a real sense of participation in the political, economic, social and cultural lifestyles of their liberated nation. The emancipation of women in interwar Poland was in practice limited only to the privileged class. For ordinary women, the basic view of Polish women as primarily good wives and mothers was not altered, and the fulfillment of these roles, consistently termed a woman's "mission", was understood and propagated as their obligatory duty to the nation. Indeed, the association of women with domesticity did not wane throughout the interwar period, and the traditional image of the national and Catholic self-sacrificing

\footnotetext{
77 For women's sports in interwar France see Stewart, For Health and Beauty, 166, 167, 172; and Holt, Sport and Society in Modern France, 8, 158, 163, 164, 177.

78 Bluszcz, 20 (15 May, 1937), 11/427; and Krawczyk, "Rola Spoleczna," 300-308.

79 Pieroth, Their Day in the Sun, xi.

80 See Guttmann, Women's Sports, 154, 155; Hargreaves, Sporting Females, 144; Nelson, "Introduction: Who We Might Become," xiv; Cahn, Coming on Strong, 68.

81 PzS, 14, 22, 926 (17 March, 1934 ), 6.

82 For new and more 'esthetic' patterns of household management see Anna Sieradzka, "Rola kobiet w ksztaltowaniu estetyki dnia powszedniego: Nowe wzorce urzadzania wnetrz mieszkalnych w dwudziestoleciu miedzywojennym," in Zarnowska and Szwarz (eds.), Kobieta i kultura zycia codziennego, 265-278.
} 
matka-polka remained the implicit ideal by which women's role in the nation was valued and judged. 83

From a comparative perspective, the much vaunted liberation of American and British women in the 1920s was wildly overestimated. 84 Even in the Soviet Union, while female athletes conditioned their physical culture to build on the national rhetoric of 'love for the motherland', urbanization and modernization, and loyalty to the Soviet state, the male definitions of sport were omnipresent, and women's participation in "heroic" endeavors were limited and controlled by men. Soviet sports created a female image of the "motherland" but retained a masculine vision of its citizens. 85 Similarly, in semi-colonial China, despite support for an anti-foot binding campaign, and acceptance of women in physical and health education, women were dissuaded from appearing in public to show off either their athletic ability or their physical form. To be sure, physical fitness remained an important part of the interwar nationalist, communist, and feminist Chinese movements. This was necessitated by the requirements of national survival in the face of considerable internal and external threats. But Chinese female athletes became symbols of full physical liberation only with the founding of the People's Republic of China in 1949, and under the Chairmanship of an equally 'athletic' Mao Zedong. 86

In response to this perceived inharmonious juxtaposition of women's "femininity" and "athleticism" in popular consciousness, the press reports in interwar Poland simultaneously celebrated the achievements of elite female champions on the one hand and, at the same time, published the viewpoints of the opponents of women's sports who advocated stronger injunctions against building women's physical culture in the interwar period. For example, the press informed its readers about the publication of Professor A.W. Niemilov's book, "The Biological Tragedy of Women". 87 Some of the harsher critics of women's sports, especially for women's cycling and football, targeted their caustic remarks toward French female athletes who increasingly made their presence visible in these sports, often with the support of their male colleagues. According to

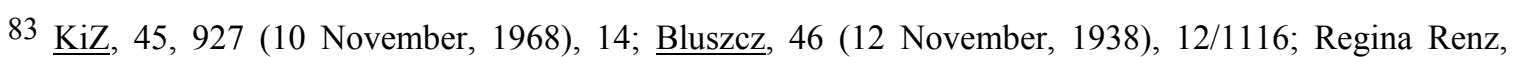
"Kobieta a planowanie rodziny w latach miedzywojennych (w swietle zrodel koscielnych z Kieleczyzny)," in Zarnowska and Szwarz (eds.), Kobieta i kultura zycia codziennego, 115-122, pp.116, 122; Mierzecki, "Prace zarobkowa kobiet w srodowsku robotniczym w polsce miedzywojennej," pp. 191, 192; Wapinski, "Kobiety i zycie publiczne," 17, 21, 22; Chojnowski, "Kobiety i polityka w drugiej rzeczypospolitej," 11, 13; and Jolluck, Gender, Identity and the Polish Experience of War, 202, 203, 205, 208, 287, 288, 294, 300.

84 Mrozek, "The Amazon and the American 'Lady'," 282-298; and Hargreaves, Sporting Females, 144.

85 For such representations of Soviet female pilots and explorers see Petrone, "Gender and Heroes," 23, 24.

86 Hong, Foot binding, Feminism and Freedom, 103, 155, 164, 173, 215, 255, 279, 289-291, 297, 298, 299, 304, 307; and Brownell, Training the Body for China, 50.

87 A. W. Niemilov was a professor at Leningrad University. See Bluszcz, 8 (24 February, 1934), 243. 
them, "since French sportswomen never forget to powder and put on rouge even in swimming, their mannish sporting interests were contradictory and utterly reprehensible". 88

In Canada, the media was quick to distort women's sporting activity, particularly in providing (or at times omitting altogether) details of the participants' clothing and personal appearance. 89 In Britain, Rudolph Kircher's Fair Play (London, 1928) summarized the social disapproval to women participating in sports: "female monstrosities standing mid-way between the sexes... "flannelled fools" capable of any extravagance', the sort of 'female lunatic' who favored cycling, or went in for athletics with 'unbecoming freakishness'.,90

The multiple weaknesses of the interwar Polish women's movement further undermined the development of women's physical culture and limited its popularity to a select few. Women's sports in interwar Poland was not a "popular" and "mass" phenomenon that could be widely enjoyed and celebrated.91 The Polish women's physical culture suffered because of the lack of feminist solidarity and the conservative character of the women's movement more generally. Women's sports sections generally remained private clubs with limited membership. They failed to establish strong bonds of friendship and solidarity between women of all social classes. 92 Even in Britain, sports for females generally retained an exclusive middle class character. 93

The inherent elitism in Polish sportswomen was characteristic not only of female athletes but of the entire Polish women's movement which remained quite exclusive in the interwar period. The women's organizations typically included women from the intelligentsia and families of officials. As in partitioned Poland, the women's movement in the Second Polish Republic remained cautious and moderate, and concentrated its objectives on promoting women's professional interests without jeopardizing traditional patriarchy. 94 Polish "feminists" of the interwar years did not identify themselves with "feminism". Instead, they preferred being designated as "Women Citizens" (Kobieta Obywatelka) who performed their new tasks in tandem with their traditional functions of wives and mothers. The "New Woman" could not imitate male behaviors and styles

\footnotetext{
88 Bluszcz, 50 (13 December, 1924), 929; and Bluszcz, 51-52 (23 December, 1924), 959.

89 Lenskyj, "Physical Activity for Canadian Women 1890-1930," 208-234.

90 Birley, Playing the Game, 203.

91 Sport Polski, 1, 8 (20 October, 1937), 3; and Bluszcz, 7 (11 February, 1922), 53.

92 Bluszcz, 12 (21 March, 1925), 274; and PzS, 10, 503 (15 February, 1930), 4.

93 Hargreaves, Sporting Females, 144.

94 Zarnowska, "Obywatelki II Rzeczypospolitej," 288, 291, 296, 297; and Chojnowski, "Aktywnosc kobiet w zyciu politycznym," 39.
} 
without criticism, nor could she aspire to the upper echelons of political influence. Although the numbers of members in women's organizations were considerable, the majority of "new women" worked in harmony with the traditional moral and ethical value system. Women's perceptions of "feminism" were still limited to providing educational and charitable assistance to their less privileged sisters. 95

While class divisions impeded the formulation of strong bonds of feminist solidarity, Polish women from all social classes collectively resisted radical modernization in all spheres of daily life. 96 From this perspective, the expressions of both class unity which resisted modernity and class conflict which undermined the evolution of popular feminist consciousness mitigated against the development of Polish women's physical culture in the interwar period.

In addition to class issues which adversely affected the organization of women's sports, ethnic differences further weakened the institutional foundations of women's physical culture in interwar Poland. For example, Jews and Ukrainians formed their separate physical cultures. The Union of Jewish Women's Sports Societies (Zrzeszenia Zydowskich Kobiecych Stowarzyszen Sport, ZZKSS) was the largest Jewish organization for women's sport in Poland. This organization also published its own sports periodical, New Woman (Kobieta Nowa, Warsaw), which reported on issues related to women's sport, "rational" health, and solidarity. The other popular Jewish sports associations included the Jewish Academy of Sports Societies (Zydowskich Akademickie Stowarzyszenie Sportowe), the Jewish Council of Physical Education (Zydowska Rada Wychowania Fizycznego RP), the Jewish Tourist Society (Zydowski Towarzystwo Krajoznawcze), the Zwiazek Zydowskich Akademickich Kol Milosnikow Krajoznawstwa, the bourgeois Jewish Union of Gymnastics and Sports Societies "Makkabi" (Zydowski Zwiazek Towarzystw Gimnastycznych i Sportowych "Makkabi" in Warsaw), the leftist Jewish Workers Sports Club "Gwiazda" (Zydowski Robotniczy Klub Sportowy "Gwiazda,") and the rightist Workers Sports Clubs "Kraft" and "Hapoel" (Robotniczy Klub Sportowy "Kraft" and "Hapoel"). All these organizations provided a necessary and separate sporting environment for the Jewish minority in Poland. Meanwhile, the other minority groups and nationalities such as the Germans, Lithuanians, and Ukrainians maintained their own sports sections and clubs. Among the Ukrainians in Poland, the

95 Kalwa, "Model kobiety aktywnej na tle sporow swiatopogladowych," 138, 139, 141, 146, 147, 152, 153; and Wapinski, "Kobiety i zycie publiczne-przemiany pokoleniowe," 36.

96 For more discussion on society's resistance to "modernization" see Sierakowska, "Macierzynstwo-wizje a rzeczywistosc," 219; and Agnieszka Janiak-Jasinska, "Unowoczesnianie gospodarstwa domowego i wyposazenia mieszkan w Polsce miedzywojennej," in Zarnowska and Szwarc (eds.), Rowne prawa i nierowne szanse, 189-207. 
Ukrainskie Krajowe Towarzystwo Ochrony Dzieci i Opieki nad Mlodzieza (1926), the Ukrainian Union of Sports (Ukrainski Zwiazek Sportowy, 1924), and the Ukrainskie Towarzystwo Turystyczno Krajoznawcze "Plaj" (1924), promoted sports among its members. However, the specific achievements of women in these sports organizations remains unclear. 97

While the lack of women's solidarity undermined the organization of women's physical culture in interwar Poland, the lack of an international feminist solidarity underscored the achievements of individual women to cross the traditional gender boundaries in the world of sports on a global scale. For example, disgruntled by the IOC's refusal to introduce women's track and field events at the Antwerp Games in 1920, Alica Milliat, together with five representatives of other lands, organized the International Women's Sports Federation (FSFI). Coubertin showed little sympathy for her efforts, proposing instead that women's events be dropped from the Games altogether. Under pressure from the IOC, she eventually changed the name to "Women's World Games", but the games were successful enough to warrant being scheduled ahead for 1926, 1930, and 1934. Eventually, the IOC settled for expanding the women's program and dissolved the FSFI. Unfortunately, to the dismay of these European women sports-activists, there was resistance among American women to participating in the Olympic Games throughout the 1920s and early 1930s. 98

Thus, similar to other countries, various societal, "national", and state-sponsored restrictions limited women's participation in sports in interwar Poland. The need for greater systematic and rationalized organization of women's physical culture was deemed imperative if Polish women's sports were to move beyond satisfying the sporting thrills of only a few "predestined" women athletes or confining women to the mothering responsibilities of aiding their children's sport as their only legitimate sporting duty. The militarization of the political, social, and cultural apparatus certainly provided more impetus for the organization of women's sports. In the second decade of the interwar period, the propagandists of Polish women's physical culture even looked toward

97 See Kobieta Nowa, 1, 3 (December, 1932), 4; Kobieta Nowa, 1, 1 (October, 1932), 1; and Kobieta Nowa, 1, 2 (November, 1932), 2, 4; Gaj in Gaj and Hadzelek, Dzieje kultury fizycznej, 196-198; Laskiewicz, Robotnicza kultura fizyczna, 52, 53, 63, 85; Skawinski, Kultura fizyczna na Lubelszczyznie, 13; and Grot, "Versuch eines abrisses," 306.

98 Alfred E. Senn, Power, Politics, and the Olympic Games: A History of the Power Brokers, Events, and Controversies That Shaped the Games (Champaign, 1999), 43, 44. 
Germany as their athletic mentor for making sport more 'democratic' with German-style 'magnanimous' results and greater involvement of the youth.99

But while the union of physical education with military schooling for men was obvious for improving soldiery abilities, the task of molding women's physical culture into a nationally enthusiastic defense mechanism to save the fatherland, without compromising women's traditional role of matka-polka, appeared a little too misty. The 'New Woman' in Poland could identify herself as a sportswoman, but the precise methodology of making her strong, healthy, and brave without jeopardizing her societally determined family and national obligations required a new discourse on the "woman question". The weight of tradition remained heavy and kept Polish "sports feminism" submerged in the increasingly contested and diluted waters of interwar patriarchy.

However, while Polish sportswomen effectively balanced the "feminist" ideals with the "national" agenda by projecting images of "energetic and athletic femininity", this new style of femininity constructed by Polish female athletes provided some buoyancy to the socially constructed image of conservative womanhood as articulated in the period of the partitions. The newer cultural and professional identities of female athletes in different social surroundings awarded women with more opportunities to effect a transformation in patriarchal gender relations in the direction toward greater independence and emancipation. Certainly, Polish sportswomen were more cautious than their western counterparts in challenging conventional gender patterns. They effectively balanced their sporting interests with their "national" obligations and "feminist" concerns by building a physical culture movement which obeyed the rules of social patriarchy. But more importantly, their decision to identify themselves as defenders of the family institution and the Polish state, as well as to participate in those sports which conformed to public opinion, earned them national respect and social prestige, far more than the expressions of gratitude or heroism which may have been awarded to sportswomen of other interwar societies.

\footnotetext{
99 PzS, 2, 26, 59 ( 30 June, 1922), 5; Sport Polski, 1, 8 (20 October, 1937), 3; Bluszcz, 51 (15 December, 1928), 12; Bluszcz, 12 (21 March, 1925), 275; Bluszcz, 40 (1 October, 1932), 14; Bluszcz, 26 (25 June, 1927), 12, 13; Bluszcz, 43 (24 October 1925), 1261; Bluszcz, 40 (4 October, 1930), 8, 9; and Sport Polski, 1, 8 (20 October, 1937), 3. Mothers were encouraged to look into question of the health, hygiene, and recreation of their children. See Katarzyna Sierakowska, "Matka i dziecko w zyciu codziennym rodziny inteligenckiej w Polsce miedzywojennej wzorce stare i nowe," in Zarnowska and Szwarz (eds.), Kobieta i kultura zycia codziennego, 103-114, pp. 105, 107, 108, 114.
} 


\section{Chapter Five}

\section{Socialist Ideology, the Images of Women, and the Construction of Women's Physical Culture in Stalinist Poland}

This chapter examines the interaction between the state-articulated socialist ideology, the multiple roles of women in the society and in the "nation", and the development of Polish women's physical culture during the years from 1944 to 1955 . In this time period, "stalinism" was forcibly imported to Poland and grafted onto the reemerging political, social, economic and cultural structures of the PRL. Polish physical culture, for both men and women, reflected the Soviet ideological and institutional implants, and accordingly, matured in response to the needs and aspirations of the socialist state. Within the stalinist walls of physical culture, Polish women were provided with unique avenues to experience, for the very first time, a "real" revolution in their sporting culture. Women became the direct and immediate beneficiary of the state's interest in sports and physical education.

However, the benefits of this "sports revolution" did not accrue to women before 1948. This was primarily because sports occupied a position of marginal interest in the immediate post-war years. Accordingly, the first part of this chapter discusses the re-birth of Polish physical culture in the midst of a chaotic political environment and widespread war-related devastation and disillusionment. This political instability, nonetheless, did provide the Polish society with the opportunity to rebuild their localized cultures in an independent manner. The reorganization of sports, for both men and women, followed a similar pattern of local autonomy.

The years between 1948-1955 were characterized by the onslaught of "stalinism" in Poland. Accordingly, the second part of this chapter explores the various identities of women as created and fostered by the stalinist ideology, and relates the images projected with the "sports revolution" during this time period. Polish women's physical culture, similar to the apparatus of men's sports, closely adhered to the Soviet model and, in consequence, became more strategized, planned, and organized. The earlier post-war reconstruction of the Polish sporting culture as being local, communitarian, and independent now changed dramatically. Instead, the male and female physical cultures increasingly articulated the values and benefits of "socialist patriotism", with an added emphasis on the carefully structured "alliance" between the Polish state and society.

Thus, this chapter presents an analysis of how the socialist construction of Poland contributed to the development of women's physical culture in the first decade of the

post-war years. How did the socialist ideology transform women's traditional roles in 
society, and how did these re-shaped gender configurations facilitate women's dynamic entry into the world of sports? What were the institutional, ideological and infrastructural support networks which encouraged women to become more physically active in the arena of sports? More simply, what factors enabled women to improve their physicality and challenge the omnipresent strictures that could be found on a global basis on women's participation in sports during this time period?

\section{"Peace" and "Partnership": Reconstructing Women's Identities and Rebuilding the Polish Sports Apparatus, 1944-48}

The organization of Polish women's physical culture at the end of the Second World War was affected by the overwhelming need to restore peace, order and stability to the war-ravaged country. The brutalities of the war, and the set of arrangements which concluded the war, transformed Poland in a fundamental fashion. As a consequence of territorial adjustments, the country became ethnically Polish and predominantly Roman Catholic by religion. Although geographically more compact and with a richer economic potential, the Poles were required to rebuild their war-devastated cities and villages with a scattered and weakened population. Harboring defeatist tendencies in the midst of widespread physical destruction and mental exhaustion, the Polish society adopted attitudes of accommodation to the Polish Workers' Party (PPR) which had emerged in the underground in 1943 under the communist leadership of Wladyslaw Gomulka. ${ }^{1}$

Upon liberation, the new Polish government was comprised of a coalition of several parties dominated by the communists who controlled the important ministries of Defense, Public Security, Industry, and Foreign Affairs. Gomulka, the party leader, directed his post-war policy toward maintaining political independence from the Soviet Union and leading the country onto the path of a "Polish road to socialism". As a communist, Gomulka tried to remain loyal to Moscow. But his ideology of 'national reconciliation' and 'gradual socialization' distanced him from the Soviet authorities. ${ }^{2}$ For Gomulka, it was to be Polish conditions, not any directives or pressure from outside, which were to determine the route and the pace of his cautious advance towards

\footnotetext{
1 Krystyna Kersten, The Establishment of Communist Rule in Poland, 1943-1948, Translated and Annotated by John Micgiel and Michael H. Bernhard (Berkeley and Los Angeles, 1991), 91, 92; Bromke, Poland's Politics, 58; and Leslie (ed.), The History of Poland, 285, 287.

2 Bromke, Poland's Politics, 59, 62; Ascherson, The Struggles for Poland, 142; Leslie (ed.), The History of Poland, 288, 295; Nicholas Bethell, Gomulka, His Poland and His Communism (London, 1969), 91; and Hansjakob Stehle, The Independent Satellite: Society and Politics in Poland Since 1945 (New York, 1965), 28, 29 .
} 
communism. ${ }^{3}$ Unfortunately, Gomulka's views aroused misgivings among many of his colleagues in the PPR leadership who had resided in Moscow during the greater part of the war, including and especially the former NKVD officer and thoroughly Sovietoriented Boleslaw Bierut. Gomulka's remarks about the virtues of parliamentary democracy proved equally misleading in the savage political struggles which ended in the final victory of the PPR in the fraudulent and violent elections of January, 1947.4

Amid the relative political confusion of the early post-war years, reconstruction went ahead. During the years 1945-48, Poland underwent an economic and social revolution. The real promise of these years were Gomulka's readiness to use the available social enthusiasm and talent to overlook political differences in rebuilding Poland. 5 The Polish government, in the initial post-war years, was committed to the goals of renewal, popular activism and social empowerment. 6 The Three Year Plan of Reconstruction, decreed in September 1946, provided for both industrial growth and improved standards of living. 7

Importantly, the newly formed Polish state sought the active assistance of women in the task of rebuilding the war-devastated country. According to the Politburo of the United Polish Workers' Party, during the period of war and occupation, thousands of Polish women struggled for national liberation. ${ }^{8}$ They were to be found in all branches of the armed forces and services, fighting at home and abroad. While living conditions for both men and women in occupied Poland were difficult, the experiences of Polish women in Soviet exile demonstrate how they adapted, protected and preserved themselves in a very foreign and hostile environment which compromised their identities as women and as citizens. 9 The early post-war films also projected women as the symbols of the suffering and heroism experienced by the whole nation against the enemies of Poland. 10

\footnotetext{
${ }^{3}$ Neal Ascherson, The Polish August: The Self-Limiting Revolution (New York, 1982), 45.

4 Ascherson, The Polish August, 45, 46; and Bethell, Gomulka, 91.

5 Ascherson, The Polish August, 47, 48; Padraic Kenney, Rebuilding Poland: Workers and Communists, 1945-1950 (Ithaca, 1997), 4; and Korbonski, "Poland: 1918-1990," 256.

${ }^{6}$ Leslie (ed.), The History of Poland, 288, 289; and Kenney, Rebuilding Poland, 335.

${ }^{7}$ Montias, Central Planning in Poland, 53.

8 AAN, Sygn. 237/XV-8, Projekt Uchwaly Biura Politycznego w sprawie pracy wsrod kobiet, Wydzial Kobiecy (1949-1952), 6.

9 Jolluck, Gender, Identity and the Polish Experience of War, 5, 97, 98, 159, 185, 186, 274, 275, 338, 593, $598,602,603$. Jolluck's dissertation explains how women exiled from Poland survived in the midst of cold, hunger, disease, sexual harassment, beatings, and the loss of a 'family life'.

10 Elzbieta Ostrowska, "Filmic Representations of the 'Polish Mother' in Post-Second World War Polish Cinema," in The European Journal of Women's Studies, 5 (1998), 419-435, p.424.
} 
As a result of this war-inflicted misery, thousands of Polish families were deprived of a living. The country was devastated, and numerous hardships were imposed on those who survived the brutalities of war. One of the worst results of the Second World War was the increase in the number of widows and orphans. In the absence of men, women and especially mothers, bore the brunt of the immediate post-war period. Many lacked professional qualifications to work, a limitation which compounded their suffering both at home and at the place of employment. 11

Accordingly, the reconstruction of the nation was not only limited to its physical contours and economic arrangements, but also included the remaking of the dismembered family unit as an important social and national institution. In the years between 19461948, the "mother" image was reinvigorated so as to reconstitute the lost family networks. In this imagery, women were "mother-citizens," instilled with the hard but honorable mission of building the "new man" and the "new family". The primary function of the newly reconvened family was to safeguard the future of children and to maintain family cohesiveness by shielding its internal structures from external agents such as adultery, divorce, alcoholism, and "intellectual decay". 12

In addition to her role as a caring mother, akin to the imagery of the Holy Mother, the "mother-citizen" in the early post-war years was encouraged to improve her professional competency and contribute to rebuilding the nation by effectively using her recently acquired or promised educational and technical qualifications. ${ }^{13}$ The women's periodicals of this time period quickly reaffirmed women's complete rights as citizens, in tandem with men. ${ }^{14}$ The Liga Kobiet (League of Women, LK) was founded in 1945 so as to enable women to use their equal status in society in order to further their professional and domestic interests. The LK remained a mass, non-party, socioideological organization for urban and rural women, and served to accomplish its mission of "Struggling for Peace and Rebuilding the Country". 15

While the political post-war apparatus had yet to endorse these equal rights for women officially, the 'mother-citizens' could be seen working not only inside the home, but also as nurses, students, and conductors on trams, in shops and industries, in local

\footnotetext{
11 AAN, Sygn. 237/XV-8, Projekt Uchwaly Biura Politycznego, 1; MiZP, 1, 28 (June, 1947), 2; and MiZP, 3, 15/63 (May, 1948), 2.

12 Kobieta Dzisiejsza, 1, 1 (February-March, 1946), 2; and MiZP, 3, 15/63 (May, 1948), 2.

13 MiZP, 6 (June, 1946), 4; and MiZP, 3, 36/84 (December, 1948), 3.

${ }^{14}$ Kobieta Dzisiejsza, 1, 1 (February-March, 1946), 1, 2; and MiZP, 2, 35/83 (December, 1948), 2.

15 On the League of Women for these years see Kobieta Wiejska, 2, 5 (May, 1948), 99; Kobieta Wiejska, 2, 11 (November, 1948), 243; and Kobieta Dzisiejsza, 1, 1 (February-March, 1946), 1.
} 
political structures, and in the various intellectual professions. ${ }^{16}$ For example, Dr. Malgorzata Nowicka was elected vice-president of the Krakow Regional People's Council (KRN). ${ }^{17}$ Irena Gumowska served as the Director of the Institute of Home Economics which was established in 1947.18 Meanwhile, the Polskie Stowarzyszenie Kobiet z Wyzszym Wyksztalceniem (Polish Society of Women with Higher Education) and the International Women's Federation for Higher Education assisted Polish women to study in American and English Universities. ${ }^{19}$ In general, however, the percentage of female workers employed in industry increased from only $25 \%$ in 1935 to $26.1 \%$ in 1947 , to $26.7 \%$ in 1949.20

From a comparative perspective, Polish women's dual images of "mothercitizens" and "worker-citizens" resembled the images of women being cast in the Soviet Union during these years. In the USSR, the massive disruptions caused by the war inspired a strong desire for family stability. This conservatism found expression in a reassertion of domestic values and associated ideas about women. On June 9, 1944, a new Soviet law on the family was issued that gave women enhanced state support but at the same time underlined the pronatalist goals of the regime. While motherhood became the official ideal for Soviet women, they were also expected to become exemplary workers. The chronic labor shortage made it difficult to send women back into the domestic sphere altogether. Peasant women especially found themselves even more burdened with domestic and work responsibilities. ${ }^{21}$

Thus, Polish women, similar to their Soviet sisters, contributed their labor to building their families and their countries' economies. To a large extent, their work both inside and outside the household was not too dissimilar from the "duties" of women in most other parts of Europe. The Second World War's unprecedented devastation of human lives, of families, and of towns and cities had all transformed European life. Women helped rebuild nations, the economy, and the future of several European

\footnotetext{
16 For examples see MiZP, 7 (June-July, 1946), 15; MiZP, 9 (August, 1946), 15; MiZP, 11 (September, 1946), 15; MiZP, 8 (July, 1946), 7; MiZP, 19 (February-March, 1947), 2; MiZP, 3, 39 (September, 1947), 10; and MiZP, 20 (March, 1947), 2.

17 Kobieta Dzisiejsza, 1, 4 (May, 1946), 12.

18 MiZP, 1, 13 (May, 1948), 10.

${ }^{19}$ MiZP, 14 (November, 1946), 14.

20 AAN, Sygn. 237/XV-8, Projekt Uchwaly Biura Politycznego, 1.

${ }^{21}$ Ronald Grigor Suny, The Soviet Experiment: Russia, The USSR, and the Successor States (New York, 1998), 375; and Clements, Daughters of Revolution, 97, 105, 106, 110, 111. For conditions in Russia during the immediate post-war years, see also Elena Zubkova, Russia After The War: Hopes, Illusions, and Disappointments, 1945-1957 (Armonk, NY, 1998)..
} 
countries. They successfully raised children, worked, borrowed money, and lived without men, transcending previous limited roles as home-makers. ${ }^{22}$

It is in this context of economic reconstruction and social initiative exhibited by both men and women in rebuilding a war-ravaged Poland that the organization of sports in the immediate post-war years must be evaluated. Certainly, many Polish athletes were not supporters of the communist government. The struggle against communist authorities took place in many areas and in many fields, including the scouting movement which had been reactivated toward the end of 1944 and assumed the name of the Union of Polish Pioneers (Zwiazek Harcerstwa Polskiego, ZHP). ${ }^{23}$ Moreover, in the initial years following the war, there were no organized sports for Polish men and women. The development of physical culture was impeded by the catastrophic state of health, the lack of qualified instructors, financial and material shortages, and the miserable working conditions.

It was in the midst of this public disillusionment with the war-time destruction and political instability that the Polish society began to re-construct their sports culture from the ground up. The years between 1944-48 were a "heroic time" in the development of Polish physical culture, marked by the formation of autonomous sport societies and a reactivation of sports activities and organizations which had emerged during the period of the Second Republic. For example, the Polish Boxing Union (Polski Zwiazek Bokserski) was one of the earliest sports organizations to re-start its operations in March, 1945. In the same month, the Center of Physical Education at Jagiellonian University (Studium Wychowania Fizycznego Uniwerstytetu Jagiellonskiego) began its activities. In December 1946, the Academy of Physical Education (AWF) in Warsaw started its work, followed by the Center of Physical Education in Wroclaw at the turn of 1946-1947. The AWF in Warsaw provided instruction in boxing and soccer, and discussed the importance of sports for building individual health and collective social solidarity. The students in Wroclaw organized their own Sports Circle on 17th June 1945, and their Academic Sports Union (Akademicki Zwiazek Sportowy, AZS) in the beginning of December. The Akademicki Zwiazek Morski (Academic Sailing Union) resumed its activities in 1945-46 and opened its branches in Warsaw, Krakow, Gdansk, and Szczecin. This organization, along with many others, encouraged sports and physical culture among students, workers,

\footnotetext{
22 Gisela Kaplan, Contemporary Western European Feminism (New York, 1992), 12.

23 Kersten, The Establishment of Communist Rule in Poland, 210; and Richard F. Staar, Poland, 19441962: The Sovietization of a Captive People (Baton Rouge, 1962), 219.
} 
administrators, technical specialists and the intelligentsia. Together they emphasized the importance of good health and the need to defend the fatherland.

Spontaneous sports activities and organizations emerged in several other parts of Poland as well. For example, in war-devastated Gorzow track and field was promoted to facilitate the social integration of its people. The work of rebuilding physical education in Poznan began on 15th February 1945 with the founding of the Wychowania Fizycznego Zarzadu Miejskiego (City Physical Education Office). In the same year, the Center of Physical Education in Poznan University (Studium Wychowania Fizycznego Uniwerstytetu Poznanskiego) started its activities. The Poznan District Associations of football, boxing, and track and field were subsequently formed, and the city organized national competitions in swimming, boxing, and field hockey. On 27 January 1946, the Poznan Workers Sports District Committee (Poznanski Robotniczy Sportowy Komitet Okregowy, RSKO, with sections in Gniezno, Pila, and Kalisz) was founded. The region also had sports sections of OMTUR, ZRSS, and Zwiazek Walki Mlodych (Union of Fighting Youth, ZWM). Meanwhile, several different sports clubs were organized in Gniezno, Szamotuly, Sroda Wielkopolska, Konin, Kalisz, and Pila.

In the tri-city coastal area of Gdansk, Gdynia and Sopot, sport was viewed as an important agent of social integration and for fostering a spirit of Polishness in a region that was formerly part of Germany. On 16 May 1945, the Sports Club "Gedania" reactivated its sporting activities. By the end of the year, 25 sports clubs had re-opened. In 1945, the district sports unions of football, boxing, track and field, weightlifting, and wrestling were reorganized, followed by those of sailing, tennis, basketball, volleyball, table tennis, and chess in the following year. Water sports such as sailing, windsurfing, and canoeing were extremely popular among the youth. The regional geography, marked by greenery in the form of parks and forests, also promoted family recreation and tourism. The Wojewodzka Rada Wychowania Fizycznego i Przysposobienia Wojskowego (Provincial Council of Physical Education and Military Preparation) and Wojewodzki Komitet Kultury Fizycznej (Provincial Committee of Physical Culture) in Gdansk, and the Miejskie Komitety Kultury Fizycznej (City Committee of Physical Culture) in Gdynia and Sopot, along with the TKKF, OMTUR, ZWM, and ZHP, sponsored several mass physical culture displays and sports festivals.

For the Polish workers, the Union of Workers' Sports Societies (Zwiazek Robotnicznych Stowarzyszen Sportowych, ZRSS) re-emerged in 1945. On 16th December 1945, the Trade Union of Employees of Physical Culture and Sports (Zwiazek Zawodowy Pracownikow Wychowania Fizycznego i Sportu) was formed. Up to 1948, however, the two currents in workers' sports remained separate. The sports clubs sponsored by the 
Central Commission of Trade Unions (Komisja Centralna Zwiakow Zawodowych, KCZZ) received the support of the PPR. But the ZRSS was patronized by the PPS. There was sharp rivalry between the two parties, although its extent and impact varied according to the regions.

Meanwhile, the State Council of Physical Education and Military Preparation (Panstwowe Rada Wychowania Fizycznego i Przysposobienia Wojskowego, PUWFiPW) was reorganized on 16th January, 1946, followed by the Provincial Offices of Physical Education and Military Preparation (Wojewodzkie Urzedy Wychowania Fizycznego $i$ Przysposobienia Wojskowego) on 30 April, 1946. An organization similar to the latter was also established at the district level on 15 June, 1946. To encourage sports research, the Ministry of Health directed a conference for doctors specializing in sports medicine in 1945. In early 1947, the Society of Sports Physicians (Stowarzyszenie Lekarzy Sportowych) was founded to provide an understanding into the theoretical and practical benefits of the relationship between medical science and physical culture. ${ }^{24}$

${ }^{24}$ For the spontaneity in formation of sports organizations during the initial postwar years, as well the role of the official and civil youth organizations for the years between 1944-1948 see Gondek, Kultura fizyczna w Polsce, 9, 10, 11, 13 14; Bernard Woltmann, "Sporthistorische Forschung in Polen," in Stadion, 12/13 (1986/87), 347-356, p.347; Gaj, Wychowanie fizyczne, 18, 55; Wilk, "Awans," 3, 4; Kedziorek, "Upowszechnienie kultury fizycznej," 22, 23; Lysakowski, Panstwowa adminstracja, 53; Jerzy Chelmecki and Slawomir Wilk, Wybor zrodel i materialow do dziejow kultury fizycznej w Polsce w latach 1944-1984 (Warsaw, 1986), 19, 23, 24, 29; Liponski, "Still and Unknown," 21-24; Kajetan Hadzelek, "W 30 rocznice rozpoczecia dzialalnosci AWF w Polsce Ludowej," in Kultura Fizyczna, 4 (1977), 176-178; Hadzelek, "Foundation," 89; Wroczynski and Hadzelek, "Development of Sciences," 90; Kus, "Zwiazki," 11-13; Edward Kus, "Akademicki Zwiazek Sportowy we Wroclawiu w latach 1945-1949," in Kultura Fizyczna, 32, 9 (September 1978), 389-392; and Wieczorek, "Problemy," 6. For the tensions between the ZRSS and KCZZ in the organization of workers' sport in Lower Silesia see Janusz Tomaszewski, Ruch zawodowy na Dolynm Slasku w latach 1945-1950 (Wroclaw, 1999), 137-149. For the development of sport in Gorzow see Anna Lutynska and Elzbieta Szumska, "Rozwoj lekkiej atletyki w Gorzowie Wielkopolskim w latach 1945-1985," in Wychowanie fizyczne i sport w 40-Leciu PRL, 119-129, p.119. For the development of sport in Greater Poland see Gawlak-Kica, Rozwoj kultury fizycznej w Wielkopolsce, 17, 20, 21, 22, 25, 26, 47, 51, 53, 55, 56, 62-73, 127, 235, 236; Wieczorek, "Problemy," 6; and Alicja Wozniak and Stefan Bosiacki, "Tourism in the Lifestyle of Inhabitants of the Poznan Province," in Wojciech Liponski and Wieslaw Siwinski (eds.), Studies in Physical Culture and Tourism (Poznan, 1994), 143-151. These authors have examined the impact of the processes of industrialization, urbanization and migration on sport has been researched for several towns in the Greater Poland region. The years between 1945-1980 dramatically transformed the urban and rural economies, as well as the demographic dynamics in towns such as Poznan, Pila, Gniezno, Wrzesnia, Kalisz, Konin, Sroda Wielkopolska, and Szamotuly. The maximum change was experienced in towns of Poznan, Pila and Konin, and the least in Szamotuly and Sroda Wlkp. For the development of sport in the tri-city area of Gdansk, Gdynia and Sopot see Zbigniew Szot, "Determinanty rozwoju kultury fizycznej na tle przemian spolecznych i kulturalnych w Gdansku w latach 1945-1946," in Krawczyk (ed.) Kulturowe wartosci sportu, 475-485; and Jerzy Gaj, "Odbudowa i rozwoj sportu na ziemi Gdanskiej w Polsce Ludowej (1945-1956)," in Zeszyty Naukowe WSWF w Gdansku, 2 (1978), 231-259; and Zbigniew Szot, "Rozwoj kultury fizycznej w Gdansku w latach 1945-49 na tle przemian spolecznogospodarczych," in Zeszyty Naukowe, 7 (1983), 5-34. According to these authors, in the period between 1945-1980, the tri-city area of Gdansk, Gdynia and Sopot experienced a dynamic growth in population and the modernization of a sea-related economy. The combined effect of these demographic and economic developments resulted in the rapid growth of sports clubs, unions and associations. 
Thus, despite the war-time devastation, the organization of sports and scientific research in physical culture resumed in cities such as Warsaw, Poznan, Krakow and Wroclaw. This independent sports activism by the society and state was more urbanbased in the immediate aftermath of the war. For this reason, the popularity of sport in the countryside remained low. 25 Also, the organization of sports in these early post-war years was more "local" than "national". For example, in the years between 1945-1948, support for workers sports teams in Wroclaw revealed an official commitment to a local patriotism. The factory provided entertainment in the form of cinema, theaters, and sports for its employees. 26 Sports, along with other forms of community expression, therefore, served as an important avenue to display local solidarity and patriotism. 27

This autonomous and localized re-construction of the Polish sports apparatus in the immediate post-war years reflected the society's strategy to defend its cultural values at a time when the goals of the communist authorities depended on the eradication of existing and potential centers of organized political opposition. Sports helped to re-build local communities and strengthened the war-devastated social structures and patterns of life. Physical culture was configured to support local re-habilitation and not necessarily to foster national unity. For this reason also, the communist authorities, though much disliked, established its power in the absence of a nation-wide, united opposition. The exhausted and demoralized society, regardless of its political outlook and attitude toward the authorities, cooperated in the task of rebuilding the country. Polish physical culture was re-built with this social mindset, and similar to the other tasks of reconstruction, contributed to a strengthening of not oppositionist but politically conformist attitudes in society. The various social and cultural groups, including physical culture activists, tried to defend their values and oppose the imposition of the new order upon them, less politically than socially, economically, and ideologically. 28 And until 1947, many sports advocates, along with the scientists and other intellectuals, enjoyed a comparatively large margin of freedom to accomplish their local and independent objectives. ${ }^{29}$

\footnotetext{
25 PzS, 76 (22 September, 1947), 4.

26 Kenney, Rebuilding Poland, 163, 164.

27 See Szczepanski, Polish Society, 191.

${ }^{28}$ For a good description of the immediate post-war political tensions, social disintegration, and resistance to communist control see Kersten, The Establishment of Communist Rule in Poland, 146, 154, 156, 165, 166, 167, 210, 231, 264, 265, 271, 310, 337, 362, 368, 381.

29 For the presence of cultural, scientific, and intellectual freedom see Krystyna Kersten, "The Terror, 1949-1954," in A. Kemp-Welch (Edited and Translated), Stalinism in Poland, 1944-1956. Selected Papers from the Fifth World Congress of Central and East European Studies, Warsaw 1995 (Basingstoke, Houndmills, Hampshire, 1999), 78-94, p.79.
} 
Thus, similar to the workers and peasants, Polish athletes in this time period were imagined as revolutionary allies rebuilding Poland. 30 In this partnership between state and society, the roles of sportsmen were more visible than those of Polish female athletes. This was largely because not many women participated in sports during these early postwar years. Stunned by the war-related devastation and anxious to rescue the collapsed family institution, many women simply preferred to partake in the more "urgent" needs of rebuilding the Polish economy and society. Certainly, there were spaces for women to play games. In the initial post-war years, the OMTUR provided opportunities for women to participate in physical culture parades and sports. ${ }^{31}$ However, their engagement in sports was largely limited. Only toward the beginning of 1947 did the popular sports newspaper Przeglad Sportowy begin to publish a few reports on women and sports. And such excerpts were confined to women's participation in track and field, volleyball and basketball.

While Polish women's participation in sports was restricted during the early postwar years, that of their Soviet counterparts was more extensive. Very 'athletic' looking women, wearing sportive outfits, performed various acrobatics and dances in the physical culture parades and festivals organized by the Soviet state. ${ }^{32}$ The Soviet state attempted to use women's engagement in physical culture to facilitate the 'integration' of the Soviet empire and encourage the 'emancipation' of women. 33 During these years, the Soviet state emphasized that physical culture was necessary for the improvement of women's hygiene and health. Physical culture and sport were needed to make women strong, and to instill in them qualities of endurance, hardiness, adroitness and dexterity. ${ }^{34}$ The socialist state took pride in the fact that its female champions were raised in Soviet families and schools. The state sought to project the image that the victories of champions were achieved not only through the efforts of sportswomen alone, but with the help and support of their comrades and fellow citizens. 35 For this reason, new international records brought honor not only to the outstanding sportswomen, but also to the Soviet people and the Soviet land. Thus, for the state, physical culture contributed to the making of strong, gracious, beautiful, intelligent, wonderful and patriotic women. 36

\footnotetext{
30 See Kenney, Rebuilding Poland, 336. According to Kenney, workers were imagined as revolutionary allies who were rebuilding industry and conquering the frontier.

31 See Kobieta Dzisiejsza, 1, 5-6 (1 June, 1946), 19; and PzS, 2, 45 (5 September, 1946), 4.

32 For images of such "athletic" women see Rabotnitsa, 8 (1945), 13; and Soviet Woman, 4 (1946), 51.

33 Rabotnitsa, 8 (1947), 4; Soviet Woman, 5 (1946), 59.

34 Rabotnitsa, 8 (1945), 18, 19.

35 Soviet Woman, 1 (1947), 60.

36 Rabotnitsa, 1 (1947), 26, 27.
} 
Thus, both the Polish and Soviet sportswomen were perceived as "partners" by their respective states in the task of reconstruction. However, Soviet female athletes were provided with more ideological and institutional opportunities to participate in sports during these early post-war years. The Polish women, by contrast, were far more concerned with the survival of their families and the nation than the fulfillment of their athletic endeavors. Nonetheless, those few women who did display their athleticism served the Polish state in rebuilding the country through their improved physicality. They remained valuable partners in the society's cooperative alliance with the Polish state.

This official view of the Polish society as a "partner" in local reconstruction would, however, soon transform into an imagery of the society being perceived as the "enemy" in socialist development by the end of 1947. Thereafter, the Polish regime would re-formulate its policies to "tame" the alleged "recalcitrant and hostile society" through the tools of communist mobilization. Interestingly, the male and female physical cultures would now play an instrumental role in the communist political methodology of "taming the shrew" and making the Polish society more obedient to state socialism. The employment of women's sports to create a "loyal" stalinist Poland, however, provided sportswomen with more exciting opportunities to experience the thrills of a "liberated bodily culture" under state socialism.

\section{“Taming the Shrew”: Stalinism, Women, and Polish Sports, 1948-1955}

The development of women's physical culture in Poland during the years between 1948-1955 was conditioned by the imposition of Stalinist rule in the PRL. In 1948, Gomulka's 'rightist-nationalist' views fell prey to Stalinist interference and the initial ripples of the Cold War. While Moscow was willing to tolerate a considerable degree of diversity in the policies of various communist parties in Eastern Europe between 194547, this was not true of the years 1947-48. With the Truman Doctrine, the Marshall Plan and the formation of the Cominform all in 1947, Stalin's policy changed. Accordingly, Gomulka was accused of 'nationalist right wing deviation' by the Muscovite faction of PPR. Throughout the summer of 1948, Bierut, the staunch Polish Stalinist, attacked Gomulka for his "mistaken" attitudes. Subsequently, on 3rd September 1948, Gomulka was dismissed as secretary of the PPR and imprisoned. He was replaced by the more "trusted" Bierut. On 15 December 1948, the PPR and the PPS fused to form the PZPR (Polish United Workers Party) which was dominated by the 'Moscow Poles' and cleansed of "rightists" in their own ranks. Thereafter, this "united" communist party 
attempted to superimpose its rule on a society still shaped largely by its non-communist past. 37

During the years 1948-53, the Polish communist regime structured its political policies to impose stalinism on every level of Polish life. Through coercion, the promise of economic reconstruction, and international acquiescence to a Soviet sphere of influence in Eastern Europe, the Polish communist elites hoped to discard symbols of local patriotism and use the varied forms of propaganda to emphasize national unity for building socialism in stalinist Poland. 38 All Polish organizations, policies and training methodologies were consequently altered to Soviet patterns and practices. 39 According to Bierut, the friendship, assistance, and example of the Soviet Union was critical in building a socialist Poland. 40 For this reason, the Polish press now displayed "friendly" images of Stalin, celebrated the Soviet-Polish "partnership", applauded Bierut's dedication to building a socialist Poland, and remembered Feliks Dzierzynski--the Polish "hero" of the Bolshevik Revolution, the founder of the Cheka, and the "great son" of Poland who 'struggled for the brotherhood of Polish and Russian workers'. 41

The four years between the end of 1949 and the end of 1953 were marked by the aggressive sovietization of Poland, both in the sense of overt Soviet domination and exploitation of the country and of the wholesale copying of Soviet policies and institutions. Such servile manifestations of admiration for the USSR and its leader Stalin were evident in all forms of Polish governance. 42 Since the organization of sports and

37 MiZP, 3, $27 / 75$ (September, 1948), 2; Michael H. Bernhard, The Origins of Democratization in Poland: Workers, Intellectuals, and Oppositional Politics, 1976-1980 (New York, 1993), 31, 32; Stehle, The Independent Satellite, 30; Ascherson, The Polish August, 45, 56; Zamoyski, The Polish Way, 371; Leslie (ed.), The History of Poland, 296-299; Davies, God's Playground, Vol II, 549, 556; Bromke, Poland's Politics, 62, 63; and Kersten, The Establishment of Communist Rule in Poland, 456.

38 For these issues see Andrzej Paczkowski, "Building the One-Party State," in Kemp-Welch, Stalinism in Poland, 41-53, p.42; Jack Bielasiak, "Poland," in Ramet (ed.), Eastern Europe, 126-158, p.128; Brzezinski, The Struggle for Constitutionalism in Poland, 61; and Kenney, Rebuilding Poland, 163, 164.

39 Ascherson, The Polish August, 57, 58.

40 The cover page of Kobieta Wiejska, 3, 14 (7 November, 1949), captions Bierut's words: "Przyjazn ZSRR, pomoc ZSRR, przyklad ZSRR to podstawowe zrodlo naszych zwyciestw".

41 For images of Stalin and Polish-Soviet friendship see Kobieta Wiejska, 3, 17 (15 December, 1949), cover page; MiZP, 35/119 (10 December, 1949), 2; MiZP, 36/120 (20 December, 1949), 3; MiZP, 29/185 (10 October, 1951), 2, 3; MiZP, 36/192 (20 December, 1951), 2; and MiZP, 3/195 (20 January, 1952), 2, 3. In the press, Bierut was often referred to as the "most popular person in the PRL who was leading Poland onto the path of socialism, liberation and independence'. For examples, see MiZP, 29/185 (10 October, 1951), 2, 3; MiZP, 9/201 (20 March, 1952), 2, 3; and MiZP, 27/219 (20 September, 1952), 2. For images of Feliks Dzierzynski in the women's press see Przyjaciolka, 29 (22 July, 1951), 3; Przyjaciolka, 35 (2 September, 1951), 9; MiZP, 20/176 (10 July, 1951), 2; MiZP, 21/177 (20 July, 1951), 4, 5; MiZP, 23/179 (10 August, 1951), 7; and Ivan T. Berend, Central and Eastern Europe, 1944-1993: Detour from the Periphery to the Periphery (Cambridge and New York, 1996), 91.

42 Leslie (ed.), The History of Poland, 302, 312, 341; and Bromke, Poland's Politics, 65, 68, 69. 
physical education for women also experienced the onslaught of sovietization, an examination of the impact of stalinist policies on the various facets of Polish life is critical to our understanding of the manner in which Polish physical culture slavishly imitated and responded to the Stalinist policies and pressures.

In the political apparatus, Bierut reaffirmed the rights of citizenship to the Polish workers, intelligentsia, women, and peasants. 43 However, in reality, these rights were limited to the "worthy" members of the socialist community. Through a process of statebuilding marked by terror, violence, arbitrary arrests, show trials, and punishments, the communists expunged the "unreliable elements" and began to remold the existing fabric of political, economic and social relationships in line with established Soviet models. 44 Social obedience to political stalinism was extracted by the party through coercion, fear of being labeled 'bandits' and 'reactionaries', and the conviction by the society that resistance and struggle against the communist authorities was useless. 45 Thereafter, political pluralism was abrogated, all branches of state apparatus were subordinated to the interests of the ruling communist party, and a new Soviet style constitution was promulgated on 22 July 1952 which renamed the country as the Polish People's Republic (Polska Rzeczpospolita Ludowa, PRL) and bestowed the party leadership with responsibilities of political coordination, social control, and economic management. 46

In the economic sphere, the communist authorities sought to mobilize popular support for its policies of reconstructing the nation's economy and improving the standard of living. 47 The press reported progress in the urban and rural economies, especially in the development of rail and sea transportation and mass communications. 48 In the countryside, the regime introduced plans for the collectivization of agriculture. However, general peasant resistance to the formation of co-operatives ultimately

\footnotetext{
$43 \underline{\text { MiZP, }}$ 8/164 (10 March, 1951), 2; and MiZP, 7/199 (1 March, 1952), 5.

44 Korbonski, "Poland: 1918-1990," 258; Kersten, "The Terror, 1949-1954," 78, 79, 93, 94; Bromke, Poland's Politics, 80; Ascherson, The Polish August, 57; and Leslie (ed.), The History of Poland, 297.

45 Bernhard, The Origins of Democratization in Poland, 34, 35; John Micgiel, "Bandits and Reactionaries': The Suppression of the Opposition in Poland, 1944-1946," in Norman Naimark and Leonid Gibianskii (eds.), The Establishment of Communist Regimes in Eastern Europe, 1944-1949 (Boulder, Colorado, 1997), 93-110, p.100, 101, 104; and Kersten, The Establishment of Communist Rule in Poland, 421 .

46 Przyjaciolka, 5 (3 February, 1952), 7-11; Brzezinski, The Struggle for Constitutionalism in Poland, 62, 64; Leslie (ed.), The History of Poland, 305-310; and Zamoyski, The Polish Way, 371.

47 Bernhard, The Origins of Democratization in Poland, 34, 35; and Kersten, The Establishment of Communist Rule in Poland, 421.

48 See for example MiZP, 1, 1/85 (January, 1949), 2; MiZP, 4/160 (1 February, 1951), 2; Kobieta Wiejska, 3, 15 (15 November, 1949), 2; and MiZP, 2, 32/80 (November, 1948), 2.
} 
undermined the state's goal to stalinize Polish agriculture. 49 In the urban economy, the communist authorities transplanted the highly centralized Stalinist system of economic planning and management, with a strong emphasis on the nationalization and rapid industrialization of the economy. 50 The regime illustrated the success of its industrial policies by establishing "model towns" such as Nowa Huta and Nowe Tychy which served as examples of the country's progressive march to industrial socialism. 51

However, while the state attempted to build workers enthusiasm for raising industrial production and fostering socialist patriotism, the Stalinist subordination of the working class did not always transform the workers into a collectivist, mobilized, and integrated social group which could demonstrate the accomplishments of communist industrialization. While the state used the Soviet methodology of labor stakhanovism to heroicize work life and increase productivity, many workers resisted competition. In addition, the Polish working class was not a homogenous social entity but quite divided along class and generational lines. As a consequence, the communist state in an effort to secure popular legitimacy was forced to compromise and accommodate to the workers' multiple identities. 52

Overall, the regime's economic policies failed to reach the planned targets in gross national product, real wages, and agricultural production. Inspite of the close surveillance and tactical repression, there was widespread absenteeism in various industries, theft of materials for the black market, and falsification of production statistics. Although Poland's economy became more modern, urban, and industrialized, it also became inefficient and shortage prone. Overcentralization and defective planning methods drastically reduced the amount of national income available for the rural economy, as well as for consumption, housing, social and communal services, and welfare. 53

\footnotetext{
49 Dariusz Jarosz, "Polish Peasants Versus Stalinism," in Kemp-Welch, Stalinism in Poland, 59-77, p. 60, 61, 67, 70, 77; Leslie (ed.), The History of Poland, 297; and KiZ, 2 (10 January, 1953), 2, 3.

50 Montias, Central Planning in Poland, 148; Kersten, "The Terror, 1949-1954," 78; and Zbigniew Fallenbuchl, The Balance of Payments Problem and the Economic Crisis in Poland (The Carl Beck Papers in Russian and East European Studies, Paper No. 406, University of Pittsburgh, 1985), 2, 3.

51 Nowa Huta was the first new socialist town. See Przyjaciolka, 35 (2 September, 1951), 2; MiZP, 27/219 (20 September, 1952), 2; Davies, God's Playground, Vol II, 579; and Bromke, Poland's Politics, 145.

52 Kenney's Rebuilding Poland is the best book on this subject. See pages 206, 207, 236-238, 247, 250, $253,270,271,285,286,288,290,293,307,329,332,333,335-337,341,343,344$. For the state's emphasis on building workers' enthusiasm see also MiZP, 3, 36/84 (December, 1948), 3; and Staar, Poland, 1944-1962, 83. For more information on the tensions between urban workers and the new peasant arrivals in industry see Ascherson, The Polish August, 58; and Leslie (ed.), The History of Poland, 313, $446,450$.

53 For these economic problems see MiZP, 3, $36 / 84$ (December, 1948), 3; MiZP, 2, 29/76 (October, 1948), 2; Ascherson, The Polish August, 59, 62; Leslie (ed.), The History of Poland, 313, 316; Bernhard, The
} 
In the socio-cultural realm, the communist authorities tried to undermine the power of the Catholic Church. The Church came under attack, and the primate of Poland, Stefan Cardinal Wyszynski, was imprisoned in September 1953. No doubt, the regime pledged an official policy of non-interference in the internal affairs of the Church. However, in reality, the communist elites launched an anti-Church offensive in an effort to not only subjugate the Catholic Church but also, and more importantly, to strengthen the state's social control over the deeply religious society. 54

The communists paid special attention to the youth. Already at the end of 1947 , intensive preparations were underway to unite the various youth organizations such as the Union of Youth Struggle (ZWM), the Youth Organization of the Society of Workers' Universities (OMTUR), the Union of Rural Youth "Wici" (ZMW-Wici), and the Union of Democratic Youth (ZMD). On July 22, 1948, the Union of Polish Youth (Zwiazek Mlodziezy Polskiej, ZMP) was born and modeled along the Soviet youth organization, the Komsomol. Subsequently, the ZMP became an enthusiastic propaganda machine of the party. 55 The ZMP would also play a significant role in promoting physical culture for both men and women in Poland.

In other forms of cultural life, the Ministry of Culture and Art became a powerful instrument for promoting socialist realism in a cultural apparatus which was planned, administered, and controlled by the state. Under state patronage, Polish literature, theater, cinema and the visual arts were required to be "comprehensible" to the general public and mandated to conform to the official propaganda campaigns to create a socialist culture. 56 However, despite the regime's efforts to ensure cultural conformity, there was still some

Origins of Democratization in Poland, 35; Ben Slay, The Polish Economy: Crisis, Reform, and Transformation (Princeton, 1994), 25; and Montias, Central Planning in Poland, 57, 61, 74, 75, 202, 263.

54 For Church-State relations see Przyjaciolka, 1 (2 January, 1949), 5; MiZP, 7/199 (1 March, 1952), 5; Leslie (ed.), The History of Poland, 328-329; Brzezinski, The Struggle for Constitutionalism in Poland, 61; Kersten, "The Terror, 1949-1954," 84; Ascherson, The Struggles for Poland, 153; Bielasiak, "Poland," 129; Bogdan Szajkowski, Next to God....Poland: Politics and Religion in Contemporary Poland (London, 1983), 9-28; and Sabrina P. Ramet, Nihil Obstat: Religion, Politics and Social Change in East-Central Europe and Russia (Durham, 1998), 100-104, 286-293.

55 MiZP, 2, 2/86 (January, 1949), 10; MiZP, 4/196 (1 February, 1952), 2; Kersten, "The Terror, 19491954," 78; Leslie (ed.), The History of Poland, 313; Kersten, The Establishment of Communist Rule in Poland, 422, 423; and Staar, Poland 1944-1962, 83.

56 For the state's interest in socialist culture see $\underline{\text { PzS }}, 19$ (8 March, 1951), 1; MiZP, 29/149 (10 October, 1950), 3; MiZP, 20/176 (10 July, 1951), 7; MiZP, 6/198 (20 February, 1952), 2, 3; MiZP, 27/219 (20 September, 1952), 2; MiZP, 2, 2/86 (January, 1949), 2; MiZP, 2, 8/92 (March, 1949), 7; Leslie (ed.), The History of Poland, 312, 313, 323, 325; Davies, God's Playground, Vol II, 603, 624; Jakub Karpinski, Poland since 1944: A Portrait of Years (Boulder, 1995), 36; Ascherson, The Struggles for Poland, 154; and Kersten, The Establishment of Communist Rule in Poland, 416, 417. See also Czeslaw Milosz, The Captive Mind. Translated by Jane Zielonko (London, 2001) for exposing and opposing socialist realism in Poland. 
room for independent cultural activity free of ideological content. 57 The political elites were quite dependent on the technical expertise of the 'socialist intelligentsia'. Their access to specialized knowledge forced the state to accommodate its interests with those of the technical and cultural intelligentsia. 58 Moreover, despite the regime's efforts to integrate the urban and provincial cultures, the omnipresent class divisions separated the social cultures of the peasants, workers, and the intellectuals. 59

Overall, during the Stalinist period in communist Poland, the PZPR embarked on accelerated systemic changes essentially directed toward establishing a political and socio-economic model similar to that existing in the USSR and aimed at deep cultural transformations. The communist leadership made a concerted effort to eradicate trends in Polish tradition and culture that impeded progress toward a socialist society. The communist party gained ascendance over the Polish state and Polish society by forcefully extolling the "benefits" of Stalinism and glorifying the infallibility of the 'Great Leader'. Thus, Poland experienced the terror, misery and absurdity of Stalinism, all in the name of social justice, class unity, intellectual advancement, and economic progress. However, though the Stalinist virus had badly infected and substantially weakened the Polish society, Bierut's Poland experienced a far less severe form of the original Stalinism. Polish stalinism, by comparison, was short-lived, less brutal, extremely superficial, and introduced too hastily. For these reasons, Stalin's impact on Poland was not as damaging as in the Soviet Union. 60 Thus, for example, the Polish peasantry was not, except marginally, collectivized. 61 Neither was the Catholic Church broken down to submission. The repressions and persecutions of the Church did not succeed in eroding the hold of religion on the population. The traditional loyalty of the Catholic masses to the church was not weakened; rather, the Church became a symbol of moral independence in the struggle against the ever-increasing communist ideological offensive. 62 Moreover, while all resistance to Stalinization was brutally suppressed, the

\footnotetext{
57 Bielasiak, "Poland," 129.

58 David Lane, "Structural and Social Change in Poland," in David Lane and George Kolankiewicz (eds.), Social Groups in Polish Society (London and Basingstoke, 1973), 1-28, p.28.

59 Stehle, The Independent Satellite, 211, 212; and Kenney, Rebuilding Poland, 314, 315, 321, 325, 327.

60 For a discussion on all these issues see MiZP, 1, 1/85 (January, 1949), 3; Ascherson, The Polish August, 62; Kersten, The Establishment of Communist Rule in Poland, 467; Brzezinski, The Struggle for Constitutionalism in Poland, 61; Bielasiak, "Poland," 129; Kenney, Rebuilding Poland, 4; Leslie (ed.), The History of Poland, 341, 342; and Ascherson, The Struggles for Poland, 151.

61 Ascherson, The Polish August, 62.

62 Ascherson, The Polish August, 62; Bielasiak, "Poland," 129; Leslie, The History of Poland, 330, 342; Davies, God's Playground, Vol II, 609; and Kersten, The Establishment of Communist Rule in Poland, 214.
} 
various purges of the party and society at large claimed relatively few victims. The police terror never attained a high pitch of ferocity in Poland. 63

Finally, following Stalin's death on 3rd March 1953, and Bierut's own "New Course" in late 1953 and 1954, there was a marked improvement in Polish cultural life. In the period between 1953-56, Gomulka was quietly released from detention, more resources were allocated to agriculture and consumer goods production, the pace of agricultural collectivization was slowed, and the party supervised cultural, intellectual, and press circles became more restive. No doubt, the PZPR continued to emphasize notions of Soviet brotherhood and friendship, and the need to develop the political economy through socialist policies of technical mechanization, industrialization, and socio-cultural conformity. 64 Indeed, the Polish population, which itself increased by 19\% between 1950-1960, gradually became more urbanized and was characterized by a high rate of social and occupational mobility for the working class. 65 However, by 1956 , the Poles had also succeeded in preserving two vital bastions of pluralism, the Church and private agriculture, and an exceptional degree of independence in intellectual and cultural life. 66

Polish women's identities, including their "sportive physicality", were fashioned according to the above-mentioned political, economic and cultural needs of the communist regime during the years 1948-1955. The official press, including women's periodicals, consciously projected images of female workers facilitating the radical transformation of the newly emerging socialist Poland. The KC PZPR sought the active and well-integrated participation of women workers from all social and professional backgrounds in promoting ideas of "positivism", "creativism", and "patriotism". The principal objective of the state was to build solidarity and a 'united front' among all women for national and international 'peace' and 'progress'. Indeed, there are numerous references in the press reflecting women's presumed enthusiasm in constructing a

63 Ascherson, The Polish August, 62; Davies, God's Playground, Vol II, 581; and Korbonski, "Poland: 1918-1990," 258.

${ }^{64}$ For the developments between 1953-56 see Przyjaciolka, 15 (12 April, 1953), 3; Przyjaciolka, 31 (2 August, 1953), 3; Przyjaciolka, 46 (15 November, 1953), 3; Przyjaciolka, 13 (28 March, 1954), 5; Przyjaciolka, 11 (14 March, 1954), 3; Davies, God's Playground, Vol II, 582; Leslie, The History of Poland, 333; Rothschild, Return to Diversity, 150, 151; Ascherson, The Polish August, 66; Bernhard, The Origins of Democratization in Poland, 34, 35; and Slay, The Polish Economy, 28.

65 David Mason, Public Opinion and Political Change in Poland, 1980-1982 (Cambridge and New York, 1985), 39; and Stehle, The Independent Satellite, 120.

66 Timothy Garton Ash, The Polish Revolution: Solidarnosc (London, 1991), 10, 11. 
fundamentally peaceful, progressive, and patriotic Polish socialist state. ${ }^{67}$ This task appeared to have become even more urgent with the Korean War and subsequent American intervention. 68

According to the images contained in the women's literature, Polish women had the greatest opportunity to advance in stalinist Poland. They became more visible in the factory and society, and gained access to the same honors and benefits as did men. 69 Official propaganda emphasized gender equity and popularized the message that state socialism aimed to liberate women from poverty and unemployment. Women were encouraged to use their varied skills in order to emancipate themselves from the

${ }^{67}$ For these issues see AAN, Sygn. 237/XV-37, Wydzial Kobiecy (1949-1952), 22; AAN, Sygn. 237/XV38, Wydzial Kobiecy (1949-1952), 3, 4, 103; MiZP, 21 (20 July, 1949), 2; Przyjaciolka, 1 (2 January, 1949), 3; MiZP, 1, 1/85 (January, 1949), 3; MiZP, 29/149 (10 October, 1950), 3; Przyjaciolka, 35 (27 August, 1950), 3; MiZP, 9/165 (20 March, 1951), 2; MiZP, 8/164 (10 March, 1951), 2; MiZP, 30/222 (20 October, 1952), 2, 3; MiZP, 7/199 (1 March, 1952), 5; and MiZP, 7/199 (1 March, 1952), 2. For the idea of a 'united front' of all women, including workers, intelligentsia, housewives, and rural women, see AAN, Sygn. 237/XV-8, "Projekt Uchwaly Biura Politycznego," 7. A note on the women's periodicals used for the purpose of identifying and analyzing women's roles during this time period: the popular Przyjaciolka began its publication in 1949 with many references to building socialism, fashion and movies, cooking, gymnastics for women, and the importance of children. Stalin received a good deal of coverage in this periodical until his death in 1953 . The magazine also provided extensive coverage of the international women's forums and conferences. The women's periodical Moda i Zycie Praktyczne (MiZP) was published from 1946-1952, after which it was published under a new title Kobieta i Zycie (KiZ). Moda i Zycie Praktyczne acquainted its readers to the latest trends in foreign and native clothing and hairstyling. The magazine emphasized a fashion that was esthetic, practical, elegant, simple and economical. The periodical, though mainly about fashion, also talked about problems in marital life, major political events, cooking, contacts with women abroad, foreign films, hygiene, nutrition, and the importance of gymnastics for women. In 1952, the magazine published regular articles on physical culture for women, with at least one article in every issue. The women's periodical Kobieta i Zycie, similar to Przyjaciolka, covered issues related to fashion, children, women's role in building socialism, hygiene, physical culture for women (especially recreational skating and skiing), home and family, foreign women (especially in the GDR and Asia), international women's solidarity, articles on "mother and children", cooperative work, the struggle against alcoholism, historical references, and the work of the League of Women. The general themes of Kobieta Wiejska (published by the Instytut Nauki Oswiaty Rolniczej Przy Zwiazku Samopomocy Chlopskiej, Warsaw) included education of children, health of women and the family, food and cooking, concern for rural hygiene, working women abroad, women in Asia and Africa, and the work of the various women's organizations in promoting cooperative work. There were repeated articles on the work of the League of Women, struggles against illiteracy, cultural activities such as dance in the Rural Housewives Circles all over Poland, and the larger Polish struggle for peace. The periodical Kobieta Dzisiejsza (published by the Liga Kobiet in Warsaw), also covered topics related to children, world congresses of women, work of LK all over Poland, theater and films, fashion, remembering the contributions of famous women in struggles for independence and emancipation, health, women at work (in factories, shops, bureaus, agriculture, schools, medical profession), the importance of mothers and maternity care, cooking, women abroad (especially Indian women), child care centers, importance of marriage, women in cooperative movement, and the idea that "Kobieta Wiejska ma Glos" (The village woman has a voice).

68 AAN, Sygn. 237/XV-39, Wydzial Kobiecy (1949-1952), 53.

69 Kenney, Rebuilding Poland, 299. 
traditional patriarchal mores and brighten the future of their children and the Polish state. 70

For this reason, the imagery of Polish women during this time period was transformed from the "mother-citizen" working to rebuild the family institution to that of a "mother-worker" dedicated to building a socialist Poland. The Political Bureau of KC PZPR (Komitet Centralny Polskiej Zjednoczonej Partii Robotniczej) rejoiced at the increasing numbers of working women in this time period. According to Bierut, Polish women, with their enhanced professional qualifications, were instrumental in the process of building the new socialist state. 71 In his words, "Polish women are struggling to build the PRL, conquering new professional qualifications, and working for the success of the 6-year plan".72 Bierut's report to the IV Plenum KC PZPR explained the importance of systematic work in educating Polish women and the need to encourage their active participation in industry, in the state apparatus, and in professional unions. Both urban and rural women's contribution in socialist work was perceived as critical in rebuilding Poland. 73

Accordingly, all forms of mass media portrayed the Polish woman as a positive female heroine, free from weakness or hesitation, representing a monolithic set of virtues, and imbued with 'instinctive' wisdom to detect "spies" hiding among the 'builders of communism'.74 The press reiterated the "progressive" views of Marx, Engels, Lenin, and Stalin about the "emancipation" of women and their role in building socialism through occupational activation. 75 The following message resonated in all forms of official communication: "Polish Women! Struggle for the blossoming of economy and national culture, for strengthening the country, for obtaining peace, and for educating children in the spirit of patriotism for the PRL".76 The Polish socialist state made it quite explicit that it was determined to move beyond the traditional watchword of the Prussian Junkers, "Kinder, Kuche, Kirche", and facilitate a "real" liberation of women.77

70 Dariusz Jarosz, Polacy a stalinizm, 1948-1956 (Warsaw, 2000), 117-119.

71 AAN, Sygn. 237/XV-8, "Projekt Uchwaly," 1, 2, 6, 7, 23.

72 AAN, Sygn. 237/XV-38, Wydzial Kobiecy (1949-1952), 81.

73 Kobieta Wiejska, 3, 16 (1 December, 1949), 13; and MiZP, 21/141 (20 July, 1950), 3.

74 See Ostrowska, "Filmic Representations of the 'Polish Mother'," 425.

75 Przyjaciolka, 12 (22 March, 1953), 4. See also Mira Marody and Anna Giza-Poleszczuk, "Changing Images of Identity in Poland: From the Self-Sacrificing to the Self-Investing Woman?" in Susan Gal and Gail Kligman (eds.), Reproducing Gender: Politics, Publics, and Everyday Life After Socialism (Princeton, 2000), 151-175, p.155.

76 Przyjaciolka, 18 (3 May, 1953), 3. For a similar view of Polish women working for the welfare of their families and the Fatherland, as well as for a re-emphasis on their complete official equality with men, see KiZ, 13 (1 May, 1954), 2, 3; KiZ, 10 (1 April, 1954), 3; and Przyjaciolka, 12 (20 March, 1955), 3.

77 Przyjaciolka, 43 (24 October, 1954), 10. 
Indeed, women's active participation in physical, industrial and intellectual work during these years helped to create the Polish 'worker's republic'. The state's perception of women's work as an important national activity resulted in an impressive increase in the numbers of female workers. In the years 1952-1955 particularly, the numbers of working women grew faster relative to men. 78 In the various categories of market employment, women worked in industries, professional establishments and institutions, transportation, mining, science, medicine, engineering, and social services to fight against alcoholism and illiteracy. Textile work remained the most accessible form of employment for women, followed by the teaching profession. ${ }^{79}$ Female textile workers, however, generally included more widows. 80 The teaching profession, meanwhile, attracted mainly educated middle-class women. 81

In addition to the above-mentioned occupations, some women participated in construction work. For example, about 1500 women worked to build Nowa Huta, the first socialist town in the PRL. 82 Many other women worked in light industries and metallurgy. 83 In Lodz, for example, women comprised $61.8 \%$ of the labor force in textile industries, $86 \%$ in chemical industries, and $63 \%$ in metal works. 84 A few women served in positions of top leadership in enterprises and institutions. For example, Wanda Piotrowska served as the director of Wroclaw Monopolu Tytoniowego (Wroclaw Tobacco Monopoly). 85

While women's engagement in the labor market increased, their interest in politics remained limited. Political work to build a "happy and strong" Poland attracted

\footnotetext{
78 MiZP, 1, 7 (March, 1949), 3; MiZP, 4 (1 February, 1950), 2; MiZP, 19 (1 July, 1952), 2; MiZP, 5 (10 February, 1952), 2, 3; Przyjaciolka, 12 (20 March, 1955), 4; and Wieruszewski, Rownosc kobiet i mezczyzn, 111.

79 AAN, Sygn. 237/XV-38, Wydzial Kobiecy (1949-1952), 163; AAN, Sygn. 237/XV-8, "Projekt Uchwaly Biura Politycznego,” 21; AAN, Sygn. 237/XV-39, Wydzial Kobiecy (1949-1952), 21; Przyjaciolka, 30 (24 July, 1949), 5; Przyjaciolka, 4 (22 January, 1950), 5; MiZP, 7 (1 March 1952), 2; MiZP, 35 (10 December, 1949), 10; MiZP, 1/121 (1 January, 1950), 3; and MiZP, 1, 7 (March, 1949), 3.

80 MiZP, 25 (1 September, 1949), 3.

81 Leslie, The History of Poland, 327.

82 MiZP, 27 (20 September, 1949), 3; MiZP, 31 (1 November, 1950), 15; AAN, Sygn. 237/XV-38, Wydzial Kobiecy (1949-1952), 19; and Dariusz Jarosz, "Wybrane problemy kultury zycia codziennego kobiet pracujacych w Nowej Hucie w latach piecdziesiatych XX wieku," in Zarnowska and Szwarc (eds.), Kobieta i kultura zycia codziennego, 405-419, pp.405, 407.

83 AAN, Sygn. 237/XV-37, Wydzial Kobiecy (1949-1952), 30; and AAN, Sygn. 237/XV-8, "Projekt Uchwaly," 21.

84 AAN, Sygn. 237/XV-38, Wydzial Kobiecy (1949-1952), 151, 162.

85 See Przyjaciolka, 6 (5 November, 1950), 5.
} 
few women, and confined them particularly to the lower provincial and district levels. ${ }^{86}$ Women's restricted participation in the political apparatus in Poland and in other parts of Eastern Europe undermined the theoretical commitment of the regional political elites to consolidate their new political system by trying to win women's allegiance and urging them to join the party and become involved in politics. 87

In order to provide some legitimacy to the projected image of Polish women's solidarity with the official claim of providing more economic opportunities to women, the KC PZPR, in several resolutions throughout the course of these years, theoretically endorsed the equality of both urban and rural women with men in all realms of daily life. The constitution of the PRL, enacted on July 22, 1952, granted women equal pay for equal work, as well as equal rights to social insurance, education, and honors and distinctions. Women could hold public office, and were entitled to paid maternity leave and child care facilities. 88 Also, since professional qualifications were a prerequisite for productive market labor, the number of technical and vocational schools for girls and women increased. For example, the number of technical schools for women increased from 3,224 in 1949 to 13,927 in 1950 in Poznan. 89 More generally, the participation of women in wage and salary employment increased by $34 \%$ in 1954, with the maximum proportion of women working in textile industries (74.9\%). 90

While the Polish socialist state projected images of women's enthusiastic participation in the nation's economy, the official press also continued to project external images of Polish women working for international peace, solidarity and socialism. This was reflected in the country's enhanced commitment to the World Congress of Women. ${ }^{91}$ The KC PZPR began the precedent of narrating the achievements of Polish

86 AAN, Sygn. 237/XV-38, Wydzial Kobiecy (1949-1952), 79, 80; and Przyjaciolka, 43 (26 October, 1952), 3. Romana Braniewska was a leading authority in the Warsaw District People's Council . See MiZP, 21/141 (20 July, 1950), 6 .

87 Sharon Wolchik, "Women and the State in Eastern Europe and the Soviet Union," in Sue Charlton, Jana Everett and Kathleen Staudt (eds.), Women, the State, and Development (Albany, 1989), 44-65, p.50.

88 On women's status as 'complete citizens' and the relevant constitutional clauses, see MiZP, 1, 7/91 (March, 1949), 3; MiZP, 9/201 (20 March, 1952), 2, 3; PzS, 19 (6 March, 1952), 1; AAN, Sygn. 237/XV37, Wydzial Kobiecy (1949-1952), 25, 91; AAN, Sygn. 237/XV-38, Wydzial Kobiecy (1949-1952), 43; AAN, Sygn. 237/XV-39, Wydzial Kobiecy (1949-1952), 27, 29, 31, 51, 52, 53; and Niedzielska, Women in Contemporary Poland, 5.

89 AAN, Sygn. 237/XV-38, Wydzial Kobiecy (1949-1952), 45; MiZP, 24 (20 August, 1949), 4; MiZP, 2/122 (10 January, 1950), 3; and AAN, Sygn. 237/XV-39, Wydzial Kobiecy (1949-1952), 20.

90 Przyjaciolka, 46 (18 November, 1956), 5.

91 Przyjaciolka, 23 (7 June, 1953), 2, 3. For Polish representation at the meetings of the World Democratic Federation of Women see MiZP, 3, 39 (September, 1947), 5; MiZP, 36/120 (20 December, 1949), 2; and MiZP, 9/201 (20 March, 1952), 3. 
women on the occasion of the International Women's Day on 8th March of every year.92 Further, there are many references to Polish women's international solidarity with Asian women. The Polish women's press took a special interest in Indian women and provided good coverage of Indira Gandhi's visit to Warsaw in 1955.93

It must be emphasized that the KC PZPR closely emulated the well-established official model of Soviet women's contribution in developing its own indigenous urban and rural economies and cultures. The Polish press provided frequent references to the 'millions of Soviet women of different nationalities building socialism', to Lenin's theorization of the complete independence of women, to the Polish 'friendship' with the Soviet Union, as well as to Soviet women's active involvement in social welfare activities in Asian countries (especially India). 94

In addition, press reports discussed efforts by other East European governments to ensure women's equality with men. In Czechoslovakia, for example, the political leadership instituted propaganda campaigns to upgrade public images of female industrial and agricultural workers. 95 The New York Times in America reported that more Czechoslovak women were being employed in factories, and even in construction, mines and heavy industry. By the end of 1949, Czechoslovak women constituted $18.5 \%$ of the total number of workers in heavy industry, $44 \%$ in light industry, and $35.4 \%$ in the food industry. 96 More generally, the popular women's periodicals in Poland argued that only socialism provided women with complete independence and liberation, and with the widest opportunities to engage in cultural and professional work on a mass scale. 97

While the image of the 'mother-worker' occupied a position of extreme importance in the years 1948-1955, the traditional image of the 'woman-mother' (kobieta-matka) came in a close second. The former image had articulated the need for the Polish mother to build socialism at her place of employment and promote women's advancement within the larger national and international community. The imagery displayed in 'kobieta-matka', however, was one of Polish mothers building socialism within the home. Accordingly, women were bestowed with the supreme responsibility of

\footnotetext{
92 Przyjaciolka, 12 (20 March, 1955), 3; and KiZ, 9 (20 March, 1955), 2.

93 KiZ, 19 (1 July, 1955), 2, 3; and KiZ, 20 (10 July, 1955), 2.

94 AAN, Sygn. 237/XV-8, "Projekt Uchwaly," 5, 30; AAN, Sygn. 237/XV-38, Wydzial Kobiecy (19491952), 6; AAN, Sygn. 237/XV-39, Wydzial Kobiecy (1949-1952), 38; MiZP, 2, 44 (November, 1947), 6; MiZP, 1, 7/91 (March, 1949), 2; MiZP, 1, 4/88 (February, 1949), 3, 10; MiZP, 2, 8/92 (March, 1949), 3; MiZP, 1, 1/85 (January, 1949), 3; $\underline{\text { PzS }}, 19$ (8 March, 1951), 1; MiZP, 31/187 (1 November, 1951), 2, 3; and MiZP, 9/201 (20 March, 1952), 2, 3.

95 Sharon L. Wolchik, "Czechoslovakia," in Ramet (ed.), Eastern Europe, 35-70, p. 39.

96 The New York Times, (1, April, 1950), 7.

97 MiZP, 1, 1/85 (January, 1949), 3; and Przyjaciolka, 36 (3 September, 1950), 5, 7.
} 
maintaining an 'excellent' family life and educating the youth in a spirit of patriotism and 'internationalism'.98 An "ideal" mother was described as one who was intelligent, understanding, 'reasonable', enthusiastic about the education of her children, and effective in restraining the 'oppositionist' ideologies of the 'dissolute' youth.99 Motherhood was perceived as a valuable contributing agent to the well-being of communist Poland. It was not good enough for women to simply give birth to children; rather, a woman was expected to give birth to the 'future working-class members' 100

To enable women to accomplish their duties as socialist mothers, the progressive Family Code of March 1950 and the constitution of 1952 placed marriage, motherhood, and family under the care and protection of the state. These official statutes recognized marriage as an important social and national institution. Women were presumably equal in marriage and had equal right to common property in the marital union. In addition, divorce procedures were simplified (especially if the children were not adversely affected), and children born in and out of wedlock granted equal rights. The state allowed women to keep their birth family names, and even prosecuted men for making their wives adopt their last names. The names of children were left to the parents to decide. The constitution of 1952 provided protection for mothers and children, granted paid vacation during maternity, and reaffirmed the need to build childcare centers and preschools. The parents were made responsible for the intellectual, physical and spiritual development of their children, in consonance with the new socialist morality. 101

Basically, all women, whether they worked or not, were expected to bear children for the welfare of the state. The state offered higher inducements to mothers with large families. The regime discouraged the use of contraceptives and formulated an elaborate system of awards and advantages to confer on 'mother heroines'.102 The party leadership confirmed its commitment to building pre-schools and child care centers, as well as other institutions and facilities with the help of trade unions for working mothers

98 AAN, Sygn. 237/XV-8 "Projekt Uchwaly," 7; AAN, Sygn. 237/XV-37, Wydzial Kobiecy(1949-1952), 34, 38; AAN, Sygn. 237/XV-38, Wydzial Kobiecy (1949-1952), 106, 165, 167; PzS, 42 (30 May, 1950), 4; MiZP, 30/222 (20 October, 1952), 2, 3; and Przyjaciolka, 11 (16 March, 1952), 3.

99 MiZP, 2, 2/86 (January, 1949), 15.

100 Ostrowska, "Filmic Representations of the 'Polish Mother'," 426.

101 AAN, Sygn. 237/XV-8, "Projekt Uchwaly," 6, 20; AAN, Sygn. 237/XV-37, Wydzial Kobiecy (19491952), 91; AAN, Sygn. 237/XV-39, Wydzial Kobiecy (1949-1952), 24; MiZP, 1, 7/91 (March, 1949), 3; MiZP, 20/104 (10 July, 1949), 2; MiZP, 28/148 (1 October, 1950), 10; MiZP, 29/149 (10 October, 1950), 10; Przyjaciolka, 11 (12 March, 1950), 3; Przyjaciolka, 15 (9 April, 1950), 3; Przyjaciolka, 35 (27 August, 1950), 5; Przyjaciolka, 5 (3 February, 1952), 7-11; MiZP, 27/219 (20 September, 1952), 3; MiZP, 7/199 (1 March 1952), 2, 5; Wieruszewski, Rownosc kobiet i mezczyzn w Polsce Ludowej, 55; and Niedzielska, Women in Contemporary Poland, 23, 24.

102 Staar, Poland 1944-1962, 101. 
and their children. 103 The need for the systematic and planned building of social institutions such as creative-educational centers, schools, libraries, kindergartens and daycare facilities was repeatedly emphasized by the state. 104 It was reported that as late as 1939, there were only 32 child care centers with room for 520 children. But in Stalinist Poland, the number of preschools exceeded over 5,000 and accommodated 260,000 children of working-class families. 105

Thus, during the years 1949-1955, women were bestowed with the dual task of building socialism both within the home and at the work place. The state identified women as pioneers of building a new kind of life for the PRL. Their socialist duties included the education of children in a patriotic spirit, work in new professions, raising the level of education in both towns and the countryside, and safeguarding their families from the social ills of alcoholism, prostitution, speculation, and illiteracy. In addition, women in the countryside were expected to engage in cooperative production and struggle against the perceived opponents of the state's agricultural policies. 106

To achieve these various "progressive" goals, the Polish communist party used the different women's organizations to assist and effect women's "real" liberation under state socialism. From March 1950 onward, the Political Bureau of the KC PZPR sought to direct the work of LK toward engaging the maximum numbers of women from both urban and rural backgrounds in promoting the socialist identity of the PRL in accordance with the objectives of the Six Year Plan. Under the presidency of Alicja Musialowa, the LK elaborated an ambitious program of socialist construction that projected a united front of urban and rural women working together to build a prosperous and peaceful nation. In terms of membership, the LK registered an increase in numbers from 730,000 in 1948 to $1,390,000$ on October $1,1949.107$

In the years between 1945-1952, the LK committed the organization to creating a national front of all families in the struggle for peace and socialism. It sought to accomplish this objective in several programs, all of which aimed to create both new opportunities for women to find employment, and promote cultural and enlightened work among women in the various professional, social, economic and political fields. The LK formed separate departments for supervising a number of tasks such as the organization

103 KiZ, 16 (1 April, 1954), 2; and Przyjaciolka, 12 (20 March, 1955), 3.

104 AAN, Sygn. 237/XV-8, "Projekt Uchwaly," 17, 26; AAN, Sygn. 237/XV-39, Wydzial Kobiecy (19491952), 24, 94, 95; and Przyjaciolka, 30 (24 July, 1949), 5.

105 AAN, Sygn. 237/XV-38, Wydzial Kobiecy (1949-1952), 79.

106 Przyjaciolka, 5 (30 January, 1949), 5; and Przyjaciolka, 41 (12 October, 1952), 3.

107 For these membership numbers, see AAN, Sygn, 237/XV-8, "Projekt Uchwaly," 14. 
of the League, press and publication, education, foreign affairs, maternity and child care, cooperative production, law and legal issues, and rural affairs. With the cooperation of social workers, female lawyers, psychologists, pedagogues, and doctors, the LK also organized consulting centers to help women. In the countryside, the LK, in association with the party and affiliated peasant organizations such as the ZSCh, struggled against the "kulaks" and speculators. The organization also formed many "model houses" for rural women.

Further, the LK was concerned about issues related to alcoholism among men and the concomitant 'social sicknesses', advancement of education for the younger generation, literacy campaigns for women to make them more 'creative', and popularizing cultural activities such as art, reading, movies, games, dance, and singing competitions. The LK sought to uplift the ideological level of all women, institutionalize facilities for maternity care and protection of children, promote cooperative work, wage a class struggle against the rich, work to improve health and hygienic conditions, improve the quality of women's daily life, and provide opportunities for women to strive for the strength and progress of the newly emerging socialist nation. The LK organized professional schools for women with courses in home economy, haircutting, textile work, and nursing to name a few. Meanwhile, in its foreign policy, the LK worked to foster the spirit of patriotism and international solidarity. Under Soviet direction, its members took part in all conferences and meetings of the International Democratic Women's Movement (SDFK) to discuss issues of 'peace, equality and democracy'.108

During the years 1949-1952, the Women's Department of the Central Committee KC PZPR (Wydzial Kobiecy KC PZPR) also played a positive role in increasing work opportunities for women. Under the direction of the party, the Women's Department strived to promote women's cooperative production work, oversaw the central and provincial activities of LK, helped increase the participation of women in all party organizations, and expressed the need to raise rural women's self-awareness. In addition, the organization elaborated programs for developing schools, created facilities for

108 For the activities of the LK from 1949-1952 see AAN, Sygn, 237/XV-8, "Projekt Uchwaly," 7, 14, 34, 35; AAN, Sygn. 237/XV-30, Wydzial Kobiecy (1949-1952), 1; AAN, Sygn. 237/XV-38, Wydzial Kobiecy (1949-1952), 14; AAN, Sygn. 237/XV-39, Wydzial Kobiecy (1949-1952), 1, 4, 16, 18; Przyjaciolka, 5 (30 January, 1949), 5; MiZP, 2, 8/92 (March, 1949), 3; MiZP, 16/100 (1 June, 1949), 12, 13; MiZP, 29/149 (10 October, 1950), 2. MiZP, 21/141 (20 July, 1950), 3; MiZP, 29/149 (10 October, 1950), 3; Przyjaciolka, 34 (20 August, 1950), 5; Przyjaciolka, 5 (4 February, 1951), 12; Przyjaciolka, 9 (4 March, 1951), 3; Przyjaciolka, 10 (11 March, 1951), 5; Przyjaciolka, 11 (18 March, 1951); Przyjaciolka, 52 (30 December, 1951), 8; MiZP, 6/162 (20 February, 1951), 2; MiZP, 7/163 (1 March, 1951), 2, 3; MiZP, 8/164 (10 March 1951), 3; MiZP, 2/194 (10 January, 1952), 7; MiZP, 27/219 (20 September, 1952), 3; and Niedzielska, Women in Contemporary Poland, 40, 41. 
maternity care and child care centers, struggled against illiteracy and prostitution, worked in women's clerical organizations, educated children in socialist morality, supervised the "progress" of Lodz textile female workers, and worked among young women in "Sluzba Polsce" ("Service to Poland"). According to the director of the Women's Department, Edwarda Orlowska, women not only enjoyed equality in marriage, but were also increasing their participation in building the socialist economy that would eventually create conditions for the complete liberation of women. 109

The National Council of Polish Women (Krajowa Rada Kobiet Polskich, KRKP), similar to the other women's organizations, also worked in unison with the party in building socialism. 110 Meanwhile, the various rural women's organizations and associations launched a "revolution in manners" to arouse peasant women's selfconsciousness. These organizations sought to defend rural women's 'public space', encourage a 'rational upbringing' of children, facilitate the social and economic rural infrastructural development, combat alcoholism, and improve peasants' material and social welfare. 111

The development of cooperative work among rural women remained the most urgent task of the communist authorities in the Polish countryside. Peasant women were burdened with too many problems and responsibilities, including the education and upbringing of children, sometimes almost exclusively. The cooperative movement was designed to ease women's obligations in the home economy, provide care for children, and improve agrarian production. Organizations such as the ZSCh, Rural Housewives Circles, LK, Community Women's Councils (Gminne Rady Kobiece), and the Polish Red Cross worked to improve rural health, scientifically modernize the agrarian economy with mechanization and electrification, provide social welfare, and promote culturaleducational activities. They sought to build libraries, cultural houses, and enlightened community centers for the rural population. They expressed the need to struggle against alcoholism and illiteracy, wage rural 'class struggle', and promote campaigns of

109 AAN, Protokol z odprawy kierowniczek wojewodzkich wydzialow kobiecych, odbytej w dniu 16.XII.1949, Sygn. 237/XV-I, Wydzial Kobiecy (1949-1952), 89, 100; AAN, Sygn. 237/XV/3, Plan pracy wydzialu kobiecego KC PZPR/ miesiace: pazdziernik, listopad, grudzien 1949, Wydzial Kobiecy(19491952), 34-53; AAN, Sygn. 237/XV-8, "Projekt Uchwaly," 31, 32; Przyjaciolka, 10 (6 March, 1949), 5; Przyjaciolka, 35 (27 August, 1950), 5; Przyjaciolka, 36 (3 September, 1950), 5; Przyjaciolka, 41 (8 October, 1950), 5; and Przyjaciolka, 46 (12 November, 1950), 5.

110 AAN, Sygn. 237/XV-38 Wydzial Kobiecy (1949-1952), 20; AAN, Sygn. 237/XV-39, Wydzial Kobiecy (1949-1952), 81, 82, 84; and MiZP, 26/146 (10 September, 1950), 2.

$111 \underline{\text { KiZ, }} 14$ (7 April, 1963), 3; and $\underline{\text { KiZ, }} 23$ (5 June, 1985), 5. See also Dariusz Jarosz, "Wzory osobowe i modele awansu spolecznego kobiety wiejskiej w Polsce w prasie periodycznej z lat 1949-1955," in Zarnowska and Szwarc (eds.), Kobieta i edukacja, Cz.I, 253-266. 
'ideological indoctrination' in the countryside. They placed special stress on helping women to 'rationalize' the management of their households, and discussed ideas of creating a "modern housewife" and a "practical woman". Overall, the cooperatives helped in technical progress in farm work, provided home-based work for women, organized recreational facilities in the countryside, and made efforts to increase women's self-consciousness. 112

The following table shows a dramatic increase in female membership in rural women's circles during these years 113 :

$\begin{array}{lll} & \frac{\text { Circles }}{2000} & \underline{\text { Members }} \\ 1946 & 4000 & 190,000 \\ 1947 & 16,000 & 693,000 \\ 1948 & 30,000 & 1,115,000 \\ 1949 & 40,000 & 1,500,000 \\ 1950 & & 2,000,000\end{array}$

All these various images of urban and rural women's enhanced commitment to jubilantly fulfilling socialist hopes and aspirations reinforced the official rhetoric of gender-based discrimination, women's "total" liberation, and women's extensive participation in all spheres of social, economic and cultural life. It was reported that for the first time in the history of Poland, women's affairs had entered on a "radical" path. 114 However, did the socialist words of affirmative action actually effect a radical transformation in the situation of women? Did the propaganda images reflect reality? Were Polish women enthusiastic collaborators of the state in building a socialist Poland? Or were they embittered resisters who protested the state's intrusion in their daily lives?

112 MiZP, 13 (November, 1946), 7, 8; Kobieta Wiejska, 1, 1-2 (February, 1947), 22; Kobieta Wiejska, 1, 7-8 (July-August, 1947), 126; Kobieta Wiejska, 1, 12 (December, 1947), 230; Przyjaciolka, 30 (24 July, 1949), 5; Kobieta Wiejska, 3, 5 (May, 1949), 110; Kobieta Wiejska, 3, 15 (15 November, 1949), 2, 7; MiZP, 25/181 (1 September, 1951), 2; AAN, Sygn. 237/XV-8, Title: Projekt Uchwaly Biura Politycznego w Sprawie Pracy Wsrod Kobiet, Wydzial Kobiecy (1949-1952), 7, 14, 18, 25, 29; AAN, Sygn. 237/XV-39 Wydzial Kobiecy (1949-1952), 22, 41, 42, 44; AAN, Sygn. 237/XV-38 Wydzial Kobiecy (1949-1952), 10, 117, 118, 124, 154; AAN, Sygn. 237/XV-32 Wydzial Kobiecy (1949-1952), 14, 15, 16, 50, 65; Niedzielska, Women in Contemporary Poland, 43, 44, 46; and Women in the Polish Cooperative Movement (Warsaw, 1963), 5, 6, 10, 20, 27. See also AAN, Sygn. 237/XV-6, "Sprawozdanie z partyjnego zebrania chlopskiego w powiecie Sokolskim/ woj.Bialostockie / odbytego w dn. 15 Stycznia 1949, Wydzial Kobiecy (1949-1952)". This folder contains lots of information on cooperative work for women. Up to 1952 at least, the main theme is women's work, especially in the cooperatives.

113 AAN, Sygn. 237/XV-39 Wydzial Kobiecy (1949-1952), 44.

114 AAN, Sygn. 237/XV-8, "Projekt Uchwaly," 5, 6, 20. 
Were women energetic or frustrated "patriots" of state socialism? These questions are important to examine since the Polish female athletes would face similar tensions and contradictions between "imagery" and "reality".

During the early years of socialist construction, the editorial office of the women's periodical Przyjaciolka received many letters from urban women expressing their concern and anguish over several issues. These letters, mostly anonymous and critical-argumentative in form, and averaging two to six daily, addressed problems related to the regime's anti-clerical stance, the collectivization of agriculture, unemployment, official propaganda (especially women's objections to official praise for Soviet films), the repatriation of Polish families from USSR, the status of invalids and widows, the hard material conditions, the 'misguided' ideology of LK, the medical problems, the lack of attention to the Katyn massacre, the nature of official contacts with foreign countries, alcoholism, the maltreatment of women, divorce, and the lack of meat and the need to ban its export. 115

The party's anti-Catholic bias particularly irked a majority of these women. ${ }^{116}$ They were concerned about the state's "struggle with God" and the elimination of religious teaching in schools, which according to the female protesters, resulted in a "crisis in the schools". 117 The strong clerical influence in cities such as Lodz, Krakow, Bialystok, and Gniezno thwarted the efforts of the "communists".118 Other letters expressed indignation with the 'Jewish hypocrisy' of LK and its 'Bolshevik-agitation'. A few letters questioned "where is democracy", "where is equality", and "where is food"? Many other letters were quite blunt in stating that "what is reality and what is written are very different." One letter exclaimed in surprise, "the Soviet Union rebuilding Warsaw?!"119 Shortages of food and especially the lack of meat was very troublesome

115 AAN, Sygn. 237/XV-31, Wydzial Kobiecy (1949-1952). In this file, see in particular, Reports from 21 January, 1949, pp. 1, 3, 5, 6, 7. See also Reports from 28 March, 1949, pp. 48, 51, 52 for problems related to anti-semitism and collectivization.

116 AAN, Sygn. 237/XV-31, Wydzial Kobiecy (1949-1952), Reports from 12 February, 1949, pp. 9, 19, 36.

117 AAN, Sygn. 237/XV-31, Wydzial Kobiecy (1949-1952), Reports from 26 February, 1949, p.20.

118 AAN, Sygn. 237/XV-I, "Protokol z odprawy kierowniczek wojewodzkich wydzialow kobiecych z dnia 12.8.1949, Wydzial Kobiecy (1949-1952)," 31, 33, 39, 42. For religious discontent see also AAN, Sygn. 237/XV-6, "Sprawozdanie z partyjnego zebrania chlopskiego w powiecie Sokolskim/ woj. Bialostockie/ odbytego w dn.15 Stycznia 1949, Wydzial Kobiecy (1949-1952)," 1.

119 AAN, Sygn. 237/XV-31, Wydzial Kobiecy (1949-1952), Reports from 26 February, 1949, pp.23-32. See also AAN, Sygn. 237/XV-31, Wydzial Kobiecy (1949-1952), Summary of reports for 1949, pp.148164. Here, there are more complaints on the failures of LK and its unwillingness to help women. There are also more references to problems related to health, housing, 'hatred' toward USSR, fear of collectivization, lack of professional courses for girls, and to the unfriendly atmosphere in the Union of Polish Youth (ZMP), especially for women. 
for many women. Some wrote: "Let our Polish pigs and poultry not be exported to the world". 120 They also expressed dismay over the very small numbers of women in the higher party apparatus and the limited professional qualifications and opportunities available to women. 121

Further, women criticized the organizational work of the women's department of KC PZPR and the LK, and accused these women's organizations and district committees for conducting their activities with extreme arbitrariness. 122 In Krakow province, there was complete lack of coordination between the ZSCh (The Union of Peasant Self-Help) and the other organizations. 123 The Krakow Provincial and District Women's Council of the ZSCh was simply a "fiction" or sham. Even the work of the women's department in Krakow province remained weak. 124

In Wroclaw province, both the community women's councils and the ZSCh were not particularly successful in promoting women's work. In this region, the children's nurseries were said to have been plagued by "adversary" propaganda. The Women's Department also remained weak in the Gdansk and Szczecin regions. In the latter, the trade unions opposed the work of the women's department. 125 According to Malgorzata Tarasiewicz, former coordinator of the Women's Section of Solidarity formed in 1989, the communist party instrumentalized women's organizations. While the legal system in Poland was favorable to women, as in other East European countries, a great discrepancy existed between the legal system and the social reality. The communist-controlled Women's League, with its conformist memberships, provided destructive and demoralizing examples of women's organizations. 126

While urban women expressed their resentment toward state authorities in writing, rural women participated in active forms of resistance to emphasize their discontent with official policies. Peasant women generally avoided collective work even when their husbands had joined the cooperatives. They blocked the paths of tractor

120 AAN, Sygn. 237/XV-31, Wydzial Kobiecy (1949-1952), Reports from 12 March, 1949, p. 38.

121 AAN, Sygn. 237/XV-38, Wydzial Kobiecy (1949-1952), 155, 156.

122 AAN, Sygn. 237/XV-6, Sprawozdanie z pobytu w wojewodztwie Bialostockim w dniu 11 Pazdziernika 1951, Wydzial Kobiecy (1949-1952), 22.

123 AAN, Sygn. 237/XV-I, Protokol ze wspolnego posiedzenia ZSCh, CRS, i Ligi Kobiet odbytego dnia 20.X.1951, Wydzial Kobiecy (1949-1952), 108.

124 AAN, Sygn. 237/XV-I, Protokol z odprawy kierowniczek wojewodzkich wydzialow kobiecych z dnia 12.8.1949, Wydzial Kobiecy (1949-1952), 42.

125 AAN, Sygn. 237/XV-I, Protokol z odprawy kierowniczek wojewodzkich wydzialow kobiecych z dnia 12.8.1949, Wydzial Kobiecy (1949-1952), 42, 43, 44.

126 Lisa DiCaprio and Merry E. Wiesner, Lives and Voices: Sources in European Women's History (Boston, 2001), 605-612. 
drivers and surveyors, and threatened to abandon their families or demand a divorce. For this reason, the regime's collectivization plans caused a "disruption to marriages". 127 More generally, daily life for rural women was hard and time-consuming. They lacked basic services, remained poorly educated, and lived in patriarchal family structures. Even though rural women 'feminized' agriculture as a consequence of male migration to urban centers, and independently performed multiple agrarian production activities, they lacked any sense of personal liberation. Their role and authority within the peasant households increased in the absence of men and with greater contact with women's organizations. However, rural women's onerous work in the countryside undermined all efforts to improve their physical and mental strength. 128

Thus, during the years 1948-1955, Polish women expressed dismay over a multitude of problems such as the limited numbers of preschools and childcare centers, the hardships of daily life, the primitive living conditions without electricity and gas, the ghettoization of women at the lower levels of workplace, the invincibility of social and cultural resistance to women's organizational work, the combined obligatory burden of motherhood and employment, and family related problems which included issues of alimony, divorce, alcoholism, prostitution, and domestic violence. 129 "Real" discussions of a women's movement and emancipation were consigned to the realm of questionable bourgeois ideologies. Men and women had equal legal rights, but women were still "alienated" and "estranged". 130 Women's departments in party and union organizations were small and neglected, and achieved little to alleviate the domestic burdens of mothers

127 Dariusz Jarosz, "Polish Peasants Versus Stalinism," 63, 64.

128 Jarosz, Polacy a stalinizm, 120, 141, 142; Wieruszewski, Rownosc kobiet i mezczyzn, 200, 202, 204; and Zofia Morecka, Danuta Graniewska, Adam Kurzynowski and Barbara Tryfan, "Aktywnosc zawodowa kobiet," in Kobieta w Polsce: Referaty na swiatowa Konferencje dekady kobiet ONZ, 1/104 (Warsaw, 1986), 36-59, pp. 47, 49. For the 'ruralization of towns' and 'feminization of agriculture' see also Leslie, The History of Poland, 446, 450; and Louise Kruszewski Stein, The Political Economy of Health and Fertility: The Case of a Group of Rural Polish Women (Dissertation, State University of New York at Buffalo, 1983), ix, x, 32, 221, 222, 226. In the 1970s and 1980s, this rural migration to urban centers included young rural women. See Wieslaw Siwinski, Mieszkancy wsi wobec kultury fizycznej i turystyki (Poznan, 1986), 19.

129 MiZP, 3, 15/63 (May, 1948), 2; Przyjaciolka, 6 (6 February, 1949), 12; Przyjaciolka, 11 (12 March, 1950), 3; Przyjaciolka, 35 (27 August, 1950), 5; MiZP, 21/141 (20 July, 1950), 3; Przyjaciolka, 15 (15 April, 1951), 12; MiZP, 3/195 (20 January, 1952), 2; and KiZ, 5 (1 February, 1981), 6-8. For issues related to prostitution see AAN, Sygn. 237/XV-1, Wydzial Kobiecy (1949-1952), 1; and AAN, Sygn. 237/XV-36, Wydzial Kobiecy (1949-1952), 1. For issues related to alcoholism see MiZP, 21 (March, 1947), 14; and Przyjaciolka, 24 (15 June, 1952), 10. For a good description of women's hard daily life at Nowa Huta, as well as issues related to alcoholism, prostitution, forced rape, and 'glaring violations of morals' see Jarosz, "Wybrane problemy kultury zycia codziennego kobiet pracujacych w Nowej Hucie w latach piecdziesiatych XX wieku," 408-419.

130 Walczewska, Damy, rycerze, i feministki, 11, 112. 
and wives. Sure enough, women's labor culture was more extensive than in the earlier time periods, and it encompassed their factory as well as their home and their church. But nightshifts, overtime, child-care problems and the difficulties of running a household left little space and time for women to enjoy their supposed intellectual, professional and physical liberation. This double bind, along with the premium placed on activism, encouraged not the emancipation of women workers but their resubjugation under state socialism. 131

Given the numerous hardships which women endured in these years, it is indeed surprising that many of them actually found the time and energy to participate in sports! Who were the Polish sportswomen and how were they able to display such phenomenal athletic prowess in the midst of deep economic, political and cultural instabilities within the socialist system? How did Polish physical culture develop under stalinism and what was its impact? And did the official imagery conform to reality in the Polish sports apparatus?

During the years between 1949-1955, Polish physical culture was orchestrated by the communist authorities to popularize the state's rhetoric of socialist morality through the medium of sports. Physical education was emphasized for instilling "disciplined" and "regulated" passions of solidarity, collectivism, patriotism, and internationalism, especially in the youth, workers, and peasants. Boleslaw Bierut and the other political elites reiterated the importance of sport for reasons of maintaining good health and physical strength, for the "modest" and "dignified" upbringing of the socialist citizenry, and for peace and happiness. ${ }^{132}$ Premier Jozef Cyrankiewicz and the Minister of National Defense, Marshal Rokossowski both reaffirmed the need for a dynamic physical culture and sport in promoting ideas of socialism and democracy, as well as for the good health of the nation and for the moral education of workers and the youth. 133 The Vice Minister of Education, Dr. Henryk Jablonski, also emphasized the need for physical education in schools. 134

131 See Kenney, Rebuilding Poland, 89, 102, 103, 124, 151, 301, 302 for female workers in Lodz and Wroclaw. See also Jarosz, Polacy a stalinizm, 120, for the injurious effects of women's work on their physical health and strength during the stalinist period in Poland.

132 MiZP, 4/160 (1 February, 1951), 2; MiZP, 1, 1/85 (January, 1949), 2; MiZP, 2, 2/86 (January, 1949), 2; PzS, 19 (6 March, 1952), 4; PzS, 31 (18 April, 1952), 1; MiZP, 25/217 (1 September, 1952), 10; PzS, 31 (21 April, 1950), 2; PzS, 19 (5 March, 1953), 2; PzS, 29 (10 April, 1953), 1; and Chelmecki and Wilk, Wybor zrodel i materialow, 87, 93.

133 PzS, 12 (9 February, 1950), 1; and PzS, 15 (20 February, 1950), 1, 3, 4.

$134 \underline{\mathrm{PzS}}, 47$ (15 June, 1950), 3. 
During the years 1948-1952, Polish physical culture aggressively emulated the Soviet organization of sports. The USSR was officially recruited as the 'athletic mentor' of Poland. The Soviet state took pride in its ability to create, for the first time in history, conditions for the physical and moral development of millions of working people. 135 The Soviet sports players read Stalin's biography and studied both the history of the Bolshevik party and the theory of Marxism-Leninsm. Sports teams viewed "appropriate" films, attended "educational" lectures, and visited museums and historic sites so as to construct a "healthy and progressive" socialist sports culture. While the "hooligan culture" never quite disappeared, the Soviet state from the very beginning took pride in the strength and might of its physical culture which nurtured record-setters and champions, as well as millions of ordinary athletes, all of whom raised the high standard of athletics in the USSR. 136

Accordingly, sports in Poland followed the model of the supposedly egalitarian, rational, and mass-based apparatus of Soviet physical culture. A law of February 25, 1948 referred to the "universal duty of occupational training, physical education and military training of young people and the organization of physical education and sports". 137 This resolution developed a broad program to popularize and democratize Polish physical education and sport. In the same month, the Central Office for Physical Culture (GUKF, Glowny Urzad Kultury Fizycznej) was established. On 20th December 1948, another parliamentary bill openly introduced the Soviet model of physical culture. ${ }^{138}$ In an address delivered in April 1949, Bierut confirmed the importance of physical culture and the sports movement in building socialism. On 28th September 1949, the Political Bureau of the KC PZPR passed an important political resolution which officially placed physical culture in the service of building the socialist 'Fatherland' and marked the real beginning of a new stage in the development of Polish physical culture and sports.

Thereafter, all state resources, including the mass media (radio, film, and print media), educational institutions, and sports unions and associations, were employed to fulfill this official objective of constructing socialism in both the urban and rural physical cultures. On 30th December 1949, the Main Committee for Physical Culture (Glowny

\footnotetext{
135 Soviet Woman, (1948), 56, 57.

136 Soviet Woman, $(1948), 56,57$.

137 Karpinski, Poland since 1944, 26, 27.

138 PzS, 17 (26 February, 1948), 1; Kedziorek, "Upowszechnienie kultury fizycznej," 22, 23; Chelmecki and Wilk, Wybor zrodel i materialow, 29, 33, 41, 42; Brzezicki, Drazdzewski, Podoski, and Romanski (eds.), Ksiega sportu polskiego, 18; Lysakowski, Panstwowa adminstracja, 14; Grys, Muzyka i sport, 122; Wroczynski and Hadzelek, "Development of Sciences," 90; and Liponski, "Still and Unknown," 21-24.
} 
Komitet Kultury Fizycznej, GKKF) was founded to control, direct, and maintain uniformity in the affairs of Polish physical culture and sports. The GKKF was invested with the centralized management of sports training and research, as well as its finances, propaganda, and international affairs. This principal central sports organization was assisted by its various branches in the towns (MKKF), provinces (PKKF) and districts (WKKF). The GKKF also received guidance from the ministries of National Defense, Health, Education, Public Safety, and Culture. In addition, the GKKF worked closely with youth organizations and the Union of Peasant Self-Help (Zwiazek Samopomocy Chlopskiej). Such cooperative work was consistent with GKKF's larger goal to initiate the dynamic development of sports in the urban areas and in the countryside, with an emphasis on attaining quick national and international achievements and recognition. ${ }^{139}$

Furthermore, Soviet-style departments or sections within the Main Committee for Physical Culture replaced the earlier federations and clubs. Akin to the Soviet system, Polish sport was divided into multi-sport federations operating in different areas of Polish society. Thus, the trade unions organized sports clubs for the workers, the military for the armed forces, and the rural organizations for the peasants. Private sponsorship was excluded, democratically-elected executive bodies were replaced by nominated officials, and voluntary sports activists were relieved by imposed bureaucrats who were, according to the then popular Polish expression 'brought in the bag from Warsaw'. 140 Thus, the Polish physical culture underwent an extensive structural re-organization and witnessed a marked official concern for indoctrinating various social groups in the socialist ideology through the medium of sport and physical culture. All centralized policies in physical culture were now directed toward popularizing sports among all social classes, including the youth, workers, women, and farmers. 141

To achieve this socialist objective, the state boldly proclaimed the need to construct many stadiums and sports halls, public parks and cultural centers, tourist facilities and other modes of modern communications, and health clinics and

139 For all these issues see $\underline{\mathrm{PzS}}, 78$ (29 September, 1949), 1, 2; PzS, 95 (28 November, 1949), 4; Lysakowski, Panstwowa adminstracja, 18; Chelmecki and Wilk, Wybor zrodel i materialow, 66-73, 76, 77, 79, 84; Gaj in Gaj and Hadzelek, Dzieje kultury fizycznej, 240; Kedziorek, "Upowszechnienie kultury fizycznej," 22, 23; Szczepanski, "Prasa," in Wychowanie fizyczne i sport w 40-leciu PRL, 137-146, p.140; Mlodzikowski, "Wklad i funkcje kultury fizycznej," 530; PzS, 79 (3 October, 1949), 1, 2; Dall, Kultura fizyczna i sport w Polsce Ludowej, 10-12; Gondek, Kultura fizyczna w Polsce, 18; Gaj, Wychowanie fizyczne, 20, 21; Wroczynski and Hadzelek, "Development of Sciences," 90, 91; and Reczek, The Development of Physical Culture in Poland, 17, 18.

140 Liponski, "Still and Unknown," 25, 26.

141 PzS, 85 (26 October, 1950), 4; Przyjaciolka, 12 (19 March, 1950), 8; Przyjaciolka, 13 (26 March, 1950), 7; PzS, 41 (25 May, 1951), 3; Wieczorek, "Problemy," 7; and Gaj, Wychowanie fizyczne, 21, 22, 23, 33. 
institutions. ${ }^{142}$ Meanwhile, Article 59 of the 1952 constitution granted the right to rest and recreation to all citizens. 143 The state organized many national races, spring marches, and Soviet-style spartakiads to project images of a popular Polish sports culture which incorporated both the urban and rural areas and which included the participation of thousands of people in these festive events. ${ }^{144}$ Further, in an effort to stimulate the development of physical culture, the GKKF adopted the Soviet slogan of "Sprawny do pracy i obrony" ("Ready for Work and Defense", SPO) in its resolution of 17 April 1950. 145 The Polish press continuously emphasized Polish-Soviet 'sporting friendship' and displayed Stalinist images of the shining bold youth engaging in mass calisthenics. ${ }^{146}$

Under state direction and surveillance, Polish physical culture, similar to the Soviet Union, experienced a dynamic development during the years 1949-1955. The Soviet 'sports industry' boasted of a sophisticated material and technological sports base with 850 stadiums, 264 outdoor swimming pools, over 12,000 multi-purpose gyms, and more than 125,000 playgrounds and soccer fields. Sports goods were manufactured by 480 specialized enterprises. ${ }^{147}$ In Poland, the number of sports organizations also increased from 7,411 in 1949 to 22,187 in 1955. ${ }^{148}$ Non-communist sports clubs were emasculated, and many other sports unions were integrated with central sports organizations. Anything suspected of having a trace of 'bourgeois legacy' was automatically closed down. ${ }^{149}$ For example, in 1951 the Polish Union of Track and Field (Polski Zwiazek Lekkiej Atletyki) was amalgamated into the section of Track and Field of GUKF. 150 Traditional names of clubs were changed to names more appropriate

142 MiZP, 19/175 (1 July, 1951), 2, 11; and MiZP, 27/219 (20 September, 1952), 2.

143 Przyjaciolka, 5 (3 February, 1952), 7-11.

144 Tuszynski, Prasa i sport, 290.

$145 \underline{\text { PzS }}, 98$ (11 December, 1950), 1; PzS, 100 (18 December, 1950), 2, 3; Przyjaciolka, 48 (2 December, 1951), 14; $\underline{\mathrm{PzS}}, 30$ (16 April, 1951), 3, 4; Kedziorek, "Upowszechnienie kultury fizycznej," 22, 23; Gutowski, Drogi rozwoju kultury fizycznej, 78; Gondek, Kultura fizyczna w Polsce, 21, 24; and Chelmecki and Wilk, Wybor zrodel i materialow, 80, 81 .

146 For references to the importance of the USSR in building sports in Poland, as well as to images of Stalin and sports in other socialist countries such as the GDR, see PzS, (21 April, 1945-21 April, 1950), 6; $\underline{\text { PzS }} 100$ (18 December, 1950), 1; Przyjaciolka, 13 (26 March, 1950), 7; PzS, 89 (15 October, 1951), 1; $\underline{\mathrm{PzS}}, 16$ (23 February, 1950), 3; Zurawlew, Stakelberg, Jananis, Codzienna Gimnastyka Kobiet, 5, 6; and Krawczyk, "Elementy historii wychowania fizycznego," 223. For more details on the nature of the sports press coverage see Tuszynski, Prasa i sport, 290; and Kenney, Rebuilding Poland, 254, 337.

147 Zaseda, The Sporting Ukraine, 8.

148 Tuszynski, Prasa i sport, 289, 290.

149 Rothschild, Return to Diversity, 95; and Liponski, "Still and Unknown,” 25, 26.

150 Ignacy Krzewinski, "Dzialalnosc organizacyjna PZLA w czterdziestoleciu Polski Ludowej," in Wychowanie fizyczne $i$ sport $w$ 40-leciu PRL, 97-118, p.103. On the liquidation of sports unions, see also Gawlak-Kica, Rozwoj kultury fizycznej, 265. 
to the new social and political system. For example, Warta in Poznan became Stal (Steel). 151 Meanwhile, the Scouting Union (ZHP) was slowly penetrated by the communists and $80 \%$ of ZHP's 'old, reactionary' instructor cadres were eliminated. 152 The Polish scouts especially played a critical role in popularizing and glorifying the stalinist model of education for the youth. Scout teams were instructed to inculcate an atheist spirit in the minds of the youth. Accordingly, the ZHP organized sports and other cultural activities to draw the children away from the practice of religion. The scouts also used their puppet theatre to propagandize anti-religious sentiments and teach the children that the church was an instrument of exploitation. 153

In the armed forces, the organization of military sports clubs was subject to the centralized control of the Central Army Sports Club (Centralny Wojskowy Klub Sportowy) in the early 1950s. 154 Similar to that of the Red Army in the Soviet Union, the Polish army played an important role in patronizing sports for the good of the country. In the Soviet Union, the army was able to construct excellent sports facilities and organize a number of sports, especially hockey and soccer, more quickly and effectively than the less endowed institutions. In the wake of victory over the Nazis, the army had come to enjoy unparalleled popularity in society, and its sports organizations were able to translate this support into strength on the playing field. ${ }^{155}$ The Polish army imitated the successes of its Soviet counterpart, though with less dynamism and excellence.

For the Polish youth, the state organized the para-military movement, "Service to Poland" (Sluzba Polsce, 1948). Its primary objective was not really premilitary training or physical preparation for the army, or even the utilization of free manpower on construction projects all over Poland, though all of these aspects were recognized as parts of its function. The main task for the "Service to Poland" was to incorporate the youth into the work of reconstruction for bringing up a new socialist man for the regime. The regime was deeply concerned about young boys and girls who neither studied nor worked professionally. Hence, in an effort to "uplift" the intellectual and physical level of the youth, the "Service to Poland" organization mandated this militarized public works/youth employment projects for all boys and girls between ages of 16-21 and for a period of 3

\footnotetext{
151 Liponski, "Still and Unknown," 25, 26.

152 Staar, Poland 1944-1962, 219-221.

153 Jarosz, Polacy a stalinizm, 197, 211.

154 For the role of sports in the army see Wozniak, Mundury i Laury, 6, 33, 37, 39, 49, 69, 81, 93; Gaj in Gaj and Hadzelek, Dzieje kultury fizycznej, 276; "Uchwala Biura Politycznego KC PZPR," 195; Gondek, Kultura fizyczna w Polsce, 121-130; and Gaj, Wychowanie fizyczne, 104-111.

155 For sports in the Soviet Union see Edelman, Serious Fun, 97, 102, 120, 177, 179, 182.
} 
years. The organization offered training in specialized sections such as aviation, artillery, and parachuting. 156

For the university students, the Main Directorate of Academic Sports Association (AZS, Akademicki Zwiazek Sportowy) was established in 1949. In the next few years, the physical education departments in Poznan, Krakow, and Wroclaw moved out of the universities and were established as independent academies of physical education. This structural breakdown of universities was consistent with the creation of Soviet-style academies of science which trained experts for the socialist economy. After their reorganization, a standardized curriculum of education and research was introduced in all academies that remained in effect with some changes until 1970. The KC PZPR emphasized the development of sports medicine and supported the organization of the First All-Poland Scientific Conference on the theory of physical culture in 1954. From 1950 onward, the buildings and facilities in AWFs were modernized and expanded to include a women's hostel as well. However, the number of men in these organizations remained much higher than that of women. The membership of AZS Wroclaw in October of 1948 included 710 members, of whom 123 were women. Also, candidates mainly came from the intelligentsia class, and very few from working and rural backgrounds. Overall, the AZS played an important role in the life of students, promoting social integration among the students and providing them with a valuable space for playing sports. 157

For the workers, the Zrzeszenie Sportowe "Start" (1952) popularized physical culture in factories and industries. Parades were important places for the dissemination of mass culture among workers. According to WKKF Krakow, the highly publicized model socialist town of Nowa Huta was to serve as a model center of physical culture for the workers. In 1954, Nowa Huta organized a Spartakiad. State sponsored paid and organized vacation provided new meanings to working-class leisure in this town. Unfortunately, the

156 On the Service to Poland (Sluzba Polsce) see Staar, Poland 1944-1962, 221-223; Kenney, Rebuilding Poland, 320; and PzS, 30 (12 April, 1948), 1.

157 PzS, 102 (28 December, 1950), 8; Wroczynski and Hadzelek, "Development of Sciences," 91; Jaworski, "Conceptions," 287; Ryszard Wieczorek, "Studium wychowania fizycznego w latach 19451950," in Gaj (ed.), Dzieje Akademii Wychowania Fizycznego w Poznaniu, 83-111, pp. 83, 84; Gondek, Kultura fizyczna w Polsce, 105, 106, 132; Hadzelek, "Foundation," 92; Teodor Tarnowski, "Ksztalcenie kadr wychowania fizycznego i sportu," in Arkadiusz Brzezicki and Antoni Miller (eds.), Kartki z historii kultury fizycznej i turystyki 1945-1964 (Warsaw, 1964), 14-24; Jerzy Gaj, "Wyzsza szkola wychowania fizycznego w Poznaniu w latach 1950/1951-1972/73," in Gaj (ed.), Dzieje Akademii Wychowania Fizycznego w Poznaniu, 112-183, pp.118, 120, 157, 128; Kus, "Zwiazki," 11-13; Kus, "Akademicki Zwiazek Sportowy we Wroclawiu w latach 1945-1949," 389-392; and Liponski, "Still and Unknown," 25, 26. For a more recent work on the sovietization of higher education in some East European countries see John Connelly, Captive University: The Sovietization of East German, Czech, and Polish Higher Education, 1945-1956 (Chapel Hill, 2000), 60. 
Nowa Huta's gymnasium halls were often used for viewing films instead of playing sports. More generally, many workers were unable to afford transportation or the minimal costs of a vacation. For workers who put in a great deal of overtime, the vacation was the only time they could spend at home with their families. Opportunities for working class tourist activities were limited and manifested all the typical weaknesses of state enterprise. 158

Meanwhile, in the countryside, rural organizations such as the Zwiazek Mlodziezy Wiejskiej Rzeczpospolitej "Wici” and Folk Sport Teams (Zrzeszenie Ludowe Zespoly Sportowe, LZS 1952) sought to undermine peasant individualism and isolationism by modernizing rural physical culture. The ongoing processes of urbanization and industrialization were used to facilitate this form of sports cultural integration. The LZS organized rural spartakiads and functioned as the principal organization in the coordination of all rural sports. The "Wici" increased its activities in rural physical education, sports, and health and hygiene. It also expressed dismay over the high death rate of children and youth in the countryside. Several games such as soccer, table tennis, volleyball, skiing, wresting, horseriding, cycling and skating attracted increasing numbers of farmers. 159

Overall, a large number of Polish cities became more "sportive" with the regime's fascination with physical culture. The second stage of rebuilding between 1950-1955 resulted in the emergence of several more organizations in many regions of the country. In the Lublin region, however, despite the resolution of KS PZPR in 1949 about the importance of health, strength and defense through the development of physical culture, very little was accomplished. Several factors prevented the planned efflorescence of

158 MiZP, 21/213 (20 July, 1952), 11; Gondek, Kultura fizyczna w Polsce, 25, 108; Lysakowski, Panstwowa adminstracja, 22; Davies, God's Playground, Vol II, 598; and Kenney, Rebuilding Poland, 319, 322-324. On the development of sport in Nowa Huta see PzS, 70 (4 September, 1950), 3; PzS, 77 (28 September, 1950), 1; PzS, 22 (18 March, 1954), 2; Jarosz, "Wybrane problemy kultury zycia codziennego kobiet pracujacych w Nowej Hucie w latach piecdziesiatych XX wieku," 417; and Zdzislaw Popielczyk, "Kultura fizyczna i turystyka w dzialalnosci zwiazkow zawodowych," in Brzezicki and Miller (eds.), Kartki z historii kultury fizycznej i turystyki, 47-69, 49.

159 For more on the LZS and these issues see $\underline{\mathrm{PzS}}, 38$ (14 May, 1951), 5; $\underline{\mathrm{PzS}}, 92$ (8 November, 1954), 2; Krawczyk, "Sport jako," 178, 179, 181; Gutowski, Drogi rozwoju kultury fizycznej, 101; Kedziorek, "Upowszechnienie kultury fizycznej," 7; Drazdzewski, Dzieziecioletnia dzialalnosc rady wychowania fizycznego glownego komitetu kultury fizycznej i turystyki, 46; Dall, Kultura fizyczna i sport w Polsce Ludowej, 15, 16, 17, 33; Gaj, Wychowanie fizyczne, 146, 155; Grzegorz Lempka, "Organizing Leisure in Polish Towns," in World Leisure and Recreation Association Journal, 26, 4 (July/August, 1984), 13-15, p.14; Wilk, "Awans," 5; Adam Izydorczyk, "O dalszy intensywny rozwoj kultury fizycznej i sportu w srodowisku wiejskim," in Kultura Fizyczna, 33, 6 (June 1979), 4-8, p. 5; "Uchwala Biura Politycznego KC PZPR," 195; Liponski, "Still and Unknown," 25, 26; Gaj in Gaj and Hadzelek, Dzieje kultury fizycznej, 230; Tomaszewski, "Zapotrzebowanie," 317; Gondek, Kultura fizyczna w Polsce, 143, 144; and Chelmecki, Polish Sport, 10. 
social and cultural organizations, including terrorist activities, apathetic political elites, the emigration of young males to former German cities such as Katowice, Szczecin and Gdansk, a high percentage of illiteracy, lack of qualified personnel in committees and institutes of physical culture, multiple failures of the Lublin District Sports Unions, the passivity of the school authorities, and persistent economic difficulties. 160

Unlike most western women, Polish women participated in a variety of sports with official encouragement during this time period. While in the interwar years Polish sportswomen found themselves "disadvantaged" in comparison to their western counterparts, the stalinist years in Poland engendered women with unique spaces and avenues to excel in their athletic endeavors. Under stalinism, Polish women received significant ideological and institutional support to build their physical culture. In the resolution of 28 September 1949, the KC PZPR emphasized the need to involve girls and women in physical education. ${ }^{161}$ The trade unions and enterprises sponsored Polish women's sport and physical fitness. For example, women's sport was perceived as an important component of work in the Lodz textile industry. 162 According to Irena Kiepuszewska, the captain of the women's volleyball team of "Minexu" (Centrali Eksp. Wytworow Przemyslu Mineralnego), women had opportunities to participate in mass sport through trade unions. With the assistance of LK, local party organizations, the Factory Council, and the director, the Minexu women formed sections of volleyball, tennis, table tennis, swimming, and oaring. 163

While the men's sports apparatus was clearly presented as being more dynamic and powerful, women's sports, in both the urban and rural areas, received a good deal of coverage. Przeglad Sportowy repeatedly discussed the importance of Lenin and Stalin in promoting the beneficial values of sport for both men and women. For this reason, the Soviet female athletes were heralded as "models" for Polish women, and well-respected for their physical strength, grace and excellence. The Polish press duly recognized the accomplishments of Soviet sportswomen and displayed photographs of Soviet and Polish female champions. Soviet women's participation in their country's parades, marches,

160 Skawinski, Kultura fizyczna na Lubelszczyznie, 16-26, 43, 47, 48, 52, 53, 57, 62, 63, 74, 80, 81, 118, $119,137,165-190$. For organizational developments in sports in Poznan for these years see Gawlak-Kica, Rozwoj kultury fizycznej w Wielkopolsce, 73-75, 78-80, 131, 262. For the organization of winter sports such as skiing and skating in this region see also Marian Szych, "Ksztalcenie studentow na obozach zimowych Poznanskiej uczelni wychowania fizycznego w okresie 40-lecia PRL," in Wychowanie fizyczne $i$ sport w 40-Leciu PRL, 291-301.

161 See Chelmecki and Wilk, Wybor zrodel i materialow do dziejow kultury fizycznej, 74.

162 For institutional support from trade unions see PzS, 37 (10 May, 1951), 6.

163 Przyjaciolka, 7 (12 February, 1950), 12. 
mass festivals and youth games was widely projected in order to demonstrate the mass engagement of women in all varieties of sports under state socialism.

Indeed, millions of Soviet girls and women trained at gymnasiums, stadiums and swimming pools to demonstrate the 'sportive' communist upbringing of the people. They scaled high mountains, skated faster, and putt the shot and threw the discus farther than their sex anywhere else in the world. In the eyes of the state, Soviet female athletes were not 'miracles' as reported by a Finnish newspaper, but a representation of the fact that physical culture and sports were a matter of concern to all the Soviet people and, most of all, to the Soviet state. 164

In the official image, Soviet sportswomen, through their participation in Soviet physical culture, encouraged the development of qualities of discipline, healthy disposition and firm character, and fostered the spirit of collectivism, friendship and socialization. 165 In the wide base of Soviet sports, ranging from the workplace to the professional arena, women of various professions were encouraged to participate and train others in sports and physical culture. The champions among them, moreover, were looked upon as the 'statespersons' of Soviet society, the society's 'elite' and the representatives of the country abroad. 166

In consonance with the socialist emphasis on women's sports, Chairman Mao Zedong in communist China placed a great deal of importance on the health of the people's bodies as a basis for the health of the nation. Chinese women were cobeneficiaries of this sportive ethos, and they enjoyed equal rights in physical education and sport, albeit in the hope of building a strong and healthy female labor force for the construction of the new China. Still, their sporting accomplishments, frequently of worldclass levels, served as a springboard for the transformation of gender relations in China. ${ }^{167}$

164 Soviet Woman, (1948), 60, 61.

165 Rabotnitsa, 7 (1949), 1, 2; Rabotnitsa, 8 (1948), 12; Rabotnitsa, 3 (1949); and Soviet Woman, 3 (1950), 59. For the rhetoric on sports as an important activity to improve women's health see Rabotnitsa, 7 (1951), 28, 29; Rabotnitsa, 7 (1949), 1, 2; Rabotnitsa, 1 (1951), 30; Rabotnitsa, 9 (1946), 16, 17 Soviet Woman, (1948), 56, 57; and Soviet Woman, 11 (1955), 47. For the importance of women's sports as a method of integrating the Soviet empire see Soviet Woman, (1948), 56, 57; Rabotnitsa, (1951), 28, 29; Soviet Woman, 3 (1950), 32, 33; Soviet Woman, 3 (1951), 61, 62; Soviet Woman, 7 (1951), 15, 16; and Rabotnitsa, 12 (1949), 12, 13.

166 Soviet Woman, 5 (1952), 46, 47; Rabotnitsa, 7 (1949), 1, 2; Rabotnitsa, 7 (1951), 28, 29. For the participation of rural women in Soviet sports see Krest'ianka, 3 (1950), 23, 24; Krest'ianka, 7 (1951), 16, 17; Krest'ianka, 2 (1952), 24, 25; Soviet Woman, 7 (1951), 62; Krest'ianka, 8 (1953), 7; and Krest'ianka, 12 (1954), 23, 24.

167 Hong, Foot binding, Feminism and Freedom, 103, 155, 164, 173, 215, 255, 279, 289, 290, 291, 297, 298, 299, 304, 307; and Brownell, Training the Body For China, 57, 58, 226. 
In contrast to the experiences of sportswomen in socialist countries, western "capitalist" societies were far more cautious in encouraging their women to play sports. For example, the British sporting culture in the 1950 s remained predominantly male. ${ }^{168}$ In the United States of America, the presence of women, even 'feminine beauties' in 'masculine athletics' clashed with the post-war conservative culture of the 1950s. ${ }^{169}$ American sportswomen in this time period wore extra-feminine attire, downplayed their competitiveness, alluded to their heterosexuality, minimized the importance of the game, and eschewed sporting careers. 170

While the general trend in the West was to limit women's participation in sports, there were some notable exceptions in these years. For example, The New York Times displayed a picture of the American Ambassador to Denmark, Mrs. Eugenie Anderson, cycling with her son near Copenhagen. ${ }^{171}$ At the more elementary level, various industrial establishments sponsored sport for women, especially basketball, bowling and softball. At a time when there was little opportunity for women to be involved in sports, industrial teams offered women a chance to compete. Industrial sports programs were egalitarian, offering both blue-collar and white-collar workers opportunities for competition. Although outwardly little appeared to be happening in women's sports, there were thousands of teams and competitions, all provided by industry that 'saved' the western women's sports movement. 172

To conclude, Polish women's physical culture in stalinist Poland was patterned after the Soviet Union, and Polish female athletes sought ideological inspiration from their counterparts in the east, and not in the west. However, the Polish feminine physical culture was clearly not as dynamic as the Soviet female physical culture movement. Unlike the Soviet sportswomen who had received significant state attention from the very beginning of the interwar period, Polish female athletes were only just benefiting from the radical political, economic, social and cultural transformations within their country under the steady importation of stalinist-style socialist ideals and practices.

While Polish "stalinism" was, by and large, quite damaging to the country's economy, society, and political culture, the strong emphasis on women's sports provided

\footnotetext{
168 Richard Holt and Tony Mason, Sport in Britain, 1945-2000 (Oxford, 2000), 175.

169 Cahn, Coming on Strong, 161.

170 Festle, Playing Nice, 3, 9, 25, 26, 27, 32, 50, 67, 60, 79.

171 The New York Times, (3 April, 1950), 14.

172 Lynne Emery, "From Lowell Mills to the Halls of Fame: Industrial League Sport for Women," in Costa and Guthrie, Woman and Sport, 107-121.
} 
some glimmer of hope to the nation's impaired national pride. Certainly, Poland would remain a colony of the Soviet imperial policies for the next several decades. However, women's sporting achievements became a potential source of national pride and provided some source of jubilance and rejoicement for an otherwise quite disillusioned and frustrated populace. This "glorious women's sporting revolution" in Poland, as in other parts of Eastern Europe, would soon unfold its "progressive" and "liberating" colors, and provide some solace, at least on the surface, to a culture destroyed by the stalinist monstrosities. Such is the subject of investigation in the following two chapters. 


\section{Chapter Six}

\section{Socialist Ideology, the Images of Women, and the Construction of Women's Physical Culture in Post-Stalinist Poland}

This chapter examines the interrelations between the post-Stalinist socialist ideology and women's identities in shaping Polish women's physical culture from 19561989. During this time period, the development of sports for women was deeply influenced by the individual political predilections and the socio-economic conditions during the successive regimes of Wladyslaw Gomulka (1956-1970), Edward Gierek (1970-1980), Stanislaw Kania (1980-1981) and Wojciech Jaruzelski (1981-1989). For this reason, depending on the nature of the elites in power, Polish physical culture experienced a cyclic pattern of de-centralization and centralization in its structure and operation. However, despite organizational changes, one factor remained constant. At all times, the Polish state continued to use sports, especially women's sports, as an important functional instrument to manipulate and control an increasingly restless society.

While sports assumed a pivotal role in state politics, the political leadership particularly hoped to use women's physical culture in order to control the feminine "bodily culture" and transmit those socialist values and opinions on women's "rights" and "duties" which were deemed "progressive" by those in power. It comes as no surprise, therefore, that Polish female athletes were always projected as being 'strong and happy heroines'. This positive imagery of sportswomen not only enabled the state to shape the course of the Polish "woman's movement", but also assisted the communist party in using female athletes to serve as a "transmission belt" in facilitating a conversation between the state and the emerging 'civil society'.

However, did the official and popular voices resonate on the same frequency in post-Stalinist Poland? Were Polish sportswomen conscious that they were being manipulated by the state? How much did the state actually control "women's bodies"? Was the Polish 'woman's movement' regulated solely by the socialist state, or did women have a say in matters which concerned them at both the individual and collective levels of consciousness? What was the place of sportswomen in the "woman question" and in the larger Polish society? Did Polish female athletes "listen" to the state directives on their officially defined roles in society? Or did the women's voices express words of resistance? Basically, how did sport reflect the paradox of socialism? How much did sportswomen change socialism and, conversely, how much did socialism change the female athletes? 
Accordingly, the purpose of this chapter is to graph the political, economic, and social trajectories of the successive regimes in post-Stalinist Poland and analyze the identities of women and the organization of Polish sports as shaped by these highly unstable forces. The Polish women's physical culture movement will be analyzed in this context of political instability and the need for the communist elites to legitimize their imposition of social control over a people which increasingly began to call into question their forced confinement within the realm of the "Big Lie".

Chronologically, the first part of this chapter discusses the "woman question" and the organization of sports under Gomulka. The second part analyzes the changes and continuities in the evolution of women's sporting culture in Gierek's Poland. The tumultuous year of 1980-81 is examined as a separate section so as to understand the connections between the Solidarity movement and Polish physical culture. The final part of the chapter analyzes the opportunities available for women's sports in Jaruzelski's Poland.

\section{"Legitimizing Illegitimacy": The Identities of Women and the Organization of Sports in Gomulka's Poland, 1956-70}

The development of Polish women's physical culture under Gomulka can be examined in two chronological phases. The first phase lasted from 1956-1959 and was characterized by the state's measures to decentralize the various branches of the government. The second phase encompassed the 1960s and was characterized by Gomulka's increasing political intransigence and efforts to centralize all forms of governance. The resultant intra-systemic and socio-economic instabilities affected the realm of women's sports as well.

\section{6-1959}

In the early months of 1956, Stalin was accorded a political burial in the Soviet Union and Bierut a natural burial in Poland. In a secret speech delivered at the Twentieth Congress of the Communist Party of the USSR in February 1956, Soviet leader Nikita Khrushchev denounced Stalin's errors and crimes. This “de-stalinization” campaign in the USSR coincided with a serious internal crisis in the ranks of the Polish Communist Party. Bierut died unexpectedly on March 13, 1956 and was succeeded by Edward Ochab. The new political leadership, in consonance with Soviet overtures to destalinization, urged far-reaching democratic reforms in the existing political system. 
Unfortunately, despite the rhetoric of political "decompression", the pace and direction of Poland's 'de-stalinization' was kept under the strict control of the party leadership. The policy of resorting to socialist legality continued, and the socialist framework was not subject to a more searching analysis. ${ }^{1}$ Still, this Polish version of de-stalinization meant that the Stalinist attempt to build a totalitarian system in Poland was shortlived and incomplete. $^{2}$

In the absence of effective political revisionism 'from above', the various social classes engaged in serious political questioning and commentary 'from below'. Acting autonomously, the workers took the initiative to form councils, the peasants decollectivised agriculture, and the intellectuals formed discussion clubs. Taken in the context of a poor economic situation, such expressions of disgust and disillusionment created a very dangerous and inflammatory situation. In June 1956, a powerful and threatening workers' protest broke out in Poznan, leading to street fighting between demonstrators and security police. Although the government commanded sufficient force to control this largely ill-coordinated workers' outburst, serious divisions now emerged within the party leadership and pressure began to grow in reformist circles, and more widely in the Polish society. ${ }^{3}$ In October 1956 , the communist party bowed to popular pressure by reinstating the more popular Gomulka as the new Polish leader, who then succeeded in convincing the Soviet leadership that Poland would retain the communist monopoly of power and keep its commitments to the Warsaw Pact. 4

In the months following the "Polish October", Gomulka promised more political, religious, cultural, economic, and intellectual freedom. Gomulka's return to power was interpreted by the population as an affirmation to a Polish 'national road to socialism'. Subsequently, over $80 \%$ of the collective farms were disbanded, Church properties were restored, industrial establishments were given wider autonomy, a limited amount of privatization was allowed, and a certain amount of cultural and media freedom was

\footnotetext{
1 Pawel Machcewicz, "Social Protest and Political Crisis in 1956," in Kemp-Welch Stalinism in Poland, 99-118, pp.101, 102; Bromke, Poland's Politics, 88, 91, 94, 96; Karpinski, Poland Since 1944, 74; Leslie, The History of Poland. 345, 351, 352, 357, 362, 366; and Montias, Central Planning in Poland, 263.

2 George Sanford, Poland: The Conquest of History (Amsterdam, 1999), 16.

3 Leslie, The History of Poland, 363; Kennedy, Professionals, Power and Solidarity in Poland, 27; Machcewicz, "Social Protest and Political Crisis in 1956," 104, 105, 108, 111, 114; Terry Cox and Bob Mason, Social and Economic Transformation in East Central Europe: Institutions, Property Relations, and Social Interests (United Nations Research Institute for Social Development, Cheltenham, UK, 1999), 35; Bernhard, The Origins of Democratization in Poland, 34; Ascherson, The Polish August, 71, 77, 250; Slay, The Polish Economy, 28; and Ascherson, The Struggles for Poland, 156, 157.

${ }^{4}$ Cox and Mason, Social and Economic Transformation in East Central Europe, 36; Bernhard, The Origins of Democratization in Poland, 35; Ascherson, The Polish August, 73, 74, 234; and Ascherson, The Struggles for Poland, 160.
} 
granted. These early years of Gomulka's rule were also marked by the strengthening of the power of parliament, the extension of local self-government, greater freedom for voluntary associations of all types, economic decentralization, and appointments based on merit to administrative posts. Gomulka's flexible political strategy, assurances of economic stability and a higher standard of living, and democratization in the domestic sphere, with more outlets for individual expression and initiative, earned the Polish communist leadership the much-needed social popularity and legitimacy at home, as well as the tolerance of its external overseer, the Soviet Union. 5

During these years of 1956-1959 when the Polish political elites secured some popular legitimacy to communist rule, the official authorities took immense pride in the increasing participation of women in all spheres of life. In 1957, there were about 2.5 million female workers. ${ }^{6}$ However, while the KC PZPR projected images of enchanted Polish women contributing their labor to developing the socialist national economy, the imagery of the "kobieta-matka" or "woman-mother" concerned with the education of her children was more pronounced than that of the "mother-worker" of the Stalin years. The closer interaction between women and the Ministry of Education, the increased focus on the education of children, the construction of more schools, the many images of women themselves reading and writing, and the re-emphasis on a 'healthy' family that was physically, intellectually, morally and psychologically strong, were some examples to suggest the predominance of the kobieta-matka imagery in building the socialist morality of the Polish youth. ${ }^{7}$ The Minister of Education, Wladyslaw Bienkowski, reaffirmed the

\footnotetext{
5 Przyjaciolka, 43 (28 October, 1956), 3, 4; Ascherson, The Polish August, 76; Brzezinski, The Struggle for Constitutionalism in Poland, 72; Bielasiak, "Poland," 131; Slay, The Polish Economy, 29; Kemp, Nationalism and Communism in Eastern Europe, 145, 146; Blejwas, Realism, 200, 202; Bromke, Poland's Politics, 131, 132; Leslie, The History of Poland, 367, 372, 374, 405; Machcewicz, "Social Protest and Political Crisis in 1956," 117, 118; Bethell, Gomulka, His Poland and His Communism, 234, 235, 236, 238, 273; Montias, Central Planning in Poland, 311; Bromke, Poland: The Protracted Crisis, 15, 16, 231; Richard J. Hunter and Leo V. Ryan, From Autarchy to Market: Polish Economics and Politics, 1945-1995 (Westport, Connecticut, 1998), 27; Kennedy, Professionals, Power and Solidarity in Poland, 27; George Sanford, Polish Communism in Crisis (London and Canberra, 1983), 83; David Lane, "The Role of Social Groups," in Lane and Kolankiewicz (eds.), Social Groups in Polish Society, 302-326, p. 324; and Bernhard, The Origins of Democratization in Poland, 36-38.

6 KiZ, 7 (1 March, 1958), 2; and KiZ, 10 (1 April, 1959), 3. For official endorsements to the active participation of women in building socialism, especially in the national economy, and particularly on the annual International Days of Women, see Przyjaciolka, 11 (18 March, 1956), 5; Przyjaciolka, 11 (17 March, 1957), 5; Przyjaciolka, 11 (16 March, 1958), 5; and Przyjaciolka, 12 (22 March, 1959), 5. The press also reported that 19 women were members of the new Sejm. See KiZ, 4 (1 February, 1957), 2.

${ }^{7}$ KiZ, 25 (1 September, 1958), 2, 3; Przyjaciolka, 11 (16 March, 1958), 5; Przyjaciolka, 46 (18 November, 1956), 5; KiZ, 1 (1 January, 1956), 10, 11; Przyjaciolka, 11 (16 March, 1958), 5; KiZ, 10 (1 April, 1959), 3; and KiZ, 19 (1 July, 1959), $2,3$.
} 
state's need to create suitable conditions for women to spend more time at home so that they could help impart "appropriate" education to their children. According to him, family education simply could not be replaced by schools or any other institutions. 8

It is for this reason that during the early Gomulka years, the question of women's 'double burden' became more agonizing. There are many references in the women's press to difficulties in harmonizing work both inside and outside of the household. Shortages in day care facilities and maternity leave were some reasons to explain this dilemma. Women's professional work and household management left little space and time for social engagements and leisure activities. Moreover, women's employment opportunities were limited to areas of health care, education, and services--not in economic planning and political governance. There were also more reports on the male violence toward women in families. Women complained of alcoholism, hooliganism, prostitution, 'immoral homes', and the spread of venereal diseases. Some wanted the Ministry of Justice to intervene and deal accordingly with such "hooligan families."9

From a comparative perspective, Soviet women fared marginally better than their Polish counterparts during these years. Khrushchev never made women's issues a high priority. But he did promote some reforms beneficial to women. Women were among the beneficiaries of new trends in recruitment as well as of deliberate efforts to draw women into positions of leadership. In other reforms, abortion was legalized in 1955 and the fees charged for divorce lowered. More generally, Khrushchev's most significant contribution for women may have been his reopening of the discussion of the difficulties in women's lives, a discussion that had been halted in the early 1930s when Stalin's government had declared that women's emancipation was already fully realized. 10

Polish women's physical culture, similar to developments in other socio-cultural activities in the years 1956-1959, moved toward greater de-centralization in its organizational apparatus. While the GKKF continued its objectives of directing, coordinating and controlling the development of Polish physical culture, bureaucratic centralism in sports activities diminished. More autonomy was given to sports sections,

\footnotetext{
$8 \underline{\mathrm{KiZ}}, 1$ (1 January, 1958), 2, 3.

9 KiZ, 10 (1 April, 1954), 3; Przyjaciolka, 26 (1 July, 1956), 7; Przyjaciolka, 39 (30 September, 1956), 12; Przyjaciolka, 46 (18 November, 1956), 5; KiZ, 2 (10 January, 1957), 4; Przyjaciolka, 52 (29 December, 1957), 11; KiZ, 15 (20 May, 1959), 2, 3; KiZ, 9 (20 March, 1957), 2, 11; Przyjaciolka, 33 (19 August, 1956), 12; KiZ, 32 (10 November, 1957), 3, 11; KiZ, 8 (10 March, 1957), 2, 3; KiZ, 28 (1 October, 1957), 2; KiZ, 26 (10 September, 1957), 2, 3; KiZ, 1 (1 January, 1958), 2, 3; and Przyjaciolka, 19 (10 May, 1959), 12.

10 Lapidus, Women in Soviet Society, 120, 245; and Clements, Daughters of Revolution, 113.
} 
and many more sports clubs and societies were organized. With some liberalization, traditional federations for different sports were revived and those previously eliminated were rehabilitated. 11 The rhetoric on the importance of sport for building socialism marginally weakened, though the noted usefulness of physical culture in improving health and physical fitness continued. 12

With the trend toward de-centralization, new sports organizations were formed and more sports publications appeared in the press. For example, the move toward selfmanagement in sports for the armed forces in 1956-1957 resulted in the formation of the Federation of Sports Clubs of Guards with sections in many cities, including Krakow, Gdansk and Bydgoszcz. 13 In 1956, the Institute of Science for Physical Culture was opened, the Zrzeszenie "Zryw" began its sports work among school youth, and the periodical Sport $i$ Turystyka (Sport and Tourism) started its publication. ${ }^{14}$ In 1957, the Society for the Propagation of Physical Culture (TKKF, Towarzystwo Krzewienia Kultury Fizycznej) was formed as an independent mass organization for promoting physical education, sports and recreation. 15

Meanwhile, an international symposium on the subject of physical education was organized under the auspices of the Polish Academy of Sciences and the International Council of Physical Education and Sport at UNESCO in Warsaw in 1959.16 To build more international linkages, the AZS became a member of the Sports Council of the International Union of Students in 1958 and the International Federation of University Sports in 1959.17 The number of graduates in the AWFs also increased from 1956 onward. Still, the qualified physical education teachers were required to demonstrate a

\footnotetext{
11 Brzezicki, Drazdzewski, Podoski, and Romanski (eds.), Ksiega sportu polskiego, 19; Gutowski, Drogi rozwoju kultury fizycznej, 111; Chelmecki and Wilk, Wybor zrodel i materialow, 123, 124, 133, 143; Urbanyi, Zarys historii sportu Bydgoskiego, 38; Liponski, "Still and Unknown," 26; and Reczek, The Development of Physical Culture in Poland, 21.

12 Przyjaciolka, 5 ( 3 February, 1957), 10; and Przyjaciolka, 47 (22 November, 1959), 10.

13 For the role of sports in the army see Wozniak, Mundury i Laury, 6, 33, 37, 39, 49, 69, 81, 93; Gaj in Gaj and Hadzelek, Dzieje kultury fizycznej, 276; "Uchwala Biura Politycznego KC PZPR," 195; Gondek, Kultura fizyczna w Polsce, 121-130; and Gaj, Wychowanie fizyczne, 104-111.

14 Gondek, Kultura fizyczna w Polsce, 25, 108; Tuszynski, Prasa i sport, 292; and Lysakowski, Panstwowa adminstracja, 22.

15 On the TKKF see Gaj in Gaj and Hadzelek, Dzieje kultury fizycznej, 321; Brzezicki, Drazdzewski, Podoski, and Romanski (eds.), Ksiega sportu polskiego, 19, 59; Gaj, Wychowanie fizyczne, 159; and Liponski, "Still and Unknown," 26. See also Zbigniew Mikolajczak, Vice-President, Council of Development of Physical Culture and Sports in Poland, "Sport For All and the Working Population in Poland Taking into Consideration the Coal Mining Industry," an official report, IX International Trim and Fitness Congress, 6-11 October 1985. Organized by the Central Council of Physical Recreation (United Kingdom) in Association with the Isle of Man Year of Sport, 1985, 114-119, p.115.

16 Wroczynski and Hadzelek, "Development of sciences," 92.

17 Gaj in Gaj and Hadzelek, Dzieje kultury fizycznej, 273; and Gondek, Kultura fizyczna w Polsce, 132.
} 
commitment to the processes of building socialism, a sense of identification with the working class and the Party, an international socialist viewpoint, involvement in public and political affairs, and a non-religious attitude. 18

The Polish pattern of decentralization and expansion of sports structures for both men and women paralleled the changes taking place in the apparatus of Soviet physical culture. Reflecting Khrushchev's concern for decentralization, government control of sports was diminished, hundreds of new stadiums were constructed, and competitive sports were expanded. But the party did continue to portray Soviet performance at the Olympics as proof of the superiority of communist methods, not only in sports but in all areas of human endeavors. 19

More importantly, Soviet women, similar to their Polish counterparts, were perceived as critical disseminators of the state's ideology in their physical culture movement. Thousands of Soviet women, both urban and rural, and from the various republics, participated in the Spartakiads or the Sports Festival of the Peoples of the USSR. The women's programs were varied, and the female athletes themselves appeared excited at the thought of participating in the intra-republican sports competitions. 20

Thus, both the Polish and Soviet physical cultures benefited from the destalinization forces in their respective countries. The years between 1956-1959 were marked by the construction of more sports facilities, as well as by the appearance of several more sports societies and unions. However, the Soviet feminine physical culture was, once again, more dynamic than the Polish women's sporting apparatus. While the ruling elites of both countries emphasized the development of women's sports, Polish women were impeded by their "double burden" to engage in sports in a more meaningful fashion. The traditional patriarchal structures remained deeply entrenched, and the persistence of conservative popular opinion limited women's mass participation in physical culture, more so in Gomulka's Poland than in Khrushchev's Soviet Union during the latter half of the 1950s.

\footnotetext{
18 Liponski, "Still and Unknown," 2, 3; and Gaj in Gaj and Hadzelek, Dzieje kultury fizycznej, 249, 250.

19 Edelman, Serious Fun, 93, 125, 149, 156-158; and Norman Shneidman, The Soviet Road to Olympus: Theory and Practice of Soviet Physical Culture and Sport (Toronto, 1978), 9.

20 For examples see Soviet Woman, 5 (1956), 45; Rabotnitsa, 9 (1956), 13, 14; Rabotnitsa, 8 (1956), 15 17; and Soviet Woman, 8 (1956), 14, 18.
} 


\section{0-1969}

Gomulka's initial determination to restore Polish national identity, economic prosperity, and political dignity, unfortunately, began to wane in the 1960s. His policies to create a more democratized, independent, and consumer-oriented nation were soon superseded by official inflexibility and political inertia, central management and economic stagnation, increasing unemployment and daily hardships, and the slavish subordination to the Soviet Union in foreign relations. The administration remained authoritarian and bureaucratic, the fundamental social and economic tasks were largely ignored, and the standard of living decreased, thereby widening the gap between Gomulka's regime and the Polish society. ${ }^{21}$ The government now reinstated commissions for the control of science, education, and culture. Censorship of newspapers was drastically tightened, workers councils were resubjected to party control, and some hard won religious and intellectual freedoms were withdrawn. ${ }^{22}$

The official press, no doubt, continued to report Gomulka's theoretical commitment to decreasing unemployment, increasing the level of education, intensifying the technical base of agrarian production, and uplifting living standards for the people through mass industrialization. ${ }^{23}$ However, Gomulka's ideological sterility, intolerance of dissent, lack of professional integrity, and opposition to radical change left him

\footnotetext{
21 Bromke, Poland's Politics 147, 157, 170, 171, 204; Staar, Poland 1944-1962, 102; Karpinski, Poland Since 1944, 107; Leslie, The History of Poland, 385, 393; Bethell, Gomulka, 242, 244; Bromke, Poland: The Protracted Crisis, 16, 17; Hunter and Ryan, From Autarchy to Market, 28; Joseph Rothschild, Return to Diversity: A Political History of East Central Europe Since World Wor II (New York, 1993), 192, 193; Slay, The Polish Economy, 29; Bernhard, The Origins of Democratization in Poland, 38; Lane, "The Role of Social Groups," 325, 326; Ray Taras, "The Local Political Elites," in Lane and Kolankiewicz (eds.), Social Groups in Polish Society, 233-301, pp. 265, 301; and Ascherson, The Polish August, 88, 89, 250. For economic tensions under Gomulka, see Bethell, Gomulka, 248; Montias, Central Planning in Poland, 311, 321, 322; Bromke, Poland: The Protracted Crisis, 16, 27; Rothschild, Return to Diversity, 195; Bielasiak, "Poland," 131; Stehle, The Independent Satellite, 42; Fallenbuchl, The Balance of Payments Problem and the Economic Crisis in Poland, 16; Bernhard, The Origins of Democratization in Poland, 39; and Paul Lewis, "The Peasantry," in Lane and Kolankiewicz (eds.), Social Groups in Polish Society, 29-87, pp. 57, 85, 86. These works have discussed in detail the disastrous economic effects of excessive centralization, the myopic vision of mediocre officials, overinvestment in heavy industry, the low productivity of peasant agriculture, and the import of industrial equipment in return for scarce agrarian produce.

22 For Gomulka's hardened attitudes toward culture and religion see Bromke, Poland's Politics, 146; Ascherson, The Struggles for Poland, 168; Leslie, The History of Poland, 387; Bromke, Poland: The Protracted Crisis, 16; Hunter and Ryan, From Autarchy to Market, 28; Rothschild, Return to Diversity, 192, 193; Sanford, Polish Communism in Crisis, 22; Szajkowski, Next to God....Poland, 9-28; Ramet, Nihil Oblast: Religion, Politics and Social Change, 100-104, 286-293; and Stehle, The Independent Satellite, 42, 198, 288, 289.

${ }^{23}$ See for example, Przyjaciolka, 28 (14 July, 1963), 3; and KiZ, 20 (16 May, 1965), 2.
} 
isolated from the concerns of society. 24 His popularity further eroded with the harsh neo-Stalinist persecution of students, Jews, intellectuals, reformists, and alleged revisionists following the student strikes of March 1968. 25

Finally, Gomulka was dismissed from office when he sharply increased food prices on December 13, 1970 in an effort to correct the economic irrationalities. The timing was so close to Christmas and the content of the decree so seemingly threatening to the real incomes of the already suspicious workers and demoralized housewives that it triggered workers' strikes across the country as well as riots and mass demonstrations that lasted for five days in the Baltic port cities of Gdansk, Gdynia, and Szczecin. The workers were alone in their insurrection, and suffered considerable bloodshed and demoralization. But the brutal suppression of this protest eventually led to the fall of the Gomulka regime. On 19th December 1970, Gomulka was replaced as Party First Secretary by Edward Gierek, the party leader in the coal-mining region of Silesia and a man who was considered to be more sympathetic to the needs of the workers. 26

During the 1960s, the official press projected images of Polish women skillfully juxtaposing their private and public spheres of interest and activity. The party leadership affirmed that the contributions of women in developing the Polish economy was of "national interest" and accordingly emphasized the increasing value of women's participation in all forms of political, economic and social work. For example, the

24 Leslie, The History of Poland, 405, 406; Rothschild, Return to Diversity, 192, 193; and Bernhard, The Origins of Democratization in Poland, 41.

25 In March 1968, Polish students and intellectuals led a wide-spread protest against cultural policies of the Gomulka's regime and its efforts to curtail concessions given in 1956. For the student unrest of 1968, as well as the subsequent anti-Semitic purge within the PZPR, the growing power of the hardline "partisan" faction, and the impact of the Soviet invasion of Czechoslovakia in August 1968 on Poland see Rothschild, Return to Diversity, 194; Grzegorz Ekiert, The State Against Society: Political Crises and Their Aftermath in East Central Europe (Princeton, 1996), 217; Lane, "The Role of Social Groups," 324; Ascherson, The Polish August, 241; Bethell, Gomulka, 262, 263; Bromke, Poland: The Protracted Crisis, 18, 27, 231; Kennedy, Professionals, Power and Solidarity in Poland, 47; Roman Laba, The Roots of Solidarity: A Political Sociology of Poland's Working Class Democratization (Princeton, 1991), 29; Sanford, Polish Communism in Crisis, 25; and Bernhard, The Origins of Democratization in Poland, 41. Other detailed books for this topic are Jerzy Eisler, Marzec, 1968: Geneza, przebieg, konsekwencje (Warsaw, 1991); and Dariusz Stola, Kampania antysyjonistyczna w Polsce, 1967-1968 (Warsaw, 2000).

${ }^{26}$ For the workers' strikes of December 1970 and Gomulka's 'dismissal' see Mason, Public Opinion and Political Change in Poland, 42; Jan Kubik, The Power of Symbols Against the Symbols of Power: The Rise of Solidarity and the Fall of State Socialism in Poland (University Park, Pennsylvania, 1994), 22; Roger E. Kanet, "Poland, the Socialist Community, and East-West Relations," in Maurice D. Simon and Roger E. Kanet (eds.), Background to Crisis: Policy and Politics in Gierek's Poland (Boulder, Colorado 1981), 371401, p. 373; Hunter and Ryan, From Autarchy to Market, 30; Bielasiak, "Poland," 133; Ascherson, The Polish August, 241; Mason, Public Opinion and Political Change in Poland, 41, 42; Rothschild, Return to Diversity, 195, 196; Laba, The Roots of Solidarity, 30, 54, 55, 57; Slay, The Polish Economy, 35; and Ekiert, The State Against Society, 218. 
number of women in party organizations increased, and women's contributions in the health services and educational institutions received a good deal of publicity. In the mid1960s, large numbers of women were employed in the medical services, followed by textile industries and trade. The Polish health service was said to have been well ahead of other Comecon member-states in recruiting female physicians. There was also an increase in the numbers of girls in secondary and higher education. The chemistry faculties especially attracted more female students at the universities. Significantly, there was an increase in the numbers of married female workers, a fact used by the regime to demonstrate the "new and happy family life" under state socialism. 27

The Polish state's endorsement of women's professional employment was quite similar to the Soviet emphasis on encouraging women to work in the 1960s. Khrushchev also authorized the establishment of "women's soviets" or zhensovetsy at the local or regional levels for better coordination and communication. The new family codes of June 27, 1968 lifted restrictions on medical abortions and divorce procedures simplified. Meanwhile, some Soviet women became national and international celebrities. For example, in 1963 cosmonaut Valentina Tereshkova became the first woman to orbit the earth. 28 Also, the number of female party congress delegates increased from $9.1 \%$ in 1939 to $22.3 \%$ in 1961.29 The state's interest in encouraging reproduction alongside women's professional labor prompted a scrutiny of the supply of kindergartens, creches, and public dining rooms. 30 However, during the late 1960s, and throughout the 1970s, the Soviet government's official position remained that its women were the freest and most privileged in the world. 31

Thus, similar to the Soviet Union, Gomulka's regime recognized women's contributions in developing Polish industrialization, urbanization, and "patriotism". At the same time, however, the Polish socialist state also narrated women's achievements in maintaining 'strong and healthy' families. An ideal woman was looked upon as one who

\footnotetext{
${ }^{27}$ For more on women's work in the 1960s see KiZ, 8 (19 February, 1961), 2, 11; KiZ, 49 (9 December, 1962), 2; KiZ, 49 (9 December, 1962), 2; KiZ, 2 (13 January, 1963), 1; Przyjaciolka, 28 (14 July, 1963), 3; KiZ, 26 (30 June, 1963), 3; KiZ, 10 (8 March, 1963), 2, 3; Przyjaciolka, 42 (20 October, 1963), 5; KiZ, 49 (3 December, 1967), 3; KiZ, 20 (14 May, 1967), 3; KiZ, 28 (10 July, 1966), 3; Przyjaciolka, 27 (3 July, 1966), 3; Przyjaciolka, 28 (10 July, 1966), 3; KiZ, 13 (27 March, 1966), 3; KiZ, 28 (10 July, 1966), 3; KiZ, 42 (20 October, 1968), 2; KiZ, 44 (3 November, 1968), 2; and Kaser, Health Care in the Soviet Union and Eastern Europe, 211.

28 Lapidus, Women in Soviet Society, 167, 239, 245; and Clements, Daughters of Revolution, 114.

29 Evan Mawdsley and Stephen White, The Soviet Elite from Lenin to Gorbachev: The Central Committee and its Members, 1917-1991 (Oxford, 2000), 248, 251.

30 Buckley, Women and Ideology, 187.

31 Barbara Clements, "Later Developments," in Clements, Engel and Worobec, Russia's Women, 267-278.
} 
could manage the home, continue her important task of raising and educating her children with "appropriate" values, and participate simultaneously in 'lively' hobbies. ${ }^{32}$ The state authorities made a conscious attempt to project "feminine" images of female workers. For example, Polish films idealized women's obligations to the motherland and to the traditional patriarchal family structure. The image of an unhappy mother in Jerzy Zarzycki's film Zagubione uczucia (Lost Feelings) was banned because it effectively opposed the communist myth of socialist happiness. 33

A large part of this official rhetoric on Polish women's achievements in building socialism within the family and in the larger social community was made possible by the efforts of prominent women's organizations which sought to help women in their daily lives. Such organizations, both urban and rural based, included the Women's Department of the KC PZPR, the Main Committee of the League of Women, and the Rural Housewives Circles. These organizations typically received assistance from the Economic Department of the KC PZPR, the Central Council of Trade Unions, the State Commission for Economic Planning, the Ministry of Labor and Social Protection, and from a variety of youth organizations. 34

Among these various women's organizations, the League of Women reaffirmed its commitment to modernizing the national economy, increasing women's cultural awareness, and encouraging women to participate in electoral campaigns. The LK recognized the complicated nature of 'women's problems', and expressed its repeated concern for improving women's professional and domestic self-consciousness so to facilitate the great modern transformation of the Polish society. The LK also organized a conference on 25-28 March 1965 to discuss the problems women faced both at work and at home. This conference was attended by about 180 people from all over the nation, including sociologists, psychologists, economists, and lawyers. The participants voiced the need for a great "women's offensive" in the direction of women's professional work and the very labor-consuming home obligations which placed multiple burdens on women.

Further, Alicja Musialowa, the president of LK and a member of the State Council (Rada Panstwa), re-emphasized the equality of Polish women in the economic, social and cultural spheres, and claimed that Polish women recognized the importance of

32 KiZ, 13 (27 March, 1966), 3; $\underline{\mathrm{KiZ}}, 45$ (10 November, 1968), 2; $\underline{\mathrm{KiZ}}, 16$ (20 April, 1969), 14; KiZ, 6 (9 February, 1969), 2; KiZ, 39 (29 September, 1963), 3; KiZ, 20 (16 May, 1965), 3; KiZ, 46 (14 November, 1965), 3; and KiZ, 39 (26 September, 1965), 2, 14.

33 Ostrowska, "Filmic Representations of the 'Polish Mother'," 427, 430, 433.

34 Przyjaciolka, 19 (8 May, 1966), 7; Przyjaciolka, 13 (27 March, 1966), 3; Przyjaciolka, 47 (24 November, 1968), 4; and Przyjaciolka, 25 (18 June, 1967), 3. 
building socialism and international solidarity for the good of society and the nation. The LK was happy to report the increasing numbers of women in its organizations, especially in Katowice, Radom, Gdansk, Wroclaw, Krakow and Lodz. The LK also lamented the death of President Bierut in 1956 since he had authored a 'historic transformation' for women. 35 However, while the LK committed itself to working in consonance with the socialist ideals of the regime, for some members of the political apparatus this confluence of interests was not good enough. For example, Ryszard Strzelecki, member of Political Bureau and Secretary of KC PZPR, opined that the LK did not challenge the sociologically accepted roles of women. The LK, according to him, needed new planning to meet its objectives and fulfill the specific needs for every problem surrounding women. 36

Another women's organization, the KRKP, aimed to enhance women's social and political consciousness by emphasizing the values of socialist education and 'rational' living, and enabling women to undertake systematic professional work in a largely maledominated working environment. The Centralna Rada Zwiazkow Zawodowcyh (Central Trade Union Council) assisted the KRKP in promoting women's professional work. At the same time, the KRKP also acknowledged women's critical role in building the new socialist family. With her new socio-professional qualifications, and with her contributions in the labor market and within families, the 'new woman' was said to be instrumental in the dynamic progress and transformation of the country. 37

Unfortunately, despite the general improvement in the situation of women's work and the increasing numbers of employed women, the existing working conditions were not conducive to women's extensive recruitment in professional occupations. Women were less keen on "building socialism", and questioned their limited participation in the National Councils, the shortages of social institutions and facilities to help women in the home economy and with children, and the double burden that left women with no time,

35 For the work of LK from 1953-1965 see Przyjaciolka, 4 (25 January, 1953), 12; KiZ, 34 (1 December, 1954), 7; Przyjaciolka, 11 (14 March, 1954), 3; Przyjaciolka, 52 (25 December, 1955-1 January, 1956), 17; Przyjaciolka, 39 (30 September, 1956), 12; KiZ, 9 (20 March, 1956), 2; KiZ, 2 (10 January, 1957), 3; KiZ, (1 August, 1957), 2, 3; KiZ, 10 (1 April, 1959), 3; Przyjaciolka, 10 (6 March, 1960), 5, 10; KiZ, 13 (26 March, 1961), 3; Przyjaciolka, 13 (26 March, 1961), 5; Przyjaciolka, 39 (24 September, 1961); Przyjaciolka, 7 (18 February, 1962), 3; KiZ, 7 (18 February, 1962), 1; Przyjaciolka, 6 (11 February, 1962), 7; Przyjaciolka, 21 (24 May, 1964), 6; KiZ, 10 (7 March, 1965), 2, 3; Przyjaciolka, 10 (7 March, 1965), 5; Przyjaciolka, 22 (30 May, 1965), 5; Przyjaciolka, 48 (28 November, 1965), 5; KiZ, 11 (14 March, 1965), 2; and KiZ, 15 (11 April, 1965), 11.

36 Przyjaciolka, 13 (27 March, 1966), 3.

37 Przyjaciolka, 48 (26 November, 1967), 9; Przyjaciolka, 45 (10 November, 1968), 3; KiZ, 28 (14 July, 1968), 2; KiZ, 45 (10 November, 1968), 2; KiZ, 48 (1 December, 1968), 3; Przyjaciolka, 52 (28 December, 1969), 5; and KiZ, 6 (9 February, 1969), 2. 
energy or inclination to participate in social life. 38 By contrast to most East European countries, Poland registered an increasing birth rate during this time period. With a baby boom, Polish women were naturally concerned with the limited social services available to them. During the years between 1960-1965, the government tried to decrease the birthrate by advertising contraceptives and establishing a network of family planning centers. 39 But little was achieved in terms of providing more preschools and other welfare institutions.

In response to the limited state assistance in provisioning women with the emancipatory keys to happiness, women increasingly began to question their "double burden" in the 1960s. In response to this state tolerated "double burden", Polish women adopted active and passive forms of "resistance". For example, it became natural for female workers to 'abuse' their privileges. Absences in textile industries were common, especially in Lodz and woj. Katowice. The 'guilty' women were invariably married women with children. Although this abuse paled in comparison to the wide-scale absenteeism of male workers, women complained that nobody really cared about male workers' 'crimes'.40 Meanwhile, some women began to take a closer look at the question: "What is feminism?" The "women's question" and "feminizacja" were social problems that now began to capture the attention of many more women. 41

Thus, Polish women during the 1960s expressed their distress over a number of issues including the patriarchal family environment, families in 'crisis', the social isolation of single women, alimony payments, 'demoralization' of youth, prostitution, alcoholic husbands and fathers, limited opportunities for women's professional advancement, the state's focus on heavy industrial work in comparison to light industries that would employ women, and the consequent feminization of low paid occupations in the textile industry, health services, and teaching. 42 Women were progressively less

\footnotetext{
38 In the first years of People's Poland (1944-1947), there were 33 women deputies out of a total membership of 448 in the Statewide National Councils (Krajowe Radzie Narodowej). Between 1947-52, the number decreased to 26 out of 444. The biggest increase in numbers came between 1952-56 ( 75 women out of 425). But by 1961 there were only 19 women out of 459. See KiZ, 9 (26 February, 1961), 2. Also, after 1962, there was less talk about women "building socialism" in Kobieta i Zycie, though all the other themes continued to be stressed.

39 Marody and Giza-Poleszczuk, "Changing Images of Identity in Poland?" 156. Beginning in the early 1960s, many of the East European countries began to experience declines in their birthrates. This reflected economic hardships which adversely impacted family life. Pronatalist measures were thus adopted. See Wolchik, "Women and the State in Eastern Europe and the Soviet Union," 58.

40 KiZ, 8 (19 February, 1961), 2; and KiZ, 1 (5 January, 1964), 3.

${ }^{41} \underline{\mathrm{KiZ}}, 40$ (6 October, 1968), 2, 3; and $\underline{\mathrm{KiZ}}, 45$ (10 November, 1968), 2.

42 There are many references to women's 'double burden' in the press for the 1960s. See for example, Przyjaciolka, 27 (2 July, 1961), 3, 5, 8, 9; KiZ, 23 (4 June, 1961), 2, 3; KiZ, 30 (23 July, 1961), 10; KiZ, 1 (7 January, 1962), 1, 2; KiZ, 48 (2 December, 1962), 3; KiZ, 43 (28 October, 1962), 11; KiZ, 19 (12 May,
} 
represented as the authority of centralized economic and political institutions increased.43 In response to these multiple constricting pressures and growing disillusionment with "socialist feminism," some women gradually began to revive the dormant Polish “woman's question”. These incipient discussions on the women's double burden in Poland paralleled the emergence of women's movements in several parts of western Europe during the 1960s. In the west, women in the labor force increased dramatically between 1960-73. With postwar economic recovery and continued expansion and growth came a significant change in the pattern of women's gainful employment in Europe as well as in the US. This growth in women's labor participation coincided with their increasing demands for women's rights to work, equal pay, divorce, contraception, abortion, and the right to operate as free individuals on equal terms with men. 44

However, Polish women's inquisitive glances at the variant forms of "feminism" by no means suggested the formation of a "feminist movement" in the PRL. Throughout Eastern Europe, women remained first and foremost mothers, fulfilling their socially defined responsibilities in the home and the family. The region, as a whole, lacked a feminist movement because of organizational and ideological limitations. 45 Even in the Soviet Union, Khrushchev and later Brezhnev, did not reexamine the theoretical status of the 'woman question'.46 Brezhnev's political generation of men displayed patriarchal reluctance to alter the course of Soviet pronatalism. 47 Moreover, shortages in contraceptives, inadequate housing, poor child care, women's double shift, increased abortions, and rising rates of infant and maternal mortality, all undermined any move toward alleviating the various burdens on women. At the same time, both men and

1963), 3; KiZ, 26 (30 June, 1963), 3; KiZ, 43 (27 October, 1963), 3; Przyjaciolka, 12 (22 March, 1964), 7; Przyjaciolka, 21 (24 May, 1964), 5; KiZ, 44 (1 November, 1964), 2, 3; KiZ, 2 (10 January, 1965), 14; KiZ, 3 (17 January, 1965), 11; KiZ, 46 (14 November, 1965), 3; KiZ, 49 (5 December, 1965), 10; Przyjaciolka, 22 (30 May, 1965), 5; KiZ, 13 (27 March, 1966), 3; iZ, 25 (19 June, 1966), 3; KiZ, 46 (13 November, 1966), 3; KiZ, 22 (2 June, 1968), 11; Przyjaciolka, 12 (24 March, 1968), 5, 12; Przyjaciolka, 47 (24 November, 1968), 4; Przyjaciolka, 10 (9 March, 1969), 7; and KiZ, 5 (1 February, 1981), 6-8. For issues related to prostitution see KiZ, 28 (15 July, 1962), 11.

43 Taras, "The Local Political Elites," 288.

44 See Prue Chamberlayne, "Women and the State: Changes in Roles and Rights in France, West Germany, Italy and Britain, 1970-1990," in Jane Lewis (ed.), Women and Social Policies in Europe: Work, Family and the State (Hants and Brookfield, 1993), 170-193, p.172; Marilyn Boxer and Jean Quataert, Connecting Spheres: European Women in a Globalizing World, 1500 to the Present (New York, 2000), 251-253; and Kaplan, Contemporary Western European Feminism, 25.

45 Wolchik, "Women and the State in Eastern Europe and the Soviet Union," 59, 61.

46 Buckley, Women and Ideology, 159.

47 Buckley, Women and Ideology, 161; Clements, Daughters of Revolution, 119; and Sue Bridger and Rebecca Kay in Pilkington (ed.), Gender, Generation and Identity in Contemporary Russia. 
women alike paid little attention to the special economic and social problems of women in Soviet society, being more absorbed in issues such as freedom of the press, the rule of law, religious freedom, and self-determination for the nationalities. 48

Thus, Polish women, similar to their counterparts in Eastern Europe, entered a labor market which was fenced by the forces of social patriarchy. They were encouraged to become professional, but not at the expense of their families. The widespread economic hardships on account of Gomulka's failed Polish 'national road to socialism' also forced women to place their families before their own self-interests. This was in contrast to many western countries where the relative economic prosperity and political stability provided women with greater opportunities to demand more rights and privileges for themselves. However, despite the fact that Polish women were less "feminist" than their western counterparts, they were, rather ironically, more "physically liberated" and "sportive" than their western peers. The socialist emphasis on sports and physical education for both men and women gave Polish female athletes the upper edge over their western counterparts.

Indeed, the membership of Polish women in sports societies increased rapidly during the 1960s. 49 Throughout the 1960s, the authorities stressed the importance of sports and the need to construct solid training facilities for the development of Polish physical culture. According to press accounts, the organization of sports during these years was dynamic. 50 Between 1948-69, there was a three-fold increase in the numbers of stadiums and recreation halls. Before the war, there were about 1900 sports arenas, with about 400 swimming pools and around 1200 sports halls. Now there were 5000 sports arenas, with 1600 swimming pools and 3400 halls for sports gymnastics. Such figures were published to illustrate the successes of Polish physical culture in constructing a national socialist culture. 51

In 1960, the GKKF and the Committee for Tourism Affairs merged into the GKKFiT. Thereafter, this central "state-social" organ of administration coordinated all

\footnotetext{
48 Clements, Daughters of Revolution, 120.

49 Sieniarski, Sport in Poland, 111-113.

50 Tuszynski, Prasa i sport, 292.

51 PzS, 163-164 (23 December, 1963), 1, 4; Glowny Komitet Kultury Fizycznej i Turystyki (Aktualne zadania kultury fizycznej oraz kierunkowe wytyczne rozwoju sportu na lata 1966-1970: Referat zastepcy przewodniczacego GKKFiT mgr. Jozefa Rutkowskiego wygloszony na plenarnym posiedzeniu podkomitetu kultury fizycznej w dniu 26 listopada 1965r, Warsaw, November 1965), 5, 7, 8, 27; and Reczek, "25 lat kultury fizycznej w Polsce Ludowej," 19.
} 
sports activities for popularizing physical culture and tourism. 52 The resolution of VII Plenum of the Central Council of Trade Unions of 4 March 1964 also outlined the importance of sport and physical culture for developing a spirit of friendship at the workplace and in the family. 53 Meanwhile, throughout the $1960 \mathrm{~s}$, the TKKF worked to promote the idea of 'Sport in the Family' in towns. 54

Considerable attention was given to sports research as well. The number of sports publications increased between 1958-1970. Regular sports-related conferences and seminars were also organized at the regional, national and international levels. The Polish Scientific Society for Physical Culture (Polskie Towarzystwo Naukowe Kultury Fizyczjne), with its main center in Warsaw, was established in 1966 to coordinate scientific research in the field of physical culture. 55

During the years 1965-1970, the School Sports Union (SZS) became more active, taking over the organization of all the school youth sports programs. The aim of the School Sports Union was to promote the well-rounded education of each student's personality and health, as well as constructively organize the free time of children and youth.56 This was consistent with the regime's interest in building socialism by

52 "Uchwala Biura Politycznego KC PZPR," 195; Gondek, Kultura fizyczna w Polsce, 27, 29, 30; Gaj, Wychowanie fizyczne, 24; Kedziorek, "Upowszechnienie kultury fizycznej," 9, 14, 22, 23; Brzezicki, Drazdzewski, Podoski, and Romanski (eds.), Ksiega sportu polskiego, 19; Lysakowski, Panstwowa adminstracja, 33; Chelmecki and Wilk, Wybor zrodel i materialow, 148, 160; and Drazdzewski, Dzieziecioletnia dzialalnosc, 3, 4, 58.

53 Chelmecki and Wilk, Wybor zrodel i materialow, 162, 163.

54 Kedziorek, "Upowszechnienie kultury fizycznej," 5, 22, 23; Gawlak-Kica, Rozwoj kultury fizycznej w Wielkopolsce, 263, 265, 294, 295; and "Uchwala Biura Politycznego KC PZPR," 195. For more on the TKKF, see also Lech Erdmann, "The Leadership Training for Recreation and Leisure Activities in Poland," 155; and Teresa Wolanska, "Kierunki rozwoju rekreacji fizycznej w Polsce," 413-415.

55 PzS, 163-164 (23 December, 1963), 1, 4; Hadzelek, "Foundation," 93, 94, 95, 101; and Gondek, Kultura fizyczna $w$ Polsce, 164.

56 For the organization of sports in schools see $\underline{\mathrm{PzS}}, 163-164$ (23 December, 1963), 1, 4; $\underline{\text { PzS }}, 104$ (29 May, 1981), 5; Gutowski, Drogi rozwoju kultury fizycznej, 104; Ministerstwo Oswiaty: Materialy z narady kuratorow I przewodniczacych WKKFiT w dniu VI 1966 (Nakladem Biuletynu Informacyjnego GKKFiT), 1; Drazdzewski, Dzieziecioletnia dzialalnosc, 76; Informacja i wnioski z posiedzenia plenarnego glownego komitetu kultury fizycznej i sportu $w$ dniu 26 Pazdziernika 1981r (Warsaw, October, 1981), 1-8; Liponski, "Still and Unknown," 3; Gaj in Gaj and Hadzelek, Dzieje kultury fizycznej, 261, 262, 263, 269, 270; "Uchwala Biura Politycznego KC PZPR," 194; Gy. Szabo Foldesi, "Postawy wobec wychowania fizycznego; relacja z badan polsko-wegierskich," in Wychowanie Fizyczne i Sport, 27, 4 (1983), 55-63, p.57; Gondek, Kultura fizyczna w Polsce, 136-139, 246, 247; Wolanska, "Wychowanie," 237; Jerzy Skorowski, "Programy kultury fizycznej w szkole okresu przejsciowego, czesc II," in Kultura Fizyczna, 32, 11 (1978), 488-490; Gaj, Wychowanie fizyczne, 82-100; H. Sozanski, “Szkolenie," Sport Wyczynowy, 1988, 13-23, p.23; R. Przeweda, "Wspolpraca klubow sportowych ze szkolami," in Wychowanie Fizyczne i Sport, 26, 2, (1982), 61, 62; Henryk Sozanski, "Sport dzieci i mlodziezy, Selekcja--wazny element systemy szkolnenia," in Sport Wyczynowy, 19, 2-3/194-195 (1981), 41-46, p.42, 43; and Pawel Kudlorz, "School Sport in Poland from the 1950s to the 1980s," in Eric F. Broom, Roy Clumpner, Brian Pendleton and Carol A. Pooley (eds.), Comparative Physical Education and Sport . Vol. 5 (Champaign, Illionis, 1988), 139-148, pp. 141, 142, 146-148. 
indoctrinating the youth with an improved system of education in secondary and high schools. For this reason, the regime encouraged sports for the physical and intellectual development of youth and children. Unfortunately for the state, the student memberships in youth organizations under Gomulka remained very small. The ZHP, the least affected by communist infiltration, recorded the largest membership. 57

During the 1960s, many more sports committees and institutional facilities emerged to coordinate physical education, tourism and sports in different parts of Poland. For example, in Greater Poland, efforts were made to increase the number of gymnastic halls and sports bases, especially in schools. The TKKF, along with the Union of Socialist Youth (Zwiazek Mlodziezy Socjalistycznej), the Union of Polish Students (Zwiazek Studentow Polskich, ZSP), the SZS, and the ZHP assisted in the organization of regional spartakiads, professional school Olympics, and the Sports-Recreational Games of Youth Workers (Igrzyska Sportowe-Rekreacyjne Mlodziezy Robotnicznej) in 1970. The membership in sports clubs in Poznan increased from 16,800 in 1960, to 29,600 in 1965, to 36,800 in 1970. Between the years 1945-1970, Poznan experienced a dynamic population increase, much more so than in the other Polish cities.

Unfortunately, this increase in population in Poznan did not keep pace with developments in the city's mass communications, educational facilities, and health services. Although the popularity of physical culture encompassed greater numbers of residents, especially between 1960-1970, the persistent disproportions, together with the limited state investments, eventually inhibited the maturation of the 'mass' sports complex in this region. Still, the efforts of schools, work establishments, local cultural and social organizations, and TKKF in expanding sports in Poznan cannot be ignored. 58

In Bydgoszcz, the years between 1957-1975 were the heyday of sports. With the assistance of the Polish People's Army, local militia units, sports societies, the LZS, and the provincial committees of the PZPR, sports athletes from Bydgoszcz achieved many victories in different sports such as track and field, oaring, boxing, and canoeing. 59 In Gdansk, the number of PTTK and TKKF circles increased 1965-1970. 'Sports Days' in the form of sportowe wakacje, Olympic Day (Dzien olimpijczyka), Days of Culture and

57 Przyjaciolka, 1 (1 January, 1961), 10; Leslie, The History of Poland, 385; and Stehle, The Independent Satellite, $14,15$.

58 Gawlak-Kica, Rozwoj kultury fizycznej w Wielkopolsce, 85-100, 107, 108, 115, 118, 122-131, 158-161, 227, 228, 238, 239, 247, 251-257, 284, 290. See also Gabriela Gawlak-Kica, Kultura fizyczna m. Poznaniu w oparciu o dane badawcze (Poznan, 1978), 51, 52, 102, 103, 112, 113, 146-175.

59 Urbanyi, Zarys historii sportu Bydgoskiego, 20, 21, 45, 182-187. For a regional study of sports in Bydgoszcz in the postwar period see Konrad Mrozik (ed.), Informator wojewodzkiego komitetu kultury fizycznej i turystyki w Bydgoszczy (Zeszyt 1, Nr. specjalny, January, 1970). 
Sports (Dni Kultury i Sportu), Ready as Soldiers (Sprawni jak zolnierze), and Victory Race (Bieg zwyciestwa) were popular in schools. 60

In Lublin province, after an initial chaotic period of 1946-1950, and the subsequent bureaucratic centralism of 1949-1956 that resulted in the closure of the Lublin District Sports Union in 1951, the move toward greater regional autonomy in 1956 was reassuring. The resolution of the National Council in Lublin province on 28th April 1963 implemented a drastic reorganization of the regional physical culture apparatus that allowed the area to secure 11th place in the II All-Polish Youth Spartakiad in 1971. Sports such as football, track and field, volleyball, boxing, weightlifting, wrestling, and cycling enjoyed maximum popularity among the peasant-workers and the intelligentsia. The sporting efforts of OMTUR, ZWM, ZMW, ZHP, ZSCh, TKKF, and SZS all helped this region to become more "sportive". However, the insufficient material base for developing physical culture and the persistence of erroneous stereotypes in social consciousness about the role of physical culture in social life hampered further progress. 61

More often than not, the regime used sports to divert popular attention from religious and anti-socialist practices. For example, on June 24, 1966 to counterbalance the Church ceremonies in honor of the millennium of Polish Christianity, state authorities organized traditional folk festivals celebrating summer solstice complete with sporting events, street performances and fireworks. On June 26, street concerts, a motor car race and two soccer matches were organized in Warsaw. On both these days, groups of party members and policemen hindered access to cathedrals and shouted slogans directed at the bishops and the primate. 62 Further, concerned with the student strikes of March 1968, the PZPR especially sought the use sports to help rebuild fractured social relations and protect the young from anti-socialist ideology. 63 During this year, the political leadership became more alert to the need to closely supervise the regulation of sports activities, especially for the youth. It is interesting that in the same year, the Soviet Union

\footnotetext{
${ }^{60}$ For sports in this region see Zbigniew Szot, Rozwoj kultury fizycznej w aglomeracji Gdanskiej, Gdansk, Gdynia, Sopot w latach 1945-1980 (Gdansk, 1986), 9, 10, 19, 33, 36-49, 51-59, 63, 67, 70, 71, 77, 80, 83, 87, 89, 99, 104, 106, 121-137, 140-144, 196, 197, 201, 204.

61 Skawinski, Kultura fizyczna na Lubelszczyznie, 16-26, 43, 47, 48, 52, 53, 57, 62, 63, 74, 80, 81, 118, 119, 137, 165-190.

62 Karpinski, Poland Since 1944, 134, 136, 137.

63 See KiZ, 31 (4 August, 1968), 2; KiZ, 45 (10 November, 1968), 3; KiZ, 48 (1 December, 1968), 2; KiZ, 19 (12 May, 1968), 3; KiZ, 19 (12 May, 1968), 3; and KiZ, 37 (15 September, 1968), 10.
} 
also reasserted government control in physical culture and increased the power of the council of ministers in the coordination of sports and physical education. 64

Overall, Polish women's physical culture benefited from the state's interest in using sports to glamorize socialist values and doctrines. Gomulka's commitment to developing physical education, recreation and tourism, and sports institutions during the 1960s remained strong and reflected the party leadership's need to optimize on sources which provided legitimacy to socialist rule in Poland. This was consistent with some of Gomulka's other notable accomplishments. For example, Gomulka supported private ownership in agriculture, curbed and published police abuses, ended arbitrary political arrests, and asserted Poland's right and determination to administer its own affairs in the context of a nonexploitative relationship with the Soviet Union. At the same time, however, Gomulka also left behind a political and economic system purged of the worst features of Stalinism, but still over-centralized and run by a narrow political elite. 65 The Polish sports apparatus likewise suffered from these strains of bureaucratization and over-centralization.

It needs to be emphasized that the proliferation of women's sports was not unique to Poland in the eastern bloc during the 1960s. In the Soviet Union, the construction of thousands of sports clubs, stadiums, skating rinks and swimming pools, together with the state's enthusiasm in organizing tournaments specifically for women provides an indication of how the state perceived the importance of physical culture for women. 66 The years from 1968-1976 also saw the meteoric rise of East Germany as a sport power, especially in women's competitions. East German women typically excelled in sports such as gymnastics, swimming and track and field. 67 Interestingly, in communist China, Chairman Mao swam across the Yangtze River in 1966 to demonstrate his fitness to rule at a time when he was losing power. His swimming feat stimulated a national swimming craze among young Chinese men and women. 68 It comes as no surprise that Chinese women have, in the recent past, excelled in swimming competitions.

\footnotetext{
64 Edelman, Serious Fun, 156, 157.

65 See KiZ, 20 (16 May, 1965), 2; Rothschild, Return to Diversity, 192, 193; Ekiert, The State Against Society, 216, 217; and Leslie, The History of Poland, 407.

66 For details see Riordan, Sport, 320, 322; Soviet Woman, 7 (1960), 31; Soviet Woman, 9 (1960), 21, 23; Soviet Woman, 12 (1961), 7; and Soviet Woman, 2 (1965), 13.

67 The New York Times, (24 May, 1965), 4-S; and Senn, Power, Politics, and the Olympic Games, 169, 170.

68 Brownell, Training the Body For China, 57.
} 
The successes of East European women in international sports competitions forced western societies to revise their earlier policies which restricted women's participation in sports. For example, in the mid-1960s, women athletes in America experienced greater tolerance and approval, and new opportunities. US officials now supported women's participation in certain sports-- a support that had an important qualification---the expectation that female athletes would adhere to all other aspects of femininity. 69 Even in Britain, the 1960s saw the emergence of female athletics as a major force. The British tabloids were, however, a little skeptical since they wanted to project images of "golden girls", and not those of simply "athletic women".70 In Australia, meanwhile, women increasingly began to challenge the male hegemony in sport from the 1960s onward. They undermined the idea of female weaknesses by taking up horse-racing, long-distance running, weight-lifting, and body-building, all of which had been previously limited to men. 71

Thus, similar to the East European and Chinese women, Polish women began to participate in sports in increasingly numbers in the 1960s. Their international sports victories forced western states to encourage their women to become more athletic and improve their physicality. Unlike in the earlier time periods when women in the east followed the lead of their western peers in sports, in the 1960s the mentorship roles were reversed and it was now western countries which were increasingly influenced in the development of their women's physical culture along the patterns predominant in the east. However, western women were still required to balance their athleticism with traditional notions of feminine propriety. They could restore their nation's pride and prestige in the international sporting arena; however, they were still required to assume their traditional motherhood roles within their countries and in the homeplace. Polish sportswomen, similar to the other east European female champions, appeared to be more liberated from this 'double burden' than their western rivals, at least in theory and imagery.

\footnotetext{
69 Festle, Playing Nice, 84, 88, 100, 102, 262, 263; and Woolum, Outstanding Women Athletes, 17.

70 Holt and Mason, Sport in Britain, 46, 47.

71 Vamplew, "Australians," 1-18.
} 


\section{"Long Live Sports!" The Images of Women and the Organization of Sport in Gierek's Poland, 1970-1979}

The development of Polish women's physical culture under Edward Gierek can be examined in two chronological phases. The first phase, from 1970-75, was marked by a resurgence in the Polish economy, which in turn fostered social stability and cultural vitality. The organization of physical culture reflected these signs of hope and prosperity during the first decade of the 1970s. Unfortunately, Gierek was unable to sustain this economic development, and the country thereafter plunged into economic and political crises. Therefore, the second phase from 1976-1980 was characterized by heightened social tensions which eventually resulted in the rejuvenation of the Polish "civil society". The development of physical culture, for both men and women, was now severely undermined by the economic hardships and social unrest. In both phases, however, the regime maintained its theoretical commitment to patronizing sports for the entire Polish society.

\section{0-1975}

On coming to power, the new party leader Edward Gierek, presented himself as an advocate of economic modernization. Gierek introduced a new economic program to address the country's serious financial problems. He undertook a series of personal dialogues with the restless workers and promised to listen to their complaints and offer improvements in return for their "help". Thus, Gierek attempted to improve the living standards of the increasingly self-confident and self-assertive workers in the expectation of eliciting their greater work effort to increase productivity as well as to gain their political support for his "New Development Strategy" which aimed at a successful economic transformation by initiating a "consumer revolution". However, Gierek's emphasis on an accelerated pace of economic development did not cause any political revision in the regime's fundamental policy of loyalty and appeasement toward the socialist alliance directed from the Soviet imperial core. Instead, the party leadership reinforced Poland's 'unshakable fraternal bond' with the Soviet Union, while simultaneously improving economic relations with the west in the hope of securing foreign credit lines to finance the regime's program of consumer socialism.

Gierek's Great Leap Forward to create a "developed socialist society" was based on rapid increases in living standards, consumerism, increased integration into the 
international economy, and a less rigid and centralized approach to the management of financial resources. Gierek wanted development in all branches of the economy, from industry to transportation to recreation. Accordingly, to stimulate the stagnant economy, Gierek engaged western economies in Poland's expansion program, gained increased access to sophisticated technology, promised the availability of consumer goods, raised pensions and minimum wages, accelerated housing construction, and committed more investments to industrial development, especially in steel projects, aviation and shipbuilding. In addition, Gierek assuaged the fears of peasants by abolishing compulsory deliveries of foodstuffs to the state and also extended free health services to nonstatesector employees. Gierek did not favor genuine market-based economic reforms. But he talked about better supply of consumer goods, the stabilization of prices for necessities, and the modernization and rapid industrialization of the economy. The rising economic fortunes of the early 1970s were hailed as a sign of dynamism and strength, and provided the material basis for Gierek's claim that national unity existed in the country. Between 1971-1975, Poland's economy and standard of living grew at an unprecedented rate, which in turn had a dramatic impact on the perceptions and expectations of the society. 72

Indeed, Gierek's attempt to build a more progressive and modern "second Poland" also reconfigured the relations between the socialist state and society. Gierek tolerated informal political opposition, spoke of 'grass root contacts' and "consultations with society", emphasized greater respect for the rights of citizens', and projected an image of directing the most liberal socialist government in Eastern Europe. Gierek's positive engagement with the Polish society, together with a higher standard of living and improvements in housing, social services, consumer goods, and leisure and cultural activities, won the regime a measure of genuine popular sympathy. ${ }^{73}$ For example,

\footnotetext{
72 For Gierek's new economic program see Laba, The Roots of Solidarity, 81, 82, 93, 94; Kubik, The Power of Symbols Against the Symbols of Power, 29, 34; Kanet, "Poland, the Socialist Community, and East-West Relations," 371, 372; Kazimierz Z. Poznanski, Poland's Protracted Transition: Institutional Change and Economic Growth, 1970-1994 (Cambridge, 1996), 7, 8, 29, 30, 63, 64, 262, 272; Przyjaciolka, 21 (21 May, 1972), 3-5; Rothschild, Return to Diversity, 196; Ash, The Polish Revolution, 16, 17; Ascherson, The Struggles for Poland, 186, 187; Keith John Lepak, Prelude to Solidarity: Poland and the Politics of the Gierek Regime (New York, 1988), 52, 65, 66, 79, 134, 145, 159, 210, 212; Hunter and Ryan, From Autarchy to Market, 30; Slay, The Polish Economy, 36, 37, 42; Kennedy, Professionals, Power and Solidarity in Poland, 38, 47; Mason, Public Opinion and Political Change in Poland, 43; Bielasiak, "Poland," 134; Jadwiga Koralewicz, "Changes in Polish Social Consciousness During the 1970s and 1980s: Opportunism and Identity," in Jadwiga Koralewicz, Ireneusz Bialecki and Margaret Watson (eds.), Crisis and Transition: Polish Society in the 1980s (Oxford, New York and Hamburg, 1987), 3-25, p. 4-5; and Bromke, Poland: The Protracted Crisis, 35-37, 40.

73 Leslie, The History of Poland, 412, 418; Bernhard, The Origins of Democratization in Poland, 42; Adam Bromke, "Policy and Politics in Gierek's Poland," in Simon and Kanet (eds.), Background to Crisis, 3-23, p.6; Jadwiga Staniszkis, Poland's Self-Limiting Revolution. Edited by Jan T. Gross (Princeton, 1984), 166; Rothschild, Return to Diversity, 196; Przyjaciolka, 7 (14 March, 1971), 10; Ascherson, The Struggles
} 
Gierek provided a more tolerant environment for religious practices and resumed dialogue with the Roman Catholic hierarchy. ${ }^{74}$ For the intellectuals, the regime eased censorship of newspapers and independent magazines, lowered restrictions on foreign travel and foreign contacts, and offered greater autonomy in educational and cultural life. 75 Even the working class of the early 1970s appeared younger, more skilled, better educated, less ideologically motivated, and more consumer oriented. 76 As for the youth, the party was certainly concerned about counteracting their supposed non-socialist, "bourgeois" tendencies. For this reason, and to foster some organizational unity in the youth organizations, the Union of Rural Youth was renamed the Socialist Union of the Rural Youth in 1973, the Circles of Military Youth became the Socialist Union of Military Youth, and the Union of Polish Students became the Socialist Union of Polish Students. These three organizations together with the Union of Socialist Youth and the Union of Polish Scouts were then organized into the Federation of the Socialist Unions of Polish Youth. 77

During the early years of the 1970s, the PZPR expressed equal interest in women's professional work and their role in preserving harmony within the family. ${ }^{78}$ On the occasion of the International Women's Day in 1973, Edward Gierek and Piotr Jaroszewicz congratulated Polish women for their patriotism, laboriousness, perseverance, and high professional, ideological and moral values. The party and government leaders not only emphasized their gratitude to women for their work in building a socialist-national culture and economy, but also commended their efforts to maintain a harmonious family life characterized by "good" social consciousness and moral character. According to Gierek, women had 'revived, brightened and animated'

for Poland, 186; Ben Slay and Louisa Vinton, Poland to 2005: The Challenge of Europe, Research Report (London, 1997), 64; Koralewicz, "Changes in Polish Social Consciousness During the 1970s and 1980s," 8; Ekiert, The State Against Society, 218; and Lepak, Prelude to Solidarity, 50.

74 Bromke, Poland: The Protracted Crisis, 46; Kanet, "Poland, the Socialist Community, and East-West Relations," 371; Staniszkis, Poland's Self-Limiting Revolution, 172; Rothschild, Return to Diversity, 196; and Poznanski, Poland's Protracted Transition, 64.

75 Ash, The Polish Revolution, 16, 21; Poznanski, Poland's Protracted Transition, 64; and Hunter and Ryan, From Autarchy to Market, 30.

76 Sanford, Polish Communism in Crisis, 78.

77 Leslie, The History of Poland, 427; Kubik, The Power of Symbols, 29; Lepak, Prelude to Solidarity, 67, 207, 208; and Ash, The Polish Revolution, 29-31.

78 Przyjaciolka, 24 (14 June, 1970), 3; Przyjaciolka, 17 (26 April, 1970), 7; KiZ, 51 (19 December, 1971), 2; KiZ, 8 (21 February, 1971), 3; KiZ, 15 (11 April, 1971), 3; Przyjaciolka, 2 (9 January, 1972), 3; Przyjaciolka, 3 (21 January, 1973), 12; iㅡ, 20 (20 May, 1973), 6, 7; iZ, 43 (28 October, 1973), 3; and KiZ, 23 (10 June, 1973), 6, 7. 
every Polish house--'a house in which children are not only born, but where they also develop their moral and intellectual strength in accordance with national ideas'.79

While the party leadership recognized the contributions of women in building this vibrant economy in the early 1970s, the state also acknowledged the difficulties faced by working women at home and at the workplace. 80 Throughout the 1970s, the women's press once again discussed the inequities in women's professional work and in home life. Despite some provisions for easing women's work, women lacked complete equality. The press articles articulated the need for more free time for female workers, especially for mothers with small children. They wanted greater opportunities for women to engage in home-based work, and expressed the need to construct more nurseries and day care centers, improve health services, control alcoholism, supply more consumer goods such as washing machines, and open larger numbers of grocery shops and kiosks for women at the work place. ${ }^{81}$

Meanwhile, the directors of women's organizations from different socialist countries met on 15-17 April, 1971 in Warsaw to discuss problems in women's work and life, as well as to affirm the solidarity of socialist countries. Participants in this fourth meeting (the first two were organized in Moscow and the third in Budapest) included Valentyna Tereshkova from USSR, Gusta Fucznikova from Czechoslovakia, and Dora Carcano from Cuba. 82

The organization of Polish sport during the early 1970s was directly related to Gierek's desire to improve the Polish self-image and cultivate national pride. Gierek used all the major domains of public discourse--i.e., visual imagery, rhetoric, and ceremonies to emphasize the desirability of endowing cultural output with national values. For example, Polish patriotism was reinforced by the rebuilding of the Royal Castle in Warsaw, and strengthening contacts with Polish emigres (Polonia). Similarly, the successes of Polish athletes were used to propagate a more optimistic image of an economically powerful and happy Polish Motherland. The carnivalesque and robust images of various town tournaments, festivals, and interfactory sports competitions not

\footnotetext{
79 Przyjaciolka, 2 (18 March, 1973), 3. For more laudatory comments of Gierek, see also Przyjaciolka, 2 (9 January, 1972), 3.

80 Przyjaciolka, 7 (14 March, 1971), 3, 12.

81 Przyjaciolka, 10 (7 March, 1971), 3; Przyjaciolka, 50 (12 December, 1971), 3; KiZ, 10 (7 March, 1971), 6; KiZ, 49 (5 December, 1971), 10, 11; Przyjaciolka, 43 (22 October, 1972), 3; Przyjaciolka, 8 (25 February, 1973), 5; KiZ, 6 (11 February, 1973), 3; KiZ, 27 (8 July, 1973), 5; and KiZ, 1 (6 January, 1974), 4. For the issue of alcoholism see also KiZ, 16 (18 April, 1971), 2.

82 KiZ, 18 (2 May, 1971), 6, 7.
} 
only fostered sentiments of a new national pride and self-confidence, but also constituted proof that the society was on the right track. This mood was further strengthened by Poland's appearance in the semifinals of the 1974 Soccer World Cup. 83

In 1972, the ruling elites reiterated their interest in promoting sports for building socialism. At the VII Plenum KC PZPR on 28th November 1972, the state discussed sports-related issues such as popularizing physical culture by encouraging regional tourism in towns and the countryside, supplying sports equipment and training cadres, researching the psychological and biological development of youth, and facilitating the complete mobilization of sports organizations and scientific research institutions. ${ }^{84}$ The state especially encouraged medical research in women's sports. 85

In January 1973, the KC PZPR renewed its commitment to the idea of 'sport in the family", as well as to the "modernization" of sports and tourism, with greater emphasis on physical education in schools. 86 On 6 April 1973, a resolution by the Council of Ministers obliged the educational ministries and the GKKFiT to emphasize the scientific and moralistic components of physical education, sport, and recreation for the youth. 87 In the same year, the Polish Sports Federation was formed for better coordinating the official physical culture apparatus. Its existence, however, proved ephemeral for in 1978 it was incorporated into the newly established GKKFiS. The provincial federations continued, until their further modifications in 1980.88 It needs to be added that until 1973, with the exception of a few months in 1951 and the beginning of 1952, the central authorities of Polish sport and physical culture were to a substantial degree composed of non-communists. 89

During the early 1970s, the AWFs made valuable contributions to historical, sociological, psychological and pedagogical research, all of which enhanced the pride and prestige of

83 For Gierek's emphasis on "national dignity" see Kubik, The Power of Symbols, 34, 51, 64, 68, 73; Sanford, Polish Communism in Crisis, 29, 30; Kemp, Nationalism and Communism in Eastern Europe, 175; Ray Taras, Ideology In A Socialist State: Poland, 1956-1983 (Cambridge, 1984), 135; and Hunter and Leo V. Ryan, From Autarchy to Market, 30.

84 Glowny Komitet Kultury Fizycznej i Turystyki: Zadania w dziedzinie kultury fizycznej i turystyki (Referat przewodniczacego GKKFiT Wlodzimierza Reczka oraz Uchwala plenum GKKFiT z dnia 16 Marca 1972, Nakladem Biuletynu informacyjnego GKKFiT, Warsaw, March, 1972), 3, 4, 5, 9, 14, 16, 19; and Chelmecki and Wilk, Wybor zrodel i materialow, 185.

85 J. Slezynski, J. Rog and H. Debska, "Budowa i postawa ciala uczennic szkoly baletowej, muzycznej i ogolnoksztalcacej," in Wychowanie fizyczne i sport, 22, 1 (1978), 37-44; and PzS, 113 (8 June, 1984), 5.

86 Chelmecki and Wilk, Wybor zrodel i materialow, 191, 192, 196; and Zbigniew Krawczyk and Zygmunt Szulc, "Sport dobrem wszystkich ludzi," in Kultura Fizyczna, 31, 8 (August, 1977), 371-374.

87 Gondek, Kultura fizyczna w Polsce, 36, 39.

88 Gawlak-Kica, Rozwoj kultury fizycznej w Wielkopolsce, 263, 265; and Gondek, Kultura fizyczna w Polsce, 68, 73, 74.

89 Liponski, "Still and Unknown," 31. 
Polish physical culture. The general AWF curriculum was reformed in 1970 to create four separate academic faculties of training, coaching, recreation, and physical rehabilitation. Popular conference themes included the pedagogical, therapeutic, egalitarian, and rational applications of physical culture. Seminar discussions focused on the need to increase sporting contacts between towns and the countryside, and popularize the idea of 'sports in the family'. The AZS also organized different types of sports and spartakiads. The number of graduates from the AWFs increased between 1956-1970 and the academic staff tripled between 1965-1975. However, the number of male sports scientists was nearly double that of women. 90

Considerable sums were invested by the state to make sports tourism and other leisure activities attractive. In the official vision, tourism was an important element of socialism which not only stimulated growth of regional economies, but also allowed the rational utilization of free time, improved the physical and psychological development of the individual, and provided a pedagogical medium for socialist education. Tourist activities received the patronage of the Zjednoczenie Gospodarki Turystycznej (1973), the AWFs, the GKKFiT, LZS, Polski Zwiazek Motorowy (Polish Motor Union), Polskie Towarzystwo Schronisk Mlodziezowych, and Polska Federacja Campingu (Polish Federation of Camping). A host of smaller enterprises such as private restaurants, cafes, and housing cooperatives, as well as professional associations of economists, geographers, ethnographers, architects, art historians, and hotel workers, all enabled the state to realize its objectives in the promotion of tourism. ${ }^{91}$

At the high performance level, while some sports for women such as gymnastics, volleyball, swimming, and skating reported a regression by the early 1970s, other sports

\footnotetext{
90 See Annette Kruger and Pawel Kudlorz, "Comparative Study of the Analysis of Objectives Within Sport Curricula from 1945-1984 between the People's Republic of Poland and the Federal Republic of Germany," in Haag, Kayser and Bennet (eds.), Comparative Physical Education and Sport, 161-173, p.168; Wroczynski and Hadzelek, "Development of Sciences," 92, 94, 96, 97, 101, 102; Gaj in Gaj and Hadzelek, Dzieje kultury fizycznej, 272; Sesja Naukowa 25-lecia kultury fizycznej w PRL, 117-124; Kazimierz Obodynski, "Wyksztalcenie i status spoleczny nauczycielow wychowania fizycznego w szkolach wyzszych," 154-157, p.155; Jaworski, "Conceptions," 287; Gondek, Kultura fizyczna w Polsce, 133, 135, 136; Gaj, Wychowanie fizyczne, 44, 46, 54; and Henryk Grabowski, "Development of Academic Staff for Physical Education," in Bohumil Svoboda (ed.), Coaches and Physical Education Teachers Training in Socialist Countries. A Collection of Studies in the International Scientific Cooperation, Task No. 6, Vol. 3 (Prague, 1984), 271-300, pp. 275, 286.

91 Boguslaw Ryba, "Glowne kierunki rozwoju oraz formy organizacyjne turystyki polskiej z uwzglednieniem jej aspektow spolecznych," in Kultura Fizyczna, 11 (1977), 483-486; and Leslie, The History of Poland, 419, 427. For the cooperation between town planners and sociologists, as evidenced in the Snieznik Mountain project planned in 1972-73 for the construction of a recreational resort see Andrzej Ziemilski and Marek Zurn, "Humanistyczne zalozenia programu Snieznika proba socjologicznej interpretacji idei 'drugiego Zakopanego'," in Zbigniew Krawczyk (ed.), Kultura fizyczna i spoleczenstwo (Warsaw, 1976), 247-285. The motives behind this project were said to be 'heroic' and 'hedonistic'.
} 
such as fencing and kayaking registered an improvement. 92 At the more popular level, however, gymnastics exercise interested large numbers of women throughout these years. Also, some "non-athletic" men and women now began to interest themselves in activities such as jogging. 93 Indeed, during these early years of the 1970s, more people began to take an interest in recreational physical culture. The workplaces and trade unions, in consonance with the theme of Praca-Rodzina-Wypoczynek (Work-Family-Recreation), aimed to increase the number of facilities and opportunities for family recreation. 94 Both the TKKF and the PTTK (Polskie Towarzystwo Turystyczno-Krajoznawcze) played a leading role in promoting all forms of water, land and mountain tourism on a mass scale for Polish families. 95 The following table provides an indication of the increasing numbers of men and women in TKKF in Kalisz between the years 1958-1987, and especially between 1970-75 96 :

$\begin{array}{cclc}\text { Year } & \text { TKKF } & \text { Men } & \text { Women } \\ 1958 & 1 & 34 & 6 \\ 1960 & 2 & 128 & 16 \\ 1965 & 19 & 1,130 & 731 \\ 1970 & 27 & 2,920 & 1,211 \\ 1975 & 36 & 5,363 & 3,908 \\ 1980 & 44 & 5,712 & 3,592 \\ 1985 & 49 & 4,752 & 3,069 \\ 1987 & 50 & 5,082 & 3,161\end{array}$

$92 \underline{\mathrm{PzS}}, 69$ (12 June, 1971), 4.

93 KiZ, 30 (29 July, 1979), 21.

94 Przyjaciolka, 50 (12 December, 1971), 3; and Przyjaciolka, 29 (22 July, 1973), 5.

95 PzS, 163-164 (23 December, 1963), 1, 4; Przyjaciolka, 2 (12 January, 1969), 3; Przyjaciolka, 27 (6 July, 1975), 12; Przyjaciolka, 33 (13 August, 1978), 9; Przyjaciolka, 1 (7 January, 1979), 11; Przyjaciolka, 28 (13 July, 1980), 8, 9; Przyjaciolka, 26 (28 June, 1984), 6; Przyjaciolka, 17 (25 April, 1985), 8, 9; KiZ, 18 (20 June, 1960), 10; KiZ, 20 (16 May, 1971), 10; KiZ, 4 (28 January, 1973), 6, 7; KiZ, 32 (12 August, 1973), 14, 15; KiZ, 29 (July, 1973), 6, 7; KiZ, 34 (25 August, 1974), 4, 5; KiZ, 32 (11 August, 1974), 4, 5; $\underline{\text { KiZ, }} 29$ (22 July, 1974), 5; KiZ, 35 (31 August, 1975), 6, 7; KiZ, 2 (9 January, 1977), cover page; KiZ, 39 (25 September, 1977), 18, 19; KiZ, 29 (16 July, 1978), 2, 3; KiZ, 40 (1 October, 1978), 6, 7; KiZ, 49 (3 December, 1978), 14, 15; Przyjaciolka, 1 (4 January, 1970), 2; Przyjaciolka, 29 (16 July, 1972), 5; Przyjaciolka, 15 (15 July, 1982), cover page; and Lempka, 13-15, p.14. For TKKF's efforts in promoting 'Sport for All' see Teresa Wolanska, "Die Entwicklung des Programms "Sport fur Alle"," in Weltrat fur Sport und Korpererziehung, 1 (1978), 28-32; and Przewada, "Wspolpraca," 61, 62, 76.

96 Tomasz Kosinski, Dzialalnosc Towarzystwa Krzewienia Kultury Fizycznej w Kaliszu w latach 19581987 (Praca Magisterska, AWF Warsaw, 1988), 30. 
While the Polish state continued to reaffirm the importance of women's sports in these years, the development of women's physical culture in the Soviet Union remained far more dynamic than in Poland. Soviet women's participation in the country's domestic spartakiads provided credence to the principal Soviet sports slogan, for "mass participation". 97 Meanwhile, the many victories of East European athletes during these years ushered in revolutionary legislative changes in the American world of sport. The signing of Title IX of the Educational Amendment Act of 1972, in particular, revolutionized women's sport in the United States. Title IX indicated that women and men would have to receive equal treatment in both high school and college athletics. The leaders of women's intercollegiate athletics now hoped for bigger and better facilities, new equipment, more coaches and a vast improvement in the sporting opportunities available to girls and women. 98

Overall, the early years of the 1970s introduced marked improvements in the Polish socio-economic and cultural environments. These were "good" years for the Poles. Polish physical culture, for both men and women, profited from the resurgence in the national economy. However, the development of the Polish women's physical culture remained less dynamic than the revolutionary changes which seemed to be transforming the Soviet and American women's physical cultures. While Polish women's sports did not necessarily "lag" behind their western rivals, the American sportswomen were now provided with the opportunities to "catch up" with the East European women. And they would soon do so, not so much because of the lack of women's self-confidence in Poland or elsewhere in the east, but more so because of the increasing social and economic instabilities within the national political structures of Eastern Europe.

\footnotetext{
97 For sports among Soviet working class women in various provinces see Rabotnitsa, 6 (1972), 23; Soviet Woman, 10 (1970), 31; Soviet Woman, 7 (1971), 38, 39; Soviet Woman, 8 (1972), 1, 4, 5; $\underline{\text { Soviet Woman, }}$ 11 (1972), 2; and Soviet Woman, 10 (1971), 37.

98 Griffin, Strong Women, Deep Closets, 41; Cahn, Coming on Strong, 250; Festle, Playing Nice, 225, 227; Woolum, Outstanding Women Athletes, 18; Kane and Greendorfer, "The Media's Role in Accommodating and Resisting Stereotyped Images," 41; Mary Boutilier and Lucinda SanGiovanni, "Politics, Public Policy and Title IX: Some Limitations of Liberal Feminism," in Birrell and Cole (eds.), Women, Sport, and Culture, 97-109, p. 103; Marcia Westkott and Jay J. Coakley, "Women in Sport: Modalities of Feminist Social Change," in Journal of Sport and Social Issues, 5, 1 (Spring/Summer, 1981), 32-45; and Patricia L. Geadelmann, "Physical Education: Stronghold of Sex Role Stereotyping," in Quest, 32, 2 (1980), 192-200.
} 


\section{6-1980}

Gierek's impressive public relations performance and consumer socialism, unfortunately, raised expectations rather than productivity. The proposed economic advances were made possible only by heavy reliance on Soviet and Western loans, which ultimately saddled the country with an ever-growing debt. In addition, the bad harvests of both 1974 and 1975 further reduced the availability of some foods, especially meats. These natural weather-related crises, together with an administrative failure to initiate extensive political and economic reforms, caused Gierek's "economic miracle" to become an increasingly expensive proposition. As a consequence, the subsequent food price increase in June 1976 revealed the illusory character of Gierek's ambitious economic reforms and shattered the society's confidence in the political leadership. Worker's riots in Warsaw and Radom in protest against the sudden, drastic, and unexpected price hikes, were particularly damaging to the regime's recently acquired pride and prestige. While the announced price increases were soon rescinded, the arrest of scores of demonstrators and the labeling of strike leaders as "hooligans" and "firebrands" heralded the return of political problems for a severely weakened regime. 99 In the late 1970s, the Polish economy stagnated under the combined pressures of high inflation, persistence of a huge foreign debt, poor harvests, worsening consumer shortages, and widespread labor discontent. While the economy experienced a continuous decline, the trend toward economic and administrative centralization, together with the pervasive official corruption and mismanagement, the ideological rigidity of the party, the appearance of state dollar stores for the wealthy, and the elaborate system of privileges for a select few, exacerbated popular frustrations. Gierek attempted to assuage public disillusionment by reaffirming the 'leading role' of the Party 'in building socialism' within the country and by doing a good deal of bridge building with the West in foreign relations. However, for all its worth, the seemingly healthy disposition of

\footnotetext{
99 For Gierek's short-lived economic boom and the workers' protests of 1976 see Bromke, Poland: The Protracted Crisis, 69; Sanford, Polish Communism in Crisis, 30; Ash, The Polish Revolution, 17, 18; Rothschild, Return to Diversity, 197; Bielasiak, "Poland," 133, 135; Kemp, Nationalism and Communism in Eastern Europe, 175, 176; Leslie, The History of Poland, 421; Slay, The Polish Economy, 42-44; Ekiert, The State Against Society, 218, 220, 221; Laba, The Roots of Solidarity, 94; Bernhard, The Origins of Democratization in Poland, 45; Kubik, The Power of Symbols, 17, 73; Bromke, "Policy and Politics in Gierek's Poland," 3-5; Lepak, Prelude to Solidarity, 159; and Mason, Public Opinion and Political Change in Poland, 48, 49.
} 
Gierek's "success propaganda" was increasingly being called into question by a society whose own real standard of health was gradually deteriorating. 100

While the drastically worsening economic situation and the party's administrative incompetence undermined Gierek's efforts to build "socialist patriotism", the regime's political credibility and moral authority was further weakened by the rapid emergence of "self-organized" unofficial opposition groups and a large and varied underground publication industry in the late 1970s. The organizational impetus for the formation of this Polish "civil society" was provided first by the Committee For The Defense Of Workers (Komitet Obrony Robotnikow, KOR). KOR, formed in September 1976 by a few Polish intellectuals, aimed to provide legal, financial and medical aid to the workers who suffered in the government reprisals of June 1976. KOR identified itself as a social not political body, and operated in a largely open and public manner. KOR not only publicized popular frustrations and disappointed aspirations, but also encouraged the various segments of Polish society to overcome their political inertia and gain knowledge in the practice of social self-defense and self-reliance.

This fledging alliance between the working class and the intelligentsia soon matured into a national oppositional movement based on the principle of self-organized and nonviolent negotiation and compromise rather than insurrection. Despite a state directed campaign of repression against members of KOR, this increasingly self-confident and growing triple entente of working-class opposition, church inspired and protected Christian patriotism, and a Polish alternative politics modeled by the intellectuals defiantly rivaled an isolated and incohesive triple alliance comprised of Gierek's conceptualization of socialist patriotism, the party corruption and mismanagement, and the Communist government's hegemonic discourses. In this system of alliances, the continued economic crisis, the formation of 'free' trade unions and numerous social selfdefense groups, the election of Polish archbishop Karol Cardinal Wojtyla as Pope John Paul II in 1978 and his symbolic visit to Poland the next year, and the regime's unwillingness to risk damaging relations with Western countries throughout these years,

\footnotetext{
100 For the persistent economic crisis in the second half of the 1970s see Staniszkis, Poland's Self-Limiting Revolution, 170, 171, 209; Ash, The Polish Revolution, 112, 113, 194; Rothschild, Return to Diversity, 198; Ascherson, The Polish August, 116, 117; Poznanski, Poland's Protracted Transition, xx, xxiii, 79, 80, 248, 249; Chris Russell Hodgson, "Health Policy and Health Service Reforms in the 1970s," in Jean Woodall (ed.), Policy and Politics in Contemporary Poland: Reform, Failure, Crisis (New York, 1982), 171-194, p.191; Kubik, The Power of Symbols, 68, 69; Mason, Public Opinion and Political Change, 51-56; Laba, The Roots of Solidarity, 94; Kennedy, Professionals, Power and Solidarity in Poland, 81, 294; Lepak, Prelude to Solidarity, 98, 99, 103, 117, 132, 133, 134, 164; Ekiert, The State Against Society, 230, 236; Brzezinski, The Struggle for Constitutionalism in Poland, 73; Ash, The Polish Revolution, 21, 22; Simon and Kanet (eds.), Background to Crisis, 3-23; Bromke, Poland: The Protracted Crisis, 69, 191, 231, 237; and Slay, The Polish Economy, 44, 45, 46, 49.
} 
all extended the liberated public space, facilitated mass politicization, and strengthened society's moral and ethical dissent against the Communist party rule. ${ }^{101}$

During the "crisis" years of 1974-1979, women's work outside the domestic sphere remained an important consideration for the various women's organizations. The League of Women, for example, advocated the importance of increasing women's role in the political, economic, social, educational and cultural realms, more so for the women themselves than for building socialism. Such were the objectives of LK's next two presidents, Maria Milczarek and Eugenia Kemparowa in the 1970s. 102

The National Council of Women, KRKP, also continued to defend women's work, provide maternity care and safeguard the institution of motherhood, and foster ideas of patriotism and internationalism. The president of KRKP, Eugenia Kemparowna, provided praiseworthy commentary on the participation of women in national life. Meanwhile, members of KRKP participated in an international seminar on "Women and Socialism" held in Moscow in 28 June-1 July, 1977. The themes of this conference included family life, equality of rights for women under socialism, and aiding women's professional aspirations. 103 In 1978, an international meeting of female journalists of socialist countries was organized by KRKP on 16-20 March in Warsaw. This meeting was attended by Polish representatives from the Department of Press, Radio and TV (including its Director, Zdzislaw Marzec), Sports and Tourism, and Foreign Affairs. The principal theme of discussion was the participation of the women's press in socialist

101 For details on KOR and the formation of "civil society" in Poland during this time period see Bernhard, The Origins of Democratization in Poland, 76, 77, 83, 97, 117, 118, 121, 123, 129, 130, 149, 196, 198, 199, 202, 207, 208; Ascherson, The Polish August, 114, 115, 118, 141; Mason, Public Opinion and Political Change in Poland, 49, 50; Rothschild, Return to Diversity, 197, 198; Bielasiak, "Poland," 135, 136; Ekiert, The State Against Society, 218, 236; Blejwas, Realism, 204-206; Lepak, Prelude to Solidarity, 70, 99, 170, 171, 178, 210; Bromke, "Policy and Politics in Gierek's Poland," 6-9, 12, 13, 16, 21; Laba, The Roots of Solidarity, 94, 95; Slay, The Polish Economy, 46, 47; Bromke, Poland: The Protracted Crisis, 44, 75, 87, 94, 97, 99; Kubik, The Power of Symbols, 48, 49, 73, 125, 156, 157; Ash, The Polish Revolution, 23, 31, 82, 83; Poznanski, Poland's Protracted Transition, 30; Jean Woodall, "The Construction of a 'Developed Socialist Society' and 'Socialist Renewal'," in Woodall (ed.), Policy and Politics in Contemporary Poland, 1-22, p.16, 17; Szajkowski, Next to God....Poland, 29-86; and Lawrence Goodwyn, Breaking the Barrier: The Rise of Solidarity in Poland (New York, 1991), 386, 387. For a more comprehensive account on KOR see Jan Jozef Lipski, KOR: A History of the Workers' Defense Committee in Poland, 1976-1981. Translated by Olga Amsterdamska and Gene M. Morre (Berkeley and Los Angeles, 1985).

102 Przyjaciolka, 48 (29 November, 1970), 3, 12; KiZ, 44 (1 November, 1970), 3; KiZ, 46 (15 November, 1970), 2; Przyjaciolka, 10 (8 March, 1970), 10; Przyjaciolka, 19 (7 May, 1972), 12; KiZ, 7 (17 February, 1974), 4; Przyjaciolka, 32 (10 August, 1975), 9; and Wieruszewski, Rownosc kobiet i mezczyzn, 209, 213.

103 Przyjaciolka, 49 (5 December, 1971), 5, 10; Przyjaciolka, 53 (31 December, 1972), 5; Przyjaciolka, 45 (5 November, 1972), 10; Przyjaciolka, 10 (10 March, 1974), 3; Przyjaciolka, 10 (6 March, 1977), 5; Przyjaciolka, 33 (14 August, 1977), 8; and KiZ, 9 (27 February, 1977), 2. 
education and women's consciousness and its role in realizing the resolutions of national communist parties, the transformations in the traditional model of families, and the 'new' position of woman in society. 104

Even in the Soviet Union, there were discussions on the changing roles of women in society. The Brezhnev elite was overwhelmingly male, but the number of female members in significant positions increased continuously. 105 Moreover, the great gulf between city and village narrowed considerably, as education improved and electronic communications brought the city closer than ever before. Women could now look beyond the edge of the fields that surrounded their villages, they could travel to the larger world or bring it into their simple wooden houses by turning on the radio or television. They were also respected more by their husbands than previously, an improvement they attributed to their education. 106

Unfortunately, while the Polish women's organizations recognized the need to enhance women's professional qualifications so as to better enable them to serve the socialist state, the domestic image of the kobieta-matka continued to dominate the official press during these years. In the 1970s, Polish women, similar to Soviet women, were increasingly valued as mothers rather than as working people by the socialist regime. 107 Successful efforts by Gomulka to control population growth backfired under Gierek since by the early 1970s, government officials had grown alarmed by Poland's declining birthrate. Thus, the government adopted a pro-natalist policy, and made more frequent and stronger references to the values of family life as a source of socialist legitimacy and ideology. 108

Accordingly, both Edward Gierek and premier Piotr Jaroszewicz exhibited more concern for the 'defense and development' of the family, especially the education of youth in those moral values which were in unison with socialist ideas. The Welfare Minister of the PRL, Prof. Jerzy Bafia, also advocated the importance of the external and internal functions of the family in building socialism. Press articles focused on the need to improve material conditions of families, to reform the processes of awarding families with subsidies and other forms of assistance, to supplement alimony with state funds, to ensure the proper upbringing of children, to combat alcoholism, and to revisit issues

\footnotetext{
104 Przyjaciolka, 15 (9 April, 1978), 5; and KiZ, 12 (19 March, 1978), 2.

105 Mawdsley and White, The Soviet Elite, 172, 251, 252.

106 Clements, Daughters of Revolution, 105, 106, 110, 111.

107 Taras, Ideology in a Socialist State 138.

108 Marody and Giza-Poleszczuk, "Changing Images of Identity in Poland," 156; and Staniszkis, Poland's Self-Limiting Revolution, 169, 209.
} 
related with maternity care. ${ }^{109}$ With a record number of 46,000 divorces registered in 1977, the late 1970s saw more discussion on questions of divorce and the lives of women after obtaining divorce. 110 Further, to improve the quality of family life, Gierek envisioned that every family would have its own residential place by 1985 . For this reason, the state prepared to draft plans to construct more housing projects. 111

Gierek's social policies thus aimed to strengthen the family unit. Accordingly, large families were to be given priority for social support, especially women with preschool age children. 112 This renewed interest in family life resulted in amendments to the Family and Guardianship Codes. Enacted on 1 March 1976, these changes reflected the official concern for the questions of alimony, divorce, and custody of children. The larger aim of the constitutional amendments was to strengthen the domestic position of women, more so for mothers and professional workers. 113 In 1977, 352,000 mothers took advantage of the three-year unpaid leave granted in the constitution. 114

Overall, the re-emphasis on family life and women's obligations as good mothers in these years was best illustrated by images of babies and children on the cover pages of women's periodicals. Indeed, the theme of 'motherhood' now overwhelmed the women's press, with several images of mothers nursing their babies splashed in the women's magazines. 115 The Polish Church, meanwhile, concurred with the socialist state in emphasizing 'an unlimited family in which men labor for just reward and women raise children in the faith'. 116

Did the Polish women decry the state's propensity to return women back to the households? Sure enough, many 'fatigued' women began to question their lack of 'internal' emancipation by emphasizing the differences in meaning between "rownouprawnienie" (equal rights) and "rownosc" (equality).117 However, this

109 Przyjaciolka, 11 (17 March, 1974), 3; KiZ, 12 (24 March, 1974), 2; KiZ, 25 (23 June, 1974), 2; Przyjaciolka, 12 (23 March, 1975), 3; Przyjaciolka, 31 (30 July, 1978), 4; KiZ, 48 (28 November, 1976), 4, 5; and KiZ, 29 (16 July, 1978), 2.

110 Przyjaciolka, 24 (12 June, 1977), 3; and KiZ, 8 (25 February, 1979), 7.

111 Przyjaciolka, 13 (26 March, 1978), 4.

112 Woodall, "The Construction of a 'Developed Socialist Society' and 'Socialist Renewal'," 15.

113 KiZ, 4 (25 January, 1976), 5; and KiZ, 9 (29 February, 1976), 3.

114 In 1968, a one-year unpaid child upbringing leave was sanctioned, which four years later were extended to three years. See Niedzielska, Women in Contemporary Poland, 30.

115 On the cover page of the issue Przyjaciolka, 49 (7 December, 1975) there is a picture of Maria Jagodzinska, delegate to the VII PZPR conference, giving milk to her children. There is another image of a new born baby on the cover page of the issue Przyjaciolka, 26 (29 June, 1975). In the 1970s, there were many more articles on "men and women" and "women and children" in Kobieta i Zycie.

116 Ascherson, The Polish August, 142.

$117 \underline{\mathrm{KiZ}}, 33$ (17 August, 1975), 2; and Wieruszewski, Rownosc kobiet i mezczyzn, 6. 
preliminary agitation for women's rights did not acquire a visible form, either in the working class or in the nation as a whole. 118

From a comparative perspective, even the more liberated western feminism of the 1960s succumbed to pressures of increasing unemployment in the 1970s and 1980s. From 1976 to 1983, the labor market expansion ended and unemployment for women in European member states of EEC rose by 15\%. 119 Certainly, western women won broader opportunities for self-expression and for personal and professional fulfillment. In sports too, women tried many ways to combat the effects of the restrictive definition of femininity. To be sure, the combination of women's athletic excellence and their growing activism in social, economic and political affairs did much to expand the opportunities available to the outstanding female athlete. The modern technological innovations such as microwave ovens, dishwashers, and washing machines gave working women more leisure time to indulge in various activities in the 1970s, including sports. However, the reduction in the sex-related fears among both men and women required not merely a tactical victory over male social authority but, more significantly, a substantial redirection of thinking. That was still not forthcoming. 120

In the arena of sports, despite the widespread economic and social instabilities, the KC PZPR's resolution of 19th April, 1977 reinforced the rhetoric of the importance of physical culture for building a socialist society. According to the party, Polish physical culture was well on the path of 'dynamic modernization'.121 The authorities acknowledged the contributions of female athletes in enhancing the nation's international prestige. In official terms, Polish sportswomen were placed 'among the best'. 122 According to Piotr Jaroszewicz, President of the Council of Ministers since 1971, Polish women made significant contributions in fields of science, education, culture, economy, and sports. 123

\footnotetext{
118 Goodwyn, Breaking the Barrier, 137, 151.

119 Kaplan, Contemporary Western European Feminism, 25, 33.

120 Festle, Playing Nice, 195, 269, 285, 286, 289, 290; Holt and Mason, Sport in Britain, 11; and Mrozek, "The Amazon and the American 'Lady'," 296.

121 Chelmecki and Wilk, Wybor zrodel i materialow, 213, 217, 219, 222; Wolanska, "Model," 491-493; and Ocena wykonania w latach 1976 i 1977 perspektywicznego programu rozwoju kultury fizycznej $i$ turystyki (Glowny Komitet Kultury Fizycznej i Turystyki, Warsaw, December 1977), 1, 4, 6, 12. The presumed dynamic sports development in the 1970s coincided with increasing industrialization and urbanization. See Zuchora "Rozwoj," 338-341.

122 Biuletym Informacyjny Glownego Komitetu Kultury Fizycznej i Turystyki, Warszawa, 10-12 (1975), 17. See also KiZ, 19 (7 May, 1978), 14; and KiZ, 12 (19 March, 1978), 14.

123 This meeting was attended by Wanda Rutkiewicz (alpinist), Irena Szewinska (track and field), and Krystyna Chojnowska-Liskiewicz (sailor). See PzS, 48 (8 March, 1979), 1, 2.
} 
The KC PZPR also recognized the indispensable contributions of sports pedagogues and other state functionaries in the spheres of physical recreation and rehabilitation, as well as for theoretically establishing the value of sport as a tool for the re-education and re-socialization of prisoners in the Polish penitentiary system. The organization of the First Scientific Congress on Physical Culture and Sports in AWF, Poznan in 1979 under the conference theme "Physical Culture and Sport in Service of Polish Socialist Society" was well received by the state. The party acknowledged the importance of the Sports Science Institute and the Polish Academy of Sciences in conducting sports research, as well as the Central Housing Cooperative Union in building sports arenas. 124

Further, to provide greater independent initiative in sports management, another resolution of 26 May 1978 separated the committees for tourism and physical culture. The former took the form of GKT and the latter transformed itself into the GKKFiS. The GKKFiS was the central organ of state administration in matters of physical culture and sport. Its principal task was to popularize and develop physical culture, physical education, and sports in Poland. The GKKFiS had various subdivisions such as a cabinet to look after the main administration and organization, a Department of Education to oversee the scientific study of sport, a Department of Finance and Economics which was responsible for the sports budget, a Department that looked after the sports bases and other infrastructural detail, another department for organizing sports spectacles for schools and for coordinating the preparation for the Olympics, and a department for external affairs that looked into sports propaganda as well. The GKKFiS was also committed to improving women's sports. This was consistent with its conceptualization of a democratic and egalitarian physical culture. 125

The resolution of GKKFiS of March 1979 also stressed the need for more work in uplifting rural health through the integrated efforts of local administration, professional unions, and social and cooperative organizations. ${ }^{126}$ In addition, the GKKFiS was keen

124 "Uchwala Biura Politycznego KC PZPR," 194-197; Gaj in Gaj and Hadzelek, Dzieje kultury fizycznej, 262; Gaj, Wychowanie fizyczne, 57, 58, 60; Maciej Luczak, "Akademia wychowania fizycnego w Poznaniu w latach 1973/1974-1993/1994," in Gaj (ed.), Dzieje Akademii Wychowania Fizycznego w Poznaniu, 183265, pp.212, 214, 215, 218, 219; Chelmecki and Wilk, Wybor zrodel i materialow, 244, 245, 246, 248, 250; and Bernard Bartoszak, "Polski system penitencjarny a kultura fizyczna," in Kultura Fizyczna, 32, 6 (June, 1978), 270-272.

125 Gawlak-Kica, Rozwoj kultury fizycznej w Wielkopolsce, 264, 265; Gaj, Wychowanie fizyczne: sport w Polsce Ludowej, 28; Marian Renke, "Organizacja i kierunki dzialania Glownego Komitetu Kultury Fizycznej i Sportu,” Kultura Fizyczna, 11 (1978), 482-487, 482; and Gondek, Kultura fizyczna w Polsce, $57,59,61$.

126 Uchwala Plenum Glownego Komitetu Kultury Fizycznej i Sportu z dnia 29 Marca 1979 (GKKFiS), 16. 
to oversee a dynamic growth in school sports. In 1978, the Ministry of Education and the GKKFiS sought to create greater uniformity in the procedures of selection and organization of youth games. They signed an agreement establishing a single permanent system of sports competition, recruitment and schooling, and a calendar of events. The years 1978 and 1979 recorded maximum youth participation, including that for girls. 127 Some parts of Poland placed extra emphasis on developing sports and physical culture for their local populations. The Gorzow region, for example, began to draft 'land modernization projects' to create 'oases of greenery' for the active relaxation of residents. 128 The games of basketball, volleyball, and football enjoyed great popularity in Szczecin Pomerania. 129 Between 1976-1980, the Town Centers for Sports and Recreation (Miejskie Osrodki Sportu i rekreacji) and the Wojewodzkie Zrzeszenie Sportowe Spoldzielczosci Pracy "Start" (Provincial Sports Association of Work Cooperatives) drafted plans for different forms of activities for physical education and tourism in the tri-city area of Gdansk, Gdynia and Sopot, including international regattas in windsurfing. 130

Certainly, a number of sports organizations and institutions constituted the organizational structure of Polish physical culture during these years. ${ }^{131}$ In addition, local dailies advertised a sports competition for weekend recreation and labeled it "Green

127 For the organization of sports in schools see PzS, 163-164 (23 December, 1963), 1, 4; PzS, 104 (29 May, 1981), 5; Gutowski, Drogi rozwoju kultury fizycznej, 104; Ministerstwo Oswiaty: Materialy z narady kuratorow i przewodniczacych WKKFiT w dniu VI 1966 (Nakladem Biuletynu Informacyjnego GKKFiT), 1; Drazdzewski, Dzieziecioletnia dzialalnosc, 76; Informacja i wnioski z posiedzenia plenarnego glownego komitetu kultury fizycznej $i$ sportu $w$ dniu 26 Pazdziernika 1981r, 1-8; Liponski, "Still and Unknown," 3; Gaj in Gaj and Hadzelek, Dzieje kultury fizycznej, 261, 262, 263, 269, 270; "Uchwala Biura Politycznego KC PZPR," 194; Foldesi, "Postawy wobec wychowania fizycznego," 57; Gondek, Kultura fizyczna w Polsce, 136-139, 246, 247; Wolanska, "Wychowanie," 237; Skorowski, "Programy kultury fizycznej w szkole okresu przejsciowego, czesc II," 488-490; Gaj, Wychowanie fizyczne, 82-100; Sozanski, "Szkolenie," 23; Przeweda, "Wspolpraca klubow sportowych ze szkolami," 61, 62; Sozanski, "Sport dzieci i mlodziezy," 42, 43; and Kudlorz, "School Sport in Poland from the 1950s to the 1980s," 141, 142, 146148.

128 Wojciech Sroczynski, “Turystyka i rekreacja w wojewodztwie gorzowskim," in Kultura Fizyczna, 31, 7 (July, 1977), 319-321, p.319; and Anna Sobolewska, "The Exploitation and Potential Possibilities of the Reclamation of Land for Leisure use in Gorzow Wlkp.," in Conference Proceedings (CESU Conference, Sheffield, GB, 15-17 July 1991), 149-157, p.154.

129 Zbigniew Szafkowski, Zespolowe gry sportowe na Pomorzu Szczecinskim w latach 1945-1996 (Mysliborz, 1996), 1.

130 For sports in this region see Szot, Rozwoj kultury fizycznej w aglomeracji Gdanskiej, Gdansk, Gdynia, Sopot, 9, 10, 19, 33, 36-49, 51-59, 63, 67, 70, 71, 77, 80, 83, 87, 89, 99, 104, 106, 121-137, 140-144, 196, 197, 201, 204.

131 Gondek, Kultura fizyczna w Polsce, 42, 43, 55; and Renke, "Organizacja i kierunki dzialania Glownego Komitetu Kultury Fizycznej i Sportu," 483, 485, 487. On TKKF and its mass sports recreation activities among youth and urban residents see Ocena wykonania w latach 1976 i 1977, 22. 
Saturdays". Polish TV also flashed its physical culture password: "Join in and run with us". 132 The mass media loudly voiced the state's rhetoric of "Long Live Sports". 133

From a comparative perspective, sports in the Soviet Union also claimed to have encompassed the diversified society. The Soviet society became more complex and articulated, as new social groups of technical specialists, middle-level bureaucrats, and practically engaged intellectuals emerged as a consequence of higher education and technical training. The working class itself fissured into a number of subgroups, while the peasantry became less isolated. This reconfigured society took advantage of the country's sports stadiums, training bases, and sport schools, all of which were built in record numbers, more so in the urban than rural areas. 134

In East Germany, meanwhile, women's sports reported many domestic and international victories from the mid-1970s onward. Unfortunately, recent research into the successes of East German female athletes has revealed that sportswomen took contraband pills from their physicians and coaches as part of a secret system that functioned through clandestine meetings and codes for drugs and athletes. East Germany had embarked on a relentless state-sponsored campaign using anabolic steroids to demonstrate women's gold medal performances at the Olympics as proof of communism's supremacy. This alliance between state research institutes, sports clubs, and the secret police resulted in the gross manipulation of women's bodies in East Germany. Many former East German women athletes have since then complained of signs of masculinity and other medical complications. 135

In the meantime, back at home, there were signs of visible dissension in the Polish physical culture. The scoutmasters and troop leaders of Warsaw's Black Troop No. I created a Band of Vagabonds to discuss contemporary issues in social and national life. The scouting authorities defended the Band of Vagabonds and recognized the legality of their meetings. As many as four members of KOR had their roots in the Band of

132 "Recreation in Poland," in WLRA Bulletin, 4 (1980), 3. For more on the organization of tourism and recreation see also Jerzy Bogucki and Lech Erdmann, "Training of Experts in Tourism, Recreation and Leisure Professions in Poland," in Liponski and Siwinski (eds.), Studies in Physical Culture and Tourism, 137-142.

133 Przyjaciolka, 15 (15 April, 1979), 7.

134 For the development of sports in the USSR see Edelman, Serious Fun, 166; Pavel Stepovol's article in Social Sciences Today: Physical Culture and Sport-Legal Guarantees, 125; Romuald Misiunas and Rein Taagepera, The Baltic States: The Years of Dependence 1940-80 (Berkeley and Los Angeles, 1983), 213; and I. M. Slepenkov and B.V. Kniazev, Rural Youth Today (Newtonville, Mass., 1977), 94, 95, 96.

135 The New York Times, (5 April, 1998), 25, 29; and The New York Times, (22 April,. 2001). The former head of East Germany's Olympics program Manfred Ewald and longtime medical director Manfred Hoppner have now been charged with giving female athletes steroids without their knowledge. 
Vagabonds. Another KOR member Miroslaw Chojecki, though not a member of the band, was a scouting activist. These people who came to KOR with an athletic interest in scouting brought with them a specific experience of the patriotic tradition connected with the scouting organization. 136

Unfortunately, as the sports movement in Poland came to increasingly reflect the immediate concerns of the Polish civil society, so did the sportswomen find their athletic opportunities become gradually limited. As the tug-of-war between the state and society increased, sports and physical education, especially for women, became increasingly marginalized. This was consistent with women's peripheral role in active "national resistance" and their confinement to their duties as "patriotic" mothers safeguarding the frontiers of family life in the ensuing time of troubles.

\section{The Solidarity Era and Polish Physical Culture August, 1980-December, 1981}

On July 1, 1980 the Polish government once again increased food prices. In response to the deteriorating economic conditions and the price hikes, Polish workers, students, intellectuals, housewives, and peasants engaged in a collective action of strikes and protests. While the workers' Gdansk Strike Committee under the leadership of electrician Lech Walesa served as the nerve center of the social unrest, this summer insurrection of 1980 was geographically and socially more encompassing than the earlier outbreaks. This powerful popular upheaval permeated all segments of Polish society and demanded economic reform, civic liberties, and the right to form a workers' trade union independent of party control. Faced with this massive civil disobedience movement, the party agreed to negotiate and compromise. In the Gdansk Accords of August 31, 1980, the political leadership acceded to the establishment of an independent trade union in return for which the workers pledged to respect the existing communist political system. In this manner, the first free trade union in the communist world, Solidarnosc, was born. In the next sixteen months, Solidarity underwent an "incremental revolution", which catapulted its development from the stages of infancy to adult maturity, until its temporary demise with the imposition of martial law in December 1981.

During the period of its legal existence from August 1980 to December 1981, Solidarity functioned as an independent and "self-governed" social movement which fused together principles of democracy, Catholic and socialist humanism, nonviolence, and egalitarianism. This "self-organized" and "self-managed" Polish civil society used

136 Lipski, KOR: A History of the Workers' Defense Committee in Poland, 17, 18, 42, 76. 
the tools of modern tele-communications and an expressive visual imagery to challenge the ideological and organizational hegemony of the Soviet form of communism in Poland, as well as to expose the marginality of the heretofore corrupt, illegitimate and arrogant authority of the communist party. However, Solidarity's "anti-politics" did not aim for the disbandonment of the monolithic socialist framework. Instead, its "selflimiting" revolution preached reforms within the existing political system and proposed extensive social and cultural remedies for a "healthy", "creative" and "dignified" national regeneration.

The freer atmosphere during the Solidarity 'era' certainly increased the availability and diversity of information and ideas. Intellectual life flourished, and popular expression focused on an open discussion of various political, social, economic, and cultural issues. However, while the Poles became collectively more creative and self-confident, their attempts to unmask the pretentious facade of official credibility were beset with problems. Solidarity lacked a functional hierarchy, an organized structure, and a coordinated program of action. Its self-limiting nature and its lack of institutionalized political and economic power caused internal fractional problems and resulted in the differentiation and fragmentation of Solidarity. In essence, Solidarity was neither a united nor an invincible civic body which could have effectively challenged the Soviet-backed communist party at its very core.

Meanwhile, the Polish economy had entered into the "deep years of crisis". Between 1979-1982, the political leadership remained conservative, forcing the economy to rapidly deteriorate. This is not to suggest that the communist party did not initiate any measures of change. On September 6,1980 Gierek was unceremoniously sacked by the PZPR and replaced with Stanislaw Kania who attempted to make the party less hierarchical, more representative, democratic, and reformist. However, Kania's appeals for patience, partnership, and a disciplined "renewal" were too little for many members of Solidarity, and too much for the party bureaucracy. On February 9, 1981, the drain in domestic confidence and simultaneous Soviet dissatisfaction obliged him to designate as his government's prime minister General Wojciech Jaruzelski, defense minister since 1968, who thereafter steadily eclipsed Kania.

Eventually, Kania was replaced as Party First Secretary by General Jaruzelski on October 18, 1981. Under the mutually reinforcing pressures of a deteriorating domestic situation and a mounting external threat, Jaruzelski proclaimed martial law during the night of December 12, 1981. He established the Military Council of National Salvation to administer the country, suspended Solidarity, interned thousands of its leaders and activists, and blocked all domestic and international communication networks. Jaruzelski 
justified martial law as a response to the economic disorder in the country and to the politicization and radicalization of Solidarity. However, though decapitated, Solidarity survived in the underground. The popular mood, on the surface, was one of resignation, apathy, and disengagement. But in the underground, dissent continued. 137

During the Solidarity Era, and especially during the period of martial law, women organized union cells in their workplaces, "provisioned" prisoners and underground workers, hid activists, served as nurses in the Solidarity medical section, worked in the collection and distribution of underground press, and were especially important in the maintenance of communication links. However, despite these important tasks, there was a systematic silence on feminist questions in the "politics of antipolitics". Solidarity had little space, conceptually and organizationally, for a specifically feminist voice. The iconography of Solidarity also overwhelmingly supported images of motherhood, and limited women's participation in the movement to "outside the gates". For this reason, as one moved up the organizational ladder of Solidarity, the representation of women declined. 138

\footnotetext{
137 For a detailed analysis on the emergence of Solidarity, the 'Solidarity Era' and the eventual Martial Law of 1981 see Bartlomiej Kaminski, The Collapse of State Socialism: The Case of Poland (Princeton, 1991), 131; David Ost, Solidarity and the Politics of Anti-Politics: Opposition and Reform in Poland Since 1968 (Philadelphia, 1990), 2; Bernhard, The Origins of Democratization in Poland, 193; Poznanski, Poland's Protracted Transition, 31, 262; Arista Maria Cirtautas, The Polish Solidarity Movement: Revolution, Democracy, and Natural Rights (London and New York, 1997), 7, 8, 19, 166, 185, 192, 204, 205; Laba, The Roots of Solidarity, 3, 95, 105, 129, 130, 133, 135, 140, 155, 174, 178, 181; Rothschild, Return to Diversity, 198-202; Bielasiak, "Poland," 137, 139, 140; Slay, The Polish Economy, 3, 48, 49, 50, 53, 132; Korbonski, "Poland," 260; Ash, The Polish Revolution, 84, 102, 105, 114, 115, 116, 288, 297, 315, 316, 322, 323; Staniszkis, Poland's Self-Limiting Revolution, 3, 17, 18, 76, 79, 81, 137, 138, 314, 319, 326, 327, 328; Kennedy, Professionals, Power and Solidarity, 81, 287, 330, 339, 344, 345; Hunter and Ryan, From Autarchy to Market, 19; Kubik, The Power of Symbols, 227, 268; Peter Raina, Poland 1981: Towards Social Renewal (London, 1985), 319, 354; Sanford, Polish Communism in Crisis, 42, 59, 68, 143, 228; George Sanford (editor and translator), The Solidarity Congress, 1981: The Great Debate (New York: St. Martin's Press, 1990), 1, 24, 25; Bromke, Poland: The Protracted Crisis, 183, 190, 230, 236, 237; Goodwyn, Breaking the Barrier, 262, 263, 273, 274, 281, 341; Mason, Public Opinion and Political Change in Poland, 33, 36, 82, 90, 91, 93, 94, 98, 100, 101, 102, 111, 114, 116, 121, 129, 130, 135, 136, 137, 139, 141, 162, 163, 171, 181, 182, 230, 232, 234, 238, 244, 245; Taras, Ideology in a Socialist State, 247; Ekiert, The State Against Society, 252, 257, 270; Werner G. Hahn, Democracy in a Communist Party: Poland's Experience Since 1980 (New York, 1987), ix-xx; and Ascherson, The Polish August, 24, 145-228, 250, 251. For the continued economic crisis see also Przyjaciolka, 42 (19 October, 1980), 4; KiZ, 6 (8 February, 1981), 2, 3; KiZ, 29 (19 July, 1981), 4; KiZ, 41 (11 October, 1981), 2; and KiZ, 42 (8 October, 1981), $2,8$.

138 Kennedy, Professionals, Power and Solidarity in Poland, 308, 310, 328; Kristi Long, We All Fought for Freedom: Women in Poland's Solidarity Movement (Boulder, 1996); and Ewa Hauser, Barbara Heyns and Jane Mansbridge, "Poland in Transition".
} 
In the arena of sports, the political leadership hoped to use physical culture and tourism to restore the confidence among young people with regard to the party's intentions and policies. As part of its "renewal" program, the party patronized sports organizations, along with trade unions and other cultural and social associations in both urban and rural areas to develop young people's personalities. ${ }^{139}$ The official authorities of GKKFiS met with representatives of Solidarity in Gdansk to discuss the problems in Polish physical culture and provide solutions to the difficulties associated with limited finances and qualified instructors. ${ }^{140}$ The official press also provided obituaries of famous women athletes. For example, the sports press mourned the demise of skiing champion Irena Piela on 16 April 1981.141 It is also interesting that in the midst of this economic and social chaos, Poland ranked fifth in the medal tally in the 1980 Moscow Olympics. 142 While the games themselves was tarnished by the boycott of some western countries, Poland's impressive performance was still quite an accomplishment for a country submerged in widespread economic and political distress.

More generally, however, this was simply not a good time for the development of physical culture in Poland, for both men and women. The academies of physical education experienced stagnation in the numbers of both students and professors. Student membership in the school sports clubs also declined in 1980. Press articles decreased between 1980-81. Meanwhile, some members of the sports organizations, such as the Climbing Fraternity, joined the Solidarity movement. Unfortunately, under martial law, no tourist or sports organizations were allowed to operate, not even indoors. Still, sports clubs remained crowded, which became a symbol of their passive resistance as the country moved into the last decade of communism in eastern Europe. 143

\section{Women and Sports in Jaruzelski's Poland, 1981-1989}

Martial law in Poland lasted from 13 December 1981 to 22 July 1983, although coercion, imprisonments and harassment continued beyond these years. However, in the post-marital law period, Jaruzelski attempted to make Polish socialism more "democratic" and less repressive by offering limited concessions to the intellectuals and workers, and by easing the party's control on all domains of public life. Unfortunately,

139 Raina, Poland 1981, 229-253.

140 PzS, 233 (27 November, 1980), 1.

141 Sport, (19 June, 1981), 2.

142 Senn, Power, Politics, and the Olympic Games, 185.

143 Paul Babler, "Climbing in Poland under Martial Law," in Summit, 28, 5 (1982), 12-13. 
this political restructuring was still too conservative and without any meaning for the stagnating economy. The Polish economy continued to suffer from excessive indebtedness, consumer shortages, inflation, and rapid aging of production.

With falling living standards, popular frustration and hopelessness worsened. The outlawed Solidarity, aided by the Catholic Church, continued its struggle to circulate alternative visions in the Polish civil society. Buoyed by papal visits in 1983 and 1987, church attendance increased, and the Catholic Church extended its charitable and cultural activities. The society also displayed a fascination with other world religions, especially Hinduism. Unfortunately, the underground opposition movement failed to mobilize enough resources and popular support to be able to effectively challenge the state monopoly of power, or to extract significant political concessions.

Meanwhile, the post-martial law political regime also failed to secure a modicum of social support and legitimacy in order to solve Poland's economic and political problems. In October 1987, Jaruzelski announced an ambitious program of economic and political reform which combined a mixture of decentralized planning, expanded private enterprise, and changes in the structure of the central bureaucracy. However, these vague promises of democracy and pluralism did little to alleviate the housing shortages, the inadequacy of the child-care system, the disastrous state of the educational system, and the near collapse of the Polish health system. ${ }^{144}$

During the years of martial law, women's contributions in the national economy decreased. 145 However, in the post-martial period, the regime once again emphasized the socialist "duties" of both men and women for Polish national happiness. 146 Accordingly, the political leadership projected visions of a 'real' equality between genders and reaffirmed women's dynamic engagement in various social and professional

\footnotetext{
144 For the political and economic conditions in Poland during the 1980s see W. Jaruzelski and Robert Maxwell, Prime Minister of Poland: Selected Speeches (Oxford, 1985), 41; Fallenbuchl, The Balance of Payments Problem, 47; Walicki, The Three Traditions in Polish Patriotism, 31; Taras, Ideology in a Socialist State, 247; Kaminski, The Collapse of State Socialism, 225; Poznanski, Poland's Protracted Transition, xi, xx, 113, 114, 115, 140, 141, 164, 165, 166, 249, 253, 254, 263, 273, 287; Rothschild, Return to Diversity, 202, 203, 227-229; Bielasiak, "Poland," 141, 142; Slay and Vinton, Poland to 2005, 65; Frances Millard, Polish Politics and Society (London and New York: Routledge, 1999), 103, 104; Slay, The Polish Economy, 56, 82, 85; Brzezinski, The Struggle for Constitutionalism in Poland, 76, 80, 207; Wiktor Osiatynski, "The Roundtable Talks in Poland," in Jon Elster (ed.), The Roundtable Talks and the Breakdown of Communism (Chicago, 1996), 21-68, pp.23, 25, 26, 59; Ekiert, The State Against Society, 284, 291, 292, 295, 300, 301, 303; and Hunter and Ryan, From Autarchy to Market, 64, 65, 68, 69.

145 Morecka, Graniewska, Kurzynowski and Tryfan, "Aktywnosc zawodowa kobiet," 40.

146 Przyjaciolka, 6 (10 February, 1980), 4; KiZ, 5 (3 February, 1980), 2; KiZ, 21 (25 August, 1982), 11; Przyjaciolka, 35 (30 August, 1984), 3; and KiZ, 11 (14 March, 1984), 2.
} 
activities. The censored popular press choreographed images of women's active participation in all forms of cultural and intellectual work, and emphasized the 'democratization' of family life. ${ }^{147}$

While the popular press cast images of the 'modern and educated' woman participating in a 'scientific-technical' revolution, there were also traditional images of women instilling qualities of responsibility, discipline and morality within the family and in the larger society. The images of motherhood continued to be displayed in the women's periodical Kobieta i Zycie throughout the 1980s. The persistence of patriarchal attitudes in society restricted women's participation in state administration, political parties, youth organizations, and professional unions. The lack of male support in the home and external support at the workplace both compromised women's professional advancement in favor of their socially defined roles of motherhood. 148 According to Janina Biedrzycka, Deputy Marshal of the Sejm and head of the Central Board of the Polish Women's League, the importance of family life did not allow an average Polish woman to be truly emancipated. For this reason, women were not socially conscious of their rights, and remained unprepared for skillfully balancing their domestic and professional responsibilities without causing a "home revolution". 149

In addition to the traditional gender patterns within the family institution, Polish women were overworked because of the under-development of social services and shortages of kindergartens. Reports of the economic crisis and pictures of women standing in lines for food forced some to wonder 'what is social welfare as far as women were concerned'?150 For many women, the way out of misery was divorce. A total of 45,772 divorces were reported in 1983, of which 38,364 were registered in towns and 7,219 in villages. 151

Faced with numerous hardships, many other women visualized a nostalgic return to traditional roles of mothers and wives at home. These embittered and disillusioned women were simply too tired struggling with issues related to women's lack of real

$147 \underline{\mathrm{KiZ}}, 48$ (26 November, 1986), cover page, 14, 15; Wieruszewski, Rownosc kobiet i mezczyznj, 103, 176, 225, 226; Niedzielska, Women in Contemporary Poland, 37; Morecka, Graniewska, Kurzynowski and Tryfan, "Aktywnosc zawodowa kobiet," 57; and Danuta Markowska, "Demokatyzacja stosunkow rodzinnych w rodzinie polskiej," in Kobieta w Polsce: Referaty na swiatowa konferencje dekady kobiet ONZ, 81-101, pp. 94, 95, 101.

148 Wieruszewski, Rownosc kobiet i mezczyzn, 103, 113, 137, 178, 224, 225, 226. See also Zdzislawa Czyzowska, "Kobieta w Polsce w latach 1975-1985," in Kobieta w Polsce: Referaty na swiatowa konferencje dekady kobiet ONZ, 11-35, 17, 20, 25.

$149 \mathrm{KiZ}$, (June, 1987), Special issue on the occasion of the World Congress of Women in Moscow, 2, 3.

150 Przyjaciolka, 17 (24 April, 1986), 6.

151 Czyzowska, "Kobieta w Polsce w latach 1975-1985," 28. 
equality, the glass ceiling and sex discrimination at work, the lack of sufficient places in cr ches and nursery schools, the omnipresent food shortages and the agonizing shopping burden, the unhealthy working conditions, alcoholism and women's demands for 'equality with men in drinking', the housing problem, the restrictions on abortion, the education of their children, and the monotonous hardships of daily life.

However, some other women, because of their continued dependence, subjugation, and oppression, began to question definitions of "women's emancipation," or rownouprawnienia (equal rights). The conservative gender relations, regulated by the predominant patriarchal opinion and supervised by the Catholic Church, demanded a more authentic, energetic, united, and strong women's movement that was genuinely interested in women's concerns. Accordingly, these women articulated the overwhelming need for a re-examination of the 'women's question', and called for the organization of a genuine 'women's movement' which would defend the interests of women and effect a 'true' women's liberation. 152

Such women also questioned the bureaucratic workings of the 'tendentious and crooked' League of Women and other women's organizations. The LK had traditional emphasized women's professional independence, alongside her family obligations. 153 According to Teresa Podgorska, a teacher and secretary of LK in Bydgoszcz province, the accomplishments of LK made some men think about forming their own Men's League. 154 Sadly, despite LK's dedication to raising the cultural and ideological awareness of women, there were almost no positive references to the League's organization and program in the women's periodicals after 1986. The communist, ineffective, dead-end organizations such as the LK needed to be replaced by independent women's organizations that could aggressively challenge the stubborn, gender-based discrimination of the communist era which transformed women into fatigued 'superwomen' who were forced to fulfill too many different roles and responsibilities. 155

152 For all these issues see Przyjaciolka, 14 (6 April, 1980), 4; KiZ, 5 (3 February, 1980), 2; Przyjaciolka, 16 (20 April, 1980), 10; KiZ, 14 (7 July, 1982), 17; KiZ, 37 (12 September, 1984), 17; KiZ, 42 (8 October, 1981), 2, 4, 7, 10, 14; KiZ, 24 (14 June, 1981), 3; KiZ, 42 (8 October, 1981), 2; Przyjaciolka, 20 (17 May, 1981), 12; Przyjaciolka, 13 (29 March, 1981), 7; Przyjaciolka, 8 (22 February, 1981), 11; KiZ, 5 (1 February, 1981), 6-8; Przyjaciolka, 6 (8 February, 1981), 10; Przyjaciolka, 38 (17 September, 1981), 3; Przyjaciolka, 8 (27 May, 1982), 4; KiZ, 38 (22 December, 1982), 11; KiZ, 11 (14 March, 1984), 2; KiZ, 51 (19 December, 1984), 11; Przyjaciolka, 10 (8 March, 1984), 2, 3; KiZ, 42 (15 October, 1986), 2; Przyjaciolka, 21 (26 May, 1988), 3; KiZ, 32 (10 August, 1988), 2, 3; and Przyjaciolka, 17 (27 April, 1989), 5.

153 Wieruszewski, Rownosc kobiet i mezczyzn, 209, 213.

154 KiZ, 42 (15 October, 1986), 2.

155 For all these issues see $\underline{\mathrm{KiZ}}, 14$ ( 5 April, 1989), 2, 3; KiZ, 35 (13 September, 1989), 5; Stachniak, "Why Did We Not Become Feminists? Women in Poland," 70, 71, 72, 75, 78; Renata Siemienska, "Polish 
Thus, Polish women responded to their double burden in three principal ways: they either chose to leave their families and opt for divorce, or they preferred to strengthen their union with the family institution, or they chose the more radical path of insisting on the opening of the "woman question" in Poland. These Polish women's responses to their marginalization in the 1980s was quite similar to the strategies adopted by their Soviet counterparts during Gorbachev's policies of 'restructuring' and 'openness'. The rapidly disappearing welfare system, plummeting living standards, 'hunting and gathering' primitive survival methods, rigors of unemployment, and the regime's policies that sought to strengthen the family and raise birth rates, all relegated Soviet women to the status of a 'homemakers'.156 At the same time, however, the successful implementation of the perestroika reforms, especially in the feminized light industries to increase consumer output, required women's increased participation in the labor force, and not their withdrawal. ${ }^{157}$ This resulted in the continuation of the double burden for Soviet women, forcing many of them to favor a 'back-to-the-home' movement. 158

But there were other Soviet women who chose to widen the boundaries of discussion about problems in women's lives. 159 Because of their efforts, and the work of some liberal minded politicians, the Soviet woman question was on the move again. 160 Unfortunately, the considerable amount of discussion on women's roles in mid-1980s did not take into account the nature of male power, or of its abuse, within either the urban or the rural family. ${ }^{161}$ Some "republican" women, meanwhile, subordinated their feminist interests to the larger nationalist interests of their native republics. This was particularly true in the Baltics, Ukraine, and Georgia where religious faith was mingled with nationalist sentiments. 162

Women and Polish Politics Since World War II," in Journal of Women's History, 3, 1 (Spring, 1991), 108125, pp. 109-111, 117, 119, 121; Walczewska, Damy, rycerze, i feministki, 12, 86; Jadwiga Paczynska, "Women in Poland and Free Time Activities," World Leisure and Recreation, 28, 4 (August 1986), 30; and Eugeniusz Hetman, Praca kobiet w gospodarstwach chlopskich (Warsaw, 1981), 7, 8, 130.

156 Susan Bridger, Rebecca Kay and Kathryn Pinnick, No More Heroines? Russia, Women, and the Market (London and New York, 1996).

157 Donald Filtzer, "Industrial Working Conditions and the Political Economy of Female Labor During Perestroika," in Marsh (ed.), Women in Russia, 214-227.

158 Francine du Plessix Gray, Soviet Women: Walking the Tightrope (1989), 47; and Clements, Daughters of Revolution, 127, 128.

159 Bridger, Kay and Pinnick, No More Heroines?

160 Buckley, Women and Ideology; Clements, Daughters of Revolution, 125.

161 Sue Bridger, "The Return of the Family Farm: a Future for Women?" in Marsh (ed.), Women in Russia, 241-254. See also Helena Goscilo, Dehexing Sex: Russian Womanhood During and After Glasnost (Ann Arbor, 1996).

162 Clements, Daughters of Revolution, 129. 
Thus, Polish women, similar to their Soviet peers, found themselves increasingly relegated to the domestic sphere. There was no real "feminist" movement which could aggressively demand an alteration in traditional patriarchal popular opinion. Both the state and society undermined women's emancipation and liberation. Large numbers of women were satisfied to work for their families alone. For this reason, they shied away from all signs of "feminism". This lack of feminist solidarity was evident even in the western countries where by the late 1980 s, feminist discourses were increasingly in conflict with each other. The consequent fractionalization of the western feminist movement dealt a painful blow to the proud 'unity' of the women's movement and its claim to speak for all women. ${ }^{163}$ Thus, the Polish women's movement, similar to those in other parts of the world, stumbled over a host of internal discrepancies. Such tensions between Polish women's domestic and professional interests would clash in the sporting arena as well during these years.

The years between 1980-83 were marked by the liquidation of sports clubs and sections and a decline in the number of participants in sports. ${ }^{164}$ The task of the GKKFiS became very complicated due to state enterprises discontinuing their activities in the sphere of mass physical culture. There was, however, some improvement in the post-martial period. For example, the number of press articles on sports increased. Aleksander Kwasniewski, the future president of Poland and at this time the President of the Committee of Youth and Physical Culture, talked about reforming Polish sport in consonance with the new socio-economic conditions and international developments. In this revised program, the structure of the regional sports federation was altered to allow greater mediation between central and provincial sports bodies. 165

In the 1980s, the official images of Polish physical culture continued to stress the importance of sports for enhancing values of national solidarity and social integration, and for improving the society's health and moral education. ${ }^{166}$ At the level of popular

163 Chamberlayne, "Women and the State," 193.

164 Gondek, Kultura fizyczna w Polsce, 250; and Gaj, Wychowanie fizyczne: Sport w Polsce Ludowej, 29.

165 PzS, 233 (29 November, 1988), 1, 3. On the Committee for Youth and Physical Culture (Komitet Mlodziezy i Kultury Fizycznej, KMiKF) and its last communist Chairman, Aleksander Kwasniewski, see Liponski, "Still and Unknown," 21-24, 27, 34-36. See also Lech Erdmann, "Trends in Sports in Poland," in Teus J. Kamphorst and Kenneth Roberts (eds.), Trends in Sports: A Multinational Perspective (Voorthuizen, The Netherlands, 1989), 205-219, pp. 205-207.

166 The official emphasis on the educative, recreative, biological, integrative, democratic, and rehabilitative values of Polish urban and rural physical culture in the 1980s has been discussed in several sources. See for example, PzS, 127 (1 July, 1980), 1; $\underline{\text { PzS }, ~} 104$ (29 May, 1981), 5; PzS, 103 (28 May, 1985), 1; PzS, 86 (3 
recreation, the political authorities projected images of cooperative interaction between the various sports organizations. These included the Towarzystwo Krzewienia Kultury Fizycznej (TKKF, Society for the Propagation of Physical Culture) for the adult urban population, the Ludowe Zespoly Sportowe (LZS, Popular Sports and Athletics clubs) for the rural population, Zrzeszenie Sportowe "Start" for the workers, Academicki Zwiazek Sportow (AZS) for students, and the "Third Age Universities" for the retired.167 At the high performance level, the state acknowledged the contributions of Polish sports champions by establishing the Polish Olympics Academy (Polska Akademia Olimpijska) in Warsaw on 11 October 1984. This Academy included intellectuals, scientists, writers and sportsmen. 168

The continued focus on the importance of sports medicine and training was evident in the organization of the Second Scientific Congress on Physical Culture and Sports in Gdansk in 1986. ${ }^{169}$ The state expressed some concern about drug use in sport and established an anti-drug laboratory in the Institute of Sport in Warsaw in 1987.170 Sport was perceived as an effective remedy in rehabilitation, convalescence, and in the prophylactic movement. The Polish state, for the first time, exhibited a special interest in the organization of sports for the disabled during this time period. ${ }^{171}$ This was in contrast to the Soviet Union where sports for the handicapped continued to remain totally ignored because, theoretically, 'handicapped' people did not exist in a society where only perfect health was possible. 172 But Poland now chose to model itself after the western nations such as Britain which trained athletes for the paralympics. ${ }^{173}$

Meanwhile, physical education was very important in several rescue organizations. Also, the Ministry of National Defense and the League of National

\footnotetext{
May, 1985), 5; Chelmecki and Wilk, Wybor zrodel i materialow, 258-286, 300, 302, 310; and Glowny komitet kultury fizycznej i sportu: Materialy informacyjne (Warsaw, March, 1984), 3-7, 16, 17, 22, 31, 45.

167 Erdmann, "Trends in Sports in Poland," 207-212; and Gondek, Kultura fizyczna w Polsce, 55, 57, 59, 61.

$170 \underline{\mathrm{PzS}}, 56$ (20 March, 1985), 2; $\underline{\mathrm{PzS}}, 209$ (26 October, 1987), 1; and Andrzej Pac-Pomarnacki, "Some Determinants and Elements of Information and Education Campaign against Doping in Sport in Poland," (National Presentation on general Aspects of AntiDoping Campaigns. Report from ESC/CDDS Seminar Education and Information Against Doping, Vienna, 6-8 November 1990).

171 Gondek, Kultura fizyczna w Polsce, 199, 200, 211, 212, 213; Kalina, "Przyczynek," 269, 271; and Przyjaciolka, 43 (25 October, 1984), 5.

172 Howell, "Sport and Glasnost: a Case Study of Estonia," (Unpublished Paper, 1993). See also Jim Riordan, "Playing to New Rules: Soviet Sport and Perestroika," in Riordan, Soviet Social Reality in the Mirror of Glasnost, 171. Before 1988, the USSR had never held domestic championships at any level for any category of handicapped person.

173 Holt and Mason, Sport in Britain, 16.
} 
Defense provided instruction in firefighting and aeronautical sports. In 1983, the Firefighters Physical Fitness Award (Pozarnicza Odznaka Sprawnosci Fizycznej) was established. 174 It is also interesting that the state permitted the organization of churchsupervised sports extravaganzas. The first 'Parafiada', or "Parish Games", was held in Krakow in 1989.175

However, despite these marginal improvements in Polish physical culture, the deteriorating economic situation, together with the catastrophic lack of equipment, trainers, sports centers and pharmaceutical products made the progress of sport in Poland throughout the 1980s quite unsatisfactory. 176 The concentration of state funding in certain sports such as track and field, boxing and fencing raised questions about the state's insistence that its budget for sports demonstrated its high priority to developing Polish physical culture. ${ }^{177}$ Further, the organizational and programmatic disfunctions in sport were also compounded by structural problems in the construction of new housing complexes with little room for physical recreation. 178

Meanwhile, discussions and debates on the need for a 'real' physical culture continued. For example, representatives from over 200 enterprises gathered in Torun to discuss the crisis situation in developing mass physical culture and express alarm at the spread of medical illnesses in society. 179 Between 1981-1984, the tri-city area of Gdansk, Gdynia and Sopot underwent a regression in sports and tourism. ${ }^{180}$ The Political Bureau of KC PZPR blamed parents and youth for not appreciating the importance of physical education. The sports leadership, including Aleksander Kwasniewski, Chairman of the Committee of Youth and Physical Culture, explained the need to uplift the role, function and place of physical culture and tourism in the social politics of the nation and in the system of education of youth. 181

\footnotetext{
174 Gondek, Kultura fizyczna w Polsce, 155-160, 217, 223, 226.

$175 \underline{\mathrm{KiZ}}, 28$ ( 8 July, 1992), 2, 3.

176 Przyjaciolka, 45 (9 November, 1980), 10; PzS, 80 (24 April, 1981), 2; and Glowny komitet kultury fizycznej i sportu, departament upowszechniania kultury fizycznej (Informacja o stanie realizacji wnioskow sejmiku kultury fizycznej, Warsaw, June 1983), 20, 22, 25.

177 See KiZ, 6 (8 February, 1984), 3. The state budget distribution was as follows: $22.4 \%$ : consumption articles and services; $22.8 \%$ : schools, health, sport and culture; 14.4\%: enterprises and transport commodities; $8.9 \%$ : national defense and public safety; and 2.4\%: state administration.

178 Lempka, "Organizing Leisure in Polish Towns," 13-15.

179 PzS, 63 (30 March, 1983), 4.

180 For sports in this region see Szot, Rozwoj kultury fizycznej w aglomeracji Gdanskiej, Gdansk, Gdynia, Sopot, 9, 10, 19, 33, 36-49, 51-59, 63, 67, 70, 71, 77, 80, 83, 87, 89, 99, 104, 106, 121-137, 140-144, 196, 197, 201, 204.

181 PzS, 56 (20 March, 1985), 1; $\underline{\text { PzS }}, 66$ (3 April, 1985), 2; $\underline{\text { PzS }}, 121$ (24 June, 1986), 1, 2; $\underline{\text { PzS }}, 209$ (26 October, 1987), 1; and PzS, 83 (28 April, 1988), 1.
} 
The Polish sporting apparatus, however, was not the only one in crisis. Even in the Soviet Union, all of the scientific, psychological, medical, technical, tactical, and intellectual resources of the Soviet sports system were not enough to produce consistent international sports success. The comparatively low level of national wealth and the limited commitment of resources undermined Soviet sport. 182 While the state continued to organize Spartakiads for Soviet men and women, the entire sports apparatus was in disarray. 183 It was therefore not surprising that leading Soviet players were often "sold" to Western teams. 184

This was similar to China where in the late 1980s, private sports clubs were frequent topics of newspaper articles. They were not engaged in a direct critique of the state or contest for public opinion, but they were part of a continuing effort by diverse groups in China to find a voice in the national arena. These voices, however, were very small compared to the public attention given to star athletes, who were supported by the state rather than by privately funded clubs. 185

During the 1980s, the Polish state continued to project images of women's strong professional contributions in sport. The state also made efforts to popularize physical culture for the maximum numbers of women at the amateur and recreational levels. For example, the Czech idea of "Saturday for women" was emphasized in the women's press. 186 Also, the authorities made an effort to include women in its Polish Championships for Invalids. 187 However, comments such as "women's participation in sport is extravagant" highlighted the gender prejudices. 188

Press reports discussed the need to organize motivated commissions to oversee women's sports affairs and the importance of exploring new sources of financial support for women's sports. ${ }^{189}$ There were concerns about physical education programs for school-going girls. In 1973, the numbers of girls engaged in active participation in sport was 77,000, and in 1982 only 54,000. This decline in numbers was suggestive of the 'bad

\footnotetext{
182 Edelman, Serious Fun, 126, 137.

183 Women from Uzbekistan and nine other republics participated in an all-women's Spartakiad in Uzbekistan. See Krest'ianka, (1988).

184 For details see Riordan, Soviet Social Reality in the Mirror of Glasnost, 168-170, 176-178.

185 Brownell, Training the Body For China, 73.

186 PzS, 47 (8 March, 1983), 1; Przyjaciolka, 15 (13 April, 1989), 5.

$187 \underline{\mathrm{KiZ}}, 32$ (10 August, 1983), 12, 13; and KiZ, 44 (30 October, 1985), 5, 13.

$188 \mathrm{KiZ}, 42$ (8 October, 1981), 10, 11.

$189 \underline{\mathrm{PzS}}, 13$ (18 January, 1984), 4.
} 
shape' of women's physical culture in Poland. 190 On 17 December, 1984 the GKKFiS confirmed the deepening crisis in women's physical culture in its resolution and reaffirmed its commitment to create a more favorable climate in women's sports in individual families, schools, and in popular consciousness, both in the towns and in the countryside. The state also resolved to provide material help for sportswomen during maternity leave. The resolution strongly favored the need for good physical training and medical supervision of women's sports. 191

Even in western societies, while more women began to participate in sport, there were problems. In Britain, women's physical culture remained largely informal and uncompetitive--more healthy and relaxing--an antidote to obesity and depression. Competitive sport was limited to a minority who were cold-shouldered in football and cricket and openly ridiculed in rugby. ${ }^{192}$ In America, the legislated gender equality in athletic programs at schools that received federal funding contributed little in changing the dominant male sporting practices. 193 There was fear that men's programs would suffer irreparable damage if forced to endure budget cuts. ${ }^{194}$ Also, the increase in women's participation in intercollegiate athletics was paralleled by a decrease in women's leadership opportunities at the administrative and coaching levels. ${ }^{195}$ Many prominent American universities refused to comply with Title IX, citing myriad reasons for favoring male over female athletes. 196 The passage of this act, meanwhile, did instigate a debate amongst "feminists" who all questioned the pervasivity of traditional epistemological assumptions in sport. 197

\footnotetext{
190 PzS, 92 (10 May, 1984), 3.

191 PzS, 9 (14 January, 1985), 4.

192 Holt and Mason, Sport in Britain, 11, 12, 169.

193 Boutilier and SanGiovanni, "Politics, Public Policy and Title IX," 107.

194 Cahn, Coming on Strong, 254, 255, 262.
}

195 R. Vivian Acosta and Linda Jean Carpenter, "The Status of Women in Intercollegiate Athletics," in Birrell and Cole (eds), Women, Sport, and Culture, 111-118, p. 117; Shari L. Dworkin and Michael A. Messner, "Just Do...What? Sport, Bodies, Gender," in Myra Marx Ferree, Judith Lorber, Beth B. Hess (eds.), Revisioning Gender (Thousand Oaks, Calif., 1999), 341-361, p.346; Nelson, "Introduction: Who We Might Become," xvii; Hult, "The Story," 83-106; and Woolum, Outstanding Women Athletes, 22, 24. See also Ellen J. Staurowsky, "Women Coaching Male Athletes," in Messner and Sabo (eds.), Sport.

196 Nelson, "Introduction: Who We Might Become," xv; and Kristin Bell Smith, The Promise of Title IX: A Critique of Sport Equity Legislation in the United States and the Constraints Inherent in a Liberal Feminist Interpretation (MA Thesis, Queen's University, Ontario, Canada 1994), 32. See also Twin, Out of Bleachers, 175.

197 Margaret Costa and Sharon Guthrie, "Feminist Perspectives: Intersections With Women and Sport," in Costa and Guthrie, Woman and Sport, 235-284; Kane and Greendorfer, "The Media's Role in Accommodating and Resisting Stereotyped Images," 39, 40; Smith, The Promise of Title IX, 83; and Boutilier and SanGiovanni, "Politics, Public Policy and Title IX," 107. 
In Australia, women finally began to play a leading role in sports in the 1980s. Some were elected to senior committee positions on major league clubs' boards of management, others qualified as coaches at junior levels. On the playing field, the umpiring fraternity opened its doors and under equal-opportunity legislation girls won places in junior football teams governed by modified rules. 198 Netball is currently the largest participation game for girls and women in Australia. 199

Thus, in the final years of communist rule in Poland, the socialist state reaffirmed its commitment to women's sports. However, while the political leadership voiced its endorsement to develop women's physical culture, these words of support did not translate into reality. Polish women suffered under the yoke of their double burden which left them with little space, time and energy to engage in sports. In the worsening socioeconomic crisis, only "superwomen" could skillfully balance their professional interests with the omnipresent hardships which challenged the survival of the family and the nation as a whole. Polish women, similar to Soviet women, accordingly became less "sportive" in their respective civil societies. On the other hand, western women, especially American sportswomen, were now expressing their grievances in a more organized and radical fashion. Liberated from the hardships of daily life which encompassed the Poles, the more prosperous American women had the time and the leisure to engage in a more meaningful discourse on the importance of women's sports. For this reason, as the fortunes of Polish and other east European sportswomen gradually became eclipsed, those of western female athletes became increasingly visible on the horizon.

\section{The Walls Come Tumbling Down: The Roundtable Talks and the Future of Women's Physical Culture in 1989}

In 1989, communism collapsed in Eastern Europe. Under the leadership of Mikhail Gorbachev, the Soviet Union attempted to save communism by restructuring the core of its empire. But, Gorbachev's policies of glasnost and perestroika unconsciously facilitated the dismantlement of the communist system in the imperial periphery. With the disappearance of the Soviet military threat, the ruling elites of Eastern Europe were required to defend their illegitimate political leaderships on their own strengths. However, popular support for their continued survival was in short supply. In the face of

\footnotetext{
198 Bernard Whimpress, “Australian Football," in Vamplew and Stoddard, Sport, 19-39.

199 Ian F. Jobling, "Netball," in Vamplew and Stoddard, Sport, 154-171.
} 
limited resources and pressures from indigenous civil societies, the walls began to tumble, first in Poland and then elsewhere in Eastern Europe.

In Poland, Jaruzelski offered "round table" talks to Lech Walesa with a view to legalizing Solidarity and giving Poland a fresh start. These talks began on February 6, 1989 and were negotiated by interior minister General Czeslaw Kiszczak for the regime and Professor Bronislaw Geremek, a medieval historian, for the Solidarity contingent. The concluded negotiations promised parliamentary elections two months hence. The elections were held openly and honestly in June, 1989, and the results inflicted a humiliating defeat for the Communists. Through prearranged agreements, Jaruzelski announced that he wished to be a 'president of consensus'. Tadeusz Mazowiecki, Catholic intellectual-journalist, was chosen to serve as Prime Minister. The future of Poland was now in the hands of Solidarity, the social and civil movement which enabled the country to liberate itself from the clutches of communism, but which still quite did not know how to serve as an architect of a modern, democratic nation. 200

While Poland entered the final decade of the 20th century as a "free" nation, the same was not true for the Polish women. That things looked only more bleak for women was evident when only one woman (out of a total of 56 present) participated in the 1989 'round table' to effect Poland's new democratic transition. Moreover, the increased fascination with women's beauty pageants and female nudity from 1988 onward suggested the plight of women as they now needed to compete in the free market. 201 Clearly, the earlier images of patriotic women constructing a rational, socialist morality had been completely discarded. Polish women's physical culture would subsequently also reflect the society's interest in women's sexual physicality.

To conclude, Polish women throughout the communist period were denied the real experience of their personal and professional 'equality'. The market conditions, the lower wages for women, the family bonds and religious considerations, the masculinization of the political apparatus, the lack of women's collective consciousness, the multiple weaknesses of the women's organizations, and the pervasive patriarchal environment all undermined the celebrated equality of women under state socialism.

200 Jan T. Gross, "Poland: From Civil Society to Political Nation," in Ivo Banac (ed.), Eastern Europe in Revolution (Ithaca, 1992), 56-71, p.64, 65, 71; Bernhard, The Origins of Democratization in Poland, 13; Rothschild, Return to Diversity, 227-230; and Slay and Vinton, Poland to 2005, 34.

$201 \mathrm{KiZ}, 13$ (29 March, 1989), 4, 5. From 1988 onward, there is an increased fascination with female nudity in the women's periodicals, almost to the point of embarrassment for those interested in reading them. Such frequent images of naked women could well classify as pornography. 
Despite the Polish state's repeated emphasis in encouraging women's dynamic participation in all aspects of life, including sports and physical education, women were gradually denied opportunities to experience a real physical emancipation.

However, when opportunities were permitted, how did the state and society respond to women's athleticism? Who were the Polish sportswomen and what motivated them to become athletic? What kinds of sports did women play and how were their achievements recognized, both at home and abroad? How did sportswomen balance their professional and domestic obligations? And how did the women's physical culture movement reflect the socio-economic tensions within the country? The images and identities of Polish female athletes will now be explored in the next chapter. 


\section{Chapter Seven}

\section{Socialist Ideology and the Images and Identities of Female Athletes in the PRL}

This chapter examines the images and identities of Polish female athletes as elaborated and regulated by the successive socialist regimes in the PRL. The Polish socialist state sought to demonstrate significant popular participation in sport, without any gender discrimination. State socialism endeavored to create "happy and healthy" Polish families who represented socialist "solidarity" and "modernity". However, were Polish sportswomen really happy and healthy? How were female athletes able to accommodate their sporting interests with their work, both inside and outside of the household? Did they successfully overcome the difficulties implicit in this infamous "double burden," or were they the victims of a "triple burden," the additional burden being the product of state socialism's fascination with producing women sports champions? If the former is true, could Polish sportswomen have served as models of the truly liberated Polish woman? If the latter is true, were Polish sportswomen the 'real' superwomen, combining work, household chores and the development of their own 'bodies'. Quite simply, were Polish sportswomen "super-sportswomen" in their physical, political, economic, and social roles?

Accordingly, the purpose of this chapter is to closely examine the "images" and "reality" of Polish sportswomen's identities. How did socialist political athleticism affect women's participation in sports? What kind of sports remained popular with women and why? How did the Polish state and society evaluate their sportswomen? What kind of opportunities existed for Polish female athletes--both at home and in the sporting arena? What were the problems in women's sports and how did the female athletes respond to the ideological and institutional constraints in their physical culture? More fundamentally, were Polish sportswomen real champions of state socialism or 'socialist heroines' who actually lived and trained in misery?

\section{Women's Individual and Team Sports in the PRL Opportunities and Limitations}

Among the various sports, the Poles were particularly attracted to football, volleyball, track and field, gymnastics and tennis. But they also participated in horseriding, boxing, basketball, swimming, oaring, rugby, weightlifting, fencing, scouting, parachuting, sailing, motor sports, shooting, gliding, and ice hockey. Polish female athletes generally excelled in gymnastics, track and field, skiing, fencing and oaring in 
the Olympic Games. ${ }^{1}$ At the more popular level, rural girls normally favored team events, while urban girls sought greater participation in individual games.

With the exception of the years 1970 and 1979, Polish women excelled in track and field events in national and international competitions. After a weak beginning in the immediate aftermath of the war, women's track and field became extraordinarily strong from the 1950s onward. The Polish women emulated their Soviet counterparts and eventually attained a very high level of success in this sport. By the end of the 1960s, Poland was ranked third in the world in women's track and field, behind the Soviet Union and the German Democratic Republic.

The Polish sports and women's press provided extensive coverage of the participation of female athletes in track and field events and reported the results they obtained in the different competitions. At the popular level, both the Polish and Soviet women and girls participated in their home-style spartakiads and mass races organized by the local authorities. At the high performance level, the press provided regular descriptions about female champions. The press (both Polish and foreign) celebrated the "unusual" talents and international accomplishments of Szewinska, and identified her as the "First Woman" in the world of Polish sports. Meanwhile, the press also acknowledged the successes of interwar champions Maria Kwasniewska, the "elegant, graceful, and First Lady of the Second Republic" Helena Konopacka, and the "history and legend of Polish sport" Stanislawa Walasiewiczowna.

Based on the track and field accomplishments of Polish women, which on many occasions were better than the men's results, the authorities reinforced the idea that women in track and field faced no discrimination, as well as the notion that this sport was important for building both character and physical fitness of an individual. Such ideas also motivated the state to support research on the biomechanical, physiological and physical aspects of training for female athletes in track and field competitions. This form

\footnotetext{
${ }^{1}$ See Przyjaciolka, 19 (13 May, 1951), 12; Przyjaciolka, 46 (18 November, 1951), 14; Przyjaciolka, 42 (21 October, 1956), 14; Przyjaciolka, 41 (14 October, 1956), 2; Przyjaciolka, 42 (20 October, 1968), 3; PzS, 40 (22 May, 1950), 3; KiZ, 13 (30 March, 1975), 15; KiZ, 30 (27 July, 1975), 6, 7; KiZ, 42 (16 October, 1977), 6, 7; Glowny Komitet Kultury Fizycznej i Turystyki: Aktualne zadania kultury fizycznej oraz kierunkowe wytyczne rozwoju sportu na lata 1966-1970, 12; Glowny komitet kultury fizycznej i sportu: Materialy Informacyjne (March, 1984), 51; Dall, Kultura fizyczna i sport w Polsce Ludowej, 33; Eugeniusz Pudelkiewicz, "Local Playing Fields in the Light of Sociological and Urban Problems," in The Australian Journal of Physical Education, 65 (September, 1974), 13-18; "'Polish Power': The Soviets Fail to Match Poland Pound for Pound," in Volleyball Magazine, 4 (Fall, 1976), 36-41; Tymoszuk, "Zainteresowanie," 102; Chelmecki, "Problematyka," 11, 12; Wohl, "Spartakiady," 17; Gaj, Wychowanie fizyczne, 212; Foldesine Szabo Gyongyi and Zbigniew Krawczyk, "The Social Role of Sports Events in Poland and Hungary," in International Review of Sport Sociology, $1 / 17$ (1982), 23-47, pp.23, 30, 43; Krawczyk, "Sport jako," 173-175; and Leszek Gondek, "Odbudowa hippiki Polskiej po drugiej wojnie swiatowej, aspekty prawno-polityczne," in Zeszyty Naukowe AWF w Gdansku, 7 (1983), 61-86.
} 
of state sponsorship was important for while women's track and field remained strong, there were some concerns about the limited numbers of female competitors in this sport, as well as the need to improve the performances of women in sprints, hurdles, high jump, and in the javelin and hammer throws. ${ }^{2}$

Polish women's participation in gymnastics (including both artistic and acrobatic gymnastics) at the workplace, in the home, and in domestic and international competitions received extensive press coverage. The state authorities patronized scientific research for improving this 'healthy' sport for women. The accomplishments of Helena Rakoczy, member of the Krakow club 'Korona' and world champion in gymnastics, were published with immense national pride. Rakoczy, referred to as the "best among the best" and a model "sportowca-obywatela" (Citizen-Sportswoman) was awarded the Order Sztandaru Pracy II Klasy for her social and sports achievements. In the official vision,

\footnotetext{
2 For all these issues and the individual accomplishments of women in track and field see PzS, 22 (8 February, 1958), 2; PzS 55 (11 April, 1961), 4; PzS, 1 , 17 (8 October, 1945), 4; PzS, 121 (14 July, 1959), 4; PzS, 86 (19 July, 1969), 3; PzS, 140 (20 September, 1969), 4; PzS, 174 (13 December, 1971), 4; Przyjaciolka, 13 (26 March, 1950), 7; Przyjaciolka, 38 (17 September, 1950), 10; Przyjaciolka, 40 (1 October, 1950), 10; Przyjaciolka, 21 (25 May, 1952), 14; KiZ, 34 (1 December, 1954), 11; PzS, 33 (24 April, 1947), 2; PzS, 44 (3 June, 1947), 3; PzS, 52 (30 June, 1947), 1; PzS, 55 (10 July, 1947), 1; Przyjaciolka, 3 (20 January, 1957), 14; PzS, 86 (27 October, 1947), 4; PzS, 49 (20 June, 1949), 1; PzS, 61 (1 August, 1949), 3; PzS, 72 (8 September, 1949), 1; PzS, 86 (27 October, 1949), 6; Tempo, 28 (18 May, 1959), 5, 6; Tempo, 12 (23 Marca 1959), 4; PzS, 36 (8 May, 1950), 1; PzS, 51 (30 June, 1950), 3; PzS, 85 (26 October, 1950), 4; $\underline{\mathrm{PzS}}$, 44 (3 June, 1951), 1; $\underline{\mathrm{PzS}}, 45$ (8 June, 1951), 1; $\underline{\mathrm{PzS}}, 74$ (31 August, 1953), 4 ; PzS, 84 (5 October, 1953), 4; PzS, 150 (23 September, 1961), 4; PzS, 174 (4 November, 1961), 4; PzS, 53 (3 April, 1958), 2; KiZ, 12 (19 March, 1978), 14; KiZ, 33 (20 November, 1956), 3; KiZ, 36 (6 September, 1964), 14; PzS, 146 (5 December, 1970), 1; PzS, 169 (1 September, 1975), 3; PzS, 172 (4 September, 1975), 1, 6; PzS, 246 (17 December, 1975), 6; PzS, 3 (6 January, 1975), 1; Przyjaciolka, 29 (18 July, 1976), 8, 9; PzS, (17 September- 2 October, 1988), 9; KiZ, 33 (15 August, 1976), 4; PzS, 80 (4 July, 1970), 1; $\underline{\text { PzS }}, 106$ (30 May, 1980), 3; PzS, 2, 45 (5 September, 1946), 1; KiZ, 29 (20 July, 1980), 12, 13; KiZ, 3 (18 January, 1981), 14, 15; PzS, 144 (26 July, 1985), 1; Przyjaciolka, 40 (2 October, 1960), 9; Przyjaciolka, 28 (13 July, 1969), 2; PzS, 21 (30 January, 1989), 1;PzS, 25 (3 February, 1989), 3; Przyjaciolka, 32 (6 August, 1950), 10; Przyjaciolka, 28 (July, 1952), 14; Przyjaciolka, 6 (6 February, 1972), 8, 9; Przyjaciolka, 24 (2 June, 1972), 4; Przyjaciolka, 38 (17 September, 1972), 3; Przyjaciolka, 40 (1 December, 1950), 10; Przyjaciolka, 24 (2 June, 1972), 4; PzS, 47 (14 June, 1951), 4; PzS, 86 (4 October, 1951), 2; PzS, 51 (19 June, 1952), 4; PzS, 86 (16 October, 1952), 3; PzS, 15 (19 February, 1953), 1; PzS, 17 (31 January, 1959), 1; Builetyn PKOI, 5/8 (1974), 18; Stanislaw Nowosielski, Problemy sportu, turystyki $i$ wypoczynku $w$ dokumentach prezydium Rady Narodowej m.st. Warszawy w latach 1960-1970 (Praca Magisterska, AWF Warsaw, 1973), 52; Miroslawa Kutzner, "Wyklad zawodniczek Wielkopolski w rozwoj lekkiej atletyki krajowej w latach 1965-1984," in Wychowanie fizyczne i sport w 40-leciu PRL, 193-199, pp.193, 194, 198; Henryk Sozanski, "Niektore uwarunkowania i elementy treningu kobiet w skokach lekkoatletycznych," in Sport Wyczynowy, 6-7 (1978), 81-96, pp. 82, 96; Biuletym Informacyjny Glownego Komitetu Kultury Fizycznej $i$ Turystyki, Warsaw, 10-12 (1975), 11, 13; Jozef Drabik, "Analiza rozwoju wynikow w rzutach lekkoatletycznych mezczyzn i kobiet w Polsce w latach 1965-1974," in Zeszyty Naukowe WSWF w Gdansku, 2 (1978), 139-145; Stanislaw Furdal, Marta Zalewska, and Daniel Grinberg, "Prognoza rozwoju najlepszych wynikow na swiecie w lekkoatletyce kobiet," in Sport Wyczynowy, 9-10 (August, 1990), 3034; and Liponski, Dzieje Sportu Polskiego, 53. Women's track and field was one area of great Soviet strength, and in the 1950s' the Press sisters, Irina and Tamara, ruled over their events in the world. See Edelman, Serious Fun, 151.
} 
Rakoczy was symbolic of the fact that 'sport in PRL was well developed and accorded many opportunities for its citizens to engage in physical culture'. 3

Gymnastics was, by and large, a feminized sport in both eastern and western societies. 4 Modern gymnastics especially gained wide popularity in the Soviet Union where it was considered to be a very suitable sport for women. This sport was said to have plasticity, beauty and grace; but it also demanded will-power, daring, and stamina. The Soviet women's magazines Rabotnitsa and Sovetskaia zhenshchina sponsored annual international competitions in women's rhythmic gymnastics. 5

While the sports press reported the accomplishments of Polish female gymnasts, there were, however, articles referring to "problems" in this sport. For example, in 1957 the press wrote that the better results of girls from Bulgaria and East Germany sounded alarm signals for the Polish gymnasts. ${ }^{6}$ Also, the press stated in 1970 that many female gymnasts were anemic, and that the poor medical supervision and insufficient funding of gymnastic centers had created an 'alarming' situation in Polish women's gymnastics. 7

Women's archery enjoyed increasing popularity in Poland, especially in the sports sections of trade unions and the LZS. The press reported the achievements of the "strong and ambitious" Janina Kurkowska-Spychajowa who was the fourth female sports figure

\footnotetext{
3 See PzS, 134 (6 November, 1969), 2; Przyjaciolka, 11 (16 March, 1952), 14; Przyjaciolka, 44 (2 November, 1952), 14; Przyjaciolka, 46 (17 November, 1963), 2; Kobieta Dzisiejsza, 2, 11 (July, 1947); Kobieta Dzisiejsza, 2, 10 (June, 1947), 11; MiZP, 3 (March, 1946); MiZP, 5 (May-June, 1946), 17; MiZP, 21/141 (20 July, 1950), 9; MiZP, 28/184 (1 October, 1951), cover page, 11; MiZP, 29/185 (10 October, 1951), 11; KiZ, 33 (20 November, 1953), 12; KiZ, 10 (9 June, 1982), 20; KiZ, 52 (30 December, 1987), 13, 14; KiZ, 8/1969 (22 February, 1989), 16; PzS, 2 (5 January, 1950), 3; PzS, 97 (20 May, 1985), 6; PzS, 194 (5 October, 1989), 1; Przyjaciolka, 24 (14 June, 1959), 9; Tempo, 16 (20 April, 1959), 6; PzS, 5 (17 January, 1952), 3; PzS, 15 (21 February, 1952), 6; $\underline{\text { PzS }, ~} 15$ (21 February, 1952), 6; $\underline{\text { zzS }, ~} 59$ (16 May, 1970), 3; PzS, 108 (23 December, 1948), 1; Tempo, 22 (1 June, 1959), 1, 4; $\underline{\text { PzS }}, 72$ (13 April, 1988), 1; Krystyna Garstka, "Wplyw uprawiania gimnastyki rekreacyjnej przez kobiety w srednim wieku na odczuwane zadowolenie z zycia," in Eugeniusz Wachowski and Ryszard Strzelczyk (eds.), Wychowanie fizyczne $i$ sport $w$ badaniach naukowych (Poznan, 1998), 107-112; AMR, notes; and Maria Szafarkiewicz, "Obszernosc ruchu wybranych odcinkow ciala w zespole gimnastyczek na Igrzyskach Mlodziezy Szkolnej," in Kultura Fizyczna, 11 (1978), 501-502. For more general descriptions of the various gymnastic exercises for women, see Z. Wedrowska, 100 minut dla urody (Warsaw, 1978); Karpinska, Wypoczywaj, cwiczac; rekreacja fizyczna kobiet. Vol. 3 (Warsaw, 1972); A. Lukowska and J. Skirlinska, Gimnastyka dziewczat (Warsaw, 1971); and Zurawlew, Stakelberg, Jananis, Codzienna gimnastyka kobiet, 4. On Helena Rakoczy see also Przyjaciolka, 33 (13 August, 1950), 10; Biuletym Informacyjny Glownego Komitetu Kultury Fizycznej i Turystyki (Warsaw, 1975), 11; MiZP, 20 (10 July, 1951), 11; PzS, 11 (8 February, 1951), 1; PzS, 106 (29 December, 1952), 3; PzS, 55 (1 July, 1954), 4; PzS, 92 (20 November, 1950), 6; PzS, 23 (20 March, 1952), 3; MiZP, 24/144 (20 August, 1950), 6; and Dall, Kultura fizyczna i sport w Polsce Ludowe, 42.

4 In Britain, for example, gymnastics was also primarily popular among women. See Holt and Mason, Sport in Britain, 61.

5 Soviet Woman, 9 (1972), 32; Soviet Woman, 10 (1977), 38, 39; and Soviet Woman, 8 (1977), 29.

6 PzS, 184 (28 November, 1957), 2.

${ }^{7} \underline{\mathrm{PzS}}, 7$ (13 June, 1970), 3.
} 
to receive the title of Zasluzony Mistrz Sportu (Distinguished Master of Sport), after J. Jedrzejowska, J. Glazewska and Helena Rakoczy. Champion Maria Maczynska was characterized as a model in qualities of ambition, congeniality and laboriousness. According to the state sports authorities, Poland had made its mark on the world champions list in archery by 1970, and that Polish female archers had much to do with this victory. In the early 1980s, there were over 70 archery clubs with about 1000 women competitors. $^{8}$

Whereas in the interwar period women's tennis had remained quite bourgeois and aristocratic in nature, the postwar Polish state proudly narrated the 'democratization' of this privileged sport. Tennis was now perceived as an 'ideal' sport for women to play, and the triumphs of Jadwiga Jedzrejowska were once again splashed in the official press. 9 However, for all the state emphasis, tennis continued to remain quite elitist, and was mainly played in Warsaw, Krakow and Wroclaw. Other press reports admitted the small participation of women in official tennis competitions and games. 10 Even in western societies such as Britain, tennis remained a suburban game, popular primarily with middle class women. 11

Similar to tennis, women's rifleshooting, though theoretically open to all, remained a sport for the privileged. Despite the accomplishments of Eulalia ZakrzewskaRolinska and Wieslawa Salwicka, few women indulged in this rather eclectic sport. 12 Some rifleshooters, such as Dorota Chytrowska-Mika and Elzbieta Bednarczuk, even complained of a tendency by the political elite to rid women, especially of the older generation, from participation in this sport. 13 Compared to women's rifleshooting, the victories of female fencers such as Barbara Piotrowska, Elzbieta Pawlasowa, Jolanta

$8 \underline{\text { PzS }}, 71$ (4 September, 1947), 4; $\underline{\text { PzS }, ~} 147$ (24 September, 1957), 2; Tempo, 29 (11 April, 1974); $\underline{\text { PzS }}, 136$ (27 August, 1962), 1; PzS, 107 (23 December, 1953), 4; PzS, 71 (20 August, 1953), 5; PzS, 66 (7 August, 1952), 4; Przyjaciolka, 34 (23 August, 1970), 15; KiZ, 35 (31 August, 1983), 6, 7; PzS, 110-111 (23 July, 1957), 1; PzS, 136 (27 August, 1962), 1; PzS, 83 (12 July, 1969), 1; PzS, 99 (3 August, 1971), 3; PzS, 115 (16 June, 1981), 1; PzS, 68 (1 September, 1981), 1; Przyjaciolka, 33 (17 August, 1952), 10; and Biuletym Informacyjny Glownego Komitetu Kultury Fizycznej i Turystyki, (Warsaw, 1975), 11.

${ }^{9}$ Przyjaciolka, 16 (16 April, 1950), 10; MiZP, 2, 20/68 (July, 1948), 7; KiZ, 19 (7 May, 1978), 14; Tempo, 25 (22 June, 1959), 5; PzS, 47 (3 June, 1954), 2; PzS, 38 (15 May, 1950), 6; PzS, (Lodz), 1, 1 (12 July, 1945), 4; PzS, 2, 34 (1 August, 1946), 1; and Biuletym Informacyjny Glownego Komitetu Kultury Fizycznej i Turystyki (Warsaw, 1975), 11.

10 PzS, 107 (20 December, 1948), 5; and PzS, 52 (2 July, 1951), 4.

11 Holt and Mason, Sport in Britain, 53, 169.

12 PzS, 66 (6 July, 1955), 1; KiZ, 36 (8 September, 1968), 2, 3; and Biuletym Informacyjny Glownego Komitetu Kultury Fizycznej i Turystyki, (Warsaw, 1975), 13.

13 PzS, 130 (5 July, 1985), 3. 
Rzymowska, and Irena Szydlowska attracted a greater following, especially between the years 1964-1972.14

In water sports, women's oaring, despite the lack of equipment and poor training facilities, retained its popularity in places such as Warsaw, Bydgoszcz, and Krakow. The successes of east European women in rowing prompted western states to encourage their female rowers to become more competitive. 15 During the economic crisis of the late 1970s, however, Polish women's enthusiasm in rowing declined. ${ }^{16}$ For example, in 1979 there was some concern for the limited participation of female rowers from the main Warsaw Oarswomen Club. ${ }^{17}$

Women's swimming experienced irregular development in communist Poland. During the Stalinist period, the state expressed dismay over the lack of interest in women's swimming and complained that 'the fair sex has not performed well in this sport'. In the years between 1955-1964 swimming began to attract increasing numbers of women. However, in response to the acute economic crisis of the late 1970s and the formation of Solidarity, its popularity once again declined from 1975-84. To be sure, the press did report the victories of its female swimmers. However, reports on the poor performance and the "deplorable" situation of Polish female swimmers exceeded the celebratory coverage on women's swimming. While swimming was considered very 'healthy', it remained weakly developed among Polish women. ${ }^{18}$ By contrast, women's

14 PzS, 190 (24 October, 1959), 3; PzS, 163-164 (23 December, 1963), 3; PzS, 89 (25 July, 1970), 3; Przyjaciolka, 38 (17 September, 1972), 3; Mlodziankowska, Poczatki i rozwoj sportu szermierczego kobiet, 36, 70; and Biuletym Informacyjny Glownego Komitetu Kultury Fizycznej i Turystyki, (Warsaw, 1975), 13.

15 In Britain, for example, female rowers only emerged in 1962, largely in response to the East European successes. See Holt and Mason, Sport in Britain, 58.

16 See Sport, 217 (9 November, 1976), 4; PzS, 75 (19 September, 1949), 3; PzS, 48 (8 March, 1979), 3; Przyjaciolka, 24 (11 June, 1950), 10; KiZ, 26 (29 June, 1969), cover page; PzS, 85 (4 October, 1948), 6; PzS, 60 (28 July, 1949), 1; Tempo, 19 (11 May, 1959); PzS, 71 (20 August, 1953), 3; PzS, 109 (11 September, 1969), 1; Biuletym Informacyjny Glownego Komitetu Kultury Fizycznej i Turystyki, Warsaw, 10-12 (1975), 12; Jolanta Kozera, "Ocena stanu zdrowia mlodych zawodniczek i zawodnikow uprawiajacych wioslarstwo," in Exercise and Health, Conference materials edited by Jozef Drabik, The Academy of Physical Education in Gdansk, Gdansk 1992, 52-59; AMR, notes; Urbanyi, Zarys Historii Sportu Bydgoskiego, 56, 110, 111, 117, 118; and Rotkiewicz, "Rozwoj spolecznych organizacji sportu kobiet w Polsce," 76.

17 Maria Rotkiewicz appealed to female oarers in Warsaw to keep up their work and participate in the activities of the WKW. See PzS, (3 January, 1979), 1.

18 For women's swimming see Przyjaciolka, 21 (21 May, 1950), 10; MiZP, 19/211 (1 July, 1952), 11; MiZP, 25/109 (1 September, 1949), 10; MiZP, 14/170 (10 May, 1951), 11; MiZP, 13/133 (1 May, 1950), 11; PzS, 19 (6 March, 1950), 2; $\underline{\text { PzS }}, 21$ (13 March, 1950), 1, 2; $\underline{\text { PzS }}, 66$ (20 August, 1951), 3; $\underline{\text { PzS }}, 112$ (16 July, 1962), 2; PzS, 131 (21 August, 1961), 1; $\underline{\text { PzS }}, 77$ (6 September, 1948), 1; $\underline{\text { PzS }}, 3$ (8 January, 1948), 1, 2; PzS, 7 (22 January, 1948), 3; PzS, 12 (9 February, 1948), 6; and $\underline{\text { PzS }}, 85$ (26 October, 1950), 4; Przyjaciolka, 24 (13 June, 1954), 14; $\underline{\text { PzS }}, 7$ (13 January, 1959), 2; $\underline{\text { PzS }, ~} 16$ (23 January, 1986), 1; PzS, 9 (14 January, 1986), 1; PzS, 99 (18 August, 1969), 2; Marian Tuliszka, "Rozwoj wynikow plywackich w 
swimming remained popular in other east European countries. Even in the west, the British women made a big impact in the post-war swimming competitions. 19

While women's rowing and swimming remained problematic, recreational water sports enjoyed immense popularity among Polish women as a form of 'family entertainment'. There are many references in the press to women's recreational sailing, sea-bathing, yachting, and kayaking. For example, the Sea Department (Wydzial Morski) in Gdynia organized water tourism for its city residents. The state also emphasized the need to organize more sailing regattas for women. Meanwhile, in order to popularize kayaking among women, the press provided coverage on the 'First Lady' of Polish kayaking, Izabela Dylewska. 20

It is interesting that a large number of sailing clubs were also organized in the Soviet Union. 21 In addition, underwater sports attracted large numbers of Soviet women. $^{22}$ They particularly excelled in underwater games of chess and football.23 Synchronized swimming or water ballet received official recognition in 1963 and was practiced in several Soviet cities. 24

In the ball-games, Polish women excelled in volleyball. Indeed, volleyball was perceived as the biggest and 'best' women's sport in Poland, and the press covered the superlative performances of women in this game. Polish women competed in inter-city, national and international volleyball competitions with honors. In the 1950s, Polish women's volleyball was second only to the USSR in the world, and the Poles were followed by women from Czechoslovakia, Bulgaria and Romania. ${ }^{25}$ In the 1970s and

Wielkopolsce w okresie 40-lecia PRL," in Wychowanie fizyczne $i$ sport $w$ 40-leciu PRL, 43-57, pp.46, 47, 56, 57; and Biuletym Informacyjny Glownego Komitetu Kultury Fizycznej i Turystyki, (Warsaw, 1975$), 13$.

19 Holt and Mason, Sport in Britain, 60.

20 Kobieta Dzisiejsza, 1, 11 (September, 1946), 16; Kobieta Dzisiejsza, 1, 12 (October, 1946), 14; MiZP, 20/104 (10 July, 1949), 11; MiZP, 20/176 (10 Lipca 1951), 11; PzS, 28 (9 April, 1951), 6; PzS, 65 (30 July, 1953), 3; Przyjaciolka, 28 (9 July, 1950), 10; $\underline{\text { PzS }}, 144$ (26 July, 1985), 3; PzS, 166 (28 August, 1989), 6; Przyjaciolka, 10 (10 March, 1988), 6, 7; Szot, Rozwoj kultury fizycznej w aglomeracji Gdanskiej, Gdansk, Gdynia, Sopot, 145; AMR, notes; and Biuletym Informacyjny Glownego Komitetu Kultury Fizycznej $i$ Turystyki, (Warsaw, 1975), 12.

21 For different sports in the Soviet Union see Miriam Morton, Pleasures and Palaces: The After-School Activities of Russian Children (New York, 1972), 24, 28, 35, 41, 50, 58, 59.

22 Rabotnitsa, 7 (1962), 24, 25.

23 Soviet Woman, 10 (1988), 41; and Rabotnitsa, 11 (1982), 20.

24 For synchronized swimming see Soviet Woman, 9 (1978), 25; Soviet Woman, 7 (1982), 24, 25; Soviet Woman, 7 (1989), 17; and Soviet Woman, 9 (1990), 25, 26, 27.

25 MiZP, 27/219 (20 September, 1952), 11; $\underline{\text { PzS }, ~} 140$ (31 October, 1963), 4; Przyjaciolka, 17 (23 April, 1950), 10; PzS, 2, 5 (28 January, 1946), 6; MiZP, 14/206 (10 May, 1952), 11; Tempo, 17 (27 April, 1959), 3; $\underline{\text { PzS }}, 9$ (29 January, 1948), 2; $\underline{\text { PzS }}, 14$ (16 February, 1948), 4; $\underline{\text { PzS }, ~} 65$ (16 August, 1951), 1; $\underline{\text { PzS }, ~} 81$ (29 September, 1952), 4; Tempo, 5, 2 (12 January, 1959), 6; and Biuletym Informacyjny Glownego Komitetu Kultury Fizycznej i Turystyki, (Warsaw, 1975), 13. 
1980s, the Chinese women began to elevate their game and their team won the World Cup in Volleyball in 1981.26 Unfortunately, despite the obvious growth in women's volleyball in Poland, there were also some press reports which articulated the need for more state initiative to further develop and 'radically' reform this ball-game for women. 27

While women's volleyball was popular in Poland, women's handball received little attention. 28 However, women's basketball experienced a 'new wave' with 'more qualified trainers and very talented girls'. For example, Halina Wyka was named the 'First Lady' in basketball. But, while this game began to attract Polish women, it never did attain the popularity awarded to men's basketball.29 The relative lack of interest in women's basketball, as well as the poor technical and physical conditions in this sport, were "disturbing". Press reports questioned the lack of women's participation in basketball from cities such as Poznan, Gdansk, and Pomorze. 30 The Soviet Union, on the other hand, displayed tremendous skill in men's and women's basketball. Women's basketball was played widely throughout the USSR, and Soviet teams achieved enormous international success. 31

With reference to the "white" sports, skiing, ice-skating, and sledding were extremely popular in both their competitive and recreational forms in Poland. 32 Polish women were particularly good skiers. One of them, Olga Krzyzanowska was also a medical doctor and activist of Gdansk "Solidarity". Skiing was looked upon as a "hygienic" sport for women and "good" for family entertainment. 33 In other winter

\footnotetext{
26 Brownell, Training the Body For China, 80.

27 PzS, 9 (30 January, 1947), 3; $\underline{\mathrm{PzS}}, 160$ (10 October, 1961), 2; and $\underline{\mathrm{PzS}}, 117$ (3 August, 1957), 2.

$28 \underline{\mathrm{PzS}}, 94$ (2 November, 1951), 3; $\underline{\mathrm{PzS}}, 13$ (14 February, 1952), 5; $\underline{\mathrm{PzS}}, 100$ (2 December, 1954), 2; $\underline{\mathrm{PzS}}$, 160 (10 October, 1961), 1; Biuletym Informacyjny Glownego Komitetu Kultury Fizycznej i Turystyki, (Warsaw, 1975), 13; and Andrzej Koniarek and Andrzej Siekierski, "Wielkopolska Pilka Reczna w 40leciu PRL," in Wychowanie fizyczne i sport w 40-Leciu PRL, 37-42, p.38.

29 PzS, 182 (18 September, 1975), 4; PzS, 224 (18 November, 1981), 1; Przyjaciolka, 22 (28 May, 1950), 10; Przyjaciolka, 31 (3 August, 1975), 8; MiZP, 20/212 (10 July, 1952), 11; PzS, 14 (17 February, 1947), 2; PzS, 25 (27 March, 1950), 1, 6; PzS, 96 (8 November, 1951), 2; PzS, 84 (5 October, 1953), 3; PzS, 74 (10 May, 1958), 3; PzS, 79 (23 April, 1975), 6; and Biuletym Informacyjny Glownego Komitetu Kultury Fizycznej i Turystyki, Warsaw, 10-12 (1975), 13.

$30 \mathrm{PzS}, 23$ (18 March, 1948), 3; and $\underline{\mathrm{PzS}}, 4$ (14 January, 1954), 3.

31 Edelman, Serious Fun, 118, 119, 186, 189.

32 Przyjaciolka, 48 (26 November, 1950), 10; Przyjaciolka, 1 (7 January, 1951), 10; Przyjaciolka, 4 (27 January, 1952), 14; Przyjaciolka, 2 (13 January, 1952), 8, 9; KiZ, 3 (16 January, 1985), 16; and KiZ, 8 (25 February, 1979), 6, 7.

33 PzS, 56 (20 March, 1981), 2; $\underline{\mathrm{PzS}}, 248-249$ (21-24 December, 1989), 6; PzS, 19 (6 March, 1950), 3; Kobieta Dzisiejsza, 2, 8 (May, 1947), 16; PzS, 4 (13 January, 1955), 1; PzS, 1 (1 January, 1948), 1; Tempo, 3 (19 January, 1959), 7; PzS, 23 (18 March, 1948), 1; MiZP, 1, 1/85 (January, 1949), 10; MiZP, 3, 6/90 (February, 1949), 2; MiZP, 36/156 (20 December, 1950), 11; MiZP, 35/191 (10 December, 1951), 11;
} 
sports, Barbara Piecha won Poland's first gold medal in sledding in 1970.34 Halina Kanasz was regarded as the best Polish tobogganer. 35

Further, the Polish press narrated the "heroic" accomplishments of its adept female mountain-climbers such as Anna Teresa Pietraszek, Wanda Rutkiewicz (the first European climber of Mount Everest), and Ewa Czarniecka.36 Soviet women, meanwhile, also participated in this traditionally defined 'sport for the intrepid' and displayed remarkable fortitude. This activity was said to foster courage, endurance and a collective spirit. 37

While Polish women actively participated in winter sports, the press also published reports of some concern in such events for women. For example, in the 1950s, a number of articles articulated the importance of improving the quality and quantity of women's winter sports. 38 In 1969, one article confirmed a 'crisis' in women's tobogganing. 39 In 1981, another press report exclaimed: 'Relay race without girls! Why have the competitions for juniors in a skiing relay for girls been canceled?'40

In other sports, women's skating (both fast and figure) developed rapidly, especially in the 1960s and 1970s. Skating, especially figure skating, was identified as an 'ideal' and 'healthy' sport which improved women's skills of 'coordination and harmony'.41

MiZP, 1/193 (1 January, 1952), 4; MiZP, 2/194 (10 January, 1952), 11; Helena Eleganczyk, "Wyniki szkolenia kobiet na obozach narciarskich w latach 1976-1984," in Wychowanie fizyczne i sport w 40-leciu PRL, 223-232, pp.223, 229; and Biuletym Informacyjny Glownego Komitetu Kultury Fizycznej i Turystyki, (Warsaw, 1975), 11, 12.

$34 \underline{\text { PzS }}, 49$ (23 April, 1970), 1.

$35 \underline{\mathrm{PzS}}, 251$ (29 December, 1975), 3.

36 Przyjaciolka, 39 (26 September, 1985), 6, 7; Przyjaciolka, 39 (24 September, 1978), 5; Przyjaciolka, 45 (5 November, 1972), 9; PzS, 46 (6 March, 1981), 3; KiZ, 15 (15 April, 1987), 8, 9; Biuletym Informacyjny Glownego Komitetu Kultury Fizycznej i Turystyki (Warsaw, 1975), 13; "Wanda Rutkiewicz," in Udzial kobiet w rozwoju upowszechnianiu i odbiorze kultury: Materialy z obrad Krakowej Rady Kobiet Polskich 26-27 Listopad 1978 (Warsaw, 1979), 42-43, p.42; and "Wanda Rutkiewicz, First European woman to climb Everest," in Climber and Rambler, 18, 5 (May, 1979), 41.

37 Soviet Woman, 10 (1951), 57, 59; and Soviet Woman, 2 (1973), 37.

$38 \underline{\mathrm{PzS}}, 17$ (28 February, 1952), 3; $\underline{\mathrm{PzS}}, 20$ (10 March, 1952), 3; $\underline{\mathrm{PzS}}, 105$ (22 December, 1952), 5; and PzS, 13 (1 February, 1957), 3.

${ }^{39} \mathrm{PzS}, 21$ (20 February, 1969), 3.

$40 \underline{\mathrm{PzS}}, 43$ (3 March, 1981), 2.

41 PzS, 215 (6 November, 1989), 6; Przyjaciolka, 9 (26 February, 1950), 7; Przyjaciolka, 51 (17 December, 1950), 10; Przyjaciolka, 10 (10 March, 1983), 5; MiZP, 5/197 (10 February, 1952), 11; Tempo, 9 (2 March, 1959), 3; PzS, 10 (3 February, 1947), 4; $\underline{\text { PzS }}, 104$ (6 December, 1951), 1; PzS, 11 (7 February, 1952), 6; $\underline{\text { PzS }}, 190$ (26 November, 1962), 1; $\underline{\text { PzS }}, 8$ (26 January, 1950), 6; PzS, 10 (24 January, 1970), 3; PzS, 19 (6 March, 1950), 3; and Biuletym Informacyjny Glownego Komitetu Kultury Fizycznej i Turystyki (Warsaw, 1975), 13. 
Meanwhile, aviation sports such as gliding, skydiving, and parachuting interested few women. But some won world championship titles in parachuting. In 1958, for example, Poland was positioned second in the world after the USSR and before Bulgaria in women's parachuting. Although the sport of flying was traditionally masculine, the sports press proudly reported that these 'friendly, nice and happy' women had taken the pilot's seat. 42 From a comparative perspective, Soviet women also established several aviation records in gliding and parachuting. Though difficulties in the form of male egoism and skepticism did exist, the number of female participants in such competitions increased every year. While gliding for women was considered 'elegant' and 'beautiful', parachute jumping remained simply a 'wonderful' sport. This passion was also the first step into space for not only Yuri Gagarin, but also for Valentina Tereshkova and Svetlana Savitskaya. 43

Among other sports, women's cycling in Poland remained at the stage of infancy. The first national women's cycling competition was organized in Rzeszow in 1957 with 20 participants. There were, however, few references to women's cycling after the 1950s. 44 On the other hand, women's motor sports had better success, and the name of Janina Jedynak became synonymous with this sport. Polish women were good motordrivers, and they received help from the LZS and the Polish Motor Society. The first AllPolish Women's Motor Race was held on 2 August, 1953. More generally, however, the numbers of women in motorcycling remained traditionally small, and this sport did not achieve the same popularity as for the Soviet women, especially after the 1950s. 45

Women's table tennis and chess also made an appearance in the PRL. But the Polish women never quite made their mark in the national and international arenas. 46

42 PzS, 129 (15 August, 1958), 1; Przyjaciolka, 17 (26 April, 1953), 12; Przyjaciolka, 34 (20 August, 1972), cover page; Przyjaciolka, 21 (27 May, 1973), 4; KiZ, 25 (19 June, 1985), 11; PzS, 60 (19 July, 1952), 2; PzS, 134 (24 August, 1958), 3; Przyjaciolka, 34 (26 August, 1973), cover page; and Biuletym Informacyjny Glownego Komitetu Kultury Fizycznej i Turystyki, (Warsaw, 1975), 13.

43 Rabotnitsa, 12 (1971), 26, 27; Rabotnitsa, 4 (1972), 14; Rabotnitsa, 9 (1973), 19; Rabotnitsa, 8 (1974), 20, 21; Rabotnitsa, 8 (1975), 20, 21; Soviet Woman, 4 (1946), 52; Soviet Woman, 3 (1950), 58, 59; Soviet Woman, 5 (1989), 16; Soviet Woman, 10 (1970), 28; Soviet Woman, 4 (1983), 14; Soviet Woman, 5 (1984), 24; and Krest'ianka, 8 (1963), 15. See also Morton, Pleasures and Palaces, 24, 28, 35, 41, 50, 58, 59.

44 There are a few references to women's cycling in the 1940s and 1950s. See for example, Przyjaciolka, 26 (25 June, 1950), 10; MiZP, 1, 19/67 (July, 1948); $\underline{\text { PzS }}, 77$ (26 September, 1949), 5; PzS, 42 (11 May, 1955), 3; and PzS, 105 (13 July, 1957), 3.

45 Przyjaciolka, 44 (4 November, 1951), 14; Przyjaciolka, 31 (2 August, 1953), 14; KiZ, 27 (20 September, 1954), 6, 7; PzS, 59 (9 July, 1953), 5; PzS, 29 (7 March, 1956), 3; PzS, 112 (24 August, 1971), 4; Przyjaciolka, 44 (4 November, 1951), 14; and Przyjaciolka, 31 (2 August, 1953), 14.

46 For women's table tennis see $\underline{\mathrm{PzS}}, 30$ (17 April, 1950), 3; PzS, 40 (22 May, 1950), 3; PzS, 14 (18 February, 1955), 5; and AMR, notes. For women's chess see MiZP, 5/125 (10 February, 1950), 6; and Tempo, 16 (20 April, 1959), 7. 
Women's football, however, reported a different story. Polish women had begun to play football in the 1920s, but the game became more popular in the 1950s and 1960s. Toward the end of the 1970s, female footballers achieved maximum popularity, both in the press and in terms of fan enthusiasm. In the 1980s, more organizational progress in women's soccer allowed the game to expand in different parts of Poland, including Krakow, Gdansk, Lodz, and Katowice. Some women, such as Anna Szlaga, also refereed this game. 47 Women footballers, according to a press article written by Barbara Dworak, were neither frightened away by this sport nor thought of as ludicrous, nor even shouted at in gendered taunts such as "goalkeeper-are you tending the soup?" (bramkarz--zupa ci kipi). 48

Similar to women's football, women's field hockey experienced a renaissance in the 1970s. But the game did not enjoy the same popularity as soccer. 49 In Britain, on the other hand, hockey remained a popular female sport. 50 Meanwhile, women's modern pentathlon and yoga received a warmer welcome in Poland. 51 The sports of judo and karate especially registered an increase in women's participation in the 1980s. But the overall numbers still remained low. 52 Karate also became popular among Soviet women in the 1980s. For example, an unusual club called "Espada" in Alma-Ata, organized by former Afghan war veterans, taught karate and other defensive techniques to both men and women for the larger purpose of controlling crime. ${ }^{53}$

Polish women still participated in horseriding; however, the number of press reports on this sport were few. Unlike the earlier time periods, horseriding appeared to have lost its appeal as an important sport for the Poles to "defend" the country. Even in other cultures, horseriding attracted a minority of women. In Britain, it took a High Court case before the Jockey Club would grant training licenses to women in 1966.54

While the Polish press encouraged women's participation in many games, it also discussed the non-suitability of certain sports for women. Traditional stereotypes limited

47 KiZ, 34 (22 August, 1976), 6; AMR, notes; Malgorzata Guttmejer, Poczatki w Polsce rozwoju pilki noznej kobiet w Polsce (Praca Magisterska, AWF Warsaw, 1984), 67, 104; and Cezary Rocki, Rozwoj pilki noznej kobiet $w$ Polsce w latach 1981-1991 (Praca Dyplomowa, Studium Nauczycielskie Nr.6 w Warszawie, Warsaw 1992), 7, 9.

48 KiZ, 11 (16 June, 1982), 15.

49 AMR, notes.

50 Holt and Mason, Sport in Britain, 61.

51 KiZ, 2 (12 January, 1969), 14; $\underline{\text { PzS, }} 153$ (8 August, 1985), 1; and PzS, 158 (15 August, 1985), 1.

52 KiZ, 10 (11 March, 1979), 18, 19; PzS, 83 (29 April, 1981), 4; PzS, 72 (10 April, 1984), 5; AMR, notes; PzS, 9 (14 January, 1987), 4; PzS, 248-249 ( 21-24 December, 1989), 4; Przyjaciolka, 12 (24 June, 1982), 11; and Przyjaciolka, 10 (10 March, 1988), 6, 7.

53 Rabotnitsa, 8 (1988), 21.

54 Holt and Mason, Sport in Britain, 85. 
women's competitive professionalism in boxing, wrestling, and weightlifting. 55 Both men and women expressed an early animosity to women's participation in the sport of boxing. 56 Others questioned the necessity of women's wrestling. 57 Also, the new 'sport' of 'kulturystyka' or bodybuilding for women invited negative criticisms throughout the latter half of the 1980s. 58 Even in China, there were concerns about women's bodybuilding, and the prospect of female athletes in this sport wearing bikinis raised an alarm in society. However, female bodybuilding remained an expression of the peasant and working class Chinese ethos. 59

Similarly, Soviet women, while they participated in 'specialized' sporting activities such as horse-riding, motorcycle racing, and applied firefighting, their interest in certain other sports similarly aroused social anguish. 60 Sports such as wrestling, boxing, marathon, football, hockey, and rugby were traditionally looked upon as being masculine and gender-specific in Soviet culture. 61 In 1973 the USSR Sports Committee issued a resolution discouraging women from participating in sports which were allegedly harmful to the female organism and encouraged male voyeurism. But despite these pronouncements, Soviet women continued to participate in soccer, body building, boxing, wrestling, ice hockey, judo, weightlifting, water polo and long distance running. 62 Thus, Soviet sportswomen could and did challenge the authority of their male leaders. From this perspective, Soviet female athletes were "sports-feminists".

Thus, Polish sportswomen, similar to their Soviet counterparts, participated in a wide variety of sports. They especially excelled in track and field competitions, rowing, gymnastics, and volleyball. However, the Polish female athletes, unlike the Soviet

55 See MiZP, 21 (March, 1947), 14; Stanislaw Jedruch, "Prawne zagadnienia sportu kobiecego," in Sport Wyczynowy, 6-7 (162-163), 1978, Glowny Komitet Kultury Fizycznej i Sportu, 119-123; Stanislaw Strzyzewski, "Stosunek mlodziezy szkolnej do wspolzawodnictwa sportowego," in Kultura Fizyczna, 9 (1977), 389-392; Gondek, Kultura fizyczna w Polsce, 146; Kawecka, "Uczestnictwo kobiet w kulturze fizycznej (stan faktyczny a oczekiwania)," 496.

56 PzS, 2, 16 (15 April, 1946), 3.

${ }^{57}$ PzS, 10 (13 January, 1989), 1.

$58 \underline{\mathrm{PzS}}, 84$ (30 April, 1986), 4; $\underline{\mathrm{PzS}}, 102$ (27 May, 1987), 1, 4; KiZ, 24 (11June, 1986), 12, 13; and PzS, 144 (26 July, 1988), 1, 2.

59 Brownell, Training the Body For China, 274-276, 287.

60 Rabotnitsa, 8 (1978), 18, 19. Applied firefighting for men and women alike was 'specialized' sport in the USSR, going back to the 1930s. Domestic and international competitions, however, were held regularly only after 1970. Soviet sportswomen participated in the seventh international competition for young firemen of the socialist countries in Romania. See Soviet Woman, 6 (1989), 39.

61 Rabotnitsa, 11 (1968), 32.

62 Jim Riordan, "The Rise, Fall and Rebirth of Sporting Women in Russia and the USSR," in Journal of Sport History, 18, 1 (Spring, 1991), 183-199; and Riordan, "Playing to New Rules," 170, 171. 
sportswomen, were more careful about engaging in those sports which aroused public dismay. They were far more obedient to the societal advisories on "harmful" sports, and accordingly, concentrated their athleticism on the sports which were perceived as "suitable" for women. Because of their high performance levels in these "suitable" sports, Polish sportswomen won the respect and gratitude of their state and society. This was evident in the nature of the press coverage and the honors bestowed on Polish female sports champions.

\section{The Female Sports Champions Press Coverage, Public Recognition and National Awards}

Women's participation in individual and team sports in the PRL received extensive coverage in the contemporary press reports. Polish women participated in many sports, and achieved national and international victories in several games. They consistently won sports medals, records, championship titles, and national honors. The sports and women's press judiciously reported women's records in all sporting events and provided coverage of their successes and failures in the Olympic Games, and in other international and domestic championships. Men's sport did receive greater coverage in the press, but this was primarily because comparatively fewer women participated in sport. Also, the Polish press reports rarely mocked female athletes; on the contrary, the newspapers and periodicals praised the Polish woman athlete. The gender-neutral press vocabulary did not force Polish women, unlike their western counterparts, to constantly subject their athletic endeavors to the strict identity regimen of sexual vigilance. 63

\footnotetext{
${ }^{63}$ For a general description of the participation of women in the various sports, and their accomplishments and records, see Przyjaciolka, 42 (21 October, 1956), 14; Przyjaciolka, 15 (9 April, 1950), 10; PzS, 117 (27 September, 1969), 3; MiZP, 3, 36 (August, 1947), 7; MiZP, 3, 18 (June, 1948), 11; KiZ, 34 (20 August, 1978), 6, 7; KiZ, 22 (1 September, 1958), 8, 9; KiZ, 36 (6 September, 1964), 14; KiZ, 29 (16 July, 1978), 6, 7; PzS, 66 (18 August, 1947), 3; PzS, 103 (29 December, 1949), 4, 5; PzS, 20 (9 March, 1950), 3; PzS, 19 (6 March, 1950), 1; PzS, 42 (30 May, 1950), 4; PzS, 102 (28 December, 1950), 4, 5; PzS, 28 (7 March, 1970), 1; Przyjaciolka, 14 (6 April, 1952), 14; PzS, 70 (4 September, 1950), 1; PzS, 90 (21 October, 1948), 2; PzS, 98/99 (21 May, 1981), 6; PzS, 153 (8 August, 1988), 1; Przyjaciolka, 38 (17 September, 1950), 10; PzS, 106 (14 August, 1971), 1; Przyjaciolka, 6 (6 February, 1972), 8, 9; PzS, 47 (7 March, 1986), 1; Krzysztof Madry and Janusz Brzozowski, "Najwazniejsze osiagniecia sportowe polskich judokow w 40leciu PRL," in Wychowanie fizyczne i sport w 40-leciu PRL, 73-82, p.77; Biuletym Informacyjny Glownego Komitetu Kultury Fizycznej i Turystyki, (Warsaw, 1975), 11; Zdzislawa Czyzowska, "Kobieta w Polsce w latach 1975-1985," in Kobieta w Polsce: Referaty na swiatowa konferencje dekady kobiet, 11-35, 33, 35; Jerzy Lapinski, Kultura fizyczna w Polsce w roku 1949 (Warsaw, 1950), 45; Adolf Treywasz, Nasz sport na dziesieciolecie polskiej rzeczypospolitej ludowe (Warsaw, 1954), 23; Brzezicki, Drazdzewski, Podoski and Romanski (eds.), Ksiega sportu polskiego 1944-1974 (this book has many photographs of urban and rural women participating in marches, gymnastics, and spartakiads); Tadeusz Klepacki, "Ruch spartakiadowy 1960-1964 r. jaka forma upowszechniania kultury fizycznej w kraju," in Brzezicki and Miller (eds.), Kartki z historii kultury fizycznej i turystyki, 225-240; Zdzislawa Wyznikiewicz, Aktywnosc
} 
The press reception of Polish female athletes was quite similar to how the Soviet media received its own sportswomen. The Soviet mass media gave excellent coverage, at all times, to all its female sports champions. It is to be noted that Polish and Soviet women were officially encouraged to participate in both team and individual competitions, much unlike in the west where team events were looked upon with marked disfavor. Moreover, official intersex competition was not widespread in Soviet sports, but where it existed there were no hidden bars. For example, when Yelena Novikova, the 1968 Olympic fencing champion, chose to enter a men's tournament in the Soviet Union in 1970, she did so without controversy. 64 It was also unheard-of in the Soviet Union to omit detailed listing of female event results when listing male, or to put the latter in bold type and the former in ordinary, as often happened in American reportage. 65

Both the Polish and Soviet sportswomen seem to have been accepted as performers in their own right within their sports movement, among the population as a whole and certainly among the sportswriters more specifically. The sporting woman was identified as a positive heroine of society, and she received a great deal of official encouragement to become more "athletic". Indeed, press reports in both countries by no means referred to their female athletes as 'athletic amusements', 'pretty players', members of the 'weaker sex', or even the 'fair sex'. Moreover, both the Polish and Soviet sportswomen gained a great deal of respect and national gratitude through repeated successes for their countries in domestic and international sports events, and this helped to enhance their social standing in society as well.

The leading Polish sports newspaper Przeglad Sportowy organized annual popular plebiscites to select the ten best sports-persons of the year. It is significant that with the exception of two years, Polish female athletes were always nominated in various categories, including that of the first place. It is to be noted that other Polish newspapers and women's periodicals such as Przyjaciolka and Dziennik Ludowy also organized their

sportowa kobiet: Aspekty biologiczne (Warsaw, 1978), 100; Chmielewski, Polish Sport, 59, 61, 63, 67, 69, 73, 75, 77, 79, 81, 83, 83, 89; Zbigniew Krawczyk and Tamasne Foldesi, "Physical Culture in Social Consciousness," in International Review for Sociology of Sport, 20/4 (1985), 321-327, p.324; Gaj, Wychowanie fizyczne, 100; Gondek, Kultura fizyczna w Polsce, 77, 78, 82, 85, 92, 93, 95, 97, 146; Erdmann, "Trends," 205-219, pp. 217, 219; Kawecka, "Uczestnictwo kobiet w kulturze fizycznej," 495; and Rotkiewicz, "Poczatki szermierki," 73. Also, Barbara Kotowska twice received the award "Nauka i Sport Ojczyznie" for her outstanding sporting and academic performance. See Przyjaciolka, 10 (10 March, 1988), 6, 7. For a picture of Irena Szewinska receiving an award from the Minister of Foreign Affairs see

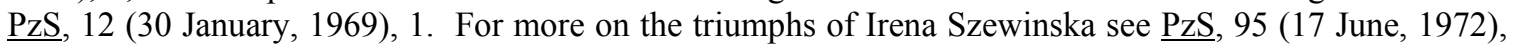
1, 4; PzS, 137 (27 August, 1972), 3; PzS, 150 (9 September, 1972), 6; PzS, 158 (21 September, 1972), 1; and $\underline{\text { PzS }}, 159$ (23 September, 1972), 1.

64 William Mandel, Soviet Women (Garden City, New York, 1975), 156, 157.

65 Mandel, Soviet Women, 158. See also Riordan, Sport in Soviet Society, 320, 322. 
own plebiscites, awarding similar recognition to Polish women sports champions. 66 The following results of the annual plebiscites of Przeglad Sportowy would probably suggest that in popular opinion, female athletes' sports laurels equaled those of men.

66 For some of these plebiscites see Przyjaciolka, 30 (25 July, 1985), 10; and PzS, 19 (28 January, 1985), 4. 
Results of the Annual Plebiscites of Przeglad Sportowy: 67

\begin{tabular}{|c|c|c|c|}
\hline Year & Name & Event & Position \\
\hline 1948 & Jadwiga Wajsowna & Track and Field & 3 \\
\hline 1949 & ------------------------- & ------------- & -- \\
\hline \multirow[t]{3}{*}{1950} & Helena Rakoczy & Gymnastics & 1 \\
\hline & Irena Kempkowna & Gliding & 4 \\
\hline & Magdalena Bregulanka & Track and Field & 6 \\
\hline 1951 & Helena Rakoczy & Gymnastics & 7 \\
\hline \multirow[t]{2}{*}{1952} & Miroslawa Zakrzewska & Volleyball & 4 \\
\hline & Maria Ciachowna & Track and Field & 7 \\
\hline 1953 & $\underline{\text { No Plebiscite }}$ & & \\
\hline \multirow[t]{2}{*}{1954} & Helena Rakoczy & Gymnastics & 5 \\
\hline & Elzbieta Dunska-Krzesinska & a Track and Field & 7 \\
\hline \multirow[t]{2}{*}{1955} & Katarzyna Wisniowska & Archery & 5 \\
\hline & Wanda Szemplinska & Gliding & 10 \\
\hline 1956 & Elzbieta Krzesinska & Track and Field & 1 \\
\hline 1957 & Elzbieta Krzesinska & Track and Field & 8 \\
\hline 1958 & Barbara Janiszewska & Track and Field & 9 \\
\hline 1959 & Natalia Kotowna & Gymnastics & 9 \\
\hline
\end{tabular}

\footnotetext{
67 For this list see $\underline{\mathrm{PzS}}, 14$ (4 February, 1971), 1; $\underline{\mathrm{PzS}}, 204$ (18 October, 1985), 4, 5; $\underline{\mathrm{PzS}}, 6$ (9 January, 1989), 1; $\underline{\mathrm{PzS}}, 7$ (12 January, 1987), 1; $\underline{\mathrm{PzS}}, 6$ (11 January, 1988), 1; $\underline{\mathrm{PzS}}, 3$ (6 January, 1986), 1; and Przyjaciolka, 10 (10 March, 1988), 6, 7.
} 
Teresa Ciepla

Elwira Seroczynska

Track and Field

Skating

Maria Piatkowska

Track and Field

Irena Kirszenstein

Teresa Ciepla

Ewa Klobukowska

1965

Irena Kirszestein

Ewa Klobukowska

1966

Irena Kirszenstein

Ewa Klobukowska

Eulalia Zakrzewska

1967

1968

1969

1970

1971

$$
\begin{aligned}
& \text { Irena Szewinska } \\
& \text { Daniela Jaworska } \\
& \text { Maria Maczynska }
\end{aligned}
$$

Irena Szewinska

Miroslawa Sarna

Teresa Sukniewicz

Barbara Piecha

Daniela Jaworska

Eulalia Rolinska
Track and Field

2

Track and Field 7

Track and Field 8

Track and Field 1

Track and Field 2

Track and Field 1

Track and Field 2

Shooting

8

Track and Field 5

Track and Field 6

Archery 7

Track and Field 2

Track and Field 3

Track and Field 1

Toboggan--sledding 4

Track and Field 7

Shooting 10 
Irena Szewinska

Track and Field 2

Jadwiga Wilejto

Archery

Alicja Ciskowska

Halina Iwaniec

Archery

Basketball

Malgorzata Tlalka

Lucyna Kalek

Dorota Tlalka

1985

$\begin{array}{lll}\text { Barbara Kotowska } & \text { Modern Pentathlon } & 3 \\ \text { Agnieszka Brustman } & & 8 \\ \text { Boguslawa Olechnowicz } & \text { Judo } & 9\end{array}$


Barbara Kotowska

Boguslawa Olechnowicz

Izabel Dylewska

1988

Dorota Idzi

Izabela Dylewska

1989
Izabela Dylewska

Dorota Idzi
Modern Pentathlon 5

Judo 8

Kayaking 9

Modern Pentathlon 7

Kayaking 10

Kayaking 4

Modern Pentathlon 8 
The accomplishments of Polish and Soviet sportswomen were also recognized by artists in their paintings, posters, tapestry and sculpture. Women's sport was a popular theme among Polish artists, and they displayed images especially of female swimmers in their paintings and posters. This iconography, quite significant in the construction and representation of historical consciousness, visually and graphically showed the use of sport as an instrument and a factor in the preservation of health, as an agent of democratization, and as an important international arena of friendly competition among the peoples of the world. 68

It should also be emphasized that many sportswomen of the Eastern bloc, including Polish female athletes, served as "models" for others to emulate. For example, in the 1960s and 1970s there was considerable traffic in Cuban male and female athletes traveling to Eastern Europe for training. East Europeans also journeyed to Cuba as coaches and technical advisors. 69 Many Soviet sportswomen especially served as sources of inspiration to other sport-oriented women, both at home and abroad. 70 For example, Olga Korbut, the champion Soviet gymnast, helped publicize women's gymnastics at the Munich Games (1972) and was the media favorite of the Montreal Games (1976). ${ }^{71}$ The East European emphasis on female sports helped other women to become more athletic by not only urging their countries to sponsor women's games, but also by direct demands on the International Olympic Committee for inclusion of more women's sports in the program. 72

It may be surmised, therefore, that East European sportswomen were not merely "patriots," but seemingly, "super-patriots." East European female athletes played a critical role in using the medium of sport to create and sustain international politics. Thus,

\footnotetext{
68 Maria Morawinska-Brzezicka, Sport w sztuce polskiej, 1945-1975 (Warsaw, 1976), 6, 9, 28. For Soviet sportswomen as subjects of art, painting, movies, and fashion see Soviet Woman, 8 (1962), 28, 29; $\underline{\text { Soviet }}$ Woman, 8 (1967), 21; Soviet Woman, 1 (1969), 31; Soviet Woman, 7 (1970), 39; Soviet Woman, 2 (1968), 20, 21; and Soviet Woman, 10 (1980), 26, 27.

69 John Sugden, Alan Tomlinson, and Eamon McCartan,"The Making and Remaking of White Lighting in Cuba," in Michael A. Malec, The Social Roles of Sport in Caribbean Societies (Australia and United States, 1995), 211-228. The Federation of Cuban Women wanted women to engage sports and asked for an end to bias against gym clothes for women. Fidel Castro himself was a great believer in sports. For details see Lois M. Smith and Alfred Padula, Sex and Revolution: Women in Socialist Cuba (New York, 1996), 52, 53.

70 See for examples Soviet Woman, 1 (1946), 32; Soviet Woman, 7 (1984), 23, 24, 25; and Soviet Woman, 8 (1984), 38, 39.

71 Senn, Power, Politics, and the Olympic Games, 159. See also Riordan, Sport, 323, 324.

72 For the Soviet influence on international women's sports see Jim Riordan, "Women in Sport, Some English Observations on Russian Women Who Have Been Trained to Smile," in Bulletin of Physical Education, 16, 3 (Autumn, 1980), 17-24; and Mandel, Soviet Women, 156, 157.
} 
the international political system was not gender-neutral, but thoroughly gendered.73 This appears to have been quite true for the ambassadorial 'world traveler' roles of East Europeans, including the Polish sportswomen.

Unfortunately, the participation of East European women in sports during the period of the Cold War resulted in the proliferation of various types of images and stereotypes in the Western countries. British tabloids, for example, talked about the "ambiguous biceps" of East European female athletes during the Cold War era.74 Nationalistic fervor and East-West rivalry muddied the issues, as did the pervasive assumption that femininity and heterosexuality were incompatible with athletic excellence. 75 Thereafter, western observers frequently questioned the character of East European women champions, including the Polish female athletes. East European sportswomen's physical, psychological and sexual identities were increasingly subject to public scrutiny by sex testing and tests for steroid usage. 76 East German female swimmers were among the first to be suspected of steroid use at the 1976 Olympics. The East German officials now admit that systematic doping of athletes, with or without their knowledge, was partly responsible for their country's sports successes in the 1970s and 1980s. 77

In this 'question of the sex', the case of naturalized American citizen from Poland Stella Walasiewicz is often cited. There had been frequent insinuations and persistent rumors that Stella Walsh (her American name) was actually a man masquerading as a woman. One Polish journalist had accused Walsh of being a man, and in response, the German Olympic officials in 1936 had issued a statement asserting that they had given Walsh a thorough physical examination and determined that the Polish star was indeed a woman. However, an autopsy report in 1980, when the star was shot to death, revealed that Walsh had the 'gross anatomy of a male'. Meanwhile, another Polish athlete, Ewa Klobukowska, was the first of about a dozen athletes to be banned from competition after the chromosome test was employed at the European Track and Field Championships in

\footnotetext{
73 See Cynthia Enloe, "Bananas, Beaches, Bases," in Linda S. Kauffman (ed.), American Feminist Thought at Century's End: A Reader (Cambridge, Mass., 1993). According to Cynthia Enloe women have generally been portrayed as victims of the international political system. But the reality is quite different. For example, many women took on the roles of colonial administrators' wives, missionaries, travel writers, and anthropologists, facilitating the process of imperialism in Africa, Asia and Latin America. Moving beyond this, it would appear that sports also enabled women to take a more active role in international politics.

74 Holt and Mason, Sport in Britain, 13.

75 Lenskyj, Out of Bounds, 86, 91.

76 For details see Senn, Power, Politics, and the Olympic Games, 143; Daddario, Women's Sport and Spectacle, 50, 51, 480; and Lenskyj, Out of Bounds, 93.

77 See Kathleen McElroy, "Somewhere to Run," in Smith (ed.), Nike is a Goddess, 3-29, 23.
} 
1967. A year earlier, she had passed the "nude parade" at the same championship. The two famous Russian athletes, Tamara and Irina Press, failed to appear.78

Thus, similar to the interwar period, Polish female athletes received national recognition and awards for their athletic accomplishments. In public opinion, they were "sports heroines", worthy of the nation's respect and gratitude. Such glorious accolades, however, were confined to the Polish sportswomen at home alone. In the international sporting arena, Polish women's physicality was questioned by their Cold War western rivals. Similar to other east European sportswomen, Polish female athletes found their physical culture subject to strict global investigation. But despite the western injunctions, Polish sportswomen were satisfied with having raised their nation's international pride and prestige. They were rewarded for their achievements at home, and provided with wide-ranging professional opportunities which they could pursue in their post-athletic careers.

\section{Polish Female Athletes and Sports-Related Professional Activities Post-Career Options}

A large number of Polish sportswomen not only participated in a variety of sports but also pursued a host of other professional activities during their active engagement in physical culture and in their post-sports careers. For example, female athletes served as sports and social activists, pedagogues, sports trainers and instructors, journalists, nurses and other health advocates. A few women assumed more prestigious positions of responsibility. For example, Barbara Laniewska worked as a trainer of figure skating in the GKKF. From 1965-69, she served as the director of the Polish School of Figure Skating. After 1969, she became the Secretary-General of Polish Union of Fast Skating. Another female athlete, Janina Maria Mieczynska-Lewakowska, authored many articles. She also kept up her interest in theater and music in Lodz. Waclawa PostawiankaWilczynska, an athlete and sports-referee, served as secretary of the district administration of swimming in Bydogszcz from 1975-77. Between 1977-1981, she was vice president of the College of Referees for the Swimming Club “Astoria”. In 1981, she

78 Michael D. Davis, Black American Women in Olympic Track and Field: A Complete Illustrated Reference (Jefferson, N.C., 1992). Refer to Appendix: Sex, Chromosomes, and Gold Medals, pp.157-161. 
received a medal for her service in developing physical culture through the Department of Physical Culture and Tourism in Bydgoszcz province. 79

Soviet women have also appeared in the role of sports coaches, journalists, authors, doctors, architects and commentators. 80 Significantly, Soviet women also assumed positions of responsibility in the sports apparatus. Whereas up to the Second World War men headed all Soviet women's commissions of the international sports federations, women soon thereafter occupied leading positions in such organizations. In 1952, Zoya Romanova was elected chair of the women's commission of the International Amateur Athletics Federation (IAAF). ${ }^{81}$ Elena Voitsekhovskaya, Olympic diving champion, was elected as Deputy of the Moscow City Soviet. 82 Women also served as council chairpersons of factory physical culture organizations, managers of stadiums, and board members of sports clubs and regional and territorial organizations. 83

Unfortunately, unlike Soviet sportswomen, Polish female athletes had fewer opportunities to assume positions of top leadership in sports. While they could participate in a variety of sports-related professions, their avenues and spaces to serve in leading administrative posts was limited. The domination of men in the sports and physical education apparatus was an important factor which contained, and eventually regressed the development of women's physical culture. ${ }^{84}$ The institutional sports structure remained very masculine, and Irena Szewinska was the only woman among the 87 members of GKKFiT. 85 According to the Warsaw City Committee of Physical Culture and Tourism (St.KKFiT), the appointment of women's commissions in special sports

\footnotetext{
79 This data has been obtained from AMR, notes. For more detailed biographical descriptions of women athletes, see Pawlak, Polskie olimpijki z lat 1924-1994. This book contains biographical data (place of birth, place of sports-related activities, competitions, hobbies, educational level of athletes and other details) on 363 Polish women Olympians. For additional comments on some individual athletes see also PzS, 6 (19 January, 1950), 6 for Halina Czajkowska, an active members of ZMP; Sport, Katowice (7 September, 1957) for Halina Bartkowiak, a diver; "Slownik," in Wychowania Fizyczne i Sport, (1982), 100, for Janina Maria Mieczynska-Lewakowska; and Sportowiec, 3 (15 January, 1974), 18, for Teresa Remiszewska, the first Polish and fourth female sailor in the world to independently cross the Atlantic in 1972.

80 For examples of Soviet sportswomen in these occupations see Riordan, "Women in Sport," 17-24; Soviet Woman, 3 (1951), 57, 58; Soviet Woman, 7 (1951), 63, 64; Rabotnitsa, 5 (1952), 26, 27; Rabotnitsa, 6 (1955), 30; Soviet Woman, 6 (1964), 33; Soviet Woman, 8 (1972), 14, 15; Soviet Woman, 4 (1960), 45; Soviet Woman, 4 (1963), 18, 19; Soviet Woman, 10 (1979), 30, 31; and Soviet Woman, (1990).

81 Soviet Woman, 3 (1968), 39.

82 Soviet Woman, 5 (1980), 1.

83 Soviet Woman, 10 (1971), 37; and Soviet Woman, 10 (1971), 37.

84 See Glowny Komitet Kultury Fizycznej i Turystyki: Aktualne zadania kultury fizycznej oraz kierunkowe wytyczne rozwoju sportu na lata 1966-1970, 8; Jaworski, Dzialacze i pracownicy kultury fizycznej w Polsce, 30; and Eleonora Bilinska-Pilawska, "Z problematyki sportu kobiecego," in Kultura Fizyczna, 10 (1978), 465-467, 465.

$85 \underline{\mathrm{PzS}}, 122$ (25 June, 1986), 3.
} 
organizations was essential to increase women's participation in political organizations, sports societies and clubs, and in the TKKF. 86 But this task was difficult because the formation of women's commissions required not only more state initiative but also a stronger collective action by women themselves to effect a radical transformation in the prevalent gender patterns of governance in the Polish physical culture. The development of this feminist solidarity, however, was hampered by the pre-existing class issues in women's physical culture in the PRL.

\section{Polish Sportswomen: "Intelligent" and "Urban" Class Issues in Women's Physical Culture}

In the PRL, female sports champions came from different parts of the country. ${ }^{87}$ Warsaw, in particular, experienced an explosion in the organization and range of sporting activities at all levels. 88 However, while Polish sportswomen came from different Polish cities, their social and class backgrounds were more similar. In comparison to the earlier time periods, women's sports were certainly more "democratic" in the PRL. Polish female athletes belonged to families of the intelligentsia, workers, peasants, and the armed forces. However, a good number of female athletes were intellectuals and workers. ${ }^{89}$ The urban-based athletes had maximum access to benefits in the form of housing, educational opportunity, holidays and leisure time.90 In addition, most women champions received secondary education, and some graduated from the AWFs. 91 Thus, Polish sportswomen appeared to be reasonably well-educated and urban-based.

\footnotetext{
86 Nowosielski, Problemy sportu, 25, 26, 52.

87 For an insight into the regional distribution of women sports champions, see $\underline{\mathrm{PzS}}, 20$ (10 March, 1952), 1; $\underline{\text { PzS }, ~} 5$ (13 January, 1947), 6; PzS, 40 (20 May, 1949), 2; PzS, 19 (8 March, 1951), 2; PzS, 109 (11 July, 1972), 1; Pawlak, Polskie olimpijki z lat 1924-1994; Biuletyn Informacyjny: Glowny Komitet Kultury Fizycznej, Warsaw, 2/53 (20 February, 1960), 5; Biuletyn Informacyjny: Glowny Komitet Kultury Fizycznej, Warsaw, 45 (31 August, 1959), 9; Szafkowski, Zespolowe gry sportowe na Pomorzu Szczecinskim, 10, 13, 25; Skawinski, Kultura fizyczna na Lubelszczyznie, 147, 160, 161; Wieslaw Andrzej Ponimasz, Odradzanie sie sportu w Lodzi w latach 1945-1946 (Praca Magisterska, AWF Warsaw, 1978), 25, 168; Maria Kwilecka, "Typ budowy ciala kobiet obslugujacych rozne maszyny wlokiennicze," 218; and Marek Zurn, "Sport i rekreacja fizyczna w czasie wolnym mieszkancow miast," in Krawczyk, (ed.), Sport $w$ spoleczenstwie wspolczesnym, 333-354, pp. 352, 353, 368. See also PzS, 32 (23 April, 1951), 6. Also, the Biuletym Informacyjny Glownego Komitetu Kultury Fizycznej i Turystyki (Warsaw) contains a wealth of information on the regional organization of sports.

88 Tkaczyk, "Wybrane," 470-474.

89 Pawlak, Polskie olimpijki z lat 1924-1994.

90 George Kolankiewicz, "The Polish Industrial Manual Working Class," in Lane and Kolankiewicz (eds.), Social Groups in Polish Society, 88-151, p.127.

91 Anna Pawlak, "Polskie olimpijki: sport, zawod i zycie rodzinne," in Zukowska (ed.), Sport w zyciu kobiety, 26-35.
} 
The Polish state did make an effort to promote sports among rural women as well. The Polish media applauded the LZS for its critical role in organizing sports and tourism in the countryside. On 21 March 1953, Marshall Konstantine Rokossowski reaffirmed the importance of building sports in rural areas, especially for young boys and girls. Thereafter, the accomplishments of rural women in sport legitimized the official interest in promoting the 'health and strength' of all women. By the end of the 1960s, over 250,000 women were members of the LZS. The LZS reported higher percentages of female membership especially in Kielce and Bydgoszcz provinces. Together with the Rural Housewives Circles and ZMW, the LZS organized rural Olympiads and other sports tournaments for peasant men and women. In other sports extravaganzas organized by the ZSCh, it was remarked that food was often served without vodka! All these sports festivals not only gave credence to the state's emphasis on 'sport for all' but supposedly symbolized a 'cultural revolution' in the Polish countryside. Popular women's sports sections in the LZS included volleyball, track and field, chess, handball, table tennis, and gymnastics. Meanwhile, the central authorities also appealed to editors of all periodicals and newspapers to provide more coverage of women and sport in the countryside. 92

From a comparative perspective, the Chinese male and female athletes, unlike their Polish counterparts, were poorly educated. The majority of Chinese sportswomen came from working-class or peasant families. The low status of female peasants makes them superior prospects for sports training because they are accustomed to physical hardship and are highly motivated to take advantage of sports opportunities in the face of limited options. It is interesting that top Chinese female athletes aspire to marry not their male colleagues, but men with advanced degrees from distinguished universities. 93

In the Soviet Union, the regime made conscious efforts to recruit sportswomen from both urban and rural backgrounds. In the cities, the trade unions played an

\footnotetext{
92 For the participation of rural women in sport see PzS, 56 (17 July, 1950), 3; PzS, 145 (1 December, 1969), 2; PzS, 153/154 (22 December, 1969), 6; Przyjaciolka, 34 (20 August, 1950), 10; Przyjaciolka, 31 (1 August, 1954), 11; Przyjaciolka, 43 (23 October, 1955), 2; Kobieta Wiejska, 3, 14 (7 November, 1949), 11; Kobieta Wiejska, 3, 9 (15 August, 1949), 13; Kobieta Wiejska, 3, 13 (15 October, 1949), 13; MiZP, 28/148 (1 October, 1950), cover page, 7; MiZP, 28/220 (1 October, 1952), 13; PzS, 9 (30 January, 1950), 3; PzS, 12 (9 February, 1950), 6; PzS, 20 (9 March, 1950), 6; PzS, 19 (8 March, 1951), 1; PzS, 9 (1 February, 1954), 1; PzS, 189 (30 November, 1961), 3; Chelmecki and Wilk, Wybor zrodel i materialow do dziejow kultury fizycznej, 90; Wanda Lysomirska-Lobozewicz, "Udzial Kobiet w upowszechnianiu kultury fizycznej na wsi," in Kultura Fizyczna, 20 (April, 1967), 162-163; Glowny komitet kultury fizycznej i sportu departament upowszechniania kultury fizycznej (June, 1983), 20; Ocena stanu i glowne kierunki rozwoju kultury fizycznej i sportu, 14, 32; Brzezicki, Drazdzewski, Podoski and Romanski (eds.), Ksiega sportu polskiego, 71; Biuletyn Informacyjny: Glowny Komitet Kultury Fizycznej, Warsaw, 12-13/63-64 (20 December, 1960), 3-6; and Andrzej Wohl, "The Contribution of Women and Girls in Sport in Light of the Evolution of the Social Structure of the Polish Countryside," 105-114.

93 Brownell, Training the Body For China, 200, 228, 229, 231.
} 
instrumental role in promoting sports for working-class women at both the professional and amateur levels. 94 Meanwhile, the far more extensive engagement of rural women in physical culture, either in the form of regular physical culture breaks on the farms or their

participation in the more formal competitions such as the rural Spartakiads, can certainly be examined in the broader context of a "rural revolution". Sports helped to build bridges between the urban centers and the countryside, and encouraged farm women to develop their physical, personal and cognitive attributes. From this perspective, Soviet sports was 'action-oriented', at least in theory, and made substantial contributions toward feminist 'self-awareness' and 'self-authorization'.

Thus, unlike the organization of Chinese physical culture, both the Soviet and Polish sporting cultures encouraged women from both the urban and rural areas to become more athletic and engage in a variety of sports. However, the Soviets achieved greater success in their efforts to facilitate a "sporting revolution" for women in the cities and countryside. Peasant women in Poland were far more burdened with daily tasks to effect a transformation in their traditional patriarchal rural culture which would have created the space and time necessary to permit farm women to improve their athletic physicality by participating in sports. But then again, did this imply that urban sportswomen in Poland were models of "liberated womanhood"? How did Polish female athletes balance their professional and domestic responsibilities? An analysis of how women's physical culture contributed to family stability or resulted in "families in crisis" would necessitate a discussion on the lifestyles of sportswomen as mothers and wives.

\section{Polish Female Athletes as Mothers and Wives Models of "Liberated Womanhood" or "Mothers in Misery"?}

While the state and its organizational sports apparatus had a defined purpose for women in sport, the question of whether Polish women themselves understood their propagandized imagery and accepted the party verbiage of the importance of women's sports in steering the country onto the path of state socialism still needs to be examined.

\footnotetext{
94 For details on the role of trade unions in physical culture and the nature of sports among working class women in the Soviet Union see Soviet Woman, (1948), 42, 43; Soviet Woman, 5 (1946), 59; Soviet Woman, 11 (1969), 38, 39; Soviet Woman, 7 (1961), 18; Soviet Woman, 5 (1973), 38, 39; Rabotnitsa, 8 (1945), 18, 19; Rabotnitsa, 8 (1948), 12; Rabotnitsa, 7 (1959), 17; Soviet Woman, 12 (1956), 6, 8; Rabotnitsa, 7 (1958), 8, 9; Soviet Woman, 2 (1964), 16, 17; Soviet Woman, 2 (1966), 30, 31; Rabotnitsa, 10 (1968), 16, 17; Krest'ianka, 3 (1974), 30; Soviet Woman, 5 (1959), 30, 31; Soviet Woman, 8 (1972), 13; Soviet Woman, 8 (1972), 6; and Soviet Woman, 10 (1971), 37.
} 
Were the prominent official images and identities of women in postwar Poland real, or were they merely imagined by state socialism? Did Polish women conscientiously accept the regime's self-interested sponsorship of women's physical culture for constructing a socialist morality that was supposedly "rational"? Did sportswomen offer any resistance or express dissent to state-imposed policies? Or were they happy and satisfied professionals, citizens, and mothers? How did female athletes 'manage' their public and private lives? What factors encouraged or limited Polish women to 'play the game,' and what benefits and privileges accrued to them as individuals in their own right?

\section{Integrating Sportswomen's Professional and Domestic Duties: The Imagery}

Most Polish female sports champions were married, resided in big cities, and had children. 95 The official press projected images of Polish female athletes successfully managing their sports careers with family life. Many women, despite having children, competed in national and international championships. Indeed, there are many images of 'happy, friendly, and extremely energetic' urban and rural mothers and wives in the sports and women's press.96 For example, according to Polish fencing champion Barbara Wysoczanska, child care was very time absorbing. But with her family's support, she was able to combine sports with her family obligations. For her, sport was more than life. 97 For javelin champion Daniela Jaworska, sport was a 'narcotic' which would not allow her to resign, despite having children. 98 According to Jadwiga Wajsowna, "physical fitness is our strength and strength is important for us in planning for the future". Wajsowna identified herself as a very happy and energetic mother, and a friend to her son. 99

The press also displayed images of the internationally renowned track and field celebrity Irena Szewinska with her newborn son, and praised her determination to return back to training after the birth of her child (and also after taking exams in economics at Warsaw University). Szewinska, referred to as a phenomenal star, the queen of queens, superathlete, and the first lady of world sprints, trained with her husband and coach

\footnotetext{
95 Pawlak, "Polskie olimpijki: sport, zawod i zycie rodzinne," 26-35.

96 For some general happy images of sportswomen see PzS, 200 (13 October, 1989), 3; Przyjaciolka, 37 (15 September, 1988), 6; PzS, 179-182 (22-27 December, 1971), 14; and Przyjaciolka, 49 (9 December, 1956), 5.

97 KiZ, 39 (24 September, 1978), 15; and PzS, 32 (15 February, 1983), 1.

98 KiZ, 21 (21 May, 1978), 14, 15.

$99 \underline{\mathrm{PzS}}, 109$ (30 December, 1951), 3.
} 
Janusz Szewinski. 100 Eventually, Szewinska would retire from an active sports career to work in the Polish Olympic Committee and the Polish Track and Field Association (PZLA). 101

For modern pentathlon champion Barbara Kotowska, her family always supported her supporting endeavors and insisted that she should not become "rusty". 102 Women rifleshooters Dorota Chytrowska-Mika and Ilona Glyda were both influenced by their fathers. 103 And a mother and daughter team (Hanna and Jolanta Brzezinska) represented Poland in international archery competitions. 104 Swimmer Agnieszka Czopkowna also acknowledged the assistance of her parents in her sporting career. ${ }^{105}$

However, skating Olympian Elwira Seroczynska did express some frustration with the amount of time devoted to training. Although sport provided immense satisfaction and a healthy life, her husband looked "sullen", and she felt like a "guest" in her own home. Many a time, she thought about ending her sports career to take care of her children. 106 According to another athlete Ewa Pruska, the only female jockey in Poland, her mother did not like this 'un-safe' and 'un-womanlike' profession. But she received the support of her husband who also loved horses. 107

Similarly, the Soviet press reported that its sportswomen adeptly accomplished their multifarious duties as ideal daughters, mothers and wives. The role of families in producing women sports champions is indicative of this theme. 108 Some female champions came from 'champion families'.109 Several Soviet female athletes, unlike their Chinese counterparts, married their male colleagues. ${ }^{110}$ Many outstanding Soviet 'mother-sportswomen' encouraged their children to engage in physical culture from the

\footnotetext{
100 Przyjaciolka, 36 (3 September, 1972), 8; KiZ, 42 (8 October, 1981), 10, 11; PzS, 28 (7 March, 1970), 1; PzS, 84 (13 July, 1970), 1; PzS, 85 (16 July, 1970), 1, 4; and PzS, 85 (10 July, 1971), 3.

101 Przyjaciolka, 35 (2 December, 1982), 11.

102 Przyjaciolka, 10 (10 March, 1988), 6, 7.

103 PzS, 130 (5 July, 1985), 3.

104 Przyjaciolka, 27 (8 July, 1973), 12.

105 PzS, 160 (17 August, 1988), 1.

106 Przyjaciolka, 13 (27 March, 1960), 12.

$107 \mathrm{PzS}, 76$ (17 April, 1981), 3.

108 For examples see Soviet Woman, 7 (1972), 16; Soviet Woman, 3 (1963), 30, 31; Soviet Woman, (1947); Soviet Woman, 8 (1972), 8; Soviet Woman, 7 (1983), 38, 39; and Soviet Woman, 5 (1979), 38.

109 For examples see Soviet Woman, 1 (1947), 60; Soviet Woman, 8 (1975), 38; Soviet Woman, 6 (1980), 19; and Soviet Woman, 8 (1960), 39.

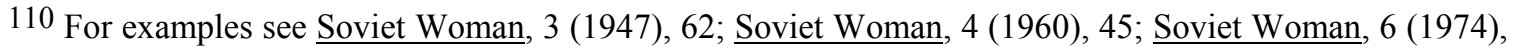
37; and Soviet Woman, 7 (1990), 27, 28.
} 
very beginning of the post-second world war period.111 Even at the "popular" recreational level, Soviet women helped to make their families more "athletic". According to the media, physical culture activities permitted the Soviet family to spend their leisure time together--to be together as much as possible. 112

Thus, both the Polish and Soviet sportswomen expressed their gratitude to their families for enabling them to achieve victories in high performance sports. At the more popular level, women from both countries contributed their labor to ensure that their families became more athletic and healthy. The media cast images of happy families and of sportswomen successfully accomplishing their duties as good mothers and wives. Both the Polish and Soviet states strongly emphasized the importance of physical culture as a source of maintaining family stability. In the socialist system, sports helped to bond and integrate all members of the family. However, did the regime's discourse on the benefits of physical culture strengthen intra-family solidarity? Or were women's sports undermined my patriarchal pressures within Polish families and the economic hardships of daily life?

\section{Ideological Discrimination and the Preservation of "Femininity": The Reality}

While images of 'happy families' in the urban centers of Poland were prolific in the state-controlled press, and discussions of developing a 'model' physical culture continued in the state apparatus, the literature also reported women's family obligations and the lack of time which undermined their mass participation in physical culture. In general, ordinary families allotted minimal time and money for sports recreation and tourist entertainment. Women's preoccupation with the home was very demanding and their domestic responsibilities functioned as a veritable barrier to their active engagement in sports. While the state made efforts to popularize a family-oriented physical culture,

111 See Rabotnitsa, 7 (1949), 1, 2; Rabotnitsa, 7 (1951), 9; Soviet Woman, 1 (1970), 38; and Soviet Woman, 2 (1981), 22, 23.

112 For these recreational physical culture activities, both conventional and unconventional, which contributed to family leisure see Soviet Woman, 6 (1980), 13; Soviet Woman, 3 (1982), 35, 36; Rabotnitsa, 2 (1955), 31; Rabotnitsa, 1 (1956), 16, 17; Rabotnitsa, 3 (1966), 32; Rabotnitsa, 11 (1966), 30, 31; Rabotnitsa, 3 (1974), 18; Rabotnitsa, 1 (1981), 3; Rabotnitsa, 1 (1982), 24, 25; Rabotnitsa, 2 (1983), 24, 25; Soviet Woman, 8 (1958), 17, 18; Soviet Woman, 8 (1962), 10, 11; Soviet Woman, 3 (1963), 28; Soviet Woman, 3 (1963), 30, 31; Soviet Woman, 8 (1964), 17, 20; Soviet Woman, 6 (1965), 18, 19; $\underline{\text { Soviet }}$ Woman, 11 (1966), 28; Soviet Woman, 12 (1968), 23; Soviet Woman, 8 (1972), 15; Krest'ianka, 1 (1962), 11; Krest'ianka, 3 (1962), 5; Soviet Woman, 7 (1951), 61; Soviet Woman, 12 (1987), 11; Rabotnitsa, 3 (1969), 32; Rabotnitsa, 2 (1984), 2; Soviet Woman, 1 (1985), 39; Soviet Woman, 4 (1968), 30, 31; Krest'ianka, 9 (1988), 12, 13; Soviet Woman, 6 (1987), 12, 13; Soviet Woman, 1 (1970), 38; and Morton, Pleasures and Palaces, 24, 28, 35, 41, 50, 58, 59. 
working women rarely had the opportunity to participate in sport and physical recreation. The situation was far worse for the unskilled female workers.

Moreover, when time permitted leisure, women generally preferred other sources of entertainment such as going to the theater, reading and watching television. Social meetings and gatherings over coffee and tea, and alcohol consumption took precedence over active sports. At all times, family life resembled a long-distance run, and the limited participation of women in physical culture on account of their duties as "good" wives and mothers raised questions of women's real emancipation and independence. The combined pressures of home management, conservative popular morality, and sheer lack of interest, not only restricted the active engagement of women in physical culture, but also rendered their sports program poorer and less attractive compared to that of men. 113

Meanwhile, various other cultural and psychological factors limited the participation of young women in sport. Many athletic-conscious girls, concerned with the idea of feminine physical attractiveness and the prevalent societal norms of 'masculinity' and 'femininity', consciously weakened the intensity of their training regimen to avoid the presumed deformation of their bodies. 114 It was also reported that some girls participated in sport because 'they like boys; although boys did not want girls in sport'. 115 Indeed, sport for such girls provided an opportunity and space for adolescent

113 For all these issues see PzS, 50 (27 April, 1956), 1; Przyjaciolka, 6 (6 February, 1986), 8; KiZ, 12 (19 March, 1978), 14; KiZ, 51 (17 December, 1978), 20; Wohl, "Spartakiady," 15-18; Zurn, "Sport i rekreacja fizyczna w czasie wolnym mieszkancow miast," 344, 345, 346, 349, 350, 351, 367; Kazimierz Obodynski and Elzbieta Ranwid, "Budzet czasu nauczycieli wychowania fizycznego w wybranych szkolach wyzszych," in Kultura Fizyczna, 32, 10 (October, 1978), 451-457; Zdzislawa Czyzowska, "Kobieta w Polsce w latach 1975-1985," in Kobieta w Polsce: Referaty na swiatowa konferencje dekady kobiet, 11-35, 33, 34; Teresa Wolanska, "Research in Family Sports and its Significance for Sports Policy," in The Tasks of Research and its Practical Application in Mass and Recreation Sports (Report Miscellany of the 10th International Seminar of CIEPSS "Sport and Leisure" Committee, Piestany, 26-30 September 1983, Prague, 1984), 67-73; Wolanska, "Wychowanie," 235; Kawecka, "Uczestnictwo kobiet w kulturze fizycznej," 495; Gawlak-Kica, Rozwoj kultury fizycznej w Wielkopolsce, 156, 157, 196-199; Gondek, Kultura fizyczna w Polsce, 144, 145; Ciupak, "Widownia," in Krawczyk, Sport w spoleczenstwie wspolczesnym, 317-331, pp. 326, 328; Lech A. Jaczynowski, "Tworzenie struktur organizacyjnych w stowarzyszeniach sportowych," in Kultura Fizyczna, 31, 8 (August 1977), 344-346, p.346; Halina Piotrowska, "Sports Skills and Participation of Older People in Life-Time Sports," in International Council of Sport Science and Physical Education Review, 9 (1986), 38-40; and Bogdan J. Kunicki, "Social Barriers in Physical Recreation," in International Review for Sociology of Sport, 20/3 (1985), 167-177. The 'family' contributed the least in enhancing social solidarity through physical culture. See Z. Zukowska, "Socializational Functions of Physical Education, Sport, and Tourism," in Ron Lidor, David Ben-Sira and Zvi Artzi (eds.), Physical Activity in the Lifecycle. Proceedings of the 1993 FIEP World Congress: March 28-April 3, Wingate Institute, Israel (Jerusalem, 1993), 158-162. At a meeting organized in Lodz under the conference theme "Rekreacja ruchowa Kobiet", the participants discussed the domestic duties of women and the role of husbands in families. See Krzysztof Zuchora, "Physical Recreation of Women as a Significant Social Problem," in Kultura Fizyczna, 3 (1976), 98-99.

114 KiZ, 19 (7 May, 1978), 14; KiZ, 12 (19 March, 1978), 14; and Krawczyka, "Rola spoleczna,” 366.

$115 \underline{\text { KiZ, }} 35$ (27 August, 1978), 10. 
flirtation. ${ }^{116}$ Many a times, women and girls would also participate in popular sports for displaying the newest 'practical and esthetic' fashions in sportswear. Polish girls appeared to be well-acquainted with the French and American womens' fashion in sport. More generally, however, many girls found active engagement in sports simply too "boring". 117

If the creation of happy and sportive families in the urban centers was difficult, the construction of a popular physical culture in the Polish countryside was much worse. For the peasantry, physical effort made sense when it served the interests of farm work, and not recreational pleasure. For this reason, sports such as weight-lifting and cycling experienced remarkable development in the countryside. But these were traditionally "male" sports. Rural women had few opportunities to develop their physical culture, both for themselves and for their families. 118

The LZS faced numerous impediments in its efforts to popularize sports among rural women. Some of the difficulties included the persistent clerical opposition, conservative patriarchal attitudes, shortages of sports halls, equipment and trainers, and a general lack of interest among women to become more 'sportive'. A high percentage of rural women were neither active nor passive enthusiasts of physical culture. For this reason, the participation of village girls in sport remained low. In fact, the participation of women always remained limited to $20-30 \%$ of the total membership of LZS. ${ }^{119}$ For example, the following table provides some indication of the numbers of women in comparison to men in the LZS organization in Bialystok province. 120

$\begin{array}{llcc}\text { 31.XII. } & \text { LZS } & \text { Members in total } & \text { Women } \\ 1975 & 458 & 11,419 & 1,875 \\ 1976 & 466 & 14,265 & 2,187 \\ 1977 & 506 & 16,428 & 3,787 \\ 1978 & 511 & 16,526 & 3,736 \\ 1979 & 517 & 17,219 & 3,987\end{array}$

$116 \underline{\mathrm{KiZ}}, 31$ (1 August, 1976), 3. See also $\underline{\mathrm{PzS}}, 173$ (3 September, 1984), 3.

117 MiZP, 8 (July, 1946), 3; MiZP, 19 (February- March, 1947), 12, 13; MiZP, 1, 22 (April, 1947), 6; MiZP, 1, 25 (May, 1947), 3; MiZP, 3, 39 (September, 1947),10; MiZP, 3/195 (20 January, 1952), 4, 5; KiZ, 22 (1 September, 1958), 8, 9; KiZ, 2 (8 January, 1961), 8, 9; KiZ, 34 (20 August, 1972), 8; and KiZ, 7 (15 February, 1976), 12, 13.

118 Kunicki, "Social Barriers," 172, 173.

119 Gaj, Wychowanie fizyczne, 151.

120 Marek Jozefowicz, Dzialalnosc ludowych zespolow sportowych $w$ dziedzinie upowszechniania wychowania fizycznego i sportu w wojewodztwie Bialostockim w latach 1975-1983 (Praca Magisterska, AWF Warsaw, 1989), 25. 
It is for these reasons that the LZS expressed dismay over the 'white plans' and unequal distribution of the GKKFiS funds in the countryside. The development of sport in the Polish countryside progressed at a much slower pace than in the urban areas. Despite the contributions of rural schools, LZS, local sports committees, youth organizations, and rural families themselves, a number of important factors hindered the effective organization of rural physical culture. The "organizational impotence" of many rural sport clubs was caused by an over-emphasis on the structure of values and aspirations belonging to an 'alien' urban culture, limited financial and infrastructural resources, and a general lack of concerted effort on the part of central and provincial administrations, professional unions and societies, and economic and other organizational cooperatives to promote sports among rural residents. This resulted in the lower numbers of athletes from rural areas in comparison to those from urban backgrounds. ${ }^{121}$

The Polish urban and rural women were, however, not alone in finding their opportunities to develop a powerful physical culture constrained by widespread ideological discrimination. Even in the Soviet Union, given the patriarchal construction of the state and society, an assumption that the smooth successes of Soviet female athletes in their sporting activities occurred without any domineering constraints or limitations is also questionable. Sure enough, there is no indication in the official sources to suggest the 'genderization' of the Soviet sports apparatus. Instead, Soviet sportswomen supposedly made substantial contributions to the feminist principles of self-determination and emancipation. They were projected as being truly representative of their identification as a 'great force' in both the rural and urban economies, as well as in international politics. They were certainly not presented as "mothers in misery"; rather

121 For the problems in building a rural physical culture, especially for women see $\underline{\operatorname{PzS}}, 171$ (3 September, 1985), 5; PzS, 107 (1 June, 1988), 1; PzS, 1 (3 January, 1949), 6; Przyjaciolka, 33 (13 August, 1978), 8; Barbara Krawczyka and Zbigniew Krawczyk, "Sociology of Sport in Poland," in International Review for Sociology of Sport, 24, 1 (1989), 19-36, p.23; Foldesi, "Postawy wobec wychowania fizycznego relacja z badan polsko-wegierskich," 60; Glowny komitet kultury fizycznej i sportu: Materialy Informacyjne (March, 1984), 27; Jerzy Rut and Krzysztof Stanczuk, "Uczestinctwo w sporcie inteligencji i rolnikow," in Krawczyk (ed.), Kulturowe wartosci sportu, 351-361; Krawczyk, "Sport jako," 180; Izydorczyk, "O dalszy intensywny rozwoj kultury fizycznej i sportu w srodowisku wiejskim," 4, 8; and Treywasz, Nasz sport na dziesieciolecie polskiej rzeczypospolitej ludowej, 11. See also Siwinski, Mieszkancy wsi wobec kultury fizycznej i turystyki, 152-154. Siwinski's book details the organization of sports and physical culture in the Polish countryside. 
they were highly publicized figures, possessing all the officially approved characteristics and serving as 'role models' for others to emulate. Their increased participation at both the professional and popular levels of sport was indicative of their growing acceptance and elevated position in Soviet society.

But surely, incongruencies are to be expected in this convergence of interests and responsibilities. Given the overarching patriarchalism of Soviet society, especially in the sphere of sports, the victories achieved by Soviet women did not translate into fans in the stands for their contests. 122 Moreover, since oppressive patriarchal attitudes were greatly reinforced during the Brezhnev years, when a new cult of bourgeois goods and values resurrected images of the ideal woman as a good housewife, it is hard to imagine how sportswomen skillfully integrated their duties of motherhood and the enormously time-consuming sports training programs with the much harsher social and economic realities. Also, since Soviet sportswomen were part of the society's 'elite', one may question how they managed to establish such strong feminist bonds of togetherness that supposedly permeated the entire society. Such an imagined solidarity, fostered among Soviet women under the aegis of Soviet sports needs to be questioned, particularly with reference to the nature of the Soviet political regimes. For example, Soviet 'elite' women most certainly prospered under Brezhnev. The special stores in which they shopped were piled high with imported goods as well as luxury Soviet products. Their children attended the best schools, and they could afford nice summer homes and even foreign travel. Meanwhile, ordinary women across the USSR, ever more aware of the disparities between their lives and those of more privileged women at home and abroad, struggled with the difficulties of the double shift. 123 The extreme hardships omnipresent in daily life, for both urban and rural women, would raise the question of whether the women's "sports revolution" in the Soviet Union was truly "revolutionary"? Most certainly, therefore, such inconsistencies in the lives of Soviet women need to be explored.

Even in communist China, parents feared that excessive exercise might affect women's childbearing abilities. Faced with tight birth control policies, women's reproductory roles remained of paramount importance. In order to became engaged or married, many athletes had to retire. Only the top athletes were in a position to bargain for the right to marry while still competing. But sportswomen who married and continued competing were few and far between, those with children even more so. However, unlike in the west, the Chinese refrained from any talk about the "biological inferiority" of

122 Edelman, Serious Fun, 186, 189.

123 For women's conditions during Brezhnev's leadership see Gray, Soviet Women 190; and Clements, Daughters of Revolution, 115. 
women. In communist China, reproduction and class are more potent components of gender symbolism; not the abstract notion of "femininity". 124

Thus, similar to the Soviet and Chinese women, Polish sportswomen found their athleticism being moderated by traditional patriarchal attitudes in society. Their participation in sport suffered because of widespread ideological discrimination. Given the pervasivity of social patriarchy, it is interesting that while Polish sportswomen were depicted as being very "energetic", their male counterparts were frequently depicted in the imagery of flowers, especially tulips. The male athletes have also been caricatured in the imagery of birds. 125 These caricatures are suggestive of some form of 'gender turbulence' in society, characterized by the 'feminization of masculinity'. However, the appearance of this jocular imagery in the press probably inflicted no 'gender damage' in popular consciousness since Polish sportswomen, despite their physical enthusiasm, were always portrayed as graceful and elegant 'feminine' athletes. Unlike the Soviet sportswomen who were referred to as 'sports stakhanovites', and presented as 'strong' and 'muscular' athletes, the Polish sportswomen remained confined to the less dynamic traditional imagery of the 'matka polka'. The Polish women's physical culture was certainly not powerless and without meaning. But the quantity and quality of women's sports was adversely affected by the damaging effects of conservative popular opinion and the regime's institutional discriminatory policies. The following section will examine how the state's administrative weaknesses undermined the development of women's physical culture and forced female athletes to accept their double discrimination at the hands of both the state and society.

\section{Women's Physical Culture and Institutional Discrimination in the PRL State Policies, Sports Administration and Women's Sports}

The socialist states in Eastern Europe exhibited an outward concern to increase mass activism of women in the sports movement. However, this expression of interest to build a strong women's physical culture remained superficial. In reality, the regimes of Eastern Europe were never willing to create the material conditions necessary for ordinary women to enjoy their physical emancipation guaranteed by their constitutions. 126 The inherent social inertia to transform traditional gender roles,

\footnotetext{
124 Brownell, Training the Body For China, 226, 235, 236, 245, 246.

$125 \underline{\mathrm{PzS}}, 37 / 38$ (26 March, 1970), 3; $\underline{\mathrm{PzS}}, 170$ (2 September, 1975), 1; and PzS, 200 (14 October, 1975), 1.

126 Guttmann, Women's Sports, 177, 179.
} 
together with numerous problems in the organization of indigenous sporting cultures, ultimately undermined the fruition of women's sporting culture in eastern Europe, including Poland.

In Poland, the organization of physical culture was intricate and complicated, and lacked any sense of uniformity and coherence. 127 The development of Polish sports suffered from "technological deformations", elitism and squabbles in sports organizations, infrastructural deficiencies, lack of effective networking between urban and rural areas, limited financial resources and trained instructors, and 'double and overlapping structures' in state administration which resulted in the lack of firm leadership. 128 State policies lacked focus and clarity which adversely affected the planning and organization of sports for both men and women in the PRL.

Some women also complained of "anti-feminist" sentiments in the sports apparatus and appealed to Polish women to "wake up!"129 The male model of physical education instruction for women was subject to criticism. The overwhelming numbers of male instructors and trainers, even for women's sports, aroused dismay. It was reported that only a few trainers understood women's 'psyche and expressions' and remained predisposed to training women. Also, while almost half the graduates of the Academies of Physical Education were women, very few assumed professional careers in this field. 130 A project conducted by the Academy of Physical Education in Warsaw showed more discrepancies in the theoretical and actual organization of women's physical culture. According to this research, there was an urgent need to make physical training for women 'less autocratic' and more "creative" and "pleasurable". Physical education instructors needed to be more respectful toward their women students and provide them with the necessary emotional and intellectual motivation. 131

While the AWFs struggled with intellectual, material and financial problems in their male and female physical cultures, physical education in schools similarly suffered

127 Lech Jaczynowski and Jolanta Zysko, "Przeksztalcenia w systemie organizacyjnym kultury fizycznej w Polsce w dobie transformacji ustrojowej, czesc II," in Kultura Fizyczna, 49, 1-2, (1995), 13-19.

128 For all these issues see PzS, 163-164 (23 December, 1963), 1, 4; Drazdzewski, Dzieziecioletnia dzialalnosc, 78; Glowny Komitet Kultury Fizycznej i Turystyki: Aktualne zadania kultury fizycznej oraz kierunkowe wytyczne rozwoju sportu na lata 1966-1970, 9, 39; Zbigniew Krawczyk, "Sport as the Subject of Sociological Studies," International Review of Sport Sociology, 1/ 18 (1983), 35-45, p.37; Reczek, "60 lat Polskiego komitetu olimpijsjiego," 4; Gondek, Kultura fizyczna w Polsce, 108; Gawlak-Kica, Rozwoj kultury fizycznej w Wielkopolsce, 266, 267, 295; Chelmecki, "Problematyka," 12; Gaj, Wychowanie fizyczne, 71; and Liponski, "Still and Unknown," 27.

129 PzS, 18 (13 February, 1971), 5.

$130 \mathrm{PzS}, 110$ (5 June, 1984), 6.

131 Zofia Zukowska, "Der Frauensport in polnishchen Untersuchungen," in Weltrat fur Sportwissenschaft und Korpererziehung, 7 (1984), $48-57$. 
because of the lack of organizational cohesiveness and limited social awareness of the need to improve the students' health. The sports culture in schools remained weak and few students demonstrated the enthusiasm to participate in sporting activities. Many parents themselves believed that participation in physical exercises and sports was a waste of time and that it was better to devote the scarce time available to study, or simply watch television at home. Thus, there was always the need for a more programmatic and systematic structure of sports in schools. The absence of a good system of talent selection and training for student athletes resulted in stagnation of sports results. 132

Overall, the sports community remained critical of the considerable gaps between theory and practice of physical education in Poland. They expressed concern over the heavy concentration of sports trainers in the major urban towns, the limited opportunities available to popularize physical culture for both men and women, and the scarce resources to expand sports research. ${ }^{133}$ For example, an anonymous inquiry of 92 physicians of different surgical specialties in Gdansk revealed the need for urgent improvements in sports medicine. 134

The fact that the state administration evaluated the effectiveness of the sports authorities according to the quantity of medals won resulted in a gross neglect of recreational and leisure sports in favor of competitive sport. The near complete lack of attention to the personal aspirations of the participant became more and more irritating in a nation characterized by strong individualism. While the general impoverishment of the majority of families resulted in the collapse of the "Sport for All" program at the amateur

132 PzS, 82 (25 April, 1980), 2; PzS, 21 (13 March, 1952), 5; PzS, 39 (10 May, 1952), 3; PzS, 18 (4 March, 1954), 2; KiZ, 51 (17 December, 1961), 3; KiZ, 17 (23 April, 1978), 20; Przyjaciolka, 5 (3 February, 1957), 10; Maciej Demel, "Wychowanie fizyczne szkolne w swietle orientacji aksjologicznej: Krytyka i propozycje modelowe," in Krawczyk (ed.), Kultura fizyczna i spoleczenstwo, 215-243, pp. 215, 219, 242, 243; Obodynski, "Wyksztalcenie i status spoleczny nauczycieli wychowania fizycznego w szkolach wyzszych," 156, 157; Wolanska, "Wychowanie," 229, 231, 242-248, 364; Sozanski, "Sport dzieci i mlodziezy, Selekcja--wazny element systemy szkolnenia," 45, 46; Barbara Krawczyk, "Attitude toward Studies and Professional Aspirations of the Students of the Academy of Physical Education," 195-208, p. 203, 204; Tkaczyk, "Wybrane," 473; Jerzy Skorowski, "Szkoly sportowe w Polsce w latach 1973-1977," in Sport Wyczynowy, 16, 9/165 (1978), 3-6, p.6; and Zygmunt Jaworski, "Some Phenomena Connected with the Employment of Graduates of Academies of Physical Education," in International Review of Sport Sociology, 3-4/9 (1974), 117-134, pp.129, 133. For the 'disgraceful' health-hygienic conditions in schools, as well as alcohol and drugs consumption by school children see also W. Osinski, "Current Developments in the Modernization of the Physical Education System in Polish Schools," 463-467.

133 Z. Zukowska, "Profession and Work of Physical Education Instructors and Coaches in Poland," in Hermann Rieder and Udo Hanke (eds.), Sportlehrer und Trainer heute (Koln, 1987)), 254-257. In research carried out between 1969-70 in four sport disciplines of boxing, judo, weightlifting and canoeing, most of the sportsmen began their training in the big towns. See Elzbieta Saar, "Sport kwalifikowany jako czynnik migracji spolecznej," in Krawczyk, Sport w spoleczenstwie wspolczesnym, 277-296.

134 Michal T. Grabowski, "Stosunek lekarzy chirurgow do sportu wyczynowego i rekreacyjnego na terenie miasta Gdanska," in Zeszyty Naukowe, 6 (1982), 55-73, pp. 55, 66, 71, 72. 
level, the persistent economic and technical deficiencies eventually produced catastrophic results at the professional level. For example, at the Seoul Olympics of 1988, as many as 32 Polish coaches were working for other national teams! 135 One report concluded that while Polish women could participate in international competitions such as the Olympics, their opportunities to win gold was rare. ${ }^{136}$ Also, while the sporting accomplishments of the female Olympians enabled them to maintain their position in the upper echelons of society, there were simply too few women who could claim this honor. In terms of statistics, a total of 838 athletes participated in the Olympic Games between 1948-1972, $82.5 \%$ of whom were men and $17.5 \%$ women. 137

Further, women's desire to improve their physical well-being by participating in sports was undermined by Poland's status as a "colony" of the "imperial" Soviet Union. The Polish struggles against the "authorities" and the need to maintain a standard of living under difficult circumstances made a Polish women's movement against sexism appear "unnecessary" and "unpatriotic" in the PRL. Instead women were required to serve alongside men, and not against them, in the society's foremost need to secure the country's independence and 'Polishness'. Polish "nationalist" opposition to stateimposed socialism once again made families the 'fortresses' of nationalistic spirit and values. Such nationalist overtones which insisted on gender cooperation and not gender struggle automatically transferred to women's sports. Polish women found themselves being denied the pleasures of their "real" physical emancipation by "Polish" institutions which wanted women to preserve the family institution and ensure its stability by refraining from all practices, including sports, which may have caused divisive forces to surface.

Thus, for example, the conservative position of the Polish Catholic Church militated against a serious commitment to women's sports. The Church, as the selfappointed guardian of Polish national, cultural, and democratic political traditions

135 Krzysztof Duszynski, "Kultura fizyczna a integracja spoleczna: teoria a rzeczywistosc," in Drozdowski and Rozynek-Lukanowska (eds.), Nauki spoleczne a kultura fizyczna, 93-99; Teresa Wolanska, "New Developments of Sport for All in Poland," in Liponski and Siwinski (eds.), Studies in Physical Culture and Tourism, 133-136; and Liponski, "Still and Unknown," 28, 29, 31. On the weak results in international sports competition and more resignations from sports participation see also Sozanski, "Szkolenie sportowe mlodziezy w polsce," 14. On the dissatisfaction of elite competitors see also Andrzej Ziemilski, "Satysfakcja ludzi sukcesu sportowego," in Krawczyk, Sport w spoleczenstwie wspolczesnym, 251-275.

136 KiZ, 36 (6 September, 1964), 14.

137 Anna Pawlak, "The Status and Style of Life of Polish Olympians after Completion of their Sports Careers," International Review for the Sociology of Sport, 19, 2, (1984), 169-183. See also Anna Pawlak, "Aspiracje kulturalne bylych olimpijczykow," in Krawczyk (ed.), Kulturowe wartosci sportu, 380-393. See again Anna Pawlak, "Losy polskich olimpijczykow po zakonczeniu kariery zawodniczej," in Wychowanie Fizyczne i Sport, 2 (1985), 101-115. 
frowned upon issues of women's rights. Because the Church's courageous and effective resistance to state encroachment was a key factor in sustaining the society's confidence and strength, Polish women respected the opinion of the Church and refrained from attacking the family structure by become "too athletic". They accorded feminism a low priority and subordinated their individual aspirations to the interests of the family and ultimately, to the needs of the society. Despite the massive socialization and indoctrination campaigns conducted by successive regimes to make Poland more "egalitarian", "efficient", and "modern", women's identities continued to be shaped by the country's historical institutions and structures, all of which espoused conservative, catholic, nationalist, and patriarchal attitudes.

Thus, a host of factors strained the weak institutional sports structure for women. These included women's low level of sports consciousness, the burden of family obligations, cultural barriers in women's sport, the weak level of physical education and talent selection in schools for girls, and the general 'decay' of social life in sports clubs. Women were much too burdened with the everyday struggles and needs, bravely running a household, raising children, and working a job. Their self-sacrifices to the family, society, and ultimately the nation, compromised their identities as sportswomen. 138

From a comparative perspective, the promotion of women's sports came to be more a matter of national pride than of women's liberation in most East European countries and even in communist China. 139 During the period of the Cold War, male and female athletes from the Eastern bloc were repeatedly reminded of their sporting competitions with 'imperialist' countries. The main aim of socialist sports was to uphold the superiority of the socialism over capitalism. Athletes of socialist countries were subject to constant surveillance by their political 'chaperones' at the Olympic Games and other international competitions, lest they defect or divulge too much information. At the same time, because genuine qualifications in sports, as in other disciplines of social and

138 For all these issues see PzS, 19 (6 March, 1950), 3; Przyjaciolka, 44 (29 December, 1950), 12; PzS, 120 (23 June, 1986), 6; Stachniak, "Why Did We Not Become Feminists?"; Anna Titkow, "Political Change in Poland,"; Hauser, Heys and Mansbridge, "Poland in Transition,"; Marody and Giza-Poleszczuk, "Changing Images of Identity in Poland," 155, 167, 173; Korbonski, "Poland: 1918-1990," 265-268; Krystyna Glinka Olechnowicz,"Udzial kobiet w rozwoju upowszechnianiu i odbiorze kultury," in Udzial kobiet w rozwoju upowszechnianiu i odbiorze kultury, 6-18, p. 18; Nowosielski, Problemy sportu, 53; Szot, Rozwoj kultury fizycznej w aglomeracji Gdanskiej, Gdansk, Gdynia, Sopot, 181, 189, 190, 204; Zukowska, "Der Frauensport in polnishchen Untersuchungen," 48-57; Szczepanski, Polish Society, 184, 187, 192, 198-200; Kennedy, Professionals, Power and Solidarity in Poland, 329; and Guttmann, Women's Sports, 172, 176. For more on the masculine construction of the Polish sports apparatus, see also Foldesi, "Podstawy," 60, 63. On the Polish Catholic Church see Ramet, Nihil Obstat, 293; and Szajkowski, Next to God....Poland, 34.

139 For China see Brownell, Training the Body For China, 237. 
civil life, became so heavily outweighed by the requirements of political reliability and the smooth handling of the new political vernacular, a new category of patriots was born, the Radishes. Red on the outside and white inside, they were more concerned with surviving and protecting their jobs than with climbing. 140 These male and female radishes in sports, though less dangerous than the bandwagon communists, proved ineffectual as moving factors of socialist societies.

There were other institutional boundaries which circumscribed the achievements of women's sports in Eastern Europe, especially in the Soviet Union. For example, an important aspect of the Soviet 'talent-seeking' sport system was to simply 'catch' boys and girls at an early age. The Soviet state could boast of thousands of young girl champions. ${ }^{141}$ An effort was made to project the image that the country did not begrudge children anything, especially when it was a matter of good health and education. ${ }^{142}$ Parents were also encouraged by the state to introduce their children to physical culture right 'from the cradle'. ${ }^{143}$ However, the objective of the Soviet state to train children from an early age was riddled with problems. For example, physical abuse of children was quite apparent in relations between coaches and athletes. This problem was particularly acute in women's gymnastics. Moreover, sports officials and other related state functionaries had not been averse to falsifying an athlete's age to gain acceptance to international tournaments. 144

More importantly, given the fact that the Soviet Union was indeed an 'empire,' it is hard to imagine how women's sports would not have reflected Soviet polices of "russification" and "republican resistance" through the medium of physical culture. NonRussian athletes were discriminated against twice: once when their triumphs on the playing fields were credited to the power that enslaved their homelands, and more basically, by the entire sports system in the USSR, which was dominated by Russian colonialism. 145 In Ukraine, for example, although sports clubs were called 'voluntary,' they were actually under the control and supervision of the Communist Party. ${ }^{146}$ Soviet

140 See Olga Connolly, The Rings of Destiny (New York, 1968), 31, 62. This is a novel about the interference of political red-tapism and Cold War politics in the love affair of Czech athlete Olga Fikotova and American athlete Harold Connolly.

141 Soviet Woman, 6 (1965), 30, 31.

142 Soviet Woman, 2 (1970), 13.

143 Soviet Woman, 7 (1972), 16.

144 Jim Riordan, "Rewriting Soviet Sports History," in Journal of Sport History, 20, 3 (Winter, 1993), $247-$ 258.

145 Riordan, "Sport and Nationalism," 9; and Osyp Zinkevych, Ukrainian Olympic Champions (Baltimore, 1984) $10,11,130,141$.

146 Kubijovyc (ed.), Ukraine: A Concise Encyclopedia, 1034, 1035, 1037. 
drug use and experimentation in sports medicine also resulted in an unusually high death rate among Ukrainian Olympians. ${ }^{147}$ In Estonia, sports led politics, and the later 'Singing Revolution' had already begun in the sports arena in 1988. ${ }^{148}$ Meanwhile, the survival of traditional folk sports and recreational activities in different republics is indicative of the limitations of the Soviet program of sports russification. 149

While there can be no question that many factors contributed to the fall of communism, it was nationalism and its capacity to mobilize broad masses of citizens for independence that proved the decisive force in the demise of Soviet hegemonic control. And republican resistance to the imposition of a coercive, alien Russian sports institution played a critical role in the 'politics of transgression' which challenged the illegitimacy of Moscow's socialist discourse. ${ }^{150}$ Local functionaries prided their "underground" autonomy in determining the limits of what was ideologically acceptable and unacceptable. 151

What was the role of the 'metropolis-satellite' relations in Soviet feminine physical culture? In China, for example, the central regime faced difficulties in promoting sports among Muslim and Tibetan women. ${ }^{152}$ Was the participation of women in Soviet sports policy illustrative of Soviet attempts to pursue its 'imperialist-integrative' policies? Was there a difference in the reception of Soviet sports policy for Russian and 'republican' women? Did the latter show a propensity toward the 'liberating' effects of sports or use it to put forward their nationalist demands? Did sports help in the creation of a 'feminist consciousness' amongst the Russian and republican women? Or were the republican women sympathizers of the 'male' demands for national autonomy? Did the republican women consider themselves representative of the image of the 'Soviet

147 Soviet Olympic Death Rate, National Discrimination and the Ukrainian Issue.: Smoloskyp at the Olympics (Baltimore, 1984), 4-7, 12, 13, 15, 35-37.

148 Howell, "Sport and Glasnost: A Case Study of Estonia," 325, 327-332; and Misiunas and Taagepera, The Baltic States, 130, 240.

149 For a detailed summary of the various local folk games and sports in different republics of the Soviet Union see Riordan, Sport, 89, 95, 96, 97, 98, 101, 105, 107, 108, 109, 110, 306; Y. Lukashin, "In the Kazakh Steppes, Uzbek Valleys and Tajik Mountains," in Yuri Lukashin (compiler), National Folk Sports in the USSR (Moscow, 1980), 114, 115, 116, 117; Elizabeth Bacon, Central Asians Under Russian Rule: A Study in Cultural Change (Ithaca, 1966), 185; and Riordan, "Sport and Nationalism," 5, 7.

150 Nadia Duik and Adrain Karatnycky, New Nations Rising: The Fall of the Soviets and the Challenge of Independence (New York, 1993), 1; and Edelman, Serious Fun, 11.

151 For reference see Serhy Yekelchyk, "Diktat and Dialogue in Stalinist Culture: Staging Patriotic Historical Opera in Soviet Ukraine, 1936-1954," in Slavic Review, 59, 3 (Fall, 2000), 597-624. According to the author, an everyday "party line" in Soviet Ukrainian culture was formulated, negotiated, and maintained by republican bureaucrats and members of the intelligentsia themselves during the Stalinist period.

152 Brownell, Training the Body For China, 226. 
woman'? What role did gender play in the metropolis-satellite sports relationship? Answers to these questions will require further research. That difficulties existed should not surprise us.

Further, Soviet sports 'astronomers' were quick to spot sport luminaries well in advance and foretell rather accurately when these athletes would become stars of the first magnitude. 153 The question is what happened to those stars, particularly the women athletes who never made it big and or whose brief meteoric sporting careers came to a sudden conclusion? Also, in the official image, sports for Soviet women were encouraged for reasons of 'health and fitness'. The overwhelming concern of the state with the health of its people, and the development of physical culture for attaining this objective would however raise the question of whether the health of the Soviet people did really improve? According to one scholar, there is certainly the recognition that a huge gap exists between the elite woman athlete and the ordinary women in terms of fitness, skill level, motivation, and general health. ${ }^{154}$ Still, the question of whether Soviet men and women were any more 'fit' and 'healthier' than others needs to be addressed.

It appears, therefore, that the vignette of sport in eastern Europe was one of hypocrisy, corruption and cheating, with falsified ages, records and figures and the use of performance-enhancing drugs supported, approved of and administered by the state. Although 'sport for all' was an avowed aim of the system, it was too costly to realize. 155 This is not to suggest that western societies were much better than societies of the eastern bloc in promoting women's sports. In Britain for example, the discrimination against female sport meant that amateur values survived more strongly in women's sport than in men's. Also, the middle-class woman remained an undervalued presence in sport, especially in games such as golf and tennis. ${ }^{156}$ However, what made things particularly hard for sportswomen in eastern Europe was the state's desire to convert women into "superwomen". The political apparatus remained conservative, choosing to cast images of 'superwomen' and narrating their achievements only to demonstrate the advantages of living in the communist system. 157 This compromised the identities of sportswomen not only in terms of their athletic accomplishments, but also in terms of their very gender.

Thus, the organization of women's physical culture in Poland, as in other parts of eastern Europe, was similarly injured by discriminatory practices, negative attitudes in

\footnotetext{
153 Soviet Woman, 3 (1965), 36.

154 M. Ann Hall, "Women and Sport Research in the Soviet Union" (Unpublished Paper, 1988), 1-5.

155 Howell, "Sport and Glasnost: a Case Study of Estonia" (Unpublished Paper, 1993).

156 Holt and Mason, Sport in Britain, 9, 61.

157 Bridger, Kay, Pinnick, No More Heroines?
} 
social consciousness, skewed logics of good morality and esthetics, poor communication between instructors and women athletes, and a general lack of enthusiasm on the part of families and the institutional sports apparatus to support women's sport at the professional level. In addition, the lack of feminist solidarity further constrained women's collective action to build their physical culture and improve their physicality. The Polish society remained divided by class and status. Certainly, the regime tried to create the 'noble' socialist working class and offered sports to women as a valuable medium of upward mobility. Engagement in physical culture in a way was symbolic of membership in a higher class. However, by the 1980s, the logic of social solidarity in sport had dissolved in a real solvent of multiple class solutions with greater acidity than alkalinity. While the Polish society struggled as a whole against the state-imposed ideological values, the social unity fostered in the midst of an acute socio-economic crisis did not cause any feminist bonding which could articulate the individualistic needs and aspirations of women. Women's sports, accordingly, suffered from the lack of women's self-awareness and self-consciousness. For all these reasons, the much vaunted physical emancipation of Polish women under socialism was undermined in reality by the masculinized, socialist sports apparatus.

\section{Conclusion}

Polish women's physical culture, no doubt, was used by the successive political regimes in the PRL to display images of women's good physical health and mental strength, and for fostering values of discipline, solidarity, collectivism, and patriotism at the family, national and international levels. The ideas of women's equality and liberation resonated in Polish physical culture and contributed to Poland's socialist development, both internally and externally. Unfortunately, the reality of tired, embittered, and disillusioned ordinary women contrasted sharply with the images of a few elite strong and healthy sportswomen. Sports, it appeared, imposed a "triple burden" on female athletes, the additional burden being the product of state socialism's fascination with improving women's physicality for political purposes. And this triple burden denied women the real experience of personal and professional equality in the realm of sports.

Thus, both the ideological constructions of gender equality in official socialist discourse and the cultural re-configurations elaborated by the official physical culture apparatus remained artificial and quite distant from the daily social practices of ordinary Polish women. The modernization of Polish sporting culture, as rightly understood by the central and provincial sports organizations in its gender dimension, foundered in its 
implementation at the popular and professional levels, and created space for dissent and resistance in Polish women's sports. 


\section{Conclusion}

This dissertation has examined the interaction between the various forces of Polish "nationalism" and "feminism" in the construction of women's physical culture in modern Poland. The basic premise of this work is that unlike most western countries where sportswomen have typically been marginalized in their athletic endeavors, Polish female athletes have earned far greater respect and recognition in the development of their physical culture. On many occasions, women's athleticism in Poland was a source of immense of pride and prestige for both the state and society, albeit for varied reasons throughout the time period. While the state used women's sports to project a kaleidoscope of well-defined objectives to strengthen its legitimacy, the society praised the accomplishments of Polish female athletes for serving the nation.

This form of public acceptance, however, does not suggest that Polish sportswomen faced no discrimination in their efforts to become more athletic. Women's physicality remained the subject of much debate throughout the history of Poland. Such scrutiny became even more intense when the socio-economic conditions worsened and threatened the survival of Polish families. Women's sports, in all the three times, were constrained by class, ethnic, and religious issues. Even today, the conservative Catholic image of the matka-polka is still embedded in popular consciousness.

Still, despite the patriarchal and other barricades, the Polish struggles for independence and women's concerns to achieve greater equity with men created significant institutional spaces and ideological avenues for Polish sportswomen to build their physical culture. Although Polish "feminism" typically subordinated itself to the larger goals of Polish "nationalism", women's sports in Poland were appreciated to a much larger extent than in most other countries of the world throughout the time period under investigation.

During the period between the late 19th century until the First World War, Poland lay partitioned between the imperial powers of Prussia, Austria and Russia. All forms of "Polish" culture, including sports, contributed to the formation of "civil society" in the dismembered country. This period was also marked by the emergence of the "woman question" which had its greatest impact on the younger generation. They were most affected by the on-going processes of modernization and industrialization, and the resultant evolution of modern mass political consciousness. As a result of these "modern" forces of Polish nationalism and feminism, women became increasingly visible in sports. However, these athletically conscious women conditioned their physical culture not according to the specifics of competitive sports or for any real feminist cause, but 
primarily to serve the national cause, however interpreted by its various and divided proponents.

Thereafter, women's participation in sports increased during the interwar years. Their greater involvement in physical culture was consistent with women's entry into other realms of public affairs as well, including participation in politics, economic development, and a host of socio-cultural activities. Unfortunately, Polish politics during the interwar period remained rather chaotic. Marshal Pilsudski restored some normalcy to the political disarray through his authoritarian rule. But more generally, the Polish political culture was beset by numerous problems, all of which limited the available institutional support for developing women's physical culture. Still, the "elite" female sports champions performed extraordinarily well. Halina Konopacka, for example, won Poland's first Olympic gold in 1928.

In the period after the Second World War, sports and physical education were awarded a position of paramount importance in the construction of socialism in Poland. The Polish communist authorities, similar to their superiors in Moscow, used women's sports for projecting images of gender equity, for broadcasting the superiority of communism over the capitalist world, for "taming" the supposedly recalcitrant nonconformists, and for facilitating the socialist integration of all "worthy citizens". For these reasons, all successive political regimes in Poland pledged support to develop women's physical culture. Unfortunately, while the objective of increasing women's participation in sports was worthwhile, the socialist state simply lacked the financial resources to translate this noble cause into reality. Poland was in many ways a colony of Moscow and, accordingly, governed by core-periphery relationships. The resultant systemic instabilities forced ordinary Poles to concentrate their efforts, not in sports, but in trying to survive the daily hardships and subsequently formulate a "civil society" to circumvent the artificial and ineffective structures of state socialism.

Still, because success in sports were a visible demonstration of socialist superiority, women were encouraged to actively participate in the state-coordinated physical culture apparatus. The champions among them received national honors and awards. Although Polish sportswomen were not depicted as Soviet-style sports stakhanovites, neither were they portrayed as "abnormalities" quite typical of the western identification for their sportswomen. The Polish female athletes were not placed in either of these two ludicrous categories; rather, they were located in the middle of these two polarities. Polish sportswomen were simply "heroic" women who took advantage of the available opportunities to build their physical culture without causing much controversy in popular discourse and official rhetoric. In this manner, they made significant 
contributions to the feminist goals of self-awareness and self-authorization, albeit within the boundaries of a still patriarchal nationalist agenda.

But what about the future? In the contemporary period, women's physical culture has been adversely affected by the on-going processes of political democratization and economic modernization in post-communist Poland. During 1989-1990, the Polish communist party disintegrated and lost its governmental hegemony to the first postcommunist government of Tadeusz Mazowiecki. The collapse of communism in Poland forced the new leadership to find immediate solutions to the country's enormous domestic challenges, including and especially the economic and financial crisis which had been created and sustained by the communist ruling elites of the past. In an effort to rid the country of its alarming foreign debt and escalating inflation, Mazowiecki's American-trained finance minister Leszek Balcerowicz launched a radical economic program to enable Poland to move beyond the static communist economic structures and institute effective reforms toward privatization and marketization. This "shock therapy" was designed to rapidly regenerate the inherited socialist economy by introducing a market-oriented liberalized economy to curb the high rate of inflation and cultivate a domestic capital market. ${ }^{1}$

Poland's transition to a free market economy was largely successful in the first year of this 'great leap forward'. The galloping inflation was controlled, exports increased, and foreign relations with countries in both the east and west gradually strengthened. Unfortunately, the government's efforts to hastily reform the Polish economy soon stumbled over the surmounting political tensions within the country. Lech Walesa, the arbiter of the nascent Polish democracy, became increasingly disillusioned with his political marginalization by the intelligentsia-dominated government. In the subsequent presidential elections of November 1990, Walesa successfully defeated both his rivals, Mazowiecki and a western businessman Stanislaw Tyminski. However, while Walesa was elected by a landslide victory, the Solidarity movement itself was terribly fractured by internal dissensions.

\footnotetext{
${ }^{1}$ Rothschild, Return to Diversity, 231; Hunter and Ryan, From Autarchy to Market, 82; Millard, Polish Politics and Society, 148, 163; Andrew A. Michta, "Democratic Consolidation in Poland After 1989," in Karen Dawisha and Bruce Parrott (eds.), The Consolidation of Democracy in East-Central Europe (Cambridge and New York, 1997), 66-108, p. 66; Bielasiak, "Poland,"; Leszek Balcerowicz, Socialism, Capitalism, Transformation (Budapest, 1995), 337; Ray Taras, Consolidating Democracy in Poland (Boulder, 1995), 234; Andrew Berg, "The Logistics of Privatization in Poland," in Olivier Blanchard, Kenneth A. Froot and Jeffrey D. Sachs (eds.), The Transition in Eastern Europe, Volume 2 (Chicago, 1994), 165-188, pp. 165, 184; and Attila Agh, Emerging Democracies in East Central Europe and the Balkans (Northampton, 1998), section on Poland, 27-72, p.37.
} 
Solidarity had always professed its high ideals of heroic virtue, integrity, unity and public service. However, with de-communization, Solidarity succumbed to individual ambition and greed, political in-fighting, and institutional fluidity which resulted from the party's "anti-political" stand during its struggle with the communist elites. Solidarity's collective identity was substantially weakened by the subsequent political fragmentation and the creation of numerous political sub-centers with separate economic, regional and religious affiliations and agendas. Walesa's abrasive and flamboyant style of leadership, as well as his partisan support of the Catholic Church, both generated more popular disillusionment. This political fragmentation and polarization resulted in the formation of over 120 registered political parties by the fall of 1991, and gave Poland six governments and eight prime ministers between 1989-1993. Factionalism and the disintegration of Solidarity not only created a mood of popular political apathy, but also undermined efforts to address the nation's ponderous economic and social problems. ${ }^{2}$

The unstable political climate and a revolving door of post-Solidarity governments delayed and politicized the privatization process. In the years between 1991-1993 especially, the Poles were confronted by the reality of severe price increases, a drop in the real incomes, unprecedented loss of jobs, persistence of inflation, declining standard of living, and a drastic cut in state spending for social welfare programs. Balcerowicz's radical economic reforms and the political instabilities bred popular sentiments of frustration, despair, anger, and cynicism. The Polish workers questioned the deplorable working conditions and wages, while the peasants expressed their grievances over the reduced state subsidies. 3

\footnotetext{
2 For all these issues see Millard, Polish Politics and Society, 169; Hubert Tworzecki, Parties and Politics in Post-1989 Poland (Boulder, Colorado, 1996), 17; Bielasiak, "Poland," 149, 150; Grzegorz Ekiert and Jan Kubik, Rebellious Civil Society: Popular Protest and Democratic Consolidation in Poland, 1989-1993 (Ann Arbor, 1999), 92; Balcerowicz, Socialism, Capitalism, Transformation, 298; Minton F. Goldman, Revolution and Change in Central and Eastern Europe: Political, Economic, and Social Challenges (Armonk, New York, 1997), 229-231, 238, 251-253, 264; Agh, Emerging Democracies in East Central Europe, 30, 35, 41, 51; John Higley, Jan Pakulski and Wlodzimierz Wesolowski, "Elite Change and Democratic Regimes in Eastern Europe," in John Higley, Jan Pakulski and Wlodzimierz Wesolowski (eds.), Postcommunist Elites and Democracy in Eastern Europe (Basingstoke, 1998), 1-33, p.10; Irena Pankow, "A Self Portrait of the Polish Political Elite," in Higley, Pakulski and Wesolowski (eds.), Postcommunist Elites and Democracy in Eastern Europe, 188-202, pp. 200, 201; Roman Frydman, Kenneth Murphy and Andrzej Rapaczynski, Capitalism with a Comrade's Face (Budapest, 1998), 109-111; Poznanski, Poland's Protracted Transition, 272; Rothschild, Return to Diversity, 232, 233; Michta, "Democratic Consolidation in Poland After 1989," 77; and Slay, The Polish Economy, 121, 122.

${ }^{3}$ Edmund Mokrzycki, "Revenge of Utopia," in Michael D. Kennedy (ed.), Envisioning Eastern Europe: Postcommunist Cultural Studies (Ann Arbor, 1994), 73-86, p.79; Millard, Polish Politics and Society, 148; Goldman, Revolution and Change, 238; Poznanski, Poland's Protracted Transition, 264; Hunter and Ryan, From Autarchy to Market, 125, 169, 187, 196, 207; Bielasiak, "Poland,"146; Balcerowicz, Socialism, Capitalism, Transformation, 300, 301; and Alain de Crombrugghe and David Lipton, "The Government
} 
In the midst of increasing economic and social concerns, the communist political elite made a comeback in late 1993 as a coalition of "modern" parties with "capitalist" and not "socialist" interests. In the 1995 presidential elections, Walesa was himself replaced by Alexander Kwasniewski. Whatever remnants of communist ideology and state-socialist political strategies persisted among the ex-communist elites, they did not seem to pose a serious threat to democratic and capitalistic development in Poland. On the contrary, growth in production and investments greatly accelerated in 1994. Grzegorz Kolodko, the deputy Prime Minister and Minister of Finance in the governments of Prime Minister Waldemar Pawlak and Wlodzimierz Cimoszewicz (1994-1997), authored the economic program termed "Package 2000" to restore economic prosperity. The program emphasized many reforms, including improvements in the governance of public sector enterprises, institutional support for developing entrepreneurship, and a reduction of unemployment. By 1998, the Polish economy had made a robust recovery and grew at an impressive rate. The rapidly rising trade and investment, declining inflation, and growing foreign exchange reserves restored consumer confidence. Poland today has a liberal democracy with an efficient market economy, and is increasingly looking toward broadening its national identity to become more "European" and eventually, more "global". 4

While the Polish economy and polity have stabilized, the costs of transition were heavy and borne by those social groups considered easily "expendable". Polish women, unfortunately, belonged to this class of the disadvantaged. To be sure, the contemporary Polish woman, as depicted in the commercial press, does not appear to be suffering from the socialist double burden; rather, she has the time for a variety of activities including 'physical conditioning', beauty and health care, intellectual and other work-related tasks, cultivating social friendships, and family recreation. 5 The "new woman" is portrayed as an individual concerned about her appearance, beauty, and dress. ${ }^{6}$ The number of

Budget and the Economic Transformation in Poland," in Blanchard, Froot and Sachs (eds.), The Transition in Eastern Europe, 111-136.

4 Poznanski, Poland's Protracted Transition, xxii, 207, 209, 210, 264, 289; Higley, Pakulski and Wesolowski, "Elite Change and Democratic Regimes in Eastern Europe," 11; Jacek Wasilewski, "Elite Circulation and Consolidation of Democracy in Poland," in Higley, Pakulski, and Wesolowski (eds.), Postcommunist Elites and Democracy in Eastern Europe, 163-187, pp. 182, 183; Hunter and Ryan, From Autarchy to Market, 203, 204; Slay and Vinton, Poland to 2005, 65, 78; Agh, Emerging Democracies, 65; Goldman, Revolution and Change in Central and Eastern Europe, 246; Millard, Polish Politics and Society, 32, 33; Sanford, Poland: The Conquest of History, 111; and Michta, "Democratic Consolidation in Poland After 1989," 66, 86, 102, 103.

${ }^{5}$ Przyjaciolka, 46 (15-21 November, 1997), 33.

6 Marody and Giza-Poleszczuk, "Changing Images of Identity in Poland," 167, 169, 170, 174. 
businesses owned and managed by women has increased significantly. ${ }^{7}$ Women's organizations have also mushroomed, with a good amount of support for the Democratic Union of Women. ${ }^{8}$ A few women have assumed leading positions in politics. 9

From a comparative perspective, words and expressions such as 'feminist', 'emancipation', women's liberation, and 'equality of the sexes' have begun to be debated more seriously in the Russian society as well.10 Russian women are now engaging themselves in a variety of occupations and organizations. They are particularly visible in secretarial jobs and in financial services. Private training courses are also offering a range of vocational subjects to women. Women's organizations such as Missiya, Guildia and Image have helped in creating avenues of employment for women. Though they provide traditional 'home-based' opportunities, their efforts are aimed not at reinforcing the 'genderization of work order' but in providing a 'safety-valve' for women until they are able to find work more appropriate to their abilities. 11

Unfortunately, while both the Polish and Russian women appear to be more emancipated on the surface, reality is a little different. Polish communism has been replaced by Catholic and free-market ideologies, both of which have victimized women in the economic, political, and social realms. ${ }^{12}$ Many ideological constraints still continue to undermine women's personal liberation and emancipation. The role and position of women in contemporary Polish society remain conditioned by traditional patriarchal attitudes and opinions. Within the home, women are perceived as the 'second' partners in marriage. Most men, and many women, consider occupational roles for women subordinate to their home obligations. 13 The reduction in the number of spaces in child-care centers and the closure of several nursery schools have both forced many

\footnotetext{
7 See Barbara Dobkiewicz and Anna Kowalczyk, Piekne, madre i bogate, czyli, Polskie biznesmenki (Warsaw, 1992) for women serving as directors and managers of several enterprises and managements. See also Krystyna Mala, "Women face Capitalist Poland's New Front," in The Boston Globe, (January 30, 2000), A-32.

8 Przyjaciolka, 15 (11 April, 1991), 2.

9 See for example a description of Barbara Bilda, the Minister of Spatial Economy and Building in Przyjaciolka, 29 (21 July, 1994), 12, 13.

10 Olga Lipovskaya, "The Mythology of Womanhood in Contemporary 'Soviet' Culture," in Anastasia Posadskaya (ed.), Women in Russia: A New Era In Russian Feminism (London and New York, 1994), 123134. See also Goscilo, Dehexing Sex. According to Goscilo, the new grammarians of gender are 'de-sexing' traditional and subordinate images of Russian womanhood associated with the accusative (object), dative (passive recipients) and instrumental (helpers of action).

11 Bridger, Kay, and Pinnick, No More Heroines?

12 Urszula Nowakowska, “The New Right and Fundamentalism," in Tanya Renne (ed.), Ana's Land: Sisterhood in Eastern Europe (Boulder, 1997), 26-33.

13 Ewa Gontarczyk-Wesola, "Women's Situation in the Process of Change in Poland," in Renne (ed.), Ana's Land, 34-41.
} 
women to remain in the home. ${ }^{14}$ In addition, single parent families are also on the increase and a large percentage of women live as 'lonely' mothers in poverty. ${ }^{15}$ And even when means permit, women's household chores, including cooking, cleaning, and 'heroically baking cakes' are all stressful activities. 16

The 'cult of motherhood' has also been reinvigorated in contemporary Russia, and women's reproductive and 'domestic' nurturing roles are seen as crucial to the survival of the national or ethnic community. The Russian society is becoming increasingly and aggressively re-masculinized. At the same time, women are suffering because subsidized child-care and paid maternity leave are no longer guaranteed. There has been a dramatic increase in single-parent homes, forcing many women to go on a "birth strike". 17

Meanwhile, outside the home, Poland's economic transition to a market economy has increased unemployment figures for women, much more so than for men. ${ }^{18}$ From 1989 to 1997 , female employment fell by $22 \%$. The feminized spheres of education and health-care services especially suffered from cutbacks. 19 While more women are establishing their own businesses, those with limited financial resources suffer from sex segregation in the labor force and occupy less prestigious jobs with lower pay. 20 Women, especially those pregnant, complain of lack of respect and consideration on the part of employers. 21 The older generation, men and women, has also been adversely affected by the transition to a capitalist economy.

The preoccupation of political leaders on 'high politics' and the corresponding neglect of local politics and social issues have contributed to the neglect of issues that are of particular concern to women. 22 This is made worse by the fact that the post-

\footnotetext{
14 Przyjaciolka, 26 (27 June, 1991), 2; and Victoria Averil Velkoff "Women in Poland," U.S. Department of Commerce Economics and Statistics Administration: Bureau of the Census, Population Division, International Programs Center (July 1995), 1-8, p. 5.

15 Przyjaciolka, 7 (13 February, 1992), 2; and Przyjaciolka, 38 (23 September, 1993), 4.

16 Przyjaciolka, 13 (29 March, 1990), 2.

17 For all these issues see Barbara Einhorn, Cinderella Goes to the Market: Citizenship, Gender, and Women's Movements in East Central Europe (London and New York, 1993); V. Perevedentsev in Vitalina Koval, Women in Contemporary Russia (Providence, 1995); Rebecca Kay, Russian Women and Their Organizations: Gender, Discrimination and Grassroots Women's Organizations, 1991-1996 (Houndmills, Basingstoke, Hampshire and New York, 2000), 34; and Lynne Attwood, "The Post-Soviet Woman in the Move to the Market: A Return to Domesticity and Dependence?" in Marsh (ed.), Women in Russia, 255266.

18 Przyjaciolka, 4 (24 January, 1991), 5.

19 Mala, "Women face Capitalist Poland's New Front," A-32. For increasing unemployment of women see also Millard, Polish Politics and Society, 149, 178.

20 Velkoff "Women in Poland," 1-8.

${ }^{21}$ Przyjaciolka, 5 (30 January, 1992), 2.

22 Sharon L. Wolchik, "Women and the Politics of Gender in Communist and Post Communist Central and Eastern Europe," in Ramet (ed.), Eastern Europe, 285-303, p. 300.
} 
communist transition has reinforced the political marginality of women. Their minimal representation in the different governmental ministries, political groups and trade unions is tragic. Women's groups remain small and are often local in scope. Moreover, various political forces as well as the Catholic Church are vigorously advocating a 'return to tradition' and have succeeded in passing harsh anti-abortion legislation. 23 The identification of Polish "nationhood" with Catholicism has nurtured a conservative social agenda which stresses the importance of child-bearing and the "dangers of feminism".24

Ironically, while the conservative political and religious climate in contemporary Poland casts images of "respectable womanhood", the prolific images of female nudity in the press undermine this Catholic tradition. Pornographic pictures of women are being published not only in the women's periodicals, but also displayed in advertisements on the streets of Warsaw. 25 A few women did protest these visual representations of female nakedness. But they were quickly reminded by the producers of these obscene portraits

23 See Przyjaciolka, 4 (24 January, 1991), 5; Velkoff, "Women in Poland," 7; Barbara Lobodzinska, "Family, Women, and Employment in Poland and Other Central European Countries: Ideology of Equality and Reality of Discrimination," in The Polish Review, XLII, 4 (1997), 447-469, p. 461; Millard, Polish Politics and Society, 122, 178; and Renata Siemienska, "Women in the Period of Systemic Changes in Poland," in Journal of Women's History, 5, 3 (Winter, 1994), 70-90, pp. 85-87. On the abortion debate, and the conservative role of the church in Poland after 1989, see Sabrina P. Ramet, Whose Democracy? Nationalism, Religion, and the Doctrine of Collective Rights in Post-1989 Eastern Europe (Lanham, Maryland, 1997), 97-110; Bielasiak, "Poland," 156; Walczewska, Damy, rycerze i feministki, 38, 39; Eleonora Zielinska, "Between Ideology, Politics, and Common Sense: The Discourse of Reproductive Rights in Poland," in Gal and Kligman (eds.), Reproducing Gender, 23-57; Wanda Nowicka, "Ban on Abortion in Poland. Why?" in Renne (ed.), Ana's Land, 42-46; Ramet, Nihil Obstat, 296-307; Mala, "Women face Capitalist Poland's New Front," A-32; Goldman, Revolution and Change in Central and Eastern Europe, 248; Malgorzata Fuszara, "Abortion in Poland"; and Wanda Nowicka, "Foundations of the Law," in Renne (ed.), Ana's Land, 47-51. For the political and economic marginalization of women in postcommunist Poland see also Malgorzata Fuszara, "New Gender Relations in Poland in the 1990s," in Gal and Kligman (eds.), Reproducing Gender, 259-285; Anna Titkow, "Polish Women in Politics," in Marilyn Rueschemeyer (ed.), Women in the Politics of Postcommunist Eastern Europe (New York, 1994), 29-34; and Joanna Regulska, "Transition to Local Democracy," in Rueschemeyer (ed.), Women in the Politics of Postcommunist Eastern Europe, 35-62.

24 Ewa Hauser, "Traditions of Patriotism, Questions of Gender: The Case of Poland," in Ellen E. Berry (ed.), Post Communism and the Body Politic (New York, 1995), 78-104, p.82; and Millard, Polish Politics and Society, 121, 140.

25 The women's periodical Kobieta $i$ Zycie displays an excessive pre-occupation with female nudity, beauty pageants, and 'seksoholism'. While some pictures are clearly erotic in nature, others cast images of maternity which includes pictures of childbirth and mothers nursing their babies. See for example, $\underline{\mathrm{KiZ}}, 24$ (13 June, 1990), 10; KiZ, 21 (23 May, 1990), several pictures throughout this issue; KiZ, 49 (4 December, 1991), 2, 3; KiZ, 34 (21 August, 1991), cover page; KiZ, 5 (30 January, 1991), 6, 7; KiZ, 18 (1 May, 1991), 6; KiZ, 35 (26 August, 1992), 8, 9; and $\underline{\mathrm{KiZ}}, 20$ (22 May, 1993), 8, 9. Even the women's periodical Przyjaciolka has become very glamorous, professional, and colorful in content. Throughout the 1990s, this magazine provided a lot of coverage on fashion, vacationing, sex, elite lifestyle, good food, beauty pageants, and female nudity. All the past rhetoric of building socialism and an 'economic crisis' has been buried. See for example, Przyjaciolka, 23 (6 June, 1995), 16, 17; and Przyjaciolka, 15 (11 April, 1991$), 6$. 
that 'this is not pornography!'26 Meanwhile, there is also growing concern over issues regarding domestic violence against women, rape, prostitution and trafficking of female adolescents in Poland. 27

Thus, the contemporary problems for Polish women include unemployment and a falling standard of living, the lack of substantial female political representation and the virtual absence of a women's agenda in the 'democratic' government, erosion of social welfare, the curtailment of reproductive rights, the lack of recognition of violence against women, and growing concerns about the deteriorating health services. The institution of motherhood, reinforced by the close nexus between Catholic Church and patriarchal postSolidarity regimes, remains the most ubiquitous construction of Polish womanhood. The masculine images of democracy have sustained the misogynist Polish culture and subordinated women's interests to that of the family and society. Thus, Polish women remain exploited and victimized both at home and at the workplace. They are concentrated in feminized occupations, receive inequitable pay, are drastically underrepresented in managerial positions and other skilled professions, and perform tedious housework. 28

The problems facing Polish women under post-communism are similar to the experiences of their Russian and Eastern European counterparts. For example, the inherent lack of solidarity and feminist consciousness, the involuntary exodus of women en masse from the workforce, the feminization of poverty, the propagation of women's 'natural mission', the male violence against women, and the development of a new sexual culture marked by teenage promiscuity, glamour modeling, commercial pornography, prostitution, and beauty pageants, have all slowed and limited the success of any program to de-masculinize the postcommunist Russian patriarchal political culture. Thus, both the

\footnotetext{
26 Zycie, $(20$ April, 1999), 3.

27 Urszula Nowakowska, "Violence Against Women: International Standards, Polish Reality," in Chris Corrin (ed.), Gender and Identity in Central and Eastern Europe (London, 1999), 41-63.

28 See Zycie Warszawy, (24-25 April, 1999), 1; Jill M. Bystydzienski, "The Effects of the Economic and Political Transition on Women and Families in Poland," in Bridger (ed.), Women and Political Change, 91109, pp. 91, 106; Long, We All Fought For Freedom; Barbara Lobodzinska, "Domestic and External Perception of Family and Women's Issues in Poland and Other Post-Socialist Countries," in The Polish Review, XLV, 3 (2000), 258-303, p. 258; Elzbieta Tarkowska, "An Underclass without Ethnicity: The Poverty of Polish Women and Agricultural Laborers," in Rebecca Jean Emigh and Ivan Szelenyi (eds.), Poverty, Ethnicity, and Gender in Eastern Europe During the Market Transition (Westport, 2001), 83-122; Barbara Lobodzinska (ed.), Family, Women, and Employment in Central-Eastern Europe (Westport, 1995), 267; and Mala, "Women Face Capitalist Poland's New Front," A-32.
} 
Russian and Polish women remain, as in the past, subordinate to the gendered definitions of politics and their resonating impact in all others spheres of daily life. 29

How have the changes and continuities in women's identities in contemporary Poland affected their participation in physical culture? How has the collapse of communism in Poland impacted the organization of sports and physical education? What are the images and identities of female athletes in Poland today? The extensive political and economic reforms have, unfortunately, forced many east European governments to marginalize the importance of physical culture and sport. In 1991, the experiment to promote a Soviet-led supra-national 'socialist patriotism' through the medium of sports failed. The athletes from the Baltic republics were the first to withdraw from the Soviet teams, heralding the collapse of the Soviet elite sport system. Goskomsport suffered the fate of the other Union structures and was dissolved in late November, 1991. Thereafter, Soviet sport began to devolve into the sport of the Soviet successor states, as each nation formed its own 'national' teams and Olympics committees. ${ }^{30}$

The dissolution of the Soviet Union adversely affected the organization of sports throughout eastern Europe. Playing standards suffered in the midst of widespread domestic unrest and deepening economic malaise in Russia and other parts of eastern Europe. The rising costs of renting stadia and training halls, the lack of state subsidies, and the typical incompetence of inexperienced new leaders have all necessitated the closure of many elite sports schools. Even at the popular level, most people do not have the time and energy to play sports. The daily struggles to survive and the frequent resort to drugs and alcohol by the youth have made the restoration of sports and physical culture in Russia and other neighboring republics an arduous task. 31

\footnotetext{
29 For the economic, social and political marginalization of Russian women in contemporary times, see Eric Shiraev, "Gender Roles and Political Transformations," in Betty Glad and Eric Shiraev (eds.), The Russian Transformation: Political, Sociological, and Psychological Aspects (New York, 1999), 199-212; Anastasia Posadskaya, "Women as the Objects and Motive Force of Change in Our Time," in Posadskaya (ed.), Women in Russia, 8-13; Paul W. Goldschmidt, "Pornography in Russia," in Adele Marie Barker (ed.), Consuming Russia: Popular Culture, Sex, and Society since Gorbachev (Durham, 1999), 318-336, p. 318; Bridger, Kay and Pinnick, No More Heroines?; and Barbara Clements, "Introduction: Accommodation, Resistance, Transformation," in Clements, Engel and Worobec, Russia's Women, 1-16.

30 See Soeren Damkjaer, "The Final Game for Soviet and CIS Sport," in Wilcox (ed.), Sport in a Global Village, 319; Howell, "Sport and Glasnost: A Case Study of Estonia," 331; and Peppard and Riordan, Playing Politics, 138, 139.

31 See Edelman, Serious Fun, 241-243; Damkjaer, "The Final game for Soviet and CIS Sport," 322; Oleg A. Milshtein, "Sport in Modern Europe," in Wilcox (ed.), Sport in a Global Village, 306-308; Howell, "Sport and Glasnost: A Case Study of Estonia," 336, 338; Riordan, "Rewriting Sports History," 258; and Hilary Pilkington, Russia's Youth and its Culture: A Nation's Constructors and Constructed (London and New York, 1994), 263-267. See also Dmitri Radyshevsky, "The Mafia and American Football," in Riordan, Soviet Social Reality in the Mirror of Glasnost, 184, 185, for an interesting example of how some
} 
In Poland, not only have several sports programs been eroded, but there has also been a consistent reduction in the number of sports participants, clubs and coaches. Industrial institutions and factories, now driven by profits, have discontinued their support for sport programs. 32 In 1990-91, state expenditures on social services were drastically curtailed, and sports and tourism, in particular, suffered a $58.1 \%$ decline in its budget. 33

The original significance and value of sport as an important source of health and education in Poland has been undermined by the unfavorable consequences of the economic and political transitions, as well as by an upsurge in hooliganism and brawls in stadiums, sports halls, and on the streets. This 'alarming' situation in sports has led many to appeal to government officials to provide some semblance of order and security in the organization of contemporary Polish physical culture. This public outcry has not only expressed the need for structural transformations in sport at both the provincial and national levels of organization, but also for reforming physical culture by forming a united front of teachers and pedagogues, parents, mass media, the military apparatus, sports institutions, and social welfare organs. 34

Meanwhile, western influence and private sponsorship have bifurcated the monolithic socialist sports structure into a dualistic combination of the old and obsolete sports clubs and a new private sports sector. Despite the fact that services rendered by private health clubs are more expensive, they are usually preferred for their attractive programs and up-to-date equipment and modern facilities. ${ }^{35}$ Unfortunately, while commercialization and privatization have begun to reinvigorate the lethargic and stagnant structural organization of Polish physical culture, this private sponsorship has promoted

ex-thieves have taken to American football. They claimed that the system had pushed them into crime, but that football gave them a chance to make honest money. They are an example of those racketeers trying to live life on the right side of the law!

32 Victor Zilberman, "East European Countries' Transition to Western Model of Sport Organization: Major Trends Reflecting Changes," 32, 4 (Summer, 1996), 31-36.

33 Slay, The Polish Economy, 113.

$34 \underline{\mathrm{PzS}}, 44$ (8 March, 1990), 1; and PzS, 88 (25 May, 1990), 2. For more on organized crime, as well as the acute economic and social problems see Bohdan Jung, "Economic, Social and Political Conditions for Enjoyment of Leisure in Central and Eastern Europe of 1992--the Polish Perspective," 8-12. For the low level of physical culture in the army see Ryszard Przeweda, "Zbior wazniejszych wynikow i wnioskow," in Ryszard Przeweda (ed.), Wychowania fizyczne w Polsce (Warsaw, 1992), 168-171, p.171.

35 Jolanta Zysko, Zmiany struktury organizacyjnej kultury fizycznej w Polsce po 1989 (Autoreferat rozprawy doktorskiej, AWF Warsaw, 1997), 20-24; and Teresa Wolanska, "Changing Society--Changing Values of Sport For All and Sports Policy in Poland," in Pekka Oja and Risto Telama (eds.), Sport For All. Proceedings of the World Congress on Sport for All, Tampere, Finland, 3-7 June 1990 (Amsterdam and New York, 1991), 407-412, p. 408. 
the idea of "sport for money; money for sport".36 For this reason, while Poland's postcommunist transition provided the space for the evolution of a new pluralistic system of sport and physical culture, the decreasing numbers of sports clubs and members due to increasing costs have awarded the benefits of this plurality to only a few who have the necessary means to afford them. While the control mechanisms of the former centralized sports apparatus have been reduced, and the sports clubs, federations and confederations provided with more autonomy, contemporary Polish physical culture is still neither efficient nor democratic. 37

The limited state budget for physical culture activities has forced many popular Polish athletes to transfer to non-Polish clubs. And such deals are usually struck in millions of dollars. 38 Poland's soccer team which received international recognition for winning a bronze medal in the 1974 World Cup, significantly deteriorated in the late 1980s for this reason. Now, any Polish athlete with talent most often chooses to play abroad. 39 Such athlete migrations have had negative effects on sports programs throughout Eastern Europe. In Russia, for example, the sport spectacles and the athletes who participate in them have all become commodities produced and consumed in an intensely competitive world market. The shift from state control and support for sports towards private commercial sport has resulted in a 'brain' and 'muscle' drain of top athletes, coaches, sports medics and scientists to the richest overseas buyer. 40

Among the many other problems in the organization of sport in contemporary Poland, the development of physical culture in the countryside is still constrained by inadequate investment, the low standard of housing and sanitation, and infrastructural deficiencies. While projects designed to promote 'agro-tourism' have been planned, linguistic barriers and the poor standard of living provide little incentive for foreign tourists to experience the richness of the Polish countryside. 41

\footnotetext{
$36 \underline{\mathrm{PzS}}, 173$ (26 September, 1990), 5; and $\underline{\mathrm{PzS}}, 218$ (29 November, 1990), 1.

37 See Kazimierz Doktor, "Sport Legislation in Poland," in Sports Legislation in Europe: Evolution and Harmonization, (19-20 September, 1991), 24-25.

38 PzS, 24 (4 February, 1997), 1. See also Lech Jaczynowski and Jolanta Zysko, "Przeksztalcenia w systemie organizacyjnym kultury fizycznej w Polsce w dobie transformacji ustrojowej, Czesc 1," in Kultura Fizyczna, 48, 11-12 (1994), 7-14.

39 Zilberman, "East European Countries' Transition to Western Model of Sport Organization," 34.

40 Robert Edelman, "There Are No Rules On Planet Russia: Post-Soviet Spectator Sport," in Barker (ed.), Consuming Russia, 217-242, pp. 219, 237; and Riordan, "Sport and Nationalism," 15.

${ }^{41}$ Nasz Dziennik, (28 April, 1999), 10. For the poor hygienic conditions in the countryside, as well as the material and infrastructural shortages to support a rural sports complex, see Wieslaw Siwinski, Kultura fizyczna: profilaktyka, zdrowotna, wychowania: raport z badan empirycznych (Poznan, 1993), 50, 51, 53, 96. For more on the need to develop tourism see PzS, 88 (25 May, 1990), 2.
} 
Meanwhile, urban housing communities have begun to address the recreational needs of city residents. The housing authorities have attached more importance to providing a suitable infrastructure which would encourage city dwellers to spend leisure time in a physically active way. Their community-family recreation programs are called "physical recreation for the benefit of the families in housing communities". 42

The Academies of Physical Education in Poland are also striving to provide an appropriate academic environment for their graduates. The Academy of Physical Education in Poznan, for example, is a member of several international organizations such as the International Society of the History of Physical Education Sport (ISHPES), the International Council of Sport Science Physical Education (ICSSPE), the International Association of Sport Kinetics (IASK), the European Leisure Recreation Association (ELRA), and the Alliance of Universities for Democracy. The Academy organizes many international and national sports conferences (for example, the International Conference of "Sports Kinetics" in 1993), and also makes arrangements for a variety of social, political, cultural and sports activities for the students. 43 The Academy of Physical Education in Warsaw is also in the process of constructing new infrastructural facilities. 44

The discussions on the lack of a 'modern' physical education system for young boys and girls in schools have also increased. Unfortunately, while spontaneous sports activity after school hours for children has become common in the residential neighborhoods, there is little interaction between students and teachers within the school. Material shortages, weak pedagogy, and lack of family support to motivate their children to engage in sports have all resulted in a 'crisis' in school physical education. 45

The State Office of Physical Culture and Tourism (Urzad Kultury Fizycznej $i$ Turystyki, UKFiT), formed in 1991, is dealing with similar problems of economic

42 "Poland: Physical Recreation in the Urban Community," in Sports Information Bulletin, (25 June, 1991), 1929-1932, pp.1929, 1930.

43 Maciej Luczak, “AWF," in Gaj, (ed), Dzieje Akademii Wychowania Fizycznego, 218-236 and 244-262. See also Wieslaw Osinski, "Akademia wychowania fizycznego im. Eugeniusza Piaseckiego w Poznaniu w roku Akademickim 1993/94 i perspecktywy rozwoju," in Gaj, (ed.), Dzieje Akademii Wychowania Fizycznego, 266-285, p.269-273. For problems in the academies, especially critical remarks on the lack of an effective model of physical education, see Elzbieta Rutkowska, Adam Fijewski, "Prospekcja w wychowaniu fizycznym mlodziezy ackademickej na przykladzie studentow medycyny," in Przeweda (ed.), Wychowania fizyczne w Polsce, 82-112, pp.89, 91.

44 During a visit to the AWF, Warsaw in the Spring of 1999, Maria Rotkiewicz very kindly gave me a tour of the institution and showed me the on-going construction of a long-awaited indoor track.

45 Przeweda, "Zbior wazniejszych wynikow i wnioskow," 169, 170; Wieslaw Osinski, "Aktualne problemy wychowania fizycznego w Polsce," in Kultura Fizyczna, 1-2 (1998), 15-17; and Anna Zukowska, "Wychowanie fizyczne w szkole," in Przeweda (ed.), Wychowania fizyczne w Polsce, 22-39, pp.23, 39. 
management and political opacity as in other branches of Poland's governmental complex. Not only is the national sports establishment struggling with post-communist political vicissitudes, but also seeking private ventures and sponsorship to keep itself afloat. 46

At the same time, sports leaders are also interested in cooperative work with the state and ecclesiastical authorities to reform and popularize the importance of physical education for good health and fitness. 47 The proclamation adopted by the participants of the first 'National Congress on Sport for All in Poland' (Warsaw, 5 May 1990), which included members of sports societies and organizations, emphasized the need for a structural reform of the physical culture apparatus with the larger objective of improving public health. These multiple voices of concern have since then become louder, and they are forcing the government to become more attentive to the need of improving the 'health culture' of contemporary Polish society and propagate active life-styles in order to increase the level of popular physical fitness. 48 Such political, social, and religious collaboration in sport has allowed the Poles to continue their participation in sports events such as basketball, volleyball, tennis, boxing, track and field, weightlifting, swimming, bridge and more recently, jogging, bicycle riding, and the martial arts. 49

With the tumbling of all kinds of walls in the former eastern bloc, what has happened to the "super-sportswomen" of eastern Europe? The collapse of communism resulted in the disintegration of the "sports for all" program in the socialist countries. Women's physical culture, in particular, was drastically affected by the east European transition to a market economy and political "democratization". The following question, for example, was raised in the Russian women's periodical Soviet Woman: "Much has been talked about the bitter fate of undeservedly forgotten sports 'stars' of the past. When will society, finally, pay attention to those whom they had only recently applauded so loudly?"50

In post-communist Poland, women are participating in a variety of sports, including events in track and field, skiing, basketball, handball, volleyball, rifleshooting,

\footnotetext{
46 Liponski, "Still and Unknown," 21-24, 27, 34, 35.

47 For a report on the meeting of archbishop Bronislaw Dabrowski with members of the Commission of Youth, Physical Culture and Sport see PzS, 31 (13 February, 1991), 2.

48 Wolanska, "Changing Society--Changing Values of Sport For All and Sports Policy in Poland," 409, $410,411$.

49 Liponski, "Still and Unknown," 27; "Poland: Physical Recreation in the Urban Community," 1932; and Trybuna, (12 April, 1999), 22.

50 Soviet Woman, 10 (1991), 37.
} 
horse-riding, archery, gymnastics, fencing, table tennis, tennis, speed and figure-skating, swimming, oaring, kick-boxing, taekwondo, judo, karate, yoga, and chess. However, their engagement in sports is sporadic and quite dependent on the nature of the sport in question. 51 For example, according to amateur kick-boxer Agnieszka Rylik, her sport was risky and not meant for all women. This game required a lot of psychological and physical preparation. 52 In motor sports, Sylwia Przon is perhaps the only woman in Poland to engage in cinder-track racing. This sport, though popular among women abroad, is not recommended for women in Poland. 53 Also, Agnieszka Bednarska is one of the few women to actively work in any Polish football organization. While Bednarska enjoys her work in the District Union of Football in Gdansk, she is against women playing football, and argues that women should simply be 'women' 54

Women's lawn tennis, however, has become quite popular in Poland. The International Women's Tennis Tournament (Warsaw Cup, 1-9 May, 1999) received good sponsorship and publicity. 55 The accomplishments of Anna Zarska, the fourteen-yearold Polish champion, has also served as a source of inspiration. 56 In other individual sporting accomplishments, the press provided coverage of the country's great new

\footnotetext{
51 For women's participation in these sports throughout the 1990s see PzS, 44 (8 March, 1990), 1; PzS, 232 (29 November-1 December, 1991), 8; PzS, 240 (11 December, 1991), 6; PzS, 165 (25 August, 1993), 1; PzS, 101 (26-28 May, 1995), 25; PzS, 82 (26 April, 1995), 4; PzS, 123 (28 June, 1995), 4; PzS, 209 (27-29 October, 1995), 8; PzS, 71 (13 April, 1999), 3; PzS, 72 (14 April, 1999); PzS, 6 (9 January, 1997), 1; PzS, 12 (17-19 January, 1997), 1; PzS, 13 (20 January, 1999), 1; PzS, 55 (18-20 March, 1994), 13; PzS, 67 (4

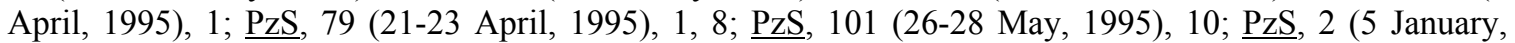
1999), 16; PzS, 72 (14 April, 1999), 2, 15; and PzS, 71 (13 April, 1999), 1, 4, 5. In other newspapers and periodicals, see also Sport, 73 (15 April, 1999), 5; Nasz Dziennik, (17-18 April, 1999), 19; Przyjaciolka, 47 (21 November, 1995), 19; Przyjaciolka, 39 (26 September, 1995), 13; Przyjaciolka, 23 (5 June, 1996), 8, 9; Zycie Warszawy, (7 April, 1999), 19; Tempo, 70 (12 April, 1999), 19; Rzeczpospolita, (9 April, 1999), 29; Rzeczpospolita, (12 April, 1999), 26; Tempo, 69 (9-11 April, 1999), 2, 7; Rzeczpospolita, (15 April, 1999), 31; Rzeczpospolita, (14 April, 1999), 28; Sport, 80 (26 April, 1999), 11; Sport, 80 (26 April, 1999), 26; Tempo, 81 (27 April, 1999), 17; Nasz Dziennik, 85 (12 April, 1999), 12; Gazeta Wyborcza, (9 April, 1999), 40; Gazeta Swiateczna, (24-25 April, 1999), 39; KiZ, 20 (22 May, 1993), 32, 33; and Magazyn Olimpijski, 3 (7 April, 1999), 4. The sports sections of the more general newspapers such as Nasz Dziennik, however, provide more coverage of masculine sporting events such as men's soccer. See for example, Nasz Dziennik, 85 (12 April, 1999). Also, for the popularity of volleyball, basketball, and handball among women see Luczak, "AWF," in Gaj, (ed), Dzieje Akademii Wychowania Fizycznego, 254; and Osinski, "Akademia wychowania fizycznego im. Eugeniusza Piaseckiego w Poznaniu," 279. For more portraits of women in the different sports see Jerzy Gorko, Sprintem przez historie: $Z$ dziejow sportu w regionie polnocno-wschodnim (Bialystok, 1996).

52 PzS, 246 (21 December, 1992), 8.

53 PzS, 50 (10-12 April, 1995), 18.

54 PzS, 149 (3 August, 1995), 7.

55 For press publicity of this event, see Rzeczpospolita, (30 April-3 May 1999), 28-30.

56 For more on Anna Zarska see $\underline{\mathrm{PzS}}, 61$ (28 March, 1994), 1; $\underline{\mathrm{PzS}}, 115$ (16-18 June, 1995), 17; and Gazeta Wyborcza, (29 April, 1999), 31.
} 
sensation in badminton, Katarzyna Krasowska. 57 Meanwhile, Zofia Borkowska, an applicant in the law office of Weil, Gotshald, and Marges, has come into the limelight for not only having won the Second Professional Grand Prix of Warsaw in bowling, but for also organizing a women's league "Czarna kula" for representatives of the important law offices. 58 Finally, in table tennis, the press mourned the demise of two-time Polish champion Magdalena Kucharska on 10th March, 1999.59

It is significant that the accomplishments of many individual female athletes are quite dependent on private sponsorship. For example, the 21-year-old Polish champion in tennis, Katarzyna Teodorowicz, received sponsorship from the Bytom firm 'Magaset',60 Wanda Panfil signed contracts with Reebok and some other US companies.61 Conversely, the survival of those who are unable to secure any form of patronage is in jeopardy. For example, according to Dorota Nowosielska, the best Polish volleyballist from Bydgoszscz, her continued position in the sports club depended on its financial survival. 62

At the high performance level, Polish sportswomen are still recognized for their sporting excellence. The results of the annual popular plebiscites of the sports newspaper Przeglad Sportowy once again reflects a popular opinion quite favorable to women's participation in sports.

${ }^{57}$ PzS, 23 (3 February, 1997), 9.

58 Zycie Warszawy, (27 April, 1999), 18.

59 Zycie Warszawy, (13-14 March, 1999), 18.

60 PzS, 43 (3 March, 1993), 1.

61 PzS, 8 (11-13 January, 1991).

$62 \underline{\mathrm{PzS}}, 32$ (16 February, 1993), 8. 
Results of the popular plebiscites of sports newspaper Przeglad Sportowy 63

\begin{tabular}{|c|c|c|c|}
\hline Year & Name & Event & Position \\
\hline \multirow[t]{2}{*}{1990} & Wanda Panfil-Gonzalez & Modern Pentathlon & 1 \\
\hline & Dorota Idzi & Modern Pentathlon & 7 \\
\hline \multirow[t]{3}{*}{1991} & Wanda Panfil-Gonzalez & Track and Field & 1 \\
\hline & Dorota Idzi & Modern Pentathlon & 6 \\
\hline & Wanda Rutkiewicz & Alpinist & 7 \\
\hline \multirow[t]{2}{*}{1992} & Iwona Kowalewska & Modern Pentathlon & 5 \\
\hline & Izabela Dylewska & Kayaking & 8 \\
\hline 1993 & Beata Maksymow & Judo & 4 \\
\hline \multirow[t]{2}{*}{1994} & Barbara Hajcel and & Kayaking & 4 \\
\hline & Elzbieta Urbanczyk & & \\
\hline \multirow[t]{2}{*}{1995} & Joanna Jakimiuk & Fencing & 6 \\
\hline & Dorota Idzi & Modern Pentathlon & 10 \\
\hline \multirow[t]{2}{*}{1996} & Renata Mauer & Shooting & 1 \\
\hline & Aneta Szczepanska & Judo & 9 \\
\hline \multirow[t]{2}{*}{1998} & Anna Sulima & Modern Pentathlon & 7 \\
\hline & Alicja Peczak & Swimming & 8 \\
\hline
\end{tabular}

63 For details on the plebiscites and gala festivities associated with the recognition ceremonies see individual January issues of the 1990s. For example, see PzS, 4 (7 January, 1991), 1; PzS, 6 (9 January, 1995), 1; $\underline{\text { PzS }}, 5$ (8 January, 1990), 1; $\underline{\text { PzS }}, 6$ (11 January, 1993), 1; $\underline{\text { PzS }, ~} 3$ (6 January, 1992), 1; PzS, 6 (10 January, 1994), 1; $\underline{\text { PzS }}, 11$ (18 January, 1999), 1; $\underline{\text { PzS }, ~} 5$ (8 January, 1996), 1; and $\underline{\text { PzS }}, 3$ (6 January, 1997), 1. 
At the recently concluded 2000 Olympic Games in Sydney, Australia, the Polish female athletes won medals in rifleshooting, hammer throw, fencing, weightlifting and kayaking. 64 These sports champions, no doubt, will find a position in the forthcoming popular plebiscites conducted by the leading Polish sports newspapers.

Unfortunately, women's participation in sports in contemporary Poland has more problems than prospects for success. The limited financial support has narrowed the opportunity to play to a small group of the rich and privileged. The other obstacles to women's physical culture include conservative resistance on the part of the 'older' generation to appreciate and adapt to the changing environment, the insufficient attention to needs of girls in school physical education, the general lack of interest and motivation, and poor sports facilities for women in rural areas. 65 In addition, the images of sports fashion and female nudity in the sports press have raised more voices of concern. 66

However, while these obstacles cause a good deal of frustration, the growing interest in the biological, medical and psychological aspects of women's participation in sport is heartening. A numbers of books and articles have been published in the recent past to discuss various medical and sociological issues in women's physical culture. 67

Several conferences have also been organized to invigorate medical research and examine the 'cultural meanings' of women's sport. For example, on 27th November, 1995 the AWF Warsaw organized a conference based on the theme "Sport in Women's Life" (Sport w Zyciu Kobiety). At this convention, discussions focused on the images of women's sports in a context of modernization and its impact on gender relations, the

64 At the 2000 Olympic Games, Polish women won gold in rifleshooting (Renata Mauer-Rozanska) and hammer throw (Kamila Skolimowska); silver in fencing and weightlifting (super heavy weight category); and bronze in kayaking. The Polish men won gold in rowing, track and field; silver in kayaking and weighlifting; and bronze in kayaking and gymnastics.

65 Ryszard Przeweda, "Koncepcja, cele i efekty badan," in Przeweda (ed.), Wychowania fizyczne w Polsce, 7-19, pp. 7, 8; Maria Sadowska, "Znaczenie spontanicznych form aktywnosci dzieci i mlodziezy oraz wczesnej inicjacji w procesie wychowania do kultury fizycznej," in Przeweda (ed.), Wychowania fizyczne w Polsce, 43-52, pp. 48, 52; and "Perspectives from Abroad," in Coaches Report, 1(2) 1994, 21-22. One bright spot in the development of privatization within Poland is the growth of health and fitness centers which will serve a need for at least the country's upper crust to exercise. These may sponsor athletic potential. See Catherine O'Brien, "The Legacy of Sport for Women in the Eastern Bloc," in Journal of Comparative Physical Education and Sport, 18, 1, (1996), 19-23, p.22.

66 For some images of nudity and sports see $\underline{\mathrm{PzS}}, 79$ (10 May, 1990), 4; and $\underline{\mathrm{PzS}}, 228$ (13 December, 1990), 6. For sports fashion in tennis see $\underline{\mathrm{PzS}}, 79$ (10 May, 1990), 4. For more images of fashion in women's sport see the women's periodical Twoj Styl, 9/98 (September, 1998), 98-101.

67 On medical research for sportswomen see Antony K. Gajewski (ed.), Kobieta sport zdrowie (Warsaw, 1998); and A. Czajkowska (ed.), Wysilek fizyczny, kobieta, zdrowie (Warsaw, 1998). The work by Elzbieta Skierska (ed.), Sport Kobiet (Warsaw, 1996) also contain many articles on the scientific-biological aspects of women's sports. For a sociological analysis of women's participation in sport, see several articles in Anna Pawlak (ed.), Polska Manager-Woman Sportu (Warsaw-Krakow, 1998); and Zukowska (ed.), Kobieta jako kreatorka aktywnosci sportowej w rodzinie. 
psychological factors in women's sports, the lack of active women's participation in sports due to family obligations and material considerations, scientific research and training, and ideas of femininity and the domination of men in the world of sports. This conference was followed by another in 1996 on the theme "Women's Sports" ("Sport Kobiet"), and in November 1997 on the theme "Women as Creators of Active Sports in the Family" ("Kobieta jako kreatorka aktywnosci sportowej w rodzinie"). 68

Further, the Polish Women's Sports Federation (Polskiego Stowarzyszenia Sportu Kobiet, PSSK), founded on 21st March 1994 under the presidency of the "First Lady" of Polish sport Irena Szewinska, has been formed to provide greater cohesion, organization, and structure to women's physical culture in contemporary Poland. This federation convenes conferences and meetings at the national and international levels, provides opportunities for developing sports and recreation for women and their families, and seeks collaboration with trainers, pedagogues, social and political organizations, and the mass media in promoting sport among women and building a healthy social life. The principal objective of the members of the Women's Sports Federation is to obtain equal opportunities for women in sports. 69 Finally, the governmental endorsements highlighting the importance of women's sport as an integral part of maintaining a healthy social life is also encouraging. 70

From a comparative perspective, the pitiful material conditions under which women live internationally, as well as the rigid religious policies and traditional ideologies of 'motherhood' still preclude the participation of women in competitive sports. However, western sportswomen, because of their relative material prosperity, remain privileged over their counterparts in other regions of the world.

In today's reconceptualization of masculinity and femininity, athletic women in the west are seen less by most men as transgressively masculine. ${ }^{71}$ Women's consciousness about

\footnotetext{
68 See Zukowska (ed.), Sport w zyciu kobiety, 5; and Zukowska (ed.), Kobieta jako kreatorka aktywnosci sportowej $w$ rodzinie, 5. For more details on the specific psychological and sociological discussions of women's engagement (or lack off) in sport, see several articles in these two edited books.

69 For the organization and objectives of the Polish Women's Sports Federation see Zycie Warszawy, (29 April, 1995), 17; PzS, 91 (11 May, 1994), 2; Rotkiewicz, "Rozwoj spolecznych organizacji sportu kobiet w Polsce," 77; Program of Activities for the Polish Women's Sport Federation for Years 1995-1997 (Polskiego Stowarzyszenia Sportu Kobiet, PSSK); Statut Stowarzyszenia Sportu Kobiet w Polsce; and Regulamin Polskiego Stowarzyszenia Sportu Kobiet (oddzial Krakow). On Irena Szewinska as the queen of sports, best sportswomen, president of the Polish Union of Track and Field, member of International Olympic Committee, and president of the Polish Sports Federation of Women see also PzS, 14 (21 January, 1997), 13; and PzS, (11 January, 1999 Wydanie Specjalne 80 Lat PKOI), 1, 5, 6.

70 For an official reaffirmation of the importance of women's sport in Katowice province see Decyzja Nr. Sp-II-253/95 Katowice, dn. 30.08.1995 (Urzad Wojewodzki w Katowicach. Wydzial Sportu i Turystyki).

${ }^{71}$ Guttmann, The Erotic, 130, 131.
} 
their own physicality is changing and sports have become social experiences that for increasing numbers of women are positive, pleasurable and empowering. ${ }^{72}$ The modern western sportswoman represents a multiplicity of ethnic and racial backgrounds and is able to pursue a variety of sports, including the traditional male disciplines such as the oriental martial arts and weightlifting. 73

In America, for example, women's football and ice hockey has become more popular in the recent years. The US women's ice hockey team won gold in the Nagano Winter Olympics in 1998. 74 The following year, the US women's soccer team won the World Championship. There is more concern now in the American popular culture to train young girls in sports from the very beginning. 75

In Britain, gender divisions in leisure are being challenged and broken down under pressure from women in conjunction with forces generated within consumer culture, so as to promote family-centered leisure and especially family-centered sporting activity. 76 More British women are competing professionally, and there is greater emphasis on the women's "keep fit movement" at the popular level. Women have also made forays into the very male-dominated football. 77

Unfortunately, even as contemporary definitions of femininity in the west have changed, the sporting institutions and resources continue to be dominated by men. The larger socio-economic and political context continues to shape and constrain the extent to which women can wage fundamental challenges in the present commercialized and maledominant structure of organized athletics. Although significant changes have taken place, the underlying assumptions regarding women's physical inferiority continue to operate in contemporary times. Ultimately women's efforts to attain meaningful leisure, unrestricted access to sport, and athletic self-determination will be part and parcel of transforming the broader social relations of gender within which sporting life takes place. 78

\footnotetext{
72 Hargreaves, Sporting Females, 289.

73 Reet Howell, "Generalizations on Women and Sport, Games and Play in the United States From Settlement to 1860," in Howell (ed.), Her Story in Sport, 87-95, p.94; and Kane and Greendorfer, "The Media's Role in Accommodating and Resisting Stereotyped Images of Women in Sport," 41; Hargreaves, Sporting Females, 281; and Mariah Burton Nelson, Are We Winning Yet? How Women are Changing Sports and Sports Are Changing Women (New York, 1991), 211.

74 Senn, Power, Politics, and the Olympic Games, 263.

75 Jean Zimmerman and Gil Reavill, Raising Our Athletic Daughters: How Sports Can Build Self-Esteem and Save Girls' Lives (New York, 1998).

76 Hargreaves, Sport, 106.

77 Holt and Mason, Sport in Britain, 12, 85, 169, 170.

78 Cahn, Coming on Strong, 278, 279; Messner, "Sports and Male Domination,” 74, 77; Pamela J. Creedon, Judith A. Cramer and Elizabeth H. Granitz, "Pandering or Empowering? Economics and Promotion of Women's Sports," in Creedon (eds.), Women, Media, and Sport, 181-203, p.181; Donald
} 
It is for this reason that American sportswomen, for example, still have to accommodate their game to the social mores that adhere to the notion that it 'just doesn't feel right' to cheer for women. 79 Even in Britain today, despite a few women sports enthusiasts, sport remains a "man's world" with men largely in control of the leading organizations. Where a sportswoman does not qualify on grounds of femininity (e.g. married women athletes with children), then she is in danger of acquiring a deviant, pejorative sexual image. 80

In Australia, despite giant strides, equality of opportunity to participate in sport has not been achieved. The prime reason for this has been the attitudes, not just of males but also of many females, who share the predominant male view that high-exertion, highly competitive, physical contact is unfeminine. Some believe that women should not participate at all; others feel that they should concentrate on those sports such as gymnastics, diving, synchronized swimming and ice-skating which emphasize grace, flexibility, and coordination. Only a radical minority seeks equal access, equal rights and equal rewards in sports. Media coverage of women's sport remains shockingly low and successful sportswomen still have to overcome opposition and media discrimination. To use an Australian colloquialism, women in Australian sport have not yet had a 'fair go'.81

The contemporary images of women athletes as 'modern mannish maidens' and 'hybrid tomboyism' suggest the omnipresence of traditional views and practices in present-day Canadian society as well. For example, Canadian women's participation in the 'flag carrier' sport of ice hockey occurs largely within a masculine value system that provides an opportunity for women to experience personal empowerment, but still institutionalizes violence and the normalization of injury in favor of an ethic of care. 82

Sabo and Michael A. Messner, "Whose Body is This? Women's Sports and Sexual Politics," in Cohen, Woman in Sport, 15-24; and Lenskyj, Out of Bounds, 144.

79 Laurel Davis's article “A Postmodern Paradox? Cheerleaders at Women's Sporting Events," in Birrell and Cole (eds.), Women, Sport, and Culture, 149-158, on American cheerleaders shows that most cheerleaders feel that cheering for male athletes is more prestigious than female athletes.

80 Hargreaves, Sport, 88, 153.

81 Vamplew, "Australians," in Vamplew and Stoddard, Sport, 1-18; and Stell, Half the Race, 229, 235. See also Shona M. Thompson, Mother's Taxi: Sport and Women's Labor (Albany, 1999), 8, 9, 68, 124, 127, 184, 227, 228, 235, 252, 253. This book examines Australian women's labor in promoting tennis, either through their active participation, or driving their children to tennis fields, all of which remained undervalued and exploited.

82 Helen Lenskyj, "Physical Activity for Canadian Women 1890-1930: Media Views," in Mangan and Park, From "Fair Sex", 208-234; and Nancy Theberge, "It's Part of the Game: Physicality and the Production of Gender in Women's Hockey," in Gender and Society, 11, 1 (February, 1997), 69-87, pp.70, 85. 
Chinese women, on the other hand, are demonstrating their superior strength in athletics. Unfortunately, while the Chinese speak of special training methods and herbal preparations for explaining their sports victories, especially in women's swimming, the westerners are suspicions of performance-enhancing drugs and have pointed to the presence of former East German trainers in the Chinese Republic. 83 The use of drugs and the "question of sex" in sports has once again raised debates over the merits and flaws of gender testing in women's physical culture.

Thus, Polish women, similar to their western counterparts, remain marginalized in their sporting cultures. However, the material prosperity in the west has empowered western sportswomen to construct more meaningful physical cultures for themselves. The women's sporting revolution in Poland and throughout eastern Europe, on the other hand, has succumbed to the pressures and burdens of post-communist transition. The sportswomen in eastern Europe have now fallen behind their western and Asian rivals. Still, not all is lost. The political and economic consequences of globalization may provide the external stimulus for bringing women from different parts of the world together, if not for any "feminist" purpose, then perhaps to simply play a game or two.

83 Senn, Power, Politics, and the Olympic Games, 265, 285. 


\section{BIBLIOGRAPHY}

\section{Primary Sources}

\section{Archival Collections}

Archiwum Akt Nowych (AAN), Warsaw

: Wydzial Kobiecy (1949-1952)

Archiwum Glowne Akt Dawnych (AGAD), Warsaw

: Kanceleria General-Gubernatora Warszawskiego (KGGW)

: Pomocnik General-Gubernatora Warszawskiego (PomGGW)

: Prokurator Warszawskiej Izby Sadowej (PWIS)

Archiwum Panstwowe m. st, Warszawy i Wojewodstwa Warszawskiego (APW)

: Warszawski Gubernialny Urzad do Spraw Stowarzyszen (WGU)

: Zarzad Oberpolicmajstra Warszawskiego (ZOW)

Archives of Maria Rotkiewicz (AMR), AWF Warsaw

(This personal archival collection of Maria Rotkiewicz includes seminar papers and Master's Thesis (Praca Magisterska) of students at AWF, Warsaw that cover many themes of Polish sport, including biographies of Polish sportswomen, development of regional sports, and details on the evolution of specific sports for women. These manuscripts and papers, though based on primary research, discuss the organization of Polish sports with little reference to the larger dynamics of Polish politics, socio-cultural transformations, patterns of economic development and the emergence of the women's movement in Poland. The archival collection also includes published and unpublished works of Maria Rotkiewicz, and publication details are cited where available. With the permission of Maria Rotkiewicz, notes taken from seminar papers of students and Rotkiewicz's own unpublished notes will simply be cited as AMR.)

\section{The Periodical Press}

Bluszcz: Spoleczno-Literacki Tygodnik Kobiecy

\section{Builetyn PKOI}

$\underline{\text { Climber and Rambler }}$

\section{$\underline{\text { Cyklista }}$}

$\underline{\text { Echa Plockie i Wloclawskie }}$ 
$\underline{\text { Gazeta Kaliska }}$

$\underline{\text { Gazeta Swiateczna }}$

$\underline{\text { Gazeta Wyborcza }}$

$\underline{\text { Glos }}$

$\underline{\text { Kalendarium XX wieku: Fakty, Dokumenty, Opinie }}$

Kobieta: Dobra Matka

$\underline{\text { Kobieta Dzisiejsza }}$

$\underline{\text { Kobieta i Zycie }}(\mathrm{KiZ})$

$\underline{\text { Kobieta Nowa: Biuletyn Miesieczny }}$

Kobieta Obywatelka, Dodatek do "Kurjera Wilenskiego" (Redagowany przez Zwiazek

Pracy Obywatelskiej Kobiet w Wilnie, Wilno).

$\underline{\text { Kobieta Polska: Obywatelka, Matka, Gospodyni }}$

$\underline{\text { Kobieta Polska (Poznan) }}$

$\underline{\text { Kobieta Pracy: Czasopismo dla kobiet pracujacych }}$

Kobiety w Pracy: Czasopismo spoldzielni Pracy Wydawniczo Propagandowej

$\underline{\text { Kobieta w Sejmie: Pismo Komitetu Wyborczego Kobiet Postepowych (KWKP) }}$

Kobieta w Swiecie i w Domu: Dwutygodnik Poswiecony Zyciu Domowemu i Modom (KSD)

Kobieta Wiejska

$\underline{\text { Kobieta Wspolcznesna : Ilustrowany Tygodnik Spoleczno-Literacki }}$

$\underline{\text { Kolarz, Wioslarz i Lyzwiarz }}$

$\underline{\text { Krest'ianka }}$

$\underline{\text { Krytyka }}$

Kurjer Sportowy 
Magazyn Olimpijski

Moda i Zycie Praktyczne (MiZP)

Moja Przyjaciolka: Ilustrowany Dwutygodnik Kobiecy

Nasz Dziennik

Ogniwo

Przeglad Kobiecy: Miesiecznik Illustrowany Poswiecony Sprawom Zycia Kobiecego

Przeglad Sportowy: Tygodnik Ilustrowany, Poswiecony Wszelkim Galeziom Sportu (PzS)

Przyjaciolka

$\underline{\text { Rabotnitsa }}$

$\underline{\text { Ruch }}$

$\underline{\text { Rzeczpospolita }}$

$\underline{\text { Soviet Woman }}$

Sport: Tygodnik Ilustrowany

Sport Europe

Sport in the USSR

Sport Polski: Tygodnik

Sport Wyczynowy

Sportowiec

Sports Information Bulletin

Sports Legislation in Europe

Stadion (Stadjon)

$\underline{\text { Start }}$

Ster (Lwow) 
$\underline{\text { Ster }}$ (Warsaw)

$\underline{\text { Swiat Kobiecy }}$

Tempo, Nowosci Sportu i Turystyki (Krakow)

The Boston Globe

The Netal Witness

$\underline{\text { The New York Times }}$

The Rand Daily Mail, Johannesburg, Transvaal

Trybuna

Twoj Styl

$\underline{\text { Volleyball Magazine }}$

$\underline{\text { Wedrowiec }}$

Zdrowie (Warsaw)

Zycie Warszawy

\section{Published Sources}

Biuletym Informacyjny Glownego Komitetu Kultury Fizycznej i Turystyki (Nr.10-12, Warsaw, 1975).

Biuletyn Informacyjny: Glowny Komitet Kultury Fizycznej, Warsaw, 45 (31 August, 1959).

Biuletyn Informacyjny: Glowny Komitet Kultury Fizycznej, Warsaw, 39 (30 April, 1959).

Biuletyn Informacyjny: Glowny Komitet Kultury Fizycznej, Warsaw, 2/53 (20 February, 1960).

Biuletyn Informacyjny: Glowny Komitet Kultury Fizycznej, Warsaw, 3/54 (15 March, 1960).

Biuletyn Informacyjny: Glowny Komitet Kultury Fizycznej, Warsaw, 12-13/63-64 (20 December, 1960). 
Borowski, Tadeusz. This Way for the Gas, Ladies and Gentlemen. Selected and Translated by Barbara Vedder (New York: Penguin Books, 1976).

Brzezicki, Arkadiusz, Stanislaw Drazdzewski, Janusz Podoski and Stanislaw Romanski (eds.). Ksiega sportu polskiego 1944-1974 (Warsaw: Wydawnictwo "Sport Turystyka", 1975).

Budzinska-Tylicka, Justyna. Hygiena kobiety $i$ kwestje spoleczne $z$ nia zwiazane (Warsaw, 1909).

Bujwidowa, Kazimiera. U zrodel kwestji kobiecej (Warsaw, 1910).

Chelmecki, Jerzy and Slawomir Wilk. Wybor zrodel i materialow do dziejow kultury fizycznej w Polsce w latach 1944-1984 (Warsaw: Wydawnictwo AWF, 1986).

Decyzja Nr. Sp-II-253/95 Katowice, dn. 30.08.1995 (Urzad Wojewodzki w Katowicach. Wydzial Sportu i Turystyki).

Glowny Komitet Kultury Fizycznej i Turystyki (Warsaw: Aktualne zadania kultury fizycznej oraz kierunkowe wytyczne rozwoju sportu na lata 1966-1970. Referat zastepcy przewodniczacego GKKFiT MGR. Jozefa Rutkowskiego wygloszony na plenarnym posiedzeniu podkomitetu kultury fizycznej w dniu 26 listopada 1965r, November 1965).

Glowny komitet kultury fizycznej i sportu: Materialy Informacyjne (Warsaw, March, 1984).

Glowny komitet kultury fizycznej i sportu departament upowszechniania kultury fizycznej (Informacja o stanie realizacji wnioskow sejmiku kultury fizycznej (Warsaw, June 1983).

Glowny Komitet Kultury Fizycznej i Turystyki: Zadania $w$ dziedzinie kultury fizycznej $i$ turystyki (Referat przewodniczacego GKKFiT Wlodzimierza Reczka oraz Uchwala plenum GKKFiT z dnia 16 Marca 1972, Nakladem Biuletynu informacyjnego GKKFiT (Warsaw, March, 1972).

Halina Konopacka: Wznosilam swiat miloscia (Lomianki: Spolka Wydawnicza Heliodor, 1994).

Hojnacki, Wladyslaw. Hygiena Kobiety. Nakladem Ksiegarni Polskiej B. Polonieckiego we Lwowie. Wyd. II (Warsaw: E. Wende i Spolka, 1903).

Hojnacki, Wladyslaw. Z dziedziny sportu: kobieta a sport $i$ sport Jazdy Konnej. Lwow, Naklad Ksiegarni Polskiej B. Polonieckiego (Warsaw: E. Wende i SP, 1905).

Hojnacki, Wladyslaw. Higjena kobiety i kosmetyka. Wydanie czwarte przerobione (Lwow i Warsaw: Nakladem Ksiegarnia Polskiej B. Polonieckiego, 1925). 
Informacja $i$ wnioski z posiedzenia plenarnego glownego komitetu kultury fizycznej $i$ sportu w dniu 26 Pazdziernika 1981r (Warsaw, October 1981).

Kalendarz Kobiety Polskiej (Warsaw: Union of Equal Rights of Polish Women, 1910).

Kuczalska-Reinschmit, Paulina. Wyborcze prawa kobiet (Warsaw, 1907).

Kuczalska-Reinschmit, Paulina. Mlodziez zenska i sprawa kobieca (Warsaw, 1906).

Kuczalska-Reinschmit, Paulina. Nasze cele $i$ drogi. Szkic do programu dzialalnosci kobiecej, Dodatek do "Steru” (Lwow, 1897).

Meczkowska, Teodora. Ruch kobiecy. Idealy etyczno-spoleczne ruchu kobiecego (Warsaw, 1907).

Milosz, Czeslaw. The Captive Mind. Translated by Jane Zielonko (London: Penguin, 2001).

Ministerstwo Oswiaty: Materialy z narady kuratorow I przewodniczacych WKKFiT w dniu VI 1966 (Nakladem Biuletynu Informacyjnego GKKFiT).

Mosczenska, Isabela. O zyciu i pracach Orzeszkowej (Warsaw, 1910).

Muller, J.P. Moj system dla kobiet: jedyna droga do utrwalenia zdrowia oraz rozwoju $i$ zachowania pieknosci (Warsaw: Gebethner i Wolff, 1912).

Nowosielska, Zofja. W huraganie wojny, pamietnik kobiety-zolnierza (New York: Nakladem Nowej Bibljoteki Polskiej; Warsaw: Druk Literacka, 1929).

Ocena wykonania w latach 1976 i 1977 perspektywicznego programu rozwoju kultury fizycznej i turystyki (Warsaw: Glowny Komitet Kultury Fizycznej i Turystyki, December 1977).

Ocena stanu i glowne kierunki rozwoju kultury fizycznej i sportu w srodowisku wiejskim: Material na plenarne posiedzenie Glownego Komitetu Kultury Fizycznej i Sportu (Warsaw: Glowny Komitet Kultury Fizycznej i Sportu, March 1979).

Program of Activities for the Polish Women's Sport Federation For Years 1995-1997 (Polskiego Stowarzyszenia Sportu Kobiet, PSSR).

Program Szkoly Gimnastyki Szwedzkiej, Lecznicznej i Masazu w Warszawie przy istniejacym od r. 1894 Instytucie Gimnastycznym Boleslawa Olszewiskiego (Warsaw: Szkola kieruje i osobiscie zarzadza dr. med. Biehler, 1908). 
Regulaminy Organizacji Sokolic Zwiazek Towarzystw Gimnastycznych "sokol” w Polsce (Warsaw, 1927).

Regulamin Polskiego Stowarzyszenia Sportu Kobiet (oddzial Krakow).

Rosenberg, D. Teoretyczne podstawy cwiczen cielesnych dla kobiet se szczegolnem uwzglednieniem gimnastyki Bertram (Warsaw, 1931).

Sprawozdanie z Drugiego Kongresu Kultury Fizycznej Kobiet odbytego w Dn. 28 i 29 Kwietnia 1934r. w Warszawie (Nakladem Towarzystwa Krzewienia Kultury Fizycznej Kobiet).

Statut Warszawskiego Klubu Wioslarek (Warsaw, 1912).

Statut Warszawskiego Klubu Wioslarek (Warsaw, 1927).

Statut Stowarzyszenia Sportu Kobiet w Polsce.

Sztandary sportu polskiego (Warsaw: Muzeum Sportu i Turystyki w Warszawie, 1996).

Turzyma, Maria and Kazimiera Bujwidowa (eds.), Glos kobiet $w$ kwestyi kobiecej (Krakow, 1903).

Turzyma, Maria. Wyzwalajaca sie kobieta (Krakow, 1906).

Uchwala Plenum Glownego Komitetu Kultury Fizycznej i Sportu z dnia 29 Marca 1979 (GKKFiS).

Udzial kobiet $w$ rozwoju upowszechnianiu $i$ odbiorze kultury: Materialy $z$ obrad Krakowej Rady Kobiet Polskich 26-27 Listopad 1978 (Warsaw: Biblioteczka Lektora FJN, 1979).

Tuszynski, Bogdan. Prasa i sport, 1881-1981 (Warsaw: Sport i Turystyka, 1981).

Warszawski klub Wioslarek, Regulamin Wioslarski (Warsaw, 1933).

Warszawski klub wioslarek swej prezesce czlonkini honorowej Dr. Zofji ZabawskiejDomoslawskiej w dowod wdziecznosci i uznania dla jej pracy dla klubu w ciagu 10letniej przesury (Warsaw, 15 December 1934).

\section{Secondary Sources}




\section{Books and Monographs}

Adamczewska, Zenona. Poczatki i rozwoj sportu kobiecego w Pabianicach (Praca Magisterska: AWF Warsaw, 1976).

Agh, Attila. Emerging Democracies in East Central Europe and the Balkans (Cheltenham, UK; Northampton, MA: E. Elgar, 1998).

Alexander, John T. Catherine the Great: Life and Legend (New York: Oxford University Press, 1989).

Ascherson, Neal. The Struggles for Poland (New York: Neal Ascherson and DNA 'Poland' Ltd., 1987).

Ascherson, Neal. The Polish August: The Self-Limiting Revolution (New York: Viking Press, 1982).

Ash, Timothy Garton. The Polish Revolution: Solidarnosc (London: Granta Books, 1991).

Atkinson, Dorothy, Alexander Dallin, and Gail Lapidus. Women in Russia (Stanford, Calif.: Stanford University Press, 1977).

Attwood, Lynne. Creating the New Soviet Woman: Women's Magazines as Engineers of Female Identity, 1922-1953 (New York: St. Martin's Press, 1999).

Bacon, Elizabeth. Central Asians Under Russian Rule: A Study in Cultural Change (Ithaca, NY: Cornell University Press, 1966).

Balcerowicz, Leszek. Socialism, Capitalism, Transformation (Budapest: Central European University Press, 1995).

Banac, Ivo (ed.). Eastern Europe in Revolution (Ithaca, NY: Comell University Press, 1992).

Banac, Ivo and Katherine Verdery (eds.). National Character and National Ideology in Interwar Eastern Europe (New Haven: Yale Center for International and Area Studies, 1995).

Bandy, Susan J. and Anne S. Darden (eds.). Crossing Boundaries: An International Anthology of Women's Experiences in Sport (Champaign, Ill.: Human Kinetics, 1999).

Barker, Adele Marie (ed.). Consuming Russia: Popular Culture, Sex, and Society Since Gorbachev (Durham, NC: Duke University Press, 1999). 
Barnett, Clifford R. Poland: Its People, Its Society, Its Culture (New Haven: HRAF Press, 1958).

Berend, Ivan T. Central and Eastern Europe, 1944-1993: Detour from the Periphery to the Periphery (Cambridge and New York: Cambridge University Press, 1996).

Bernhard, Michael H. The Origins of Democratization in Poland: Workers, Intellectuals, and Oppositional Politics, 1976-1980 (New York: Columbia University Press, 1993).

Bernstein, Laurie. Sonia's Daughters: Prostitutes and their Regulation in Imperial Russia (Berkeley and Los Angeles: University of California Press, 1995).

Berry, Ellen E. (ed.). Postcommunism and the Body Politic (New York: New York University Press, 1995).

Bethell, Nicholas. Gomulka, His Poland and His Communism (London: Longmans, Green and Co Ltd., 1969).

Birley, Derek. Land of Sport and Glory: Sport and British Society, 1887-1910 (Manchester: Manchester University Press, 1995).

Birley, Derek. Playing the Game: Sport and British Society, 1910-1945 (Manchester: Manchester University Press, 1995).

Birley, Derek. Sport and the Making of Britain, Upto 1888 (Manchester: Manchester University Press, 1993).

Birrell, Susan and Cheryl Cole (eds.). Women, Sport and Culture (Champaign, Ill.: Human Kinetics, 1994).

Blanchard, Olivier, Kenneth A. Froot, and Jeffrey D. Sachs (eds.). The Transition in Eastern Europe, Volume 2 (Chicago: University of Chicago Press, 1994).

Blanke, Richard. Orphans of Versailles: The Germans in Western Poland, 1918-1939 (Lexington, KY: University Press of Kentucky, 1993).

Blanke, Richard. Prussian Poland in the German Empire, 1871-1900 (New York: East European Monographs. Distributed by Columbia University Press, 1981).

Blejwas, Stanislaus A. Realism in Polish Politics: Warsaw Positivism and National Survival in Nineteenth Century Poland (New Haven: Yale Concilium on International and Area Studies, 1984).

Blobaum, Robert. Feliks Dzierzynski and the SDKPiL: A Study of the Origins of Polish Communism (New York: East European Monographs. Distributed by Columbia University Press, 1984). 
Blobaum, Robert E. Rewolucja: Russian Poland, 1904-1907 (Ithaca: Cornell University Press, 1995).

Blue, Adrianne. Grace Under Pressure: The Emergence of Women in Sport (London: Sidgwick and Jackson, 1987).

Bogucka, Maria (ed.). Society and Culture: Poland in Europe (Warsaw: Polish Academy of Sciences, Committee of Historical Sciences, Institute of History, 1995).

Bogucka, Maria. Bialoglowa $w$ dawnej Polsce: kobieta $w$ spoleczenstwie polskim XVIXVIII wieku na tle porownawczym (Warsaw: Wydawnictwo Trio, 1998).

Bonnell, Victoria E. Iconography of Power: Soviet Political Posters under Lenin and Stalin (Berkeley: University of California Press, 1997).

Bordo, Susan. Unbearable Weight: Feminism, Western Culture and the Body (Berkeley: University of California Press, 1993).

Borkowska, Malgorzata. Zycie codzienne Polskich klasztorow zenskich w xvii-xviii wieku (Warsaw: Panstwowy Instytut Wydawniczy, 1996).

Boutilier, Mary and Lucinda SanGiovanni, The Sporting Woman (Champaign, IL: Human Kinetics, 1983).

Boxer, Marilyn and Jean Quataert. Connecting Spheres: European Women in a Globalizing World, 1500 to the Present (New York: Oxford University Press, 2000).

Bridger, Susan (ed.). Woman and Political Change: Perspectives from East-Central Europe. Selected Papers from the Fifth World Congress of Central and East European Studies, Warsaw 1995 (New York: St. Martin's Press, 1999).

Bridger, Susan, Rebecca Kay and Kathryn Pinnick. No More Heroines? Russia, Women, and the Market (London and New York: Routledge, 1996).

Brine, J. J., Maureen Perrie, Geoffrey Barker, and Andrew Sutton (eds.), Home, School and Leisure in the Soviet Union (London and Boston: Allen and Unwin, 1980).

Bromke, Adam. Poland's Politics: Idealism vs. Realism (Cambridge, Massachusetts: Harvard University Press, 1967).

Bromke, Adam. Poland: The Protracted Crisis (Oakville, Ontario: Mosaic Press, 1983).

Broniewski, Stanislaw. Calym zyciem: szare szeregi $w$ relacji naczelnika (Warsaw: Panstwowe Wydawn. Nauk., 1983). 
Broom, Eric F., Roy Clumpner, Brian Pendleton, Carol A. Pooley (eds.). Comparative Physical Education and Sport, Vol. 5 (Champaign, Illinois: Human Kinetics Books, 1988).

Brovkin, Vladimir. Russia After Lenin: Politics, Culture and Society, 1921-1929 (London and New York: Routledge, 1998).

Brownell, Susan. Training the Body for China: Sports in the Moral Order of the People's Republic (Chicago: University of Chicago Press, 1995).

Brzezicki, Arkadiusz and Antoni Miller (eds.). Kartki z historii kultury fizycznej $i$ turystyki 1945-1964 (Warsaw: Wydawnictwo Sport i Turystyka, 1964).

Brzezinski, Mark. The Struggle for Constitutionalism in Poland (Basingstoke: Macmillan, 1998).

Buckley, Mary. Women and Ideology in the USSR (Ann Arbor: University of Michigan Press, 1989).

Butterwick, Richard. Poland's Last King and English Culture: Stanislaw August Poniatowski, 1732-1798 (Oxford and New York: Clarendon and Oxford University Press, 1998).

Cahn, Susan. Coming on Strong: Gender and Sexuality in Twentieth-Century Women's Sport (New York: Free Press and Maxwell Macmillan International, 1994).

Calhoun, Donald. Sport, Culture, and Personality (Champaign, Illinois: Human Kinetics Publishers, 1987).

Cayleff, Susan E. Babe: The Life and Legend of Babe Didrikson Zaharias (Urbana: University of Illinois Press, 1995).

Charlton, Sue, Jana Everett and Kathleen Staudt (eds.). Women, the State, and Development (Albany: State University of New York Press, 1989).

Chmielewski, Zbigniew. Polish Sport (Warsaw: Interpress Publishers, 1980).

Chojnowski, Andrzej. Koncepcje polityki narodowosciowej rzadow polskich $w$ latach 1921-1939 (Wroclaw: Zaklad Narodowy im. Ossolinskich, 1979).

Ciesielska, Grazyna. Rozwoj rekreacji ruchowek kobiet w Lodzi do 1939 (Praca Magisterska, AWF Warsaw, 1979).

Cirtautas, Arista Maria. The Polish Solidarity Movement: Revolution, Democracy and Natural Rights (London and New York: Routledge, 1997). 
Clark, Katerina. The Soviet Novel: History as Ritual (Bloomington: Indiana University Press, 2000).

Clarke, Gill and Barbara Humberstone (eds.). Researching Women and Sport (Houndmills, England: Macmillan, 1997).

Clements, Barbara. Daughters of Revolution: A History of Women in the USSR (Arlington Heights, Ill.: Harlan Davidson, Inc. 1994).

Clements, Barbara, Barbara Engel, Christine Worobec (eds.), Russia's Women: Accommodation, Resistance, Transformation (Berkeley: University of California Press, 1991).

Clowes, Edith, Samuel D. Kassow, and James L. West (eds.), Between Tsar and People, Educated Society and the Quest for Public Identity in Late Imperial Russia (Princeton: Princeton University Press, 1991).

Coates, Anne. Women and Sport (Hove: Wayland, 1989).

Cohen, Greta (ed.). Women in Sport: Issues and Controversies (Newbury Park: Sage Publications, 1993).

Connelly, John. Captive University: The Sovietization of East German, Czech, and Polish Higher Education, 1945-1956 (Chapel Hill: University of North Carolina Press, 2000).

Connolly, Olga. The Rings of Destiny (New York: D. McKay Co., 1968).

Corrin, Chris (ed.). Gender and Identity in Central and Eastern Europe (London and Portland: Frank Cass, 1999).

Corrsin, Stephen. Warsaw Before the First World War: Poles and Jews in the Third City of the Russian Empire, 1880-1914 (Boulder and New York: East European Monographs. Distributed by Columbia University Press, 1989).

Costa, Margaret and Sharon Guthrie (eds.). Women and Sport: Interdisciplinary Perspectives (Champaign, Ill.: Human Kinetics, 1994).

Costlow, Jane, Stephanie Sandler, and Judith Vowles (eds.). Sexuality and the Body in Russian Culture (Stanford, Calif.: Stanford University Press, 1993).

Cox, Terry and Bob Mason. Social and Economic Transformation in East Central Europe: Institutions, Property Relations, and Social Interests. United Nations Research Institute for Social Development (Cheltenham, UK: Edward Elgar Publishing Limited, 1999). 
Creedon, Pamela J. (ed.). Women, Media, and Sport: Challenging Gender Values (Thousand Oaks, Calif.: Sage Publications, 1994).

Crosset, Todd W. Outsiders in the Clubhouse: The World of Women's Professional Golf (Albany: State University of New York Press, 1995).

Czajecka, Boguslawa. "Z domu w szeroki swiat”: Droga kobiet do niezaleznosci w zaborze austriackim w latach 1890-1914 (Krakow: Towarzystwo Autorow i Wydawcow Prac Naukowych, Universitas Krakow, 1990).

Czajkowska, A. (ed.). Wysilek fizyczny, kobieta, zdrowie (Materialy konferencyjne, AWF Warsaw, 15 September, 1998).

Daddario, Gina. Women's Sport and Spectacle: Gendered Television Coverage and the Olympic Games (Westport, Conn.: Praeger, 1998).

Dall, Z. Kultura fizyczna i sport w Polsce Ludowej. Nr. 12, Poradnik Organizatora SPO (Wydawnictwo Glownego Komitetu Kultury Fizycznej, 1951).

Davidson, Scooter Toby and Valerie Anthony. Great Women in the Sport of Kings: America's Top Women Jockeys Tell Their Stories (Syracuse, NY: Syracuse University Press, 1999).

Davies, Norman. God's Playground: A History of Poland-The Origins to 1795. Vol. 1 (New York: Columbia University Press, 1982).

Davies, Norman. God's Playground: A History of Poland, 1795 to the Present. Vol. II (New York: Columbia University Press, 1982).

Davis, Michael D. Black American Women in Olympic Track and Field: A Complete Illustrated Reference (Jefferson, NC: McFarland and Co., 1992).

Dawisha, Karen and Bruce Parrott (eds.). The Consolidation of Democracy in EastCentral Europe (Cambridge and New York: Cambridge University Press, 1997).

De Grazia, Victoria. How Fascism Ruled Women: Italy, 1922-1945 (Berkeley: University of California Press, 1992).

De Madariaga, Isabel. Catherine the Great: A Short History (New Haven: Yale University Press, 1990).

De Madariaga, Isabel. Russia in the Age of Catherine the Great (New Haven: Yale University Press, 1981).

Demel, Maciej. Pedagogiczne aspekty warszawskiego ruchu higienicznego, 1864-1914 
(Wroclaw-Warszawa-Krakow: Zaklad Narodowy im. Ossolinskich Wydawnictwo Polskiej Akademii Nauk, 1964)

Denisiuk, Ludwik, Kazimierz Fidelus and Marian Krawczyk. Elementy teorii $i$ historii wychowania fizycznego (Warsaw: Panstwowe Zaklady Wydawnict Szkolnych, 1969).

DiCaprio, Lisa and Merry E. Wiesner. Lives and Voices: Sources in European Women's History (Boston: Houghton Mifflin, 2001).

Diuk, Nadia and Adrian Karatnycky. New Nations Rising: The Fall of the Soviets and the Challenge of Independence (New York: John Wiley and Sons, Inc., 1993)

Dobkiewicz, Barbara and Anna Kowalczyk. Piekne, madre i bogate, czyli, Polskie biznesmenki. Wydanie I (Warsaw: Polska Oficyna Wydawnicza "BGW”, 1992).

Dowiat, Jerzy (ed.). Kultura polski sredniowiecznej x-xiii w. (Warsaw: Panstwowy Instytut Wydawniczy, 1985).

Dowling, Colette. The Frailty Myth: Women Approaching Physical Equality (New York: Random House, 2000).

Drabik, Jozef (ed.). Exercise and Health. Conference Materials. (Gdansk: The Academy of Physical Education in Gdansk, 1992).

Drazdzewski, Stanislaw. Dzieziecioletnia dzialalnosc rady wychowania fizycznego glownego komitetu kultury fizycznej i turystyki, 1960-1970 (Warsaw: Wydawnictwo "Sport i Turystyka", 1970).

Drozdowski, Zbigniew and Wanda Rozynek-Lukanowska (eds.). Nauki spoleczne a kultura fizyczna: Ogolnopolska Konferencja Naukowa. Poznan, dnia 3 Czerwca, 1988r. Monografie, Podreczniki, Skrypty, Nr. 267 (Poznan: AWF w Poznaniu, 1989).

Dulebianka, Marja. Polityczne stanowisko kobiety(Warsaw, 1908).

Dworecki, Zbigniew. Poznan i Poznaniacy w latach drugiej Rzeczypospolitej, 1918-1939 (Poznan: Media Rodzina of Poznan, 1994).

Edelman, Robert. Serious Fun: A History of Spectator Sports in the USSR (New York: Oxford University Press, 1993)

Edmondson, Linda. Feminism in Russia, 1900-1917 (Stanford: Stanford University Press, 1984).

Edmondson, Linda (ed.), Women and Society in Russia and the Soviet Union (Cambridge and New York: Cambridge University Press, 1992). 
Einhorn, Barbara. Cinderella Goes to the Market: Citizenship, Gender, and Women's Movements in East Central Europe (London and New York: Verso, 1993).

Eisler, Jerzy. Marzec, 1968: Geneza, przebieg, konsekwencje (Warsaw: Panstwowe Wydawn. Nauk, 1991).

Eisen, George. Children and Play in the Holocaust: Games Among the Shadows (Amherst: The University of Massachusetts Press, 1988).

Eisen, George and David Wiggins (eds.). Ethnicity and Sport in North American History and Culture (Westport, Conn.: Greenwood Press, 1994).

Ekiert, Grzegorz. The State Against Society: Political Crises and Their Aftermath in East Central Europe (Princeton: Princeton University Press, 1996).

Ekiert, Grzegorz and Jan Kubik. Rebellious Civil Society: Popular Protest and Democratic Consolidation in Poland, 1989-1993 (Ann Arbor: University of Michigan Press, 1999).

Elster, Jon (ed.). The Roundtable Talks and the Breakdown of Communism (Chicago: Chicago University Press, 1996).

Emigh, Rebecca Jean and Ivan Szelenyi (eds.). Poverty, Ethnicity, and Gender in Eastern Europe During the Market Transition (Westport, Conn.: Praeger, 2001).

Engel, Barbara. Between the Fields and the City: Women, Work, and Family in Russia, 1861-1914 (Cambridge and New York: Cambridge University Press, 1994).

Engelstein, Laura. The Keys to Happiness: Sex and the Search for Modernity in Fin-DeSiecle Russia (Ithaca: Cornell University Press, 1992).

Fallenbuchl, Zbigniew. The Balance of Payments Problem and the Economic Crisis in Poland (Pittsburgh: The Carl Beck Papers in Russian and East European Studies, Paper No. 406, University of Pittsburgh, 1985).

Farnsworth, Beatrice and Lynne Viola (eds.). Russian Peasant Women (New York: Oxford University Press, 1992).

Fedorowicz, J. K. (ed.). A Republic of Nobles: Studies in Polish History to 1864 (Cambridge and New York: Cambridge University Press, 1982).

Felski, Rita. The Gender of Modernity (Cambridge, Mass.: Harvard University Press, 1995).

Ferree, Myra Marx, Judith Lorber and Beth B. Hess (eds.). Revisioning Gender (Thousand Oaks, Calif.: Sage Publications, Inc. 1999). 
Festle, Mary Jo. Playing Nice: Politics and Apologies in Women's Sports (New York: Columbia University Press, 1996).

Fisher, Ralph. Pattern for Soviet Youth (New York: Columbia University Press, 1959).

Fishman, David E. Russia's First Modern Jews: The Jews of Shklov (New York: New York University Press, 1995).

Fitzpatrick, Sheila. Everyday Stalinism. Ordinary Life in Extraordinary Times: Soviet Russia in the 1930s (New York: Oxford University Press, 1999).

Fountain, Alvin Marcus. Roman Dmowski: Party, Tactics, Ideology, 1895-1907 (Boulder: East European Monographs. New York: Distributed by Columbia University Press, 1980).

Frank, Stephen P. and Mark D. Steinberg (eds.), Cultures in Flux: Lower Class Values, Practices and Resistance in Late Imperial Russia (Princeton: Princeton University Press, 1994).

Frydman, Roman, Kenneth Murphy and Andrzej Rapaczynski. Capitalism with a Comrade's Face: Studies in Postcommunist Transition (Budapest: Central European University Press, 1998).

Fus, Elzbieta. Poczatki i rozwoj sportu kobiecego w Kaliszu do 1939 (Praca Magisterska, AWF Warsaw, 1982).

Gal, Susan and Gail Kligman (eds.), Reproducing Gender: Politics, Publics, and Everyday Life After Socialism (Princeton: Princeton University Press, 2000).

Gaj, Jerzy (ed.). Dzieje Akademii Wychowania Fizycznego w Poznaniu, 1919-1994: praca zbiorowa. Seria: Monografie Nr. 312 (Poznan: Akademia Wychowania Fizycznego im. Eugeniusza Piaseckiego w Poznaniu, 1996).

Gaj, Jerzy. Wychowanie fizyczne $i$ sport w Polsce Ludowej (Warsaw: Panstwowe Wydawnictwo Naukowe, 1987).

Gaj, Jerzy and Kajetan Hadzelek. Dzieje kultury fizycznej w Polsce w xix i xx wieku. Koncepcje, uwarunkowania, i efekty instytucjonalnej dzialalnosci. Seria: Monografie Nr. 289 (Poznan: Akademia Wychowania Fizycznego im. Eugeniusza Piaseckiego w Poznaniu, 1991).

Gajewski, Antony K. (ed.). Kobieta sport zdrowie. Wydanie I (Warsaw: Polskie Stowarzyszenie Sportu Kobiet, 1998).

Gardner, Jane. Women in Roman Law and Society (London: Croom Helm, 1986). 
Garlicki, Andrzej. Jozef Pilsudski, 1867-1935. Edited and translated by John Coutouvidis (Hants: Scolar Press, 1995).

Garlinski, Jozef. Poland in the Second World War (Houndmills, Basingstoke, Hampshire: Macmillan, 1985).

Gawlak-Kica, Gabriela. Rozwoj kultury fizycznej w Wielkopolsce w latach 1945-1980: diagnoza i elementy prognozy na przykladzie wybranych miast. Seria: Monografie Nr.243 (Poznan: Akademia Wychowania Fizycznego w Poznaniu, 1987).

Gawlak-Kica, Gabriela. Kultura fizyczna m. Poznania $w$ oparciu o dane badawcze. Monografie, Podreczniki, Skrypty, Nr. 85 (Poznan: AWF w Poznaniu, 1978).

Gee, Malcolm, Tim Kirk and Jill Steward. The City in Central Europe: Culture and Society from 1800 to the Present (Aldershot, England and Brookfield, VT: Ashgate, 1999).

Geremek, Bronislaw (ed.). Kultura polski sredniowiecznej xiv-xv w. (Warsaw: Instytut Historii Polskiej Akademii Nauk, Wydawnictwo Naukowe "Semper", 1997).

Glad, Betty and Eric Shiraev (eds.). The Russian Transformation: Political, Sociological, and Psychological Aspects (New York: St. Martin's Press, 1999).

Gniewkowski, Waclaw. Rozwoj glownych europejskich systemow WF i ich wplyw na ksztaltowanie sie systemu WF $w$ Polsce od oswiecenia do 1939. Studia: Monografie 4 (Warsaw: Akademia Wychowania Fizycznego, 1972).

Gockowski, Janusz and Andrzej Walicki (eds.). Idee i koncepcje narodu w polskiej mysli politycznej czasow porozbiorowych (Warsaw: Panstwowe Wydawnictwo Naukowe, 1977).

Goldman, Minton F. Revolution and Change in Central and Eastern Europe: Political, Economic, and Social Challenges (Armonk, New York: M.E. Sharpe, 1997).

Goldman, Wendy. Women, The State and Revolution: Soviet Family Policy and Social Life, 1917-1936 (Cambridge and New York: Cambridge University Press, 1993).

Gondek, Leszek. Kultura fizyczna w Polsce, 1944-1984: Zarys podstawowych struktur, form i efektow zarzadzania kultura fizyczna w czterdziestoleciu PRL (Gdansk: Akademia Wychowania Fizycznego w Gdansku, 1986).

Goodwyn, Lawrence. Breaking the Barrier: The Rise of Solidarity in Poland (New York: Oxford University Press, 1991). 
Gorko, Jerzy. Sprintem przez historie: Z dziejow sportu w regionie polnocno-wschodnim (Bialystok: Bialostocki Komitet Olimpijski, 1996).

Gorsuch, Anne E. Youth in Revolutionary Russia: Enthusiasts, Bohemians, Delinquents (Bloomington: Indiana University Press, 2000).

Goscilo, Helena. Dehexing Sex: Russian Womanhood During and After Glasnost (Ann Arbor: University of Michigan Press, 1996).

Gounot, Andre, Toni Niewerth, Gertrud Pfister (eds.). Welt der Spiele-Politische, soziale und padagogische aspekte. Proceedings of the 2nd ISHPES Congress Games of the World--The World of Games, Berlin 1993, Part II (Sankt Augustin: Academia Verlag, 1996).

Grabowski, T.A. Z lamusa Warszawskiego sportu (Warsaw: Nasza Ksiegarnia, 1957).

Gray, Francine du Plessix. Soviet Women: Walking the Tightrope (New York: Doubleday, 1989).

Griffin, Pat. Strong Women, Deep Closets: Lesbians and Homophobia in Sport (Champaign, Ill.: Human Kinetics, 1998).

Griffith, Hubert (ed.). Playtime in Russia (London: Methuen, 1935).

Grobis, Jerzy (ed.). Oswieceni wobec rozbiorow Polski (Lodz: Wydawnictwo Uniwersytetu Lodzkiego, 1998).

Gross, Jan Tomasz. Polish Society Under German Occupation: The Generalgouvernement, 1939-1944 (Princeton: Princeton University Press, 1979).

Grot, Zdzislaw and Teresa Ziolkowska. Dzieje kultury fizycznej do roku 1918 (WarsawPoznan: Panstwowe Wydawnictwo Naukowe, Monografie pod reczniki skrypty AWF w Poznaniu, 1990).

Grys, Iwona. Muzyka i sport (Warsaw: Muzeum Sportu i Turystyki, 1998).

Gutowski, Aleksander. Drogi rozwoju kultury fizycznej w Polsce Ludowej w latach 19441956 (Warsaw: Sport i Turystyka, 1965).

Guttmann, Allen. Games and Empires: Modern Sports and Cultural Imperialism (New York: Columbia University Press, 1994).

Guttmann, Allen. The Erotic in Sports (New York: Columbia University Press, 1996).

Guttmann, Allen. Women's Sports: A History (New York: Columbia University Press, 1991). 
Guttmejer, Malgorzata. Poczatki w Polsce rozwoju pilki noznej kobiet w Polsce (Praca Magisterska, AWF Warsaw, 1984).

Haag, Herbert, Dietrich Kayser and Bruce Bennett (eds.). Comparative Physical Education and Sport, Vol.4 (Champaign, Illinois: Human Kinetics Publishers, Inc., 1987).

Hagen, William. Germans, Poles and Jews: The Nationality Conflict in the Prussian East, 1772-1914 (Chicago: University of Chicago Press,1980).

Hahn, Werner. Democracy in a Communist Party: Poland's Experience Since 1980 (New York: Columbia University Press, 1987).

Hall, Ann M. Feminism and Sporting Bodies: Essays on Theory and Practice (Champaign, Ill.: Human Kinetics, 1996).

Hargreaves, Jennifer. Sporting Females: Critical Issues in the History and Sociology of Women's Sports (London and New York: Routledge, 1994).

Hargreaves, John. Sport, Power and Culture: A Social and Historical Analysis of Popular Sports in Britain (New York: St. Martin's Press, 1986).

Harris, Dorothy V. (ed.). Women and Sport: A National Research Conference (Penn State HPER Series No. 2. College of Health, Physical Education and Recreation. The Pennsylvania State University. Proceedings from the National Research Conference, Women and Sport, held at The Pennsylvania State University, August 13-18, 1972).

Heitlinger, Alena. Women and State Socialism: Sex Inequality in the Soviet Union and Czechoslovakia (London: Macmillan, 1979).

Held, Joseph (ed.). The Columbia History of Eastern Europe in the Twentieth Century (New York: Columbia University Press, 1992).

Hetman, Eugeniusz. Praca kobiet w gospodarstwach chlopskich. Polska Akademia Nauk, Wydzial Nauk Rolniczych 1 Lesnych. Serial D-Monografie-Tom 183 (Warsaw: Panstwowe Wydawnictwo Naukowe, 1981).

Heywood, Leslie. Bodymakers: A Cultural Anatomy of Women's Body Building (New Brunswick, NJ: Rutgers University Press, 1998).

Higley, John, Jan Pakulski and Wlodzimierz Wesolowski (eds.). Postcommunist Elites and Democracy in Eastern Europe (Basingstoke: Macmillan, 1998).

Himka, John-Paul. Socialism in Galicia: The Emergence of Polish Social Democracy and 
Ukrainian Radicalism, 1860-1890 (Cambridge, Mass.: Harvard Ukrainian Research Institute. Distributed by Harvard University Press, 1983).

HISPA. International Association for the History of Physical Education and Sport (Paris: VII International Congress, March 28-April 2, 1978).

Hoberman, John. Sport and Political Ideology (London: Heinemann, 1984).

Hoffman, Shirl. Sport and Religion (Champaign, Ill.: Human Kinetics Books, 1992).

Holt, Richard (ed.). Sport and the Working Class in Modern Britain (Manchester: Manchester University Press, 1990).

Holt, Richard. Sport and Society in Modern France (London: Macmillan in association with St. Antony's College, Oxford, 1981).

Holt, Richard and Tony Mason. Sport in Britain, 1945-2000 (Oxford; Malden, Mass.: Blackwell, 2000).

Hong, Fan. Footbinding, Feminism and Freedom: The Liberation of Women's Bodies in Modern China (London and Portland: F. Cass, 1997).

Howell, Reet (ed.). Her Story in Sport: A Historical Anthology of Women in Sports (West Point, NY: Leisure Press, 1982).

Hull, Isabel V. Sexuality, State and Civil Society in Germany, 1700-1815 (Ithaca, NY: Cornell University Press, 1996).

Hunter, Richard J. and Leo V. Ryan, From Autarchy to Market: Polish Economics and Politics, 1945-1995 (Westport, Connecticut: Praeger Publishers, 1998).

Ilic, Melanie. Women Workers in the Soviet Interwar Economy: From 'Protection' to 'Equality' (New York: St. Martin's Press in Association with Center for Russian and East European Studies, University of Birmingham, 1999).

Ingham, Alan and John Loy. Sport in Social Development: Traditions, Transitions, and Transformations (Champaign, Ill.: Human Kinetics Publishers, 1993).

Jakubowsk, Henryk. Wybrane zagadanie z historii kultury fizycznej (AWF Warsaw, 1959).

Janos, Andrew C. East Central Europe in the Modern World: The Politics of the Borderlands from Pre to Post Communism (Stanford: Stanford University Press, 2000).

Jarosz, Dariusz. Polacy a stalinizm, 1948-1956 (Warsaw: Instytut Historii PAN, 2000). 
Jaruzelski, W. and Robert Maxwell. Prime Minister of Poland: Selected Speeches (Oxford and New York: Pergamon Press, 1985).

Jarvie, Grant and Maguire Joseph. Sport and Leisure in Social Thought (London and New York: Routledge, 1994).

Jasienica, Pawel. Jagiellonian Poland. Translated by Alexander Jordan (Miami, Fla.: The American Institute of Polish Culture, 1978).

Jaworksi, Rudolf and Bianka Pietrow-Ennker (eds.). Women in Polish Society (Boulder: East European Monographs. Distributed by Columbia University Press, New York 1992).

Jaworski, Zygmunt. Dzialacze i pracownicy kultury fizycznej w Polsce w 1960 roku (Warsaw: "Sport i Turystyka", 1961).

Jedlicki, Jerzy. A Suburb of Europe: Nineteenth Century Polish Approaches to Western Civilization (Budapest: Central European University Press, 1999).

Jedynak, Barbara. Obyczaje domu Polskiego w czasach niewoli, 1795-1918 (Lublin: Agencja Wydawnictwo-Handlowa Antoni Dudek, 1996).

Jedynak, Barbara. Kobieta w kulturze i spoleczenstwie. Interdyscyplinary Zespol Badan Feminologicznych, Tom I (Lublin: Wydawnictwo Uniwersytetu Marii CurieSklodowskiej, 1990).

Jobda, Robert Marek. Dzialalnosc stowarzyszenia "Rodzina Wojskowa" w zakresie kultury fizycznej kobiet (Praca Magisterska, AWF Warsaw, 1980).

Jolluck, Katherine R. Gender, Identity and the Polish Experience of War, 1939-1945 (Dissertation, Stanford University, August 1995).

Jonczyk, Jan. Ochrona pracy kobiet i mlodocianych $w$ Polskim przemysle $w$ latach 1918 1939 (Warsaw: Ksiazka i Wiedza, 1961).

Jozefowicz, Marek. Dzialalnosc ludowych zespolow sportowych $w$ dziedzinie upowszechniania wychowania fizycznego $i$ sportu $w$ wojewodziwie Bialostockim w latach 1975-1983 (Praca Magisterska, AWF Warsaw, 1989).

Kaczkowska-Duda, Ewa. Problematyka wychowania fizycznego $i$ sportu kobiet na lamach tygodnika Bluszcz w okresie 1865-1939 (Praca Magisterska, AWF Warsaw, 1980).

Kadziecka, Jolanta. Dzialalnosc kobiet w robotniczym ruchu sportowym Lodzi do 1949 (Praca Magisterska, AWF Warsaw, 1980). 
Kaminski, Bartlomiej. The Collapse of State Socialism: The Case of Poland (Princeton: Princeton University Press, 1991).

Kamphorst, Teus J. and Kenneth Roberts (eds.). Trends in Sports: A Multinational Perspective (Voorthuizen, The Netherlands: Giordano Bruno Culemborg, 1989).

Kaplan, Gisela. Contemporary Western European Feminism (New York: New York University Press, 1992).

Kargul, Jozef (ed.) Domy kultury w Polsce Ludowej. No. 876 (Wroclaw: Uniwersytet Wroclawski im. Boleslawa Bieruta, 1985).

Karpinska, Bozena. Wypoczywaj, cwiczac; rekreacja fizyczna kobiet. Tomik 3 (Warsaw: Wydawnictwo "Sport i Turystyka", 1972).

Karpinski, Andrzej. Kobieta $w$ miescie polskim $w$ drugiej polowie xvi $i$ w xvii wieku (Warsaw: Instytut Historii PAN, 1995)

Karpinski, Jakub. Poland since 1944: A Portrait of Years (Boulder, Colo.: Westview Press, 1995).

Kaser, Michael. Health Care in the Soviet Union and Eastern Europe (London: Croom Helm Limited, 1976).

Kauffman, Linda S. (ed.). American Feminist Thought at Century's End: A Reader (Cambridge, MA: Blackwell, 1993).

Kay, Rebecca. Russian Women and their Organizations: Gender, Discrimination and Grassroots Women's Organizations, 1991-1996 (New York: St. Martin's Press; Basingstoke, Houndmills, Hampshire: Macmillan Press, 2000).

Kelly, Catriona and David Shepherd (eds.). Constructing Russian Culture in the Age of Revolution, 1881-1940 (Oxford and New York: Oxford University Press, 1998).

Kemlein, Sophia (ed.). Geschlecht und Nationalismus in Mittel-und Osteuropa, 18481918 (Osnabruck, Germany: Fibre Verlag, 2000).

Kemp, Walter A. Nationalism and Communism in Eastern Europe and the Soviet Union: A Basic Contradiction? (Houndmills, Basingstoke, Hampshire: Macmillan Press; and New York: St. Martin's Press, 1999).

Kemp-Welch, A. (Edited and Translated). Stalinism in Poland, 1944-1956. Selected Papers from the Fifth World Congress of Central and East European Studies, Warsaw 1995 (Basingstoke, Houndmills, Hampshire: Macmillan Press, 1999). 
Kennedy, Michael D. Professionals, Power and Solidarity in Poland: A Critical Sociology of Soviet-Type Society (Cambridge and New York: Cambridge University Press, 1991).

Kennedy, Michael D. (ed.). Envisioning Eastern Europe: Postcommunist Cultural Studies (Ann Arbor: University of Michigan Press, 1994).

Kenney, Padraic. Rebuilding Poland: Workers and Communists, 1945-1950 (Ithaca: Cornell University Press, 1997).

Kent, Susan Kingsley. Gender and Power in Britain, 1640-1990 (London and New York: Routledge, 1999).

Kersten, Krystyna. The Establishment of Communist Rule in Poland, 1943-1948. Translated and Annotated by John Micgiel and Michael H. Bernhard (Berkeley and Los Angeles: University of California Press, 1991).

Kesik, Jan. Wojsko Polskie wobec tezyzny fizycznej spoleczenstwa, 1918-1939 (Wroclaw: Wydawn. Akademii Wychowania Fizycznego we Wroclawiu, 1996).

Kieniewicz, Stefan. The Emancipation of the Polish Peasantry (Chicago: The University of Chicago Press, 1969).

Kobieta w Polsce: Referaty na swiatowa konferencje dekady kobiet ONZ, 1/104. Wybrane Informacjne Tematyczne (Warsaw: Instytut Pracy i Spraw Socjalnych, 1986).

Kobiety $w$ Polskiej Weterynarri. Streszczenia referatow przygotowanych na sesje naukowa sekcji Historii Medycyny Weterynaryjnej PTNW, Ciechanowiec, 25-26 Wrzesnia 1997 (Warsaw: Wydawnictwo SGGW, 1997).

Kodisowa, Jozefa. Kwestja rodziny w sprawie kobiecej (Warsaw, 1909).

Kofman, Jan. Economic Nationalism and Development: Central and Eastern Europe Between the Two World Wars (Boulder, Colorado: Westview Press, 1997).

Kolek, Leszek. Polish Culture: A Historical Introduction (Lublin: Maria CurieSklodowska University Press, 1997).

Kollmann, Nancy Shields. By Honor Bound: State and Society in Early Modern Russia (Ithaca, NY: Cornell University Press, 1999).

Komadel, L'udovit (ed.). Physical Education and Sports of Children and Youth. Proceedings of the International Conference held in Bratislava, Slovakia, August 13-16, 1995 (Bratislava: Slovak Scientific Society for Physical Education and Sports and Faculty of Physical Education and Sports, Comenius University, 1995). 
Koralewicz, Jadwiga, Ireneusz Bialecki and Margaret Watson (eds). Crisis and Transition: Polish Society in the 1980s (Oxford and New York: Berg, 1987. Distributed by St. Martin's Press).

Kosinski, Tomasz. Dzialalnosc Towarzystwa Krzewienia Kultury Fizycznej w Kaliszu w latach 1958-1987 (Praca Magisterska, AWF Warsaw, 1988).

Kostkiewiczowa, Teresa. Oswiecenie: prog naszej wspolczesnosci (Warsaw: Wydawnictwo Naukowe Semper, 1994).

Koval, Vitalina. Women in Contemporary Russia (Providence: Berghahn Books, 1995)

Kowieska, Urszula. Kultura fizyczna w programach i dzialalnosci zwiazkow zawodowych w II Rzeczypospolitej (Wroclaw: AWF we Wroclawiu, 1997).

Kozelsky, Mara. The Vorontsov Women: Gender and Power in Eighteenth Century Russia (MA Thesis, West Virginia University, 1996).

I Krajowa konferencja naukowa. Polonijna kultura fizyczna Lubniewice, 16-17 grudnia 1978r. Seria: Monografie Nr.132 (Poznan: Akademia Wychowania Fizycznego w Poznaniu, 1980).

II Krajowa konferencja naukowa. Polonijna kultura fizyczna, rogi, 25-26 Pazdziernika 1982r. Seria: Monografie Nr.210 (Poznan: Akademia Wychowania Fizycznego w Poznaniu, 1986).

III Krajowa konferencja naukowa. Polonijna kultura fizyczna (Akademia Wychowania Fizycznego w Poznaniu, Seria: Monografie Nr.239, Poznan 1987).

IV Krajowa konferencja naukowa. Polonijna kultura fizyczna rogi, 8-9 Stycznia 1988 r. Monografie, Podreczniki, Skrypty, Nr. 264 (Poznan: AWF w Poznaniu, 1990).

Kraskowska, Ewa. Piorem niewiescim: Z problemow prozy kobiecej dwudziestolecia miedzywojennego (Poznan: Uniwersytet im. Adama Michiewicza w Poznaniu, 1999).

Krawczyk, Jerzy. Sport w spoleczenstwie wspolczesnym. Praca zbiorowa pod red. Zbigniewa Krawczyka (Warsaw: Panstwowe Wydawnictwo Naukowe, 1973).

Krawczyk, Zbigniew (ed.). Kultura fizyczna $i$ spoleczenstwo. Studia teoretycznometodologiczne (Warsaw: Panstwowe Wydawnictwo Naukowe, 1976).

Krawczyk, Zbigniew (ed.) Kulturowe wartosci sportu: materialy VI miedzynarodowego sympozjum socjologii sportu (Warsaw, August 20-24, 1979).

Kruger, Arnd and James Riordan, The Story of Worker Sport (Champaign, Ill.: Human Kinetics, 1996). 
Kubik, Jan. The Power of Symbols Against the Symbols of Power: The Rise of Solidarity and the Fall of State Socialism in Poland (University Park, Pennsylvania: The Pennsylvania State University Press, 1994).

Kubijovyc, Volodymyr (ed.). Ukraine: A Concise Encyclopedia, Vol. II. Prepared by Shevchenko Scientific Society (Toronto: University of Toronto Press, 1971)

Kuchowicz, Zbigniew. Wizerunki niepospolitych niewiast staropolskich xvi-xviii wieku (Lodz: Wydawnictwo Lodzki, 1972).

Kuchowicz, Zbigniew. Z dziejow obyczajow polskiej $w$ wieku xvii i pierwszej pol. xviii (Warsaw: Ludowa Spoldzielnia Wydawnicza, 1957).

Kuchowicz, Zbigniew. Leki $i$ gusla dawnej wsi: stan zdrowotny polskiej wsi panszczyznianej w xvii-xviii w. (Warsaw: Ldowa Spoldzielnia Wydawnicza, 1954).

Kuklo, Cezary. Kobieta samotna w spoleczenstwie miejskim w schylku Rzeczypospolitej szlacheckiej (Bialystok: Wydawnictwo Uniwersytetu w Bialymstoku, 1998).

Kulczycki, John J. School Strikes in Prussian Poland, 1901-1907: The Struggle Over Bilingual Education (Boulder, Colo.: East European Monographs. Distributed by Columbia University Press, 1981).

Kultura fizyczna ludnosci rodzimej na bylym pograniczu niemieckim $i$ w wolnym miescie Gdansku, do 1939 roku. Monografia Nr.14. Materialy z Krajowej Konferencji Naukowej, Gdansk 28-29 Marca, 1975 r. (Gdansk: Wyzsza Szkola Wychowania Fizycznego im. Jedrzeja Sniadeckiego w Gdansku, 1975).

Kwiatosinska, Zofia Krystyna. Problematyka higieny $i$ wychowania fizycznego kobiet na lamach miesiecznika Zdrowie (1885-1933), i Zdrowie Publiczne (1934-1939) (Praca Magisterska, AWF Warsaw, 1980).

Laba, Roman. The Roots of Solidarity: A Political Sociology of Poland's Working Class Democratization (Princeton: Princeton University Press, 1991).

Lane, David and George Kolankiewicz (eds.). Social Groups in Polish Society (London and Basingstoke: Macmillan Press, 1973).

Lange, Jozef. O prawach kobiety jako zony $i$ matki wedlug przepisow kodesku obowiazujacego (Warsaw, 1907).

Langhamer, Claire. Women's Leisure in England, 1920-60 (Manchester and New York: Manchester University Press, 2000). 
Lapidus, Gail. Women in Soviet Society: Equality, Development, and Social Change (Berkeley: University of California Press, 1978).

Lapinski, Jerzy. Kultura fizyczna w Polsce w roku 1949 (Warsaw: Wydawnictwo Glownego Komitetu Kultury Fizycznej, 1950).

Laskiewicz, Henryk. Robotnicza kultura fizyczna w Polsce w latach 1918-1939. Tom Szosty (Warsaw: Wydawnictwo "Sport i Turystyka", 1971).

Lednicki, Waclaw. Life and Culture of Poland: As Reflected in Polish Literature (New York: Roy Publishers, 1944).

Lenskyj, Helen. Out of Bounds: Women, Sport, and Sexuality (Toronto, Ont.: Women's Press, 1986).

Lenskyj, Helen J. Women, Sport and Physical Activity: Selected Research Themes (Gloucester, Ont.: Sport Information Resource Center for Sport, 1994).

Lepak, Keith John. Prelude to Solidarity: Poland and the Politics of the Gierek Regime (New York: Columbia University Press, 1988).

Lesinski, Bogdan. Stanowisko kobiety w Polskim prawie ziemskim do polowy xv wieky (Wroclaw: Zaklad im. Ossolinskich, 1956).

Leslie, R.F. (ed.) The History of Poland Since 1863 (Cambridge and New York: Cambridge University Press, 1980).

Lever, Janet. Soccer Madness (Chicago: University of Chicago Press, 1983).

Levin, Eve. Sex and Society in the World of the Orthodox Slavs, 900-1700 (Ithaca, NY: Cornell University Press, 1989).

Lewis, Jane (ed.). Women and Social Policies in Europe: Work, Family and the State (Aldershot, Hants and Brookfield: Edward Elgar, 1993).

Lidor, Ron, David Ben-Sira and Zvi Artzi (eds.). Physical Activity in the Lifecycle. Proceedings of the 1993 FIEP World Congress, March 28-April 3, Wingate Institute, Israel (Jerusalem: Wingate Institute, 1993).

Lindenmeyr, Adele. Poverty is Not a Vice: Charity, Society, and the State in Imperial Russia (Princeton: Princeton University Press, 1996).

Liponski, Wojciech. Dzieje sportu polskiego (Poznan: Wydawnictwo Podsiedlik Raniownski i Spolka, 1997). 
Liponski, Wojciech and Wieslaw Siwinski (eds.). Studies in Physical Culture and Tourism. No.3 (Poznan: University School of Physical Education in Poznan, 1994).

Lipski, Jan Jozef. KOR: A History of the Workers' Defense Committee in Poland, 19761981. Translated by Olga Amsterdamska and Gene M. Morre (Berkeley and Los Angeles: University of California Press, 1985).

Lobodzinska, Barbara (ed.). Family, Women, and Employment in Central-Eastern Europe (Westport, Conn.: Greenwood Press, 1995).

Long, Kristi. We All Fought For Freedom: Women in Poland's Solidarity Movement (Boulder, Colo.: Westview Press, 1996).

Louis, Victor and Jennifer Louis, Sport in the Soviet Union (Oxford and New York: Pergamon Press, 1980).

Lowe, Maria R. Women of Steel: Female Bodybuilders and the Struggle for SelfDefinition (New York: New York University Press, 1998).

Lowe, Benjamin, David Kanin and Andrew Strenk (eds.). Sport and International Relations (Champaign, Illinois: Stipes Pub. Co., 1978).

Lowerson, John. Sport and the English Middle Class, 1870-1914 (Manchester: Manchester University Press, 1993).

Lukashin, Yuri (compiler). National Folk Sports in the USSR (Moscow: Progress Publishers, 1980).

Lukowska, A. and J. Skirlinska. Gimnastyka dziewczat (Warsaw: Sport i Turystyka, 1971).

Lukowski, Jerzy. The Partitions of Poland, 1772, 1793, 1795 (London and New York: Addison Wesley Longman Ltd., 1999).

Lysakowski, Jerzy. Panstwowa adminstracja sprawami kultury fizycznej i turystyki $w$ $P R L$ od 1944 do 1975 roku (Warsaw: Praca dyplomowa napisana pod kierunkiem dr. Marka Wierzbowskiego, Nr. alb. 5152, Uniwersytet Warszawski, Wydzial prawa i administracji zawodowe studium administracyjne, 1976).

Makowski, Boleslaw. Krzewienie i popularyzacja kultury fizycznej na Pomorzu od czasow zaborczych do roku 1939 w swietle dzialalnosci organizacji gimnastycznej "Sokol" (Ku czci 1000-lecia Panstwa Polskiego na 100-lecie polskiej gimnastyki 18671967, July 1966).

Mala encyklopedia sportu. Tom II (Warsaw, 1987). 
Malec, Michael A. The Social Roles of Sport in Carribean Societies (Australia and the United States: Gordon and Breach Publishers, 1995).

Malolepszy, Eligiusz. Kultury fizyczna i przysposobienie wojskowe $w$ Czestochowie $i w$ powiecie czestochowskim $w$ latach 1918-1939 (Czestochowa: Wyzsza Szkola Pedagogiczna w Czestochowie, 1996).

Mandel, William. Soviet Women (Garden City, New York: Anchor Books, 1975).

Mangan, J.A. (ed.). Shaping the Superman. Fascist Body as Political Icon: Aryan Fascism (London and Portland: Frank Cass, 1999).

Mangan, J.A (ed.). Sport in Europe: Politics, Class, Gender (London: Frank Cass, 1999).

Mangan, J. A. and Roberta Park. From "Fair Sex" to Feminism: Sport and the Socialization of Women in the Industrialization and Post-Industrial Eras (London, England and Totowa, NY: F. Cass, 1987).

Marconnet, P., J. Gaulard, I. Margaritis and F. Tessier (eds.). Book of Abstracts (Nice, France: First Annual Congress, Frontiers in Sport Science, The European Perspective, May 28-31, 1996).

Marsh, Rosalind (ed.). Women in Russia and Ukraine (Cambridge and New York: Cambridge University Press, 1996).

Mason, David S. Public Opinion and Political Change in Poland, 1980-1982 (Cambridge and New York: Cambridge University Press, 1985).

Materialy sesji naukowej 25-lecia kultury fizycznej w PRL (Warsaw: Wydawnictwo GKKFiT, 2-4.VI.1970).

Mawdsley, Evan and Stephen White. The Soviet Elite From Lenin to Gorbachev: The Central Committee and its Members, 1917-1991 (Oxford and New York: Oxford University Press, 2000).

McCrone, Kathleen. Playing the Game: Sport and the Physical Emancipation of English Women, 1870-1914 (Lexington, KY: University Press of Kentucky, 1988).

Mehnert, Klaus. Youth in Soviet Russia. Translated by Michael Davidson (Westport, Conn.: Hyperion Press, 1993).

Messner, Michael and Donald Sabo (eds.). Sport, Men and the Gender Order: Critical Feminist Perspectives (Champaign, Ill.: Human Kinetics Books, 1990).

Millard, Frances. Polish Politics and Society (London and New York: Routledge, 1999). 
Misiunas, Romuald and Taagepera, Rein. The Baltic States: The Years of Dependence 1940-80 (Berkeley and Los Angeles: University of California Press, 1983).

Mlodziankowska, Anna. Poczatki i rozwoj sportu szermierczego kobiet w Polsce do 1980 (Praca Magisterska, AWF Warsaw, 1982).

Montias, John. Central Planning in Poland (New Haven: Yale University Press, 1962).

Moraczewska, Zofja. Zwiazek Pracy Obywatelskiej Kobiet (Warsaw, 1932).

Morawinska-Brzezicka, Maria. Sport w sztuce polskiej, 1945-1975 (Warsaw: Sport i Turystyka, 1976).

Morton, Henry. Soviet Sport, Mirror of Soviet Society (New York: Collier Books, 1963).

Morton, Miriam. Pleasures and Palaces: The After-School Activities of Russian Children (New York: Atheneum, 1972).

Mrozik, Konrad (ed.). Informator wojewodzkiego komitetu kultury fizycznej i turystyki w Bydgoszczy (Zeszyt 1, Nr. specjalny, January, 1970).

Muszalowna, K. and E. Reicherowna (eds.). Uszkodzenia sportowe u kobiet. Tomik I (Warsaw: Glowna Ksiegarnia Wojskowa, Panstowy Urzed W. F i P.W. Wychowanie Fizyczne Kobiet, 1935).

Muszalowna, K. and E. Reicherowna (eds.). Wioslarstwo kobiece. Tomik 6 (Warsaw: Glowna Ksiegarnia Wojskowa, Wychowanie Fizyczne Kobiet, 1936).

Muszalowna, K. and E. Reicherowna (eds.). 10 minut gimnastyki pracownic fabrycznych. Tomik 9 (Warsaw: Glowna Ksiegarnia Wojskowa, Wychowanie Fizyczne Kobiet, 1937).

Naimark, Norman and Leonid Gibianskii (eds.), The Establishment of Communist Regimes in Eastern Europe, 1944-1949 (Boulder, Colorado: Westview Press, 1997).

Nelson, Mariah Burton. The Stronger Women Get, The More Men Love Football: Sexism and the American Culture of Sports (New York: Harcourt Brace, 1994).

Nelson, Mariah Burton. Are We Winning Yet? How Women are Changing Sports and Sports are Changing Women (New York: Random House, 1991).

Niedbala, Wiktoria. Poczatki i rozwoj kobiecego sportu w Bialymstoku do 1939 (Praca Magisterska, AWF Warsaw, 1983).

Niedzielska, Krystyna. Women in Contemporary Poland: A Sketch to a Portrait (Warsaw: CZS, Wydawnictwo Sp-ldzielcze, 1985). 
Nowak, Leonard. Wychowanie fizyczne $i$ sport $w$ panstwowym szkolnictwie og-lnoksztalcacym $w$ Polsce $w$ latach 1918-1939. Monografie Nr. 325 (Poznan: Akademia Wychowania Fizycznego im. Eugeniusza Piaseckiego, 1996).

Nowak, Leonard. Wystawa sportowo-przemyslowa w Warszawie w 1912 (Praca Magisterska, AWF Warsaw, 1975).

Nowosielski, Stanislaw. Problemy sportu, turystyki $i$ wypoczynku $w$ dokumentach prezydium Rady Narodowej m.st. Warszawy w latach 1960-1970 (Praca Magisterska, AWF Warsaw, 1973).

O'Connell, Sean. The Car and British Society: Class, Gender and Motoring, 1896-1939 (Manchester and New York: Manchester University Press, 1998).

Oglesby, Carole. Women and Sport: From Myth to Reality (Philadelphia: Lea and Febiger, 1978).

Oja, Pekka and Risto Telama (ed.). Sport For All. Proceedings of the World Congress on Sport for All, Tampere, Finland, 3-7 June 1990 (Amsterdam and New York: Elsevier Science Publishers, 1991).

Olsen, Morgan A. (ed.). Sport und Politik 1918-1939/40. ICOSH Seminar, October 2226, 1984. Proceedings/Bericht, Sormarka, Oslo, Norway (Oslo: Universitetsforlaget A.S, 1986).

Ost, David. Solidarity and the Politics of Anti-Politics: Opposition and Reform in Poland Since 1968 (Philadelphia: Temple University Press, 1990).

Pallot, Judith (ed.). Transforming Peasants: Society, State and the Peasantry, 1861-1930. Selected Papers from the Fifth World Congress of Central and East European Studies, Warsaw, 1995 (New York: St. Martin's Press, 1998).

Pawlak, Anna. Polskie olimpijki z lat 1924-1994: Miniatury czyli filigranowe portrety wielkich dam polskiego sportu. Wydanie I (Warsaw: Polskie Stowarzyszenie Sportu Kobiet, 1995).

Pawlak, Anna (ed.). Polska Manager-Woman Sportu (Warsaw-Krakow: Polskie Stowarzyszenie Sportu Kobiet i Katedra Socjologii i Filozofii Kultury Fizycznej, Akademii Wychowania Fizycznego Bronislawa Czecha, 1998).

Peiss, Kathy. Cheap Amusements: Working Women and Leisure in Turn-of-the Century New York (Philadelphia: Temple University Press, 1986).

Peppard, Victor and James Riordan. Playing Politics: Soviet Sport Diplomacy to 1992 (Greenwich, Connecticut; London, England: JAI Press, 1993). 
Petrone, Karen. Life Has Become More Joyous, Comrades: Celebrations in the Time of Stalin (Bloomington, Ind.: Indiana University Press, 2000).

Piasecki, Eugenjusz. Dzieje wychowanie fizycznego z licznemi ilustracjami (LwowWarszawa-Krakow: Wydawnictwo Zakladu Narodowego imienia Ossolinskich, 1925).

Pieroth, Doris. Their Day in the Sun: Women of the 1932 Olympics (Seattle: University of Washington Press, 1996).

Pilkington, Hilary (ed.). Gender, Generation and Identity in Contemporary Russia (London and New York: Routledge, 1996).

Pilkington, Hilary. Russia's Youth and its Culture: A Nation's Constructors and Constructed (London and New York: Routledge, 1994).

Polish Women in Combat, 1939-1945 (Warsaw: Biweekly "Rada-Narodowa-GospodarkaAdminstracja”, 1980).

Polonsky, Antony. Politics in Independent Poland 1921-1939: The Crisis of Constitutional Government (Oxford: Clarendon Press, 1972).

Polubiec, Zofia (ed.) By nie odeszly w mrok zapomnienia: udzial kobiet Polskich w II wojnie swiatowej (Warsaw: Ksiazka i Wiedza, 1976).

Ponczek, Miroslaw. Geneza i rozwoj kultury fizycznej na Gornym Slasku 1895-1945: zarys problematyki (Katowice: Wydawnictwo Muzeum Slaskie, 1989).

Ponczek, Miroslaw. Z przeszlosci ruchu sportowego z Zaglebiu Dabrowskim do 1939 roku (Sosnowiec: Sosnowiecka Oficjna Wydawniczo-Autorksa SOWA Press, 1992).

Ponimasz, Andrzej Wieslaw. Odradzanie sie sportu w Lodzi w latach 1945-1946 (Praca Magisterska, AWF Warsaw, 1978).

Porter, Brian. When Nationalism Began to Hate: Imagining Modern Politics in Nineteenth-Century Poland (New York and Oxford: Oxford University Press, 2000).

Posadskaya-Vanderbeck, Anastasia (ed.). Women in Russia: A New Era in Russian Feminism (London and New York: Verso, 1994).

Pouncy, Carolyn (ed.). The "Domostroi": Rules For Russian Households in the Time of Ivan the Terrible (Ithaca, NY: Cornell University Press, 1994).

Poznanski, Kazimierz Z. Poland's Protracted Transition: Institutional Change and Economic Growth, 1970-1994 (Cambridge and New York: Cambridge University Press, 1996). 
Prebish, Charles. Religion and Sport: The Meeting of Sacred and Profane (Westport, Conn.: Greewood Press, 1993).

Pronger, Brian. The Arena of Masculinity: Sports, Homosexuality, and the Meaning of Sex (New York: St. Martin's Press, 1990).

Przeweda, Ryszard (ed.). Wychowania fizyczne w Polsce (Warsaw: Wydawnictwo AWF, 1992).

Pushkareva, Natalia. Women in Russian History From the Tenth to the Twentieth Century. Translated and Edited by Eve Levin (Armonk, NY: M.E. Sharpe, Inc., 1997).

Raina, Peter. Poland 1981: Towards Social Renewal (London and Boston: G. Allen and Unwin, 1985).

Raivio, Marjo (ed.). Reports of Physical Culture and Health 66, Vol. 1. Proceedings of the Jyvaskyla Congress on Movement and Sport in Women's Life, August 17-21, 1987 (Jyvaskyla, Finland: The Press of the University of Jyvaskyla, 1989).

Ramet, Sabrina P. (ed.). Eastern Europe: Politics, Culture, and Society since 1939 (Bloomington and Indianapolis: Indiana University Press, 1998).

Ramet, Sabrina P. Nihil Obstat: Religion, Politics and Social Change in East-Central Europe and Russia (Durham: Duke University Press, 1998).

Ramet, Sabrina P. Whose Democracy? Nationalism, Religion, and the Doctrine of Collective Rights in Post-1989 Eastern Europe (Lanham, Maryland: Rowman and Littlefield Publishers, 1997).

Ransel, David L. (ed.). The Family in Imperial Russia: New Lines of Historical Research (Urbana: University of Illinois Press, 1978).

Ransel, David. Mothers of Misery: Child Abandonment in Russia (Princeton: Princeton University Press, 1988).

Reading, Anna. Polish Women, Solidarity, and Feminism (Houndmills, Basingstoke, Hampshire: Macmillan Academic and Professional Ltd., 1992).

Rechowicz, Henryk (ed.). Z dziejow kultury fizycznej na Slasku i w Zaglebiu Dabrowskim (Katowice: AWF w Katowice, 1989).

Reczek, Wlodzimierz. The Development of Physical Culture in Poland (Warsaw: Polonia Publishing House, 1958).

Renne, Tanya (ed.). Anna's Land: Sisterhood in Eastern Europe (Boulder, Colo.: Westview Press, 1997). 
Renson, Roland, Pierre Paul de Nayer and Michel Ostyn (eds.). The History, The Evolution, and Diffusion of Sports and Games in Different Cultures. Proceedings of the 4th International HISPA Seminar, Leuven, Belgium April 1-5, 1975 (Belgium, 1975; Brussels: B.L.O.S.O., Bestuur voor de Lichamelijke Opvoeding, de Sport en het Openluchtleven, 1976).

Rieder, Hermann and Udo Hanke (eds.). Sportlehrer und trainer heute. Band 2, Bericht uber den AIESEP-Weltkongress vom 22-26, August 1986 anlasslich der 600-Jahrfeier der Universitat Heidelberg (Koln: Sport und Buch Strauss, 1987).

Riordan, James. Soviet Sport Background to the Olympics (New York: Washington Mews Books--a division of New York University Press, 1980).

Riordan, James (ed.). Soviet Social Reality in the Mirror of Glasnost (New York: St. Martin's Press, 1992).

Riordan, James. Sport in Soviet Society: Development of Sport and Physical Education in Russia and the USSR (Cambridge and New York: Cambridge University Press, 1977).

Riordan, James (ed.). Sport Under Communism: the USSR, Czechoslovakia, the GDR, China, Cuba (London: C. Hurst, 1978).

Roberts, Cheryl. Against the Grain: Women and Sport in South Africa (Cape Town, South Africa: Township Pub. Cooperative, 1992).

Rocki, Cezary. Rozwoj pilki noznej kobiet w Polsce w latach 1981-1991 (Warsaw: Praca Dyplomowa, Studium Nauczycielskie Nr.6 w Warszawie, 1992).

Rodkiewicz, Witold. Russian Nationality Policy in the Western Provinces of the Empire, 1863-1905 (Lublin: Scientific Society of Lublin, 1998).

Romanska, Lola and Andrzej Romanski (eds.). "In Their Country's Service”: Women Soldiers of the 2nd Polish Corps, 1941-1946 (Rome: Published by the Headquarters of the Polish Women's Auxiliary Corps. 2nd Polish Corps, October, 1946).

Rose, Mary Beth. Women in the Middle Ages and the Renaissance: Literary and Historical Perspectives (Syracuse, NY: Syracuse University Press, 1986).

Rothschild, Joseph. East Central Europe Between the Two World Wars (Seattle and London: University of Washington Press, 1974).

Rothschild, Joseph. Return to Diversity: A Political History of East Central Europe Since World War II (New York: Oxford University Press, 1993).

Rudzki, Edward. Damy Polskie xviii wieku (Warsaw: Wydawnictwo Veni, 1997). 
Rueschemeyer, Marilyn (ed.). Women in the Politics of Postcommunist Eastern Europe (Armonk, New York: M.E. Sharpe, 1994).

Ryan, Joan. Little Girls in Pretty Boxes: The Making and Breaking of Elite Gymnastics and Figure Skaters (New York: Doubleday, 1995).

Rygier-Nalkowska, Sofja. Kobiety. Translated from the Polish by Michael Henry Dziewicki. (New York: G.P. Putnam's Sons, 1920).

Sanford, George. Polish Communism in Crisis (London and Canberra: Croom Helm, 1983).

Sanford, George. Poland: The Conquest of History (Amsterdam: Harwood Academic Publishers, 1999).

Sanford, George (editor and translator). The Solidarity Congress, 1981: The Great Debate (New York: St. Martin's Press, 1990).

Sapia-Drewniak, Eleonora. Aktywnosc kulturalna i oswiatowa kobiet na Slasku Opolskim w latach 1922-1939 (Opole: Zwiazek Gornoslaski w Opolu, 1991).

Seager, Joni. The State of Women in the World Atlas (London and New York: Penguin, 1997).

Segner, Adolf. Polski ruch sportowy na Slasku Opolskim w latach 1922-1939 (Wroclaw: Nadbitka Z, T. IV, Rozpraw Naukowych Wyzszej Szkoly Wychowania Fizycznego we Wroclawiu, 1966).

Senior, John. Marie and Pierre Curie (Gloucestershire: Sutton Publishing, 1998).

Senn, Alfred. Power, Politics and the Olympic Games: A History of the Power Brokers, Events, and Controversies that Shaped the Games (Champaign, Ill.: Human Kinetics, 1999).

Sesja Naukowa 25-lecia kultury fizycznej w PRL, 2-4.VI.1970, Wydanie I (Warsaw, 1970).

Shneidman, Norman. The Soviet Road to Olympus: Theory and Practice of Soviet Physical Culture and Sport (Toronto: Ontario Institute for Studies in Education, 1978).

Sieniarski, Stefan. Sport in Poland (Warsaw: Interpress, 1972).

Simon, Maurice D. and Roger E. Kanet (eds.), Background to Crisis: Policy and Politics in Gierek's Poland (Boulder, Colorado: Westview Press, Inc. 1981). 
Singh, M.K. Indian Women and Sports (Jaipur: Rawat Publications, 1990).

Siwinski, Wieslaw. Kultura fizyczna: profilaktyka zdrowotna, wychowania: raport $z$ badan empirycznych. Monografie Podreczniki Skrypty AWF w Poznaniu, Nr. 298 (Poznan: Akademia Wychowania Fizycznego, 1993).

Siwinski, Wieslaw. Mieszkancy wsi wobec kultury fizycznej i turystyki. Monografie, Podreczniki, Skrypty, Nr. 240 (Poznan: AWF w Poznaniu, 1986).

Skawinski, Marek. Kultura fizyczna na Lubelszczyznie w latach 1944-1974 (Warsaw, 1989).

Skierska, Elzbieta (ed.). Sport Kobiet. Wydanie I (Warsaw: Polskie Stowarzyszenie Sportu Kobiet, Katedra Biologii i Medycyny, Akademii Wychowania Fizycznego Jozefa Pilsudskiego, 1996).

Slay, Ben. The Polish Economy: Crisis, Reform, and Transformation (Princeton: Princeton University Press, 1994).

Slay, Ben and Louisa Vinton. Poland to 2005: The Challenge of Europe. Research Report (London: The Economic Intelligence Unit, 1997).

Slepenkov, I. M. and B.V. Kniazev. Rural Youth Today (Newtonville, Mass.: Oriental Research Partners, 1977).

Smarzynski, Henryk. Dr. Henryk Jordan: Pionier nowoczesnego wychowania fizycznego $w$ Polsce (Krakow: Panstwowe Wydawn. Naukowe, 1958).

Smith, Bonnie. Changing Lives: Women in European History Since 1700 (Lexington, Mass.: D.C. Heath and Co., 1989).

Smith, Kristin Bell. The Promise of Title IX: A Critique of Sport Equity Legislation in the United States and the Constraints Inherent in a Liberal Feminist Interpretation (MA Thesis, Queen's University, Ontario, Canada, 1994).

Smith, Lissa (ed.). Nike is a Goddess: The History of Women in Sports (New York: Atlantic Monthly Press, 1998).

Smith, Lois M. and Alfred Padula. Sex and Revolution: Women in Socialist Cuba (New York: Oxford University Press, 1996).

Snyder, Eldon and Elmer Spreitzer. Social Aspects of Sport (Englewood Cliffs, N.J.: Prentice Hall, 1989).

Snyder, Timothy. Nationalism, Marxism, and Modern Central Europe: A Biography of 
Kazimierz Kelles-Krauz, 1872-1905 (Cambridge, Mass.: The Harvard Ukrainian Research Institute, 1997).

Sobolev, S. L. Soviet Youth at Work and Play (Moscow: Foreign Languages Publishing House, 1939).

Soland, Birgitte. Becoming Modern: Young Women and the Reconstruction of Womanhood in the 1920s (Princeton: Princeton University Press, 2000).

Soviet Olympic Death Rate, National Discrimination and the Ukrainian Issue: Smoloskyp at the Olympics (Baltimore: Smoloskyp Publishers, 1984).

Spears, Betty and Richard Swanson. History of Sport and Physical Activity in the United States (Dubuque, Iowa: W.C. Brown Co., 1983).

Spence, Jonathan. Mao Zedong (New York: Viking, 1999).

Sport na progu polski niepodleglej: materialy z sesji popularno-naukowej odbytej $w$ dniu 16 listopada 1988 (Warsaw: Komitet do Spraw Mlodziezy i Kultury Fizycznej Stowarzyszenie "Wisla-Odra" i Muzeum Sportu i Turystki, 1990).

Spuscizna komisji edukacji narodowej w dziedzinie wychowania fizycznego. Materialy Ogolnopolskiego sympozjum zorganizowanego z okazji 200 rocznicy powstania komisji edukacji narodowej, Warszawa 6-7.XII.1973 (Warsaw: 'Sport i Turystyka', 1978).

Staar, Richard F. Poland, 1944-1962: The Sovietization of a Captive People (Baton Rouge: Louisiana State University Press, 1962).

Stachura, Peter D. (ed.). Poland Between the Wars, 1918-1939 (Basingstoke and New York: Macmillan and St. Martin's Press, 1998).

Stachura, Peter D. Poland in the Twentieth Century (Basingstoke and New York: Macmillan and St. Martin's Press, 1999).

Staniszkis, Jadwiga. Poland's Self-Limiting Revolution. Book Edited by Jan T. Gross (Princeton: Princeton University Press, 1984).

Stanley, John Dudley. A Political and Social History of the Duchy of Warsaw, 1807-1813 (Ph.D. Dissertation, University of Toronto, 1979).

Stehle, Hansjakob. The Independent Satellite: Society and Politics in Poland Since 1945 (New York: Frederick A. Praeger, 1965).

Stein, Louise Kruszewski. The Political Economy of Health and Fertility: The Case of a Group of Rural Polish Women (Dissertation, State University of New York at Buffalo, 1983). 
Steinberg, Mark and Stephen Frank (eds.). Cultures in Flux: Lower-Class Values, Practices, and Resistance in Late Imperial Russia (Princeton: Princeton University Press, 1994).

Stell, Marion. Half the Race: A History of Australian Women in Sport (North Ryde, Australia: Angus and Robertson, 1991).

Steuer, Antoni. Sport na Gornym Slasku, 1896-1996 (Katowice: Muzeum Historii Katowic, 1997).

Stewart, Mary Lynn. For Health and Beauty: Physical Culture for Frenchwomen, 1880s1930s (Baltimore: John Hopkins University Press, 2001).

Stites, Richard. The Women's Liberation Movement in Russia: Feminism, Nihilism, and Bolshevism, 1860-1930 (Princeton: Princeton University Press, 1978).

Stites, Richard. Russian Popular Culture: Entertainment and Society Since 1900 (Cambridge and New York: Cambridge University Press, 1992).

Stola, Dariusz. Kampania antysyjonistyczna w Polsce, 1967-1968 (Warsaw: Instytut Studiow Politycznych Polskiej Akademii Nauk, 2000).

Stone, David. Hammer and Rifle: The Militarization of the Soviet Union, 1926-1933 (Lawrence: University Press of Kansas, 2000).

Strong, George V. Seedtime for Fascism: The Disintegration of Austrian Political Culture, 1867-1918 (Armonk, NY: M.E. Sharpe, 1998).

Cultural Policy in the Byelorussian Soviet Socialist Republics (Paris: United Nations Educational, Scientific and Cultural Organization, 1979).

Suchodolski, Bogdan. A History of Polish Culture (Warsaw: Interpress Publishers, 1986).

Suny, Ronald. The Soviet Experiment: Russia, The USSR, and the Successor States (New York: Oxford University Press, 1998).

Suny, Ronald and Michael Kennedy (eds.), Intellectuals and the Articulation of the Nation (Ann Arbor: The University of Michigan Press, 1999).

Svoboda, Bohumil (ed.). Coaches and Physical Education Teachers Training in Socialist Countries. A Collection of Studies in the International Scientific Cooperation, Task No. 6 (Prague: Central Committee of the Czechoslovak Union of Physical Education. Faculty of Physical Education and Sport, Charles University, 1984). 
Szafkowski, Zbigniew. Zespolowe gry sportowe na Pomorzu Szczecinskim w latach 1945-1996 (Mysliborz: Publickacja dotowanan przez autora i wydana przy wspolpracy "Mysliborskich Wiesci” oraz OSiR Gorzow Wlkp., 1996).

Szajkowski, Bogdan. Next to God....Poland: Politics and Religion in Contemporary Poland (London: Frances Pinter, 1983).

Szczepanski, Jan. Polish Society (New York: Random House, Inc. 1970).

Szot, Zbigniew. Rozwoj kultury fizycznej w aglomeracji Gdanskiej, Gdansk, Gdynia, Sopot w latach 1945-1980. Diagnoza i proba prognozy do roku 2000 (Gdansk: Akademia Wychowania Fizycznego im. Jedrzeja Sniadeckiego w Gdansku, 1986).

Szymanski, Bernard. Poczatki oraz rozwoj sportu kobiecego w Plocku w Wloclawku do 1939 roku--analiza porownawcza (Praca Magisterska, AWF Warsaw, 1979).

Szymanski, Leonard. Kultura fizyczna w polityce II rzeczypospolitej. Studia i Monografie 47 (Wroclaw: Akademia Wychowania Fyzycznego we Wroclawiu, 1995).

Szymanski, Leonard. Higiena $i$ wychowanie fizyczne w szkolnictwie ogolnoksztalcacym $w$ krolestwie polskiem, 1815-1915 (Wroclaw: Panstwowe Wydawnictwo Naukowe, 1979).

Taras, Ray. Ideology in a Socialist State: Poland, 1956-1983 (Cambridge and New York: Cambridge University Press, 1984).

Taras, Ray. Consolidating Democracy in Poland (Boulder, Colo.: Westview Press, 1995).

The Tasks of Research and its Practical Application in Mass and Recreation Sports. Report Miscellany of the 10th International Seminar of CIEPSS "Sport and Leisure" Committee, Piestany, 26-30 September 1983 (Prague: Sportpropag, Metasport, 1984).

The Way of Life: Leisure and Cultural Development. A Book of Papers Presented at the International Symposium in Liblice, Vol.II. (XIth World Congress of Sociology, New Delhi, India, 1986).

Thompson, Shona M. Mother's Taxi: Sport and Women's Labor (Albany: State University of New York Press, 1999).

Todd, Jan. Physical Culture and the Body Beautiful: Purposive Exercise in the Lives of American Women, 1800-1870 (Macon, Ga.: Mercer University, 1998).

Tomaszewski, Janusz. Ruch zawodowy na Dolynm Slasku w latach 1945-1950 (Wroclaw: Wydawn. Uniwersytetu Wroclawskiego, 1999).

Toporowicz, Kazimierz. Eugeniusz Piasecki (1872-1947): zycie i dzielo (WarsawKrakow: Panstwowe Wydawnictwo Naukowe, 1988). 
Treywasz, Adolf. Nasz sport na dziesieciolecie polskiej rzeczypospolitej ludowej (Warsaw: Sport i Turystyka, 1954).

Trybowska, Stanislawa Lidia. Poczatki rozwoju sportu kobiecego w Krakowie do 1939 roku (Praca Magisterska, AWF Warsaw, 1978).

Trzeciakowski, Lech. The Kulturkampf in Prussian Poland. Translated from the Polish by Katarzyna Kretkowska (New York: East European Monographs. Distributed by Columbia University Press, 1990).

Twin, Stephanie. Out of Bleachers: Writings on Women and Sport (New York: McGrawHill, 1979).

Tworzecki, Hubert. Parties and Politics in Post-1989 Poland (Boulder, Colorado: Westview Press, 1996).

Ulatowski, Tadeusz, et. al. (eds.). Rola tradycji $w$ kstaltowaniu wspolczesnego modelu kultury fizycznej (Warsaw: Wydaw. AWF, 1986).

Urbanyi, Zbigniew. Zarys historii sportu Bydgoskiego 1886-1975 (Bydgoszcz, 1980).

Vamplew, Wray. Pay Up and Play the Game: Professional Sport in Britain, 1875-1914 (Cambridge and New York: Cambridge University Press, 1988).

Vamplew, Wray and Brian Stoddart (eds.). Sport in Australia: A Social History (Cambridge and New York: Cambridge University Press, 1994).

Vaz, Kim Marie (ed.). Black Women in America (Thousand Oaks, Calif.: Sage Publications, 1994).

Vertinsky, Patricia. The Eternally Wounded Woman: Women, Doctors, and Exercise in the Late Nineteenth Century (Manchester and New York: Manchester University Press, 1990).

Wachowski, Eugeniusz, and Ryszard Strzelczyk (eds.). Wychowanie fizyczne i sport $w$ badaniach naukowych. V Konferencja Srodowiskowa Poznan, dnia 22 Maja 1997r. Monografie Nr. 335 (Poznan: Akademia Wychowania Fizycznego im. Eugeniusza Piaseckiego w Poznaniu, 1998).

Wagner, Wenceslas J. (ed.). Polish Law Throughout the Ages (Stanford, Calif.: Hoover Institution Press, 1970).

Walczewska, Slawomira. Damy, rycerze i feministki: kobiecy dyskurs emancypacyjny w Polsce (Krakow: Wydawnictwo eFKa, 1999). 
Walewska, Cecylja. Z dziejow krzywdy kobiet (Warsaw, 1908).

Walicki, Andrzej. The Enlightenment and the Birth of Modern Nationhood: Polish Political Thought from Noble Republicanism to Tadeusz Kosciuscko. Translated by Emma Harris (Notre Dame, Indiana: University of Notre Dame Press, 1989).

Walicki, Andrzej. The Three Traditions in Polish Patriotism and Their Contemporary Relevance (Bloomington, Indiana: The Polish Studies Center, Indiana University, 1988).

Walicki, Andrzej. Poland Between East and West: The Controversies over Self-Definition and Modernization in Partitioned Poland. The August Zaleski Lectures, Harvard University, 18-22 April 1994 (Cambridge, Mass.: Ukrainian Research Institute, Harvard Papers in Ukrainian Studies, 1994).

Wandycz, Piotr S. The Lands of Partitioned Poland 1795-1918 (Seattle: University of Washington Press, 1974).

Wapinski, Roman. Historia polskiej mysli politycznej xix i xx wieku. Wydanie I (Gdansk: Wydawnictwo ARCHE, 1997).

Wapinski, Roman. Narodowa demokracja 1893-1939: Ze studiow nad dziejami mysli nacjonalistycznej (Wroclaw: Zaklad narodowy im. Ossolinskich Wydawnictwo, 1980).

Ware, Susan. Modern American Women: A Documentary History (New York: McGrawHill, 1997).

Warsicki, Seweryn. Kultura fizyczna w Wielkopolsce w latach 1919-1927. Seria Historia Nr.23 (Poznan: Uniwersytet im. Adama Mickiewicz w Poznaniu Prace Wydzialu Filozoficzno-Historycznego, 1966).

Wasztyl, Ryszard. Wychowanie fizyczne i sport $w$ Krakowie $w$ latach 1773-1890. Monograph, Nr.60 (Krakow: Akademia Wychowania Fizycznego im. Bronislawa Czecha w Krakowie, 1993).

Watt, Richard M. Bitter Glory: Poland and Its Fate, 1918 to 1939 (New York: Simon and Schuster, 1979).

Wedrowska, Z. 100 minut dla urody. Wydanie IV (Warsaw: Sport i Turystyka, 1978).

Weeks, Theodore R. Nation and State in Late Imperial Russia: Nationalism and Russification on the Western Frontier, 1863-1914 (DeKalb, Ill.: Northern Illinois University Press, 1996).

Wereszycki, Henryk. Historia polityczna Polski, 1864-1918 (Paris: Libella, 1979). 
White, Anne. De-Stalinization and the House of Culture: Declining State Control Over Leisure in the USSR, Poland, and Hungary, 1953-1989 (London and New York: Routledge, 1990).

Wieruszewski, Roman. Rownosc kobiet $i$ mezczyzn w Polsce Ludowej (Poznan: Wydawnictwo Poznanskie, 1975).

Wiesner, Merry. Women and Gender in Early Modern Europe (Cambridge and New York: Cambridge University Press, 1993).

Wilcox, Ralph C. (ed.). Sport in a Global Village (Morgantown: Fitness Information Technology, Inc., 1994).

Wiles, Timothy (ed.). Poland Between the Wars:1918-1939 (Bloomington, Indiana: Indiana University Polish Studies Center, December 1989).

Williams, Cicely. Women on the Rope: The Feminine Share in Mountain Adventure (London: Allen and Unwin, 1973).

Wohl, Andrzej. Spoleczno-historyczne podloze sportu (Warsaw: Wydawnictwo Sport i Turystyka, 1961).

Woloch, Nancy. Early American Women: A Documentary History, 1600-1900 (New York: McGraw-Hill, 1997).

Woltmann, Bernard. Polska kultura fizyczna na wschodnim pograniczu niemieckim, 1919-1939. Seria: Monografie Nr. 125 (Poznan: Akademia Wychowania Fizycznego w Poznaniu, 1980).

Woltmann, Bernard (ed.). Z najnowszej historii kultury fizycznej w Polsce. Tom III, VI Ogolnopolska Konferencja Historykow Kultury Fizycznej, Chycina 1997 (Gorzow WLKP.: Polskie Towarzystwo Naukowe Kultury Fizycznej Sekcja Historii KF, Instytut Wychowania Fizycznego Poznanskiej AWF w Gorzowie WLKP, 1998).

Women in the Polish Cooperative Movement (Warsaw: CRS Publications for the Supreme Cooperative Movement, 1963).

Wood, Elizabeth. The Baba and the Comrade: Gender and Politics in Revolutionary Russia (Bloomington: Indiana University Press, 1997).

Woodall, Jean (ed.). Policy and Politics in Contemporary Poland: Reform, Failure, Crisis (New York: St. Martin's Press, 1982).

Woolum, Janet. Outstanding Women Athletes: Who They Are and How They Influenced Sports in America (Phoenix, AZ: Oryx Press, 1992). 
Wozniak, Edward. Mundury i Laury: Sport $i$ wychowanie fizyczne $w$ ludowym wojsku polskim (Warsaw: Wydawnictwo Ministerstwa Obrony Narodowej, 1977).

Wychownie fizyczne kobiet w przemysle i handlu (Poznan: Miejski Komitet W.F.iP.W. W Poznaniu, 1935).

Wychowanie fizyczne $i$ sport w 40-Leciu PRL. Konferencja popularno-naukowa, Poznan, dnia 12 Kwietnia 1985r. Seria: Monografie Nr. 235 (Poznan: Akademia Wychowania Fizycznego w Poznaniu, 1987).

Wynot, Edward D. Warsaw Between the World Wars: Profile of the Capital City in a Developing Land, 1918-1939 (Boulder, Colo.: East European Monographs. Distributed by Columbia University Press, 1983).

Wynot, Edward D. Polish Politics in Transition: The Camp of National Unity and the Struggle for Power, 1935-1939 (Athens: University of Georgia Press, 1974).

Wyzsza Szkola Wychowania Fizycznego w Krakowie. T. VI. (Rocznik Naukowy, 1967).

Wyznikiewicz, Zdzislawa. Aktywnosc sportowa kobiet: Aspekty biologiczne (Warsaw: Akademia Wychowania Fizycznego im. Gen. Karola Swierczewskiego w Warszawie, Panstowe Wydawnictwo Naukowe, 1978).

Yessis, Michael and Richard Trubo. Secrets of Soviet Sports Fitness and Training (New York: Arbor House, 1987).

$Z$ dziejow kultury fizycznej $w$ Polsce. Materialy na plenum GKKFiT z okazji 100-lecia sportu polskiego (Warsaw: Komisja Historyczna Glownego Komitetu Kultury Fizycznej i Turystyki, 7 February 1967).

Zamoyski, Adam. The Polish Way, A Thousand-Year History of the Poles and Their Culture (New York: Hippocrene Books, 1994).

Zarnowska Anna and Andrzej Szwarc (eds.). Kobieta i edukacja na ziemiach polskich w xix $i x x$ w. Tom II, Cz.I (Warsaw: Instytut Historyczny Uniwersytetu Warszawskiego, 1992).

Zarnowska, Anna and Andrzej Szwarc (eds.). Kobieta i edukacja na ziemiach Polskich w xix $i \quad x x$ wieku. Tom II, Cz. 2 (Warsaw: Instytut Historyczny Uniwersytetu Warszawskiego, 1992).

Zarnowska, Anna and Andrzej Szwarc (eds.). Kobieta i kultura, Kobiety wsrod tworcow kultury, intelektualnej $i$ artystycznej $w$ dobie rozbiorow $i w$ niepodleglym panstwie polskim. Tom IV (Warsaw: Wydawnictwo DiG, 1996). 
Zarnowska, Anna and Andrzej Szwarc (eds.). Kobieta i kultura zycia codziennego wiek xix i xx. Tom V (Warsaw: Wydawnictwo DiG, 1997).

Zarnowska, Anna i Andrzej Szwarc (eds.). Kobieta i spoleczenstwo na ziemiach Polskich w xix $w$ (Warsaw: Instytut Historyczny Uniwersytetu Warszawskiego, 1990).

Zarnowska, Anna i Andrzej Szwarc (eds.). Kobieta i spoleczenstwo na ziemiach Polskich w xix wieku (Warsaw: Wydawnictwo DiG Instytut Historyczny Uniwersytetu Warszawskiego, 1995).

Zarnowska, Anna and Andrzej Szwarc (eds.). Kobiet i swiat polityki: Polska na tle porownawczym $w$ xix $i$ w poczatkach $x x$ wieku (Warsaw: Wydawnictwo DiG, Instytut Historyczny Uniwersytetu Warszawskiego, 1994).

Zarnowska, Anna and Andrzej Szwarc (eds.). Rowne prawa i nierowne szanse : Kobiety w Polsce miedzywojennej (Warsaw: Wydawn. DiG, 2000).

Zarnowska, Anna and Andrzej Szwarc (eds.). Kobieta i swiat polityki w niepodleglej Polsce, 1918-1939 (Warsaw: Wydawnictwo Sejmowe, 1996).

Zaseda, Igor. The Sporting Ukraine (Kiev: Ukraina Society, 1979).

Zawacka, Elzbieta. Czekajac na rozkaz:Pogotowie spoleczne organizacji Przysposobienia Wojskowego Kobiet w przededniu II wojny swiatowej (Lublin: Redakcja Wydawn. Katolickiego Uniwersytetu Lubelskiego, 1992).

Zawadzka, Anna. Harcerstwo zenskie w Warszawie w latach 1911-1949 (Warsaw: Wydawnictwo "Municipium" SA, 1995).

Ziemianski, Ignacy. Praca kobiet w P.O.W--Wschod (Warsaw: Wydano Nakladem Autora, 1933).

Zimmerman, Jean and Gil Reavill. Raising Our Athletic Daughters: How Sports Can Build Self-Esteem and Save Girls' Lives (New York: Doubleday, 1998).

Zinkevych, Osyp. Ukrainian Olympic Champions (Baltimore, Md.: Symonenko Smoloskyp Publishers, 1984).

Zi-lkowska, Teresa. Kultura fizyczna $w$ Poznaniu $w$ latach 1870-1918. Seria: Monografie Nr. 303 (Poznan: Akademia Wychowania fizycznego im. Eugeniusz Piasecki w Poznan, 1992).

Zolem ojczyznie, szponem wrogowi, Historia Sokolstwa Polskiego, 1867-1939 (Warsaw: Muzeum Niepodleglosci, Muzeum Sport i Turystyki, Wystawa Czerwiec-Listopad 1998). 
Zubkova, Elena. Russia After the War: Hopes, Illusions, and disappointments, 1945-1957 (Armonk, NY: M.E. Sharpe, 1998).

Zukowska, Zofia (ed.). Kobieta jako kreatorka aktywnosci sportowej $w$ rodzinie (Warsaw: Polskie Stowarzyszenie Sportu Kobiet, Katedra Nauk Humanistycznych, Akademii Wychowania Fizycznego Jozefa Pilsudskiego, 1998).

Zukowska, Zofia (ed.). Sport $w$ zyciu kobiety. Wydanie I (Warsaw: Polskie Stowarzyzenie Sportu Kobiet, 1995).

Zurawlew, E., L. Stakelberg and C. Jananis. Codzienna Gimnastyka Kobiet (Warsaw: Wydawnictwo Glownego Komitetu Kultury Fizycznej, 1951).

Zysko, Jolanta. Zmiany struktury organizacyjnej kultury fizycznej w Polsce po 1989 (Autoreferat rozprawy doktorskiej, AWF Warsaw, 1997).

\section{Selected Articles}

Grot, Zdzislaw. "Versuch eines Abrisses der Geschichte des Sports und der Korperkultur in Polen vom MittelAlter bis zum Zweiten Weltkriege," in Stadion, 1, 2 (1975), 284-315.

Jaczynowski, J. "Struktura celow kultury fizycznej," in Wychowanie Fizyczne i Sport, 4 (1989), 3-13.

Lobodzinska, Barbara. "Family, Women, and Employment in Poland and Other Central European Countries: Ideology of Equality and Reality of Discrimination," in The Polish Review, XLII, 4 (1997), 447-469.

Ostrowska, Elzbieta. "Filmic Representations of the 'Polish Mother' in Post-Second World War Polish Cinema," in The European Journal of Women's Studies, 5 (1998), $419-435$.

Rotkiewicz, Maria. "Rozwoj sportu kobiet w Polsce okresu miedzywojennego," in $\underline{\text { Sport }}$ Wyczynowy, 3-4/171-172 (1979), 3-21.

Siemienska, Renata. "Women in the Period of Systemic Changes in Poland," in Journal of Women's History, 5, 3 (Winter, 1994), 70-90.

Stachniak, Eva. "Why Did We Not Become Feminists? Women in Poland," in The National Women's Studies Association, 7, 3 (Fall, 1995), 69-80.

Wohl, Andrzej. "Spartakiady zakladowe i ich rola w upowszechnianiu kultury fizycznej," in Kultura Fizyczna, 33, 5 (May, 1979), 15-18.

Woltmann, Bernard. "Sporthistorische Forschung in Polen," in Stadion, 12/13 (1986/87), $347-356$. 
Wonneberger, Ingeburg and Gerda Lehnert. "Vergleichende betrachtung zu sportabzeichen in sozialistischen landern," in Theorie und Praxis der Korperkultur, 5 (May, 1975), 403-420.

Zarnowska, Anna. "Social Change, Women, and the Family in the Era of Industrialization: Recent Polish Research," in Journal of Family History, (Translated into English by Robert Blobaum), 22, 2 (April, 1997), 191-203.

Ziolkowska, Teresa. "Rozwoj sportu wsrod kobiet polskich w okresie zaborow," in Roczniki Naukowe AWF w Poznaniu, 29 (1990), 201-205.

Zukowska, Zofia. "Der Frauensport in polnishchen Untersuchungen," in Weltrat fur Sportwissenschaft und Korpererziehung, 7 (1984), 48-57. 